$\begin{array}{lll}10 & \end{array}$

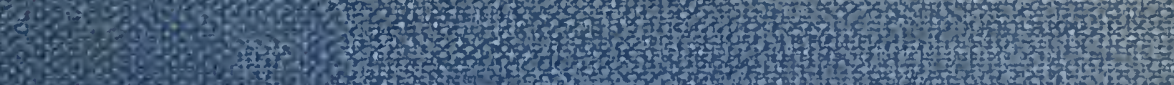

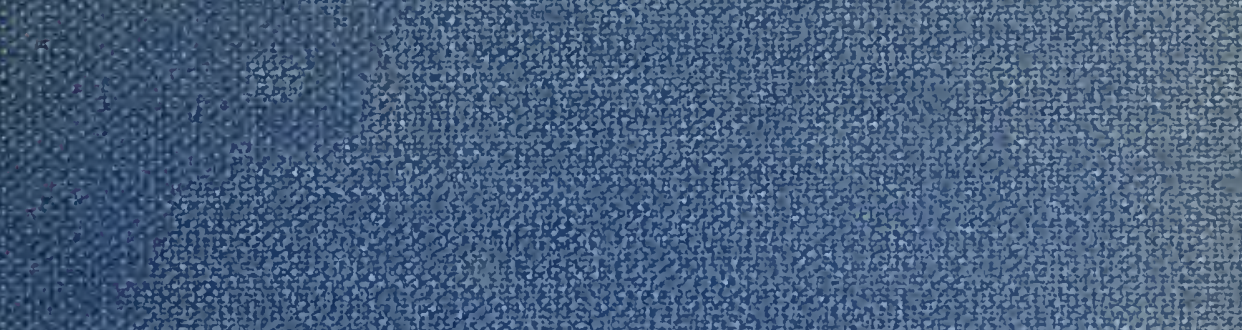

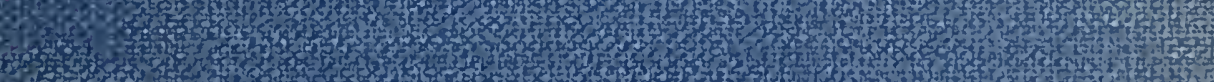

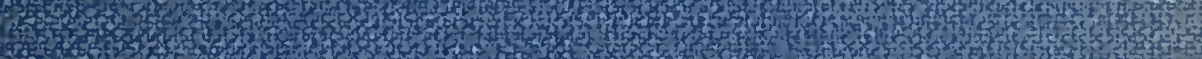
3.5.5.

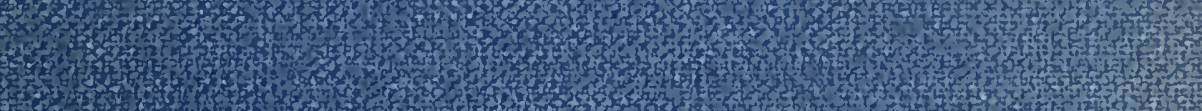
7.

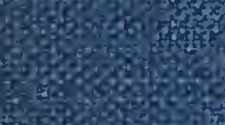
3.t.

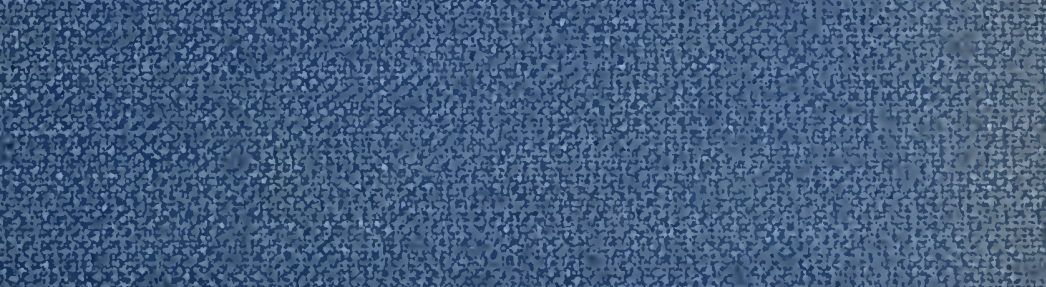
H.7.

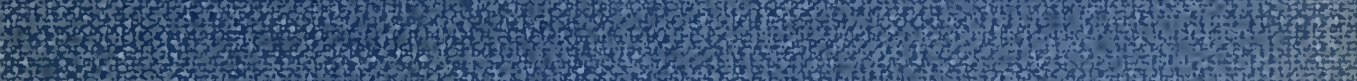

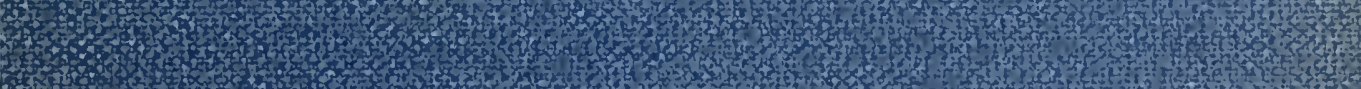
6.

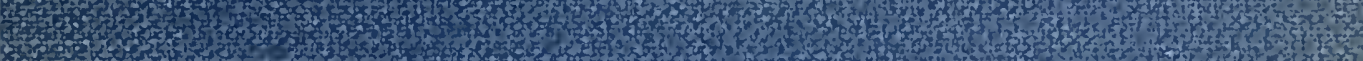

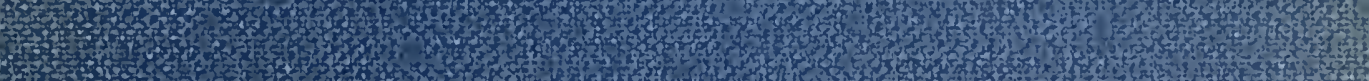
4.

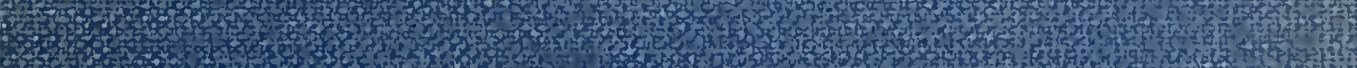

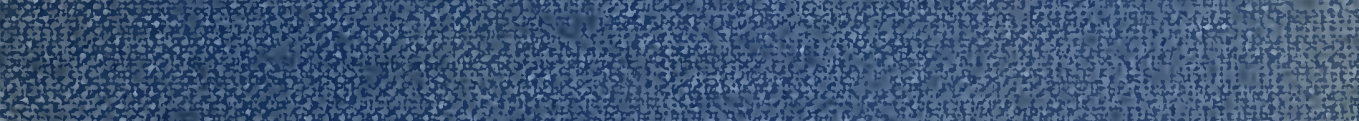

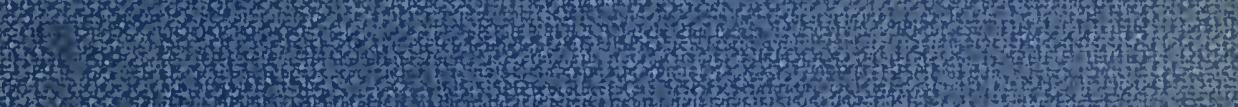

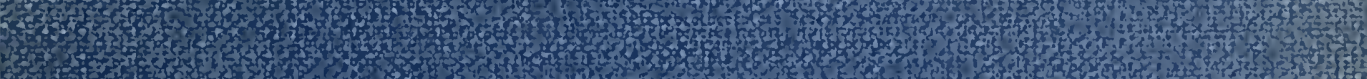

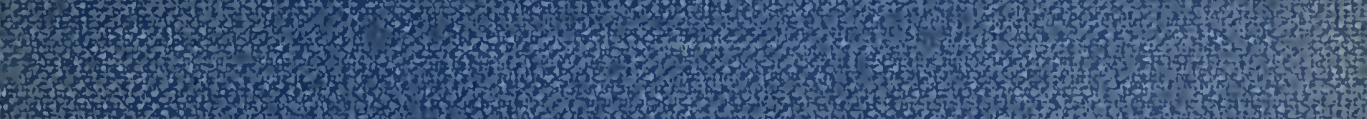

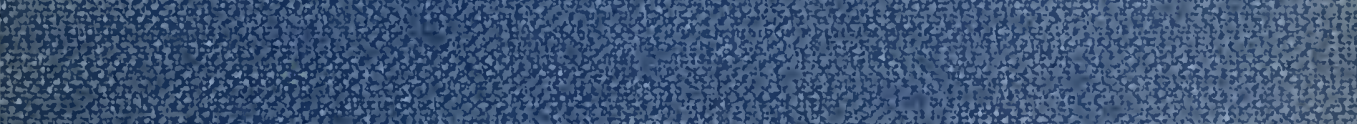
10.5. 



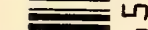

$\overline{0}=$

드믈

$\$$

$\infty$

507

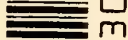

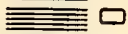

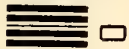

$\equiv$

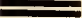

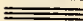

$=$ 

THE NORTH AMERICAN

CUP-FUNGI 


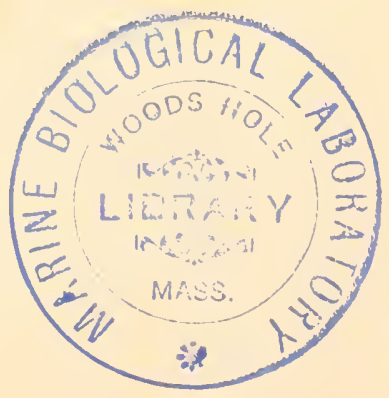




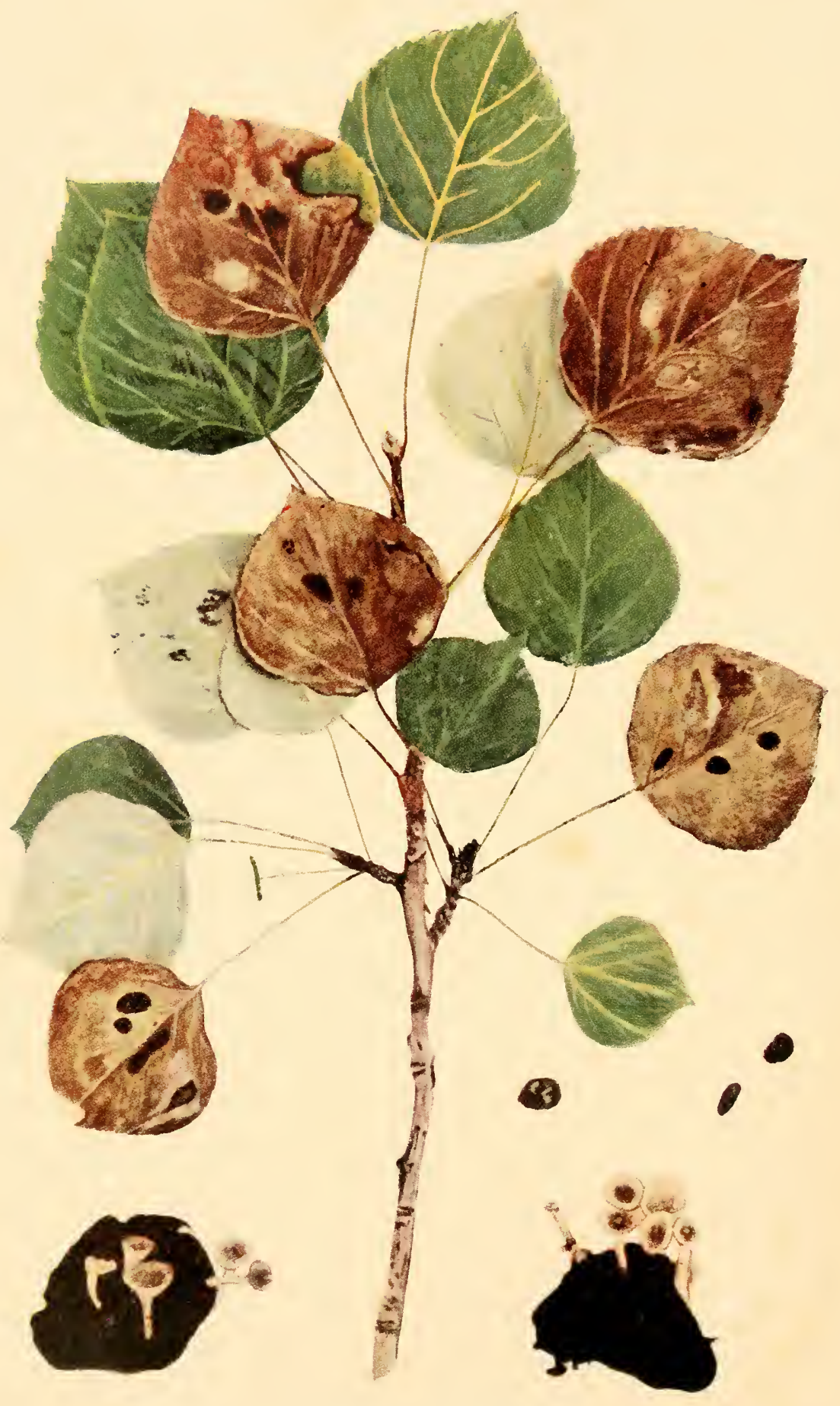

CIBORINIA BIFRONS 


\section{The North American Cup-fungi}

\section{(Inoperculates)}

BY

FRED JAY SEAVER, M.S., Ph.D., Sc.D. Visiting Professor of Biology, Florida Southern College Formerly Head Curator in The New York Botanical Garden AND

Managing Editor of Mrcologia

\section{ILLUSTRATED}

NEW YORK

PUBLISHED BY THE AUTHOR 
Copyright 1951

By Fred Jay Seaver

PRINTED IN THE UNITED STATES OF AMERICA BY THE LANCASTER PRESS, INC., LANCASTER, PA. 
I) EDI C A T E D)

TO MY WIFE

Ifinetta Ifry Sestrex

I A APRECIATION OF

INSPIRATION AND COLIABORATION 



\section{TABI.E OF CONTEN'TS}

Preface ............................... is

Introductory . . . . . . . . . . . . . . . . . . . . . . . . $\quad 1-6$

This comprises a brief account of the writer's early work on this group of fungi and a discussion of the habits of the Inoperculates in contrast with the Operculates.

Taxonomic treatment. . . . . . . . . . . . . . . $7-373$

Explanation of plates . . . . . . . . . . . . 374-384

Host index . . . . . . . . . . . . . . . . . . . . . 385-396

Index to illustrations . . . . . . . . . . . . . . . 397-398

Index to recognized genera. . . . . . . . . . . . . 399

Index to genera and species. . . . . . . . . . . 400-428 



\section{PREFACE}

When the North American Cup-Fungi (()perculates) was issued in 1928, it was expected that this would be followed in a reasonable time by a similar volume on Inoperculates. As the work progressed, however, it became obvious that the task was so tremendous that nothing approaching completeness could be accomplished in one short life time.

Fully realizing this, it has been flecided to bring together at this time, in one volume, the results of the observations of the writer extending over a period of more than forty-five years as well as those of his colleagues and coworkers in various parts of North America.

There are many controversial questions and the writer makes no pretense that this is the last word in the treatment of species, genera or families but merely a summary of the available facts as they appear at the present time. It is hoped that this volume may be as useful as the preceding one in stimulating observation, and research in this obscure, interesting, and apparently inexhaustible field.

NEW YORK, 1948

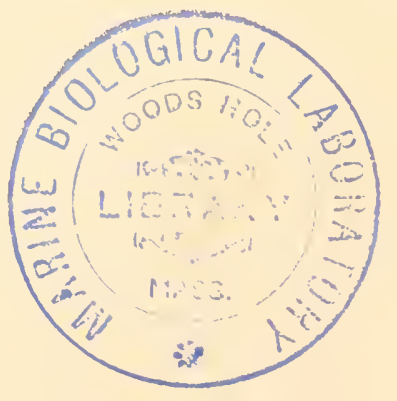





\section{IN'TRODUC'TION}

The writer's interest in the inoperculate cup-fungi coincides with that of the operculates. In fact, when these studies were begun as a student in Iowa, the separation of the cup-fungi or Discomycetes into the operculate and inoperculate forms had not come to be generally recognized although the importance that should be attached to the dehiscence of the asci in the classification of the Discomycetes was announced by Boudier more than twenty years before (Grevillea 8: 45. 1879.). The steps leading up to the present work will be discussed here in some detail.

Although the operculates may seem to have absorbed most of the writer's attention up to the present time, some of the first novelties encountered in student days were of the inoperculate group. One of these will be mentioned here. In the spring of 1905 the writer's attention was called to a small disco appearing under the trees of wild cherry across the river from the University of Iowa, the region at that time consisting of wooded hills and open ficlds constituted one of our favorite collecting grounds. Careful search revealed many of the small discs each attached by a stem to a partially buried seed of the wild cherry, Prunus serotina. This was at once recognized as belonging to the genus Sclerotinia as at that time known. Being unable to find any record of a Sclerotinia on this host, in his youthful enthusiasm the writer transmitted a specimen to Dr. H. Rehm of Germany, then the outstanding world authority on this group of fungi. When Dr. Rehm later reported this to be a new species and named it in honor of the collector Sclerotinia Seaveri (Plate 85) it was an event of no small importance in the writer's young life and furnished an added incentive to continue the researches started on this group of fungi.

A few years later G. M. Reade of Cornell University published a paper (Ann. Myc. 6: 109-115. 1908.) entitled "Preliminary notes on some species of Sclerotinia" in which he listed the writer's namesake and recorded with it the coniclial stage which had later been discovered and recorded as Monilia Seaveri. In the meantime both stages of the fungus had been collected at various places in New York State. Reade at the same time 
recorded another of the writer's early collections made at Mt. Pleasant, Iowa, on the seeds of basswood as Sclerotinia Tiliae.

As a result of the work clone by Reade at Cornell University, the writer some time after coming to The New York Botanical Garden invited Professor H. H. IThetzel to monograph the genus Sclerotinia for North American Flora, thinking at the time that this little task could be accomplished over a summer vacation. This, however, proved to be the beginning of a lifelong research problem which has been prosecuted by Whetzel up to the time of his death and by his students and collaborators, Honey, Drayton, White and others up to the present time. Unfortunately, much of Whetzel's work was still unpublished, at the time of his death.

Although the task of monographing the genus Sclerotinia was assigned to Whetzel, the writer never entirely lost interest in the genus and its allies, and other members of the genus or tribe as it is now regarded kept forcing them onto his attention in such a manner that they could not be disregarded. One illustration of this should be mentioned.

During the early days at The New York Botanical Garden occasional afternoons were spent in field work in the suburbs of New York City, especially the Van Cortlandt Park section when that region was more natural and unsophisticated than it is at the present time. For several seasons the writer had collected every spring on the rootstocks of wild geranium a discomycete growing in large clumps which could not be identified. No record of any such fungus growing on this host could be found. Finally it was decided to name and describe the fungus so as to have a record of it. It was regarded as a Sclerotinia and knowing from experiences previously recorded that some of these had conidial stages on the foliage of the host, a careful search was made for such connections. About this time a letter was addressed to Professor Whetzel as follows: "For several years past I have been collecting each spring a Sclerotinia on the rootstocks of wild geranium. Perhaps you recall that I referred to this species while you were here. During the present spring I have found it as usual and have been following it up in the field with a hope of finding its conidial stage. I have been unable to find anything which appeared to be its conidial stage on the leaves of the same host. However, I have in culture a number of rootstocks which were infected with apothecia and in about a 
week I had the most beautiful growth of a Botrytis. I am sending a small specimen of this to you for examination. While the occurrence of Botrytis might be purely coincidence, it occurs with such great abundance in connection with the apothecia and rootstocks that I am inclined to suspect that there might be some connection between the two. If you can give me any light on the Botrytis as to its identity, the favor will be very greatly appreciated."

To this Professor Whetzel replied as follows: "I very much doubt that the Botrytis can be a coniclial stage of your fungus on wild geranium. Nevertheless this is quite possible, and I shall see what I can make out of it. However, I coukl come a great deal nearer answering the question if you could get me apothecia of the same fungus from which I could make ascospore cultures. The probability is that cultures from the Botrytis will give only Botrytis."

Since Professor Whetzel seemed doubtful of any connection between the Botrytis and Sclerotinia, it was cultured at The New York Botanical Garden and the connection established. On June 28, 1917 the following report was made to our Cornell associate: "Since writing you we have cultured out the Sclerotinia on wild geranium and proved beyond the question of a doubt that the Botrytis is the conidial stage of this fungus. Professor Horne is here for a time and being interested he offered to culture the fungus. Excellent growth of conidia can be produced from the ascospores in four or five days. I thought you might be interested in knowing our results. We will publish a short paper in the near future. I would be glad to send you some of the perfect stage of the fungus but the last time I was out I could find none. It lasts only about a month in the spring. Unless we can decide on the specific name of the Botrytis we will call the fungus Sclerotinia Geranii. According to our rules the specific name of the Botrytis provided it has one would be tenable for the species."

On July 2, 1917 a letter was received from Professor Whetzel containing the following statements: "I want to congratulate you upon having made the connection between a Botrytis and the Sclerotinia . . So far as I am aware this is the first authentic case of the connecting up of the Botrytis with the Sclerotinia, and it will be a very important contribution to the general subject."

Our Cornell associate still seemed doubtful of our results, and 
in the spring of 1919 by previous arrangement came to New York with an assistant to check up our conclusions for his own personal satisfaction. The work was done in New York since at that time the fungus had not been collected in any other place, and it was desired to make first hand field observations. No difficulty was encountered in collecting the material, and after careful culture work our results were substantiated.

The importance of this contribution lies in the fact that De Bary (Comparative Morphology and Biology of the Fungi 238. 1887.) claimed a connection between Botrytis cinerea and Sclerotinia Fuckeliana, a claim that could never be substantiated. To use his exact words: "the conidiophores of Sclerotinia Fuckeliana were made a species under the name of Botrytis cinerea." Neither had any other connection been made between a Sclerotinia and a Botrytis, so far as we are aware, until the connection was made in The New York Botanical Garden between Sclerotinia Geranii and an unnamed Botrytis. However, when we refer to Sclerotinia this is used in a broad sense as it was then applied. It is now used in a much more restricted sense. Since the establishment of the one connection several others have been made, which will be reported in the proper place.

\section{Habits and Life History}

As stated in the volume on operculates, very few of those were even suspected of being parasitic in their habits. At the same time the conidial stages are either lacking or obscure and inconspicuous. On the other hand, many of the inoperculates are destructive parasites and in these the conidial stages are often much more highly developed and conspicuous. From these facts we conclude that the high development of the coniclial stages in these forms is in some way associated with their parasitic habits.

Take as an illustration the species just discussed, Sclerotinia Seaveri. In this species the ascigerous stage appears the early part of May, at which time the asci discharge their spores vigorously just about the time young foliage of the host plant begins to appear. The spores germinate on the young leaves producing monilioid spores in great abundance and forming conspicuous blotches on the leaves and inflorescence. The coniclia thus constitute the summer or repeating stage, the mycelium passing to the seeds which fall to the ground and carry 
the fungus over the winter. Here the high development of the conidial stage is obviously an adaptation to the parasitic habits of the fungus. Other similar illustrations might be cited.

From this high development of the conidial stages in some of the fungi of this group and their adaptation to their hosts have resulted the most complicated pleomorphic life cycles. To trace these requires the most careful laboratory studies, and it is needless to say that only a small percentage of the forms have been so studied. Many do not respond easily to this kind of treatment, or it may be possible that the right technique has not been employed. And since the classification of these forms is often based on their conidial stages, it follows that any treatment of genera adopted now is purely tentative.

While many of the inoperculates are parasitic, many more are strictly saprophytic, and in many of these the conidial stages are as yet unknown, or possibly lacking a condition similar to that found in the operculates. The types of conidia found in the inoperculates are most varied and no attempt will be made to enumerate them here. They will be treated with the species to which they are organically connected.

\section{Sex in the Cup-fungi}

Definite sex organs were observed by Tulasne and DeBary at an early date, but whether these actually functioned has remained a controversial question. Tulasne, as early as 1865 , observed minute bodies in certain of the discomycetes which he called spermatia or conidiola, which he believed would be found to function like that of the pollen. They were believed to be male sperms, like the spermatia of the lichens. Reccnt authors held the same view.

\section{Spermatization}

In 1932, F. I. Drayton (Mycologia 24: 345-348.) proved that microconidia, which were found in many species of Sclerotimia and other fungi, and which were probably morphologically identical with the spermatia or conidiola of Tulasne, stimulated the production of apothecia when placed on certain structures which develop on another thallus of the same fungus. To this process he applied the term "spermatization."

His preliminary experiments were carried on with Sclerotinia Gladioli. Isolates of this fungus transferred to suitable culture 
media procluced layers of sclerotized tissue with scattered sclerotia. From this crust-like growth so called receptive bodies are formed which are more or less columnar and about $1 \mathrm{~mm}$. in height. These structures when spermatized with microconidia from another thallus finally produce mature apothecia. The receptive bodies of each isolate do not, however, react with their own microconiclia.

\section{Heterothallism}

While from the above we appear to have a condition of heterothallism in Sclerotinia Gladioli, Drayton (Mycologia 26: 69. 1934) believes that while this is in a sense heterothallism, it is not true heterothallism as the term is usually understoor since while microconidia and receptive bodies must be produced on different thalli, these may have arisen from a single hyphal tip, while in true heterothallism the series are segregated on different thalli. However, the term heterothallism is used differently by the various authors and there is a chance for a difference of opinion on this point. 


\section{Order PEZIZALES (continued)}

(For diagnosis see North American (up-fungi. (Operculates)

Asci inoperculate (opening by a simple pore at

the apex).

Section 2. INOPERCULATES

A-cophores stipitate, clavate, spathulate, or pileate, rarely diccoid or turbinate, on the ground or more rarely on plant tissues.

Family 3. Geoglossaceat.

Ascophores typically cup-shaped or discoid, not as above, usually on living or dearl plant tissues, never or rarely on the ground.

Apothecia for the most part soft and fleshy or waxy, superficial from the first, or erumpent on herbaceous plant tissues.

Family 4. Helotiaceae.

Apothecia soft or more often hard, leathery, or horny, erumpent through the substratum, often cespitose, usually on living or recently killed woody plant tissues.

Family 5. ('entnoriceate.

\section{Family 3. GEOGLOSSACEAE}

Ascophores mostly club-shaped, or clavate, more rarely discoid or turbinate, the hymenium arising directly from the surface of the clavula and forming a uniform stratum over it, usually covering only a part of the ascophore but in some cases extending over the whole of it, or pileate, the hymenium occupying the upper surface only; consistency fleshy but usually elastic or fibrous rather than brittle, a few leathery, others distinctly gelatinous; asci usually 8 -spored; spores varying from ellipsoid to fusiform, hyaline, or colored.

Ascophore stipitate, clavate, or spathulate, the ascigerous portion usually more or less compressed, rarely subglobose.

Clavate, the ascigerous portion not or only slightly decurrent on opposite sides of the stem.

Spores small, ellipsoid, cylindric, or fusiform, simple.

1. Mitrul.A. 
Spores long-elliptic to cylindric, 3-many-septate when mature.

Ascophores bright-colored.

2. Microglossum.

Ascophores black or blackish.

Spores hyaline.

3. Corynetes.

Spores fuliginous, or brown.

Hymenium without spines or setae.

Apothecia viscid.

Apothecia not viscid.

Hymenium beset with spines or setae.

Spathulate or fan-shaped, ascigerous portion de-

current on opposite sides of the stem.

Ascophores stipitate, pileate.

Spores ellipsoid-fusiform; ascophore gelatinous.

Spores filiform, or filiform-clavate.

Ascophores fleshy-gelatinous; asci very narrow; spores filiform; plants aquatic or semiaquatic.

4. Gloeoglossum

5. Geoglossum.

6. Trichoglosstim.

7. SP.ithLLiRIi.

8. LEOTIA.

Ascophores fleshy-leathery; asci broadly clavate; spores filiform-clavate; plants terrestrial.

9. Vibrissea.

10. Cudonia.

Note. The treatment of the Geoglossaceae is based on Durand's monograph (Ann. Myc. 6: 388-482. 1908.) with additions and such alterations as seemed necessary to make it conform with the style of the present work. While the nomenclature does not in some cases conform to the present international rules, the writer does not feel justified in diverging from his conchusions.

1. MITRULA Pers. Neues Mag. Bot. 1: 116. 1794.

Heyderia (Fries) Boud. Bull. Soc. Myc. Fr. 1: 110. 1885. Not C. Koch 1873. Microglossum Boud. Bull. Soc. Myc. Fr. 1: 110. 1885. Not Gill. 1879.

Ascophores fleshy, erect, stipitate, clavate, the hymenium covering only the upper portion, or the ascigerous portion ellipsoid to subglobose, usually sharply delimited from the stem and often slightly free from it below, bright-colored (usually yellow or brownish); asci clavate-cylindric, opening by a pore, 8-spored; spores 1-seriate, or 2-seriate in the ascus, ellipsoid to narrowly fusiform, hyaline, continuous, or rarely 1 -septate when mature; paraphyses present or absent.

Type species, Mitrula Heyderi Pers. 
Spores broadly ellipsoid; paraphyses absent.

Ascophores very irregular and contorted; spores 4-5

$\times 6-10 \mu$.

Ascophores regularly clavate; spores $3-4 \times 4-6 \mu$.

1. M. irregularis.

2. M. vitellina.

Spores narrowly ellipsoid, clavate, or fusiform; paraphyses present.

Ascigerous portion vitelline-yellow; stem satiny white.

Ascigerous portion cream-color to brownish; stem darker, at least not white.

Growing on coniferous leaves; ascigerous portion cream-buff when fresh; stem darker.

Growing on living moss.

Hymenium nearly even; when dry ascigerous portion orange-brown; stem paler.

Hymenium more or less convoluted.

3. M. phalloides.

t. M. cucullata.

5. H. gracilis.

6. M. muscicola.

1. Mitrula irregularis (Peck) Durand, Ann. Myc, 6: 398. 1908.

Geoglossum irregulare Peck, Ann. Rep. N. Y. State Mus. 32: 45. 1879.

Mitrula vitellina irregularis Sacc. Syll. Fung. 8: 36. 1889.

Mitrula luteola Ellis, Am. Nat. 17: 192. 1883.

Mitrula crispata Berk. Grevillea 3: 149. 1875.

Spragueola americana Massee, Jour. Bot. 34: 150. 1896.

Ascophores usually cespitose, rarely solitary, clavate, or irregular in form, usually twisted or contorted, compressed, obtuse, sometimes lobed, $1.5 \mathrm{~cm}$. high; ascigerous portion vitelline-yellow, commonly occupying one-half to two-thirds the total length, up to $15 \mathrm{~mm}$. broad; stem tapering downward, satiny white, pruinose, fibrillose or thinly tomentose, up to $1.5 \mathrm{~cm}$. high, 2-5 $\mathrm{mm}$. thick, sometimes absent; substance yellowish white; asci clavate-cylindric, the ascigerous hy phae repeatedly brancher below, the apex rounded, not or slightly blue with iodine, variable in length, reaching a length of $90-150 \mu$ and a diameter of 5-6 $\mu$, 8-spored; spores 1-seriate, hyaline, continuous, smooth, cllipsoid, often slightly reniform, $4-5 \times 6-10 \mu$ (majority $5 \times 8$ ); paraphyses absent.

On bare soil, mossy damp soil or of ten among pine leaves.

Type Locality: Sandlake, New York.

Distribution: Ontario and New Brunswick south to District of Columbia, and west to Colorado.

Illustrations: Bull. N. Y. State Mus. $1^{2}: p l .1, f .5-7$; Ann. Rep. N. Y. State Mus. 48: pl. 5, f. 8-14; Ann. Bot. 11: pl. 12, f. 2.3-24a; Ann. Myc. 6: pl. 5, f. 7-8; Jour. Bot. 34: pl. 357, f. 8, 9.

Exsiccati: Ellis, N. Am. Fungi 978. 
2. Mitrula vitellina (Bres.) Sacc. Syll. Fung. 8: 36. 1889.

Geoglossum vitellinum Bres. Rev. Myc. 4: 212.1882.

Microglossum vitellinum Boud. Bull. Soc. Myc. Fr. 1: 110.1885.

Ascophores clavate, 2-3 cm. high, "when fresh creamyyellow," when dry yellowish cream-colored or brownish in one specimen, the ascigerous portion occupying about one-half the total length, about $3 \mathrm{~mm}$. wide, compressed, obtuse, not sharply differentiated from the stem; stem terete, somewhat flexuous, equal, about $1 \mathrm{~mm}$. in diameter, whitish, fibrillose; asci slender, cylindric, branched below, apex rounded, not blue with iodine, reaching a length of 75-80 $\mu$ and a diameter of 5-6 $\mu, 8$-spored; spores 1 -seriate, hyaline, continuous, smooth, broadly ellipsoid, 3-4 $\times 4-6 \mu$; paraphyses absent.

On rotten wood.

Type Locality : Tyrol.

Distribution: Tennessee; also in Europe.

Illustrations: Bres. Fungi Trid. pl. 45, f. 1; Rab. Krypt.-Fl. $1^{3}: 1143$ f. 1-3; Ann. Bot. 11: pl. 12, f. 3-ta; Ann. Myc. 6: pl. 5, f. 5-6.

3. Mitrula phalloides (Bull.) Chev. Fl. Paris 1: 114. 1826. (Plate 76.)

?Helvella laricina Vill. Hist. Pl. Dauph. 4: 1045. 1789.

Clavaria phalloides Bull. Hist. Champ. Fr. 214. 1791.

Mitrula paludosa Fries, Syst. Myc. 1: 491. 1821.

Leotıa uliginosa Grev. Scot. Crypt. F1. 6: pl. 312. 1828.

Leotia elegans Berk. London Jour. Bot. 5: 6. 1846.

Mitrula elegans Fries, Nov. Symb. Myc. 103. 1851.

Mitrula laricina Massee, Ann. Bot. 11:271. 1897.

Ascophores solitary, or usually more or less densely gregarious, sometimes as many as fifteen to twenty closely aggregated and cohering at their bases, 2-6 cm. or more high, ascigerous portion clear vitelline-yellow, sharply differentiated from the stem, at first solid, becoming vesiculose or inflated and hollow when old, in outline ellipsoid, ellipsoid-obovoid, or pyriform, the apex rounded, obtuse, even or somewhat longitudinally furrowed especially below, often somewhat compressed, rarely more than one-fifth the total height of the plant, .5-2 cm. high, 4-10 $\mathrm{mm}$. wide; stem terete, of ten flexuous, pure satiny white or sometimes with a pinkish tint, 1.5-2 mm. thick, smooth, when moist translucent and viscid; the whole plant soft and subtremellose; asci 


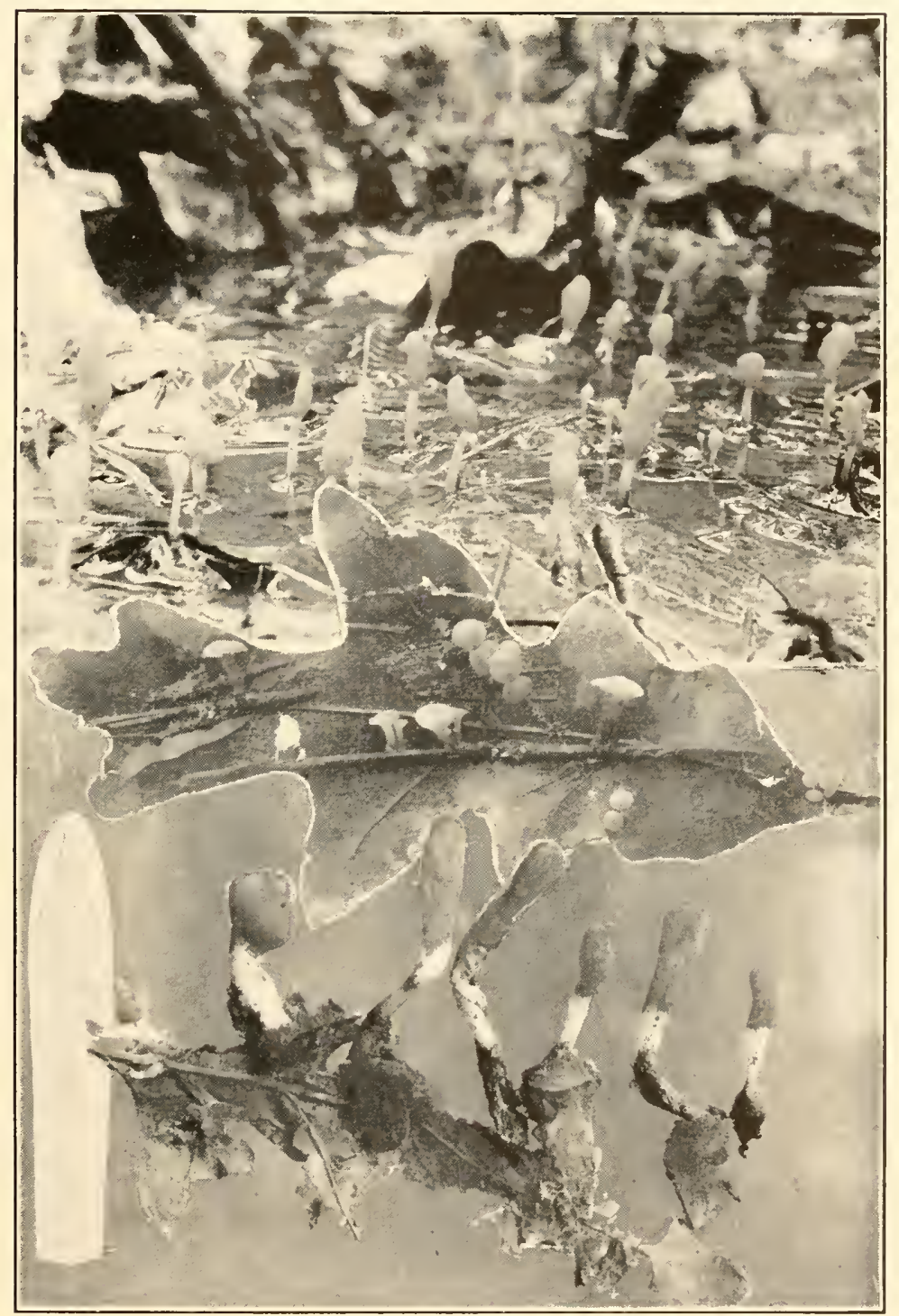

1. MITRULA PHALLOIDES

2. OMBROPHILA CLAVUS 

clavate, apex much narrowed, acute, very slightly blue with iodine, long-stipitate, reaching a length of $60-150 \mu$ and a diameter of 6-8 $\mu, 8$-spored; spores 2-seriate, hyaline, continuous, smooth, contents granular, cylindric to clavate-cylindric, 2.5$3 \times 10-18 \mu$; paraphyses filiform, usually branched, septate, scarcely thickened above.

On decaying vegetation, often on or among Sphagnum, in wet places, pools and ditches.

Type locality: Europe.

Distribution: Ontario to Alabama and west to British Columbia.

Illustrations: Bull. Herb. Fr. pl. 463, f. 3; Grev. Scot. Crypt. Fl. pl. 312; Phill. Brit. Discom. pl. 2, f. 6; Gill. Champ. Fr. Discom. pl. 28, f. 1; Cooke, Mycographia, pl. 45, f. 175; pl. 46, f. 182; Ann. Bot. 11: pl. 13, f. 69; Rab. Krypt.-Fl. 13: 1143. f. 1-4; Ann. Myc. 6: pl. 17, f. 185.

Exsiccatr: Rav. Fungi Car. 5: 36; Ellis, N. Am. Fungi 433; Wilson \& Seaver, Ascom. 38.

4. Mitrula cucullata (Batsch) Fries, Epicr. Myc. 584. 1838.

Elvela cucullata Batsch, Elench. Fung. Cont. 1: 189. 1786.

Mitrula Heyderi Pers. Neues Mag. Bot. 1: 116. 1794.

Leotia Mitrula Pers. Syn. Fung. 611. 1801.

Ascophores small, solitary, or gregarious, very slender, I-2.5 $\mathrm{cm}$. high ; ascigerous portion ellipsoid, ovate, or obovate, rounded above, distinct from the stem below and free from it for a slight distance, scarcely compressed, 1-3 mm. long, .5-2 mm. thick, cream-colored to yellowish-ochraccous; stem terete, equal, or tapering slightly upward, yellowish-brown above, darker below, granular-pruinose, the lower end frequently enveloped in and attached by a yellowish-brown tomentum, .5-.75 mm. thick (all parts become slightly darker in drying); asci clavate, apex narrowed, the pore blue with iodine, reaching a length of 45$70 \mu$ and a diameter of $6 \mu, 8$-spored; spores obliquely 1-seriate, or 2-seriate, hyaline, continuous, smooth, narrowly fusiform, straight, or curved, 2-3 $\times 13-16 \mu$; paraphyses rather stout, gradually thickened upwards, septate, brownish, 3-4 $\mu$ thick.

On fallen leaves of conifers.

Type locality: Europe.

Distribution: Northeastern United States to Idaho; also in Europe. 
Illustrations: Batsch, Elench. Fung. Cont. 1: f. 132; Neues Mag. Bot. 1: pl. 3, f. 12; Cooke, Mycographia pl. 45, f. 176; Gill. Champ. Fr. Discom. pl. 28, f. 2; Sow. Engl. Fungi pl. 84; Ann. Bot. 11: pl. 12, f. 39-41; Ann. Myc. 6: pl. 5, f. 1 .

\section{Mitrula gracilis Karst. Hedwigia 22: 17. 1883.}

Mitrula gracilis var. flavipes Peck, Ann. Rep. N. Y. State Mus. 49: 321896.

Ascophores solitary, slender, $1-1.5 \mathrm{~cm}$. high; ascigerous portion obovate-globose, rounded above, not or very slightly free from the stem below, about $1 \mathrm{~mm}$. diameter, orange-brown, even or nearly so; stem slender, flexuous, .5-.75 mm. thick, smooth, pale brownish-yellow, nearly translucent; asci clavate, apex rounded, pore blue with iodine, reaching a length of 65 $80 \mu$ and a diameter of 6-8 $\mu$; spores 2 -seriate, hyaline, smooth, oblong-fusiform to fusiform, continuous, or possibly becoming 1-septate, 2-3 $\times 10-14 \mu$; paraphyses filiform, 1.5-2 $\mu$ thick.

Attached to and evidently parasitic on Paludella squarrosa in bogs.

Type locality: Europe.

Distribution: Labrador, Newfoundland, and Colorado (about 10,000 feet elevation); also reported from Greenland.

Illustrations: Ann. Myc. 6: pl. 5, f. 3-4.

6. Mitrula muscicola P. Henn. Oefv. Sv. Vet.-Akad. Förh. $42^{5}$ : 71. 1885.

Ascophores cespitose, erect; pileus yellowish to tan-colored, obtuse, slightly Morchella-like, with a tendency to be ribbed or rugose, glabrous, about $4 \mathrm{~mm}$. long; stipe lighter colored to whitish, glabrous, solid, about $10 \mathrm{~mm}$. long; asci clavate, apex narrowed, pore blue with iodine, reaching a length of $65-75 \mu$ and a diameter of 6-8 $\mu, 8$-spored; spores 2-seriate, hyaline, continuous, smooth, narrowly oblong-ellipsoid, $2-3 \times 10-13 \mu$; paraphyses filiform, very slightly thickened upward, hyaline, $2 \mu$ thick.

On moss stems (Webera nutans), in moist spruce and balsam woods at about 7000 feet elevation.

Type locality: Europe.

Distribution: Alberta; also in Europe.

Illustrations: Oefv. Sv. Vet.-Akad. Förh. $42^{5}:$ pl. $8, f .6-8$; Ann. Myc. 6: pl. 5, f. 2. 
Durand (Mycologia 13: 185. 1921.) states that this is "doubtfully distinct" from the preceding 1 . gracilis, which has been found by the writer in quantity in Colorado (see Mycologia 3: 57. 1911.).

\section{Excluded Species}

Mitrula inflata Fries, Elench. Fung. 1: 234. 1828.

This is Physalacria influta (Fries) Peck, a basidionycete. Mitrula roseola Morgan, Jour. Cin. Soc. Nat. Hist. 18: 42. 1895.

"Mr. Morgan later concluded that this was a lichen."

2. MICROGLOSSUM Gill. Champ. Fr. Discom. 25. 1879.

Helote Hazsl. Magyar. Akad. Ertek. Termesz. Kör. 1119: 8. 1881.

Geoglossum subg. Leptoglossum Cooke, Mycographia 250. 1879. (in part.)

Ascophores fleshy, erect, stipitate, clavate, ascigerous only in the upper portion, bright-colored (usually yellow, brown or green); asci clavate-cylindric, 8-spored; spores 2-seriate, hyaline, smooth, ellipsoid, fusiform, or cylindric, becoming 3-manyseptate; paraphyses present.

Type species, Geoglossum viride Pers.

Paraphyses strongly curved or uncinate and slightly thickened at the tips.

Spores of one kind in the ascus.

Ascophores bright-yellow.

Ascophores yellow-clay or tawny.

1. H. rufum.

2. M. fumosum.

Spores of two kinds in the ascus, the larger $60-100 \mu$ long, 14-16-septate; ascophores cinnamonbrown.

3. M. longisporum

Paraphyses straight or flexuous; ascophores usually with a greenish tint.

Stem smooth, fibrous.

Stem squamulose, scarcely fibrous.

4. M. olivaceum.

5. M. viride.

1. Microglossum rufum (Schw.) Underw. Minn. Bot. Studies 1: 496. 1896.

Geoglossum rufum Schw. Trans. Am. Phil. Soc. II. 4: 181.1832.

Clazaria contorta Schw. Trans. Am. Phil. Soc. II. 4: 182.1832.

Geoglossum luteum Peck, Ann. Rep. N. Y. State Mus. 24: 94. 1872.

Mitrula lutescens Berk.; Cooke, Hedwigia 14: 9. 1875.

Geoglossum pistillare Berk. \& Cooke; Cooke, Mycographia 206. 1878.

Mitrula rufa Sacc. Syll. Fung. 8: 38. 1889.

Mitrula pistillaris Sacc. Syll. Fung. 8: 38. 1889.

Leptoglossum luteum Sacc. Syll. Fung. 8: 48.1889.

Xanthoglossum luteum Kuntze, Rev. Gen. 2: 875. 1891.

Leptoglossum lutescens mitruloides Rehm, Ann. Myc. 2: 32. 1904 
Ascophores solitary, gregarious or subcespitose, clavate, 2-5 $\mathrm{cm}$. high, rather slender; ascigerous portion one-third to one-half the total length, ellipsoid-obovate, ellipsoid to subcylindric, obtuse, usually compressed or longitudinally furrowed, .5-2 cm. long, 6-12 $\mathrm{mm}$. wide, sharply differentiated from the stem, usually clear vitelline or orange-yellow, rarely of a duller shade; stem terete, yellow, paler than the ascigerous portion, usually prominently squamulose, $1.5-3 \mathrm{~cm}$. high, 2-3 mm. thick; whole ascophore becoming dingy-yellowish or reddish-brown when dry; asci clavate, apex narrowed, pore blue with iodine, reaching a length of $100-140 \mu$ and a diameter of $10-12 \mu, 8$-spored; spores 2-seriate, hyaline, smooth, cylindric or slightly narrowed toward the obtuse ends, straight or curved, for a long time continuous, then multiguttulate, finally 5-10-septate, 5-6 6 18$38 \mu$ (25-35); paraphyses filiform, 2-3 $\mu$ thick below, the apices slightly thickened and strongly curved or uncinate.

On rotten wood and humus, rarely on mossy banks, frequent.

Type locality: New Jersey.

Distribution: New Hampshire to Minnesota and south to Louisiana.

Illustrations: Peck, Ann. Rep. N. Y. State Mus. 24: pl. 3, f. 20-24; Cooke, Mycographia pl. 3, f. 12; pl. 45, f. 178; pl. 96,f. 346 \& 348; Ann. Bot. 11: pl. 12, f. 28-30.

Exsiccati: Ellis, N. Am. Fungi 58.

2. Microglossum fumosum (Peck) Durand, Ann. Myc. 6: 408. 1908.

Leptoglossum luteum var. fumosum Peck, Ann. Rep. N. S. State Mus, 43: 40. 1889.

Leptoglossum fumosum Peck, Bull. N. Y. State Mus. 116: 25. 1907.

Ascophores solitary, or more of ten densely cespitose, clavate, 2-6 cm. high, robust; ascigerous portion obovate, ellipsoid, or oblong, rounded above, more or less compressed and longitudinally furrowed, about one-third to one-half the total length of the ascophore, but little distinct from the stem, smoky-yellowish, clay-colored, or tawny, .75-3 cm. long, 3-12 mm. thick, rarely twisted or contorted, more or less puckered below where it joins the stem; stem terete, or slightly compressed, 1-3 cm. long, 3-5 mm. thick, clay-colored, slightly squamulose, or sometimes smooth and shining, with several longitudinal cavities, rather fibrous; asci clavate, the apex narrowed, pore blue with iodine, 
reaching a length of $100-150 \mu$ and a diameter of $10-12 \mu, 8$ spored; spores 2-seriate, hyaline, smooth, cylindric, or slightly narrowed toward the obtuse ends, usually slightly curved, $5 \times 20-50 \mu(35-43)$, at first continuous, finally $7-15$-septate; paraphyses filiform, septate, $2 \mu$ thick, slightly thickened and strongly curved above.

On much decayed rotten logs and about the bases of stumps.

Type locality: New York.

Distribution: New York and Massachusetts.

Illustrations: Ann. Mỹc. 6: pl. 5, f. 15, 16; pl. 19, f. 203, $20+, 205$.

3. Microglossum longisporum Durand, Ann. Myc. 6: 409. 1908.

Ascophores solitary, gregarious, clavate, often curved or contorted, rich cinnamon-brown, 3-6 cm. high; ascigerous portion occupying about one-third to one-half the total length, slightly differentiated from the stem, oblong to ellipsoid, obtuse, more or less compressed and longitudinally furrowed, slightly darker than the stem, often with an umber tint, $1-2.5 \mathrm{~cm}$. long, 4-10 $\mathrm{mm}$. wide, flesh yellowish-brown; stem terete, squamulose, sometimes later becoming nearly smooth and hygrophanous, clammy or slightly viscid below, 2-4 cm. long, 2-4 mm. thick, equal; asci cylindric-clavate, apex rounded, only slightly narrowed, the pore blue with iodine, reaching a length of $100-140 \mu$ and a diameter of 12-15 $\mu, 8$-spored; spores of two kinds in the ascus; the first 2 in number (very rarely 3 or 4 ), lying side by side and nearly as long as the ascus, hyaline, smooth, cylindric or a very little broader in the middle, ends rounded, straight or curved, at first continuous and multiguttulate, finally becoming about 14-16septate, $4-5 \times 60-100 \mu$; the second 6 (rarely less) usually placed irregularly near the apex of the ascus, similar to the first kind but smaller, $3 \times 12-18 \mu$, rarely longer, usually continuous; paraphyses filiform, $2 \mu$ thick, hyaline, the apices slightly thickened and strongly curved or uncinate.

On the ground among leaves in the midst of grasses and sedges, in rich woods and ravines.

Type Locality: New York.

Distribution: New York to Michigan and North Carolina.

Illustrations: Ann. Myc. 6: pl. 5, f. 17, 18; pl. 19, f. 206 $206 a$.

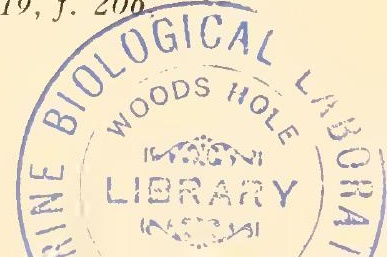


4. Microglossum olivaceum (Pers.) Gill. Champ. Fr. Discom. 25. 1879.

Geoglossum olivaceum Pers. Obs. Myc. 1: 40. 1796.

Geoglossum olizaceum Cooke, Mycographia 250. 1879.

Mitrula olivacea Sacc. Syll Fung 8: 38. 1889.

Microglossum contortum Peck, Bull. Torrey Club 25: 328. 1898.

Microglossum obscurum Peck, Bull. Torrey Club 26: 71. 1899.

Ascophores solitary, or clustered, clavate, either regular, twisted, or contorted, $2-8 \mathrm{~cm}$. high ; ascigerous portion occupying about one-third to one-half the total length, continuous with the stem but sharply delimited by color, greenish-brown, often with a yellow or buff tint, compressed, obtuse, up to $3 \mathrm{~cm}$. long, 10 $\mathrm{mm}$. wide; stem terete, or compressed above, perfectly smooth, shining, hygrophanous, yellowish-buff, tawny-buff, smoky-olivebuff or brownish-cervine, fibrous, solid, 2-8 mm. thick; asci cylindric-clavate, apex rounded, rarely narrowed, pore blue with iodine, reaching a length of $75-100 \mu$ and a diameter of 9-10 $\mu$, 8 -spored; spores 2-seriate above, 1-seriate below, hyaline, smooth, oblong-fusiform to fusiform, straight, curved, or sigmoid, for a long time simple, finally becoming 3 -septate, $4-6 \times 12-18 \mu$; paraphyses filiform, often branched, septate, straight or slightly curved, or flexuous, not thickened above, hyaline.

On the ground among leaves or in grassy places in rich woods.

Type Locality : Europe

Distribution: Northeastern United States and Ontario; also in Europe.

Illustrations: Pers. Obs. Myc. 1: pl. 5, f. 7 ; Cooke, Mycographia pl. t, f. 13; Pat. Tab. Fung. f. 65; Berk. Outl. Brit. Fung. pl. 22,f. 3; Ann. Myc. 6: pl. 5, f. 19, 20; pl. 20, f. 209.

Exsiccati: Ellis \& Ev. Fungi Columb. $17+5$.

5. Microglossum viride (Pers.) Gill. Champ. Fr. Discom. 25. 1879.

?Clavaria mitrata viridis Holmsk. Coryph. 24. fig. 1790.

?Clavaria viridis Schrad. Gmel. Linn. Syst. Nat. 2: 1443. 1791.

Geoglossum viride Pers. Neues Mag. Bot. 1: 117. 1794.

Mitrula viridis Karst. Myc. Fenn. 1: 29. 1871.

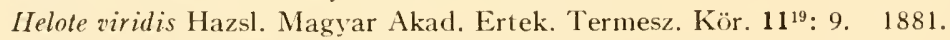

Leptoglossum alabamense Underw. Bull. Torrey Club 24: 82. 1897.

Ascophores solitary, or more often gregarious, or cespitose, clavate, up to $5 \mathrm{~cm}$. high; ascigerous portion about one-half the 
total length, sharply delinited from the stem, lanceolate to ellipsoid, obtuse, strongly compressed and deeply longitudinally furrowed in older specimens 3-10 mm. wide, olive-buff, or oliveochraceous; stem terete, or slightly compressed, 2-5 mm. thick, conspicuously squamulose, pale pea-green; dried plants are darker, sometimes almost black; crushed flesh pea-green to olive, usually pale; asci clavate-cylindric, apex rounded or slightly narrowed, pore blue with iodine, slender below, reaching a length of 110-150 $\mu$ and a diameter of 8-10 $\mu$, 8-spored; spores 2 -seriate above, 1-seriate below, hyaline, smooth, cylindricoblong, ellipsoid-oblong, or oblong-clavate, ends obtuse, straight, curved, or sigmoid, for a long time continuous, finally becoming clearly 3-4-septate, 5-6 × 14-22 $\mu$; paraphyses filiform, branched hyaline, the apices often slightly pyriform-thickened and tinged green, forming a green epithecium.

On the ground, in moist woods, often along the borders of old wood roads.

Type locality : Europe.

Distribution: Eastern L'nited States; also in Europe.

Illustrations: Cooke, Mycographia pl. f,f. 14; Gill. Champ. Fr. Discom. pl. 26, f. 2; Ann. Bot. 11: pl. 13, f. 68; Rab. Krypt.F1. $1^{3}$ : 1144, f. 1-4: Phill. Brit. Discom. pl. 2, f. 8; Ann. Myc. pl. 5,f. 23-24; pl. 20,f. 208 .

Exsiccatr: Ellis \& Ev. N. Am. Fungi 203(); Fungi Columb. $17+6$.

3. CORYNETES Hazsl. Magyar. Akad. Ertek. Termesz. Kör. 1119: 7. 1881.

Geoglossum subg. Leptoglossum Cooke, Mycographia 250. 1879, (in part). Microglossum Sacc. Bot. Cent. 18: 214. 1884. (Not Gill. 1879.)

Leptoglossum Sacc. Bot. Cent. 18: 214. 1884. (Not Karsten, 1879.)

Thuemenidium Kuntze, Rev. Gen. 2: 873. 1891.

Nanthoglossum Kuntze, Rev. Gen. 2: 875. 1891.

Ascophores fleshy, erect, stipitate, clavate, the hymenium covering only the upper portion, black, brownish-black or purplish-black; asci clavate-cylindric, opening by a pore, 8spored; spores usually 2-seriate, hyaline, smooth, cylindric, ends rounded, becoming 3-many-septate; paraphyses present.

Type species, Geoglossum microsporum Cooke \& Peck. 
Paraphyses hyaline, or only slightly purplish tinted at the tips.

Asci and paraphyses agglutinated at the tips into a conspicuous, vinous-brown epithecium.

Paraphyses clavate to pyriform, thickened at the tips.

Paraphyses not or only very slightly thickened at the tips.

Epithecium lacking or inconspicuous; ascophores robust; paraphyses slightly clavate-thickened and more or less curved at the tips.

1. C. purpurascens.

2. C. atropurpureus.

3. C. robustus.

4. C. arenarius.

Paraphyses conspicuously brown.

1. Corynetes purpurascens (Pers.) Durand, Ann. Myc. 6: 413. 1908.

?Clararia mitrata Holmsk. Coryph. 21. 1790.

Geoglossum purpurascens Pers. in Holmsk. Coryph. 171. 1797.

Leotia atropurpurea Corda, Ic. Fung. 5: 79.1842.

Geoglossum atropurpureum Cooke, Mycographia 10. 1875. (Not Pers.)

Microglossum atropurpureum Sacc. Syll. Fung. 8: 40. 1889.

Thuemenidium atropurpureum Kuntze, Rev. Gen. Pl. 2: 873. 1891.

Mitrula purpurascens Massee, Ann. Bot. 11: 266. 1897.

Ascophores solitary, or cespitose, 3-6 cm. high, every part with a distinct purplish-brown tint when fresh, blackish when dry, the crushed flesh vinous-brown; ascigerous portion irregular, clavate, sometimes lobed or forked at the apex, more or less compressed, 1-2 cm. long, up to $1 \mathrm{~cm}$, broad, occupying about one-third to one-half the total length; stem cylindric, minutely squamulose; asci clavate, apex narrowed but rounded, pore blue with iodine, reaching a length of $105-120 \mu$ and a diameter of 10-12 $\mu$, 8-spored; spores 2-seriate, hyaline, smooth, cylindric, slightly narrowed from the middle to the rounded ends, straight, or curved, at first simple, then multiguttulate, finally 6-septate, 5-6 $\times 20-37 \mu(20-30)$; paraphyses filiform, hyaline, $3 \mu$ thick, the apices straight and abruptly obovate-pyriform thickened, 8-10 $\mu$ thick, agglutinated with amorphous matter to form a vinous-brown epithecium.

On the ground or humus.

Type locality: Europe.

Distribution: Maine and New York; also in Europe.

Illustrations: Corda, Ic. Fung. 5: pl. 9, f. 71; Cooke, Mycographia pl. 4, f. 16; Ann. Bot. 11: pl. 12, f. 27; Ann. Myc. 6: pl. $6, f .36-39$. 
2. Corynetes atropurpureus (Pers.) Durand, Ann, Myc. 6: 414. 1908.

Geoglossum atropurpureum Pers. Obs. Myc. 2: 62. 1799.

Mitrula glabra Karst. Myc. Fenn. 1: 30. 1871.

Geoglossum microsporum Cooke \& Peck; I'eck, Ann. Rep. N. Y. State Mus.

25: 97.1873.

Geoglossum tremellosum Cooke, Mycographia 206. 1878.

Geoglossum microsporum var. tremellosum Cooke, Grevillea 4: 109. 1876.

Leptoglossum microsporum Sacc. Bot. Cent. 18: 214.1884.

Microglossum atropurpureum Karst. Acta Soc. Fauna F1. Fenn. 26: 110.1885.

Xanthoglossum microsporum Kuntze, Rev. Gen. Pl. 2: 875. 1891.

Mitrula microspora Massee, Brit. Fungus-Fl. 4: 483. 1895.

Ascophores solitary, or cespitose, entirely black, at least when dry, rather slender, $2-3 \mathrm{~cm}$. high; ascigerous portion about onehalf the total length, narrowly clavate-oblong, obtuse; stem slender, minutely squamulose; asci clavate, apex narrowed but rounded, reaching a length of 100-127 $\mu$ and a diameter of $10 \mu$, 8 -spored; spores 2 -seriate, hyaline, smooth, cylindric but tapering slightly toward the obtuse ends, at first simple, finally becoming up to 10-septate, 3-4 $\times 25-35 \mu$; paraphyses filiform, hyaline. branched, straight, the apices scarcely thickened and rarely only slightly bent, the tips of the asci and paraphyses being united by a vinous-brown amorphous layer forming an epithecium.

On the ground in woods.

Type locality: Europe.

Distribution: New Hampshire and New York; also in Europe.

Illustrations: Pers. Obs. Myc. 2: pl. 3,f. 5; Cooke, Mycographia pl. 3, f. 11; pl. 96,f. 347; Ann. Bot. 11: pl. 13,f. 55-57; Ann. Myc. 6: pl. 6, f. 27-35.

3. Corynetes robustus Durand, Ann. Myc. 6: 416. 1908.

Ascophores solitary, or gregarious, of ten cespitose, black or brownish-black, 2.5-8 cm. high, stout; ascigerous portion occupying about one-fourth to one-half the total length, not sharply differentiated from the stem, black with an olive-brown tint, pyriform-ellipsoid, obtuse, 1-3 cm. long, 6-15 mm. broad, more or less compressed, or longitudinally furrowed, sometimes twisted, hollow, flesh dark-brown; stem terete or compressed, paler, shining brownish-black, hygrophanous, lightly squamulose above, 1-4 cm. high, 3-8 mm. thick; asci clavate, stout, sessile, or short-stipitate, apex narrowed, pore blue with iodine, 
reaching a length of $100-150 \mu$ and a diameter of $10-15 \mu$, 8spored; spores 2-seriate above, 1-seriate below, hyaline, smooth, cylindric, slightly narrowed toward each end, at first simple, multiguttulate, finally 7-11-septate, straight or curved, 4-6 $\times$ $25-50 \mu(30-40)$; paraphyses hyaline, filiform, branched, $2-3 \mu$ thick, the apex slightly irregularly thickened, usually curved or uncinate at the tips which are not, or only slightly, agglutinated into an epithecium.

On rich sandy humus among leaves in damp woods.

Type locality: North Carolina.

Distribution: Maine to Michigan and Mississippi.

Illustrations: Ann. Myc. 6: pl. 6,f. 40-4; pl. 19,f. 199-202.

4. Corynetes arenarius (Rostrup) Durand, Ann. Myc. 6: 417. 1908.

Microglossum arenarium Rostr. Med. Grønl. 3: 606. 1891.

Leptoglossum latum Peck, Bull. Torrey Club 22: 210. 1895. Mitrula arenaria Massee, Ann. Bot. 11: 283. 1897.

Ascophores single, or cespitose, broadly clavate, black, 1-4 $\mathrm{cm}$. high; ascigerous portion about one-half the total length, .5-2 cm. broad, irregularly bent, or contorted, compressed, furrowed, black; stem brownish-black or olive-black, pruinose, or squamulose; asci stout, clavate-cylindric, apex narrowed, pore blue with iodine, reaching a length of 100-125 $\mu$ and a diameter of $12-15 \mu, 8$-spored, spores 2 -seriate above, 1-seriate below, hyaline, smooth, cylindric or cylindric-oblong, ends rounded, straight or curved, $6 \times 25-35 \mu$, for a long time simple, finally becoming at least 4 -septate, (probably 10 or more); paraphyses brown, cylindric, septate, longer than the asci, $3 \mu$ thick below the apices, usually somewhat clavate-thickened and more or less curved.

In sand.

Type Locality: Greenland.

Distribution: Greenland, Newfoundland, and Labrador.

Illustrations: Ann. Myc. 6: pl. 6, f. 45-49; pl. 18, f. 194-197.

4. GLOEOGLOSSUM Durand, Ann. Myc. 6: 418. 1908. Geoglossum of authors in part.

Ascophores viscid-gelatinous, erect, stipitate, clavate, usually ascigerous only in the upper portion, black or brownish-black; 
asci clavate-cylindric, pore blue with iodine, 8-spored; spores fascicled, or multiseriate in the ascus, cylindric or clavatecylindric, 3-15-septate (rarely simple in one species), brown or fuliginous; paraphyses numerous, septate, thickened, or coiled and brown above, not confined to the hymenium but continued down the stem to its base.

Type species, Geoglossum difforme Fries.

Spores $0-7$-septate when mature.

Spores 0-7-septate, clavate-cylindric, 55-102 $\mu$ long.

1. G. glutinosum.

Spores 7 -septate, clavate, $43-65 \mu$ long.

Spores 15 -septate when mature.

2. G. affine.

3. G. difforme.

1. Gloeoglossum glutinosum (Pers.) Durand, Ann. Myc. 6: 419. 1908.

Geoglossum glutinosum Pers. Obs. Myc. 1: 11. 1796.

?Geoglossum viscosum Pers. in Holmsk. Coryph. 39. 1797.

Geoglossum glutinosum lubricum Pers. Myc. Eur. 1: 197. 1822.

Ascophores solitary or clustered, 5-8 cm. high, viscidgelatinous; ascigerous portion clavate, or narrowly elliptic, more or less compressed, apex obtuse, $1.5-2.5 \mathrm{~cm}$. long, 5-10 mm. thick, black, not sharply differentiated from the stem; stem 4-6 cm. long, 3-4 mm. thick, terete or slightly compressed, brown or brownish-black, very smooth and viscid, covered to the base by the paraphyses; flesh brown, composed of parallel septate hyphae, rather looser in the center; asci narrowly clavate, narrowed from the middle toward the apex, the pore blue with iodine, reaching a le1,gth of $250 \mu$ and a diameter of 12-15 $\mu, 8$ spored; spores multiseriate in the ascus, cylindric, or slightly narrowed toward the rounded ends, fuliginous, at first simple, then 3-septate, finally in most cases 7-septate, 5-6 X 55-102 $\mu$ (75-85); paraphyses cylindric, septate, $3 \mu$ thick, longer than the asci, the apices pale-brown and abruptly pyriform to globose thickened, 8-10 $\mu$ thick.

On the ground and on rotten wood, in rich woods.

Type locality: Europe.

Distribution: Ontario to North Carolina; also in Europe.

Illustrations: Cooke, Mycographia pl. 2, f. 6; pl. 3, f. 10; Gill. Champ. Fr. Discom. pl. 25, f. 2; pl. 26, f. 1; Grev. Scot. Crypt. F1. pl. 55; Massee, Ann. Bot. 11: pl. 13, f. 66, 67; Ann. Myc. 6: pl. 8, f. 70-72; pl. 14, f. 149-155. 
2. Gloeoglossum affine Durand, Ann. Myc. 6: 420. 1908.

Ascophores solitary, or gregarious, black, viscid-gelatinous when fresh, clavate, $1.5-2.5 \mathrm{~cm}$. high; ascigerous portion narrowly clavate-oblong, obtuse, compressed, occupying about onehalf the total length up to $3 \mathrm{~mm}$. thick, not sharply differentiated from the stem; stem slender, smooth; asci clavate, the apex rounded, reaching a length of $130-160 \mu$ and a diameter of $15 \mu$, 8-spored; spores fasciculate, smoky-brown, clavate, 7-septate, 5-6 $\times 43-65 \mu$; paraphyses slenderly cylindric below, $2.5 \mu$ thick, slightly and gradually thickened above, the terminal portion septate, brownish, the terminal cell abruptly ellipsoid to globose thickened, $7-8 \mu$ in diameter, the lower ones either cylindric, or nodulose, or abruptly and conspicuously thickened below the septa, in extreme cases almost globose, either straight or more less curved, or coiled above, and continuing down the stem to its base.

On soil or humus in swamps.

Type Locality: New York.

Distribution: New York.

Illustrations: Ann. Myc. 6: pl. \&, f. 73-74; pl. 16,f. 165-167.

3. Gloeoglossum difforme (Fries) Durand, An11. Myc. 6: 421. 1908.

Geoglossum difforme Fries, Obs. Myc. 1: 159. 1815. (Not of authors.) Geoglossum Peckianum Cooke, Hedwigia 14: 10. 1875.

Ascophores solitary, or gregarious, sometimes two or three together, black, smooth, viscid, especially below, evenly clavate, with no line of demarcation between ascigerous portion and stem, strongly compressed, apex obtuse, $36 \mathrm{~cm}$. high, 8-14 $\mathrm{mm}$. wide; flesh brown, composed of parallel, cylindric, septate hyphae, rather looser in the center but not hollow; asci clavate, gradually narrowed from the middle toward the apex, the latter rounded, the apical plug blue with iodine, reaching a length of $240-275 \mu$ and a diameter of 18-25 $\mu, 8$-spored; spores in a parallel fascicle in the ascus, brownish-fuliginous, clavate-cylindric, slightly narrowed from the middle each way, ends rounded, straight, or slightly curved, smooth, 15-septate at maturity, the cells about as long as wide, $6-7 \times 95-125 \mu$; paraphyses longer than the asci, slender, septate, tips slightly thickened, brownish, much coiled and twisted, continued down the stem to the base. 
On soil, humus, decayed wood, or among pine needles in rich woods.

Type locality : Europe.

Distribution: Maine to Ontario, Florida and Michigan; also in Europe.

Illustrations: Cooke, Mycographia pl. 2, f. 5; Massee, Ann. Bot. 11: pl. 12,f. 42-43; Ann. Myc. 6: pl. 8,f. 75-77; pl. 15, f. $156-160$.

Exsiccati: Ellis \& Ev. Fungi Columb. 1731.

5. GEOGLOSSUM Pers. Neues Mag. Bot. 1: 116. 1794.

Ascophores fleshy, erect, stipitate, clavate, hymenium covering only the upper portion, black, or brownish-black; asci clavate-cylindric, 8-spored; spores fascicled, or multiseriate in the ascus, cylindric or clavate-cylindric, 3-15-septate, fuliginous; paraphyses numerous, septate, usually brownish above, confined to the ascigerous portion.

Type species, Geoglossum glabrum Pers.

Paraphyses and asci free above, the apices not agglutinated to form a brown epithecium; spores early becoming brown.

Spores 7- or 7-12-septate at maturity.

Mature spores uniformly 7-septate; ascophore black or brownish-black; paraphyses brown above.

Paraphyses normally clavate in the distal third, closely septate, usually constricted or moniliform.

1. G. glabrum.

Paraphyses remotely septate, scarcely moniliform, the thickening confined to the terminal cell.

Mature spores 7-12-septate; ascophore tawnybrown; paraphyses nearly hyaline.

Mature spores 15 -septate.

Paraphyses and asci agglutinated above forming a conspicuous brown epithecium; spores usually remaining for a long time hyaline.

Spores 0-7-septate; paraphyses brown, the tips pyriform.

5. G. cohaerens.

Spores 7-12-septate; paraphyses nearly hyaline.

6. G. intermedium.

Spores 15-septate, clavate-cylindric.

Ascophores large, up to $5 \mathrm{~cm}$. high.

7. G. alveolatum.

Ascophores small, usually $1 \mathrm{~cm}$. high or less.

8. G. pumilum. 
1. Geoglossum glabrum Pers. Neues Mag. Bot. 1: 116.1794.

?Clazaria ophioglossoides L. Sp. Pl. 2: 1182. 1753.

Geoglossum sphagnophilum Ehrb. Sylv. Myc. Ber. 30. 1818.

Geoglossum difforme sensu Cooke, Mycographia 6, pl. 2, f. 7. 1875.

Geoglossum simile Peck, Bull. Buff. Soc. Nat. Sci. 1: 70. 1873.

Ascophores solitary, or rarely clustered, gregarious, 3-7 cm. high; ascigerous portion black, about one-third the total length of the ascophore, lanceolate, compressed, 1-3 cm. long, 3-8 mm. thick, obtuse or acute, not sharply delimited from the stem; stem terete or slightly compressed, brownish-black, rather slender, densely squamulose, $2-5 \mathrm{~cm}$. high, $1.5-5 \mathrm{~mm}$. thick, but commonly about $2 \mathrm{~mm}$., the tissue composed of a fascicle of parallel, septate, brown hyphae 10-12 $\mu$ in diameter, those in the center of the ascigerous part loose, those on the surface of the stem projecting to form flexuous, septate hairs up to $100 \mu$ long, single or agglutinated into groups; asci rather stout, clavatelanceolate, apex narrowed but rounded, pore blue with iodine, short-stipitate, reaching a length of $170-200 \mu$ and a diameter of 20-22 $\mu, 8$-spored; spores in parallel fascicle in the ascus, clavate, dark-fuliginous, 7-septate, usually slightly curved, 7-9 $\times 60-105 \mu$ (the majority 75-95); paraphyses slightly longer than the asci, typically clavate in the distal third, closely septated into cells rarely more than twice as long as broad, usually constricted at the septa and the cells often swollen so as to give a moniliform appearance, brown above, straight, or curved, about $3 \mu$ thick below, 5-9 $\mu$ thick above.

On very rotten wood, logs, stumps, or rich humus, rarely on soil.

Type locality: Europe.

Distribution: Newfoundland to Florida and California; also in Europe.

Illustrations: Cooke, Mycographia pl. 2, f. 7; Gill. Champ. Fr. Discom. pl. 24, f. 3; Rab. Krypt.Fl. 132: 1145, f. 1-4; Ann. Bot. 11: pl. 12, f. 44-46; Boud. Ic. Myc. pl. 423; Ann. Myc. 6: pl. 7, f. 50-56; pl. 12, f. 121-129.

2. Geoglossum nigritum (Pers.) Cooke, Mycographia 205. 1878. Clavaria nigrita Pers. Syn. Fung. 604. 1801.

Ascophores usually solitary, clavate, black, or brownishblack, up to $8 \mathrm{~cm}$. high ; ascigerous portion lanceolate, compressed, 
rather acute, one-half the total length of the ascophore or less, 2-5 mm. thick; stem terete, slender, 1-2 mm. thick, furfuraceous, minutely squamulose, or almost smooth; asci clavate or clavatelanceolate, apex narrowed but rounded, reaching a length of $150-175 \mu$ and a diameter of $18 \mu, 8$-spored; spores in a parallel fascicle in the ascus, clavate, fuliginous, 7 -septate, $6 \times 54-85 \mu$; paraphyses rather longer than the asci, cylindric, septate, the cells 2-10 times as long as wide, not constricted, rarely slightly swollen below the septa, pale-brown above, either only slightly thickened, or the apex of the terminal cell pyriform, usually more or less curved.

On wet ground, banks, or among leaves on rich humus, rarely on rotten ground.

Type locality: Europe.

Distribution: Maine to North Carolina and California and Bermuda; also in Europe.

Illustrations: Cooke, Mycographia pl. 96, f. 345; Peck, Ann. Rep. N. Y. State Mus. 29: pl. 1, f. 20-22; Ann. Myc. 6: pl. 7,f. 57-59; pl. 12, f. 130-132.

This species has been found to be very common in Bermuda, having been collected there by the writer in 1912, 1926, 1938, and 1940 .

3. Geoglossum fallax Durand, Ann. Myc. 6: 428. 1908.

?Geoglossum glabrum paludosum Pers. Myc. Eur. 1: 194.1822.

Ascophores solitary, clavate, $2-8.5 \mathrm{~cm}$. high, entirely tawnybrown to umber-brown; ascigerous portion one-fifth to one-half the total length of the ascophore, lanceolate, obtuse, slightly compressed, about 8-15 mm. long, 3-5 $\mathrm{mm}$. thick; stem short, or elongated and slender, squamulose especially above, slightly thickened upward, 1-2 $\mathrm{mm}$. thick below, $2 \mathrm{~mm}$. thick above, terete; asci clavate-cylindric, the apex narrowed, pore blue with iodine, reaching a length of 150-175 $\mu$ and a diameter of 18-20 $\mu$, 8-spored; spores 2 -seriate to multiseriate in the ascus, clavatecylindric, straight, or curved, at first continuous and multiguttulate, then 3 - finally $7-12$-septate, $5-7 \times 65-105 \mu(80-100)$, for a long time hyaline, finally becoming fuliginous; paraplyses entirely hyaline, cylindric, not closely septate, 5-6 $\mu$ thick, usually strongly curved, or circinate above, the apex abruptly. ellipsoid to globose thickened. 
On clay or loamy soil in woods or on slopes of ravines.

Type Locality: I thaca, New York.

Distribution: New York to Michigan.

Illustrations: Ann. Myc. $7:$ pl. 7,f. 61-64; pl. 13,f. 133-137.

4. Geoglossum pygmaeum Gerard; Durand, Ann. Myc. 6: 429. 1908.

Ascophores very small, .5-2 cm. high, brownish-black when dry; ascigerous portion occupying about one-half the total length of the ascophore, narrow, compressed; stem terete, very slencler, minutely hairy; asci clavate, apex narrowed, reaching a length of 175-200 $\mu$ and a diameter of $17-18 \mu, 8$-spored; spores in a parallel fascicle in the ascus, brown or fuliginous, cylindric-clavate, tapering slightly each way from above the middle, 15-septate, 6-7 $\times 122-140 \mu$; paraphyses straight, about as long as the asci, cylindric, $3 \mu$ thick, pale, and sparingly septate below, the apex brown, septated into cells about 12-14 $\mu$ long, slightly constricted at the septa, the terminal two or three cells clavatethickened, the apical one usually more swollen and pyriform to ellipsoid in outline, $7-8 \times 10^{-14} \mu$.

On ligneous earth.

Type locality: Poughkeepsie, New York.

Distribution: Known only from the type locality.

Illustrations: Ann. Myc. $6: p l .7, f .60 ; p l .13, f .140-141$.

5. Geoglossum cohaerens Durand, Ann. Myc. 6: 430. 1908.

Ascophores clavate, 2.5-3.5 cm. high, black; ascigerous portion about one-half the total length, terete or compressed, obtuse; stem squamulose; asci clavate, reaching a length of $150 \mu$ and a diameter of 12-15 $\mu, 8$-spored; spores multiseriate in the ascus, cylindric-clavate, straight, or curved, for a long time hyaline, later becoming pale-brown, from simple to 7 -septate, $5 \times 40-$ $55 \mu$; paraphyses very numerous, rather longer than the asci, cylindric, sparingly but irregularly septate, the tip rather abruptly clavate to pyriform thickened, conspicuously brown above, the apices cohering with amorphous matter to form a brown epitheceium above the asci.

On sandy soil in a dooryard.

Type locality: Newfield, New Jersey.

Distribution: Known only from the type locality.

lllustrations: Ann. Myc. 6: pl. $8, f .65 ;$ pl. 13,f. 138-139. 
6. Geoglossum intermedium Durand, Ann. Myc. 6: 431. 1908.

Ascophores solitary, black, 3-4.5 cm. high; ascigerous portion one-fourth to one-third the total length, oblong to ovatelanceolate, compressed, obtuse or rounded above, usually abruptly narrowed to the stem below, . $75-1.5 \mathrm{~cm}$. long, 2-6 mm. broad, the hymenium prettily alveolate when dry, the meshes less than $.5 \mathrm{~mm}$. across; stem slender, terete, usually more or less flexuous, brownish-black, .75-1 mm. thick, nearly smooth below, provided toward the top with slender, flexuous, sparingly septate, obtuse, brown hairs, up to $100 \mu$ long; asci clavate-cylindric, very short-pediceled, apex narrowed but rounded, reaching a length of $150-200 \mu$ and a diameter of $20 \mu$, pore deep-blue and entire ascus slightly blue with iodine, 8-spored; spores multiseriate, stout, clavate, but not much narrowed toward the lower end, ends rounded, somewhat curved, at first hyaline, becoming 1-3septate, finally rather pale-brown, 7-11-septate, $6 \times 55-75 \mu$; paraphyses cylindric, nearly or quite hyaline, straight or only slightly curved above, sparingly septate, very gradually and slightly thickened upward, the apex tending to become pyriform to globose thickened, the apical portion of the asci and paraphyses agglutinated by an amorphous brown mass.

In swamp and on rotten wood.

Type Locality: Knoxboro, New York.

Distribution: New York and Ontario.

Illustrations: Ann. Myc. 6: pl. $8, f .66-67 ; p l .13, f .1+2-1+\mathrm{H}$.

7. Geoglossum alveolatum Durand, Ann. Myc. 6: 432. 1908.

Ascophores solitary, or gregarious, with the aspect of $G$. glabrum, slenderly clavate, $1.5-5 \mathrm{~cm}$. high; ascigerous portion about one-third the total length, lanceolate, obtuse, compressed, black, 4-12 $\mathrm{mm}$. long, 3-4 mm. thick, when moist with an even surface, which on drying often becomes pitted or distinctly ridged in an alveolate manner; stem slender, terete, 1-2 $\mathrm{mm}$. thick, slightly thickened upwards, distinctly squamulose or hairy; flesh black, composed of a fascicle of parallel, septate hyphae $8-10 \mu$ in diameter, the ectal ones of the stem being produced to form slender, brown, flexuous, obtuse, septate hairs up to $125 \mu$ long; asci clavate-cylindric, apex slightly narrowed but rounded, pore blue with iodine, reaching a length of $150-$ $170 \mu$ and a diameter of $15 \mu, 8$-spored; spores fascicled, or multi- 
seriate in the ascus, narrowly cylindric, straight, or curved, ends obtuse, one end sometimes narrower than the other, contents granular, at first continuous, then 7-finally 15 -septate, $4-5 \times$ 60-95 $\mu$, for a long time hyaline but ultimately becoming palebrown or fuliginous; paraphyses conspicuously brown above, cylindric, septate, $3 \mu$ thick, the tips abruptly ellipsoid to globose thickened, 6-8 $\mu$ thick and agglutinated together into a brown epithecium.

On very rotten wood and logs, in ravines and moist woods.

Type locAlity: Canandaigua, New York.

Distribution: New York and Idaho?

Illustrations: Ann. Myc. 6: pl. 8,f. 68-69; pl. 14,f. 145-1+8.

8. Geoglossum pumilum Winter, Grevillea 15: 91.1886.

Ascophores very small, .5-2 cm. high, usually not exceeding $1 \mathrm{~cm}$., slender, black; ascigerous portion distinct from the stem, clavate-ellipsoid to oblong spherical, 1.5-3 $\mathrm{mm}$. long, 1-2 $\mathrm{mm}$. thick when dry, rounded above; stem very slender, brownishblack, squamulose, especially above, $.5 \mathrm{~mm}$. thick when dry; asci clavate, stout, reaching a length of 185-200 $\mu$ and a diameter of 20 to $27 \mu$, 8-spored; spores fasciculate in the ascus, clavate-cylindric, tapering each way from above the middle, 15 septate, $6 \times 104-125 \mu$ (majority 110-115 $\mu$ long), deeply colored; paraphyses longer than the asci, pale-brown above, nearly hyaline below, the distal end stout, clavate, rather remotely septate, usually nearly straight but sometimes strongly curved, inclined to be constricted at the septa, $8-12 \mu$ thick.

On soil.

TyPe LoCAlity: Brazil.

Distribution: Virginia, Bermuda and Porto Rico.

Two minute fruiting bodies of this species were collected by the writer in Bermuda (Britton, Brown \& Seaver 1364) and two in Porto Rico (Sci. Survey Porto Rico and the Virgin Islands 8: 74. 1926.). It will be noted that only two fruiting bodies of this species were found at one time in Bermuda and in Porto Rico.

\section{Doubtful and Excluded Species}

Geoglossum album A. E. Johnson, Bull. Minn. Acad. Nat. Sci. 1: 341. 1878; Mitrula Johnsonii Sacc. Syll. Fung. 8: 36. 1889; Microglossum album Underw. Minn. Bot. Stud. Bul. 9: 495. 1896; Mitrula alba Massee, Ann. Bot. 11: 284. 1897. This species was recorded from Minnesota but is exceedingly doubtful. The name was changed by Saccardo to avoid making a homonym. 


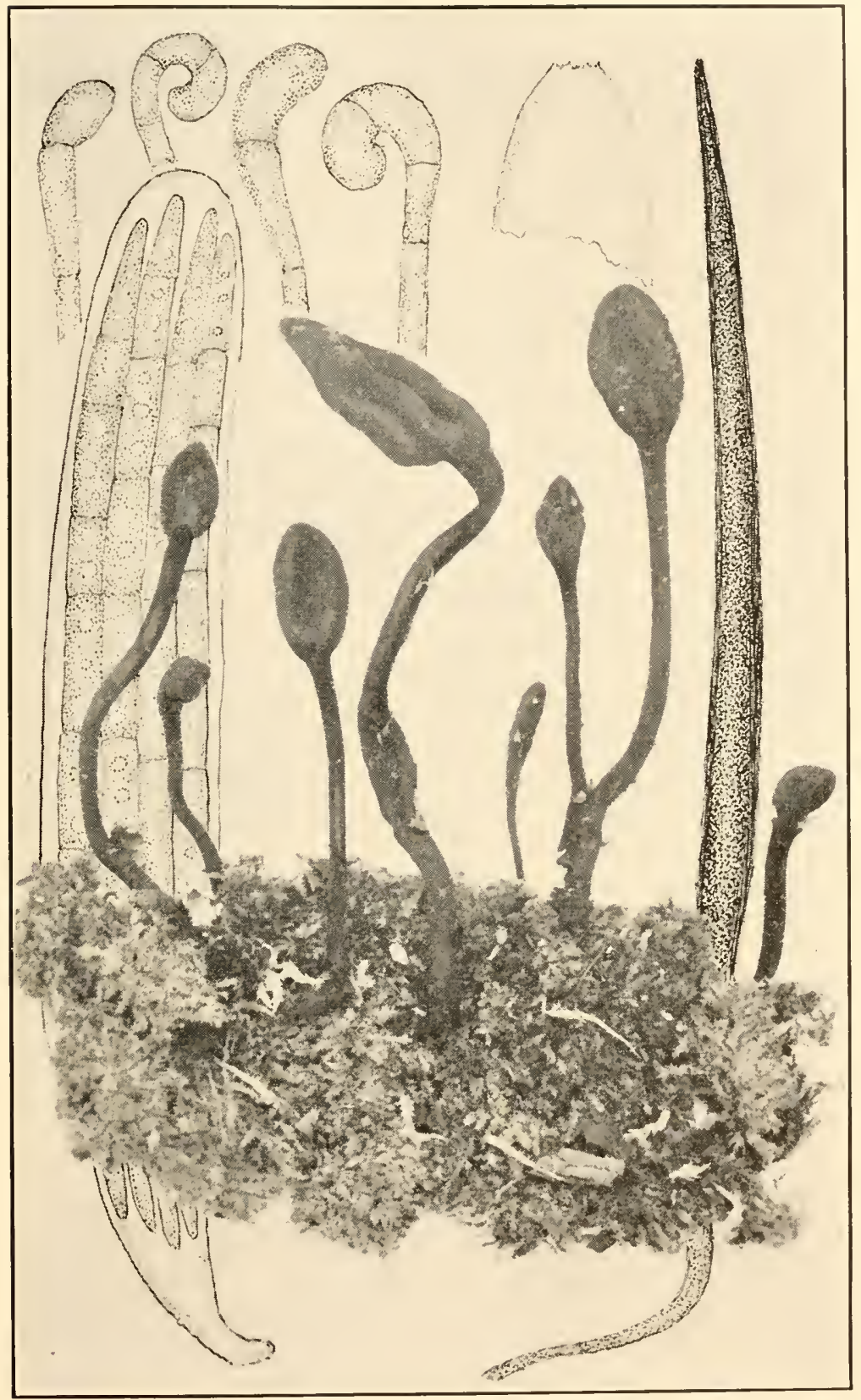

TRICHOGLOSSUM VELUTIPES 

Geoglossum farinaceum Schw. Schr. Nat. Ges. Leipzig 1: 113. 1822. The type is missing from Schweinitz's herbarium and no specimens are known to exist elsewhere. It is probably not a discomycete.

6. TRICHOGLOSSUM Boud. Bull. Soc. Mỹc. Fr. 1: 110. 1885. Geoglossum Pers. in part.

Ascophores fleshy, erect, stipitate, clavate, hymenium covering only the upper portion, black; asci clavate or ligulate, 4-8spored; spores fasciculate, or multiseriate in the ascus, clavatecylindric, up to 15-septate, fuliginous, or brown; paraphyses numerous, septate, brown above, confined to the ascigerous portion, both the stem and hymenium beset with black, thickwalled, acicular spines or cystidia which are usually longer than the asci; paraphyses usually stout, straight or strongly curved.

Type species, Geoglossum hirsutum Pers.

Spores normally $100-170 \mu$ long, narrowed each way

from above the middle.

Spores 4 in each ascus.

Spores 8-11-septate.

1. T. velutipes.

Spores 15 -septate.

2. T. tetrasporum.

Spores 8 in each ascus.

Spores 15 -septate.

3. T. hirsutum.

Spores 8-9-septate.

4. T. Irrightii.

Spores 7-septate.

5. T. octopartitum.

Spores normally 45-100 $\mu$ long.

Spores 0-5-septate, clavate-cylindric.

6. T. Farlowi.

Spores 7-septate.

Spores 55-73 $\mu$ long, clavate.

Spores 75-100 $\mu$ long, clavate-cylindric.

7. T. confustm.

8. T. Walteri.

1. Trichoglossum velutipes (Peck) Durand, Ann. Myc. 6: 434. 1908. (Plate 77.)

Geoglossum hirsutum var. americantum Cooke, Mycographia 3. 1875.

Geoglossum americanum Sacc. Syll. Fung. 8: 46. 1889.

Geoglossum velutipes Peck, Ann. Rep. N. Y. State Mus. 28: 65. 1876.

Ascophores solitary, or gregarious, sometimes cespitose, up to $10 \mathrm{~cm}$. high, black or brownish-black; ascigerous portion lanceolate, ellipsoid, or subrotund, one-fifth to one-third the total length of the fruiting body, 3-15 mm. long, 4-10 mm. thick, more or less compressed, rounded above, usually rather sharply delimited from the stem; stem terete, somewhat flexuous, 2-3 mm. thick, equal, black, velvety; asci short-stipitate, clavate, apex narrowed, reaching a length of $175-210 \mu$ and a diameter of 
$18 \mu, 4$-spored; spores in a parallel fascicle in the ascus, smokybrown, narrowed each way from above the middle, 8-11-septate when mature, reaching a length of 115-166 $\mu$ and a diameter of 6-7 $\mu$; paraphyses pale-brown, cylindric, sparingly septate, slightly thickened and curved or uncinate at the tips; spines variable in length, usually projecting one-third to one-half their length beyond the asci, sometimes shorter, acicular, black.

On soil, humus, or rotten wood.

Type Locality: Northville, New York.

Distribution: New York to North Carolina and Minnesota.

Illustrations: Cooke, Mycographia pl. 1, f. 1; Peck, Ann. Rep. N. Y. State Mus. 29: pl. 1, f. 16-19; Ann. Myc. 6: pl. 9, f. 86-88; pl. 16, f. 169-173; Mycologia 22: pl. 13,f. 1, 2.

2. Trichoglossum tetrasporum Sinden \& Fitzp. Mycologia 22: 60. 1930.

Ascophores black, 3-8 cm. high; ascigerous portion ellipsoid to subrotund, not more than one-fifth the total length of the entire ascophore, more or less compressed, rounded above, rather sharply delimited from the stem; stem terete, rather flexuous, 1-2 $\mathrm{mm}$. thick, equal, black, velvety; asci clavate, apically narrowed, reaching a length of $175-220 \mu$ and a diameter of $20-25 \mu$, 4-spored; spores in a fascicle, brown, cylindric-clavate, broadest above the middle, tapering each way to subobtuse ends, normally 15 -septate at maturity, 6-7 $\times 110-160 \mu$ (mostly 125-150); paraphyses smoky-brown, cylindric, septate; tips somewhat curved, slightly thickened, $3 \mu$ thick below to $7 \mu$ thick above; setae black, projecting slightly beyond the hymenium.

Type locality : Labrador Lake near Apulia, New York.

Distribution: Known only from the type locality.

Illuustrations: Mycologia 22: pl. 13, f. 5-8.

3. Trichoglossum hirsutum (Pers.) Boud. Hist. Class. Discom. Eu. 86. 1907. (Plate 78.)

Geoglossum hirsutum Pers. Neues Mag. Bot. 1: 117. 1794.

?Geoglossum capitatum Pers. Obs. Myc. 1: 11.1796.

Ascophores solitary, or gregarious, black, 3-8 cm. high; ascigerous portion more or less ellipsoid, or lanceolate in outline, hollow, obtuse, more or less compressed, up to $1.5 \mathrm{~cm}$. long, $.5-.75 \mathrm{~cm}$. thick, usually not more than one-fifth as long as the stem from which it is rather sharply delimited; stem terete, 
\&? 

equal, up to $6 \mathrm{~cm}$. long, 2-3 mm. thick, densely velvety, composed of a fascicle of parallel, brown hyphae, 5-8 $\mu$ thick, looser in the center, those at the surface projecting as short, septate hairs, giving rise also to numerous acicular, black spines up to $225 \mu$ long; asci broadly clavate, apex narrowed, the pore blue with iodine, reaching a length of $210-225 \mu$ and a diameter of 20-22 $\mu, 8$-spored; spores in a parallel fascicle in the ascus, brown, cylindric-clavate, broadest above the middle, tapering each way to the obtuse ends, 15 -septate at maturity, $6-7 \times 100^{-}$ $160 \mu$ (120-150); paraphyses brown, cylindric, septate, usually strongly curved, or coiled at the slightly thickened tips, $3 \mu$ thick below, up to $8 \mu$ thick above; hymenial spines numerous, usually projecting about one-third their length beyond the hymenium, straight, acute, black, opaque, 8-10 $\mu$ thick, variable in length.

On rotten wood or on humus among leaves.

Type locality: Europe.

Distribution: Ontario to California and south to Louisiana and the West Indies.

Illustratrons: Cooke, Mycographia pl. 1,f. 3; Gill. Champ. Fr. Discom. pl. 24, f. 2; Phill. Brit. Discom. pl. 2, f. 9; Rab. Krypt.Fl. 1 ${ }^{3}$ : 1145, f. 5-6; Ann. Bot. 11: pl. 12, f. 31-32; Ann. Myc. 6: pl.9,f.78-80; pl. 17,f. 176-181; Mycologia 22: pl.13,f.3.

Exsiccatı: Ellis \& Ev. Fungi Columb. 1729.

A capitate form of this species was received from Mr. Fred L. Lewis which seemed almost distinct enough to be regarded as a distinct species (Plate 78). However, since the ascophores are very variable in form it is recorded simply as a capitate form of the above species.

4. Trichoglossum Wrightii Durand, Mycologia 13: 187. 1921. (Plate 79.)

Trichoglossum hirsutum f. Wrightii Durand, Ann. Myc. 6: 438. 1908.

Ascophores clavate, or flattened, black, velvety with numerous black cystidia, variable in size but often $2-3 \mathrm{~cm}$. high; ascigerous portion occupying one-third the entire length; asci clavate-cylindric, reaching a length of 250-265 $\mu$ and a diameter of $20-25 \mu, 8$-spored; spores fasciculate, reaching a length of 105 $145 \mu$ and a diameter of $7 \mu$, brown, clavate, broadest about the middle, mostly 8-9-septate, rarely 5-6- or 7-septate, stout; paraphyses cylindric, septate, pale-brown above, only slightly 
thickened and strongly curved; spines black, acute, projecting only slightly above the hymenium.

On damp soil in open places.

Type locality: Cuba.

Distribution: Cuba and Bermuda.

Illuustrations: Mycologia 22: pl. 13, f. 4; 32:390, f. 1; Ann. Myc. 6: pl. 9,f. 83; pl. 16,f. 174 .

This form was first reported by Durand on two specimens from Cuba. Later collections of the author from Bermuda in 1912 (Britton, Brown \& Seaver 1407) convinced Durand that it was a distinct species. Abundant material was collected in Bermuda in 1926 by the author and H. H. Whetzel, and again in 1940 by the author and J. M. Waterston. It is one of the commonest species in Bermuda.

5. Trichoglossum octopartitum Mains, Am. Jour. Bot. 27: 325. 1940.

Ascophores clavate, $1.5-4 \mathrm{~cm}$. high, slender, 2-4 mm. thick above, black, hirsute; stem slender 1-1.5 mm. thick; asci clavate, reaching a length of 175-200 $\mu$ and a diameter of 18-20 $\mu$; spores fusoid-clavate, attenuated toward both ends from above the middle, $6 \times 100-140 \mu$, usually 7 -septate; setae brown, acuminate, reaching a length of $240 \mu$, projecting considerably above the hymenium; paraphyses slender slightly enlarged above and curved at their apices.

On the ground.

TyPe LOCAlity: British Honduras.

Distribution: Smoky Mountains, National Park, Tennessee; also in British Honduras.

Illustrations: Am. Jour. Bot. 27: 324, f. 10.

6. Trichoglossum Farlowi (Cooke) Durand, Ann. Myc. 6: 438. 1908. (Plate 80.)

Geoglossum Farlowi Cooke, Grevillea 11: 107. 1883.

Geoglossum velutipes Peck, Ann. Rep. N. Y. State Mus. 28: 65. 1876.

Ascophores solitary, or clustered, two or three together, 2-6 $\mathrm{cm}$. high; ascigerous portion lanceolate in outline, not sharply distinguished from the stem, brownish-black, about one-third the total length of the plant, 1-3 cm. long, 3-5 mm. or more thick; stem terete, equal, often flexuous, rarely somewhat compressed, $2 \mathrm{~mm}$. thick, 2-4 cm. long, black, densely velvety with 


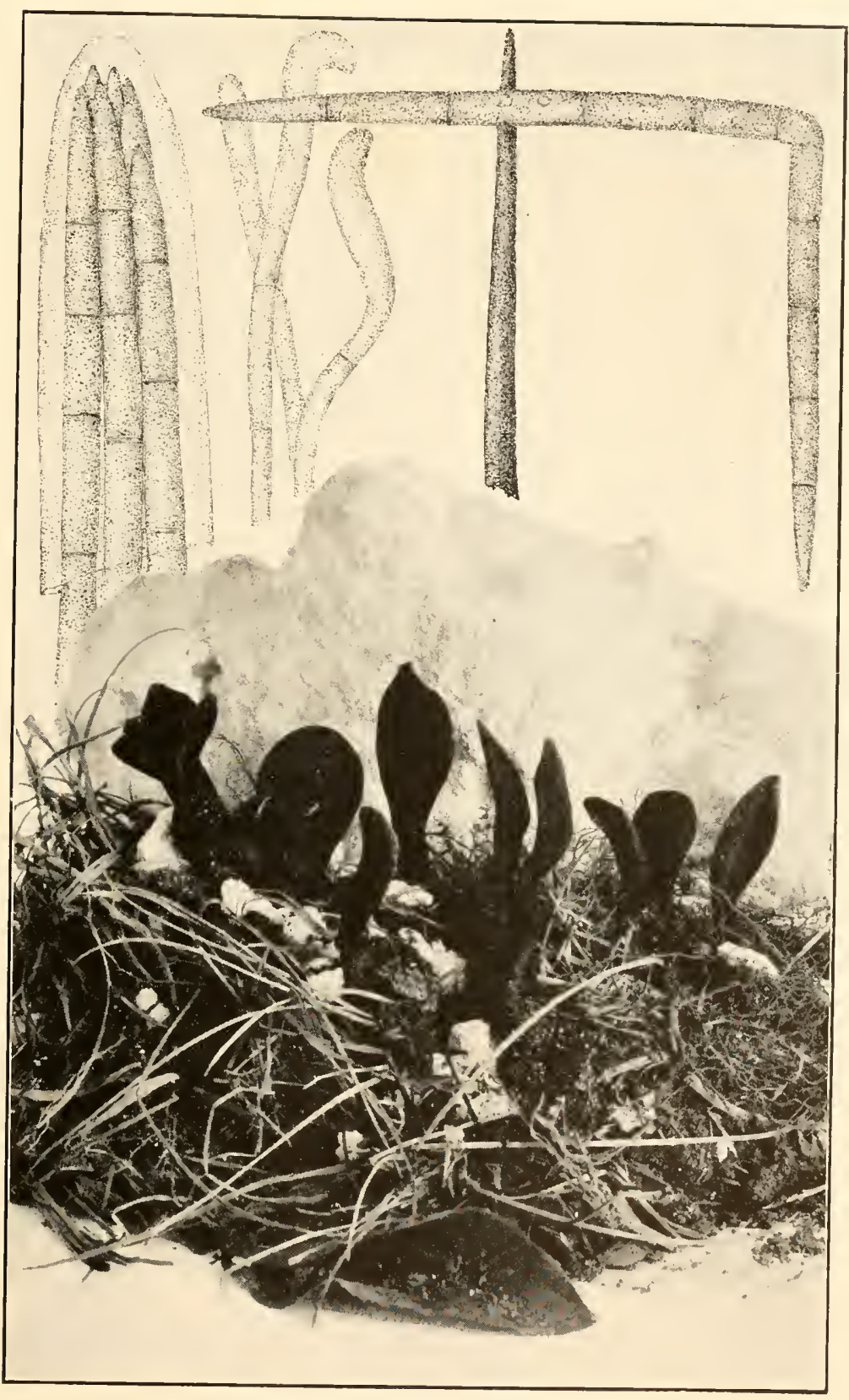

TRICHOGLOSSUM WRIGHTII 

acicular spines; asci clavate, apex somewhat narrowed but rounded, pore blue with iodine, reaching a length of 170-200 $\mu$ and a diameter of 15-18 $\mu, 8$-spored; spores multiseriate in the ascus, clavate-cylindric, tapering very little or not at all above the middle, fuliginous, or brownish, $6 \times 48-85 \mu(60-75)$, either continuous, or 1-3-5-septate, paraphyses cylindric, septate, curved to circinate at the somewhat thickened tips, brownish above; spines projecting about one-third to one-half their length beyond the hymenium.

In open grassy woods, on humus among leaves, or in moss.

TyPe locality: Massachusetts.

Distribution: New York and New Hampshire to Florida and Mississippi.

Illustrations: Ann. Myc. 6: pl. 10, f. 89-92; pl. 18, f. $186-189$.

7. Trichoglossum confusum Durand, Mycologia 13: 185. 1921.

Ascophores solitary, when dry $1.5-2.5 \mathrm{~cm}$. high; ascigerous portion one-third to one-half the total length, obovate, even or longitudinally furrowed, rather irregular; stem terete, $1-2 \mathrm{~cm}$. high, 1-1.5 mm. thick, velvety with black spines; asci narrowly clavate, apex rounded, reaching a length of $175 \mu$ and a diameter of $12 \mu, 8$-spored; spores multiseriate, clavate-cylindric, straight, or curved, fuliginous, at first 3 -septate, finally 7 -septate, $4-5 \times$ 55-73 $\mu$ (60-68); paraphyses pale-brown, slightly thickened above, straight, or curved; spines projecting but little beyond the hymenium.

On soil.

Type locality: Brazil.

Distribution: North Carolina; also in South America.

Illustrations: Ann. Myc. 6: pl. 10, f. 93; pl. 16, f. 168.

This species was reported by Durand (Ann. Myc. 6: 439. 1908.) as Trichoglossum Rehmianum (P. Henn.) Durand. Later observations showed it to be different.

8. Trichoglossum Walteri (Berk.) Durand, Ann. Myc. 6: 440. 1908.

Geoglossum Walteri Berk. Hedwigia 14: 39. 1875.

Geoglossum Rehmianum P. Henn. Hedwigia 39: (80). 1900.

Trichoglossum Rehmianum Durand, Ann. Myc. 6: 439.1908. 
Ascophores solitary, or aggregated, 3-7 cm. or more high, brownish-black; ascigerous portion narrowly ellipsoid to lanceolate, obtuse, not distinct from the stem, one-third to one-half the total length of the plant, 1-2 cm. long, 3-5 mm. or more wide, compressed; stem terete or compressed, about $2 \mathrm{~mm}$. in diameter, densely velvety with black, acicular spines; asci clavate, apex narrowed, obtuse, pore blue with iodine, reaching a length of $175-200 \mu$ and a diameter of 18-20 $\mu$, 8-spored; spores multiseriate in the ascus, clavate-cylindric, not narrowed above the middle, fuliginous, or pale-brown, $6 \times 82-107 \mu$ (87-100); paraphyses cylindric, septate, curved at the tips which are slightly thickened and brown; spines acicular, projecting about one-fourth to one-third their length beyond the hymenium.

On rotten wood or humus.

Type Locality: Australia.

Distribution: New Hampshire to Minnesota and south Alabama; also in Europe and Australia.

Illustrations: Cooke, Mycographia pl. 1, f. 4; Ann. Myc. 6: pl. 10, f. 94-97; pl. 18, f. 190-193.

7. SPATHULARIA Pers. Neues Mag. Bot. 1: 116. 1794.

Ascophores fleshy, erect, stipitate; ascigerous portion spathulate, much compressed, fan-shaped, decurrent on opposite sides of the stem from which it is sharply delimited; bright-colored; asci clavate, 8-spored; spores fasciculate in the ascus, filiformclavate, multiseptate; paraphyses present.

Spathularia differs from other genera of the family in having bright-colored, spathulate or fan-shaped ascophores. The consistency and spore characters are those of Cudonia.

Type species, Spathularia flavida Pers.

Stem pallid or yellowish-pallid; mycelium pale-yellow.

Stem bay-brown, minutely velvety; mycelium orange.

1. S. clavata.

2. S. velutipes

1. Spathularia clavata (Schaeff.) Sacc. Michelia 2: 77. 1882. (Plate 81, Fig. 2.)

Elvela clavata Schaeff. Fung. Bavar. 4: Ind. 59. 1774.

Spathularia flavida Pers. Neues Mag. Bot. 1: 116.1794.

Spathularia flava Pers. in Holmsk. Coryph. 166. 1797.

Spathularia flavida var. rugosa Peck, Ann. Rep. N. Y. State Mus. 39: 58.1887. Spathularia rugosa Peck, Ann. Rep. N. Y. State Mus. 50: 118. 1897.

Mitruliopsis flavida Peck, Bull. Torrey Club 30: 100. 1903. 


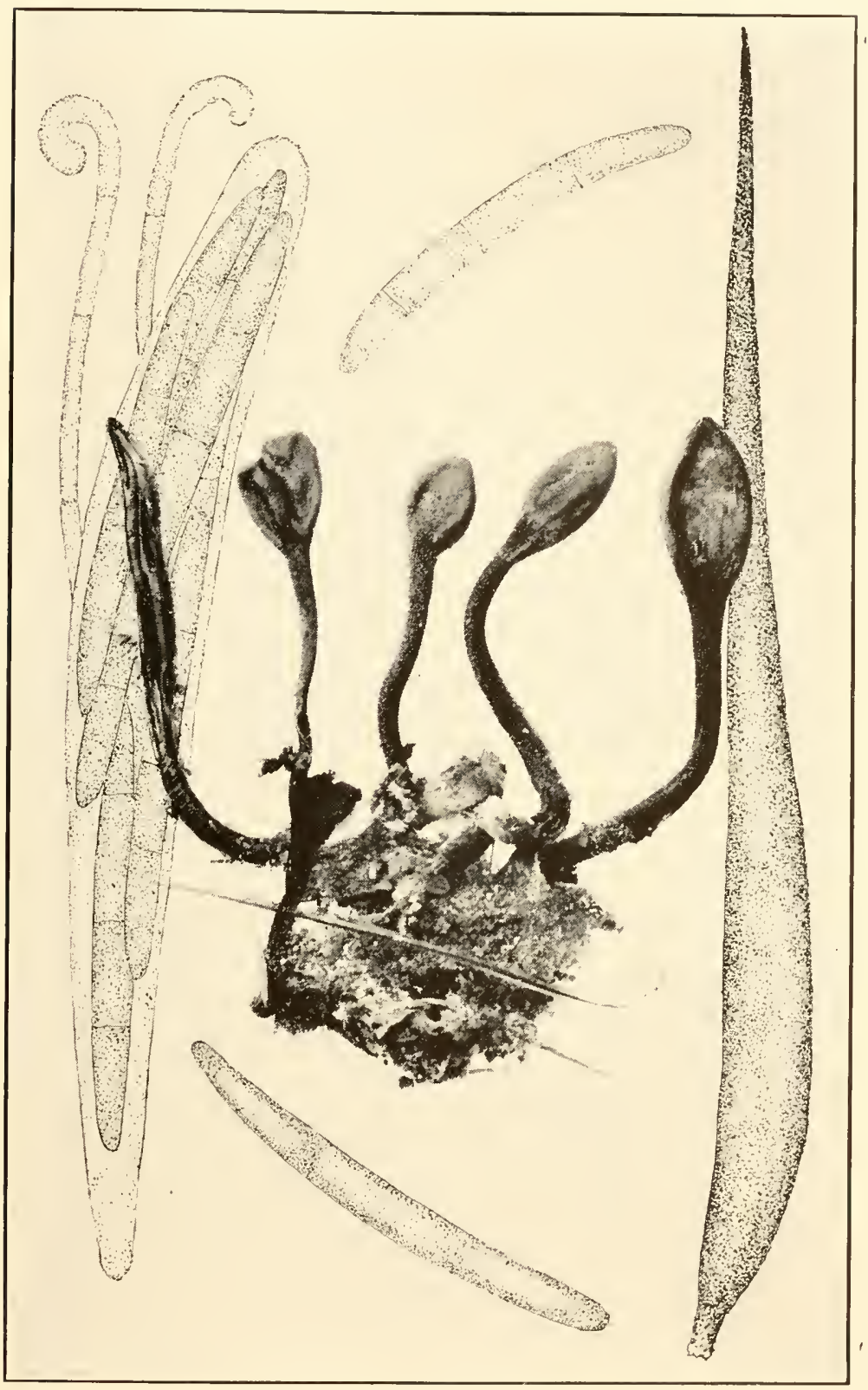

TRICHOGLOSSUM FARLOWII 

Ascophores solitary, or usually gregarious, rarely cespitose, with two or three together, sometimes growing in lines or circles, fleshy up to $10 \mathrm{~cm}$. high, whole plant pallid when young and fresh, then becoming yellowish, or brownish; ascigerous portion darker than the stem, much compressed, fan-shaped, obtuse or rounded, decurrent on opposite sides of the stem, even, undulate, or radiately rugose, sometimes contorted, clavate, or almost capitate, occupying about one-third to one-half the total length of the ascophore, up to $2.5 \mathrm{~cm}$. widle; stem hollow, smooth or farinose, terete or somewhat compressed, tapering slightly upward, often swollen or bulbous below, slightly brownish at the base, up to $1 \mathrm{~cm}$. in diameter, attached by a pallid, or yellowish mycelium; flesh white; ascophores usually becoming yellowishbrown when dry; asci clavate, apex conspicuously narrowed, often submammiform, not blue with iodine, reaching a length of 100-125 $\mu$ and a diameter of 12-14 $\mu, 8$-spored; spores in a paralle] fascicle in the ascus, often twisted together above, smooth, clavate-filiform, multiseptate, hyaline, $2.5-3 \times 35-65 \mu(40-50)$; paraphyses filiform, branched, hyaline, much curled, or coiled at the apices, not thickened.

On soil or humus, but most commonly under pines among the needles.

Type locality: Europe.

Distribution: New Brunswick to California; also in Europe.

Illustrations: Schaeff. Ic. Fung. pl. 1+9; Cooke, Mycographia pl. 95, f. 342; Gill. Champ. Fr. Discom. pl. 27, f. 1; Phill. Brit. Discom. pl. 2, f. 7; Grev. Scot. Crypt. Fl. pl. 165; Berk. Outl. Brit. Fung. pl. 21, f. 7; Sow. Engl. Fung. pl. 35; Seaver, Bull. Lab. Nat. Hist. State Univ. Iowa pl. 1, f. 1; Ann. Myc. 6: pl. 10, f. 98-100; pl. 22, f. 220.

Exsiccatı: Ellis, N. Am. Fungi 1268; Clements, Crypt. Form. Colo. 127.

2. Spathularia velutipes Cooke \& Farlow; Cooke, Grevillea 12: 37. 1883. (Plate 81, Fig. 1.)

Ascophores solitary, or usually gregarious, occasionally cespitose several being united by a common base, up to $5 \mathrm{~cm}$. high, 1-3 cm. wide, fan-shaped; ascigerous portion much compressed, yellowish to brownish-yellow, decurrent on opposite sides of the stem, the margin rounded, even, or often wavy or incised or lobed, sometimes contorted, about $1 \mathrm{~cm}$. high at the 
top; stem varying from nearly terete or compressed to broadly expanded and flattened above, rather rounded in outline at its junction with the ascigerous part, $2-4 \mathrm{~cm}$. high, up to $1.5 \mathrm{~cm}$. broad above, 3-5 $\mathrm{mm}$. thick at the base, solid, bay-brown and minutely velvety, attached by an orange mycelium; the ascophore shrinks but little in drying, the color becomes brownish and the stem more or less longitudinally rugose or striate; asci clavate, apex narrowed, not blue with iodine, reaching a length of $80-105 \mu$ and a diameter of $10 \mu, 8$-spored; spores in a parallel fascicle in the ascus, hyaline, smooth, clavate-filiform, straight, or curved, becoming multiseptate, $2 \times 33-43 \mu$ (35-40); paraphyses filiform, hyaline, branched, strongly curved, or coiled at the tips.

On rotten logs, humus among leaves, or especially on the ground under pines.

Type locality: New Hampshire.

Distribution: New Hampshire to North Carolina and Minnesota, and Idaho?

Illustrations: Ann. Bot. 11: pl. 13, f. 85-88; Ann. Myc. 6: pl. 11,f. 101-102; pl. 22, f. 221-222.

\section{Doubtful Species}

Spathularia linguatus A. E. Johnson, Bull. Minn. Acad. Nat. Sci. 1: 370. 1880. "Head tongue-shaped, flat, thin, nearly even, white, or white tinged with yellow or buff; stem white or yellowish white, thick, solid; asci very long, clavate; sporidia filiform, nearly as long as the asci, straight or curved, multinucleate. Gregarious, seldom solitary, one to two inches high; head as long or longer than the stem, one-fourth to three-fourths of an inch broad. On moss in tamarck swamps. October. Scarce." The above is all that is known about this species.

8. LEOTIA Pers. Neues Mag. Bot. 1: 97. 1794.

Hygromitra Nees, Syst. Pilz. Schu. 157. 1816.

Cudoniella Sacc. Syll. Fung. 8: 41. 1889.

Ascophores more or less gelatinous, stipitate, erect; ascigerous portion pileate, horizontal, supported in the center, bearing the hymenium spread over its upper convex surface, sterile beneath; asci clavate; spores hyaline, oblong-fusiform, at first simple, finally 3-5-septate; paraphyses present.

Type species, Elvela lubrica Scop. 


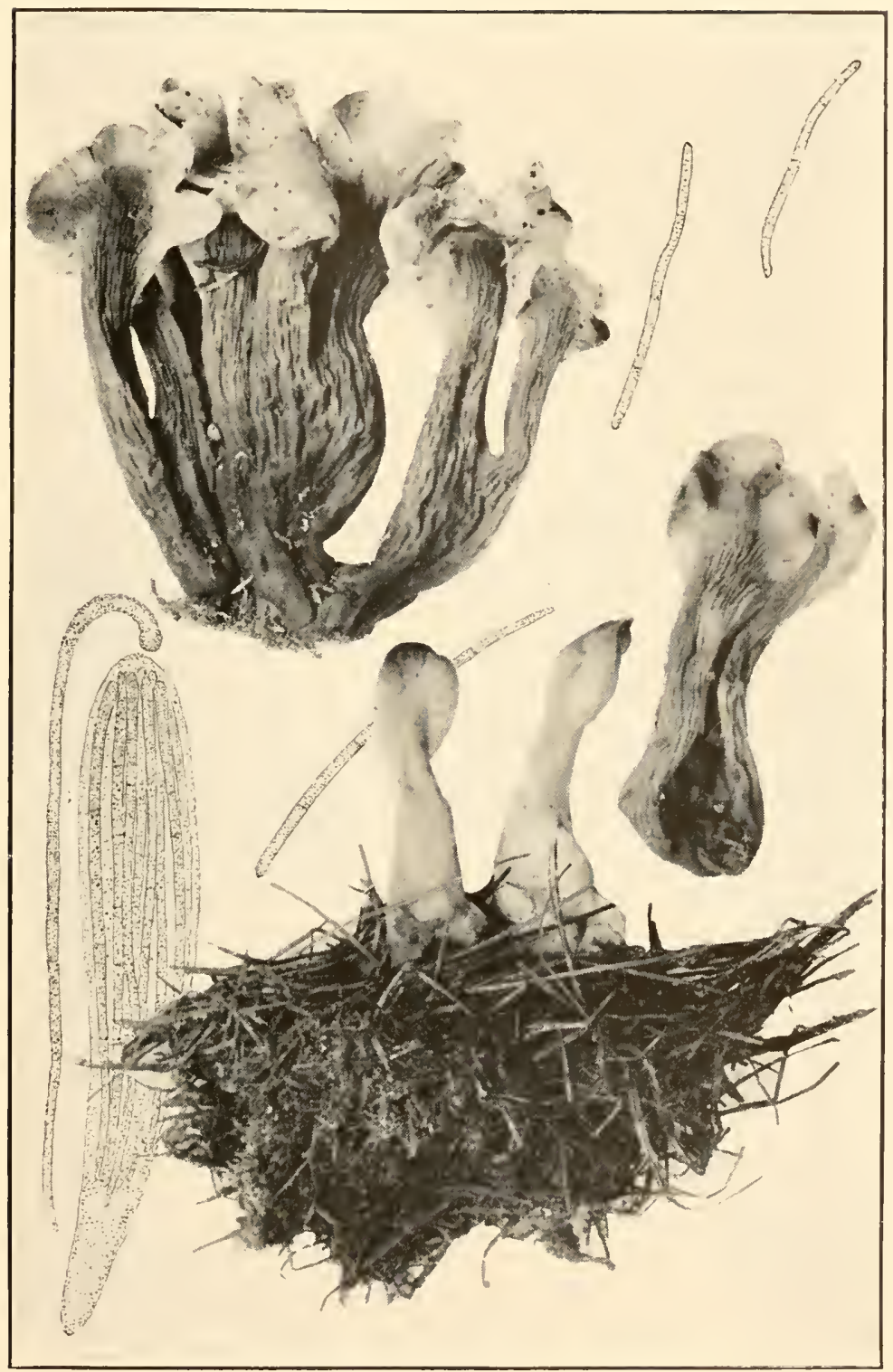

1. SPATHULARIA VELUTIPES

2. SPATHULARIA CLAVATA 

Ascuphores entirely yellowish-ochraceous, sometimes olivaceous.

I. L. lubrica.

Hymenium aeruginous-green; stem white to yellowish.

Ascophores entirely green; stem furfuraceous, substance

2. L. stipitata. firm, stems slender.

3. L. chlorocephala.

According to Durand the type of Cudoniella is a Leotia.

The color varies much in the species listed above, but the three listed seem to be reasonably distinct.

1. Leotia lubrica (Scop.) Pers. Neues Mag. Bot. 1: 97. 1794. (Plate 82, Fig. 1.)

Elvela lubrica Scop. F1. Carn, 2: 477. 1772.

Helvella gelatinosa Bull. Hist. Champ. Fr. 296. 1791.

Ascophores usually densely cespitose, stipitate, more or less viscid-gelatinous, ochraceous-yellow, often with a greenish or olive tint, 3-6 cm. or more high; ascigerous portion pileate, convex above, the surface often irregularly furrowed, with a recurved margin, wrinkled or nodulose, $1-1.5 \mathrm{~cm}$. or more broad; stem terete or somewhat compressed, usually tapering slightly upward, the adjacent ones of ten coalescing below, about $1 \mathrm{~cm}$. thick below, $.5 \mathrm{~cm}$. above, up to $5 \mathrm{~cm}$. or more high, minutely squamulose, sometimes with innate, greenish granules; asci narrowly clavate, apices rounded, slightly narrowed, not blue with iodine, reaching a length of $130-160 \mu$ and a diameter of 10-12 $\mu, 8$-spored; spores 2-seriate above, 1 -seriate below, hyaline, smooth, cylindric-oblong to fusiform, ends obtuse, or subacute, straight or curved, 5-6 × 18-28 $\mu$ (20-23), at first simple, then with three to eight oil-drops, finally becoming 5-7-septate; paraphyses filiform, branched, the apices clavate to pyriform, hyaline, the tips agglutinated by amorphous matter.

On rich humus or sandy soil rarely on rotten wood, in woods.

TyPE Locality: Europe.

Distribution: Ontario to Alabama and Iowa; also in Europe.

Illustrations: Bull. Herb. Fr. pl. 473, f. 2; Sow. Engl. Fungi pl. 70: Fl. Dan. pl. 719; Berk. Outl. Brit. Fung. pl. 22, f. 1; Grev. Scot. Crypt. Fl. pl. 56; Cooke, Mycographia pl. 44, f. 17 1; Gill. Champ. Fr. Discom. pl. 23; Rab. Krypt.-Fl. 13: 1161, f. 1-4; Ann. Bot. 11: pl. 13, f. 61-6t; Atk. Mushrooms f. 221; Ann. Myc. 6: pl. 11, f. 106; pl. 20, f. 213; Seaver, Bull. Lab. Nat. Hist. State Univ. Iowa pl. 2, f. 1; Mycologia 2: pl. 17, f. 1 .

Exsiccati: Ellis, N. Am. Fungi 57; Ellis \& Ev. Fungi Cclumb. 1738 . 
2. Leotia stipitata (Bosc.) Schröt. E. \& P. Nat. Pfl. 1²: 166. 1897.

Tremella stipitata Bosc. Berl. Mag. 5: 89. 1811.

Leotia viscosa Fries, Syst. Myc. 2: 30. 1822.

Ascophores solitary, or clustered, stipitate, viscid-gelatinous, 3-6 cm. or more high; ascigerous portion 1-2 cm. or more broad, margin incurved toward the stem, even or irregularly nodulose, hymenium clear deep aeruginous-green, whitish below; stem terete or tapering slightly upward, usually pure-white, or less often with an ochraceous or orange tint, 2-4 cm. high, .5-1 cm. thick, often beset, especially above, with minute, green squamules; asci narrowly clavate-cylindric, not or only slightly narrowed, not blue with iodine, reaching a length of 118-150 $\mu$ and a diameter of $10 \mu, 8$-spored; spores 2 -seriate above, 1seriate below, hyaline, smooth, at first simple, finally 5 - or moreseptate, ends obtuse, or subacute, straight or curved, 5-6 $\times$ 16-28 $\mu$ (20-24); paraphyses filiform, branched, the apices pyriform, intense green when fresh.

In rich humus or soil, especially among leaves in woods or on the slopes of ravines.

Type Locality: South Carolina.

Distrubution: Maine to Florida and California; also in Europe.

Illustrations: Berl. Mag. 15: pl. 6, f. 14; Cooke, Mycographia pl. 44,f. 173; Ann. Bot. 11: pl. 13, f. 65; Ann. Myc. 6: pl. 11,f. 109; pl. 20,f. 210.

Exsiccati: Ellis, N. Am. Fungi 663; Ellis \& Ev. N. Am. Fungi 2032; Rav. Fungi Car. 4: 22; Fungi Am. 173.

3. Leotia chlorocephala Schw. Schr. Nat. Ges. Leipzig 1: 114. 1822.

Ascophores solitary to densely clustered, subgelatinous, entirely green, 1-5 cm. high; ascigerous portion hemispherical, convex, margin incurved, obtuse, hymenium smooth or furrowed, the margin often lobed or nodulose, pea-green to aeruginous, 2-10 $\mathrm{mm}$. wide; stem terete, firm, the middle layer green, surface densely squamose, or furfuraceous with green granules, 1-4.5 $\mathrm{cm}$. high, 2-4 $\mathrm{mm}$. thick, shrinking much in drying, the color changing but little; asci narrowly clavate, apex rounded not blue with iodine, reaching a length of $125-150 \mu$ and a diameter of 10-12 $\mu, 8$-spored, short-stipitate; spores subbiseriate above. 


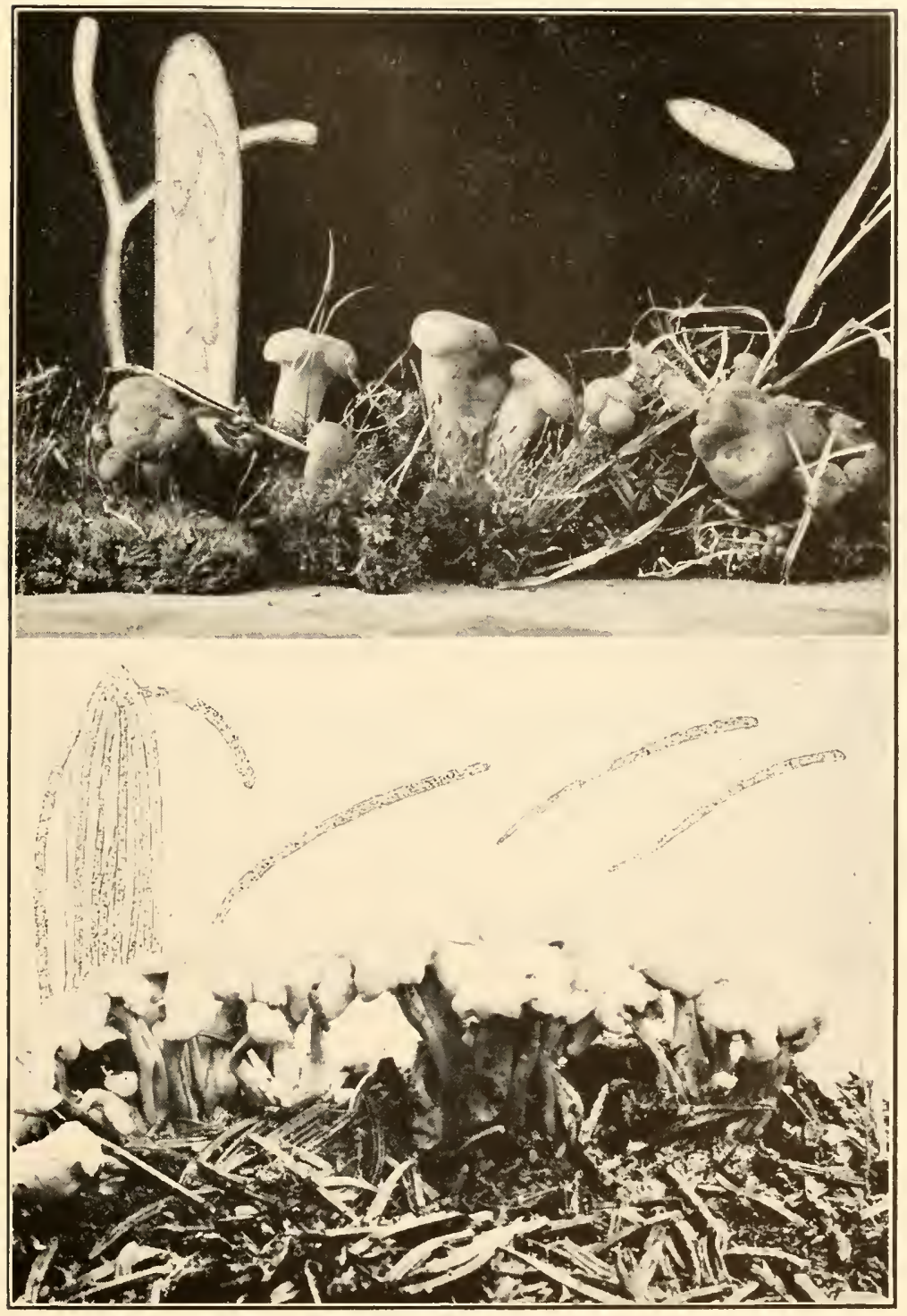

1. LEOTIA LUBRICA

2. CUDONIA CIRCINANS 

1-seriate below, hyaline or with a faint greenish tint, narrowly ellipsoid to ellipsoid-fusiform, ends obtuse or subacute, at first simple, finally about 5-septate, straight or curved, 5-6 $\times 18-20 \mu$; paraphyses filiform, branched, the apices pyriform, green.

On sandy soil in rich woods, on knolls, or along wood roads or among mosses in ravines.

Type locality: Salem, North Carolina.

Distributiox: New Hampshire to Alabama.

Illustrations: Cooke, Mycographia pl. 4t, f. 174; Ann. Myc. 6: pl. 11,f. 110; pl. 20,f. 211, 212; Mycologia 2: pl. 17,f. 2.

\section{Doubtful and Excluded Species}

Leotia exigua Schw. Schr. Nat. Ges. Leipzig 1: 113. 1822; Mitrula exigua Fries, Elench. Fung. 1: 235. 1828. Durand states: "No specimens are known to be in existence, certainly not in the herbaria of Schweinitz or Fries. It was probably Helotiaceous."

Leotia infundibuliformis (Schaeff.) Fries, Obs. Myc. 2: 299. 1818; Elvela infundibuliformis Schaeff. Fung. Bavar. 4: Ind. 111. 1774. Durand states: "Whatever may be thought of the European specimens the one preserved in the Schweinitzian herbarium, from New York, is an Helvella related to H. elastica."

Leotia marcida (Müll.) Pers. Syn. 613. 1801; Phallus marcidus Müll. Fl. Dan. Fasc. 11: 7, pl. 654,f. 1. 1777. Durand states: "This species has been reported several times from the Inited States, but all the specimens which I have been able to examine, both from Europe and America, are indistinguishable internally from L. lubrica."

Leotia rufa Rostrup, Med. Grơnl. 3: 536. 1888. "Pileus repandus, margine revoluto, latit. $1-2 \mathrm{~mm}$. rufus; stipes inaequaliter teres, furo-ferrugineus, altit. 5-6 mm. Asci cylindraceo-clavati, pedicellati, long. 60-70 $\mu$ crass. $2 \mu$. Inter. muscos. Agdluitsok [Greenland] (Vahl)." Durand states: "The above is Rostrup's original description. I saw a small fragment of the original collection in the Botanical Museum Copenhagen, but did not examine it microscopically. It is probably Helotiaceous."

Leotia chlorocephala f. Steriensoni (Berk. \& Br.) Massee, Brit. Fungus-F1. 4: 472. 1895; Leotia Stevensoni Berk. \& Br. Ann. Mag. Nat. Hist. V. 3: 212. 1879. This form has been reported from Missouri by J. B. Routien (Mycologia 34: 579. 1942). The writer has no knowledge of the form.

9. VIBRISSEA Fries, Syst. Myc. 2: 31. 1822.

Ascophores stipitate, pileate, soft, waxy, or subgelatinous; ascigerous portion hemispherical, bearing the hymenium on its upper, convex surface, sterile below; asci long-cylindric, narrow, 8-spored, spores in a parallel fascicle and nearly as long as the ascus, hyaline, filiform, many-septate; paraphyses slender. 
Type species, Leotia truncorum Alb. \& Schw.

Spores $175-250 \mu$ long.

1. V. truncorum.

Spores $85-100 \mu$ long.

2. V. foliorum.

1. Vibrissea truncorum (Alb. \& Schw.) Fries, Syst. Myc. 2: 31. 1822.

Leotia truncorum Alb. \& Schw. Consp. Fung. 297. 1805.

Leotia Clavus Pers. Myc. Eur. 1: 200. 1822.

Vibrissea truncorum var. albipes Peck, Ann. Rคp. N. Y. State Mus. 44: 37. 1891.

Ascophores solitary, gregarious, or in clusters of two or three each, 4-5 $\mathrm{mm}$. high; ascigerous portion hemispherical-convex, margin obtuse, 3-5 $\mathrm{mm}$. in diameter, yellow, orange, or reddishorange, rarely pallid; stem terete, up to $1.5 \mathrm{~cm}$. high, 1-2 mm. thick, white to bluish-gray, or brownish, minutely squamulose, due to minute, spreading hyphae, rather darker below; asci slenderly cylindric, apex rounded, not blue with iodine, reaching a length of 200-325 $\mu$ and a diameter of 5-6 $\mu$, 8-spored; spores in a parallel fascicle in the ascus, hyaline, very slenderly filiform, slightly narrowed toward each end, nearly as long as the ascus, multiseptate, up to $1 \times 250 \mu$; paraphyses filiform, occasionally forked, the apices somewhat clavate-thickened and colored.

On wholly or partly submerged sticks etc., in brooks, mostly in higher altitudes.

Type locality: Europe.

Distribution: Laborador to Alaska and West Virginia.

Illustrations: Trans. Linn. Soc. II. 2: pl. 1, f. 1-9; Phill. Brit. Discom. pl. 10, f. 60; Rab. Krypt.-Fl. 133: 1164, f. 1-4; Ann. Bot. 11: pl. 12, f. 15-17a; Gill. Champ. Fr. Discom. pl. 29, f. 1; Kromb. Myk. Heft pl. 5,f. 34-36; Ann. Myc. 6: pl. 11, f. 111, 112; Pers. Myc. Eu. 1: pl. 11, f. 9.

Exsiccati: Ellis, N. Am. Fungi 134.

2. Vibrissea foliorum Thaxter; Durand, Ann. Myc. 6: 454. 1908.

Ascophores solitary, or gregarious, stipitate, of soft consistency; ascigerous portion convex, 1-1.5 $\mathrm{mm}$. in diameter, yellowish-orange; stem pallid, 2-3 times as long as the diameter of the head, slender, translucent, slightly furfuraceous with projecting hairs below; asci narrowly cylindric, apex rounded, not blue with iodine, reaching a length of $150-180 \mu$ and a diameter of 5-6 $\mu, 8$-spored; spores in a parallel fascicle in the ascus, hyaline, slenderly filiform, $1 \times 85-100 \mu$; paraphyses filiform, hyaline, 
not exceeding the asci, simple, or occasionally forked near the distal ends, very slightly pyriform-thickened at the tips.

On dead oak leaves, acorn-cups etc. in a wet place.

Type locality: IV'est Haven, Conn.

Distribution: Known only from the type locality.

Il.ustrations: Ann. Myc. 6: pl. $11, f .113$.

10. CUDONIA Fries, Summa Veg. Scand. 348. 1849.

Ascophores stipitate, erect, fleshy-leathery; ascigerous portion pileate; hymenium on the upper, convex surface, sterile beneath, margin acute, incurved toward the stem; asci clavate, 8-spored; spores hyaline, clavate-filiform, multiseriate, or fasciculate in the upper part of the ascus, multiseptate; paraphyses present.

Type species, Leotia circinans Pers.

Spores $30-45 \mu$ long; ascophores pale-brownish to buff,

often with a rosy tint.

1. C. circinans.

Spores 45-78 $\mu$ long; ascophores entirely yellowish.

Spores 18-25 $\mu$ long.

2. C. lutea.

Caps ochraceous, or reddish-brown.

Caps $5 \mathrm{~mm}$. in diameter.

3. C. ochrolenca.

Caps $10-30 \mathrm{~mm}$. in dianeter.

4. C. monticola.

Caps gray.

5. C. griser.

1. Cudonia circinans (Pers.) Fries, Summa Veg. Scand. 348. 1849. (Plate 82, Fig. 2.)

Leotia circinans Pers. in Holmsk. Coryph. 163. 1797.

Tibrissea circinans Hazsl. Magyar. Akad. Ertek. Termesz. Kör. 11 19: 9.1881.

Ascophores solitary, or gregarious, fleshy, becoming more distinctly leathery in drying, 2-6 cm. high; ascigerous portion .5-2 cm. broad, rather thin, margin acute and recurved, even or undulate, hymenium convex, even, wrinkled, or convoluted, cream-buff with a faint rosy tint, or sometimes yellowish, or palebrownish; stem tapering slightly upward, often stout below where it is $2-10 \mathrm{~mm}$. thick, $1.5-5 \mathrm{~mm}$. thick above, darker than the hymenium especially below, often longitudinally striate especially above, the striae being prolonged as radiating veins on the lower side of the cap, somewhat farinaceous, sometimes becoming hollow in age; asci clavate, apex narrowed, not blue with iodine, reaching a length of $85-130 \mu$ and a diameter of 8 $10 \mu, 8$-spored; spores fasciculate, hyaline, smooth, clavate-filiform, broadest above the middle or at the distal end, $2 \times 30-45 \mu$ 
(34-40); paraphyses hyaline, filiform, strongly curved above, often branched, tips only slightly thickened, $2 \mu$ thick.

On rotten wood or humus among leaves, often uncler coniferous trees.

TyPE LOCAlity : Europe.

Distribution: Newfoundland to Colorado, Iflaho, and Alberta; also in Europe.

Illustrations: Pers. Ic. Descr. Fung. pl. 5, f. 5-7; Bres. Fungi Trident. pl. 145; Rab. Krypt.-Fl. 13 : 1163,f. 1-t; Cooke, Mycographia pl. 4t,f. 172; Phill. Brit. Discom. pl. 2, f. 5; Ann. Myc. 6: pl. 11,f. 103; pl. 21,f. 214, 215.

2. Cudonia lutea (Peck) Sacc. Atti Inst. Venet. VI. 3: 725. 1885.

Tibrissea lutea Peck, Bull. Buffalo Soc. Nat. Sci. 1: 70. 1873.

Leotia lutea Cooke, Bull. Buffalo Soc. Nat. Sci. 2: 287. 1875.

Ascophores solitary or gregarious, rarely clustered, 1-6 cm. high, but usually about $3 \mathrm{~cm}$., fleshy-leathery; ascigerous portion pileate, convex, the margin acute, reflexed, hymenium when young covered by a volva-like membrane which later cracks irregularly and falls away leaving remnants attached to the margin, usually slightly depressed above, sometimes furrowed, beautiful flesh-color to orange-buff, the under surface often with radiating striac which continue down the stem, $5-15 \mathrm{~mm}$. in diameter; stem terete, or slightly compressed, sometimes inflated below, even or longitudinally striate, mealy, pale-yellow, 1-5 cm. high, 2-5 $\mathrm{mm}$. thick, the whole ascophore when dry becoming about the color of chamois skin or of Otidea ieporina; asci clavate, apex narrowed, not blue with iodine, variable in size, reaching a length of $100-170 \mu$ and a diameter of $10-12 \mu$, 8 -spored; spores in a fascicle in the upper part of the ascus, hyaline, smooth, with a hyaline, gelatinous sheath, clavatefiliform, lower end acute, not narrowed above the middle, $2 \times$ 45-78 $\mu$ (55-65); paraphyses filiform, branched, not thickened but strongly circinate at the tips.

On decaying leaves in thickets, rarely on rotten wood, chestnut burrs etc.

Type Locality: North Elba, New York.

Distribution: Ontario to Tennessee.

Illustrations: Ann. Rep. N. Y. State Mus. 25: pl. 1, $f$. 19-23; Ann. Bot. 11: pl. 12, f. 5-7; Ann. Myc. 6: pl. 11, f. 105; pl. 21-22, f. 216-219.

Exsiccati: Ellis \& Ev. N. Am. Fungi 3533. 
3. Cudonia ochroleuca Cooke \& Hark.; Durand, Ann. Myc. 6: 461. 1908.

Leotia ochroleuca Cooke \& Hark. Grevillea 9: 8. 1880. V'ibrissea ochroleuca Massee, Ann. Bot. 11: 262. 1897.

Ascophores scattered, stipitate, pileate; ascigerous portion convex, ochroleucous, $6 \mathrm{~mm}$. in diameter when dry; stem slender, flexuous, white, longitudinally striate, or rugulose, 8-10 mm. high; whole ascophore when dry dark reddish-brown, substance apparently not subgelatinous; asci clavate, slenderly stipitate, apex narrowed, not blue with iodine, reaching a length of $75-100 \mu$ and a diameter of $8-9 \mu, 8$-spored; spores multiscriate in the ascus, clavate-filiform, acute at each end, hyaline, 3 -moreseptate, $2 \times 18-25 \mu$; paraphyses filiform, very slender.

On damp ground.

Type locality: San Rafael, California.

Distribution: Known only from the type locality.

Illustrations: Ann. Bot. 11: pl. 13, f. 70 72; Ann. Myc. 6: pl. 11, f. 104.

4. Cudonia monticola Mains, Am. Jour. Bot. 27: 322. 1940.

Ascophores single, gregarious, or cespitose, pileate, fleshyleathery, 3-10 cm. high; pileus variable in form, convex, irregularly hemispherical, laterally compressed or subspathulate, 10-30 $\mathrm{mm}$. broad, incarnate-cinnamon; stem 5-7 mm. thick below, somewhat attenuated upward, wood-brown; asci clavate, reaching a length of $90-100 \mu$ and a diameter of 8-10 $\mu$, attenuated below, 8 -spored; spores acicular, $2 \times 20-24 \mu$, hyaline; paraphyses filiform, hyaline, curved at their apices.

On spruce needles and coniferous debris.

Type Locality: Lake Crescent, Washington.

Distribution: Washington.

Illustrations: Am. Jour. Bot. $27: 324, f$. 1.

5. Cudonia grisea Mains, Am. Jour. Bot. 27: 322. 1940.

Ascophores gregarious, pileate, stipitate, fleshy, $1.5-5 \mathrm{~cm}$. high; pileus convex, thick, 5-15 $\mathrm{mm}$. broad, drab or dark-gray, smooth; stem 3-8 mm. thick, attenuated above, smooth, brown; asci clavate, reaching a length of $70-90 \mu$ and a diameter of $6-8 \mu$, attenuated below; spores acicular, $1.5-2 \times 18-22 \mu$, hyaline; paraphyses filiform, hyaline, curved at their apices. 
On rotten coniferous wood.

Type Locality: Hoh River, Washington.

Distribution: Washington.

Illustrations: Am. Jour. Bot. $27: 324, f .2$.

\section{Excluded Genera And Species}

Cudoniella fructigena Rostrup. Med. Gronl. 3: 605. 1891. According to Durand this belongs with the Helotiaceae. He states further that he believes the genus Cudoniella to be ill founded since the species thus far referred to it might better be placed elsewhere.

Helotium aciculare (Bull.) Pers. Syn. Fung. 677. 1801; Helvella acicularis Bull. Hist. Champ. Fr. 296. 1791; Peziza acicularis Fries, Syst. Myc. 2: 156. 1822; Cudoniella acicularis Schröt. in E. \& P. Nat. Pfl. 1' ${ }^{1}$ 166. 1897.

Roesleria hypogaea Thüm. \& Pass. Durand states: "I have seen this species growing on buried grape canes in New York and Missouri. Schröter placed it in the Geoglossaceae, while Rehm and others regard it as synonymous with Coniocybe pallida (Pers.) Körb., and refer it to the Calicieae. Judging from the specimens seen its affinities lo not seem to be at all close to the Geoglossaceae, so that 1 exclucle it from that family."

\section{Family 4. HELOTIACEAE}

Apothecia extremely variable, ranging in size from a fraction of a millimeter to 2 or 3 centimeters in diameter, sessile to longstipitate, varying much in the same species, superficial, or more rarely erumpent on herbaceous stems, colors varying from white, bright-yellow, or red to green, olive, blue, brown, or nearly black, smooth, or hairy; asci cylindric to broad-clavate; spores simple or compound, globose to long-filiform, hyaline or more rarely colored; paraphyses hyaline or more rarely colored, filiform, or rarely with lanceolate, pyriform, or subglobose ends.

Apothecia not distinctly hairy.

Apothecia arising from a sclerotium or sclerotium-like substratum.

Tribe 1. Sclerotineae.

Apothecia not springing from a sclerotium, but occasionally on a subiculum.

Apothecia fleshy, waxy, leathery, or subcartilaginous.

Stipitate or sessile, usually brightcolored, more rarely dark-brown or blackish.

Sessile, sordid, gray or blackish.

Apothecia cartilaginous or gelatinous to subtremelloid.

Apothecia hairy.

Tribe 2. HeLotieaE.

Tribe 3. MOLLISIEAE.

Tribe 4. ASCOTREMELLEAE. Tribe 5. LACHNELLEAE. 
Tribe 1. Sclerotineae. Apothecia arising from a definite sclerotium of variable form, usually on or in the tissues of a living or recently killed host (more rarely isolated or in one case formed on the dung of animals) or from a stromatized portion of the host; conidial stage present and well developed, or unknown; apothecia cup-shaped to subdiscoid, or more rarely verpoid, usually stipitate, the length of the stem variable; asei usually 4-8-spored; spores ellipsoid, hyaline or subhyaline, or occasionally brown; spermatia often present.

The following genera have been adopted from $\mathrm{H}$. H. Whetzel who spent many years in critical research on this group of fungi, the results of which were posthumously published by Dr. H. M. Fitzpatrick (Mycologia 37: 648-714. 1945).

Conidial stage present, well developed.

Conidial stage monilioid or botryoid.

Conidial stage a Monilia; on woody plants. 1. Monilinis.

Conidal stage of the Botrytis type.

Conidiospores rough.

2. Seaverinia.

Conidiospores smooth.

Conidiophores twisted or kinked.

3. Streptotinia.

Conidiophores not twisted or kinked.

4. BOTRYOTINIA.

Conidial stage not monilioid or botryoid.

Conidial stage a Gloeosporium.

5. Septotinia.

Conidial stage not a Gloeosporium, conidia large-ovoid.

6. OVULINIA.

Conidial stage absent, unknown or obscure.

Ascospores brown.

Sclerotia indefinite or diffused.

Sclerotia definite, hemispherical.

7. LAMBERTELLA.

8. Martinia.

Ascospores hyaline or subhyaline.

On plant tissues.

Sclerotia discoid or subdiscoid, foliicolous.

Apothecia cup-or saucer-shaped.

Apothecia verpoid.

9. CiBORINIA.

10. VERPATINIA.

Sclerotia not discoid or subdiscoid.

Sclerotia definite, isolated or associated with the host.

11. Sclerotinia.

Sclerotia indefinite on or within the host.

In flowers or fruit of the host.

12. Ciboria.

On stems or other host tissues.

13. Stromatinis.

On dung of animals.

14. Coprotinia.

Tribe 2. Helotieae. Apothecia stipitate, or sessile, usually highly colored, bright-ycllow, light-brown, blue, or some shade of green or rarely dark-colored, brownish-black, regular or irregular in form; stem very variable in length even in the same 
species; asci cylindric or clavate, usually 8-spored; spores ellipsoid to fusoid, fusiform, or filiform, simple or septate, hyaline or more rarely colored; paraphyses present and variable.

Spores hyaline.

Apothecia usually, elongated on one side.

15. Midotis.

Apothecia not elongated.

Color yellow-olive or greenish.

Opening with a stellate aperture.

16. Podophacidium.

Not opening as above.

Bright-green, medium large, $5 \mathrm{~mm} .-1$ $\mathrm{cm}$. broad.

17. ChLOROCIBORIA.

Yellowish to olive, small, less than 5 mm. broad.

Spores large, $20 \mu$ or more long. Spores small, $10 \mu$ or less long.

18. Kriegeris.

19. ChLorosple Nitu.

Color varied but never green.

Apothecia medium large, $t^{-5} \mathrm{~mm}$. or more broad.

On over wintering buds; conidial stage, an Acarosporium.

20. PyCNOPEZiza.

On plant debris; conidial stage not as above.

Spores simple.

Spores compound.

21. Ciboriella.

22. CaLyCina.

Apothecia small usually less than $4 \mathrm{~mm}$.; bright-colored, white, yellow or rel.

Margin toothed.

23. CуATHICULA.

Margin not toothed.

Spores simple.

Apothecia stipitate or substipitate.

Apothecia entirely sessile.

24. Helotium.

25. ORBILIA.

Spores becoming septate.

Spores fusiform.

Apothecia entirely sessile.

Seated on a subiculum.

Without definite subiculum.

Spores 1-septate.

Spores 3- or more-septate.

Apothecia stipitate.

26. TRICHOBELONIUM.

27. Calloria.

28. Belonium.

29. BeLONIOSCYPHA.

Spores filiform.

Asci not strongly protruding.

Apothecia sessile.

Apothecia stipitate.

30. Gorgoniceps.

31. Pocillum.

Asci strongly protruding.

Spores brown.

32. Apostemidium.

33. Phaeohelotium. 
Tribe 3. Mollisieae. Apothecia entirely sessile, mostly minute, sordid-gray to black, superficial, or erumpent, occurring on living plants or more often on dead plant debris; asci cylindric to clavate, usually 8-spored; spores simple, or septate, hyaline, or faintly colored; paraphyses filiform to clavate.

Occurring on living plants.

Apothecia erumpent.

Spores simple.

Spores septate.

Apothecia superficial.

Occurring on dead plant debris.

Spores simple.

Apothecia subliscoid, superficial.

Seated on a subiculum.

Not seated on a subiculum.

Spores hyaline; apothecia minute.

Spores ellipsoid, on woody tissues.

Spores globose, on ascomycetous fungi.

Spores green; apothecia medium large, up to $1 \mathrm{~cm}$.

Apothecia, cupulate, often erumpent.

Spores with 3 or more septa.

Tribe 4. Ascotremelleae. Apothecia more or less gelatinous and Tremella-like, ranging in size from $1 \mathrm{~mm}$. to several cm., stipitate, or sessile; spores from ellipsoid to filiform, hyaline, or colored, simple, or septate; paraphyses filiform to clavate.

Apothecia not on a stromatic base.

Apothecia small and delicate, usually less than 1 $\mathrm{cm}$. broad.

Erumpent, sessile or subsessile.

Superficial, stipitate.

Apothecia large, usually exceeding $1 \mathrm{~cm}$. broad.

Spores simple.

Spores brown.

Spores hyaline.

Spores septate.

Spores fusoid to fusiform.

Spores filiform or vermiform.

Apothecia on a stromatic base, large $4 \mathrm{~cm}$. in diameter.
34. Pseudopeziza.

35. FABRAEA.

36. J'ESTALOPEZIA.
37. TAPESIA.

38. Mollisia.

39. Nollisiella.

40. Citinella.

41. Pyrenopezizi.

28. BELONIUM.

Tribe 5. Lachnelleae. Apothecia ranging in size from minute bodies less than $1 \mathrm{~mm}$. in diameter to nearly $1 \mathrm{~cm}$., externally clothed with well developed hairs which are sometimes closely adpressed but often presenting a wooly appearance; hairs rigid or more often flexuous, thin-walled and of ten delicately 
roughened, more rarely smooth, usually septate, varying in color from white (hyaline) to yellow, green, purple or pale- to dark-brown; asci cylindric to clavate, usually 8-spored; spores hyaline or subhyaline, globose to ellipsoid, fusiform, or filiform; paraphyses filiform, clavate, or lanceolate, in one genus with coniclium-like apices.

Spores simple or very rarely sparingly septate.

Apothecia not seated on a definite mycelial subiculum.

Spores ellipsoid to fusoid.

Paraphyses filiform-clavate, or lanceolate, without conidium-like apices.

Paraphyses with easily detached conicliumlike apices.

Spores globose.

Apothecia seated on a definite mycelial subiculum. Spores definitely septate, fusoid to filiform.

Apothecia seated on a definite subiculum.

Apothecia not on a definite subiculum.

Spores 1-septate.

Spores 3-many septate.

Hairs hyaline.

Hairs dark-brown or black.

49. LACHNELLA.

50. Diplocarpa.

51. I ACHNELLULA.

52. ERIOPEZIZA.

53. ARACHNOPEZIZA.

54. Helotiella.

55. ERINellina.

56. ECHINELLA.

1. MONILINIA Honey, Mycologia 20: 153. 1928.

Apothecia of variable size, occurring singly, or several developing from pseudosclerotia which are commonly formed within fruits of the higher plants; conidial stage consisting of a Monilia; asci clavate 8-spored; spores simple, hyaline or subhyaline; paraphyses slender, often slightly enlarged above.

Type species, Ciboria fructicola Wint.

I am indebted to Dr. Edwin E. Honey for the following notes on the genus: "All known North American species are vernal. During the life-history of members of Monilinia two types of stroma are developed (1) the ectostroma which is developed first, and which functions in the rupture of the epidermis of the host, and upon which develop the typical monilioid conidia and (2) as a result of the initial levy on the food supply of the newly invaded host or some other factor, a change takes place and in affected fruits, under favorable environmental conditions, there results the development of an entostroma, which after overwintering may give rise to apothecia. The entostroma is a 
composite stroma, that is, it is an admixture of living fungous hyphac and dead host cells in contrast to the typical sclerotium characteristic of the genus Sclerotinia as represented by Sclerotinia sclerotionum in which the sclerotium is composed entirely of fungous hyphae. The term pseudosclerotium has been used to designate this composite stroma which is so characteristic of the monilioid group.

"Emphasis has been placed on the life-history of the various species in showing relationships. It is felt that the study of any one stage, as for example, the stromatic, the apothecial or the conidial in the life-history of these species is not sufficient to adequately show true phylogenetic relationships. In order to obtain either the specific or the generic concept, all stages developed during the life-history must be given consideration. On the basis of life-histories which appear to be correlated with certain morphological characteristics, the genus Monilinia may be divided into two general groups:-

"(1) Those species in which in the spring ascospores infect the young leaves and stems resulting in the development of an ectostroma. Upon these host organs the ectostroma gives rise to conidia which in turn function as inoculum for blossom infection. Young developing fruits become infected through the blossom, and as a result pseudosclerotia are formed which commonly drop to the ground and overwinter, giving rise in the spring to apothecia which produce ascospores (the primary inoculum which again infects the young leaves and stems). Commonly but a single cycle occurs. The majority of the North American representatives fall in this sub-group, the members of which are also characterized by the presence of disjunctors within the conidial chains (a specialization for the dissemination of conidia). They are furthermore characterized by a marked sweetish odor (mandelic acid; benzaldehyde and hydrocyanic acid) emitted from infected parts of the host at about the time of conidial production and they appear to be more specialized and limited in their host range. In the Vaccinium-inhabiting members there is a tendency to suppress the development of the ectostroma in infected fruits, and to further segregate the conidial production from the apothecial production which, according to certain European workers (Fischer, Ed., etc.) reaches its climax in such forms as Monilinia Ledi ( = Sclerotinia heteroica Woronin and Nawaschin) and Monilinia Rhododendri (Sclero- 
tinia Rhododendri Fischer) in which heterocism is said to occur and in which the conidial stage occurs upon one host and the pseudosclerotial and apothecial stages upon another host.

"(2) Those members in which ascospores normally infect blossoms, upon which conidia then develop and function as inoculum for secondary cycles on fruits (chiefly). Pseudosclerotia develop within infected fruits, overwinter upon the ground and give rise to apothecia, thus furnishing ascosporic inoculum for blossom infection in the spring. Commonly many successive secondary cycles may occur. In this subgroup the sweetish odor is not evident, disjunctors between the conidia are lacking, and the members appear to be less specialized as to host. North American representatives of this group are Monilinia fructicola and Monilinia laxa.

"All known members of this genus occur as parasites on members of the three following families of plants: the Rosaceae, the Cornaceae, and the Ericaceae."

On plants of the family Rosaceae.

On plants of the genus Prumus.

Conidial stage forming brown spots on fruit.

Conidial stage Monilia cinerea americana.

Conidial stage Monilia cinerea.

1. M. fructicola.

2. M. laxa.

Conidial stage not forming brown-rots.

Conidia large, $10-20 \mu$ long.

3. M. Padi.

Conidia medium $7-15 \mu$ long.

On Prunus serotina.

On Prunis demissa.

4. M. Seaveri.

5. M. demissa.

Not on Prunus.

On Amelanchier.

6. M. Amelanchieris.

On Crataegus.

Ascospores 6-8 $\times 12-15 \mu$.

Ascospores 2-3.5 $\times 8-12 \mu$.

On plants of the family Ericaceae.

On Polycodium.

On Vaccinium.

On blueberry.

7. M. Johnsoni.

8. M. gregaria.

On cranberry.

On Azalea.

9. M. Polycodii.

10. M. T'accinii-

11. M. Oxycocci.

12. M. Azaleae.

1. Monilinia fructicola (Wint.) Honey, Mycologia 20: 153. 1928. (Plate 83.)

Ciboria fructicola Winter, Hedwigia 22: 131. 1883.

Sclerotinia fructicola Rehm; Sacc. Syll. Fung. 18: 41.1906.

Monilia cinerea forma americana Wormald, Ann. Bot. 34: 168. 1920.

Sclerotinia americana Norton \& Ezek. Phytopathology 14: 31. 1924. 


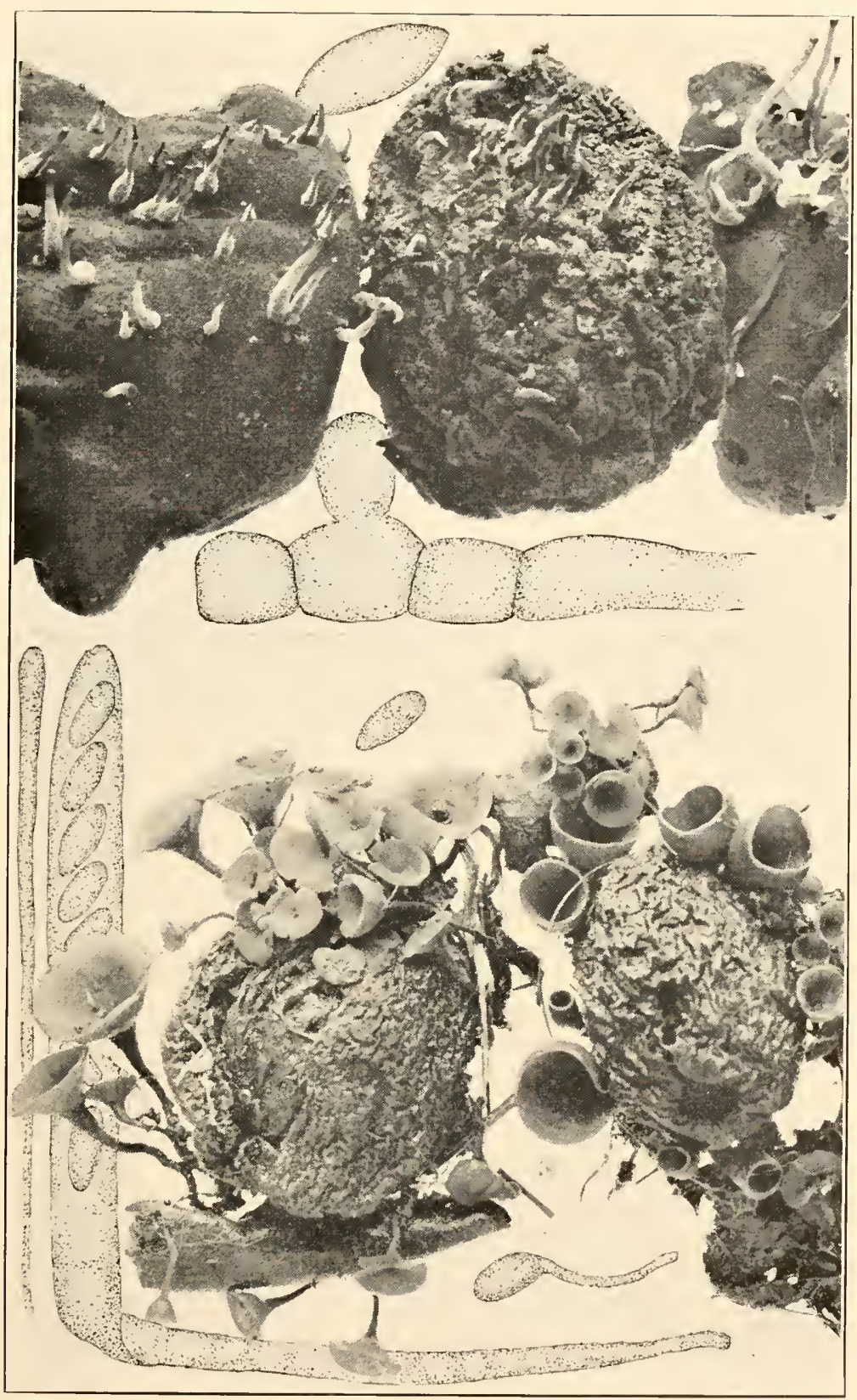

MONILINIA FRUCTICOLA 

Conidiophores commonly arising from a well-developed ectostroma which ruptures the epidermis of the host, ash-gray or dark-olivaceous, producing simple, or branched conidial chains; conidia ellipsoid, elongate-ellipsoid, or rarely spherical, developed in chains, hyaline, or light-colorerl; microconidia present small, spherical, hyaline on short-clavate conidiophores.

Apothecia occurring in consiclerable numbers from a mummified fruit, stipitate, shallow cup-shaped, or nearly planc at maturity, reaching a diameter of $1-1.5 \mathrm{~cm}$., pale-brown; hymenium usually concave, darker than the outside of the apothecium; stem of variable length but often reaching $2-3 \mathrm{~cm}$; asci cylindric-clavate, 8 -spored; spores ellipsoid, containing one or more oil-drops, $3-3.5 \times 6-7 \mu$, hyaline or slightly colored: paraphyses simple, or branched near their bases.

On overwintering orchard fruits.

Type Locality : Europe.

Distribution: Eastern North America; also in Europe.

Illustrations: Mycologia 20: 149, f. $1-2 ; 154, f .3-f ; p l$. 17-19; 37: 671, f. 8-10; Phytopathology 32: 635, f. 1 .

The cause of brown-rot of fruits throughout Eastem North America. Not to be confused with Sclerotinia fructigena (Pers.) Schröt. of Europe, with which it was at first thought to be identical.

2. Monilinia laxa (Ehrenb.) Honcy, Am. Jour. Bot. 23: 105. 1936.

Oidium laxum Ehrenberg, Sylvae Mỵc. Ber. 22. 1818.

Acarosporium laxum Pers. Myc. Eu. 1: 25. 1822.

Oospora laxa Wallr. in Bluff \& Fing. Fl.-Crypt. Ger. 4: 183.1883.

Monilia cinerea Bonord. Handbk. Myk. 76. 1851.

Monilia laxa Sacc. \& Vogl.; Sacc. Syll. Fung. 4: 35. 1886.

Sclerotinia cinerea Schröt. in Cohn, Krypt.-Fl. Schles 3²: 67. 1893.

Sclerotinia laxa Aderh. \& Ruhl, Gesundheits Arbeit. Land.-Forstw. Berlin 4:

437. 1905. (Citation from Whetzel.)

Sclerotinia cinerea Schröt.; Wormald, Ann. Bot. 35: 134. 1920. (in part.)

Stromatinia laxa Chifflot. Ann. Ephip. 7: 317. 1921.

Monilia oregonensis Barss \& Posey; Barss, Oregon Exp. Sta. Cir. 53: 5. 1923.

Conidial stage consists of a Monilia of the cinerea type; conidia 9-15 $\times 12-23 \mu$.

Apothecia springing from a mummified fruit, usually several from the same stroma, stipitate, at first clavate, expanding and becoming cup-shaped, finally nearly plane with an umbilicate center, reaching a diameter of $49 \mathrm{~mm}$., gray, or almost white; 
hymenium concave, or nearly plane; asci cylindric, narrowed below, reaching a length of about $175-180 \mu$ and a diameter of 8-9 $\mu, 8$-spored; spores ellipsoid, 1-seriate, or becoming partially 2-seriate, about $6 \times 12 \mu$ in diameter; paraphyses slender, slightly enlarged above, $2-2.5 \mu$ in diameter.

On mummified plums, Prumus.

Type locality : Europe.

Distribution: Wisconsin and the Pacific Coast; also in Europe, and reported from Japan.

Illustrations: Ann. Bot. 35: pl. 6, 7 .

3. Monilinia Padi (Wor.) Honey, Am. Jour. Bot. 23: 105.1936.

Sclerotinia Padi Woronin, Mem. Acad. Sci. St. Petersburg V'lll. 2: 3-14. 1895. Sclerotinia angustior Reade, Ann. Myc. 6: 113. 1908.

Monilia Peckiana angustior Sacc. Syll. Fung. 10: 517. 1902.

Monilia angustior Reade, Ann. Myc. 6: 113. 1908.

Conidial stage (Monilia) effused, ash-gray, occurring on the stems, petioles, sometimes on the principal veins on the backs of the leaves, later on the immatured fruit in minute, scattered cespitulae, the conidia citron-shaped, hyaline, simple, 10-20 $\mu$ long, in long di- or trichotomously branched chains with slender, fusiform disjunctors $2-3 \mu$ long; microconiclia in clusters, globose, $2.5-3 \mu$; sclerotia in mummified fruits.

Apothecia one or two from a single mummy, 5-20 $\mathrm{mm}$. high, at first closed, expanding to saucer-shaped, 2-5 mm. in diameter, Isabel-colored; stem smooth, slender, cylindric, slightly tapering toward the base, reaching a length of 3-15 mm. and a diameter of $1 \mathrm{~mm}$; asci cylindric-clavate, reaching a length of 150-160 $\mu$ and a diameter of 8-10 $\mu, 8$-spored; spores obliquely 1-seriate, ellipsoid, simple, 5-6 $\times 10-11 \mu$; paraphyses scattered, slender, $2 \mu$ thick below, enlarged above to $4 \mu$.

Parasitic on twigs, leaves, and fruits of Prumus virginiana, apothecia appearing during the latter part of April and the conidial stage on leaves in May and on fruit in June.

Type Locality: Ithaca, New York.

Distribution: Known only from the type locality.

This species is said to be closely related to Monilinia Seaveri but differs in having larger conidia borne upon the twigs and petioles rather than upon the upper surface of the leaves and in the occurrence on a different host. 
4. Monilinia Seaveri (Rehm) Honey, Am. Jour. Bot. 23: 105. 1936. (Plate 84.)

Sclerotinia Seaveri Rehm, Ann. Myc. 4: 66. 1906.

Monilia Seaveri Reade, Ann. Myc. 6: 112. 1908.

Conidial stage (Monitia) effused, ash-gray, epiphyllous or sometimes on the twigs also, still later in minute cespitulae on immature fruits, the conidia citron-shaped, simple, hyaline, 7-15 $\mu$ long, in long di- or trichotomously branched chains with slender, fusiform disjunctors 3 or $4 \mu$ long; sclerotia formed in mummified fruits.

Apothecia one or two from a single mumny, about $1 \mathrm{~cm}$. high, long-stipitate, at first closed then expanding and becoming saucer-shaped to convex and umbilicate, reaching a diameter of $11 \mathrm{~mm}$.; stem slender, reaching a length of 5-20 mm.; asci cylindric-clavate, reaching a length of $155-180 \mu$ and a diameter of 8-11 $\mu, 8$-spored; spores obliquely 1 -seriate, ellipsoid, hyaline, simple, 5-8 × 11-17 ; paraphyses sparse, filiform, slightly enlarged above.

Parasitic on leaves, twigs, and fruits of Prunus serotina.

Trpe locality: Iowa City, Iowa.

Distribution: New York to Iowa, and south to Georgia.

Illustrations: Phytopathology 30: 89, f. 1 .

Exsiccati: Rehm, Ascom. 1633.

This species has been reported as destructive to young cherry seedlings by John C. Dunegan of Fayetteville, Arkansas (Phytopathology 30: 89. 1940.), as follows: "A Blight of Wild Cherry Seedlings.-A blighting of wild cherry (Prunus serotina.) seedlings has been under observation since 1924. The disease, caused by Sclerotinia Seaveri Rehm, appears each spring about the time the second pair of true leaves unfolds. The first symptom is the development of a brown water-soaked region near the apex of the stem. This condition is accompanied by a loss of turgor and the infected seedlings are readily detected by the characteristic drooping of the affected portion of the stem. The infection spreads from the stem into the leaves through the petiole and midrib. The basal portion of the leaf turns brown and finally the whole leaf is affected, assuming a bleached grey color. Conidial masses frequently develop on the leaves. The fungus continues to spread down the stem and, when it reaches the ground line, the young plant dies. 
"The disease was observed in Fort Valley, Georgia, from 1924 to 1928 and subsequently has been observed in the vicinity of Fayet teville, Arkansas.

"In 1928, 3 quadrats, each 1 sq. $m$. in area, were laid out at random under a large tree near Fort Valley, Georgia. Although the total number of seedlings blighted during the period of seedling germination was not ascertained, the counts made on April 4 showed from 34 to 62.5 per cent of the seedlings affected on that date. It is evident from these figures that the disease must be considered as a factor limiting the reproduction of Prumus serolina in the South."

5. Monilinia demissa (Dana) Honey, Am. Jour. Bot. 23: 105. 1936.

Sclerotinia demissa Dana, Phytopathology 11: 106. 1921.

Conidia (Monilia) produced in unbranched chains, ovoid to globose, hyaline, cream-colored in mass, simple, 3-9 $\times 7-14 \mu$; sclerotia in mummied fruits.

Apothecia mostly solitary, sometimes two from a mummy, long-stipitate, brown, glabrous, at first cup-shaped, later flat; stem 1-3.5 cm. long; asci hyaline, 8-spored, reaching a length of $150-160 \mu$ and a diameter of $7 \mu$; spores ellipsoid, 1-seriate, hyaline, one end narrower than the other, 5-6 $69-15 \mu$; paraphyses slender.

Conidial stage on living leaves, twigs, and fruits of Prumus demissa; the perfect stage on overwintered mummies of the same host.

Type Locality: Pullman, Washington.

Distribution: Known only from the type locality.

Illustrations: Phytopathology $11: p l .8, f .4-6$.

6. Monilinia Amelanchieris (Reade) Honey, Mycologia 34: 575. 1942.

Sclerotinia Amelanchieris Reade, Ann. Myc. 6: 114. 1908.

Entostroma formed within the fallen, overwintering, mummied fruits; microconidia small, 2.5-3.5 $\mu$ in diameter, globose, hyaline, associated with mummied fruits containing entostroma, produced at one or both poles of the ascospores remaining in old apothecia, on conidia, on mycelium directly, or on single or clustered, flask-shaped spermatiophores. 


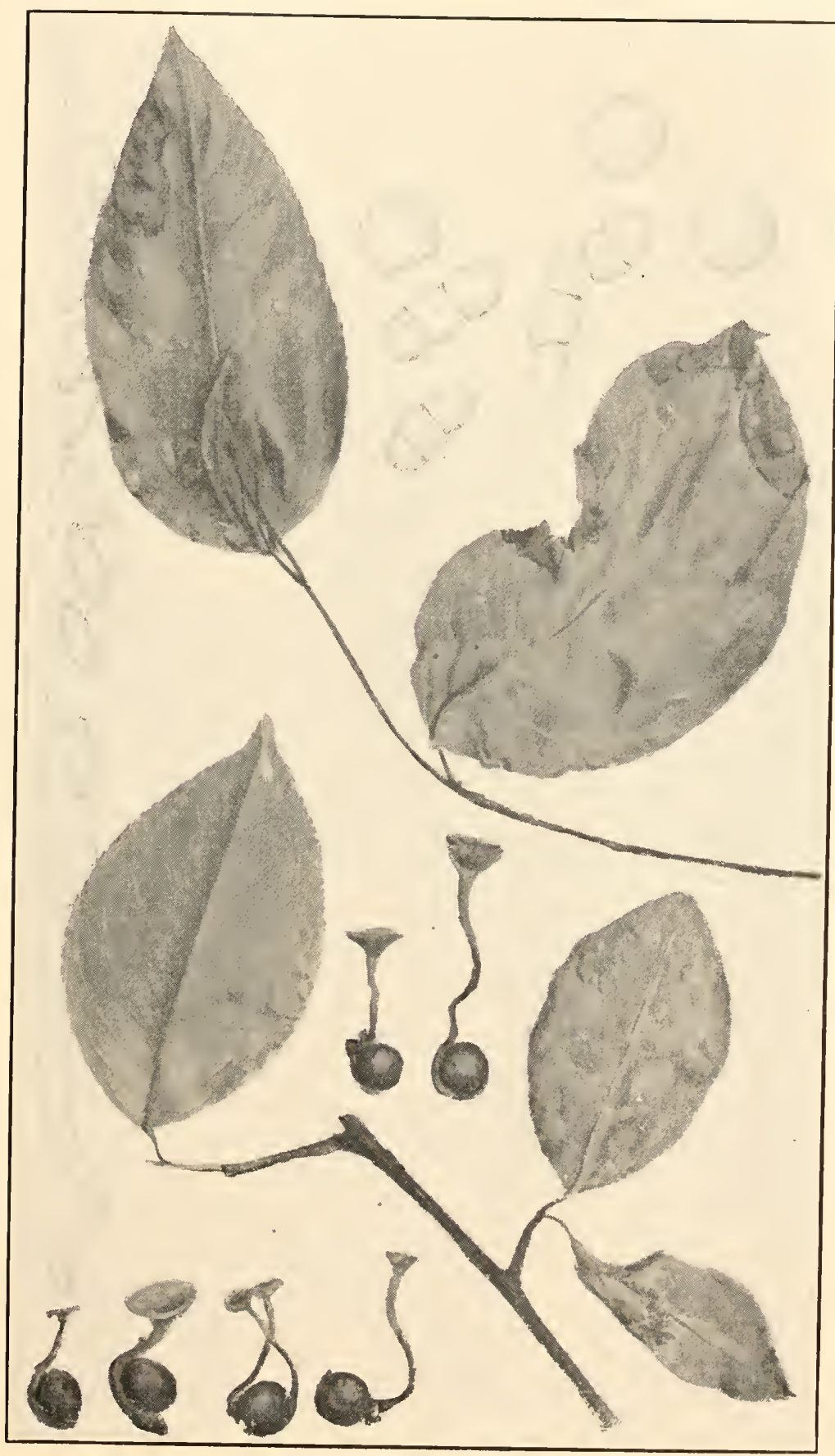



Apothecia one to three, generally one arising as small, pointed fundaments from the entostroma, commonly from the blossom end but may appear at any point, reaching a height of $34 \mathrm{~cm}$., cyathoid, 1.5-9 mm. in diameter, stipitate; stem smooth, slender, cylindric, tapering below, $1 \mathrm{~mm}$. thick and reaching a length of $3.5-4 \mathrm{~cm}$; asci cylindric-clavate, reaching a length of 117-188 $\mu$ and a diameter of 6-13 $\mu, 8$-spored; spores commonly obliquely 1-seriate, ellipsoid, 5.5-9 $\times 10-15 \mu$; paraphyses moderately abundant, filiform, slightly swollen above, 3.3-5.5 $\mu$ in diameter.

Apothecial stage on overwintering mummied fruits of $A$ melanchier intermedia on the ground during April and May; conidial stage parasitic on Amelanchier intermedia, A. camadensis. A. oblongifolia and unnamed species of Amelanchier about the middle of June.

Type locality: New York.

Distribution: New York.

7. Monilinia Johnsoni (Ellis \& Ev.) Honey, Am. Jour. Bot. 23: 105. 1936.

Ciboria Johnsoni Ellis \& Ev. Proc. Acad. Phila. 1894: 348.1894.

Monilia Crataegi Diedicke, Ann. Myc. 2: 529.1904.

Sclerotinia Crataegi Magnus, Ber. Deutsch. Bot. Ges. 23: 197.1905.

Sclerotinia Johnsoni Rehm, Ann. Myc. 4: 338. 1906.

Conidial stage (Monilia) on leaves of the host, epiphyllous, effused, ash-gray to olive-buff, the conidia citron-shaped to globose, hyaline, 11-20 $\mu$ in cliameter, in long di- and trichotomously branched chains with fusiform disjunctors 5-6 $\mu$ long; sclerotia formed in mummified fruits.

Apothecia one to several from a single mummy, $1-4.5 \mathrm{~cm}$. high, long-stipitate, fawn-colored, clarker with age; at first closed, then expanding, becoming cup-shaped or saucer-shaped, umbilicate, reaching a diameter of 3-10 $\mathrm{mm}$.; stem smooth, slender, cylindric, tapering slightly below, reaching a length of $1-4 \mathrm{~cm}$. and a diameter of $1 \mathrm{~mm}$.; asci cylindric-clavate, reaching a length of $140-150 \mu$ and a diameter of $8-10 \mu, 8$-spored; spores obliquely 1-seriate, ellipsoid, hyaline, simple, 6-8 8 12-15 $\mu$; paraphyses filiform, clavate, hyaline.

Parasitic on leaves of Crataegus punctata.

Type Locality: Ann Arbor, Michigan.

Distribution: New York to Michigan.

Illustrations: Ber. Deutsch. Bot. Ges. 23 : pl. 5.

Exsiccati: Ellis \& Ev. N. Am. Fungi 3131. 
8. Monilinia gregaria (Dana) Honey, Am. Jour. Bot. 23: 105. 1939.

Sclerotinia gregaria Dana, Phytopathology 11: 106. 1921.

Conidia light-gray in mass, globose to lemon-shaped, 4-13 $\times$ 5-13 $\mu$; microconidia globose produced singly on short sporophores 2-3.5 $\mu$ in diameter.

Apothecia gregarious pale-gray in color at first, later becoming darker, at first cup-shaped later flat, circular, 1-5 mm. in diameter, stipitate; stem 1-3 $\mathrm{mm}$. in length; asci clavate, reaching a length of 48-57 $\mu$ and a diameter of 5-6 $\mu$, 8-spored; spores 1 -seriate, hyaline, containing two oil-drops, pointed at one end, 2-3.5 $\times 8-12 \mu$; paraphyses simple, or branched reaching a diameter of $2 \mu$.

Conidial stage on living leaves and fruits of Amelanchier Cusickii; the ascigerous stage on mummied fruits of the same host.

Type Locality: Pullman, IVashington.

Distribution: Known only from the type locality.

Illustrations: Phytopathology $11: p l .8, f .1-3$.

While this species has been recorded, Honey expresses some doubt, suspecting that the wrong fungus may have been reported as the perfect stage of the Monilia.

9. Monilinia Polycodii (Reade) Honey, Am. Jour. Bot. 23: 106. 1936.

Sclerotinia Polycodii Reade, Ann. Myc. 6: 110. 1908. Monilia Polycodii Reade, Ann. Myc. 6: 110. 1908.

Coniclial stage (Monilia) on blighted shoots of the host, effused, powdery, ash-gray to olive-buff, on stems, petioles, and miclribs at the base of the leaf-blades, or in minute cespitulae on mummified fruits, the conidia citron-shaped, simple, hyaline 11-13 $\times 15-18 \mu$ in long di- or trichotomously branched chains with fusiform disjunctors $3-5 \mu$ long; sclerotia formed in the mummified fruits; microconidia on mummified fruits in the open and on spores and mycelium in cultures, sphaerical, $2.5-3 \mu$ in diameter, hyaline with a central refractive spot.

Apothecia single, or three or four from a mummy, 1-3.5 cm. high, at first closed then expanding, cup-shaped or sometimes convex and umbilicate .5-1 mm. in diameter, stipitate; hymenium wood-brown, darker outside; stem smooth, cylindric, 1-3 mm. thick and 1-3 cm. long; asci cylindric-clavate, reaching a length 
of 200-240 $\mu$ and a diameter of $10-14 \mu, 8$-spored ; spores obliquely 1-seriate, ellipsoid, hyaline, simple, with two oil-clrops, 10-12 $\times$ 15-20 $\mu$; paraphyses slender, simple, $2 \mu$ thick, slightly enlarged above.

Parasitic on twigs and fruits of Polycodium stamineum.

TyPE locality: Ithaca, New York.

Distribution: New York.

10. Monilinia Vaccinii-corymbosi (Reade) Honey, Am. Jour. Bot. 23: 105. 1936.

Sclerotinia Vaccinii-corymbosi Reade, Ann. Myc. 6: 109. 1908.

Monilia l'accinii-corymbosi Reade, Ann. Myc. 6: 109. 1908.

Conidial stage (Monilia) on blighted shoots of the host, effused, powdery, ash-gray to olive-buff, on stems, petioles and midribs at the base of the leaf-blades or on peduncles of blighted flowers; citron-shaped, continuous, hyaline, the conidia 19-25 $\times$ 23-32 $\mu$, in long di- or trichotomously branched chains, with fusiform disjunctors $2 \times 3-5 \mu$; sclerotia formed on mummified fruits, microconidia on spores and mycelium in cultures 2.5-3 $\mu$, globose, hyaline with a central refractive spot.

Apothecia one to several from a single mummy, $1-3.5 \mathrm{~cm}$. high and 5-10 $\mathrm{mm}$. in diameter, cup-shaped, somewhat convex, or cyathiform, stipitate; hymenium fawn-colored, outer surface darker and satiny; stem smooth, slender, cylindric, reaching a length of 1-3 cm. and a diameter of 1-2 mm., slightly tapering and shading into clove-brown below; asci cylindric-clavate, reaching a length of $200-260 \mu$ and a diameter of $10-12 \mu, 8$ spored; spores obliquely 1-seriate, ellipsoid, 9-10 $\times 14-18 \mu$, simple, hyaline, containing a few granules; paraphyses slender, simple, 2-3 $\mu$ in diameter, slightly swollen at the tips,

Parasitic on twigs and fruits of Vaccinium corymbosum.

Type Locality: Malloryville, New York.

Distribution: New York and Massachusetts.

Illustrations: Mycologia 20:pl. 13, f.d, $e, i$.

11. Monilinia Oxycocci (Moron.) Honey, Am. Jour. Bot. 23 : 105. 1936.

Sclerotinia Oxycocci Woronin, Mem. Acad. Sci. St.-Petersburg. 36" 28.1888.

Coniclial stage as in Monilinia Vaccinii-corymbosi.

Apothecia arising from sclerotia in the mummified fruits, usually one from each sclerotium, stipitate, the stem often $4-5$ 
cm. long and slender, about $1 \mathrm{~mm}$. in diameter, gradually expanding above into the cup which is at first rather deep, becoming shallow cup-shaped, or often reflexed, reddish-brown, about $5 \mathrm{~mm}$. in diameter and often as deep; hymenium concave, plane, or convex, similar in color to the outside of the apothecium; asci clavate, reaching a length of $150 \mu$ and a diameter of 5-6 $\mu$, 8-spored; spores ellipsoid, $6 \times 12-14 \mu$; paraphyses gradually enlarged above.

On fallen fruits of cranberry, Taccinium Oxycoccos.

Type locality : Europe.

Distribution: Where the cranberry is cultivated.

Illustrations: Mem. Acad. Sci. St. Petersburg $36^{6}:$ pl. 7.

12. Monilinia Azaleae Honey, Phytopathology 30: 537. 1940.

Ectostroma developed beneath the epidermis, particularly on the leaves, the young succulent shoots and fruits forming as ashgray coating of the conidial fructification, commonly on the upper surface of the midrib of the leaf and the surface of the fruits; conidia limoniform, simple, hyaline, 8.5-19 $\times 5.5-14.5$ borne on long di- and trichotomously branched chains, disjunctors commonly present between the conidia; microconidia not observed; pseudosclerotia developing in the infested capsules, at maturity filling the loculi of the immature fruit with a solid mass of thickwalled, hyaline hyphae, falling to the ground and overwintering.

Apothecia one or two arising as small fundaments from the outer surface of the pseudosclerotia, reaching a height of .8-3.5 cmi., cyathoid to patelliform, .2-1.4 cm. in diameter, stipitate; stem smooth, slender, cylindric, tapering downward, reaching a length of .4-3 cm. and a diameter of .5-2 mm.; asci cylindricclavate, reaching a length of $178-258 \mu$ and a diameter of $11-$ $16.5 \mu, 8$-spored; spores obliquely 1-seriate, or occasionally irregularly arranged, ellipsoid, 5-14 × 9-20 $\mu$; paraphyses filiform slightly swollen above.

Apothecia in May on overwintering fruits of Rhododendron roseum; conidial stage on leaves, young shoots and on the young fruits of Rhododendron spp. in June and July.

TyPE Locality: Ithaca, New York.

Distribution: New York and Georgia.

\section{Doubtful Species}

Monilinia Corni (Reade) Honey, Am. Jour. Bot. 23: 105. 1936; Sclerotinia Corni Reade, Ann. Myc. 6: 113. 1908; Monilia Corni Reade, Ann. Myc. 6: 113. 1908. According to Reade the apothecial stage of this species is un- 


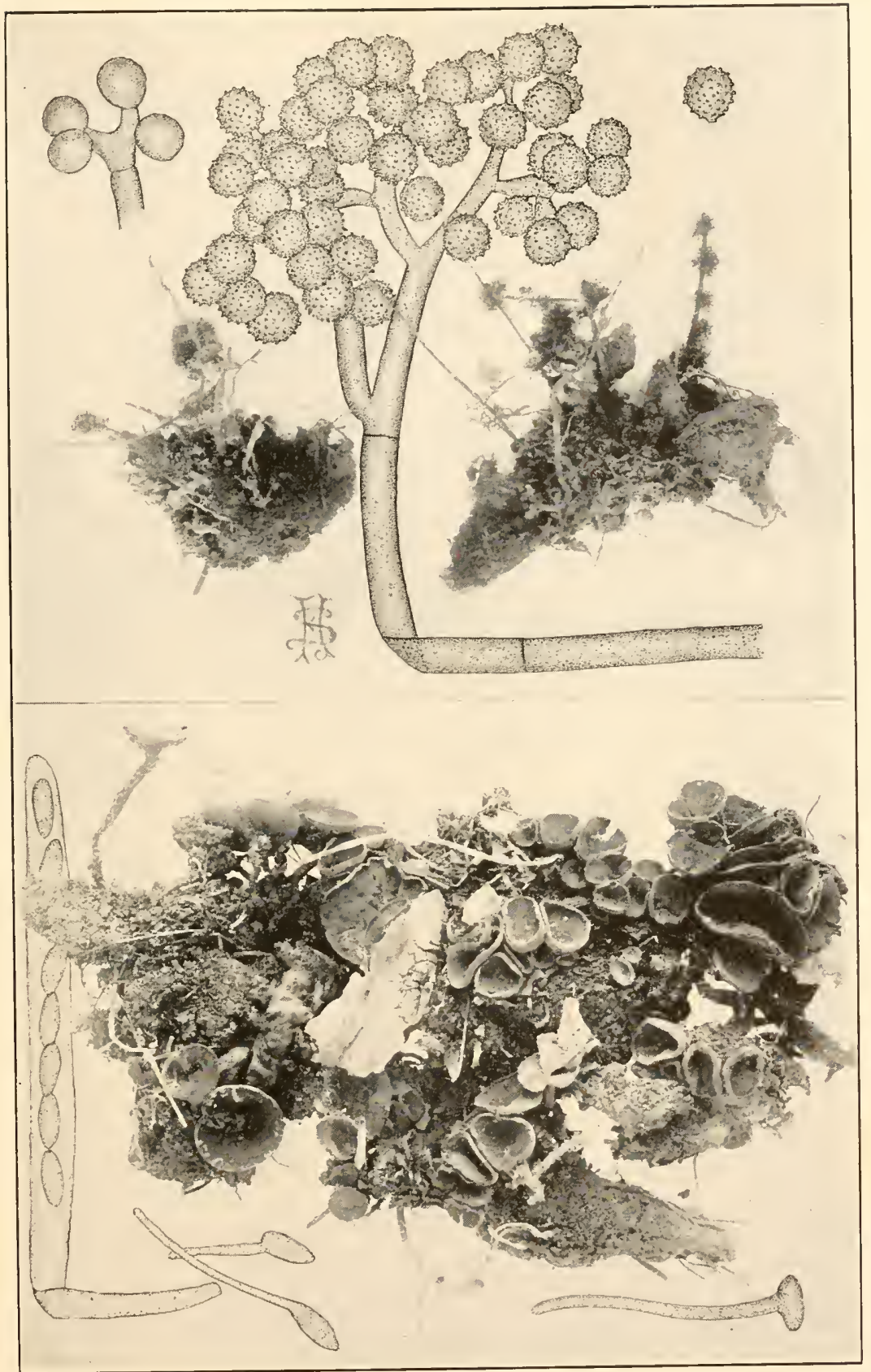



known. Honey believes that this is a good species even though the connection with a perfect has not actually been proven.

In addition to the species listed above, two others were listed by Edwin E. Honey (Am. Jour. Bot. 23: 105. 1936) as follows: Monilinia emarginata on Prunus emarginata and Monilinia Aroniae on Aronia spp. So far as we are aware these are still unpublished and must remain in doubt.

Monilinia Urmula (Weinm.) Whetzel, Mycologia 37: 673. 1945; Peziza Lrmula Weinm. Flora 15: 455. 1832; Pesiza (Phialea) Lrmula Veinn. Hymeno-Gastero-Mycetes 459. 1836; Sclerotinia Vaccinii Woron. Nem. Acad. Sci. St. Petersb. 36: 3. 1888. This species has been reported from Washington by Dr. B. Kanouse on I'accinium sp. There seemed to have been some doubt in Whetzel's mind as to the identity of Phialea C'mula Weinm. and Sclerotinia V'accinii Woron.

\section{SEAVERINIA Whetzel, Mycologia 37: 703. 1945.}

Stroma substratal, poorly developed, perhaps vestigial, not a definite sclerotium, formed in the rhizonles of the host and visible on its surface usually as a narrow, black line; spermatia not observed; conidial stage a Botrylis; conidiophores botryose $1 \mathrm{~mm}$. or more in length, pale-brown, sparingly septate, formed in tufts on the rhizome and roots of the host and, uncler moist conditions, profusely developeel, bearing conidia in rather dense clusters, conidia pale-brown, minutely, but definitely tuberculate, subglobose, tapering somewhat to the point of attachment.

Apothecia arising from the partially decayed rhizome, stipitate, the length of the stem varying considerably depending on the depth to which the rhizome is buried, shallow cup-shaped, reaching a diameter of $15 \mathrm{~mm}$; asci cylindric or subcylindric, 8spored; spores ellipsoid, hyaline.

Type species, Sclerotinia Geranii Seaver \& Horne.

1. Seaverinia Geranii (Seaver \& Horne) Whetzel, Mycologia 37: 705. 1945. (Plate 85.)

Sclerotinia Geranii Seaver \& Horne, Mem. Torrey Club 17: 205. 1918. Stromatinia Geranii Seaver \& Horne, Mem. Torrey Club 17: 206. 1918.

Conidial stage (Botrytis) occurring on the roots and rootlets of the host, being especially abundant when left in moist chamber for a few clays and even developing on the outside of the apothecia, usually appearing in tufts and often springing from minute, sclerotium-like bodies, although the latter are not always present, dark-brown in mass at maturity; conidiophores reaching a length of $1 \mathrm{~mm}$. or more and a diameter of $10-15 \mu$, pale-brown, sparingly septate and branched, the conidia borne in rather large masses like bunches of grapes; conidia subglobose 
or pyriform, the small end representing the point of attachment, reaching a diameter of $10 \mu$ or rarely as large as $12 \mu$, slightly longer than broad, at first smooth, becoming quite strongly roughened, pale-brown with transmitted light.

Apothecia springing from the partially decayed rootstocks in clusters of variable numbers, stipitate, shallow-cup-shaped, or subcliscoid, reaching a diameter of $1 \mathrm{~cm}$. or rarely larger, palebrown externally; hymenium concave or nearly plane, a little clarker than the outside of the apothecium; stem reaching a diameter of $2 \mathrm{~mm}$. and of ten reaching a length of several $\mathrm{cm}$., though often short and occasionally almost wanting, the length varying with the depth to which the rootstocks of the host are buried; asci cylindric or subcylindric, 8-spored, reaching a length of $120-140 \mu$ and a diameter of $8-10 \mu$; spores hyaline, ellipsoid, or almond-shaped, $4-5 \mu \times 12 \mu$, usually containing two very small oil-drops.

On the rootstocks of wild geranium (Geranium maculatum).

Type locality: Van Cortlandt Park, New York, N. Y.

Distributions: New York and Wisconsin.

Illustrations: Mem. Torrey Club 17: pl. 3; Mycologia 37: 704, f. 32, 33; 706, f. 3t-36; 39: 117, f. 1 .

This fungus occurs regularly season after season in abundance in the same region in the suburbs of New York City.

3. STREPTOTINIA Whetzel, Mycologia 37: 684. 1945. (Plate 86.)

Stroma a small, black sclerotium, flattened, or hemispherical, firmly attached to the substratum and flat or flattish on the attached surface; conidiophores as in Botrytis except that the branches are strikingly and characteristically twisted tightly as in Streptothrix; conidia smooth, hyaline or nearly so; apothecia minute, short-stipitate; asci 8 -spored; spores hyaline, ellipsoid.

Type species, Streptotinia Arisaemae Whetzel.

Streptotinia Arisaemae Whetzel, Mycologia 37: 686. 1945.

Stroma and conidia as above.

Apothecia stipitate, $1 \mathrm{~mm}$. or less in diameter; asci reaching a length of $100-150 \mu$ and a diameter of $8-10 \mu$; ascospores, 4-6 $\times 8-14 \mu$.

On disintegrating leaves of Arisaema triphyllum.

Type Locality: Ithaca, New York.

Distribution: Known only from the type locality.

Illustrations: Mycologia 37: 685, f. 22-24. 


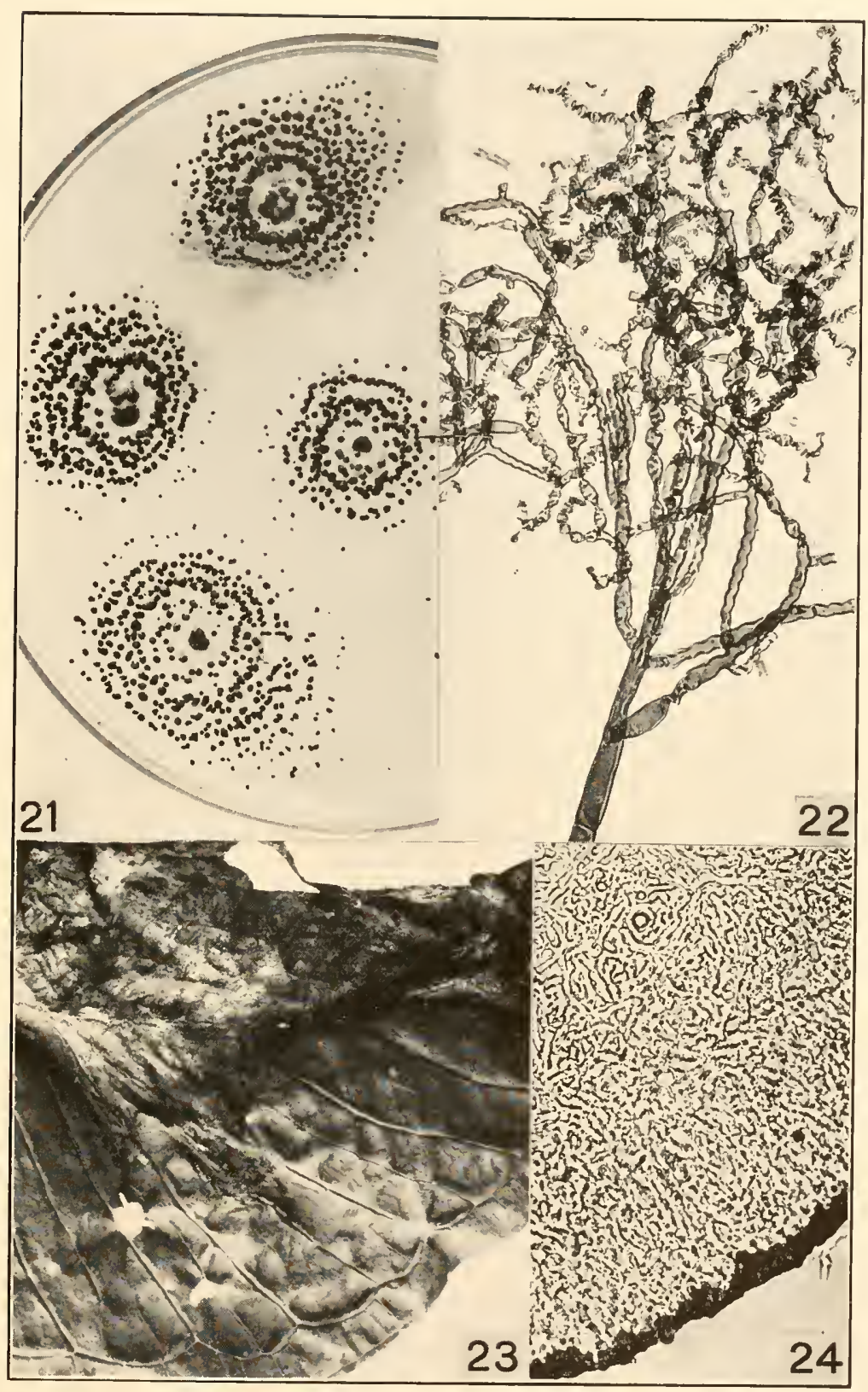

STREPTOTINIA ARISAEMAE 

4. BOTRYOTINIA Whetzel, Mycologia 37:678. 1945.

Stroma consisting of a black, flattened, or irregularly hemispherical sclerotium, usually formed just beneath the cuticle of the epidermis, finally erumpent, remaining firmly attached to the host; spermatia globose, borne on branching spermatiophores, enveloped in a mucilaginous matrix; conidial stage a Botrytis; conidia on short sterigmata in dense clusters, smooth, subglobose to pyriform.

Apothecia cupulate, stalked, some shade of brown, infundib. uliform to discoid, or margin reflexed; asci cylindric, or subcylindric; spores hyaline, simple, ellipsoid.

Type species, Sclerotinia convoluta Drayton.

On garden Iris.

On Ricinus.

In stems of Gladiolus.

On Narcissus.
1. B. convoluta.

2. B. Ricini.

3. B. Draytont.

4. B. narcissicola.

1. Botryotinia convoluta (Drayton) Whetzel, Mycologia 37:679. 1945.

Botrytis conwoluta Whetzel \& Drayton, Mycologia 24: 475. 1932.

Sclerotinia convoluta Drayton, Mycologia 29: 314. 1937.

Sclerotia shining-black, convolute, agglomerated, reaching a size of $16 \times 18 \mathrm{~mm}$., frequently hollow in the center; conidiophores brown, erect, fasciculate, branched at the apex, about 1 mm. tall and 9-12 $\mu$ thick at the base, tapering toward the apex; coniclia light-brown, simple, smooth, ovoid to slightly pyriform, borne in dense clusters on sterigmata produced from the ultimate branchlets of the conidiophores, averaging $9 \times 11 \mu$; microconidia present, $4-4.5 \mu$ in diameter.

Apothecia densely gregarious, arising from the sclerotial agglomerations, infundibuliform to cyathiform, becoming discoid, reaching a diameter of $2.5-4 \mathrm{~mm}$., stipitate; stems reaching a length of 3-6 mm.; asci cylindric, reaching a length of 150-195 $\mu$ and a diameter of $9-13 \mu, 8$-spored; spores 1-seriate, ellipsoid, hyaline, simple, at maturity with several oil-elrops, averaging $7 \times 15 \mu$; paraphyses abundant, filiform, hyaline, $2.5-3 \mu$, slightly enlarged above.

On garden Iris.

Type Localoty: Central Experimental Farm, Ottawa, Canada. 
Distribution: New York and Canada.

Illustrations: Mycologia $24: 473, f .1 ; p l .15, f .1,2 ; p l .16$, f. 3-5; Mycologia 29: 307, f. 1, 2; 309, f. 3 5; 312, f. 6; 313, f. $7-9 ; 37: 681, f .19,20$.

2. Botryotinia Ricini (Godfrey) Whetzel, Mycologia 37: 680 . 1945.

Sclerotinia Ricini Godfrey, Phytopathology 9: 566.1919.

Conidlial stage (Botrytis) forming wide-spread, cobwebby or somewhat woolly masses, pale drab-gray, dried specimens dark olive-gray; fertile hyphae long slender, olivaceous when mature, dichotomously branched, terminal branches compact, collapsing when conidia fall; conidia borne on sterigmata, globose, smooth, hyaline, 6-12 $\mu$ in diameter; microconidia globose, hyaline, $2-3.5 \mu$ in diameter, on short, obclavate conidiophores from the sides of the hyphae or tips of special branches; sclerotia black, rough, elongate, irregular, 1-25 mm. in diameter.

Apothecia one to several from a single sclerotium, 5-30 $\mathrm{mm}$. high, usually 6-15 mm., infundibuliform to cyathiform and discoid, stipitate, cinnamon-brown to chestnut-brown, becoming saucer-shaped, with the margin somewhat recurved, 1-7 $\mathrm{mm}$. in diameter; stem cylindric, slender, smooth, flexuous; asci cylindricclavate, reaching a length of $50-110 \mu$ and a diameter of 6-10 mm., 8-spored; spores ellipsoid to subfusoid, hyaline, simple, containing two oil-drops, $4-5 \times 9-12 \mu$; paraphyses abundant, filiform, septate, hyaline, $1.5-2 \mathrm{~mm}$. in diameter.

Parasitic on Ricinus communis, on inflorescence, or on leaves.

Type locality: Orlando, Florida.

Distribution: Florida to Texas and Cuba.

Illustrations: Phytopathology 9: pl. 40, 41.

3. Botryotinia Draytoni (Buddin \& Wakef.) Seaver, comb. nov. Sclerotinia Draytoni Buddin \& Wakefield, Trans. Brit. Myc. Soc. 29: 150. 1946.

Sclerotia black, smooth, applanate, then convex-lenticular, about 3-7 $\times$ 8-12 mm., in irregular masses about $2.5 \mathrm{~cm}$. long, agglutinate, white within; microconidia globose, $2-2.5 \mu$ in diameter; macroconidiophores, springing from the sclerotium, erect, brown below, $12-15 \mu$ in diameter, above hyaline, two to three branched, the branches capitate, with numerous minute sterigmata; conidia hyaline, or pale-brown, ellipsoid, or broadly. ovoid, 5-7.5 $\times 8-16 \mu$. 
Apothecia long-stipitate, occurring singly, or several from each sclerotium, at first infundibuliform with the margin incurved, then umbilicate-discoid, finally slightly convex with the margin reflexed, 2.5-5 $\mathrm{mm}$. in diameter; hymenium yellowisholivaceous, the margin at first brown, then pallid; stem 10-13 $\mathrm{mm}$. long, flexuous, enlarged above, same color as the hymenium, brown below; asci cylindric, 8 -spored, reaching a length of 140-190 $\mu$ and a diameter of 9-10 $\mu$; spores 1-seriate, broadellipsoid, or subfusiform, hyaline, often with two oil drops, $6-8 \times$ 12-17 $\mu$; paraphyses filiform, enlarged above.

On the stems of cultivated Gladiolus.

Trpe locality : Europe.

Distributiox: Known only from the type locality.

This species is included since it was named in honor of an American mycologist, Dr. F. L. Drayton, although it has not been reported from America. It is not unlikely that it will be found here also.

Illustrations: Trans. Brit. Myc. Soc. 29: 151, f. 11.

4. Botryotinia narcissicola (Gregory) Seaver, comb. nov.

Sclerotinia narcissicola Gregory, Trans. Brit. Myc. Soc. 25: 37. 1941.

Conidial stage a Botrytis (Botrytis narcissicola Kleb.); sclerotia black; smooth, more or less globose, $1-1.5 \mathrm{~mm}$.

Apothecia occurring singly on the sclerotium, cup-shaped, becoming funnel-shaped, or expanded and plane, reaching a diameter of $2.5 \mathrm{~mm}$., sepia to raw-umber when moist; stem 1.5-5 $\mathrm{mm}$. or more long, tapering below; asci reaching a length of $126-$ $140 \mu$ and a diameter of $8 \mu$; spores 1 - or 2-seriate, hyaline, navicular, often with two oil-drops, 5-9 × 10-20 ; paraphyses filiform.

On old leaves and bud scales of species of Narcissus.

Type locality: Europe.

Distribution: Conidial stage widely distributed in the United States. The apothecia stage has not been seen but doubtless could be found.

Illustrations: Trans. Brit. Myc. Soc. 25 : pl. 2, f. 2-8.

\section{SEPTOTINIA Whetzel, Mycologia 29: 134. 1937.}

Conidia on massed, branched conidiophores, hyaline, elongate, septate; sclerotia angular, elongate, or circular, thin, black formed in the tissues of the host usually after they have fallen 
to the ground; spermatia ovoid, very minute, produced on short, indian-club-shaped spermatiophores, clustered to form minute spermaclochia on decaying tissues, accompanying formation of sclerotia.

Apothecia shallow cup-shaped, stipitate, arising in the spring from sclerotia in the soil or leaf-mold; asci cylindric; spores hyaline, ovoid; paraphyses simple or branched with swollen tips.

Type species, Gloeosporium podophyllina Ellis \& Ev.

1. Septotinia podophyllina (Ellis \& Ev.) Whetzel, Mycologia 29: 135. 1937.

Gloeosporium podophyllinum Ellis \& Ev. Jour. Myc. 4: 103. 1888. Septogloeum podophyllinum Sacc. Syll. Fung. 10: 497. 1892.

Conidia hyaline, often becoming 0 -septate, straight or curved, often breaking apart at the septa when mature, truncate at the base, attenuated toward the apex, very variable in length; about $6 \mu$ wide, borne on branched, hyaline, septate conidiophores which are densely clustered to form minute, white, sporodochia which become horny and of ten amber-colored when dry; sporodochia gregarious or scattered over both sides of the leaf; usually most numerous on the upper surface; sclerotia formed in the tissues of the dead leaves and stalks on the ground, mostly along the veins, angular elongated, or circular, thin, black, 3-5 $\mathrm{mm}$. long, $1 \mathrm{~mm}$. broad; spermatia accompanying the formation of sclerotia, minute, ovoid, 1-2 $\times 2-3.6 \mu$, hyaline.

Apothecia shallow cup-shaped, stipitate, arising from sclerotia on or in the soil or leaf-mold, $1 \mu \mathrm{mm}$. in dianeter, pale fawncolored; stem tapering downward; asci cylindric, 8-spored, reaching a length of $148 \mu$ and a diameter of $10 \mu$; spores ovoid, hyaline, 5-6 $\times 10-16 \mu$; paraphyses slender, swollen above.

On leaves of Podophyllum peltatum.

Type locality: Concordia, Missouri.

Distribution: New York to Delaware and Missouri.

Illustrations: Mycologia 29: 137, f. 9-10; 141, f. 11-18.

Exsiccati: Ellis \& Ev. N. Am. Fungi $2++2$.

6. OVULINIA Weiss, Phytopathology 30:242. 1940.

Sclerotia irregularly discoid to shallow cup-shaped, thin, black, formed within but distinct from the host tissue; microconidia minute, globose, produced in chains on short, fusoid hyphae forming tufts on the surface of the host accompanying 
the sclerotia; conidia, large, obovoid, hyaline, produced singly on short, simple, or branched conidiophores, forming a thin mat on the surface of the host.

Apothecia arising singly or in groups from the sclerotium; asci slender, cylindric or subcylindric, 8-spored; spores ellipsoid; paraphyses mostly simple.

Type species, Ovulinia Azaleae Weiss.

Conidia large, $21-36 \times 40-60 \mu$; on Ericaceae.

1. O. Azaleae.

Conidia small, $6-10 \times 8-15 \mu$; on vegetables.

2. O. perplexa.

1. Ovulinia Azaleae IVeiss, Phytopathology 30:243. 1940.

Sclerotia, microconidia and conidia as above.

Apothecia two or three or occasionally as many as eight in a group, stipitate, urceolate, or cyathiform, expanding at maturity, becoming subdiscoid, ochraceous to brown, 2-5 $\mathrm{mm}$. in diameter; stem typically $2-3 \mathrm{~mm}$. long and $1-1.5 \mathrm{~mm}$. thick, but occasionally $15-18 \mathrm{~mm}$. long; asci cylindric, reaching a length of 140-260 $\mu$ and a diameter of 9-14 $\mu, 8$-spored; spores 1-seriate, 8-10 $\times$ 10-18 $\mu$, hyaline; paraphyses simple enlarged above.

On flowers of cultivated species of Azalea and Rhododendron causing blight, the apothecia appearing in late winter or spring from sclerotia lying on or in the soil. It is said also to infect Kalmia and Vaccinium.

Type Locality: North Carolina.

Distribution: Southeastern United States from North Carolina to Texas.

Illustrations: Phytopathology 30: 238, f. 1, 239, f. 2; 240, f. 3 .

2. Ovulinia perplexa (Lawrence) Seaver, comb. nov.

Sclerotinia perplexa Lawrence, Western Wash. Exp. Sta. Bull. 107: 10. 1912.

Sclerotia gray when young, becoming dull-black, snow-white within, becoming pink or brown with age, depressed-subglobose, reaching a diameter of 1-3 $\mathrm{mm}$., forming thin, black crusts of considerable extent; conidial stage on or accompanying the sclerotia, consisting of straight, or branched conidiophores of ten several mm. long, producing ovoid conidia 6-10.5 $\times 8-15 \mu$.

Apothecia stipitate one to many from a single sclerotium, flesh-colored, reaching a diameter of 2-8 $\mathrm{mm}$.; stem reaching a length of 1-2 mm.; asci cylindric, or subcylindric, reaching a length of $115-145 \mu$ and a diameter of $5-7 \mu, 8$-spored; spores subellipsoid, 3.5-5 $\times 8-10 \mu$; paraphyses, filiform. 
On Jerusalem artichoke, onions, cucumber, cabbage and a large number of cultivated vegetables.

TyPE LOCALITY: Western Washington.

Distribution: Known only from the type locality.

Illustrations: Western Wash. Exp. Sta. Bull. 107:f. 1-9.

7. LAMBERTELlA Höhn.'Sitz.-ber. Akad. Wien I. 127: 375. 1918.

Apothecia springing from a more or less definitely outlined, dark-colored, stromatic base consisting of a single layer of cells and loosely interwoven hyphace, stipitate, gregarious, or scattered, fleshy, becoming coriaccous, or corncous on drying, some shade of brown, or yellowish-brown when fresh; hymenium slightly darker; stem relatively stout, variable in length, or occasionally wanting, hirsute, or furfuraceous; asci cylindric to clavate, attenuated below, rounded or truncate at the tip, 8-spored; spores usually 1 -seriate, or occasionally becoming partially 2 seriate, simple, broadly ellipsoid, ovoid, or lunate, usually unequal sided, or lunate, smooth, or rough, golden-brown, or olivaceous when mature; paraphyses often branched, hyaline, slightly enlarged above. Spermatia usually present. No conidial stage observed.

Type species, Lambertella Corni-maris Höhn.

Spores small, not over $10-11 \mu$ long.

On stromatized hulls of Carya.

1. L. Hicoriae.

On mummied berries and leaves.

On Jasminum and Citharexylum in Bermuda.

2. L. Jasmini.

On Coccoloba? leaves in British Honduras.

3. L. tropicalis. Spores large, 12-18 $\mu$ long.

On mummied fruits of Prunus.

4. L. Pruni.

On fallen or hanging leaves.

On leaves of Tiburnum.

On leaves of Cephalanthus.

5. L. Tiburni.

6. L. Cephalanthi.

1. Lambertella Hicoriae Whetzel, Lloydia 6: 33.1943.

Apothecia arising from stromatized hickory-nut hulls partially buried in soil or leaf-mould, about $2 \mathrm{~mm}$. in diameter, fleshy, stipitate, brown or tawny-olive to dark vinaceous-brown; hymenium olive-brown or fuscous; stem stout, light above, darkbrown toward the base; asci cylindric-clavate, attenuated below, rounded or truncate above, reaching a length of 10I-127 $\mu$ and a diameter of $6-8 \mu$; spores obliquely 1-seriate, later becoming 2- 
seriate, broadly ellipsoid, flattened on one side, with two oildrops, and hyaline when young, becoming olivaceous-brown when mature, $46 \times 7-10 \mu$; paraphyses slender, branched, slightly enlarged above. Spermatia globose, $2-3 \mu$ in diameter.

On stromatized hulls of Carya ovata.

Trpe Locality: Woods east of Cayuta Lake, New York.

Distribution: Known only from the type locality.

Illustrations: Lloydia 6 : pl. $3, f .1-5 ;$ p. $35, f .2$.

2. Lambertella Jasmini Seaver \& Whetzel, Lloydia 6:37. 1943.

Apothecia one to several arising from the stroma in fruits, pedicels, or leaves of the host, 1-5 mm. in diameter, fleshy, stipitate, dark olive-buff, outside of the apothecium fibrillose, the short tips of the hyphae forming a fringe about the margin: hymenium darker brown; stem stout to slender, usually relatively short, cinnamon-brown below, lighter above, nore or less hairy; asci cylindric, attenuated below, rounded above, reaching a length of $95-135 \mu$ and a diameter of $7-8 \mu$; spores 1 -seriate, broadly ellipsoid, flattened on one side, slightly roughened, with two prominent oil-drops, becoming dark golden-brown at maturity, about 4-5 × 6-9 $\mu$; paraphyses hyaline, slender, branched, slightly enlarged above.

On mummied berries and leaves of Jasminum gracile and on leaves of Citharexylum spinosum.

Type Locality: Walsingham, Bermuda.

Distribution: Bermuda.

Illustrations: Lloydia 6: 36, pl. $f, f .1-3 ;$ p. $38, f .3$.

3. Lambertella tropicalis (Kanouse) Whetzel, Lloydia 6: 49. 1943.

Ciboria tropicalis Kanouse, Mycologia 33: 463. 1941.

Apothecia scattered over a stromatic area on the upper surface of the leaf, the stroma forming an irregular area along the midrib and side veins of the leaf, the individual apothecia small, about $2 \mathrm{~mm}$. in diameter, very short-stipitate or nearly sessile, waxy, white when fresh, alutaceous when dry, minutely furfuraceous beneath; hymenium nearly plane; stem very short and thick; asci cylindric-clavate, broadest at the apex, the tip rouncled and thickened, reaching a length of $90-100 \mu$ and a diameter of $8-11 \mu$; spores 1-seriate or irregularly 2-seriate, almost completely filling the ascus, inequilateral, slightly allan- 
toid, granular, becoming golden-brown, 4-5 $\times 11-14 \mu$; paraphyses filiform, sparingly branched.

On leaves of Coccoloba?

Type Locality: British Honduras.

Distribution: Known only from the type locality.

ILLUSTRATIONS: Lloydia $6: 50, f .7$.

4. Lambertella Pruni Whetzel \& Zeller, IJloydia 6: 40. 1943.

Apothecia gregarious, as many as a hundred springing from a single stromatized fruit, the stroma consisting of a thin, wrinkled, black crust surrounding the host, the individual apothecia $1.5 \mathrm{~mm}$. in diameter when mature, short-stipitate to sessile, externally furfuraceous, the margin fringed with short hyphal tips, brown; hymenium plane or convex, pale-brown, darker with age; stem very short, sharply constricted at point of attachment and black at the base; asci cylindric, slightly narrowed above, attenuated at the base, reaching a length of $115-$ $150 \mu$ and a diameter of $10-14 \mu$; spores 1 -seriate, lunate, with broad, blunt ends, smooth, containing two oil-drops, goldenbrown, beconing dark olivaceous-brown at maturity, $7-8 \times 12-$ $15 \mu$; paraphyses branched, septate, slightly enlarged above.

On mummied fruits and seedlings of sweet cherry, Prunus avium.

Type Locality : Reynold's Estate near Salem, Oregon.

Distribution: Known only from the type locality.

Illustrations: Lloydia $6: 36, p l . t, f .4 ; \mathrm{p} .41, f .4$.

5. Lambertella Viburni Whetzcl, Lloydia 6: 43. 1943.

Apothecia scattered, stipitate, arising from a subcuticular stromatic base, restricted largely to the veins of the leaves, individual apothecia small, .5-2 $\mathrm{mm}$. in diameter, externally fibrillose, light-buff, the margins dark-brown, incurved, rimmed with hyphal tips; hymenium shallow-concave to plane, lightbrown; stem stout, cinnamon-brown, lighter above, hirsute; asci slender-cylindric, tapering slightly below, rounded above, reaching a length of 60-114 $\mu$ and a diameter of 8-9 $\mu$; spores ellipsoid, bluntly apiculate, flattened on one side, light-brown, becoming darker after discharge, $4-6 \times 12-18 \mu$, with two oil-drops; paraphyses apparently simple, actually fasciculately 3 -branched near the base, septate, slightly enlarged at the tips.

On hanging dead leaves of Viburnum cassinoides. 


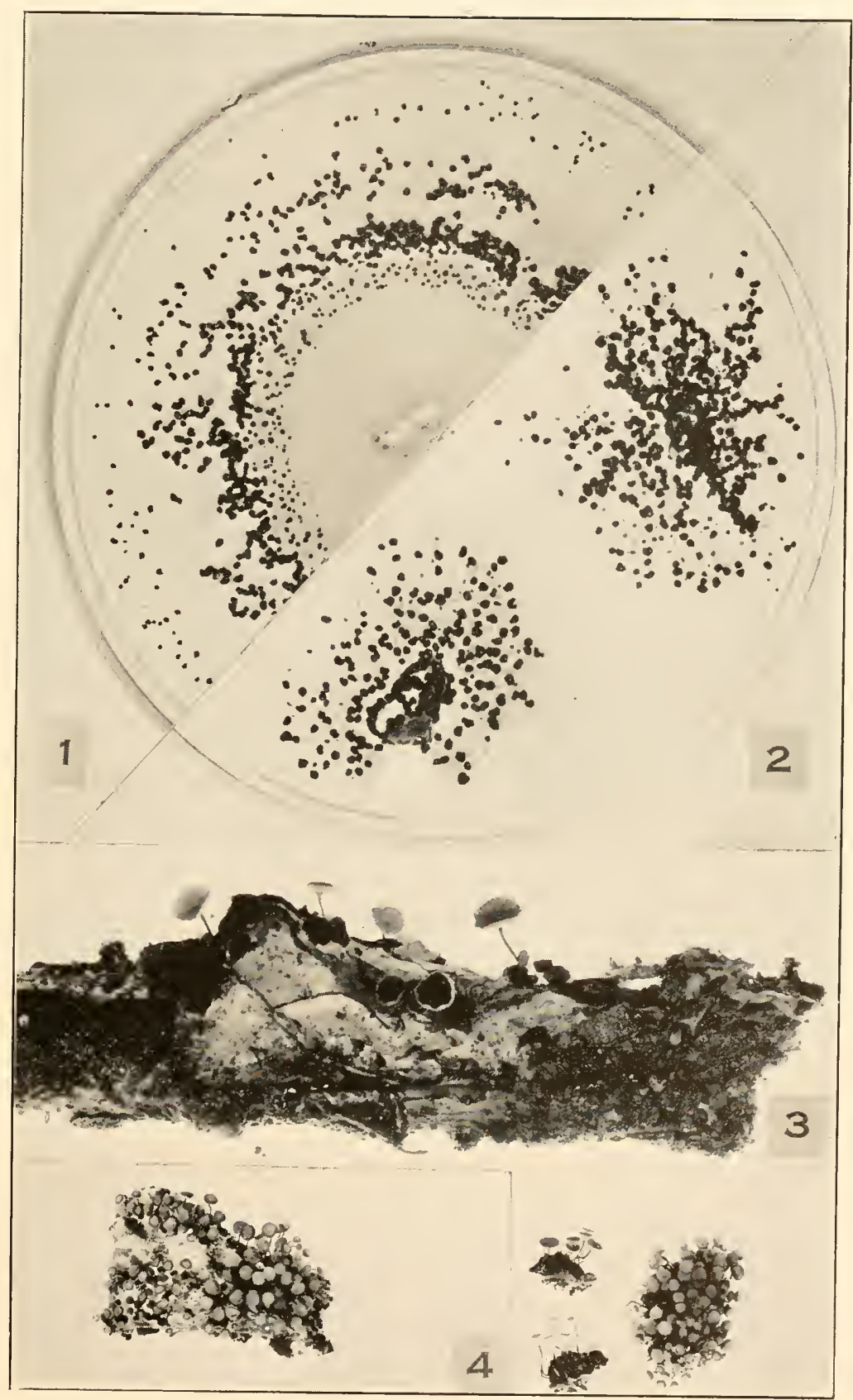

MARTINIA PANAMAENSIS 

Type Locality: The "Bottomless Pit" near Hanover, New Hampshire.

Distribution: Known only from the type locality.

Illustrations: Lloydia $6: 44, p l .5 ;$ p. $45, f .5$.

6. Lambertella Cephalanthi W'hetzel, Lloydia 6: 47. 1943.

Apothecia scattered, arising from the surface of the leaf without any distinct stromatization, minute, not exceeding $1 \mathrm{~mm}$. in diameter, stipitate, pale-brown, the margin fringed with short hyphal tips; hymenium dark-brown, deeply concave, paler after spore discharge; stem dark-brown below, pruinose and colored like the outside of the apothecium; asci short, stout, broadly cylindric, tapering slightly toward the base, slightly narrowed above, the apex rounded or more or less truncate, reaching a length of 90-117 $\mu$ and a diameter of 10-12 $\mu$; spores 1-seriate, or becoming 2 -seriate, nearly filling the entire ascus, broadly ellipsoid, olivaceous-brown with a thickened, darker band on one side, containing two oil-drops, 5-8 $\times 12-17 \mu$; paraphyses 3 -branched, septate, swollen above.

On fallen leaves of Cephalanthus occidentalis.

Type Locality: West Roxbury, Massachusetts.

Distribution: Massachusetts and Cayuta Lake, New York. IlLustrations: Lloydia 6: $48, f .6$.

8. MARTINIA IThetzel, Mycologia 34:585. 1942.

Apothecia arising singly or several from minute, hemispherical sclerotia on the surface of the substratum, thin, membranous, shallow cup-shaped, reaching a diameter of 2-3 mm., stipitate; hymenium olivaceous to olive-brown when spores are mature; stem long, slender, hair-like; asci 8-spored; spores simple, ellipsoid, olive-brown.

Type species, Martinia panamaensis Whetzel.

This name is apparently untenable having previously been used. See Vaniot, Acad. Geogr. Bot. 12:31. 1903.

1. Martinia panamaensis Whetzel, Mycologia 34: 586. 1946.

Stromata and apothecia as above; asci cylindric above, attenuated below, reaching a length of 35-40 $\mu$ and a diameter of $5 \mu$; spores ellipsoid, slightly flattened on one side, $2.5 \times 4.5 \mu$; paraphyses branched near the base, scarcely enlarged above.

On the surface of bark and wood of some undetermined tree. 
Type locality: Near Balboa, Panama.

Distribution: Known only from the type locality.

Iliustrations: Mycologia 34: 587, f. 1-4.

9. CIBORINIA Whetzel, Mycologia 37:667. 1945.

Stroma a definite sclerotium of the discoid type, black, circular, subcircular, or occasionally elongated, thin, flat, or on drying somewhat concavo-convex, foliicolous, persistent, or deciduous; spermatia present, globose or ovoid, hyaline, in mass pale-yellow.

Apothecia, one to several arising from each sclerotium, cupshaped to shallow saucer-shaped or discoid, small to medium, 1-5 mm. in diameter, reddish to brown, or nearly white; asci usually 8-spored; spores simple, hyaline, ellipsoid; paraphyses slender, usually swollen at the tips.

Type species, Sclerotinia Whetzelii Seaver.

On leaves of Populus tremuloides.

Apothecia usually one to each sclerotium, large, 2-10

mm. in diameter.

1. C. Whetzelii.

Apothecia several to each sclerotium small, .5-1.5 mm. in diameter.

2. C. bifrons.

Not on Populus tremuloides.

On leaves of Salix.

3. C. foliicola.

On Erythronium.

4. C. Erythronii.

On petioles of Magnolia.

5. C. gracilipes.

1. Ciborinia Whetzelii (Seaver) comb. nov. (Plate 89.)

Sclerotinm bifrons Ellis \& Ev. Fungi Columb. 155; Sacc. Syll. Fung. 14: 1169. 1899. (in part).

Sclerotinia bifrons Whetzel, Nycologia 32: 126. 1940. Not Sclerotinia bifrons Seaver \& Shope. 1930.

Sclerotinia Whetzelii Seaver, Mycologia 32: 127. 1940.

Ciborinia bifrons Whetzel, Mycologia 37: 668. 1945.

Sclerotia formed in the living leaves, circular, or irregularly subcircular in form, persistent or dehiscent.

Apothecia occurring on sclerotia lying on the ground, stipitate, at first cup-shaped, expanding and becoming subdiscoid, brownish, 2-10 $\mathrm{mm}$. in diameter; stems $5-25 \mathrm{~mm}$. long; asci clavate or subclavate, reaching a length of $150-200 \mu$ and a diameter of 9-12 $\mu$; spores 1-seriate, ellipsoid, $4-7 \times 11-16 \mu$.

On sclerotia dehisced from the leaves of Populus tremuloides and lying on the ground. 


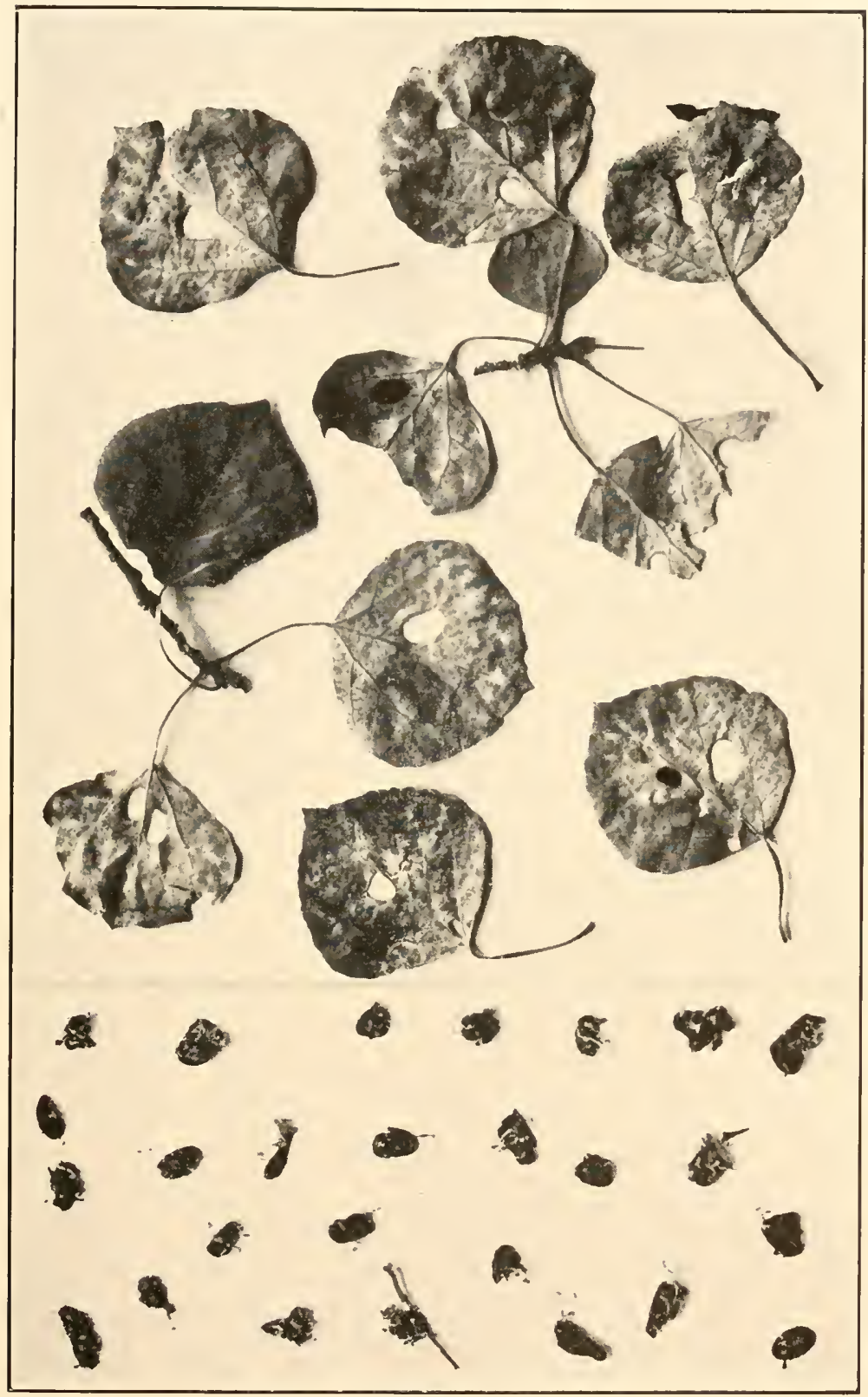

CIBORINIA BIFRONS 

TyPe Locality: New York.

Distribution: New York and Quebec, Canada.

Illustrations: Mycologia 37: 669, f. 6, 7; Canadian Jour. Res. 18: pl. 1, f. 1-10.

2. Ciborinia bifrons (Ellis \& Ev.) Scaver, comb. nov. (Plate 75 (frontispiece), 88.)

Sclerotium bifrons Ellis \& Ev. N. Am. Fungi 155; Sacc. Syll. Fung. 14: 1169. 1899. (in part).

Sclerotinia bifrons Seaver \& Shope, Mycologia 22: 3. 1930.

Sclerotinia confundens Whetzel, Mycologia 32: 126. 1940.

Ciborinia confundens Whetzel, Mycologia 37: 668. 1945.

Sclerotia formed in the living leaves of the host, irregularly circular in form, persistent, or clehiscent, black, thin; apothecia stipitate, several to each sclerotium, minute, whitish, or slightly yellowish, .5-1.5 mm. in diameter; stems variable in length, usually 2-3 mm.; asci clavate, or subcylindric, 8-sporeel, reaching a length of $50-75 \mu$ and a diameter of $4-7 \mu$; spores fusoid, or ellipsoid, hyaline, $2-3 \times 7-10 \mu$; paraphyses slender.

On sclerotia dehisced from the leaves of Populus tremuloides and lying on the ground in moist places, usually embedded in humus.

Type Locality: University of Colorado summer camp near Boulder, Colorado.

Distribution: Known only from the type locality.

Illustrations: Mycologia 22: pl. 4; 37: No. 6, frontispiece, $645, f .2$.

Exsiccati: Ellis \& Ev. Fungi Columb. 155; Barth. Fungi Columb. 255t.

3. Ciborinia foliicola (Cash \& Davidson) Whetzel, Mycologia 37: 668. 1945.

Sclerotinia foliicola Cash \& 1)avidson, Mycologia 25: 269. 1933.

Sclerotia surrounding the midribs of overwintering leaves of the host, .5-1 $\mathrm{mm}$. wide and 1-4 cm. long, thick and appearing on both sides of the leaf-blade.

Apothecia stipitate at first cup-shaped, expanding and becoming ahost discoid at maturity, up to $1 \mathrm{~cm}$. in diameter, grayish-brown; stems .5-1 mm. thick, reaching a length of 1-3 $\mathrm{cm}$., rather stout when young, becoming slender at maturity, asci cylindric, or subcylindric, attenuated below, reaching a 
length of $120-140 \mu$ and a diameter of 8-10 $\mu$; spores 1 -seriate, ellipsoid, hyaline, $5 \times 9-13 \mu$; paraphyses filiform, septate, gradually enlarged above to 3-4 $\mu$ thick.

On leaves of Salix sp.

Type locality: Mesa Lakes, Colorado.

Distribution: Known only from the type locality.

Illustrations: Mycologia 25: pl. 37, f. 8, 9.

4. Ciborinia Erythronii Whetzel, Mycologia 37: 668. 1945.

?Sclerotinia gracilis Clements; Bessey, Contr. Bot. Dep. Univ. Nebr. 3: 47. 1892.

Sclerotinia Erythronii Whetzel, Mycologia 18: 232. 1926.

?Ciborinia gracilis Whetzel, Mycologia 37: 668. 1945.

Sclerotia usually more or less pointed, black, deeply buried, or flat and ovate lying on the surface of the soil, $1-1.5 \times 5-$ $10 \mathrm{~mm}$.

Apothecia slightly elevated above the surface of the soil, cupshaped to shallow saucer-shaped, finally expanded and subdiscoid, or convex, brown, 3-5 $\mathrm{mm}$. in diameter; stems often very long, reaching a length of $5-10 \mathrm{~cm}$. the length varying according to the depth at which the sclerotia are buried; asci cylindric, or subclavate, reaching a length 200-275 $\mu$ and a diameter of $12 \mu, 8$-spored; spores long-ellipsoid, 7-10 $\times 20-30 \mu$; paraphyses filiform, only slightly swollen above.

Parasites on Erythronium americamum, occurring on shaded knolls or wooded hillsides.

Type locality: Labrador Lake, near Tulley, New I'ork.

Distribution: New York and Nebraska?

Illustrations: Mycologia 18: 232.f. 1, pl. 27.

5. Ciborinia gracilipes (Cooke) Seaver, comb. nov.

Peziza gracilipes Cooke, Bull. Buffalo Soc. Nat. Sci. 2: 294. 1875.

Sclerotinia gracilipes Sacc. Syll. Fung. 8: 200. 1889.

Sclerotia thin, rounded, or ellipsoid, formed on the petioles of the host.

Apothecia stipitate, at first cup-shaped, finally becoming discoid, submembranaceous, yellowish-brown, reaching a diameter of 2-3 cm.; asci cylindric, or subcylindric, 8-spored; spores ellipsoid, $4 \times 8 \mu$.

From sclerotia on the petioles of Magnolia glauca.

Trpe locality: Newfield, New Jersey. 


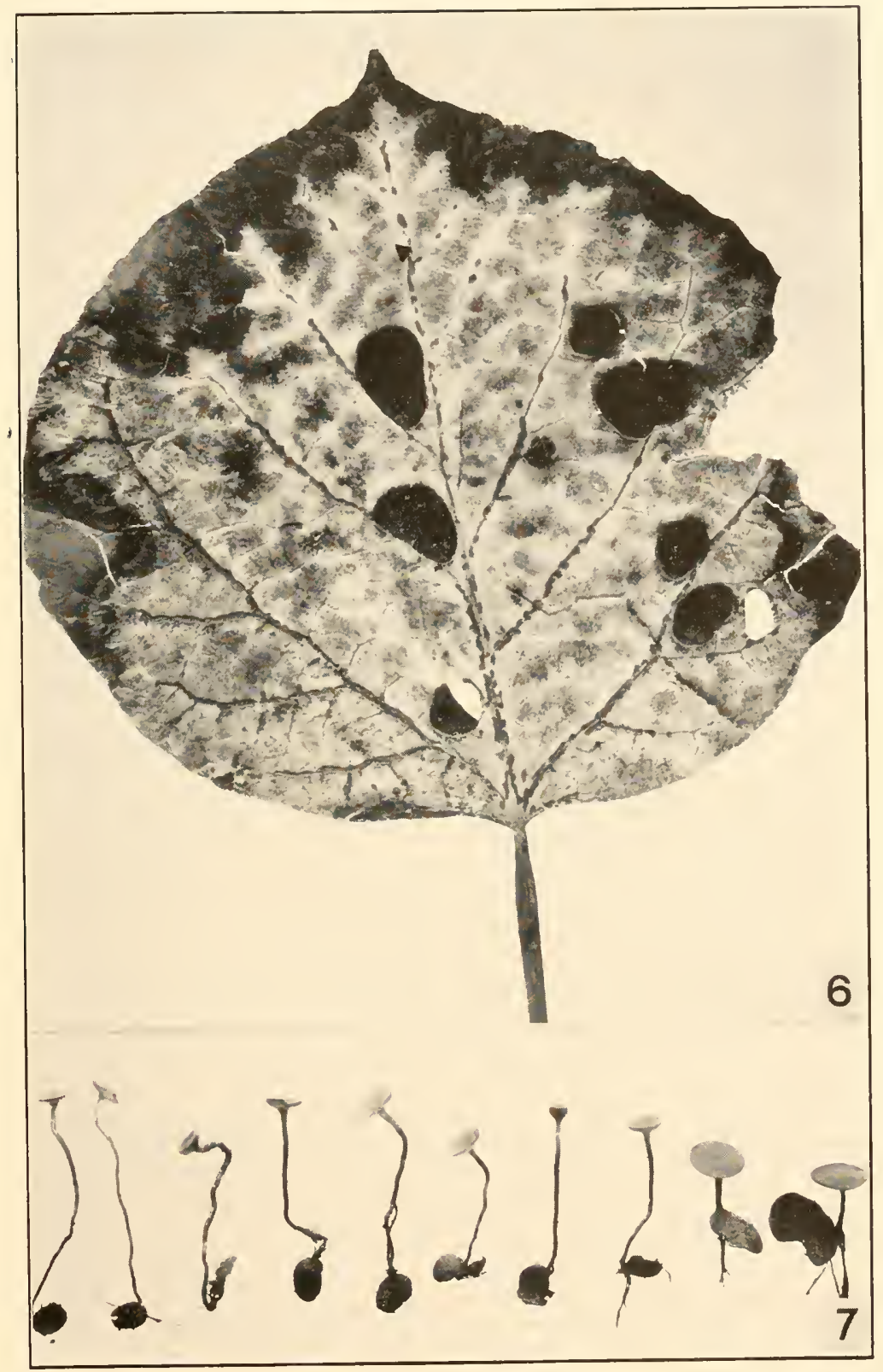

CIBORINIA WHETZELII 

Distribution: Known only from the ype locality.

Exsiccati: Ellis, N. Am. Fungi. 390.

Specimens in the herbarium of the New York Botanical Garden show excellent sclerotia and apothecia.

10. VERPATINIA Whetzel \& Drayton, Mycologia 37:

690. 1945.

Stroma an elongated, black sclerotium of the discoid type identical with that of Ciborinia, foliicolous, formed beneath the cuticle of the host; conidial stage believed to be wanting.

Apothecia arising from the sclerotia singly or in pairs, stipitate, campanulate to cylindric or subturbinate; the hymenial surface pitted or often longitudinally furrowed; asci S-spored: spores ellipsoid to fusiform.

Type species, Verpatinia calthicola IThetzel.

On old leaves of Caltha palustris.

On old leaves of Betula lntea.
1. I. calthicola.

2. I. duchesnayensis.

1. Verpatinia calthicola IVhetzel, Mỵcologia 37: 692. 1945.

Stroma and sclerotia as above.

Apothecia campanulate, or turbinate, 2-3 mm. long and 1-2 mm. thick, clay-colored to pale-brown, long-stipitate; stem slender, slightly swollen at the base, 5-15 $\mathrm{mm}$. long and $.5 \mathrm{~mm}$. in diameter; asci cylindric, gradually tapering below, reaching a length of 30-38 $\mu$ and a diameter of 3-6 $\mu$; spores subellipsoid with one side flattened, $2-3 \times 6-10 \mu$.

On overwintering petioles of Caltha palustris.

Type locality: Ithaca, New York.

Distribution: Known only from the type locality.

IlLustrations: Mycologia 37: 687. $f$. 25-28.

2. Verpatinia duchesnayensis Whetzel, Mycologia 37: 694. 1945.

Sclerotia elongated, at maturity as long as $25 \mathrm{~mm}$. though often much shorter, varying from short-fusiform in early stages to long, slender-cylindric, rather abruptly tapering toward the ends, dull to shining, formed in the midrib or one of the primary ribs of the host.

Apothecia, stipitate, arising singly, or in pairs from the embedded sclerotium, cylindric to barrel-shaped, or turbinate, ap- 
proximately $2 \mathrm{~mm}$. long, $1 \mathrm{~mm}$. thick, pale ashy-gray, surface irregularly furrowed or wrinkled; stem of uniform diameter throughout, brownish, smooth, paler above; asci cylindric, or subcylindric; spores, fusoid, one side often flattened, 3-4 $\times 9-12 \mu$; paraphyses thick, enlarged at their apices.

On disintegrating leaves of Betula lutea.

Type locality: Duchesnay, Quebec, Canada.

Distribution: Known only from the type locality.

Illustrations: Mycologia 37: 691, f. 30, 31 .

11. SCLEROTINIA Fuckel, Symb. Myc. 330. 1871.

Apothecia arising from a definite tuberoid, elongated, or irregular sclerotium, usually formed in the living or recently killed tissues of the host, more rarely apparently disconnected with any host, at first rounded, becoming cup-shaped, urnshaped or discoid; asci clavate-cylindric, usually 8-spored; spores ellipsoid to fusoid, simple, hyaline; paraphyses filiform, or slightly enlarged above.

Type species, Peziza sclerotiorum Lib.

Sclerotia occurring unattached to any host.

1. S. tuberosa.

Sclerotia closely associated with a host plant.

On monocotyledons, grasses or sedges.

On seeds of Secale.

2. S. temulenta.

On stems or leaves.

On Juncus.

On Carex.

Apothecia large, $2-4 \mathrm{~cm}$. in diameter.

3. S. juncigena.

4. S. Caricis-

Apothecia small, less than $1 \mathrm{~cm}$.

Sclerotia small, .3-1 mm. in diameter on leaves of host.

Sclerotia large, $7 \mathrm{~mm}$. $-2 \mathrm{~cm}$. long.

Sclerotia 1-7 mm. long.

Sclerotia $2-2.5 \mathrm{~cm}$. long.

ampullaceae.

On dicotyledons, various species.

On flowers or seeds.

On seeds.

On Tilia americana.

On Nyssa sylatica.

8. S. Tiliae.

9. S. nyssaegena.

On flowers of Camellia.

10. S. Camelliae.

On leaves or stems.

On leaves.

On Potentilla.

On lettuce, Lactuca and other garden plants.

11. S. fallax

12. S. minor. 


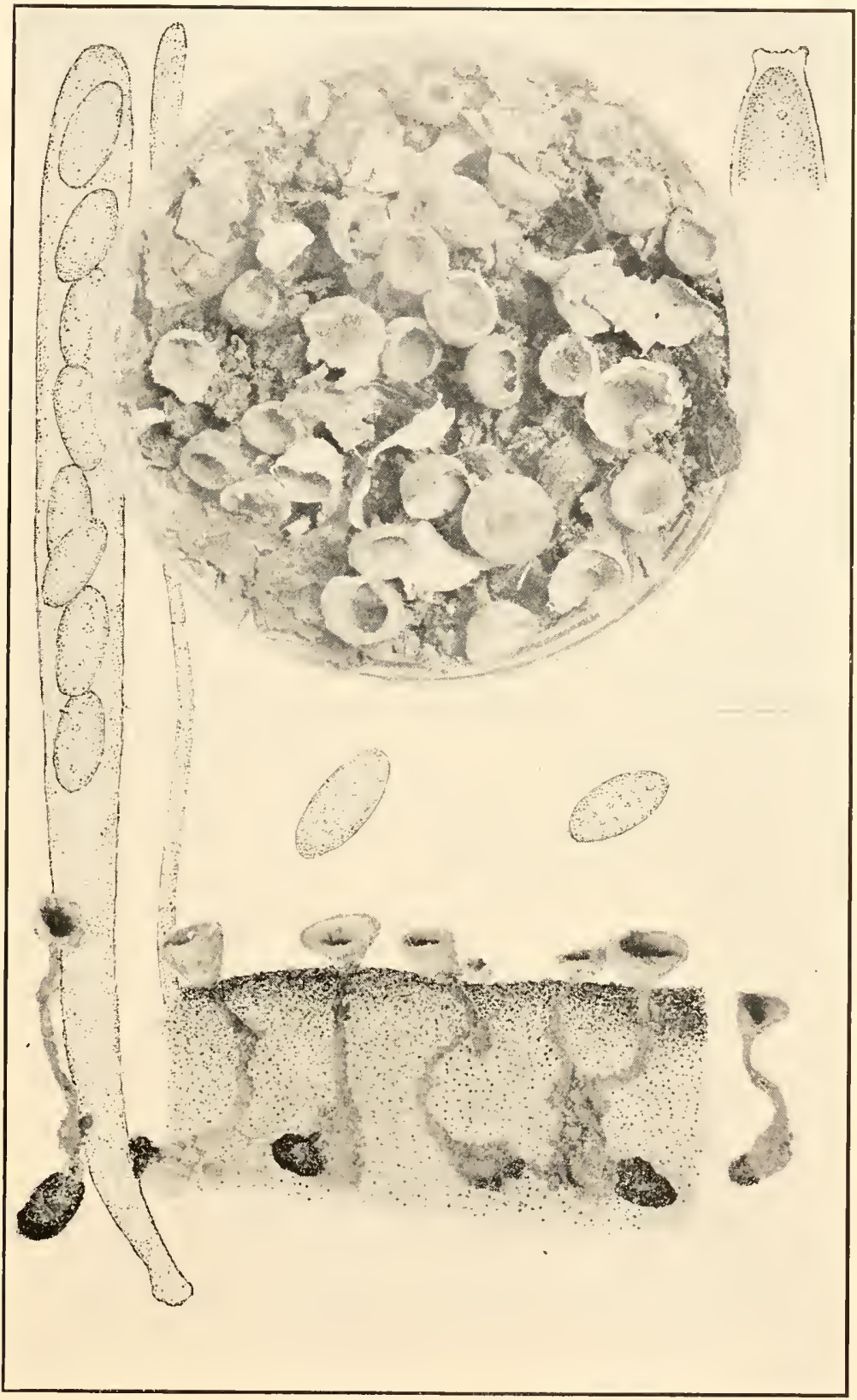

SCLEROTINIA TUBEROSA 

On stems or seerl pods.

On V'eratrum californicum. 13. S. T'eratri.

On stems or seed-pods of Pedicularis. 14. S. coloradensis.

On bulbs, tubers or roots.

On roots of Tragopogon and Daucus.

On bulbs or tubers.

On tubers of Panax.

15. S. intermedia.

On bulbs of Tulip and Medicago.

16. S. Panacis.

17. S. satiza.

1. Sclerotinia tuberosa (Hedw.) Fuckel, Syml, Mrc. 331. 1869. (Plate 90.)

Octospora tuberosa Hedw. 1)escr. 2: 39. 1788.

Pesiza tuberosa Bull. Hist. ('hamp. Fr. 266. 1791.

Macroscyphus tuberosus S. F. Gray, Nat. Arr. Brit. Pl. 1: 672. 1821.

Rutstroemia tuberosa Karst. Myc. Fenn. 1: 105. 1871.

Phialea tuberosa Gill. Champ. Fr. Discom. 97. 1882.

Hymenoscypha tuberosa Phill. Brit. Discom. 113. 1887.

Sclerotia buried in the ground, forming irregular nodules 5-7 $\mathrm{mm}$. in cliameter, occasionally larger, externally black, internally white, strongly convoluted when dry.

Apothecia infundibuliform to cup-shaped, more or less expanded at maturity, margin often inturned, pale umber-brown, stipitate, $1 \mathrm{~cm}$. or more in diameter; hymenium slightly darker than the outside of the apothecium, even, or occasionally slightly. convoluted; stem slender, about $2 \mathrm{~mm}$. in diameter, gradually expanding into the cup above, and with the base more or less swollen, reaching a length of several cm., usually one fruiting body from each sclerotium but occasionally several; asci cylindricclavate, reaching a length of $150 \mu$ and a diameter of 8-10 $\mu$, 8 -spored; spores ellipsoid, the ends slightly narrowed, $6 \times 12$ $14 \mu$; paraphyses filiform, the ends slightly enlarged above, $3-4 \mu$ in diameter.

On sclerotia buried in the ground, the stem of the apothecia being long enough to reach the surface of the ground.

Type locality: Europe.

Distribution: New York to North Dakota and south to Tennessee, probably distributed in North America; also in Europe.

Illustrations: Hedwig, Descr. 2: pl. 10, f. B; Bull. Herb. Fr. pl. 485, f. 2-3; Rab. Krypt.-Fl. $1^{3}$ : 802, f. 1-3; E. \& P. Nat. Pfl. $1^{1}: 193, f .156 \mathrm{~K}$.

European authors report this species as occurring on the rhizomes of Anemone nemorosa. The writer has collected hundreds of sclerotia and apothecia of this species in the suburbs of 
New York City, over a period of years, and in no case has the fungus been associated with the rhizomes of this or any other host. While there might be a mycelial connection, none was apparent. This leads us to suspect that our American form may be distinct from the European. However, the two agree so well in other characters that for the time being our species are regarded as identical with the European.

2. Sclerotinia temulenta (Prill. \& Delacr.) Seaver, comb. nov. Phialea temulenta Prill. \& Delacr. Bull. Soc. My'c. Fr. 8: 23. 1892.

?Endoconidium temulentum Prill. \& Delacr. Bull. Soc. Myc. Fr. 7: 116. 1891.

Conidial stage consisting of globose, or subglobose coniclia produced in chains within the branches and near the tips of the conidiophores.

Apothecia solitary, or gregarious on a sclerotium formed in the seed of the host, stipitate, at first partly closed, pallid, from ochraceous to honey-colored, .5-7 $\mu$ in diameter; hymenium plane to slightly convex; stem slender, 7-10 $\mathrm{mm}$. long and .5-1 mm. thick; asci cylindric, reaching a length of $130 \mu$ and a diameter of $5 \mu, 8$-spored; spores, 1 -seriate, fusoid, $4-5 \times 10 \mu$; paraphyses filiform, slightly enlarged above $1.5-2 \mu$ thick.

On fruits of Secale cereale to which it gives poisonous properties. Said to be a very destructive parasite.

Type locality: Europe.

Distribution: Williamette Valley, Oregon; also in Europe. Illustrations: Bull. Soc. Myc. Fr. 7: 116, $f .1$ (conidia).

If Prillieus and Delacroix are correct in assuming that this is the perfect stage of Endoconidium temulentum and we follow the Whetzel scheme of separating genera on the basis of their conidial stages this should be made a separate genus since it is the only member of the tribe which has an Endoconidium as the conidial stage.

3. Sclerotinia juncigena (Ellis \& Ev.) Whetzel, Farlowia 2: 432. 1946.

Ciboria juncigena Ellis \& Ev. Proc. Acad. Sci. Phila. 1894: 348. 1894.

Sclerotia one, possibly more within a diseased culm, slender, cylindric, with truncate, slightly rounded ends, reaching a length of $15 \mathrm{~mm}$. and a diameter of $2 \mathrm{~mm}$., externally black, sulcate, internally white when mature, enclosed in a cavity in the pith region of the culm. 


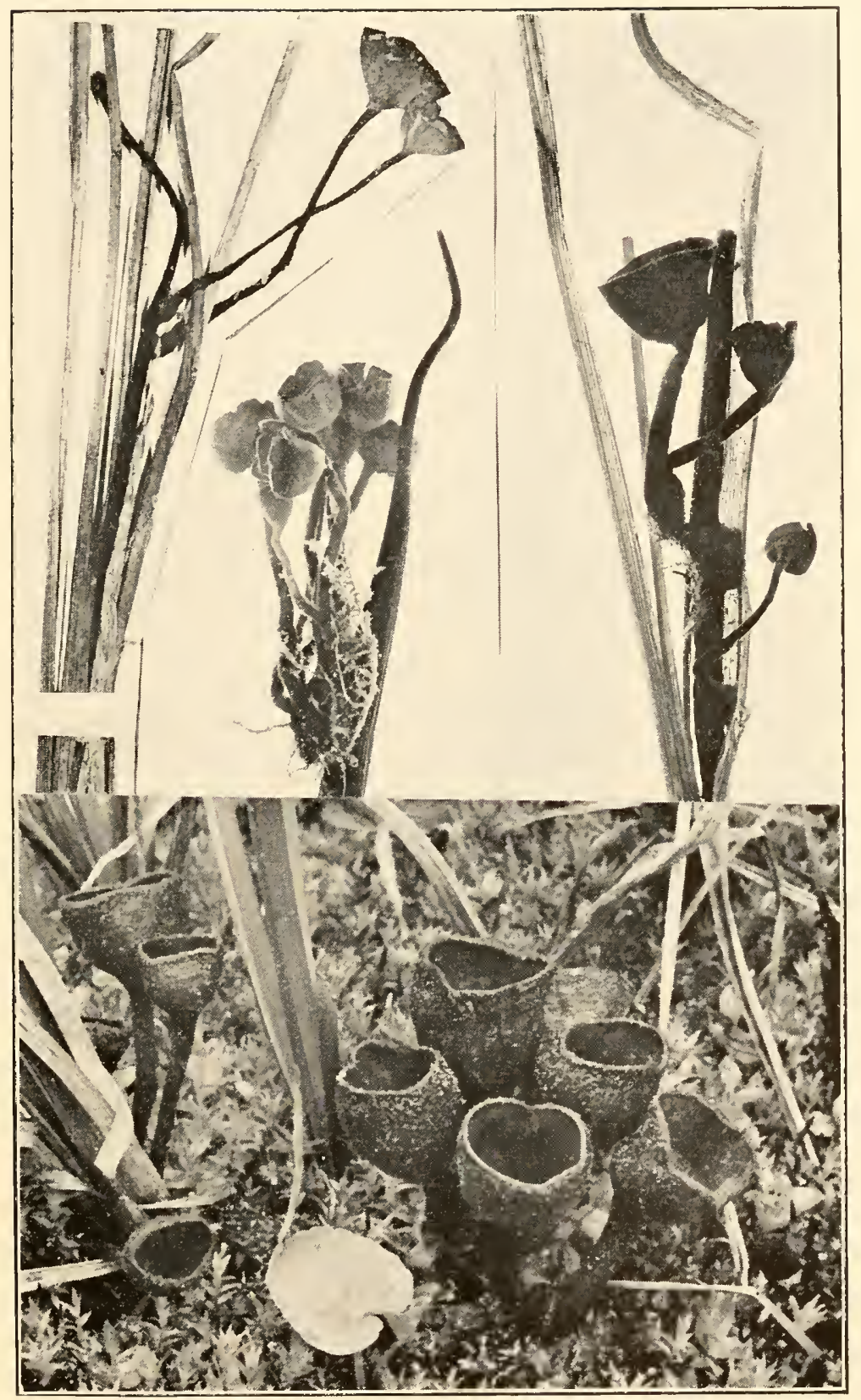

SCLEROTINIA CARICIS-AMPULLACEAE 

Apothecia usually but one from each sclerotium, longstipitate, thin membranous, shallow, cup-shaped, subumbilicate, 4-5 $\mu$ in diameter, reddish-brown; stem relatively long, reaching a length of $1 \mathrm{~cm}$. and a diameter of $1 \mathrm{~mm}$. attached below by a spreading, dark hyphal mat; asci clavate-cylindric, reaching a length of $60 \mu$ and a diameter of 4-5 $\mu$, 8-spored; spores allantoid, slender, distinctly curved, hyaline, $1-1.5 \times 8-9 \mu$; paraphyses not apparent.

In culms of Juncus (probably $J$. effusus var. californica). Type Localitr: Falcon Valley, Mashington State.

Distributiox: Known only from the type locality.

4. Sclerotinia Caricis-ampullaceae Nyberg, Mem. Soc. Fauna F1. Fenn. 10:22. 1933. (Plate 90.)

Sclerotia externally black (inside white), longitudinally sulcate, bowed or S-shaped, usually broader below and tapering above, the bow often variable, reaching a length of $1-10 \mathrm{~cm}$. and a diameter of $1 \mathrm{~mm}$. to $1 \mathrm{~cm}$, each producing one to twenty apothecia.

Apothecia stipitate, often funnel-shaped at first, later cupshaped, finally expanding and becoming nearly flat and umbilicate, reaching a diameter of $2-4 \mathrm{~cm}$., externally finely tomentose, some shade of brown; hymenium concave to plane, brown; stems 1-2 $\mathrm{mm}$. thick and reaching a length of 5-10 cm., gradually expanding above into the cup, darker below, almost black; asci cylindric, rounded above, reaching a length of 200-300 $\mu$ and a diameter of $11 \mu$; spores 1-seriate, ellipsoid, smooth, without oildrops, 6-9 × 11-15 $\mu$; paraphyses thread-like, branching below, 1-2 $\mu$ thick, scarcely enlarged above.

In culms of Carex aquatilis, $C$. ampullacea $(C$. rostrata) and $C$. inflata.

Type locality: Europe.

Distribution: Medicine Bow Mountains, IVyoming; also in Europe.

Illustrations: Mycologia 35: 387, f. 1; 393, f. 2-3; 395, f. 1-6; Farlowia 2: 406, pl. 6, f. 23-25.

5. Sclerotinia paludosa Cash \& Davidson, Mycologia 25: 271. 1933.

Sclerotia on leaves of host, often on edges, inconspicuous, 3-1 $\mathrm{mm}$. in diameter, sometimes elongated up to $1.7 \mathrm{~mm}$., black. 
Apothecia brown, small, cupulate, then becoming almost plane, reaching a diameter of $1.2-2 \mathrm{~mm}$.; stem reaching a length of 2-4 mm. and a thickness of .3 mm.; asci cylindric, attenuated at the base, with a short, stem-like base, 8-spored; spores 1-2seriate, simple, containing two oil-drops, $5 \times 12-14 \mu$; paraphyses numerous, filiform, septate, agglutinated and brown at the tips, 1-4 $\mu$ thick.

On overwintering leaves of Carex exsiccata.

Type locality: Grand Mesa, Colorado.

Distribution: Grand Mesa National Park, Colorado.

Illustrations: Mycologia 25: pl. 37, f. 6-7.

6. Sclerotinia longisclerotialis Whetzel, Mycologia 21:28. 1929.

Sclerotia usually one or two or sometimes three in each culm, remaining enclosed even at maturity, not discharging by the breaking of the culm as in Sclerotinia Duriceana, somewhat exposed by a narrow slit in the epidermis, at maturity black, oblong, truncate, uniform in thickness, more or less 3-angled, striate due to the pressure of the vascular strands of the culm during development, originating as a loose, cottony weft of white mycelial hyphae in the interior of the culm, gradually thickening, forming a firm body at first of a pinkish color, gradually changing to a smoky-gray on the exterior, finally black, the ends capped by a long, pointed weft of white mycelium continuous with the mycelium in the tissues of the culm, at maturity varying in size with the slenderness of the host culm, reaching a length of 1-7 cm. and a diamater of 1-2 $\mathrm{mm}$.

Apothecia 2-5 $\mathrm{mm}$. broad, goblet-shaped with mouth constricted, stipitate, dark fawn-colored, usually one to each sclerotium; stem slender, reaching a length of $15-30 \mathrm{~mm}$.; asci cylindric, attenuated below, reaching a length of $170-230 \mu$ and a diameter of 9-15 $\mu, 8$-spored; spores strongly unequilateral, flat, or incurved on one side, averaging $8 \times 18 \mu$; paraphyses simple, very slender, slightly clavate.

On species of Carex, C. prairea, C. interior, C. crinita, C. vesicaria and $C$. retrorsa.

Type Locality: New York.

Distribution: New York and Maine.

Illustrations: Mycologia 21 : pl. 4, pl. 5, f. 20-22; Farlowia $2^{3}:$ pl. 5, f. 19-22. 


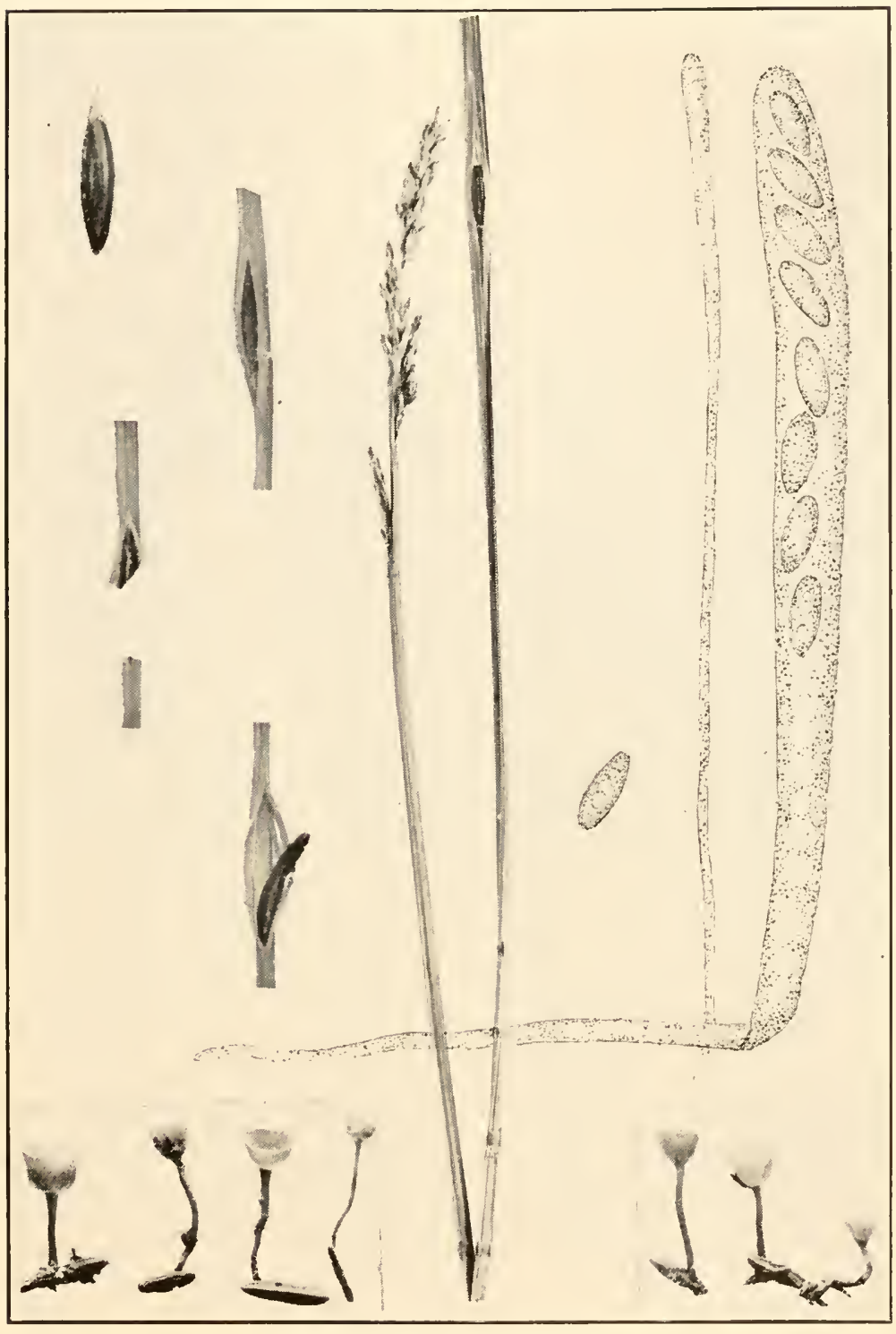

SCLEROTINIA DURIAEANA 

7. Sclerotinia Duriaeana (Tul.) Rehm, Hedwigia 21: 66.1882. (Plate 92.)

Sclerotium sulcatum Roberge; Desm. Ann. Sci. Nat. III. 16: 329.1851.

Epidochium ambiens Desm. Ann. Sci. Nat. 1II. 20: 231. 1853.

Epidochium affine Desm. Ann. Sci. Nat. III, 20: 232. 1853. (in part).

Peziza Duriaeana Tul. Fung. Carp. 1: 103. 1861.

Sphacelia ambiens Sacc. Syil. Fung. 4: 666. 1886.

Hymenoscypha Duriaeana Phill. Brit. Discom. 115. 1887.

Sclerotia one to three in each culm, when mature cxposed by the rupture of the epidermis along one or two faces of the culm which thus weakened soon breaks over widening the slit and allowing the sclerotia to fall, black, fusiform, much resembling ergot, the sclerotia of Claviceps, often inequilateral, or slightly curved in larger specimens, of variable size according to the host, reaching a length of 20-25 mm. and a diameter of 3-4 mm. but of ten smaller, 3 -angled.

Apothecia stipitate, reaching a diameter of 2-10 $\mathrm{mm}$., deep cup-shaped when young, expanded when mature, fawn-colored, varying in size with the sclerotia from which they arise; stem short, 5-20 $\mathrm{mm}$. long; asci slightly attenuated below, reaching a length of 150-180 $\mu$ and a diameter of 7-11 $\mu, 8$-spored; spores 1-seriate, long-ovoid, often inequilateral, $5-9 \times 8-18 \mu$; paraphyses slender, slightly swollen at their apices.

On Carex stricta, Carex prairea, Carex hystericina, Carex riparia var. lacustris. Carex flava, Carex rostrata, Carex crinita, and Carex nebraskensis.

Type locality: Ithaca, New York.

Distribution: New York and Oregon; also known in Europe.

Illustrations: Mycologia $21: 21, f .1 ;$ pl. 2, 3, 5, f. 14, 15, 16; Farlowia $2^{3}:$ pl. $1,2,3,+$ (as $S$. sulcata).

Whetzel (Farlowia 2: 397) treats S. sulcata as distinct from S. Duriaeana.

8. Sclerotinia Tiliae Reade, Ann. Myc. 6: 114. 1908.

Apothecia mostly solitary, cyathoid, long-stipitate, .5-1 cm. high, Isabela color, 1-3 $\mathrm{mm}$. in diameter; stem smooth, slender, cylindric, $.5 \mathrm{~mm}$. or less thick; asci clavate-cylindric, reaching a length of $140-170 \mu$ and a diameter of $8-10 \mu, 8$-spored; spores obliquely 1 -seriate, ellipsoid, hyaline, simple, $4-5 \times 9-11 \mu$; paraphyses sparse, filiform, hyaline.

From sclerotia in seeds of Tilia americana lying on the ground. 
Type Locality: Mt. Pleasant, Iowa.

Distribution: Known only from the type locality.

This species was collected in the spring of 1906. So far as we know it has not been reported from any other place.

9. Sclerotinia nyssaegena (Ellis) Rehm, Ann. Myc. 4: 338. 1906.

Peziza nyssaegena Ellis, Bull. Torrey Club 8: 73. 1881.

Ciboria nyssaegena Sacc. Syll. Fung. 8: 207. 1889.

Helotium nyssaegenum Sacc. Syll. Fung. 8: 207. 1889. (as synonym)

Apothecia arising singly, gregarious, or cespitose, concave, becoming nearly plane, pale-yellow to yellowish-brown, reaching a diameter of 3-5 mm.; hymenium concave, or becoming nearly plane, similar in color on the outside of the apothecium; stem very variable in length but often reaching $1-2 \mathrm{~cm}$., about $1 \mathrm{~mm}$. in thickness, of ten branched, usually imbedded in soil; asci clavate, reaching a length $100-110 \mu$ and a diameter of $6-8 \mu$ at their apices; spores partially 2 -seriate, or irregularly crowded, fusoid, narrowed toward the base, $3-4 \times 12-14 \mu$; paraphyses slender, reaching a cliameter of 1-2 $\mu$.

On seeds of $N$ yssa sylvatica, buried under dead leaves.

Type locality: Newfield, New Jersey.

Distributiox: New Jersey, Pennsylvania and New York.

Exsiccati: Ellis, N. Am. Fungi 389.

A small collection of this species was obtained by the author in The New York Botanical Garden, September, 1930, growing with Helotium nyssicola from which it differs in size, color and in its spore measurements.

10. Sclerotinia Camelliae Hansen \& Thomas, Phytopathology 30: 170.1940.

Sclerotia dark-brown to black, usually compound, impregnating and surrounding the petal tissue, variable in form, reaching a size of $12 \times 30 \mathrm{~mm}$.; conidia none; microconidia globose to pyriform, 2.5-3.5 $\mu$ in diameter, produced in long chains on conidiophores which are produced in clusters.

Apothecia occurring singly or in groups, buff-olive, becoming darker with age, scantily pubescent, cyathiform to discoid, reaching a diameter of 5-20 $\mathrm{mm}$.; stem 2-3 mm. thick and reaching an extreme length of $40 \mathrm{~mm}$., tapering below; asci 
cylindric, reaching a length of 100-125 $\mu$ and a diameter of 4-6 $\mu$, 8 -spored; spores 1-scriate, ellipsoid, simple hyaline, $2.5-3.5 \times$ 5-7 $\mu$; paraphyses filiform, 1.2-2.5 $\mu$ thick, slightly swollen above.

On diseased flowers of Camellia japonica.

Type locality: Hayward, California.

Distribution: Californic and Ontario, Canada.

Illustrations: Phytopathology 30: 167, f. 1; 169, f. $A-D$.

11. Sclerotinia fallax (Sacc.?) Cash \& Davidson, Mycologia 25: 270.1933.

?Sclerotium fallax Sacc. Nuovo Giorn. Bot. Ital. 23: 197. 1916.

Sclerotia on leaf, reaching a length of .3-2 mm., a width of $1 \mathrm{~mm}$. and a thickness of $.5 \mathrm{~mm}$., falling out and leaving holes in the leaf.

Apothecia small, patellate, $1-1.5 \mathrm{~mm}$. in diameter, palebrown, long-stipitate; stem reaching a length of $1.4 \mathrm{~cm}$; asci cylindric, attenuated at the base, reaching a length of $55 \mu$ and a diameter of 5-6 $\mu, 4$-spored; spores 1 -seriate in the upper half of the ascus, narrowed at the lower end, 3-4 $\times 9-12 \mu$; paraphyses filiform, septate, simple, $2 \mu$ thick.

On Potentilla sp.

Type locality: Mesa Lakes, Colorado.

Distribution: Known only from the type locality.

12. Sclerotinia minor Jagger, Jour. Agr. Res. 20: 333. 1920.

Sclerotia formed on the recently killed leaves of the host, small, .5-2 mm. in diameter; microconidia present, 3-4 $\mu$ in diameter.

Apothecia occurring singly, or rarely more than one to each sclerotium, stipitate, .5-2 $\mathrm{mm}$. in diameter; stem cylindric, slender, flexuous, attenuated downward, .5-12 mm. long; asci cylindric, or subcylindric, reaching a length of $125-175 \mu$ and a diameter of $8-11 \mu, 8$-spored; spores cllipsoid to ovoid, $6-8 \times 12$ $16 \mu$; paraphyses filiform, enlarged above, $3-4 \mu$ in diameter.

Parasitic on lettuce, Lactuca, celery, A pium and other plants.

Type locality: New York

Distribution: New York, Massachusetts, Pennsylvania, and Florida.

Illustrations: Jour. Agr. Res. 20:332, f. 1, pl. 59, f. C. 
13. Sclerotinia Veratri Cash \& Davidson, Mycologia 25: 267. 1933.

Sclerotia flat, elliptic, or irregularly elongate, embedded in stems and when infection is severe, diffused over considerable area, dark reddish-brown to black, white within, reaching a length of 3-7 mm. and a width of 1-3 $\mathrm{mm}$. and a thickness of $1 \mathrm{~mm}$.

Apothecia recldish-brown, cupulate at first with inrolled margins, becoming almost flat, usually reaching a diameter of 3-7 $\mathrm{mm}$., or occasionally as large as $1 \mathrm{~cm}$., wrinkled when dry; hymenium brown, becoming lighter, grayish-brown at maturity; stem black, swollen toward the base, .5-1 cm. long and .5-1 $\mathrm{mm}$. thick; asci cylindric, attenuated near the base, reaching a length of $140-150 \mu$ and a diameter of 11-13 $\mu, 8$-spored; spores irregularly 1-seriate, oblong-elliptic, simple, hyaline, usually with two oil-drops, 5-6.5 $\times 15-17.6 \mu$; paraphyses filiform, simple or branched near the base, pale-brown, 2-2.5 $\mu$ thick at the apex.

On Veratrum californicum.

Type locality: Mesa Lakes Reservoir, Colorado.

Distribution: Known only from the type locality.

Illustrations: Mycologia 25: pl. 36, f. 4.

14. Sclerotinia coloradensis Cash \& Davidson, Mycologia 25: 268. 1933.

Sclerotia on stems and seed-pods, thin, flat, elongated, sometimes confluent, black, white within, .2-3 cm. long and 2-5 $\mathrm{mm}$. broad, $.5 \mathrm{~mm}$. thick, inconspicuous on weathered material.

Apothecia one to several from each sclerotium, cup-shaped, becoming flat, margin inrolled when dry, pale-brown, reaching a diameter of 2-3.5 $\mathrm{mm}$.; hymenium pale-brown; stem brown, reaching a length of 4-7 $\mathrm{mm}$. and a diameter of $.5 \mathrm{~mm}$.; asci cylindric, short-stipitate, reaching a length of $135-155$ and a diameter of 7.5-9.5 $\mu, 8$-spored; spores ellipsoid, hyaline, simple, $4-5 \times 10-12 \mu$; paraphyses filiform, septate, simple, $2.5 \mu$ in diameter at their apices.

On Pedicularis groenlandica and Pedicularis bracteosa.

Type locality: Grand Mesa, Colorado.

Distribution: Known only from the type locality.

Illustrations: Mycologia 25: pl. 38, f. 12. 
15. Sclerotinia intermedia Ramsey, Phytopathology 14: 323. 1924.

Sclerotia black, irregular, 1-3 $\mathrm{mm}$. in diameter, often joined together in long chains; microconiclia globose, hyaline, $3.8 \mu$ in diameter formed on short, flask-shaped sterigmata.

Apothecia funnel-shaped to discoid, one to several from a single sclerotium, stipitate, reaching a diameter of $6 \mathrm{~mm}$.; stem 7-12 $\mathrm{mm}$. long, 1-1.25 $\mathrm{mm}$. in diameter, expanding upward into the apothecium; hymenium tawny-olive at first, changing to snuff-brown at maturity, buff after the ejection of the spores; asci cylindric to cylindric-clavate, reaching a length of $130 \mu$ and a diameter of 7-8 $\mu$; spores ellipsoid to ovoiel, with one oildrop, hyaline, $4-6 \times 10-15 \mu$; paraphyses filiform, simple.

On roots of salsify (Tragopogon porrifolius) and carrot (Daucus Carota) from the markets.

Type Locality: Chicago, Illinois.

Distribution: Known only from the type locality.

Illustrations: Phytopathology $14: 324, f .1 ; 325, f$. +6.

16. Sclerotinia Panacis Rankin, Phytopathology 2: 30. 1912.

Sclerotia large, .3-1 cm. in diameter, irregularly depressedglobose, solitary, or aggregated, black; conidia in potato-agar cultures, globose, small, 3-5.5 $\mu$ in diameter, borne on verticillatebranching conidiophores.

Apothecia scattered, or gregarious and sometimes cespitose. fleshy to subcoriaceous, closefl at first, then expanding, finally flat with a distinct elepression in the center from which radiate folds in the hymenium, more or less irregular, reaching a diameter of $1.5-2.5 \mathrm{~cm}$., brown, stipitate; stem smooth, variable in length, tortuous, 2-3 $\mathrm{mm}$. thick; asci narrowly cylindric, reaching a length of $125-137 \mu$ and a diameter of $6.5 \mu$; spores obliquely 1 -seriate, hyaline, with two oil-drops, simple, smooth, ellipsoid, 5-7 × 11-16 $\mu$; paraphyses scarce, slightly thickened above.

On sclerotia of "black-rotted" tubers of cultivated ginseng, Panax quinquefolium.

Type Locality: Labrador Lake, New York.

Distribution: Known only from the type locality.

Illustrations: Phytopathology $2: 29, f . a-c, p l .3$. 
17. Sclerotinia sativa Drayton \& Groves, Mycologia 35: 526. 1943.

Sclerotia black, irregular in shape, usually more or less circular to elongated, 1-5 mm. in length or rarely longer and 1-2 mm. thick, frequently becoming laterally fused and forming irregular crusts not adhering closely to the substratum.

Apothecia appearing singly, or in clusters, stipitate, reaching a diameter of 1-5 mm., shallow cup-shaped to almost plane, or finally convex, slightly hairy to almost glabrous; hymenium concave to plane or convex, brown; stem reaching a length of 2-6 $\mathrm{mm}$., tapering downward less than $1 \mathrm{~mm}$. thick, dark-brown to almost black at the base; asci cylindric with a slender tapering base, reaching a length of $100-130 \mu$ and a diameter of $7.5-10 \mu$; spores ellipsoid to ovoid, hyaline, 1-seriate, $4-7 \times 9-12 \mu$; paraphyses filiform, septate, simple or branched, 2.5-3.5 $\mu$ thick, the tips enlarged to $4-5 \mu$; spermatia present.

On bulbs of Tulipa and roots of Medicago sativa, Melilotus alba, and Melilotus officinalis.

TyPe Locality: New York.

Distribution: New York to Quebec and Alberta, Canada. Illustrations: Mycologia $35: 520, f .1,7 ; 525, f .8$.

\section{Dotbiful Species}

Sclerotinia incondita (Ellis) Sacc. Syll. Fung. 8: 200. 1889; Pesiza incondita Ellis, Bull. Torrey Club 8: 73. 1881. Apothecia occurring on sclerotia the origin of which was undetermined; asci 4-spored; spores 7-8 $\times 10-12 \mu$. Distributed by Ellis (N. Am. Fungi 391). Nothing more is known of this species.

Sclerotinia wisconsinensis Rehm, Ann. Myc. 6: 317. 1908. Occurring on unattached sclerotia in the soil in Wisconsin. This appears to be close to Sclerotinia tuberosa.

\section{CIBORIA Fuckel, Symb. Myc. 311. 1870.}

Stroma a sclerotium, mummiform, occurring in the flowers or fruits of the host which retain much their original form scarcely suggesting a sclerotium; spermidium often present, manteling the developing sclerotium; spermatia globose, or ovoid, hyaline, in mass faintly yellowish; conidia unknown.

Apothecia cupulate to shallow saucer-shaped, often becoming flat, expanded or even reflexed, usually some shade of brown, rarely red, yellow, or whitish, medium sized; asci cylindric or 


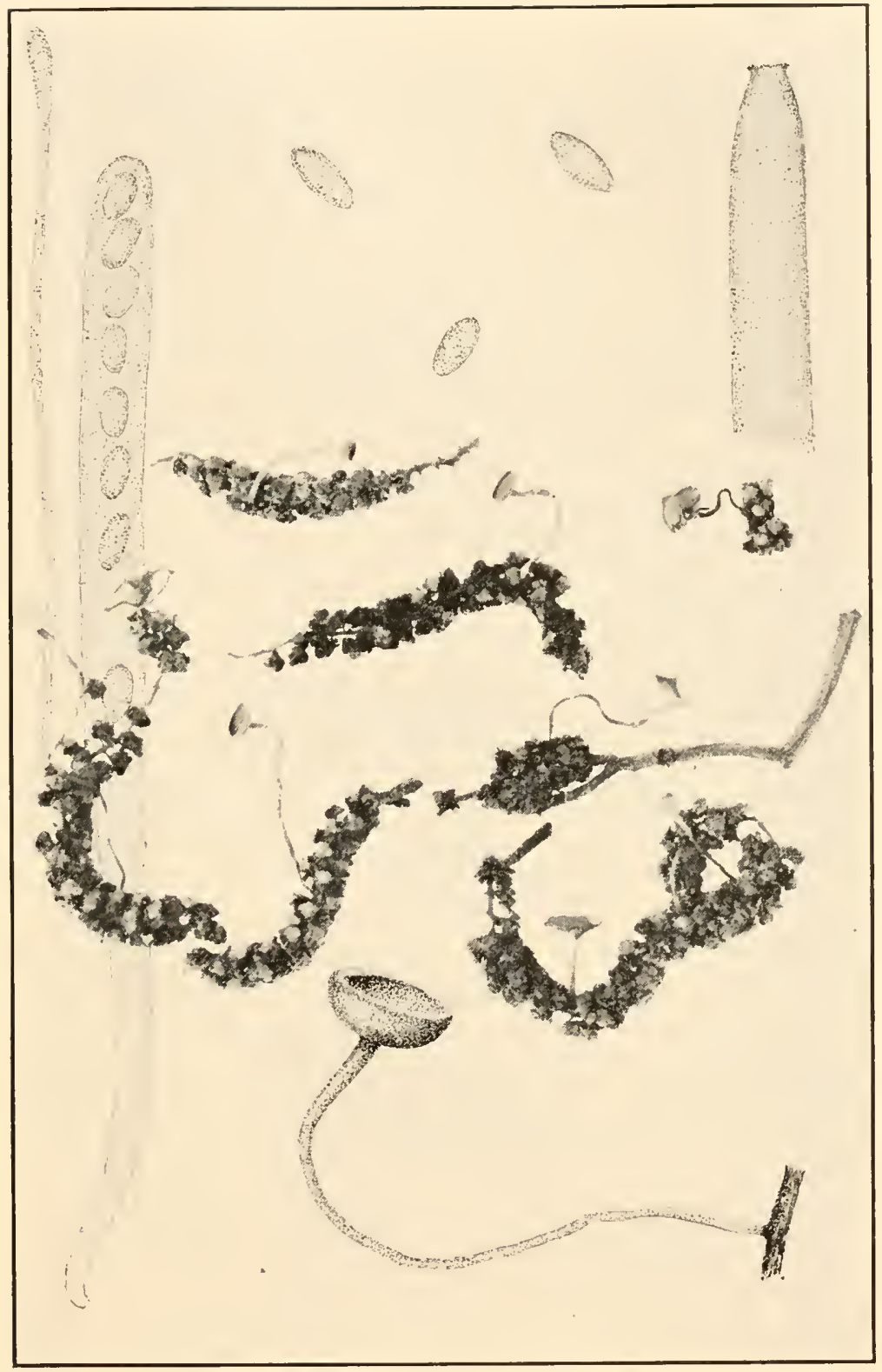

CIBORIA AMENTACEA 

subcylindric, usually 8-spored, rarely 4-spored; spores ellipsoid, or subellipsoid, simple, hyaline, smooth, or minutely roughened; paraphyses, hyaline, or colored, filiform, slightly thickened above.

Type species, Peziza Caucus Rebentich.

On mummified flowers.

On overwintering flowers of Acer.

1. C. acerina.

On catkins of Salix, and Populus.

Apothecia minute, $1 \mathrm{~mm}$. in cliameter, whitish.

2. C. amenti.

Apothecia medium, 2-8 mm. in diameter, brown.

Spores $4-5 \times 9-13 \mu$.

3. C. amentacea.

Spores 5-6 $\times 9-10 \mu$.

4. C. Caucus.

On fruits.

On mulberry fruits, Morus.

5. C. carunculoides.

On old acorns, Quercus.

On mummified apples and other fruits.

6. C. pseudotuberosa.

7. C. aestivalis.

On involucres of Castanea.

8. C. americana.

1. Ciboria acerina Whetzel \& Buchw. Mycologia 28: 516.1936.

Apothecia stipitate, from one to several from the black stromatized male (rarely the female) inflorescence of the host, small, 1-4 $\mathrm{mm}$. in diameter, funnel-shaped to shallow cupshaped. finally expanded and subdiscoid; stem variable in length, 1-10 $\mathrm{mm}$. long, somewhat darker than the apothecium, slightly pubescent when young; asci clavate, reaching a length of 75$100 \mu$ and a diameter of 7-9 $\mu$, 4-spored; spores ellipsoid, slightly flattened on one side, 1-seriate, hyaline, smooth; paraphyses unbranched, slender, gradually enlarged above.

On overwintering male and female flowers of Acer rubrum and on male flowers of Acer saccharinum, Myrica Gale, Salix discolor and Ostrya virginiana.

Type Locality: Cornell University Campus, Ithaca, New York.

Distribution: New York and New Jersey.

Illustrations: Mycologia 28: $517, f$. $7-12 ; 521, f .13-19$.

2. Ciboria amenti (Batsch) Whetzel, Mycologia 37:675. 1945.

Peziza amenti Batsch, Elench. Fung. Cont. 1: 211. 1786.

Helotium amenti Fuckel, Symb. Myc. 313. 1870.

Phialea amenti Quél. Bull. Soc. Bot. Fr. 26: 234. 1879.

Hymenoscypha amenti Phill. Brit. Discom. 143. 1887.

Apothecia scattered, stipitate, whitish, or grayish, reaching a diameter of nearly $1 \mathrm{~mm}$.; hymenium pallid, concave, or nearly plane; stem slender, reaching a length of $5 \mathrm{~mm}$, similar in color 
to the apothecium; asci cylindric-clavate, reaching a length of $60-70 \mu$ and a diameter of $6-7 \mu, 8$-spored; spores ellipsoid, or ovoid, 3-4 $\times 7-10 \mu$; paraphyses filiform, reaching a diameter of $3 \mu$.

On fallen catkins of Salix and Populus.

Type locality: Europe.

Distribution: New York and Oregon; also in Europe.

Illustrations: Batsch, Elench. Fung. Cont. 1: pl. 27, f. 148; Boud. Ic. Myc. pl. 496; Gill. Champ. Fr. Discom. pl. 90, f. 1.

3. Ciboria amentacea (Balbis) Fuckel, Symb. Myc. 311. 1870. (Plate 93.)

Peziza amentacea Balbis, Mem. Acad. Sci. Turin II. 2: 79. 1805.

Rutstroemia amentacea Karst. Myc. Fenn. 1: 106, 1871.

Hymenoscypha amentacea Phill. Brit. Discom. 120. 1887.

Apothecia springing from the sclerotium formed in the mummified catkins of the host, gregarious, stipitate, yellowishbrown, shallow cup-shaped, then expanded, reaching a diameter $1 \mathrm{~cm}$. or rarely larger; stem variable in length, often reaching a length of 2-4 cm.; asci cylindric, or subcylindric, reaching a length of $110-120 \mu$ and a diameter of 7-10 $\mu, 8$-spored; spores 1-seriate,

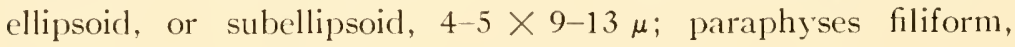
1-2 mm. in diameter, slightly enlarged above.

On catkins of Alnus incana and Salix discolor.

Type locality: Europe.

Distribution: New York to Oregon.

Illustrations: Mycologia 37: 677, f. 11-13; Rab. Krypt.Fl. $1^{3}: 750, f .1-3$; Friesia $3: 247, f .6 ; 249, f .7: 250, f .8$.

4. Ciboria Caucus (Reb.) Fuckel, Symb. Myc. 311. 1870.

Peziza Caucus Rebentisch, Prodr. Fl. Neomarch 386. 1804.

Phialea Caucus Gill. Champ. Fr. Discom. 110. 1882.

Hymenoscypha Caucus Phill. Brit. Discom. 120. 1887.

Apothecia stipitate, springing from a mummified sclerotium within the tissues of the host, cup-shaped with margin incurved, finally expanding and becoming saucer-shaped, or subdiscoid, 2-8 $\mathrm{mm}$. in diameter, brown; stem 2-8 $\mathrm{mm}$. long, $5 \mathrm{~mm}$. thick; asci cylindric-clavate, reaching a length of $130 \mu$ and a diameter of $9 \mu, 8$-spored; spores ellipsoid, or subellipsoid, 5-6 $\times 9-10 \mu$, hyaline; paraphyses filiform, slightly enlarged above.

On fallen catkins of Populus tremuloides and Salix.

Type locality: Europe. 


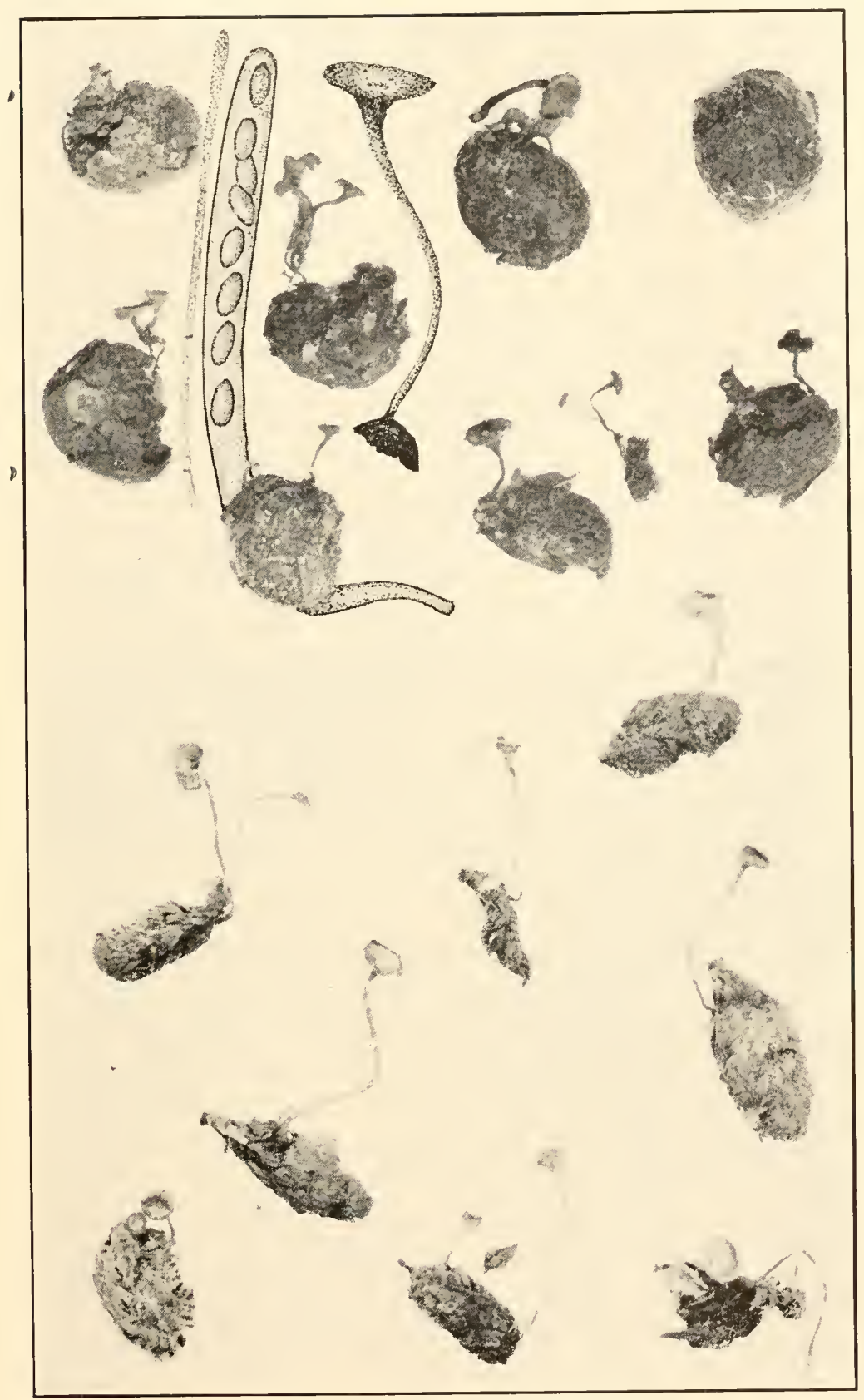

1. CIBORIA PSEUDOTUBEROSA

2. CIBORIA CAUCUS 

Distribution: New York to Oregon and Minnipeg, Canada; also Europe.

Illustrations: Mycologia $37: 677, f .17,15$.

This and the preceding species are very close both in habitat and in morphological characters. They should be studied more carefully from living material.

5. Ciboria carunculoides (Siegler \& Jenkins) Whetzel \& IVolf, Mycologia 37: 676. 1945. (PLATE 95.)

Sclerotinia carunculoides Siegler \& Jenkins, Jour. Agr. Res. 23: 835. 1923.

Sclerotia formed in the ovaries and calyx lobes of mulberry, preventing the formation of normal fruits, black, fairly regular, subspherical; microconidia produced in great numbers, subglobose $2-4 \times 2-3.2 \mu$.

Apothecia one to several from a single sclerotium, cupulate, or subcupulate, 4-12 mm. in diameter, inside snuff-brown, outside Prout's brown, stipitate; stem cylindric, flexuous, smooth, attenuated upwards, 15-42 mm. long, reaching a diameter of 1.5 mm.; asci cylindric, or cylindric-clavate, reaching a length of $104-123 \mu$ and a diameter of 6-8 $\mu$. 8-spored, spores 1-seriate, reniform, hyaline, $2.4-4 \times 6-9.6 \mu$, with two bodies on the concave surface, one more or less rhombic as seen from above about $2 \times 4 \mu$ and adjoining it a more or less hemispherical body $3 \mu$ in its longest diameter; paraphyses filiform to cylindricclavate.

On mulberry fruits (Morus alba).

Type locality: Scranton, South Carolina.

Distribution: South Carolina; also reported from other southern states.

Illustrations: Jour. Agr. Res. 23: 834, f. 1, pl. 1, 2; Mycologia $37: 479, f .1 ; 481, f .2 ; 482, f .3 ; 485, f .4$.

6. Ciboria pseudotuberosa Rehm, Ascom. 106: 1872; Ber. Nat. Ver. Augsburg 26: 28. 1881.

Hymenoscypha pseudotuberosa Phill. Brit. Discom. 119.1887.

Sclerotinia pseudotuberosa Rehm in Rab. Krypt.-Fl. 133: 809. 1893.

Stromatinia pseudotuberosa Boud. Ic. Myc. 278. 1911.

Apothecia springing from a sclerotium-like growth within the seeds of the host, stipitate, at first closed, opening and becoming cup-shaped, later expanding and becoming nearly plane, or umbilicate, reaching a diameter of $1-2 \mathrm{~cm}$. or rarely larger, brown or brownish; stem variable in length, often reaching $1-2 \mathrm{~cm}$; 
asci cylindric or subcylindric, reaching a length of 120-150 $\mu$ and a diameter of 6-10 $\mu, 8$-spored; spores ellipsoid, 5-6 $\times 8-10 \mu$; paraphyses slender, $3 \mu$ in diameter, slightly enlarged above.

On old acorns, Quercus.

Type locality: Europe.

Distribution: New Jersey to Iowa; also in Europe.

Illustrations: Rab. Krypt. Fl. $1^{3}: 800, f$. 1-5; Phill. Brit. Discom. pl. 5, f. 25; Boud. Ic. Myc. pl. 480.

Exsiccatı: Ellis, N. Am. Fungi 983 (as Peziza pseudotuberosu Rehm).

7. Ciboria aestivalis (Pollock) Whetzel; Harrison, Mycologia 27: 317. 1935.

Sclerotinia aestizalis Pollock; Harrison, Mycologia 27: 303. 1935.

Apothecia from one to fifty on a single mummified apple, stipitate, light reddish-brown, at first cup-shaped, discoid at maturity, 1-7 mm. in diameter, with radiating ridges and furrows outside; stem rarely reaching $1 \mathrm{~cm}$. long, $.5 \mathrm{~mm}$. thick; asci clavate or nearly cylindric, reaching a length of $5085 \mu$ and a diameter of $6-8 \mu, 8$-spored; spores narrow ellipsoid, $2-3.5 \times$

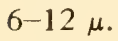

On mummified fruits, especially apples, Malus sp. in the early spring.

Type locality: Ann Arbor, Michigan.

Distribution: Michigan and Maryland?; also in Australia on various fruits.

Illustrations: Mycologia 27: 310, f. A;312, f. B.

8. Ciboria americana Durand, Bull. Torrey Club 29: 461. 1902. Rutstroemia americana White, Lloydia 4: 188. 1941.

Apothecia solitary, stipitate, cup-shaped, usually becoming plain or with the margin reflexed and umbilicate, thin, waxymembranous, pale-cinnamon to brown, 3-10 $\mathrm{mm}$. in diameter; stem 2-10 mm. long, slencler; asci clavate, usually curved, reaching a length of $75 \mu$ and a diameter of $9 \mu, 8$-spored; spores 2-seriate, hyaline, smooth, ellipsoid to ovoid, slightly unsymmetrical, $4-5 \times 9-12 \mu$; paraphyses filiform.

On stromatized involucres of Castanea vesca lying on the ground among leaves.

Type Locality: Ithaca, New York.

Distribution: New York and Pennsylvania to Ontario. 


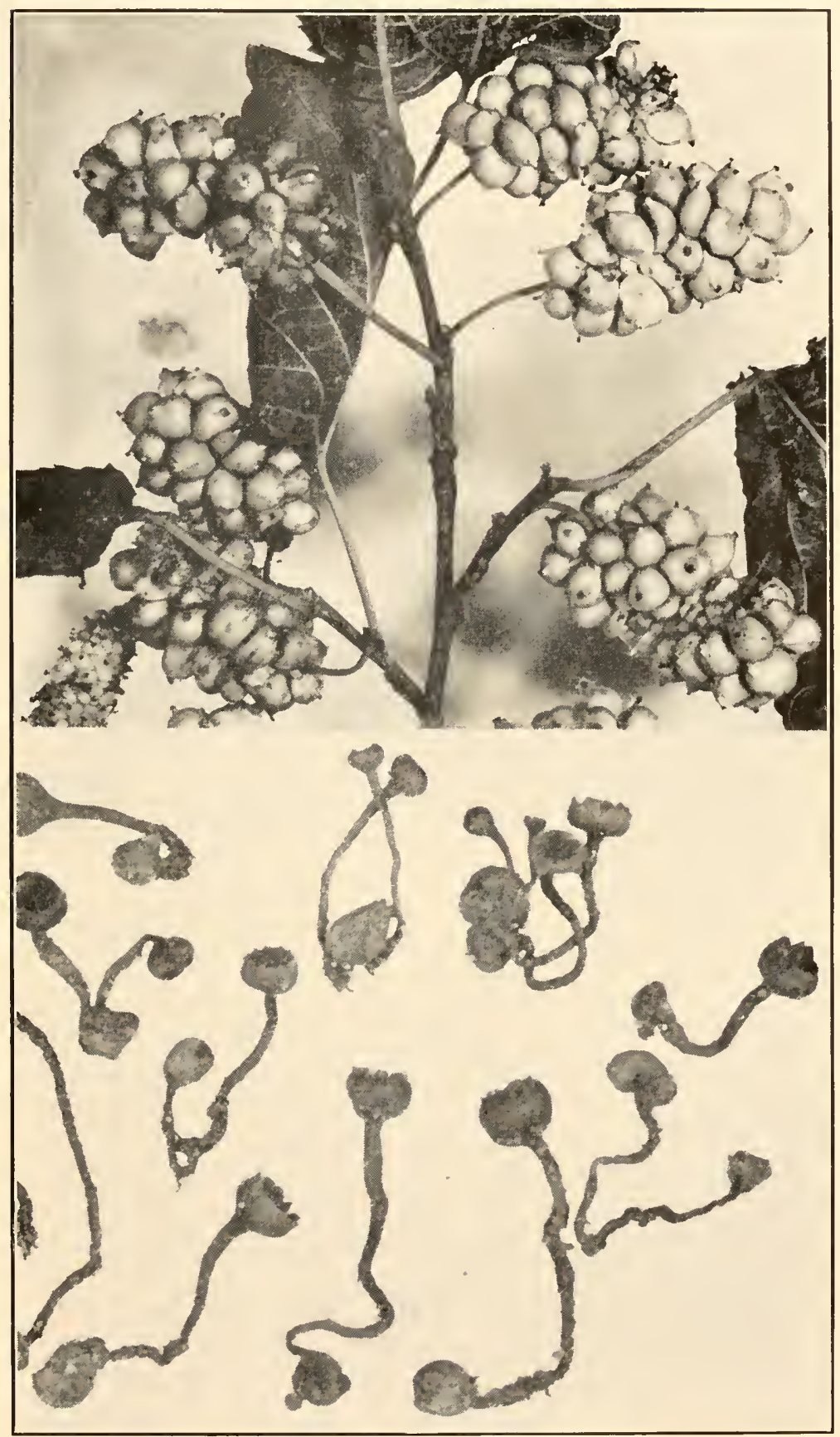





\section{Doubtfll Species}

Ciboria Liquidambaris Ellis \& Ev. Proc. Acad. Sci. Phila. 1895: 428. 1895. Apothecia stipitate, $2 \mathrm{~mm}$. in diameter; hymenium convex, brownish; stem whitish, $4 \mathrm{~mm}$. long; asci clavate, $7-8 \times 75-80 \mu$; spores ellipsoid, $3 \times$ 8-11 $\mu$. On decaying capsules of Liquidambar, Naamans Creek, Delaware. Type material very scant.

Ciboria rufofusca (Weberb.) Sacc. Syll. 8: 203. 1889; Peziza rufofusca Weberb. Pilze Norddeuts. 7. 1875. On scales of cones of Abies, Washington. Whether this species is a Ciboria in the sense here used is uncertain.

13. STROMATINIA Boud. Hist. Class. Discom. Eu. 108. 1907.

Stroma of two types, a thin, black, subcuticular sclerotium covering or manteling the affected portion of the host from which the apothecia are produced and small, black sphaerules borne free on the mycelium and not producing apothecia; spermatia globose.

Apothecia as in Sclerotinia; spores hyaline, simple.

Type species, Peziza Rapulum Bull.

On dead rhizomes of Smilacina.

1. S. Smilacinae.

On Gladiolus and other ornamentals.

2. S. Gladioli.

1. Stromatinia Smilacinae (Durand) Whetzel, Mycologia 37: 674. 1945. (Plate 96.)

Sclerotinia Smilacinae Durand, Bull. Torrey Club 29:462. 1902.

Sclerotia small, not exceeding 1-2 $\mathrm{mm}$. in diameter, irregularly globose, aggregated and sometimes coalesced into a thin, crust-like mass $1-2 \mathrm{~cm}$. in diameter.

Apothecia scattered, or gregarious, long-stipitate, fleshyleathery, closed and subglobose at first, expanding to cupshaped, finally becoming campanulate, usually with a depression in the center, sometimes contorted or irregular, reaching a diameter of 1-3 cm., bright cinnamon-brown, externally smooth; stem reaching a length of 2-6 cm. and a thickness of 2-3 mm., tapering downward, sometimes tomentose below; asci narrowly cylindric, apex rounded, reaching a length of $120-140 \mu$ and a diameter of 6-8 $\mu, 8$-spored; spores obliquely 1-seriate, hyaline, simple, smooth, narrowly ellipsoid, often with two oil-drops, 4-5 $\times 12-15 \mu$; paraphyses filiform, scarcely thickened above.

On dead rhizomes of Smilacina racemosa buried in rich humus.

Type Locality: Fall Creek, Ithaca, New York.

Distribution: New York.

Illustrations: Jour. Agr. Res. 5 : pl. 29. 
Dr. Edwin E. Honey (Mycologia 20: 139. 1923.) states that it is believed by him and others that Durand misidentified the host of his fungus, and that his species is identical with Stromatinia Rapulum (Bull.) Boud. which occurs on Polygonatum.

2. Stromatinia Gladioli (Massey) Whetzel, Mycologia 37:674. 1945.

Sclerotium Gladioli Massey; Drayton, Phytopathology 18: 521. 1928.

Sclerotinia Gladioli Drayton, Phytopathology 24: 400. 1934.

Sclerotia black, 90-300 $\mu$ in diameter; microconidia globose, $1.2-1.8 \mu$ in diameter, apparently functioning as spermatia.

Apothecia densely cespitose, stipitate, 3-7 mm. broad, 6-10 mm. high; hymenium umbilicate, convex-discoid, sometimes convolute, cinnamon-brown; stem chestnut-brown; asci cylindric to cylindric-clavate, reaching a length of $190-235 \mu$ and a diameter of $8-10 \mu, 8$-spored; spores 1-seriate, ellipsoid, hyaline, usually with one oil-drop, 5.6-9.5 $\times 10-16 \mu$; paraphyses abundant, filiform, slightly clavate, $2.8-3.2 \mu$ in diameter at their apices.

Parasitic on species of Gladiolus, Freesia and Crocus.

Type locality: Ithaca, New York.

Distribution: United States and Canada; also in Europe and New Zealand.

Illustrations: Phytopathology 24: 401, f. 1; 402, f. 2; 403, f. 3 .

14. COPROTINIA IVhetzel, Farlowia 1:484. 1944.

Stroma not observed in nature, of indefinite form, 1-2 $\mathrm{mm}$. thick and several cm. in diameter, consisting of one to several layers of black hyphae; spermatia not seen; conidial stage wanting.

Apothecia gregarious, numerous, long, slender-stipitate, some shade of brown, relatively small; stem hair-like, minutely roughened by the ends of the hyphal tips; asci very small, clavate; spores 2-scriate, crowded near the end of the ascus, hyaline.

Type species, Coprotinia minutula Whetzel.

1. Coprotinia minutula Whetzel, Farlowia 1:484. 1944.

Stroma as above.

Apothecia arising in large numbers from all over the surface of the stroma, very long-stipitate, 1-2 mm. in diameter, chestnut 


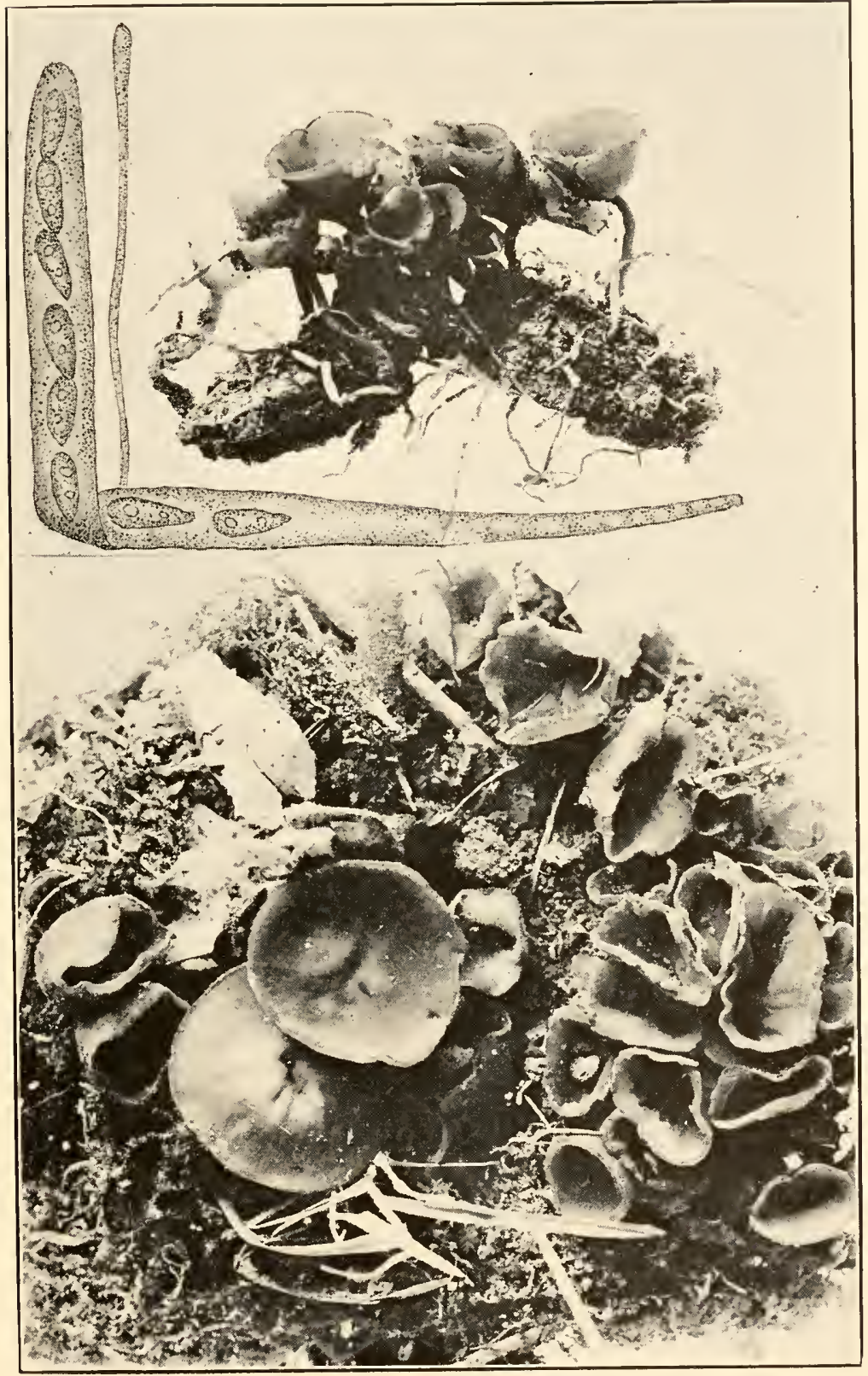

SCLEROTINIA SMILACINA 

brown; stems very slender, hair-like, reaching a length of $20 \mathrm{~mm}$. and one-fourth of a mm. thick; asci short, stout, clavate, reaching a length of $31-47 \mu$ and a diameter of $3-5 \mu, 8$-spored; spores ellipsoid, $1.5-2 \times 4-6 \mu$; paraphyses cylindric, 3-3.5 $\mu$ thick.

On a small dung ball of some unknown animal. Found only once.

Type Locality: Malloryville, New York.

Distribution: Known only from the type locality.

Illustrations: Farlowia $1: 485, f .1-3 ; 486, f$. 4-6.

15. MIDOTIS Fries, Syst. Orbis Veg. 363. 1825; Elench. Fung. 2: 29. 1828.

Rutstroemia Karst. Myc. Fenn. 1: 105. 1871.

Ionomidotis Durand, Proc. Am. Acad. Sci. 59: 8. 1923.

Apothecia superficial, solitary, or several springing from the same substratum, at first subglobose and closed, expanding and usually becoming vertically elongated on one side when mature, yellow, brown, dark-blue or olivaceous; the excipulum subcoriaceous, composed of interwoven hyphae which often project from the surface as short, stout, septate, hair-like hyphae, often violet with transmitted light, or when treated with K. O. H.; asci cylindric, or clavate, 8 -spored; spores small, hyaline, simple; paraphyses filiform, or in one species lanceolate above.

Type species, Midotis Lingua Fries.

This genus corresponds with Scodellina or Otidea of the operculates on the one hand, and Wynnea and Phillipsia on the other, but differs from both in the inoperculate asci and the relatively minute size of its asci and spores. Saccardo combined Wynnea and Midotis although they are widely separated, the former being an operculate and the latter an inoperculate.

Rutstroemia Karst. was founded on Peziza bulgarioides Rab. which in the opinion of the writer is a Midotis. Karsten's genus contained several other species not now regarded as congeneric which has resulted in much confusion. We cannot accept White's version of the genus in which the last species mentioned by Karsten is adopted as the type.

Apothecia dark-blue, violet, or purple, nearly black in mass.

Paraphyses with lance-like tips; apothecia large, several $\mathrm{cm}$. in diameter.

1. M. irregularis. 
Paraphyses filiform, without lance-like tips.

Apothecia large 1-2 cm.; spores 5-7 $\times 15-18 \mu$. 2. M. nicaraguensis.

Apothecia small 1-2 mm.; spores $2-3 \times 5-8 \mu$. 3. M. plicata. Apothecia not blue, violet, or purple.

Apothecia olivaceous.

Apotheica large, $1-3 \mathrm{~cm}$.

Apothecia small, not exceeding $5 \mathrm{~mm}$. in diameter.

Spores medium, $3 \times 7-8 \mu$.

Spores minute, $1 \times 3-4 \mu$.

4. M. v'ersiformis.

5. M. olivascens.

6. M. floridana.

Apothecia yellow, reddish, or brownish.

Apothecia externally bright-yellow; hymenium darker.

7. M. heteromera.

Apothecia pale- to dark-brown.

Occurring singly usually.

8. M. occidentalis.

Occurring in dense cespitose clusters.

9. M. Westii.

1. Midotis irregularis Cooke; Sacc. Syll. Fung. 11: 422. 1895.

Peziza irregularis Schw. Trans. Am. Phil. Soc. II. 4: 171. 1832.

Cordierites irregularis Cooke, Bull. Buffalo Acad. Sci. 3: 26. 1875.

Peziza doratophora Ellis \& Ev. Jour. Myc. 1: 90. 1885.

Otidea doratophora Sacc. Syll. Fung. 8: 96. 1889.

Ionomidotis irregularis Durand, Proc. Am. Acad. Sci. 59: 9. 1923.

Apothecia occurring singly, or more often in cespitose clusters from a common stem-like base up to $2 \mathrm{~cm}$. in length which penetrates the substratum, at first closed then opening and becoming much elongated on one side and irregularly lobed or lacerated, reaching a length and width of $3 \mathrm{~cm}$., the entire cluster reaching a diameter of 5-7 cm., externally scurfy, dark chestnutbrown; hymenium darker than the outside of the apothecium, almost black; asci cylindric-clavate, the apex truncate-rounded, reaching a length of 50-70 $\mu$ and a diameter of $4-5 \mu, 8$-spored; spores 1-seriate, or partially 2 -seriate, hyaline, or subhyaline, smooth, containing two or three oil-drops, 3-4 4 8-10 $\mu$; paraphyses with a violet tint, each terminated by a lanceolate, 1-3-septate head 3-4 $\times 18-30 \mu$ which project beyond the hymenium and is easity detached.

On rotten wood and branches lying on the ground.

Type locality: Bethlehem, Pennsylvania.

Distribution: New Hampshire to Oregon, Pennsylvania and Ohio.

Illustrations: Proc. Am. Acad. Sci. 59: pl. 1.

A specimen in the herbarium from Ohio is labeled Diplocarpa tinctoria Massee \& Morgan (type). The writer could find no 


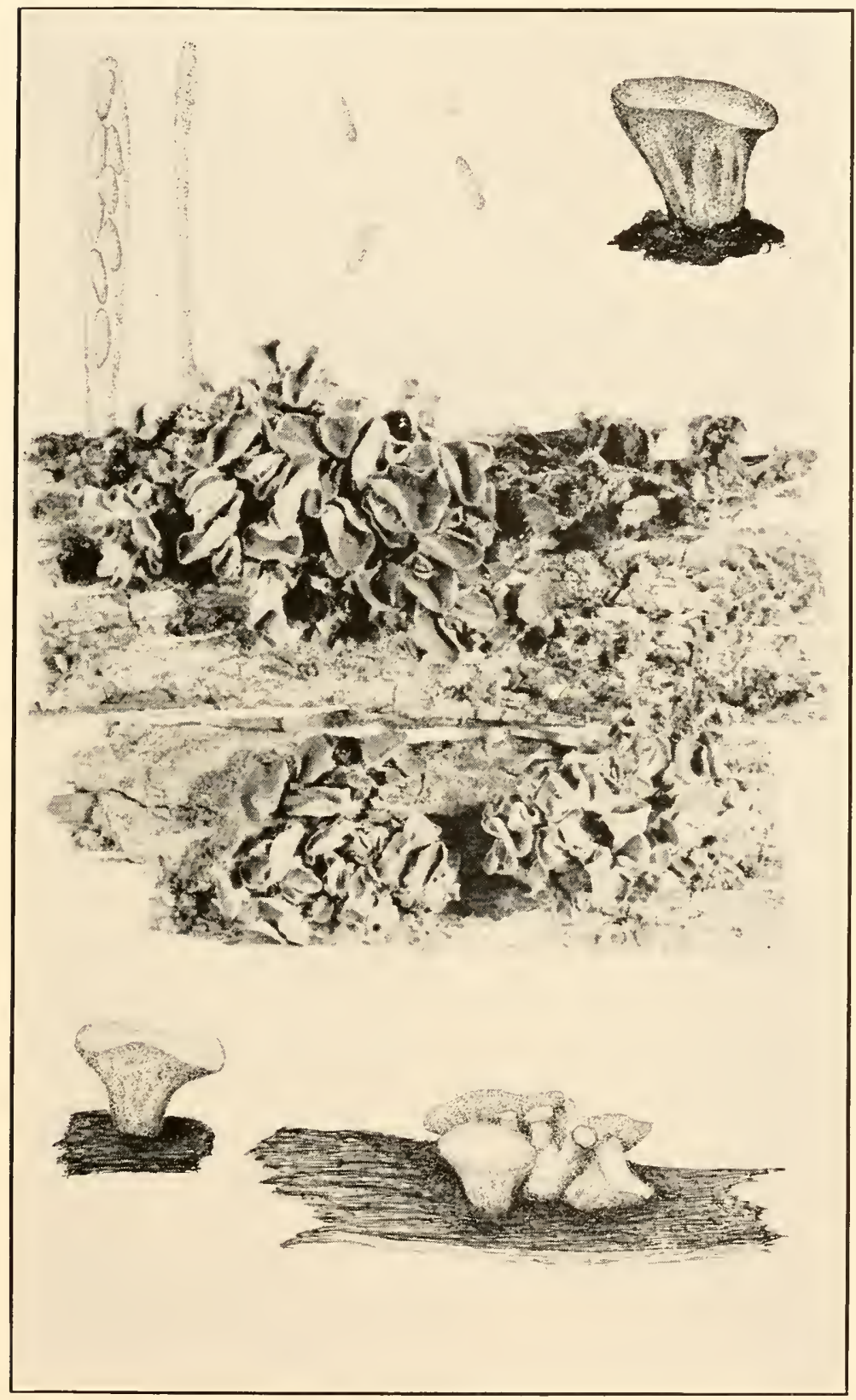



record of its publication but we record it here in order to call attention to the name.

\section{Midotia nicaraguensis (Durand) Seaver, comb. nov.}

Ionomidotis nicaraguensis Durand, Proc. Am. Acad. Sci. 59: 11. 1923.

Ciboria caespitosa Seaver, Mycologia 17: 48. 1925.

?Ionomidotis portoricensis Seaver, Mycologia 17: 50. 1925.

Apothecia closely clustered, or coalesced at the base, at first closed, then opening and expanding so as to become applanate (when (lry), sessile, attached at one side of the base, reaching a diameter of 1-2 cm., externally dark ferruginous-brown, verrucose; hymenium blackish-brown, becoming lark reddish-purple when wet; asci cylindric-clavate, the apex rounded, reaching a length of 135-150 and a diameter of $8 \mu, 8$-spored; spores 1seriate, hyaline, smooth, 5-7 × 15-18 ; paraphyses slender, hyaline, below, slightly thickened and brownish at their apices.

On rotten logs.

Type locality: Nicaragua.

Distribution: Nicaragua and Porto Rico.

Illustrations: Proc. Am. Acarl. Sci. 59: pl. 1.

Our species from Porto Rico agrees so closely with Durand's description that we feel safe in combining them. Ionomidotis portoricensis is close to Ciboria caespitosa and may be identical. The material is scant.

3. Midotis plicata Phill. \& Hark. Bull. Calif. Acad. Sci. 1: 24. 1884.

Ionomidotis plicata Durand, Proc. Anı. Acad. Sci. 59: 12.1923.

Apothecia small, clustered, or several arising from a common base, at first closed, then opening by a pore, becoming unsymmetrically goblet-shaped, resembling a minute Urmula Craterium, reaching a height and width of 1-2 mm., externally black when moist, brownish-black when dry, externally granular-furfuraceous, the substance thin, dark violet-brown and opaque under the microscope; asci cylindric-clavate, the apex rounded, reaching a length of 65-70 $\mu, 8$-spored; spores irregularly 2-seriate, smooth, hyaline, narrowly ellipsoid, straight or strongly curved, 2-3 $\times 5-8 \mu$; paraphyses abundant and often forked, the contents pale violet-brown, the tips slightly swollen and darker.

On dead Umbellularia californica. 
Type locality: Sausalito, California.

Distribution: Known only from the type locality.

Illustrations: Proc. Am. Acad. Sci. 59: pl. 1.

4. Midotis versiformis (Pers.) Seaver, comb. nov. (Plate 99, FIG. 1.)

Peziza versiformis Pers. Ic. Descr. 25. 1798.

Chlorosplenium versiforme DeNot. Comm. Critt. Ital. 1: 376.1864.

Helotium versiforme Berk. Outl. Brit. Fung. 372. 1860.

Helotium rugipes Peck, Ann. Rep. N. Y. State Mus. 26: 82. 1874.

Lanzia rugipes Sacc. Syll. Fung. 8: 480. 1889.

Coryne versiformis Rehm in Rab. Krypt.-Fl. 132: 492. 1891.

Chlorociboria versiformis Seaver, Mycologia 28: 393. 1936.

Apothecia short-stipitate, becoming expanded and subdiscoid, or more often elongated on one side, entirely light-green, or olivaceous, occasionally brownish or orange, reaching a diameter of $1-3 \mathrm{~cm}$.; stem short, usually not exceeding 4 or $5 \mathrm{~mm}$., rather stout; asci clavate, reaching a length of $100-110 \mu$ and a diameter of 5-7 $\mu$, 8-spored; spores irregularly long-ellipsoid, straight, or curved, $3-4 \times 9-14 \mu$ occasionally becoming 1 septate; paraphyses strongly enlarged above where they reach a diameter of $2-3 \mu$, containing a greenish coloring matter.

On decaying wool.

Type locality: Europe.

Distribution: New York and Massachusetts to Iowa and south to Mexico.

Illustrations: Boud. Ic. Myc. pl. 486; Bull. Lab. Nat. Hist. State Univ. Iowa 6: pl. 24, f. 2; Pers. Ic. Deser. pl. 7, f. 7; Berk. Outl. Brit. Fung. pl. 2, f. 6; Mycologia 28: 392 (upper figure).

Exsiccati: Ellis, N. Am. Fungi 988.

\section{Midotis olivascens (Durand) Seaver, comb. nov.}

Ionomidotis olinascens Durand, Proc. Am. Acad. Sci. 59: 13. 1923.

Apothecia stipitate, solitary, gregarious, or rarely cespitose, at first closed, then opening by a pore, finally becoming discoid, nearly plane with a slightly upturned margin, reaching a diameter of $1.5-3 \mathrm{~mm}$., becoming unsymmetrical and Otidea-like, entirely blackish-olive, externally granular, or nearly smooth; stem slender, reaching a length of 1-2 $\mathrm{mm}$. and a diameter of .5 $\mathrm{mm}$. attached at one side; hymenium nearly plane with a yel- 
lowish tint; asci clavate, the apex rounded, reaching a length of 45-50 $\mu, 8$-spored; spores 2-seriate, hyaline, smooth, straight, or slightly curved, narrow-cllipsoid, $3 \times 7-8 \mu$; paraphyses filiform, scarcely thickened above.

On rotten wood.

Type locality: Coconut Grove, Florida.

Distribution: Known only from the type locality.

Illustrations: Proc. Am. Acad. Sci. 59: pl. 1.

\section{Midotis floridana Seaver, sp. nov.}

Apothecia occurring singly, or often several in cespitose clusters from a common base, stipitate, at first regular in form, soon becoming strongly one-sided, reaching a diameter of 3-4 mm., externally olive-green and pruinose; stem slender, gradually expanding into the apothecium, about $2 \mathrm{~mm}$. long, more or less longitudinally striated; hymenium slightly darker than the outside of the apothecium and stem; asci clavate, reaching a length of $30-55 \mu$ and a diameter of $4 \mu, 8$-spored; spores minute, baccilloid, often slightly curved, $1 \times 4-6 \mu$; paraphyses filiform, about $1 \mu$ in diameter.

Apotheciis sparsis aut caespitosis, stipitatis, difformis, 3-4 mm. diam., extus viridis; ascis clavatis, 8 -sporis, $4 \times 30-55 \mu$; sporis minutis, $1 \times 4-6 \mu$; paraphysibus filiformibus, $1 \mu \mathrm{diam}$.

On rotten wood.

Type locality: Gainesville, Floricla.

Distribution: Florida.

7. Midotis heteromera (Mont.) Fires, Summa Veg. Scand. 362. 1849.

Peziza heteromera Mont. Ann. Sci. Nat. II. 13: 206. 1840.

Midotis zerruculosa Berk. \& Curt. Jour. Linn. Soc. 10: 370. 1869.

Apothecia occurring singly, or several arising from a common, stem-like base, irregularly elongated on side, tough, corky to leathery when dry, reaching a length and width of $2-3 \mathrm{~cm}$.. externally verrucose, rhubarb-colored to citrine; hymenium reddish-brown; asci clavate-cylindric, the apex rounded, reaching a length of $80-90 \mu$ and a diameter of $5 \mu, 8$-spored; spores 1 -seriate, hyaline, smooth, ellipsoid to cymbiform, 3.5-4 $\times 8$ $10 \mu$; paraphyses slender projecting above the asci.

On rotten wood. 
Type Locality: South America.

Distribution: West Indies and Costa Rica; also in South America.

Illustration: Ann. Sci. Nat. II. 13: pl. 6, f. 3.

8. Midotis occidentalis Durand, Proc. Am. Acad. Sci. 59: 6. 1923.

Apothecia small, scattered, or closely gregarious, stipitate, coriaceous, elongated on one side and split to the stem on the other, reaching a length and width of 3-5 mm., externally blackish-brown, vertically striated; hymenium brownish; stem reaching a length of 3-7 $\mathrm{mm}$. and a thickness of $1 \mathrm{~mm}$., gradually expanding above into the apothecium; asci clavate-cylindric, apex rounded, reaching a length of $80 \mu$, 8-spored; spores 1 seriate, hyaline, smooth, ovoid-ellipsoid, $3 \times 5-6 \mu$; paraphyses slender, hyaline, not thickened above, longer than the asci.

On a decaying log.

Type locality: Mabess River, Jamaica.

Distribution: Known only from the type locality.

\section{Midotis Westii Seaver, sp. nov. (Plate 97.)}

Apothecia in dense, semiglobose clusters springing from a common base, the clusters reaching a diameter of $1-2 \mathrm{~cm}$. and consisting of twelve to fifteen apothecia closely crowded together, individual apothecia subturbinate and vertically striated outside. the striations very prominent in dried specimens, the flesh thick and coriaceous when fresh, corky when dry, becoming more or less one sided, externally pale-brown, lighter below, reaching a diameter of $7 \mathrm{~mm}$; hymenium slightly concave, darker than the outside of the apothecium; asci clavate, reaching a length of $60 \mu$ and a diameter of 5-6 4 , 8-spored; spores minute, about $2 \times$ 4-5 $\mu$; paraphyses slender, slightly enlarged above, not over $2 \mu$ in diameter at their apices.

Apotheciis dense caespitosis, subturbinatis, extus verticalis striatis, $7 \mathrm{~mm}$. diam., hymenio concavo, dilute bruneo; ascis clavatis, 8-sporis, 5-6 $660 \mu$; sporis $2 \times 4-5 \mu$; paraphysibus clavatis, $2 \mu$ diam.

On wood of Ostrya.

Type Locality: Sanchez Hammock, near Gainesville, Florida.

Distribution: Known only from the type locality. 


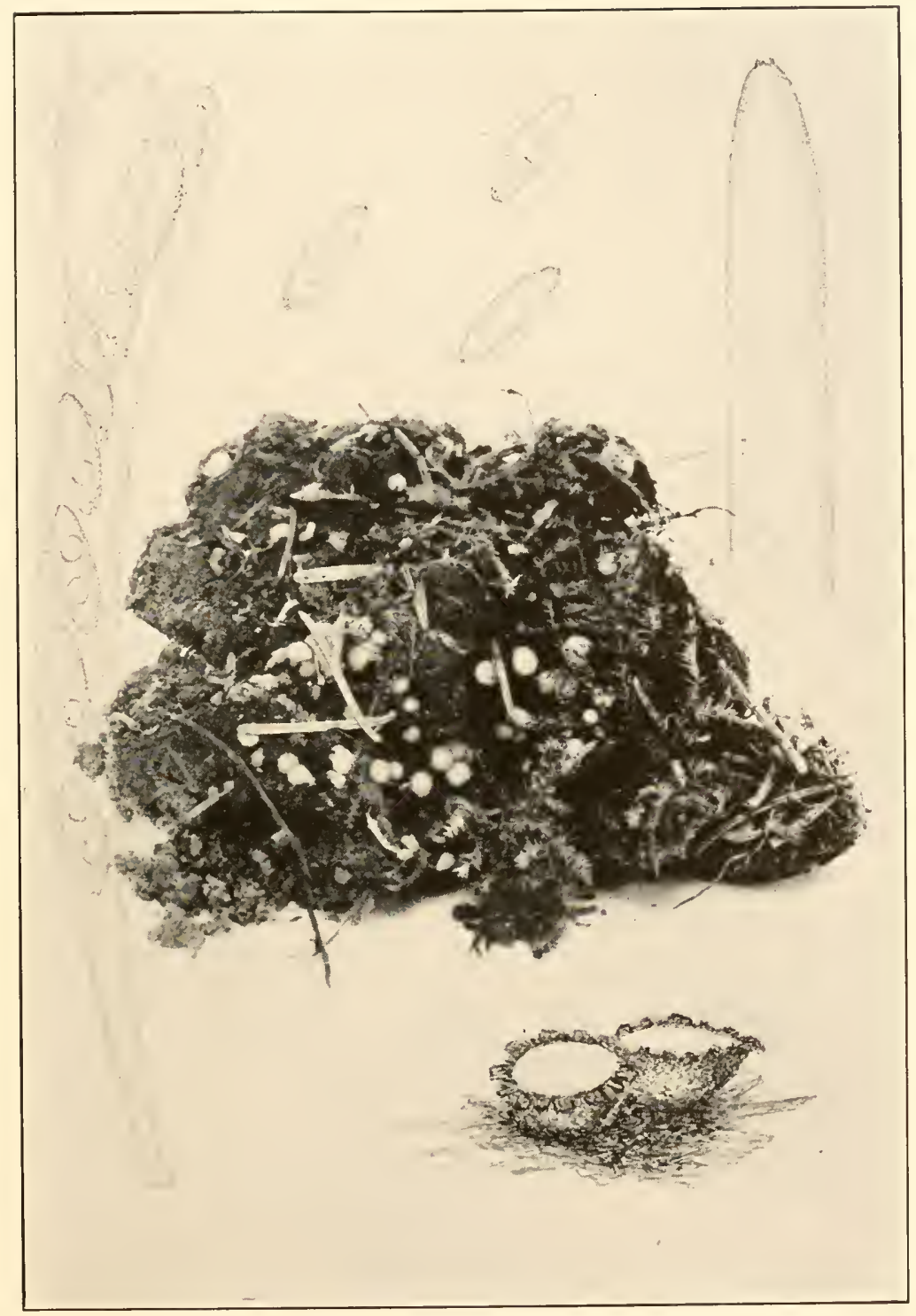

PODOPHACIDIUM XANTHOMELUM 



\section{DoubtFul Species}

Ionomidotis fulvotingens (Berk. \& Curt.) Cash, Jour. Wash. Acad. Sci. 29: 50. 1939; Cenangium fulvotingens Berk. \& Curt. Grevillea 4: 4. 1875. According to Miss Cash, this species belongs with the present genus. One specimen collected by L. O. Overholts (16856) in Pennsylvania has been referred to this species by him. No authentic material has been seen.

16. PODOPHACIDIUM Niessl in Rab. Fungi Eu. 1153.1868. Melachroia Boud. Hist. Class. Discom. Eu. 96. 1907.

Apothecia contracted at the base, substipitate, obconic to turbinate, opening with a laciniate aperture; hymenium freely exposed at maturity and bright-colored, yellow-olivaceous; asci clavate, 8-spored; spores simple, hyaline.

Type species, Podophacidium terrestre Niessl.

Only one species of the genus known to the author.

1. Podophacidium xanthomelum (Pers.) Kavina, Crypt. Cech. Exsicc. 217. 1936. (Plate 98.)

Peziza zanthomela Pers. Syn. Fung. 665. 1801.

Peziza xanthomela Pers. Myc. Eu. 1: 296. 1822.

Podophacidium terrestre Niessl in Rab. Fungi Eu. 1153. 1868.

Aleuria xanthomela Gill. Fr. Champ. Discom. 207. 1886.

Humaria xanthomela Sacc. Syll. Fung. 8: 128. 1889.

Urnula terrestris Sacc. Syll. Fung. 8: 550. 1889.

Melachroia xanthomela Boud. Hist. Class. Discom. Eu. 97. 1907.

Melachroia terrestris Boud. Hist. Class Discom. Eu. 97. 1907.

Apothecia thickly gregarious, occasionally a few closely crowded, the hymenium bright-yellow with a slightly olive tint, surrounded with a dark-brownish or almost black laciniate border, the outside of the apothecium dark-brownish or nearly black, reaching a diameter of 3-4 $\mathrm{mm}$.; asci clavate, reaching a length of $90-125 \mu$ and a diameter of $7-9 \mu$; spores ellipsoid, the ends slightly attenuated, usually with two oil drops, 5-6 $610-17 \mu$; paraphyses very slender, branched.

On soil in coniferous woods.

Type locality: Europe.

Distribution: Washington to northern New York, Toronto and Quebec; also in Europe.

Illustrations: Rab. Fungi Eu. 1153; Niessl Beit. pl. 7, f. 50; Boud. Ic. Myc. pl. $7+4$ (as Melachroia xanthomela (Pers.) Boud.); Cooke, Mycographia, pl. 11, f. 41 (as Peziza xanthomela Pers.), Papers Mich. Acad. Sci. 22: pl. 15, f. 2; Mycologia 31:351, f. 1. 
17. CHLOROCIBORIA Seaver, Mycologia 28: 390. 1936.

Chlorosplenium DeNot. Comm. Critt. ItaI. 1: 376. 1864. Not Fries 1849.

Apothecia stipitate, or substipitate, of ten reaching a diameter of $1 \mathrm{~cm}$., or rarely as large as $2 \mathrm{~cm}$., the stem usually about half as long as the diameter of the apothecium, resembling Ciboria, color green, or olivaceous, staining the substratum green; asci usually 8-spored; spores irregularly ellipsoid to vermiform, simple, hyaline; paraphyses slender, clavate.

Type species, Elvela aeruginosa Oed.

The reasons for the establishment of this genus are given in detail in Mycologia (28: 390. 1936). This genus has some characters in common with Midotis, one species, C. versiformis, having been transferred to that genus.

Occurring on rotten wood, staining the wood verdigris green.

1. C. aeruginosa.

Occurring on spruce cones, not staining the substratum.

2. C. strobilina.

1. Chlorociboria aeruginosa (Oed.) Seaver, Mycologia 28: 391. 1936.

Elvela aeruginosa Oed. Fl. Dan. 9: 7. 1770.

Peziza aeruginosa Pers. Obs. Myc. 1: 27. 1796.

?Cantharellus viridis Schw. Trans. Am. Phil. Soc. II. 4: 153.1832.

? Peziza chlorascens Schw. Trans. Am. Phil. Soc. II. 4: 175.1832.

Helotium aeruginosum Fries, Summa Veg. Scand. 355. 1849.

Chlorosplenium aeruginosum DeNot. Comm. Critt. Ital. 1: 376. 1864.

Peziza aeruginescens Nyl. Not. Fauna F1. Fenn. 10: 42. 1869.

Chlorosplenium aeruginescens Karst. Myc. Fenn. 1: 103. 1871.

Chlorosplenium viride Morgan, Jour. Myc. 8: 185. 1902.

Chlorociboria aeruginescens Kanouse, Mycologia 39: 641. 1947.

Apothecia gregarious, stipitate, or subsessile, at first cupshaped, becoming expanded and subdiscoid with the margin slightly elevated, verdigris-green and producing a similar color in the wood on which it grows, reaching a diameter of $5 \mathrm{~mm}$.; hymenium plane or slightly concave, similar in color to the outside of the apothecium, or lighter and sometimes yellowish; stem darker, scarcely exceeding in length one-half the diameter of the apothecium and about $1 \mathrm{~mm}$. thick; asci clavate, reaching a length of $45-50 \mu$ and a diameter of 3-4 $\mu$; spores 2-seriate, or irregularly crowded, narrow ellipsoid, $2-2.5 \times 5-7 \mu$ (rarely 10-12); paraphyses very slencler, about $1.5 \mu$ in diameter, scarcely enlarged above.

On dead wood. 


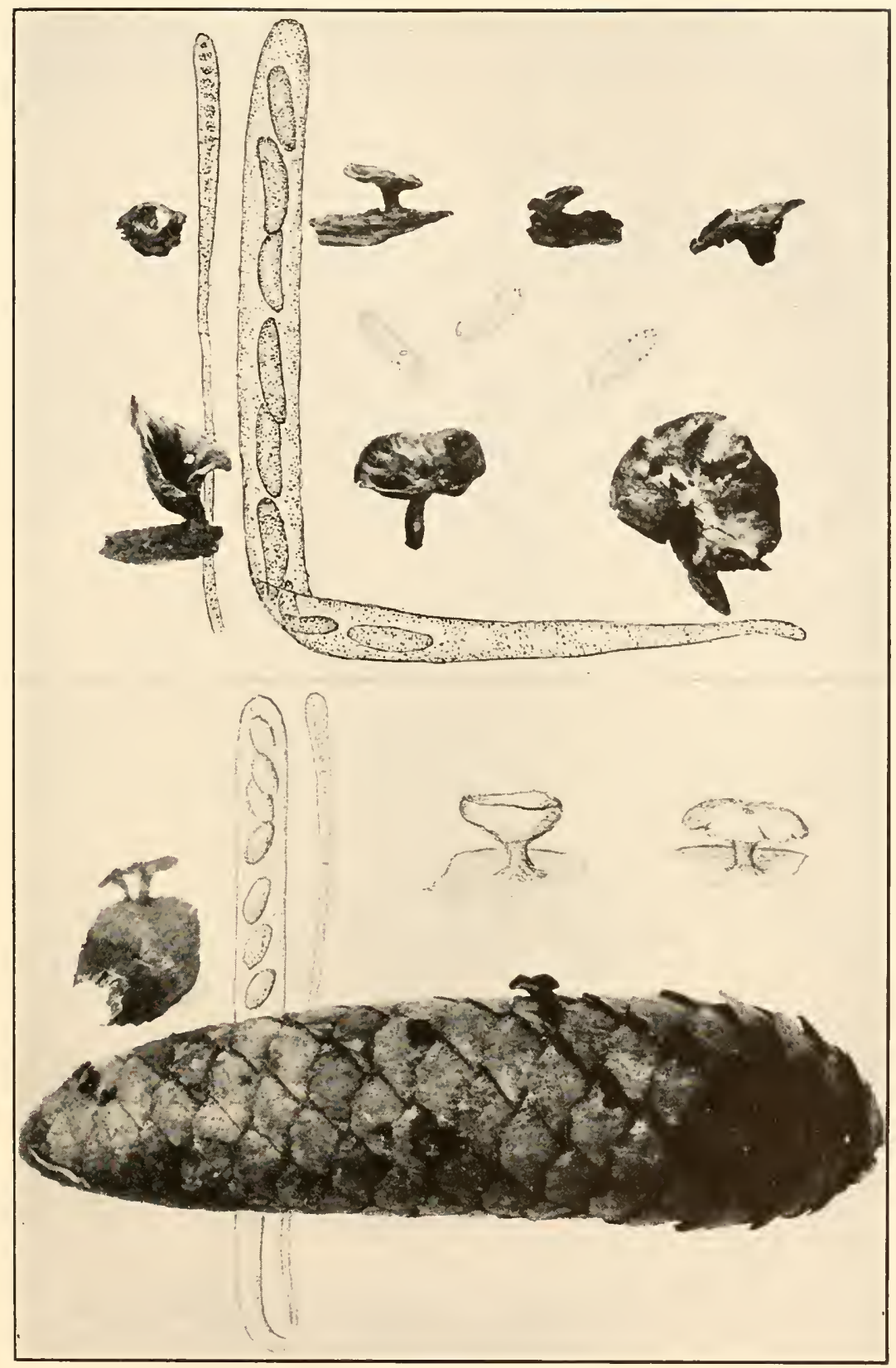

1. MIDOTIS VERSIFORMIS

2. CHLOROCIBORIA STROBILINA 

Type locality: Europe.

Distribution: New York to Colorado, south to Mexico and the IVest Indies; also in South America, Europe, Asia and Australia.

Illustrations: Bourl. Ic. Myc. pl. 485; Fl. Dan. pl. 534 , f. 2; Cooke, Austr. Fungi pl. 20, f. 158; Gill. Champ. Fr. Discom. pl. 88, f. 1; Grev. Scot. Crypt. Fl. pl. 2+1; Bull. Lab. Nat. Hist. State Univ. Iowa 6: pl. 24,f. 1; Phill. Brit. Discom. pl. 5, f. 28; Rab. Krypt.-Fl. $1^{3}$ : 749, f. 1-5; E. \& P. Nat. Pfl. $1^{1}$ : f. 155, II-L; Massee, Brit. Fungus-Fl. 4: 156, f. 41, 42; Sow. Engl. Fungi pl. 347 .

Exsiccati: Ellis, N. Am. Fungi 987; Ellis \& Ev. N. Am. Fungi 20+7; Rav. Fungi Car. 5: 40.

Some European authors recognize Chlorosplenium aeruginescens as distinct from Chlorosplenium aeruginosum. The writer has been unable to detect any difference of specific importance in the material which he has examined.

2. Chlorociboria strobilina (Alb. \& Schw.) Seaver, comb. nov. (Plate 99, Fig. 2.)

Peisiza tuberosa strobilina Alb. \& Schw. Consp. Fung. 313. 1805.

Peziza versiformis livida Alb. \& Schw. Consp. Fung. 314. 1805.

Peziza Abietis strobilina Alb. \& Schw. Consp. Fung. 342. 1805.

Chlorosplenium iersiforme nigrescente-olivacea Weinm. Hymeno-Gastro-Mycetes 467.1836.

Pezia ciborioides strobilaria Nyl. Not. Fauna Fl. Fenn. 10: 36. 1869.

Cenangium strobilinum Sacc. Fung. Ital. pl. 1306. 1883.

Chlorosplenium lividum Karst. Acta Soc. Fauna Fl. Fenn. II. 6: 124. 1885.

Pesisa bulgarioides Rehm in Rab. Fungi Eu. 1311; Hedwigia 9: 136. 1870.

Rustroemia bulgarioides Karst. Myc. Fenn. 1: 105. 1871.

Ombrophila strobilina Rehm in Rab. Krypt.-Fl. 133: 482. 1891.

Ciboria strobilina Bresadolae Boud. Ic. Myc. 4: 279. 1907.

Apothecia stipitate, or subsessile, at first concave, becoming expanded and subdiscoid or shallow cup-shaped, occasionally repand, reaching a diameter of $1 \mathrm{~cm}$. or rarely larger, regular or slightly irregular in form, brownish-black or with a slightly olive tint; hymenium similar in color to the outside of the apothecium; stem short, scarcely exceeding one-half the diameter of the apothecium, slightly lacunose; asci clavate, reaching a length of $85 \mu$ to 100 and a diameter of $5-7 \mu$; spores irregularly ellipsoid, 3-4 $\times 7 \mu$; paraphyses filiform.

On spruce cones, Picea sp. 
Type Locality: Europe.

Distribution: Nova Scotia to Michigan; also in Europe.

Illustrations: Sacc. Fungi Ital. pl. 1306; Boud. Ic. Myc. pl. 480 bis; Mycologia 28: 392 (lower figure).

\section{Excluded Species}

Chlorosplenium striisporum Ellis \& Dearn. See Ascobolus striisporus (Ellis \& Dearn.) Seaver, N. Am. Cup-fungi Operculates 90. 1928.

Chlorosplenium epimyces Cooke. See Ascobolus epimyces (Cooke) Seaver, N. Am. Cup-fungi Operculates 91. 1928.

Chlorosplenium canadense Ellis \& Ev. See Holwaya gigantea.

18. KRIEGERIA Rab. Hedwigia 17: 32. 1878.

Chloroscypha Seaver, Mycologia 23: 248. 1931.

Apothecia gregarious, or scattered, sessile, or stipitate, minute, or of medium size, yellowish-green to blackish when dry, the substance yellowish-green by transmitted light and resembling that of Ascobolus, occurring on the foliage of conifers, Thuja, Sequoia, Libocedrus, and Juniperus and apparently parasitic; asci when young greenish, normally 8-spored; spores comparatively large, at first granular and appearing greenish, but hyaline when mature, typically fusiform, or more rarely broad-ellipsoid, usually simple, rarely 1 -septate; paraphyses slender, simple, or branched, surrounded by a greenish matrix.

Type species, Ombrophila Kriegeriana Rab.

Occurring on foliage of Thuja.

Apothecia subsessile; spores broad-fusoid.

1. K. Seaveri.

Apothecia stipitate; spores narrow-fusoid.

2. K. enterochroma. Not on Thuja.

On Sequoia; spores fusoid, $5 \times 10 \mu$.

3. K. chloromela.

On Juniperus; spores broad-ellipsoid or fusoid, $10 \times$ $20 \mu$.

On leaves; spores simple.

4. K. juniperina.

On branches; spores often 1-septate.

5. K. cedrina.

On Libocedrus; spores $4-5 \times 18-19 \mu$.

6. K. alutipes.

1. Kriegeria Seaveri (Rehm) Seaver, Mycologia 35: 493.1943. (Plate 100.)

?Ombrophila thujina Peck, Bull. N. Y. State Mus. 150: 60. 1911.

Helotium Seaveri Rehm (in litt.). 1912.

Chloroscypha Seaveri Seaver, Mycologia 23: 249.1931.

Apothecia minute, scarcely exceeding $.5 \mathrm{~mm}$. in diameter, short-stipitate, occurring singly, or in small, cespitose clusters 


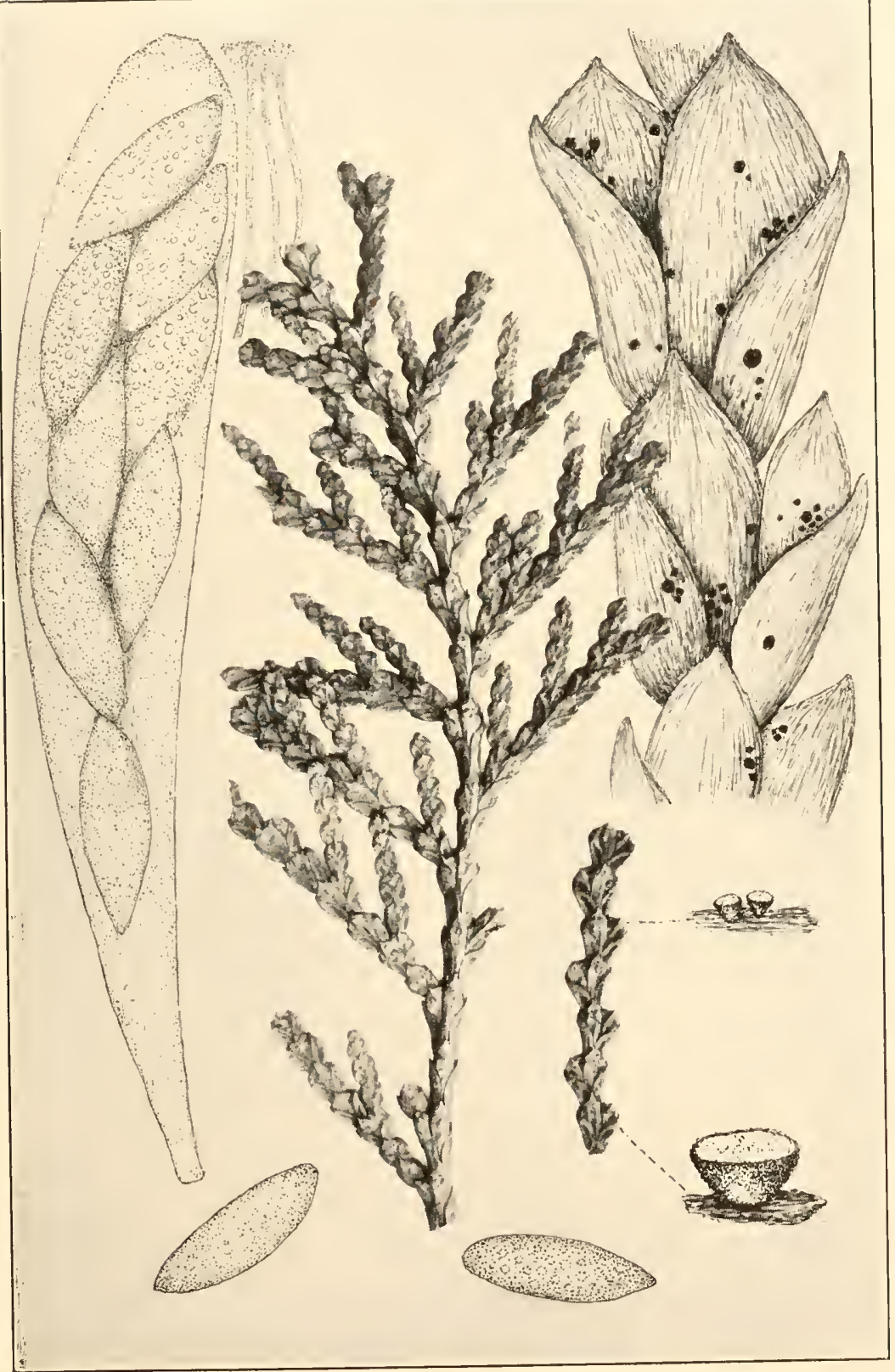

KRIEGERIA SEAVERI 

from the leaves of the host, turbinate, greenish, becoming almost black in dried material; hymenium plane or nearly so, lighter than the outside of the apothecium, the substance of the apothecium pale olivaceous-green when teased out and viewed by transmitted light; asci clavate, reaching a length of 100-135 $\mu$ and a diameter of 25-30 $\mu$, the contents greenish; spores irregularly 2-3-seriate, fusoid to fusiform, the lower end more pointed than the upper, densely filled with granules and slightly yellowishgreen, simple, about $8-9 \times 25-28 \mu$, smooth, or very minutely roughened; paraphyses filiform, scarcely enlarged above.

On foliage of white cedar, Thuja plicata.

Type Locality : Libby, Montana.

Distribution: Montana and (New York?).

Illustrations: Mycologia 23: pl. 23.

According to the late J. R. Weir this fungus is the cause of a very destructive blight. Ombrophila thujina Peck apparently differs only in the smaller size of the spores. The type has been examined.

2. Kriegeria enterochroma (Peck) Seaver, comb. nov. (Plate 101.)

Peziza enterochroma Peck, Ann. Rep. N. Y. State Mus. 32: 47.1879.

Ombrophila enterochronta Sacc. Syll. Fung. 8: 619. 1889.

?Helotium limonicolor Bres. Fungi Trid. 2: 81. (1898?).

Chloroscypha Jacksoni Seaver, Mycologia 23: 249. 1931.

Kriegeria Jacksoni Seaver, Mycologia 38: 493. 1943.

Apothecia scattered, stipitate, at first closed, gradually opening and becoming shallow cup-shaped, then discoid, externally yellowish, becoming darker with age, reaching a diameter of $2 \mathrm{~mm}$; hymenium concave, plane, or slightly convex, yellowish with a greenish tint, often becoming nearly black with age; stem slender, reaching a length of $2 \mathrm{~mm}$., similar in color to the outside of the apothecium; asci clavate, reaching a length of $100-130 \mu$ and a diameter of $12-14 \mu, 8$-spored; spores irregularly 2 -seriate, fusoid, or fusiform, often with two distinct oil-drops, or granular, apparently greenish when young, usually hyaline when mature, often minutely roughened or smooth, simple, 7-8 $\times$ 20-38 $\mu$; paraphyses slender, rather abruptly enlarged above and surrounded with a greenish-yellow substance.

On Thuja occidentalis.

Type Locality: Adirondack Mountains, New York.

Distribution: New York to Ontario. 
Illustrations: Mycologia 23: pl. 24;? Bres. Fungi Trid. pl. 195, f. 3; Ic. Myc. pl. 1235, f. 2.

This species differs from the preceding which also occurs on Thuja in the much narrower spores and stipitate apothecia; whether this species is also parasitic has not been determined.

3. Kriegeria chloromela (Phill. \& Hark.) Seaver, Mycologia 35 : 493. 1943.

?Peziza sphaerophoroides Phill. \& Hark. Bull. Calif. Acad. Sci. 1: 21. 1884. Peziza chloromela Phill. \& Hark. Grevillea 13: 22. 1884.

?Helotium sphaerophoroides Sacc. Syll. Fung. 8: 236.1889.

Chlorosplenium chloromelum Sacc. Syll. Fung. 8: 319.1889.

Chloroscypha chloromela Seaver, Mycologia 35: 493. 1943.

Apothecia scattered, or gregarious, short-stipitate, externally smooth, greenish-black, reaching a diameter of $.6 \mathrm{~mm}$; hymenium becoming nearly plane, yellowish-green; stem reaching a length of $1 \mathrm{~mm}$, a little paler than the outside of the apothecium; asci clavate-cylindric; spores clavate, or fusiform, usually curved, at first hyaline, becoming greenish, simple, $4-5 \times 20-$ $25 \mu$; paraphyses filiform, indistinct, adhering together.

On leaves of Sequoia sempervirens.

Type locality : California.

Distribution: Known only from the type locality.

A note from the Royal Botanic Garden states that the material of Peziza chloromela at Kew is very scanty. Through the kindness of the Director of that institution a microscopic slide has been examined. The spores, as indicated in the description, are smaller than in the species on white cedar.

In 1932 specimens of what appears to be this, collected by H. E. Parks at 'Trinidad, California, were sent to the writer by Dr. Lee Bonar. This is the first material of this species seen. In 1935 it was collected by H. E. Parks in Humboldt Co., California.

4. Kriegeria juniperina (Ellis) Seaver, Mycologia 35: 493. 1943.

Dermatea juniperina Ellis, Am. Nat. 17: 192. 1883.

Chloroscypha juniperina Seaver, Mycologia 23: 250. 1931.

Apothecia gregarious, at first rounded, expanding and becoming turbinate, tapering into a stem-like base, black to the unaided eye, greenish with transmitted light, reaching a diameter of $.25 \mathrm{~mm}$.; asci clavate, reaching a length of $130 \mu$ and a diameter of $20 \mu$, tapering rather abruptly below; spores ellipsoid, or 


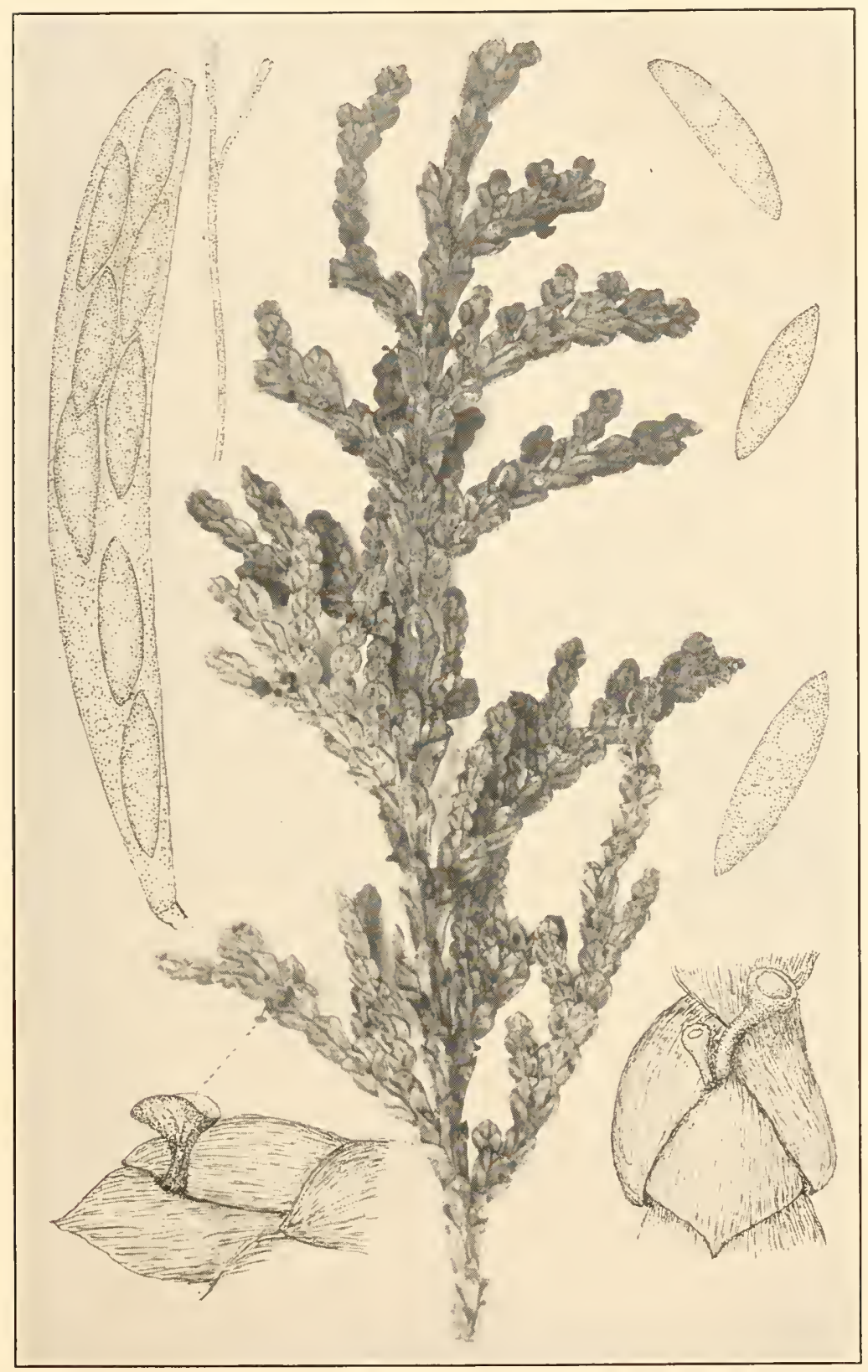

KRIEGERIA ENTEROCHROMA 

fusoid, about 9-10 $\times 18-20 \mu$, granular within, of ten appearing greenish from the greenish material which surrounds the asci and paraphyses, simple; paraphyses slender, enlarged above, reaching a diameter of $4 \mu$, adhering together at their tips, yellowish-green.

On leaves of Juniperus communis.

Type Locality: Decorah, Iowa.

Distribution: Iowa and New Jersey.

This species is quite similar in general appearance to Kriegeria Seaveri but differs in the form and size of the spores as well as in the host.

5. Kriegeria cedrina (Cooke) Seaver, Mycologia 35: 493. 1941. (Plate 102.)

Pesiza cedrina Cooke, Bull. Buffalo Soc. Nat. Sci. 2: 294. 1875.

Lachnella cedrina Sacc. Syll. Fung. 8: 395. 1889.

Chloroscypha cedrina Seaver, Mycologia 30: 594. 1938.

Apothecia gregarious, sessile, reaching a diameter of $1 \mathrm{~mm}$. and nearly as deep, black and vertically striated with dark mycelium; hymenium concave, dark; asci cylindric, or subclavate, reaching a length of $140-160 \mu$ and a diameter of 12 $14 \mu, 8$-spored but some of the spores often immature; spores usually 1 -seriate, ellipsoid with the ends lightly attenuated, densely filled with granules and oil-drops, usually simple but occasionally becoming tardily 1 -septate, $10 \times 20 \mu$; paraphyses slender, about $3 \mu$ in diameter below, strongly enlarged above where they reach a diameter of $5 \mu$, the ends strongly curved, becoming greenish-brown.

On branches of Juniperus virginiana.

TyPe locality: New York.

Distribution: New York and North Carolina.

Illustrations: Mycologia 30: 595, $f .1$.

6. Kriegeria alutipes (Phill.) Seaver, comb. nov.

Peziza alutipes Phill. Grevillea 7: 23. 1878.

Phialea alutipes Sacc. Syll. Fung. 8: 266. 1889.

Apothecia gregarious, stipitate or subsessile, yellowish to pale-brown, darker, almost black in dried specimens, yellowishgreen with transmitted light, 1-2 $\mathrm{mm}$. in diameter; hymenium similar in color to the outside of the apothecium; stem very short, or 1-2 $\mathrm{mm}$. long, gradually expanding into the apothecium; asci clavate, reaching a length of $90 \mu$ and a diameter of $10-12 \mu$; 
spores fusoid, 5-8 $\times 18-20 \mu$, multinucleate; paraphyses filiform, rather abruptly enlarged above, the ends agglutinated together and surrounded with a yellowish substance.

On dead foliage of Libocedrus decurrens.

Type locality: Blue Canon, California.

Distribution: California and Oregon.

Authentic material collected by Dr. Harkness in California has been studied.

\section{Doubtful Species}

Rutstroemia elatina (Alb. \& Schw.) Rehm in Rab. Krypt.-Fl. $\mathbf{1}^{3}: 767$. 1893; Pesiza elatina Alb. \& Schw. Consp. Fung. 330. pl. 2, f. 3. 1805; Chlorosplenium elatimum Sacc. Syll. Fung. 8: 318. 1889. This species is regarded by White as synonymous with Ombrophila Kriegeriana on which this genus was founded. It has been doubtfully recorded from North America.

19. CHLOROSPLENIUM Fries, Summa Veg. Scand. 356.1849.

Apothecia sessile, or short-stipitate, not exceeding 1-3 mm. in diameter with the margin upturned, yellowish; hymenium concave, becoming olivaceous green; spores simple, hyaline; paraphyses filiform, slightly clavate.

Type species, Peziza chlora Schw.

Apothecia yellowish.

1. C. chlora.

Apothecia sage-green or pea-green.

Spores $1-1.25 \times 3-4 \mu$.

2. C. salviicolor.

Spores $3-4 \times 9-10 \mu$.

3. C. olivaceum.

1. Chlorosplenium chlora (Schw.) Massee, Jour. Linn. Soc. 35: 116. 1901.

Pesiza chlora Schw. Schr. Nat. Ges. Leipzig 1: 122. 1822.

Chlorospleniun Schweinitzii Fries, Summa Veg. Scand. 356. 1849.

Peziza crocitincta Berk. \& Curt.; Cooke \& Peck, Grevillea 1: 6. 1872.

?Peziza pomicolor Berk. \& Rav.; Berk. Grevillea 3: 157. 1875.

Pezizella crocitincta Sacc. Syll. Fung. 8: 286.1889.

?Pseudohelotium pomicolor Sacc. Syll. Fung. 8: 300. 1889.

Apothecia thickly gregarious, sessile, or subsessile, at first closed and subglobose, becoming shallow cup-shaped with the margin slightly incurved, externally slightly roughened but not hairy, bright-yellow, reaching a diameter of 1-2 mm.; hymenium concave, or nearly plane, at first yellow, gradually becoming green; asci clavate, reaching a length of $40-50 \mu$ and a diameter of 6-8 $\mu$; spores 2-seriate above, narrow-ellipsoid, or fusoid, $2 \times 8 \mu$; paraphyses slender, reaching a diameter of $2 \mu$. 


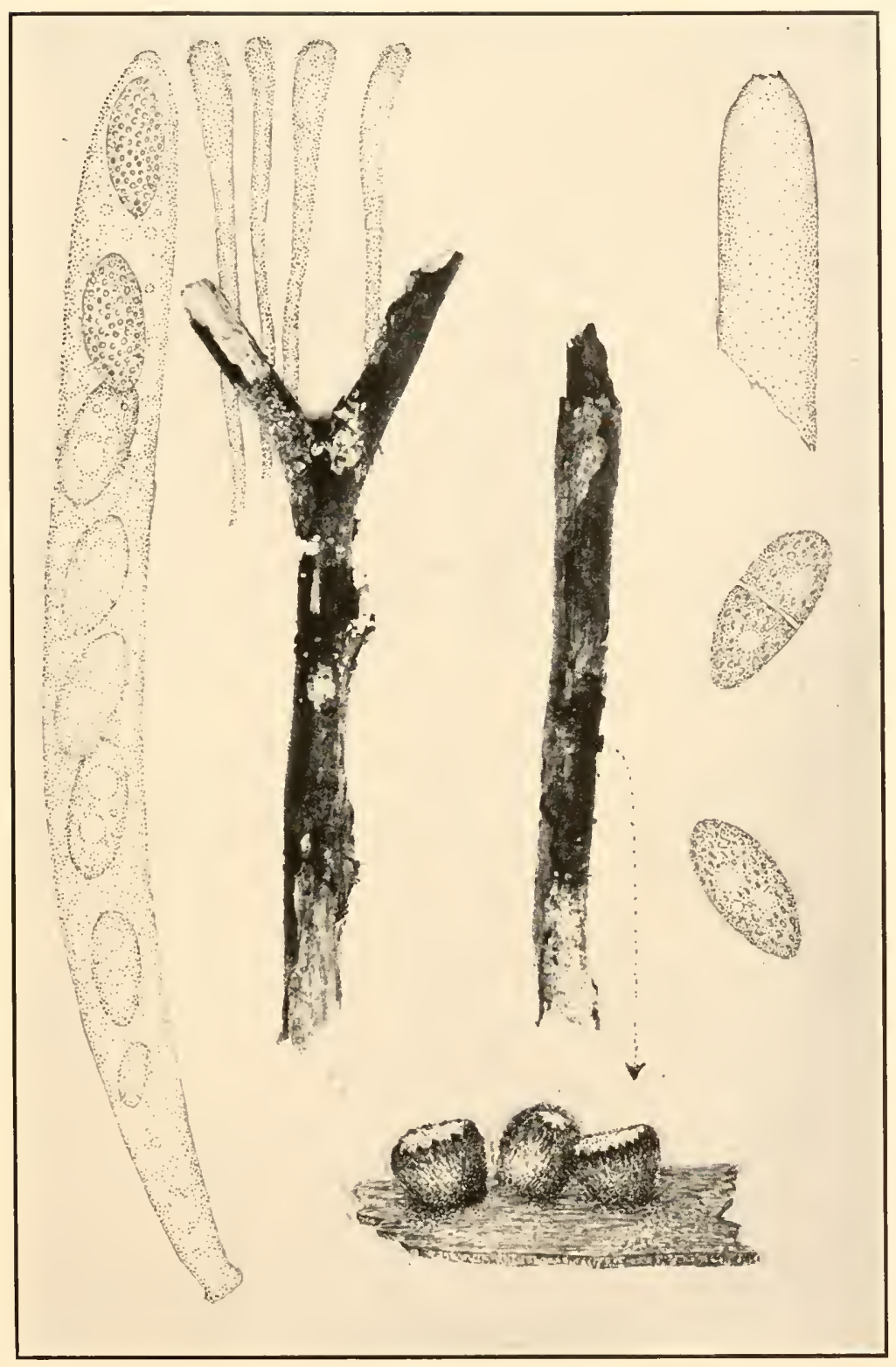

KRIEGERIA CEDRINA 

On rotten wood.

Type locality: North Carolina.

Distribution: New York and Connecticut to Alabama and North Dakota.

Illustrations: Grevillea 1: pl. 1, f. 5; Bull. Lab. Nat. Hist. State Univ. Iowa 6: pl.23,f. 3.

Exsiccatı: Ellis, N. Am. Fungi 664; Ellis \& Ev. Fungi Columb. 249; Rav. Fungi Car. 5: 39; Wilson \& Seaver, Ascom. 1; ? Brenckle, Fungi Dak. 667 (as Phialea sordida); Reliq. Farlow. 107.

2. Chlorosplenium salviicolor Ellis \& Dearn.; Ellis \& Ev. Proc. Acad. Sci. Phila. 1893: 146. 1893.

Apothecia at first subhemispheric with the margin incurved, expanding and becoming subdiscoid, externally dark sage-green, reaching a diameter of $1.5-2 \mathrm{~mm}$., contracted below into a very short, stem-like base; asci clavate-cylindric, reaching a length of $30 \mu$ and a diameter of $2.5-3 \mu$; spores 2 -seriate, minute, elongated, hyaline, $1-1.25 \times 3-4 \mu$; paraphyses slender, branched above.

On dead stems of Vitis vulpina.

Type Locality: St. Martinsville, Louisiana.

Distribution: Known only from the type locality.

3. Chlorosplenium olivaceum Seaver, sp. nov.

Apothecia thickly gregarious, entirely sessile, shallow cupshaped to scutellate, the margin often irregularly wavy, externally slightly furfuraceous, dark olive-green, reaching a diameter of 2-3 mm.; hymenium concave, light pea-green; asci clavate, reaching a length of 55-60 and a diameter of $6-7 \mu, 8$-spored; spores irregularly 2-seriate, narrow-ellipsoid, 3-4 $\times 9-10 \mu$; paraphyses slender, slightly enlarged above, reaching a diameter of $2-3 \mu$.

Apotheciis gregariis, sessile, scutellatis, margine plicato-crenato, extus pallide viridis, $2-3 \mathrm{~mm}$. diam.; hymenio palidiore; ascis clavatis 8 -sporis, 6-7 $\times$ 50-60 $\mu$; sporis ellipsoideis, 3-4 $\times$ 9-10 $\mu$; paraphysibus filiformibus, sursum clavatis, $2-3 \mu$ diam.

On rotten wood of Quercus sp.

Type locality: Princeton, Georgia.

Distribution: Georgia and North Carolina. 


\section{Doubtful Species}

Chlorosplenium ? atrovirens (Pers.) DeNot. Comm. Critt. Ital. 1: 377. 1864; Peziza atrovirens Pers. Syn. Fung. 635. 1801; Calloria atrovirens Fries, Summa Veg. Scad. 359. 1849; Coryne virescens Tul. Fung. Carp. 3: 193. 1865; Coryne atrovirens Sacc. Syll. Fung. 8: 641. 1889. This species has been reported from North America but no material has been seen which could be ascribed to it with any certainty. This species was treated by DeNotaris under Chlorosplenium but he did not actually make the combination attributed to him.

Chlorosplenium tortum (Schw.) Sacc. Syll. Fung. 8: 320. 1889; Peziza torta Schw. Trans. Am. Phil. Soc. II. 4: 175. 1832. Described as $8 \mathrm{~mm}$. broad and high, externally aeroginous-green. Identity uncertain.

20. PYCNOPEZIZA White \& Whetzel, Mycologia 30:187. 1938.

Pycnidial stage an Acarosporium.

Apothecia small, not over $5 \mathrm{~mm}$. in diameter, solitary, or gregarious, very short-stipitate to practically sessile, brown or brownish, at first closed, opening irregularly or by a pore, finally expanded, the margin stellate or circular; hymenium lightbrown or buff; asci clavate or cylindric-clavate; spores small, ellipsoid, hyaline, simple; paraphyses filiform, simple.

Type species, Pycnopeziza sympodialis White \& Whetzel. Apothecia opening irregularly, beconing stellate. 1. P. sympodialis. Apothecia opening by a circular pore, becoming scutellate. 2. P. quisquiliaris.

1. Pycnopeziza sympodialis White \& Whetzel, Mycologia 30: 190.1938.

Acarosporium sympodiale Bubak \& Vlengel, Ber. Deuts. Bot. Gesell. 29: 385. 1911.

Apothecia solitary, scattered, short-stipitate, at first erect, pyriform and closed, opening by splitting Geaster-like into 4-6 stellate rays, $3-5 \mathrm{~mm}$. in diameter; stem short but usually distinct, .5-1.5 $\mathrm{mm}$. long and $1 \mathrm{~mm}$. thick, black; hymenium nearly plane, buff to ochraceous, slightly umbilicate; asci cylindric-clavate, reaching a length of $75-85 \mu$ and a diameter of $6.5-7.5 \mu, 8$-spored; spores narrow-ellipsoid, 3-3.5 $\times 7-9 \mu$ irregularly 1-seriate; paraphyses filiform, scarcely enlarged above, $2.5 \mu$ in diameter.

For description of the pycnidial stage see Mycologia.

On buds and staminate flowers of Acer rubrum, catkins of Populus canadensis, and buds and catkins of Populus tremuloides.

Type Locality: Malloryville Bog, near Ithaca.

Distribution: Known only from the type locality.

Illustrations: Mycologia 30: 189, f. 1-6; 194, f. 11-13. 
2. Pycnopeziza quisquiliaris (Ellis \& Ev.) White \& Whetzel, Mycologia 30: 192. 1938.

Cyathicula quisquiliaris Ellis \& Ev. Proc. Acad. Sci. Phila. 1893: 451.1893.

Apothecia solitary, or gregarious, attached by a narrow stipe-base, opening by a circular pore, finally saucer-shaped, 1-4 mm. in diameter, with a few dark squamules about the base, furfuraceous above, yellowish or cream-colored; hymenium concave, same color as the outside of the apothecium; asci clavatecylindric, reaching a length of $75-85 \mu$ and a diameter of $6-7 \mu$, 8-spored; spores ellipsoid, irregularly 1 -seriate, $3-4 \times 7-9 \mu$; paraphyses filiform, $2.5 \mu$ in diameter, scarcely enlarged above.

For description of pycnidial stage (Acarosporium quisquiliaris) see Mycologia.

On various kinds of over-wintering buds; also on leaf debris, apparently of some herbaceous plants.

Type Locality: Nuttalburg, W'est Virginia.

Distribution: West Virginia and New York.

Illustrations: Mycologia 30: 189, f. 7-9; 194, f. 10; 197, f. 14 .

\section{CIBORIELLA Seaver, gen. nov.}

Apothecia stipitate, or substipitate, as in Ciboria, not stromatic; asci clavate, 8-spored; spores simple, ellipsoid to fusoid, hyaline; paraphyses filiform.

Apotheciis stipitatis vel substipatitis; Ciboria sine sclerotio; ascis clavatis, 8-sporis; sporis ellipsoideis vel fusoideis, hyalinis; paraphysibus filiformibus.

Type species, Ciboria rufescens Kanouse.

The genus Ciboria Fuckel has been restricted by $\mathrm{H}$. H. Whetzel to those forms occurring on flowers and fruits and included in the Sclerotineae. The present genus is to include similar forms which would be excluded from the Sclerotineae.

1. Ciboriella rufescens (Kanouse) Seaver, comb. nov.

Ciboria rufescens Kanouse, Mycologia 33: 463. 1941.

Apothecia short-stipitate, firm-fleshy, gregarious, pale-orange when fresh, blood-red when dry, exuding a red juice when bruised in water, 2-5 $\mathrm{mm}$. in diameter; stem slender, 1-2 $\mathrm{mm}$. long; asci clavate, reaching length of $35-60 \mu$ and a diameter of $7-8 \mu$, 8 -spored; spores fusoid, hyaline, simple, $3.5 \times 7-8 \mu$; paraphyses filiform. 
On decaying leaves of Almus.

Trpe locality: Hoh River, Oregon.

Distribution: Known only from the type locality.

\section{Doubtful Species}

Discinella washingtonensis Kanouse, Mycologia 39: 650. 1947. Apothecia described as 6-12 $\mathrm{mm}$. in diameter with a stem 3-5 mm. long. Spores fusoid, $4 \times 12-14 \mu$; paraphyses filiform. It would seem to the writer that the species might be included here.

22. CALYCINA S. F. Gray, Nat. Arrang. Brit. Pl. 1: 669.1821. Ciboria Fuckel, Symb. Myc. 311. 1869. (in part only).

Rutstroemia White, Lloydia 4: 169. 1941 (in part). Not Rutstroemia Karst. 1871.

Apothecia medium large, up to $1 \mathrm{~cm}$. in diameter stipitate, or subsessile, the length of the stem varying with the conditions, light-colored or dull, externally smooth, or with very poorly developed, hair-like structures; asci cylindric or clavate, usually 8-spored; spores ellipsoid to fusoid, hyaline, for a long time simple, later often becoming septate with one to several septa.

Type species, Peziza firma Pers.

This is a Ciboria-like fungus with a septate spore.

Spores comparatively small, not over $20 \mu$ long.

On wood or twigs.

Substance of the apothecium not golden-yellow. 1. C. firma.

Substance of the apothecia golden-yellow. $\quad$ 2. C. bolaris.

On overwintering leaves.

Spores large, $30-35 \mu$ long.

3. C. petiolorum.

4. C. macrosporum.

1. Calycina firma (Pers.) S. F. Gray, Nat. Arrang. Brit. Pl. 1: 670. 1821.

?Peziza ochroleuca Bolton, Fungi Halifax 3: 105. 1789.

Peziza firma Pers. Syn. Fung. 658. 1801.

Ciboria firma Fuckel, Symb. Myc. 312. 1869.

Helotium firmum Karst. Not. Soc. Fauna Fl. Fenn, 11: 233. 1871.

Rutstroemia firma Karst. Not. Soc. Fauna Fl. Fenn. 13: 233.1873.

Phialea firma Gill. Champ. Fr. Discom. 101. 1882.

Hymenoscypha firma Phill: Brit. Discom. 123. 1887.

Ciboria ochroleuca Massee, Brit. Fungus-Fl. 4: 274. 1895.

Apothecia gregarious, infundibuliform, becoming expanded and often nearly discoid, stipitate, brownish, reaching a diameter of $1 \mathrm{~cm}$. though often smaller; hymenium brown, darker than the outside of the apothecium; stem variable in length, but up to 12 $\mathrm{mm}$. and $.5 \mathrm{~mm}$. in diameter, but gradually expanding above; 


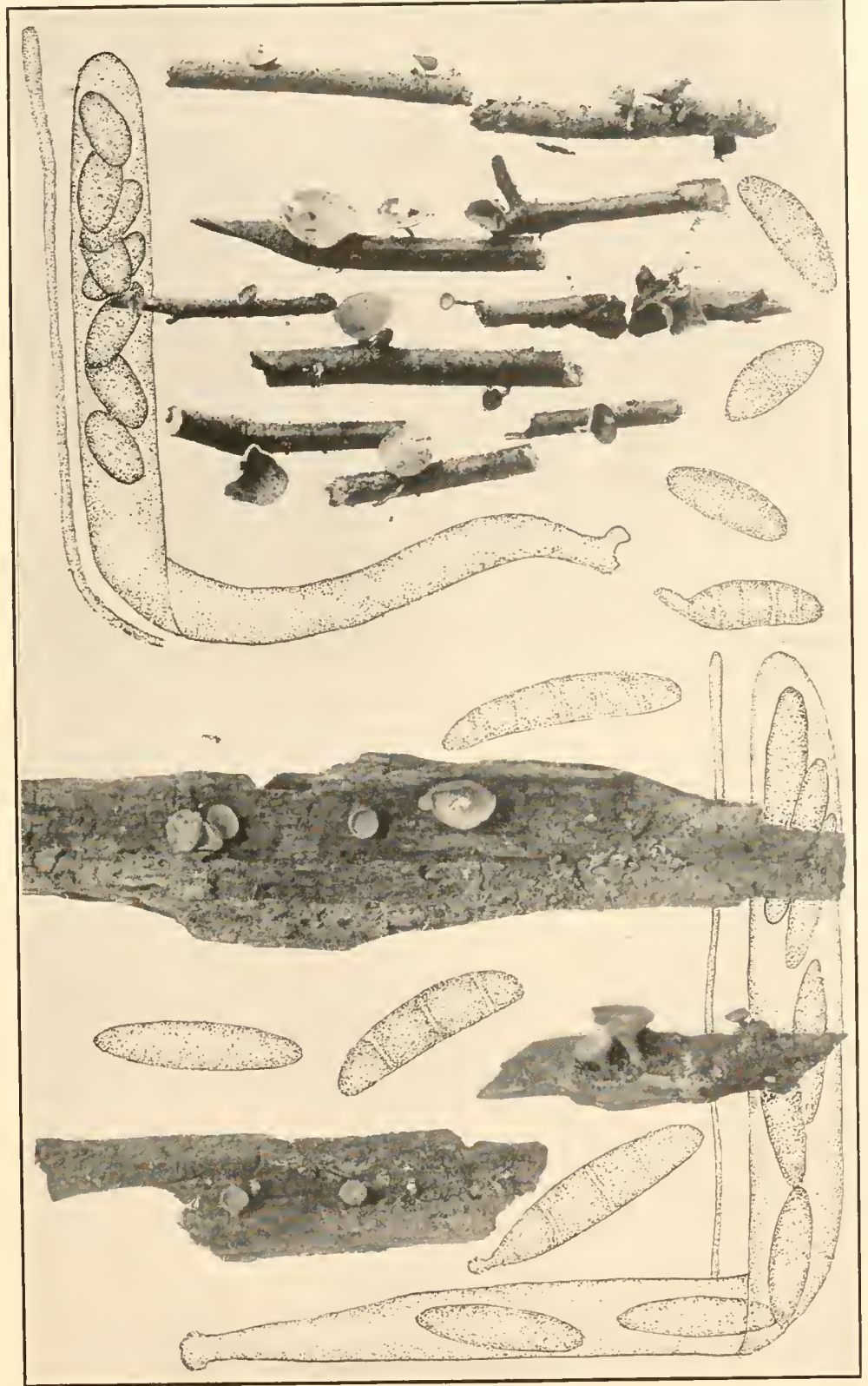

1. CALYCINA BOLARIS

2. CALYCINA MACROSPORA 

asci cylindric, or subcylindric, reaching a length of $130 \mu$ and a diameter of 9-12 $\mu, 8$-spored; spores ellipsoid, or fusoid, obliquely 1-seriate with the ends overlapping, $4-6 \times 15-20 \mu$, at first simple, occasionally becoming 1-3-septate; paraphyses filiform, enlarged, above, reaching a diameter of $2 \mu$.

On woods of various kinds.

Type locality: Europe.

Distribution: Doubtfully reported from North America, also in Europe.

Illustrations: ?Bolton Hist. Fung. 3: pl. 105; Boud. Ic. Myc. pl. 483; Gill. Champ. Fr. Discom. pl. 7f, f. 2; E. \& P. Nat. Pfl. 195, f. 155, O, P; Sow. Engl. Fungi pl. 155; Lloydia 4: 174, f. $1-9$.

For full discussion of this species see White (Lloydia 4: 173-181.). According to $\mathrm{W}$. L. White all American reports of this species are based on miscleterminations. It is not unlikely that the species will eventually be found in this country.

2. Calycina bolaris (Batsch) Seaver, Mycologia 26: 346.1934. (Plate 103, Fig. 1.)

Pesiza bolaris Batsch, Elench. Fung. Cont. 1: 221. 1786?

Ciboria bolaris Fuckel, Symb. Myc. 311. 1869.

Phialea bolaris Boud. Bull. Soc. Myc. Fr. 1: 116. 1885.

Iymenoscypha bolaris Phill. Brit. Discom. 124. 1887.

Apothecia gregarious, stipitate, or subsessile, expanding and becoming discoid, or slightly convex, externally yellowish, reaching a diameter of 5-6 mm., with a few club-shaped hair-like structures about the margin; hymenium slightly concave, plane, or a little convex, yellowish-brown, a little darker than the outsicle of the apothecium, (substance of the apothecia when crushed, golden-yellow); stem short, usually a little less than the diameter of the apothecium, about .5 $\mathrm{mm}$. in liameter, expanding rather abruptly into the apothecium; asci cylindric, or clavate, 8spored, reaching a length of $200 \mu$ and a diameter of 12-14 $\mu$; spores ellipsoid, usually slightly curved, $7-9 \times 18-20 \mu$, for some time simple, finally 1 -septate and often with apiculi at one or both ends, later 3 -septate; paraphyses filiform, enlarged above, the contents yellow.

On twigs of various kinds.

Type locality: Europe.

Distribution: New York; also in Europe. 
Illustrations: Boud. Ic. Myc. pl. 482; Mycologia 26: pl. 40 (upper figure); Lloydia 4: 182, f. 10-14; 185, f. 15-26.

This species is close to Calycina firma but seems to differ in that it is less robust and lighter colored, yellowish instead of brownish. The only American specimen seen is one collected by H. H. Whetzel, No. 10784.

3. Calycina petiolorum (Roberge) Seaver, comb. nov.

Peziza petiolorum Rob. Pl. Crypt. Fr. 1158; Ann. Sci. Nat. II. 17: 96. 1842. Helotium petiolorum DeNot. Comm. Critt. Ital. 1: 378. 1864.

Phialea petiolorum Gill. Champ. Fr. Discom. 102. 1882.

Calycella petiolorum Quél. Elench. Fung. 305. 1886.

Hymenoscypha petiolorum Phill. Brit. Discom. 132. 1887.

Cyathicula petiolorum Sacc. Syll. Fung. 8: 305. 1889.

Ciboria petiolorum Schröt in Cohn, Krypt.-Fl. Schles 3²: 61. 1893.

Apothecia solitary, scattered, becoming patellate, stipitate, reaching a diameter of $4 \mathrm{~mm}$., externally showing faint longitudinal striations, pale-brown, the margin dentate; stem slender, usually tapering gradually below, becoming reddish-brown, nearly black at the base; hymenium slightly concave, ochraceous to cinnamon-brown; asci clavate, reaching a length of $95-120 \mu$ and a diameter of 9-12 $\mu, 8$-spored; spores 1-seriate, or 2-seriate above, oblong-reniform, $4.5-5.5 \times 14-17 \mu$, at first 1 -septate, later 2-3-septate, producing spermatia from the tips of the ascospores; paraphyses simple, enlarged above, $2.5-3.8 \mu$ at their apices.

On rudimentary stromatic base on the petioles and midribs of overwintering leaves usually of Fagus and Quercus.

Type locality: Europe.

Distribution: Iowa to Maine and North Carolina; also in Europe.

Illustrations: Grevillea 4: pl. 65, f. 301; Ann. Myc. 4: 228, f. 46, 299, f. 47; Lloydia 4: 198, f. 35-29.

As will be seen, from the synonymy, this species has been placed in several genera at different times and by different authors. Saccardo placed it in Cyathicula because of the slightly dentate margin. It seems to the writer to belong to the present genus, largely on the basis of its spore characters.

4. Calycina macrospora (Peck) Seaver, Mycologia 26: 346. 1934. (Plate 103, Fig. 2.)

Helotium macrosporum Peck, Ann. Rep. N. Y. State Mus. 26: 82. 1874. Bulgaria decolorans Berk. \& Curt. Grevillea 4: 6. 1875. 
Peziza nebulosa Cooke, Mycographia 163. 1877.

Geopyxis nebulosa Sacc. Syll. Fung. 8: 70. 1889.

Ombrophila decolorans Sacc. Syll. Fung. 8: 615. 1889.

Ciboria Dallasiana Ellis \& Ev. Jour. Myc. 9: 165. 1903.

Tarzetta cinerascens Rehm, Ascom. 1853; Ann. Myc. 2: 352.1904.

Ciboria fuscocinerea Rehm, Ann. Myc. 2: 525. 1909.

Apothecia gregarious, stipitate, or occasionally subsessile, at first closed and subglobose, gradually expanding and becoming nearly discoid, attenuated at the base, reaching a diameter of $1 \mathrm{~cm}$., cinereous to yellowish-brown; hymenium concave, or nearly plane, similar in color to the outside of the apothecium; stem reaching a length of $1 \mathrm{~cm}$. and a diameter of about $1 \mathrm{~mm}$.; asci cylindric, or clavate, 8-spored, reaching a length of $150 \mu$ and a diameter of 10-12 $\mu$; spores narrow-ellipsoid, or fusoid, straight, or slightly curved, hyaline, granular, for a long time simple, finally becoming 1-5-septate, and often with an apiculus at one or both ends and an oil-drop between each two septa, reaching a length of 30-35 $\mu$ and a cliameter of 6-7 $\mu$; paraphyses filiform, slightly enlarged above.

On rotten wood.

Type locality: South Carolina.

Distribution: New York to Alabama, North Dakota and Colorado; also reported from Europe as Ombrophila decolorans.

Illustrations: Cooke Mycographia, pl. 73, f. 281; Seaver, Bull. Lab. Nat. Hist. State Univ. Iowa 6: pl. 20, f. 2; Mycologia 26: pl. to (lower).

Exsiccatı: Ellis, N. Am. Fungi 477; Rehm, Ascom. 1853; Seaver, North Dakota Fungi 6.

\section{CYATHICUlA DeNot. Comm. Critt. Ital. 1: 381. 1863. (in part).}

Hyalinia Boud. Bull. Soc. Myc. Fr. 1: 114. 1885.

Calycella Quél Ench. Fung. 305. 1886.

Pezoloma Clements, Gen. Fungi 175. 1909; Minn. Bot. Stud. 4: 186. 1911. Pezizellaster Höhn. Ann. Myc. 15: 349. 1917.

Apothecia scattered, stipitate, at first closed and subglobose, expanding, the margin beset with sharp teeth, the outsicle of the apothecium smooth; asci cylindric-clavate, 8-spored; spores fusoid, elongated, finally 1 -septate; paraphyses filiform.

Type species, Peziza coronata Bull.

When the genus was established no species was designated as the type. Later authors have regarded Peziza coronata as the 
type, a species originally included by DeNotaris but not the first one mentioned. This species is therefore regarded as the type.

The genus Pezoloma was proposed by F. E. Clements for sessile species of Cyathicula. The character seems to the writer to be of no generic significance.

Occurring on herbaceous stems.

1. C. coronata.

Occurring on living Marchantia.

2. C. Marchantiae.

1. Cyathicula coronata (Bull.) Rehm in Rab. Krypt-Fl. $1^{3}: 740$. 1893.

Peziza coronata Bull. Hist. Champ. Fr. 251. 1809.

Peziza radiata Pers. Myc. Eu. 1: 234. 1822.

Helotium coronatum Karst. Myc. Fenn. 1: 136. 1871.

Hymenoscypha coronata Phill. Brit. Discom. 127. 1887.

Pesiza denticulata Fl. Dan. Fasc. 17: 10, pl. 1016, f. 3. 1790.

Apothecia scattered, or gregarious, stipitate, at first rounded and closed, opening and becoming pitcher-shaped, finally expanded, the margin beset with long teeth, pale rose-colored or yellowish, .5-3 mm. in diameter; stem 1-6 mm. long, .2-.5 mm. thick, smooth, white, or yellowish-white; asci cylindric-clavate, reaching a length of $80-110 \mu$ and a diameter of $8-9 \mu, 8$-spored; spores elongated, fusoid, simple, or 1-septate, 3-4.5 × 15-18 $\mu$; paraphyses filiform, $2 \mu$ thick.

On herbaceous stems of various kinds.

TyPe locality: Europe.

Distribution: New York to Michigan; also in Europe.

Illustrations: Bull. Herb. Fr. pl. 416 ; Phill. Brit. Discom. pl. 5, f. 26; Nees, Syst. Pilze f. 293; E. \& P. Nat. Pfl. 1' ${ }^{1}$ 205, $f$. 160, N-O; Papers Mich. Acad. Sci. 20: pl. 15, f. 1 .

2. Cyathicula Marchantiae (Sommerf.) Sacc. Syll. Fung. 8: 307. 1889.

Peziza Marchantiae Sommerf. Fl. Lap. Suppl. 295. 1826.

Apothecia solitary, turbinate, sessile, or with a short, thick stem, substance fleshy to waxy, thin, translucent, pallid-white, usually with a pale-lilac tint, reaching a diameter of .5-2 $\mathrm{mm}$.; hymenium plane, or slightly concave, the margin ornamented with ciliate teeth composed of bundles of narrow cells; asci clavate-cylindric, not conspicuously narrowed below, apex rounded, reaching a length of $60-75 \mu$ and a diameter of 6-8 $\mu$; 


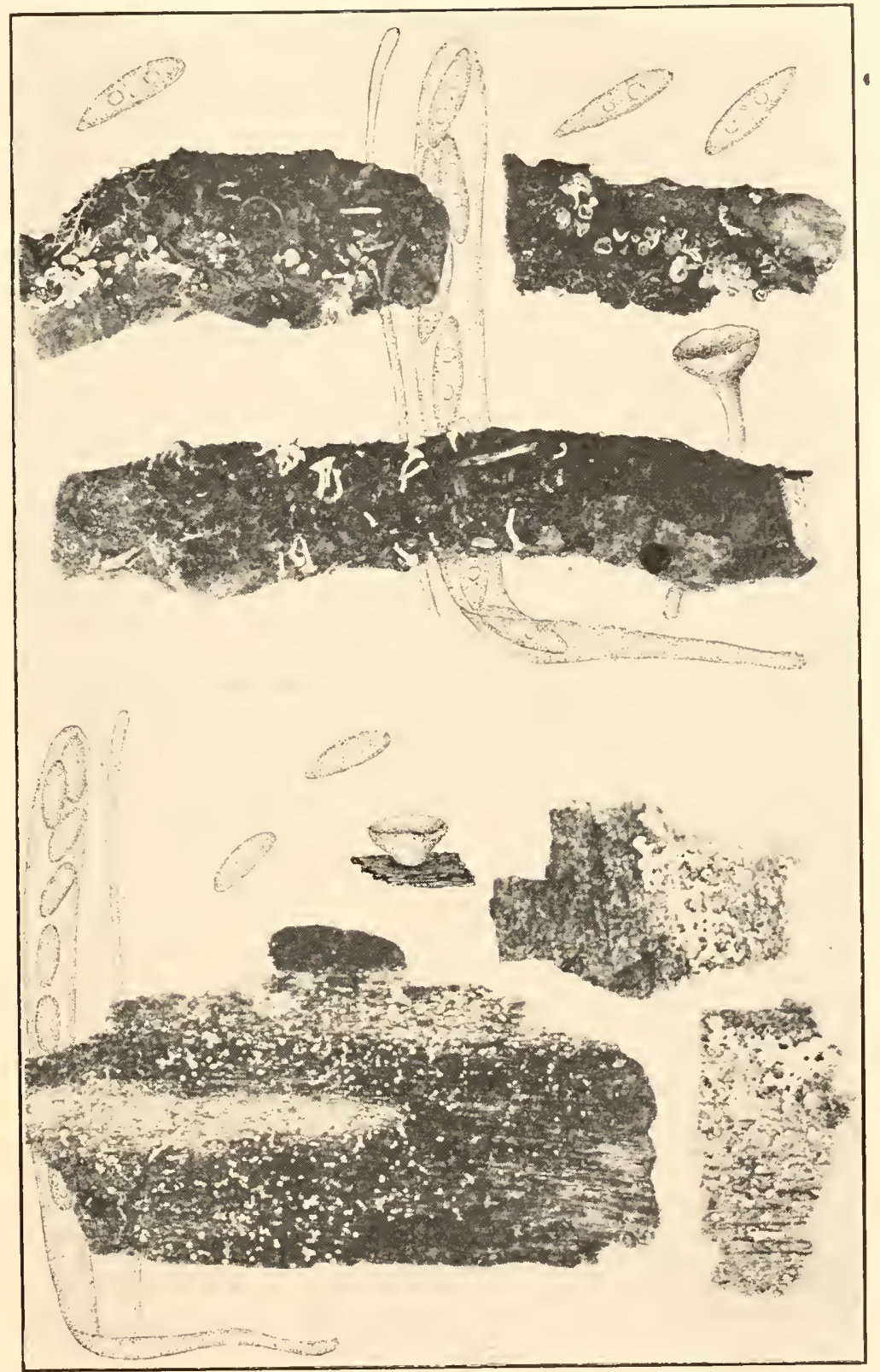

1. HELOTIUM VIRGULTORUM

2. HELOTIUM CITRINUM 

spores 1 - or 2-seriate, smooth, ovoid, or ellipsoid, $4 \times 8-10 \mu$, usually with two small oil-drops; paraphyses filiform.

On living Marchantia polymorpha.

Type Locality: Europe.

Distribution: New York and Michigan; also in Europe.

Our only knowledge of this species is Durand's report in Bull. Torrey Club 29: 463. 1902, and a report of its occurrence in Michigan by Dr. B. Kanouse.

\section{Doubtful and Excluded Species}

Cyathicula alpina Ellis \& Ev. Proc. Acad. Sci. Phila. 1894: 349. 1894. Apothecia minute, about $.5 \mathrm{~mm}$. in diameter and less than $1 \mathrm{~mm}$. high; pallid, the margin fibrous, the extremities of the fibers prolonged and subfasciculate so as to make the margin obscurely dentate; asci clavate-cylindric, 8-spored; spores subcylindric, 1.5-2 $\times$ 8-10 $\mu$; paraphyses filiform. On dead stems of Pedicularis and culms of Elymus condensatus, Colorado, alt. $9500 \mathrm{ft}$. It is doubtful if this species belongs here.

Cyathicula aquilina (Rehm) Sacc. Syll. Fung. 8: 307. 1889; Coronellaria Aquilinae Rehm, Hedwigia 24: 231. 1885. This species has been reported from Washington by Dr. B. Kanouse on fern debris and on Gaultheria Shallon. Rehm makes this a synonym of Mollisia pteridina Karst.

Cyathicula dentata (Pers.) Sacc. Syll. Fung. 8: 307. 1889; Peziza dentata Pers. Ic. Descr. Fung. 5. pl. 1, f. 6, 7. 1798; Niptera dentata Fuckel, Symb. Myc. Nacht. 1: 47. 1871; Cistella dentata Quél. Ench. Fung. 319. 1886; Mollisia dentata Gill. Champ. Fr. Discom. 124. 1882; Calloria dentata Phill. Brit. Discom. 332. 1887. This species has been reported from Michigan under the name Cistella dentata. It is also reported from Washington under the name Pezizellaster radiostriatus (Feltig) Höhn. Von Höhnel regarded these as identical.

Pezoloma griseum Clements, Gen. Fungi 175. 1909; Minn. Bot. Stud. 4: $186, p l .25, f .2$. 1911. The illustration shows the apothecium beset with a border of very long, tooth-like structures consisting of a fascicle of mycelial threads. The spores are described as 3-4 $\times 15-18 \mu$. The species should be further investigated. It is known only from the type collection in Colorado.

Lachnaster miniatus Kanouse, Mycologia 39: 662. 1947. Described as having long, whiplash hairs arranged in teeth, pale-yellow; spores $1-1.5 \times$ 6-8 $\mu$; paraphyses lanceolate. The toothed margin would place this in the genus Cyathicula. On Pteridium aquilinum, Washington.

\section{HELOTIUM Fries, Summa V'eg. Scandl. 354. 1849.}

Pseudohelotium Fuckel, Symb. Myc. 298. 1869.

Phialea (Fries) Boud. Bull. Soc. Myc. Fr. 1: 112. 1885.

Discinella Boud. Hist. Class. Discom. Eu. 96. 1907.

?Pseudociboria Kanouse, Mycologia 36: 460. 1941.

Apothecia long-stipitate to sessile or subsessile, externally smooth (not hairy), usually small (not exceeding 2-3 $\mathrm{mm}$. in 
diameter), for the most part bright-colored, whitish, yellowish, or occasionally dingy-brown, reddish, or with a greenish tint, usually with a whitish vegetative mycelium; asci usually 8spored; spores simple (1-celled), or occasionally spuriously septate, ellipsoid, fusoid, or allantoid, hyaline or subhyaline; paraphyses very slender.

Type species, Helrella acicularis Bull.

The genus Pseudociboria is characterized by having two kinds of paraphyses, hyaline and colored, which in the opinion of the writer would scarcely warrant the establishment of a separate genus.

This is a large and cumbersome genus. Attempts to break it up have not been very successful. The separation of Phialea on the presence of a stem has been disregarded by recent workers. Many species have been described from scant material and never re-collected so that their value must remain uncertain at best. If it were possible to call a moratorium on the description of new species until the old ones could be better known it would be a great advantage to the monographer but that is probably too much to expect. The species are keyed out to the best of our ability.

Spores $20 \mu$ or more long.

Spores more than $30 \mu$ long.

On fallen leaves of Alnus.

On fallen leaves of Steironema.

1. H. fastidiosum.

2. H. Dearnessii.

Spores rot usually exceeding $30 \mu$.

Spores clavate.

3. H. serotinum.

Spores fusoid.

On herbaceous stems.

On fallen leaves of Salix.

4. H. Scutula.

5. H. salicellum.

Spores usually $15-20 \mu$ long.

On fruits.

$\begin{array}{ll}\text { On old acorns and hickory-nuts. } & \text { 6. H. fructigenum. }\end{array}$

On seeds of Nyssa sylratica.

Not on fruits.

On cryptogams.

On living mosses.

On old fungi, Fomes.

8. H. turbinatum.

9. H. mycetophilum.

On phanerogams.

On monocot. leaves, Iris.

10. H. nigromaculatum.

On dicots. of various kinds.

On fallen leaves or petioles.

On petioles of Acer.

11. H. fraternum.

Not on petioles. 
On fallen leaves of Betula etc.

On decaying leaves.

Spores clavate.

Spores fusoid.

On rotten wood.

Apothecia cudonioid.

Apothecia not cudonioid.

Spores usually $10-15 \mu$ long.

On coniferous plants.

On fallen leaves of Picea.

Apothecia pallid, with Fumosa.

Apothecia sulphur-yellow.

On fallen leaves of Larix.

Not on coniferous plants.

On seeds of Almus oregona.

Not on seeds.

On old fungus, Dichaena strumosa.

Not on fungi.

On herbaceous plants.

Apothecia dark-brown or black.

On stems of Erigeron.

On leaves of Antenuaria.

Apothecia yellowish or cinereous.

On stems of Eschscholtzia.

On various plants especially. Impatiens.

Not on herbaceous plants.

Spores reniform.

Apothecia yellowish-green, on (usually) petioles of Fraxinus. Apothecia not yellowish-green.

On rotten wood.

Apothecia lemon-yellow. Apothecia pallid or yellowish.

Spores clavate, on Symphoricarpus.

Spores not clavate.

Apothecia not over $1 \mathrm{~mm}$. in diam.

Apothecia $3 \mathrm{~mm}$.

in diam. on Salix.

()n dead leaves.

Apothecia yellow to paleorange.

On leaves of Fagus. 32. II. albopunctum.
13. H. naviculasporum.

14. H. epiphyllum.

15. H. cudonioides.

16. II. virgultorum.

17. H. fumosellum.

18. I1. sulphuratum.

19. H. acicularum.

20. 1I. seminicola.

21. II. strumosum.

22. II. nigrescens.

23. II. phacoconium.

24. II. Eschscholtziae.

25. H. herbarum.

26. II. renisportm.

27. II. luteovirescens.

28. H. citrinum.

29. H. dakotense.

30. H. pallescens.

31. II. amplum. 


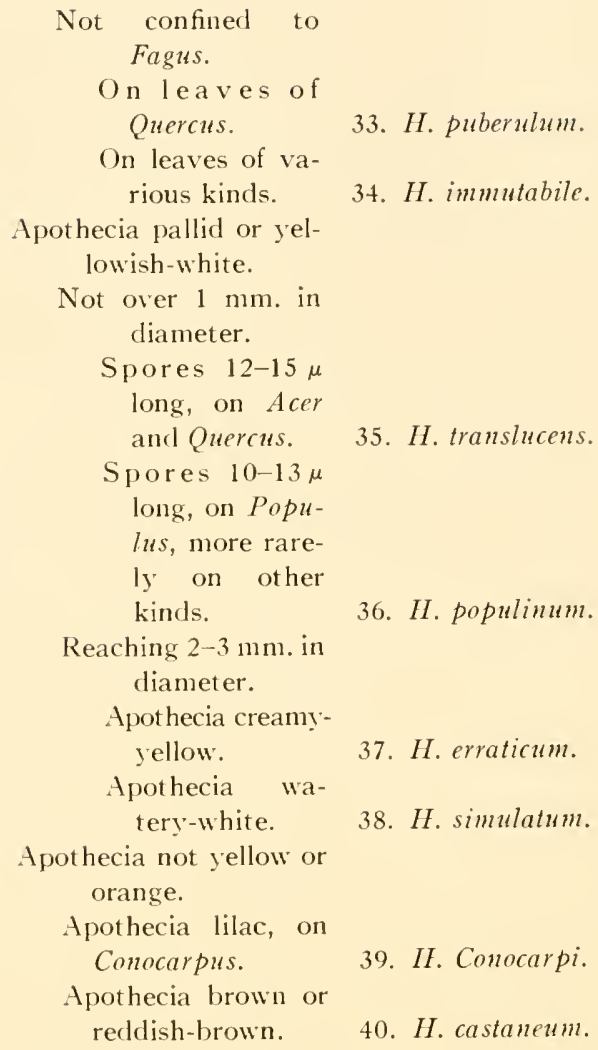

Spores usually less than $10 \mu$ long.

Occurring on cryptogams.

On living mosses and liverworts.

On fungi, Hypoxylon, Nylaria, etc.

41. H. destructor.

42. H. episphaericum.

Occurring on phanerogams.

On coniferous trees.

On needles of Larix.

On bark of Picea.

43. H. laricinum.

44. II. aurantium.

Not on coniferous trees.

On monocotyledons.

On palm, Archontophoenix.

On grasses or sedges.

Apothecia lemon-yellow, on Carex.

45. H. atrosubiculatum.

Apothecia pale-yellow, on $A n d r o-$ pogon.

46. H. citrinulum.

47. HI. planodiscum.

On dicotyledons.

On herbaceous plants.

On stems of various plants.

Apothecia distinctly stipitate.

Apothecia subsessile.

48. H. cyathoideum.

49. H. consanguineum. 
On exposed roots of Polygonum

and Collinsonia.

On woody plants.

On bud scales of Populus.

Not on bud scales.

On the wood or woody stems.

Apothecia waxy-white, on rotten wood.

Apothecia yellow, or yellowish on woody stems. Paraphyses lanceolate, on Spiraea.

Paraphyses not lanceolate.

On bark of Acer and quince.

On bark of Carpinus. On branches of Cornus.

(On leaves.

Apothecia white, minute, on Cassandra.

Apothecia yellow or orange.

On leaves of Populus and Betula.

On leaves of Quercus and pods of Gleditsia.

Apothecia yellowish-brown or brown.

On sandy soil, probably on submerged roots.
50. H. rhizicola.

51. II. gemmarum.

52. H. Craginianum.

53. II. lanceolatoparaphysatum.

54. H. albuminum.

55. If. ammoides.

56. H. propinquum.

57. H. Cassandrae.

58. II. Friesii.

59. H. midlandense.

60. H. umbrinum.

61. II. arenicola.

1. Helotium fastidiosum Peck, Ann. Rep. N. Y. State Mus. 27 : 107. 1875.

Calycina fastidiosa Kuntze, Rev. Gen. P1. 33: 448. 1898.

Apothecia small, stipitate, pale-yellow, reaching a diameter of about $1 \mathrm{~mm}$., rarely larger; hymenium plane, or slightly concave, yellow; stem slender, about equal in length to the diameter of the apothecium, brownish, or yellow with a brownish base; asci narrow-clavate, reaching a length of $80-100 \mu$ and a diameter of 9-12 $\mu, 8$-spored; spores crowded, or 2-seriate, elongate, subclavate, multiguttulate, about $4-4.5 \times 32 \mu$; paraphyses slender.

On petioles and midribs of fallen leaves of Alnus in wet places; also reported on catkins of (Almus?). 
Type Locality: Forestburgh, New York.

Distribution: New York to Quebec and Oregon. Probably common.

Illustrations: Mycologia 34: 158,f. 2; 166, f. 9; Farlowia 1: 153. f. 7 .

This species seems to be distinct in its very long, slender spores. A part of the original collection in the herbarium of The New York Botanical Garden has been examined.

2. Helotium Dearnessii (Ellis \& Ev.) White, Mycologia 34: 167. 1942.

Phialea Dearnessii Ellis \& Ev. Proc. Acad. Sci. Phila. 1893: 146. 1893. Hymenoscyphus Dearnessii Kuntze, Rev. Gen. Pl. 332: 485.1898.

Apothecia scattered, stipitate, nearly sulphur-yellow, $.7 \mathrm{~mm}$. in diameter, at first subolivaceous, becoming yellow, the margin subfimbriate; stem short, stout, less than the diameter of the apothecium; asci cylindric-clavate, reaching a length of $100-$ $108 \mu$ and a diameter of $10-13 \mu, 8$-spored; spores 2-seriate, fusoid to clavate, slightly curved, with two large oil-drops, 4-4.5 $\times 30-35 \mu$, gradually attenuated below; paraphyses filiform, scarcely enlarged above.

On dead stems of Steironema ciliatum.

Type locality: London, Ontario, Canada.

Distribution: Known only from the type locality.

Illustrations: Farlowia 1: 615, f. 31-3t.

Exsiccatı: Ellis \& Ev. N. Am. Fungi $262+$ (as Peziza Deurnessii).

3. Helotium serotinum (Pers.) Rehm in Rab. Krypt.-Fl. $1^{3}: 781$. 1893.

Peziza serotina Pers. Syn. Fung. 661. 1801.

Hymenoscypha serotina Phill. Brit. Discom. 125. 1887.

Apothecia gregarious, stipitate, at first club-shaped and closed, finally opening and becoming cup-shaped, then plane or nearly so, .25-.5 mm. in diameter, bright-yellow; stem 2-10 $\mathrm{mm}$. long, .2-.5 mm. thick; asci clavate, reaching a length of $100-150 \mu$ and a diameter of 10-12 $\mu, 8$-spored; spores clavate, straight, or slightly curved, sharp-pointed, $4 \times 22-24 \mu$ (Rehm states $30-36 \mu$ long and occasionally 1 -septate); paraphyses filiform, $2 \mu$ in diameter.

On fallen leaves and branches of different kinds. 
Type locality: Europe.

Distribution: Ohio; also in Europe.

Illustrations: E. \& P. Nat. Pf. 1': 207. f. 162, E; Rab. Krypt.-Fl. $1^{3}: 770, f, 1-4$.

Although this species has been reported from North America by Saccardo the only specimen seen is one from Ohio determined by Dr. B. Kanouse.

4. Helotium Scutula (Pers.) Karst. Not. Soc. Fauna Fl. Fenn. $11: 233 . \quad 1871$.

P'ezizu Scutula Pers. Myc. Eu. 1:284. 1822.

Ciboria ciliatospora Fuckel, Symb. Myc. 311. 1869.

Helotium Scutula caudatum Karst. Myc. Fenn. 1: 112. 1871.

Helotium gracile Cooke \& Peck; Peck, Ann. Rep. N. Y. State Mus. 26: 83. 1874.

Helotium vitellinum Rehm, Ber. Naturh. Ver. Augsburg 26: 124. 1881.

Phialea Scutula Gill. Champ. Fr. Discom. 108. 1882.

Helotium virgultorum Scutula Rehm, Ascon. Lojk. 7. 1882.

Helotium Scutula Rubi Rehm, Hedwigia 24: 229. 1885.

Calycella Scutula Quél. Ench. Fung. 305. 1886.

Hymenoscypha Scutula Phill. Brit. Discom. 136. 1887.

Hymenoscypha Scutula Lysimachiae Phill. Brit. Discom. 137. 1887.

Hymenoscypha Scutula Rudbeckiae Phill. Brit. Discom. 138. 1887.

Phialea vitellina Sacc. Syll. Fung. 8: 262. 1889.

Phialea gracilis Sacc. Syll. Fung. 8: 265. 1889.

Phialea Scutula Rudbeckiae Sacc. Syll. Fung. 8: 266. 1889.

Helotium Verbenae Cavara, Rev. Myc. 11: 178. 1889.

Phialea appendiculata Oud. Versi. Med. Akad. Wet. 7: 313. 1890.

Belonioscypha ciliatospora Rehm in Rab. Krypt.-Fl. 13: 744. 1893.

IIelotium Scutula vitellina Rehm in Rab. Krypt.-F1. 13: 794. 1893.

Helotium Scutula Lysimachiae Massee, Brit. Fungus-F1. 4: 254. 1895.

Helotium Scutula Rudbeckiae Massee, Brit. Fungus-Fl. 4: 254. 1895.

Hymenoscyphus gracilis Kuntze, Rev. Gen. Pl. 33: 485. 1898.

IIelotium vitellinum pallidostriatum Fairman, Jour. Myc. 10: 231. 1904.

Phialea vitellina pallidostriata Sacc. \& D. Sacc. in Sacc. Syll. Fung. 18: 56. 1906.

Helotium appendiculatum Boud. Hist. Class. Discom. Eu. 114. 1907.

Helotium ciliatosporum Boud. Hist. Class. Discom. Eu. 114. 1907.

Belospora ciliatospora Clements, Gen. Fungi 175. 1909.

Hymenoscypha Scutula Grossulariae Kauffm. Papers Mich. Acad. Sci. 1: 107. 1921.

Apothecia thickly gregarious, stipitate, or occasionally almost sessile, often springing from a dark-colored subiculum at first shallow cup-shaped, becoming nearly plane, reaching a diameter of 1-2 mm., pale-yellow; hymenium slightly concave, similar in color to the outside of the apothecium; stem relatively slender and 
variable in length, often reaching $5 \mathrm{~mm}$., usually about $.3 \mathrm{~mm}$. thick; asci clavate, reaching a length of $90-100 \mu$ and a diameter of 8-10 $\mu, 8$-spored; spores irregularly 2 -seriate, fusoid, or clavate, slightly curved, often spuriously $1-3$-septate, $3-4 \times 20-28 \mu$, occasionally with a cilium at one or both ends; paraphyses filiform, reaching a diameter of $7 \mu$.

On herbaceous stems of various kinds.

Type LOCALITY: Europe.

Distribution: New York to Oregon, and Missouri, probably throughout North America; also in Europe.

Illustrations: Rab. Krypt.-Fl. $\mathbf{1}^{3}$ : 771, f. 1-5; Trans. Brit. Myc. Soc. 18: 76-83, f. 1-5; Mycologia 34:158, f. 1 .

Exsiccatı: Ellis \& Ev. Fungi Columb. 2339; Clements, Crypt. Form. Colo. 80.

5. Helotium salicellum Fries, Summa Veg. Scand. 356. 1849.

Pesiza salicella Fries, Syst. Myc. 2: 133. 1822.

Apothecia scattered, springing through the bark of the host, short-stipitate, at first globose, then expanding and becoming shallow cup-shaped, brownish-yellow, reaching a diameter of 2 mm.; hymenium slightly concave, or nearly plane, yellowish; stem scarcely exceeding $1 \mathrm{~mm}$. in length and $.3 \mathrm{~mm}$. thick; asci clavate, reaching a length of $75-100 \mu$ and a diameter of 12-25 $\mu$, 8-spored; spores fusoid, with the ends acute, straight, or curved, usually containing one or two oil-drops, becoming spuriously 1-3-septate, 5-7 $\times 25-30 \mu$; paraphyses filiform, reaching a diameter of $2 \mu$.

On fallen branches of Salix.

Type Locality: Europe.

Distribution: Oregon; also in Europe.

This species has been reported from North America by Saccardo. No American material was found in the collection at The New York Botanical Garden, except the Oregon specimens. Fuckel regards this as a variety of Helotium virgultorum.

6. Helotium fructigenum (Bull.) Karst. Myc. Fenn. 1: 113. 1871.

Peziza fructigena Bull. Hist. Champ. Fr. 236. 1791.

Phialea fructigena Gill. Champ. Fr. Discom. 99. 1882.

Hymenoscypha fructigena Phill. Brit. Discom. 135. 1887.

Apothecia gregarious, stipitate, at first closed, then opening and expanding, becoming plane or nearly so, reaching a diameter 


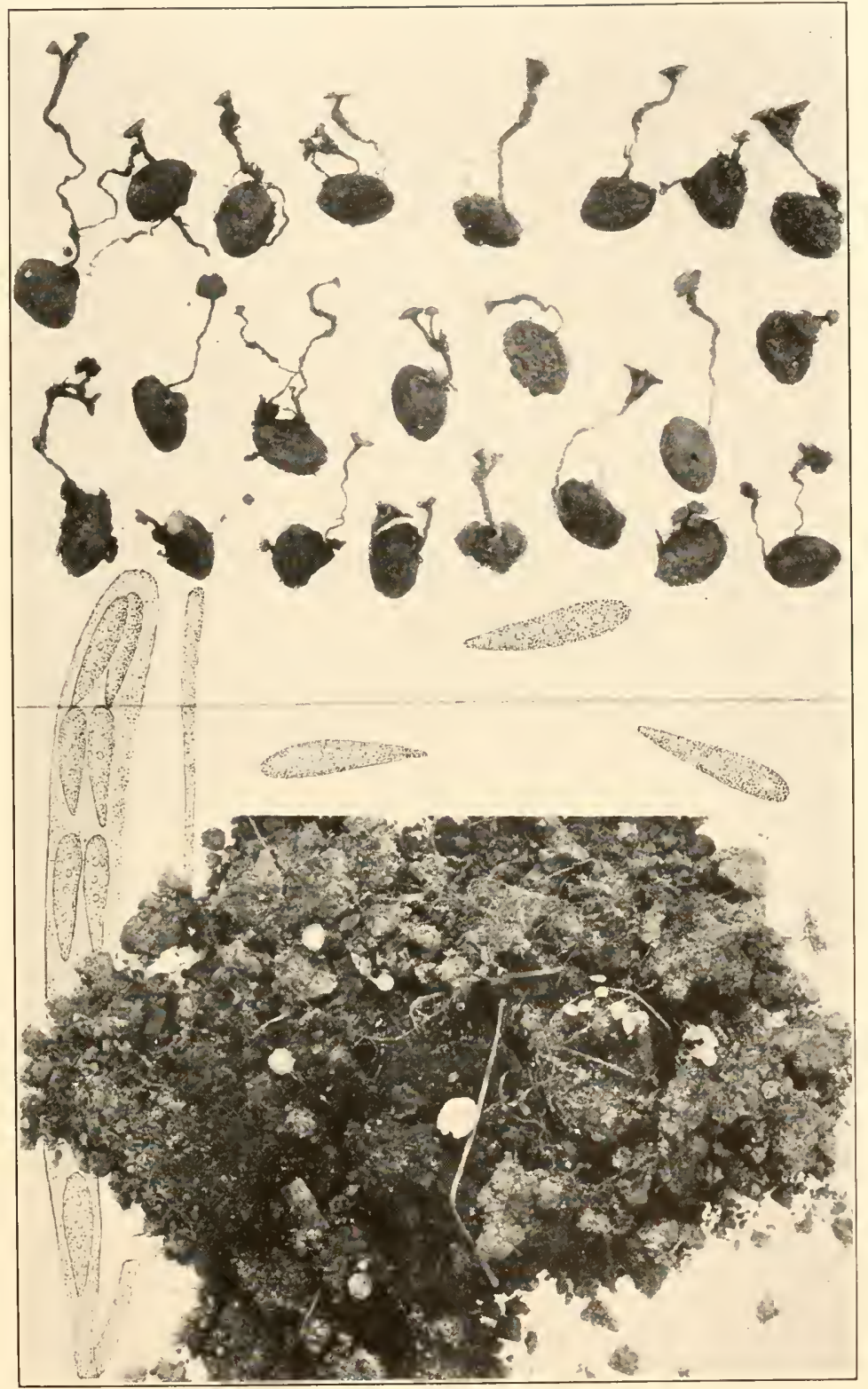

HELOTIUM NYSSICOLA 

of 1-3 mm., pale-yellow; hymenium plane, or slightly concave, similar in color to the outside of the apothecium; stem slender, very variable in length, sometimes reaching nearly $1 \mathrm{~cm}$., at other times so short that the apothecia appear subsessile; asci clavate, reaching a length of $80-100 \mu$ and a diameter of $7-9 \mu$, 8 -spored; spores fusoid, or subclavate, of ten with two oil-drops and numerous smaller ones, $3-5 \times 12-18 \mu$; paraphyses filiform, slightly enlarged above, reaching a diameter of $3 \mu$.

On acorns and hickory-nut husks, Quercus and IIicoria.

TyPe locality: Europe.

Distribution: New York to Iowa and Pennsylvania; also in Europe.

Illustrations: Bull. Herb. Fr. pl. 228; Gill. Champ. Fr. Discom. pl. 73; Bull. Lab. Nat. Hist. State Iniv. Iowa 6: pl. 23, f. 1 .

Exsiccati: Ellis \& Ev. N. Am. Fungi 2048.

There seems to be considerable variation in the size of the spores in this species. The spores are often smaller than indicated. As the plants are otherwise typical this may be due to immaturity. Occasionally the spores seem to be septate. This has been reported from Minnesota by Miss Daisy S. Hone as IIelotium virgultorum fructigenum, following Rehm.

7. Helotium nyssicola Seaver, Mycologia 30: 79. 1938. (Plate 105.)

Apothecia gregarious, or occasionally occurring singly, stipitate, or subsessile, reaching a diameter of 2-4 mm., paleyellow, orbicular, or with the margin irregularly split; hymenium concave, or nearly plane, pale-yellow; stem very slender, short, or reaching a length of 2 or more $\mathrm{cm}$., the length depending upon the depth of the substratum; asci clavate, reaching a length of $125 \mu$ and a diameter of $8 \mu$, gradually tapering below into a slender, stem-like base, 8 -spored; spores fusoid, or clavate, about $5-5.5 \times 15-20 \mu$, containing a number of small granules; paraphyses rather stout, granular, reaching a diameter of 3-4 $\mu$.

On buried or partially buried seeds of Nyssa sylvatica.

Type Locality: The New York Botanical Garden.

Distribution: Known only from the type locality.

Illustrations: Mycologia $30: 80, f .1$.

This species has been collected season after season under one tree in The New York Botanical Garden. It has not been found in any other locality. 
8. Helotium turbinatum (Fuckel) Boud. Hist. Class. Discom. Eu. 113. 1907.

Leucoloma turbinata Fuckel, Symb. Myc. 318. 1869.

Helotium bryogenum Peck, Ann. Rep. N. Y. State Mus. 30: 61. 1878.

Humaria hurbinata Sacc. Syll. Fung. 8: 127. 1889.

Plicaria turbinata Rehm in Rab. Krypt.-F1. 133: 1009. 1894.

Belonium bryogenum Rehm, Ascom. 1279; Hedwigia 38: Beibl. (244). 1899. Calycina bryogena Kuntze, Rev. Gen. Pl. $3^{3}: 448.1898$.

Calycella turbinata Höhn. Sitz.-ber. Akad. Wien 127: 594. 1918.

Apothecia solitary, sparse, short-stipitate, fleshy, brown when dry, .8-1 mm. in diameter, waxy to waxy-cartilaginous; hymenium plane, or slightly concave, dark-brown in dried specimens; stem short, stout, about .3 mm. long; asci clavate, reaching a length of 70-90 $\mu$ and a diameter of 8-11 $\mu, 8$-spored; spores elongated, straight, or very slightly curved, usually simple, or rarely 1 -septate, $3-4 \times 12-15 \mu$, somewhat attenuated at the ends; paraphyses, simple, or once branched near the base.

On living mosses, especially Bryum.

Type Locality: Europe.

Distribution: New York; also in Europe.

Illustrations: Mycologia 34: 166, $f .10$.

According to W. L. White, Helotium bryogenum Peck is synonymous with the above. This was described as pallid or yellowish-white when moist, livid-red or subolivaceous when dry.

9. Helotium mycetophilum Peck, Ann. Rep. N. Y. State Mus. 43: 33.1890.

Calycina mycetophila Kuntze, Rev. Gen. Pl. 33: 448. 1889.

Apothecia scattered, or gregarious, appearing singly, or more rarely two in close contact, substipitate, .1 to $.3 \mathrm{~mm}$. in diameter, more or less turbinate in form, dark-red; stem very slort, tapering upward; hymenium plane, or slightly concave; asci clavate, reaching a length of $100-120 \mu$ and a diameter of 13-15 spores 1 -seriate below, irregularly 2 -seriate above, narrowellipsoid, slightly curved, or at least flattened on one side, occasionally becoming 1 -septate but usually 1 -celled, 5.5-7 $\times$ 17-20 $\mu$; paraphyses simple, slightly flexuous, scarcely more than $1 \mu$ in diameter.

On pileus of old sporophore of Fomes fomentarius.

Type Locality: Rainbow Lake, New York.

Distribution: Known only from the type locality.

IlLUSTRATIONS: Mycologia 34: 166, $f .16$. 
10. Helotium nigromaculatum (Earle) Seaver, comb. nov.

Hymenoscypha nigromaculata Earle, Bull. N. Y. Bot. Gard. 2: 338.1902. Phialea nigromaculata Sacc. Syll. Fung. 18: 57. 1906.

Apothecia occurring on black spots which are .5-1 cm. in diameter, gregarious, brown, sessile, or substipitate, the margin inrolled when dry, becoming turbinate when moist, about $.3 \mathrm{~mm}$. in diameter and of equal height, externally fibrillose, the ends of the fibers extending slightly above the margin of the apothecium; asci broadly clavate, reaching a length of $70 \mu$ and a diameter of $14 \mu, 8$-spored; spores 2-seriate, or irregularly disposed, irregularly ellipsoid, $6 \times 18-20 \mu$; paraphyses sparse and rather stout.

On dying leaves of Iris sp.

Type locality: Palmetto, Floricla.

Distribution: Known only from the type locality.

No material has been seen.

11. Helotium fraternum Peck, Ann. Rep. N. Y. State Mus. 32: 47. 1879.

Apothecia solitary, scattered, stipitate, reaching a dianeter of $2 \mathrm{~mm}$., at first cylindric, or columnar, finally expanding above, becoming globose, then cup-shaped and finally fully expanded, yellowish to whitish; hymenium at first concave, becoming convex when moist, wax-yellow to ochraceous-orange, when dry becoming concave and redklish-brown; asci clavate-cylindric, reaching a length of $70-100 \mu$ and a diameter of $10-12 \mu, 8$-spored; spores 2-seriate or partially so, elongate-fusiform, often slightly curved, usually with an oil-clrop in either end, 4-5 × 16-20 $\mu$; paraphyses filiform, scarcely enlarged above.

On decaying petioles of various species of Acer.

Trpe Lochlitr: Adirondack Mountains, New York.

Distribution: Maine to Indiana and West Virginia.

Illustrations: Mycologia 34: 166. $f .1 \%$.

The type specimen in the herbarium of The New York Botanical Garden has been examined.

12. Helotium Linderi White, Farlowia 1: 154. 1943.

Apothecia scattered, stipitate, reaching a diameter of $1 \mathrm{~mm}$, pure-white when fresh, becoming cinereous to nearly black on drying; stem stender, white when fresh, drying to hyalineochraceous, smooth, slightly thickened above; hymenium becoming plane, or slightly concave, white, drying darker than the 
outside of the apothecium, often nearly black; asci clavate, reaching a length of 65-75 $\mu$ and a diameter of 9-10 $\mu, 8$-spored; spores 2-seriate, elongated, narrowed toward the lower end, rounded above and somewhat curved, 3.5-4 × 16-18 $\mu$, containing several oil-drops; paraphyses simple, or once forked below the middle, scarcely enlarged above, about $3 \mu$ in diameter at their apices.

On fallen leaves of Belula sp. and others.

Type Locality: Chimney Trail, Great Smoky Mts. National Park, Tennessee.

Distribution: Tennessee and Wisconsin.

Illustrations: Farlowia $1: 153, f .9$.

13. Helotium naviculasporum Ellis, Bull. Torrey Club 5: 46. 1874.

?Peziza caudata Karst. Fungi Fenn. 547. 1866.

Helolium saprophyllum Cooke \& Peck; Peck, Ann. Rep. N. Y. State Mus. 29: 55. 1878.

Calycina naviculaspora Kuntze, Rev. Gen. Pl. $3^{3}: 448.1898$.

Calycina saprophylla Kuntze, Rev. Gen. Pl. 333 449.1898.

Helotium sparsum Boud. Hist. Class. Discom. Eu. 111. 1907.

Apothecia scattered, sparse, minute, delicate, slenderstipitate, hyaline-white when fresh, becoming opaque and more or less yellowish, or ochraceous on drying, reaching a diameter of .4 to $1.3 \mathrm{~mm}$.; stem slender, delicate, smooth, similar in color to the apothecium, scarcely $1 \mathrm{~mm}$. long; hymenium plane, or slightly convex, white to pale-yellow, or ochraceous; asci clavate, reaching a length of $80-90 \mu$, or rarely $110 \mu$, and a diameter of 8-11 $\mu$; spores irregularly 2 -seriate, slightly curved and attenuated at the lower end, 4-5 × 16-20 $\mu$, granular within; paraphyses simple, scarcely enlarged above, reaching a diameter of $2-3 \mu$.

On fallen leaves usually from the midribs or veins, more rarely on petioles: Acer, Almus, Carya, Fagus, and Tilia.

Type locality: Newfield, New Jersey.

Distribution: New York to New Jersey and Michigan; also in Europe.

Illustrations: Boud. Ic. Myc. pl. 495; Mycologia 34: 158, f. 3 ; 166, f. . 3; Farlowia 1: 153, f. 8 (as Helotium caudatum (Karst.) Vel.)

Exsiccati: Ellis, Fungi Nova-Caesar. 53; N. Am. Fungi 62. 


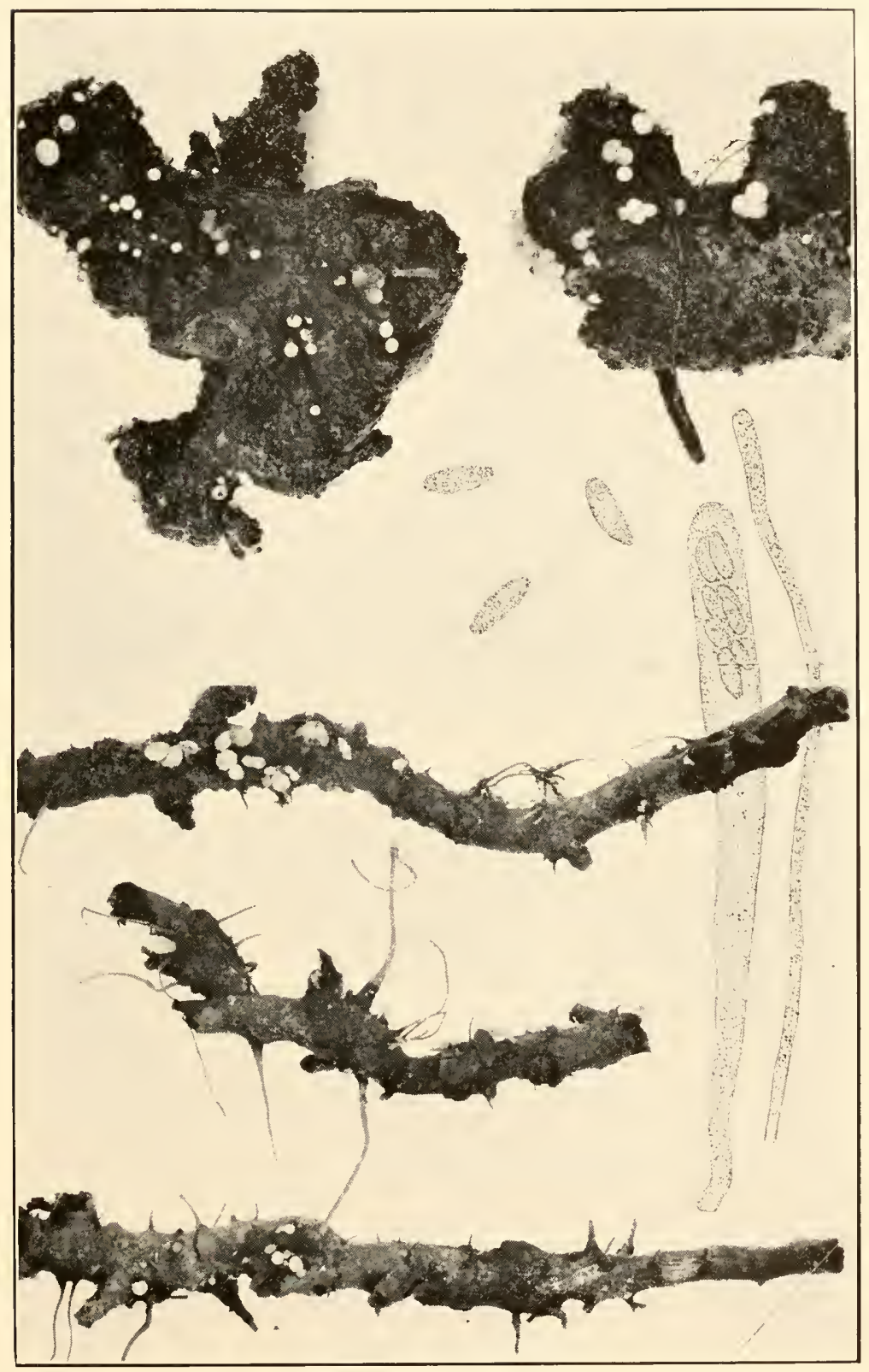

HELOTIUM RHIZICOLA 

14. Helotium epiphyllum (Pers.) Fries, Summa Veg. Scand. 356. 1849.

Pesiza epiphylla Pers. Tent. Disp. Fung. 72. 1797.

Calycina aurantiaca Kuntze, Rev. Cen. Pl. $3^{3}: 448.1898$.

Hymenoscypha epiphylla Rehm; Kauffm. Papers Mich. Acad. Sci. 9: 177. 1929.

Apothecia scattered, or in groups of two to four, sessile to short-stipitate, bright-yellow, or dull-orange when fresh, the color not changing much on drying, fleshy to waxy, reaching a diameter of $4 \mathrm{~mm}$; stem when present exceedingly short, paleyellow; hymenium slightly concave to plane, or sometimes repand, becoming yellow to orange, or occasionally dull-red; asci clavate, reaching a length of $90-130 \mu$ and a diameter of 9-12 $\mu, 8$-spored; spores fusoid, more or less unsymmetrical or slightly curved, simple, 1 -seriate below, 2-seriate above, $4-5 \times$ 16-20 $\mu$, granular, often with two or three definite oil-drops; paraphyses straight, scarcely thickened above, reaching a diameter of $2-3 \mu$.

On leaves of various deciduous or more rarely coniferous trees; also on forest debris.

Type Locality: Europe.

Distribution: Probably throughout the ITnited States and Canada; also in Europe.

Illustrations: Farlowia 1: 143, f. 1.

Exsiccatr: Ellis \& Ev. N. Am. Fungi 2328.

On Sept. 13, 1935, the writer examined a specimen of this species in the Persoon Herbarium at Leiden, Holland, and it showed three yellowish apothecia about $3 \mathrm{~mm}$. in diameter on a leaf labeled Corylus. No microscopic examination was possible.

15. Helotium cudonioides Seaver, Mycologia 37: 267. 1945.

Apothecia stipitate, single, or cespitose, at first concave, soon becoming strongly convex, reaching a diameter of $2 \mathrm{~mm}$., paleto dark-brown; stem white or nearly white, reaching a length of 2-3 $\mathrm{mm}$. and less than $1 \mathrm{~mm}$. in diameter; asci clavate, 8-spored, reaching a length of $100 \mu$ and a diameter of $10-12 \mu$; spores 1 seriate below and irregularly 2-seriate above, fusoid, hyaline, about $5 \times 16-20 \mu$; paraphyses filiform, $1 \mu$ or less in diameter.

On rotten wood.

Type locality: Cleveland, Ohio. 


\section{Distribution: New York and Ohio.}

ILlUSTRATIONS: Mycologia 37:268, $f .1$.

This species has been sent in several times for determination. As the name signifies it looks like a miniature Cudonia.

16. Helotium virgultorum (Vahl.) Fries, Summa Veg. Scand. 355. 1849. (Plate 104, Fig. 1.)

Peziza virgultorum Vahl. Fl. Dan. 17: 10. 1790.

Hymenoscypha virgultorum Phill. Brit. Discom. 134. 1887.

Phialea virgultorum Sacc. Syll. Fung. 8: 266. 1889.

Apothecia gregarious, stipitate, at first closed, expanding and becoming shallow cup-shaped to patellate, or occasionally even convex, reaching a diameter of $1-3 \mathrm{~mm}$., whitish to paleyellowish; hymenium usually concave, bright-yellow; stem cylindric, two to three times as long as the diameter of the apothecium, whitish, or yellowish; asci clavate, reaching a length of $100-120 \mu$ and a diameter of 9-10 $\mu, 8$-spored; spores partially 2 -seriate, fusoid, or subclavate, usually containing two oil-drops with several smaller ones, $4-5 \times 15-20 \mu$, occasionally spuriously septate; paraphyses filiform, slightly enlarged above.

On partially buried sticks and roots.

Type locality: Europe.

Distribution: Toronto to Colorado, Washington, and California; also in Europe.

Illustrations: Fl. Dan. pl. 1016, f. 2.

Excellent material collected in Colorado on roots of Alnus has been studied and is the basis of the illustrations shown in this work. The distribution is difficult to determine since this species has been confused with two others which are here regarded as distinct, Ilelotium fructigenum and Helotium Scutula.

17. Helotium fumosellum (Cooke \& Ellis) Seaver, comb. nov. Peziza fumosella Cooke \& Ellis, Grevillea 6: 91. 1878.

Phialea fumosella Sacc. Syll. Fung. 8: 269. 1889.

Allophylaria fumosella Nannf. Nova Acta Soc. Sci. Upsal. IV. 8: 291.1932.

Apothecia minute, stipitate, fumose, at first clavate, then expanding, becoming cyathiform, .25-.7 mm. in diameter and .5 mm. high; hymenium pallid; asci cylindric-clavate, 8-spored; spores elongated, straight, or curved, $10 \mu$ long.

On fir leaves, Abies, accompanying IIymenula fumosa which may be its conidial stage. 
Type locality: Newfield, New Jersey.

Distribution: Known only from the type locality.

18. Helotium sulphuratum (Fries) Phill. Brit. Discom. I61. 1887.

Pesiza sulphurea Schum. Pl. Saell. 2: 428. 1803. Not Pers. 1797.

Peziza sulphurata Fries, Syst, My'c. 2: 72. 1822.

?Helotium Piceae (Kauffm.) Kanouse, Mycologia 33: 465. 1941.

Apothecia scattered, or occasionally two or three together, stipitate, or subsessile, at first rounded and closed, expanding and becoming shallow cup-shaped, or nearly plane, $1-2 \mathrm{~mm}$. in diameter, externally pale-yellow; hymenium sulphur-yellow; asci cylindric-clavate, 8-spored; spores fusiform, about $3-4 \times 10^{-}$ $12 \mu$; paraphyses filiform.

On leaves of conifers matted on the ground, Picea.

Trpe locality: Europe.

Distribution: Colorado and Manitoba, Canada.

Illustrations: Fl. Dan. pl. 1915, f. 2.

Helotium Piceae was based on specimens collected by C. H. Kauffman and regarded by him as a variety of $H$. sulphuratum. The difference, in our opinion, is too slight to segregate it as a distinct species.

19. Helotium acicularum (Roll.) Sacc. Syll. Fung. 10: S. 1892.

Calycella acicularum Rolland, Bull. Soc. Myc. Fr. 5: 170. 1889.

Phialea acicularum Rehm in Rab. Krypt.-Fl. 13: 719. 1892.

Apothecia short-stipitate, at first closed and rounded, finally opening and becoming cup-shaped, then plane, externally yellowish-white, .2-.3 mm. in diameter, fleshy-waxy; hymenium concave to plane, egg-yellow; asci clavate, reaching a length of $160 \mu$ and a diameter of $10-12 \mu, 8$-spored; spores ellipsoid, slightly bent, 5-8 $\times 10-12 \mu$; paraphyses filiform.

On fallen needles of larch, Larix sp.

Type locality: Europe.

Distribution: Michigan; also in Europe.

Illustrations: Bull. Soc. Mỵc. Fr. 5: pl. 15, f. 3.

20. Helotium seminicola Keinh. \& Cash, Mycologia 29: 82. 1937.

Apothecia stipitate, occurring singly, or two or three arising from a seed, at first cup-shaped, expanding and often plane. 
reaching a diameter of $6 \mathrm{~mm}$.; hymenium fawn-colored, plane, or concave; stem reaching a length of $10 \mathrm{~mm}$. and usually $.5-.8 \mathrm{~mm}$. thick, sometimes hairy toward the base when young; asci clavate, reaching a length of 75-130 $\mu$ and a diameter of 7-12 $\mu, 8$-spored; spores fusoid-ellipsoid, with ends attenuated, with several small oil-drops, $\quad 3.5-5 \times 12-20 \mu$; paraphyses filiform simple, or branched below, slightly enlarged above, reaching a diameter of $4 \mu$, hyaline.

On seeds of Alnus oregona.

Type locality: Hood River, Oregon.

Distribution: Known only from the type locality.

ILlustrations: Mycologia 29: 83, $f .1-4$.

21. Helotium strumosum Ellis \& Ev. Jour. Myc. 4: 56. 1888. Pseudohelotium strumosum Sacc. Syll. Fung. 8: 300. 1889.

Apothecia gregarious, sessile or subsessile, bright lemonyellow, closed and subspherical at first, then opening and becoming cup-shaped and finally expanding to nearly plane, about .3 $\mathrm{mm}$. in diameter, tomentose-pubescent outside and attached to the matrix by fine, white hairs at the base; asci clavate, reaching a length of $70-80 \mu$ and a diameter of $10-12 \mu, 8$-spored; spores 2-seriate, ellipsoid, with two or three oil-drops, and indications of a medial septum, 3-4.5 $\times 10-12 \mu$; paraphyses stout, slightly yellowish and thickened above.

On old Dichaena strumosa on Quercus coccinea.

Type Locality: Newfield, New Jersey.

Distribution: New Jersey and Delaware.

22. Helotium nigrescens (Cooke) Rehm, Ascom. 307; Ber. Naturh. Ver. Augsburg 26: 77. 1881.

Peziza nigrescens Cooke, Hedwigia 14: 83. 1875.

Apothecia stipitate, brownish-black, becoming black, at first clavate, then expanded, $.3 \mathrm{~mm}$. in diameter; hymenium pallid or subcinereous; stem thick, expanding into the apothecium, .5 mm. long; asci cylindric, or subcylindric, reaching a length of $60 \mu$ and a diameter of $9 \mu, 8$-spored; spores elongatefusiform, straight, or slightly curved, $3 \times 12 \mu$; paraphyses not observed.

On dead stems of Erigeron.

Type locality: Newfield, New Jersey.

Distribution: Known only from the type locality. 


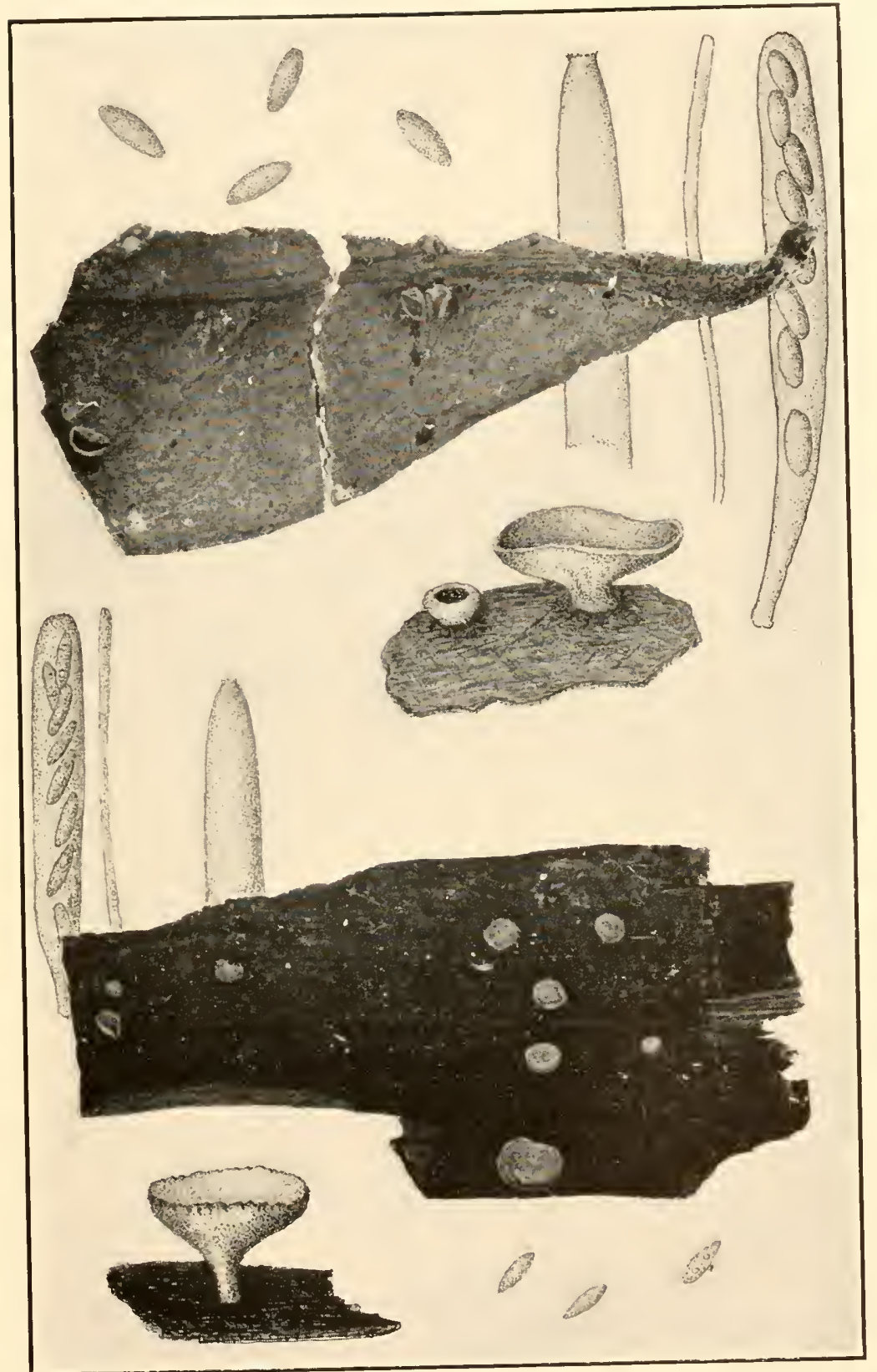

HELOTIUM CONOCARPI

HELOTIUM ATROSUBICULATUM 

Exsiccati: Ellis, N. Am. Fungi 140; Thüm. Myc. Univ. 214; Rehm, Ascom. 307 (both from Newficld, New Jersey).

23. Helotium phaeoconium (Fairman) Seaver, comb. nov.

Phialea phaeoconia Fairman, Ann. Myc. 9: 151. 1911.

Apothecia gregarious, stipitate, occurring on the under side or projecting from the margins of the leaves, dark-brown, or black, with a light-brown, or grayish margin, globose and closed, finally opening and becoming deep cup-shaped, $.25 \mathrm{~mm}$. in diameter; hymenium concave, light-brown; stem about as long as the diameter of the apothecium, swollen just below the point of attachment; asci clavate-cylindric, reaching a length of $50 \mu$ and a diameter of $10 \mu, 8$-spored; spores long-ellipsoid, or fusoid, straight, or curved, irregularly 1-seriate, or partially 2-seriate, 3-4 $\times 10-13 \mu$; paraphyses filiform.

On dead leaves of Antennaria plantaginifolia.

Type Locality: Lyndonville, New York.

Distribution: Known only from the type locality.

Illustrations: Ann. Myc. 9: 150, f. 6,7 .

24. Helotium Eschscholtziae (Phill. \& Hark.) Seaver, comb. nov. Pesiza Eschscholtsiae Phill. \& Hark. Bull. Calif. Acad. Sci. 1:22. 1884. Phialea Eschscholtziae Sacc. Syll. Fung. 8: 271. 1889.

Apothecia scattered, short-stipitate, cyathiform, cinereous, pruinose, .5-.7 $\mathrm{mm}$. in diameter; hymenium same color as outside of apothecium; asci cylindric, 8-spored; spores fusoid, usually with an oil-drop in each end, $2 \times 10 \mu$; paraphyses not observed.

On dead stems of Eschscholtzia californica.

Type locality: California.

Distribution: Known only from California.

Exsiccati: Ellis \& Ev. N. Am. Fungi 20+2; Rab.-Winter, Fungi Eu. 3272 (from California).

This species seems to be very close to IIelotium cyathoideum.

25. Helotium herbarum (Pers.) Fries, Summa V'eg. Scand. 356. 1849.

Peziza herbarum Pers. Tent. Disp. Fung. 72. 1797.

Apothecia thickly gregarious, very short-stipitate, or sessile, at first rounded, expanding and becoming shallow cup-shaped, or discoid, yellowish, or whitish, reaching a diameter of $1-2 \mathrm{~mm}$; hymenium nearly plane, light-yellow; stem vrey short, usually 
less than $1 \mathrm{~mm}$. long, or absent; asci clavate, gradually tapering below, reaching a length of $80 \mu$ and a diameter of 6-7 $\mu, 8$ spored; spores irregularly 2 -seriate, fusoid, slightly curved, containing several small oil-drops, of ten spuriously septate, 3-4 $\times$ 10-14 $\mu$; paraphyses filiform, reaching a diameter of 1-2 $\mu$.

On herbaceous stems of various kinds, Impatiens and Eupatorium.

Type locality: Europe.

Distribution: New York to Maine, Michigan and Kansas; also in Europe.

Illustrations: Boud. Ic. Myc. pl. 497; Gill. Champ. Fr. Discom. pl. 89, f. 2; E. \& P. Nat. Pfl. 1' ${ }^{1}: 207, f .162$ C-D; Rab. Krypt.-Fl. $1^{3}: 770, f .1-t$.

Exsiccatı: Ellis, N. Am. Fungi 670; Ellis \& Ev. Fungi Columb. 740, 1309; Reliq. Farlow. $12+$ (as Helotium herbarum Rubi).

26. Helotium renisporum Ellis; Cooke, Bull. Buffalo Soc. Nat. Sci. 2: 299.1875.

?Ciboria Sydowiana Rehm, Hedwigia 24: 226. 1885.

Hymenoscypha renispora Phill. Brit. Discom. 143. 1887.

Ciboria renispora Sacc. Syll. Fung. 8: 207.1889.

Rutstroemia renispora White, Lloydia 4: 215.1941.

Apothecia stipitate, slightly concave, or plane, from black stromatic lines in the leaf, cinnamon, or brownish-yellow, reaching a diameter of $2 \mathrm{~mm}$., externally clothed with adpressed, brown, club-shaped hair-like structures; hymenium similar in color to the outside of the apothecium, usually plane, or convex at maturity; stem blackish, reaching a length of 3-6 mm.; asci cylindric, or subcylindric, reaching a length of $65-100 \mu$ and a diameter of $7-10 \mu$; spores reniform, with two or three oil-drops, 5-6 × 10-14 $\mu$; paraphyses slender, slightly clavate.

On decaying leaves.

Type Locality: Newfiełd, New Jersey.

Distribution: New Jersey and Pennsylvania to South Carolina.

Illustrations: Lloydia 4: 214, f. 62-65.

Exsiccatr: Ellis \& Ev. N. Am. Fungi 2049.

Phillips, in his British Discomycetes cited above, regards Rehm's European species as identical with Ellis' American form, characterized by its reniform spores. W. L. White claims that 
Phillips was in error in making Ciboria Sydowiana synonymous with Helotium renisporum.

27. Helotium luteovirescens (Rob.) Seaver, comb. nov.

Peziza luteovirescens Rob. in Desm. Pl. Crypt. Fr. 15+1. 1846; Ann. Sci. Nat.

III. 8: 188. 1847.

?Peziza longipes Peck, Bull. Buffalo Soc. Nat. Sci. 2: 295. 1875.

Pesiza pallidovirescens Phill.; Phill. \& Plow: Grevillea 6: 24. 1877.

Helotium sulfurellum Ellis \& Ev. Bull. Torrey Club 10: 98. 1883.

Ciboria tabacina Ellis \& Holw.; Arthur, Bull. Geol. Nat. Hist. Surv. Minn. 3:

35. 1887.

Ciboria luteovirescens Sacc. Syll. Fung. 8: 206.1889.

Ciboria sulfurella Rehm; Durand, Bull. Torrey Club 29: 461. 1902.

?Phialea anomala Peck, Bull. N. Y. State Nlus. 167: 29. 1913.

Apothecia gregarious, or scattered, stipitate, reaching a diameter of 2-5 mm., sulphur-yellow when fresh with a tinge of green; hymenium concave, or plane; stem very variable in length, sometimes as long as $2 \mathrm{~cm}$. or often very short; hymenium concave, plane, or slightly convex, darker than the outside of the apothecium, reddish, or reddish-brown, when dry entire apothecium almost black; asci clavate, 8 -spored, reaching a length of $7590 \mu$ and a diameter of $7-10 \mu$; spores 1 -seriate with the ends overlapping, cllipsoid, 3-5 × 10-12 $\mu$; paraphyses filiform.

On sticks and leaf petioles, Fraxinus especially; also reported on Acer, Tilia and Platinus.

Type locality: Europe.

Distribution: New England to North Dakota, Iowa and Pennsylvania; also in Europe.

Exsiccati: Ellis, N. Am. Fungi 1275 (as Helotium sulfurellum); Rehm, Ascom. 1880. (as Ciboria labacina).

Durand has reported Ciboria luteovirescens from this country, but regards Helotium sulfurellum as distinct mainly on color. He states that the latter is never green. The writer has often collected this in Iowa on ash petioles and described it as sulphuryellow with a tinge of green. It seems doubtful if the two forms are distinct, although for lack of material it is difficult to be certain.

28. Helotium citrinum (Hedw.) Fries, Summa V'eg. Scand. 355. 1849. (Plate 104. Fig. 2.)

?Pesiza lenticularis Bull. Hist. Champ. Fr. 248. 1791.

Octospora citrina Hedw. Descr. 2: 33. 1789.

Pezisa citrina Batsch, Elench. Fung. Cont. 2: 95. 1789.

Pesiza confluens Schw. Trans. Am. Phil. Soc. 11. 4: 176. 1832. 
?Helotium citrinum sublenticulare Fries, Summa l'eg. Scand. 355. 1849.

Phialea citrina Gill. Champ. Fr. Discom. 109. 1882.

Calycella citrina Boud. Bull. Soc. Myc. Fr. 1: 112. 1885.

Helotium confluens Sacc. Syll. Fung. 8: 222. 1889.

?Helotium lenticulare Sacc. Syll. Fung. 8: 225. 1889.

?Helotium sublenticulare Rehm in Rab. Krypt.-Fl. 1²: 784. 1893.

Helotium alaskae Sacc.; Sacc. Peck, \& Trelease in Harriman Alaska Exped. 5:

25. 1904.

Apothecia thickly gregarious and often running together in confluent masses, the individuals with a short and relatively thick stem, reaching a diameter of .5-3 mm.; hymenium plane or nearly so, bright lemon-yellow; stem seldom exceeding $1 \mathrm{~mm}$. in length and often nearly wanting, lighter colored than the hymenium; asci clavate, 8-spored, reaching a length of 75-100 $\mu$ and a diameter of $10 \mu$; spores ellipsoid, or fusoid, usually with an oil-drop in either end and sometimes pseudoseptate, $3-4 \times$ 9-14 $\mu$; paraphyses filiform, reaching a diameter of $1.5 \mu$.

On decaying wood, of all kinds; also on humus.

TyPe locality: Europe.

Distribution: Throughout North America; probably worldwide.

Illustrations: Hedw. Descr. 2: pl. $8, f . B$; ? FI. Dan. pl. 1971, f. 3; Batsch Elench. Fung. Cont. 2: pl. 39, f. 218; Sow. Engl. Fungi pl. 150 (as Peziza aurea Bolt.), 151; Bull. Herb. Fr. pl. 300 .

Exsiccati: Ellis, N. Am. Fungi 1315, 1316; Clements, Crypt. Form. Colo. 79; Shear, N. Y. Fungi 326; Reliq. Farlow. 123.

One of the most common and widely distributed of the cupfungi. It is quite easily recognized by the bright lemon-yellow color and short, thick stem-like base.

29. Helotium dakotense (Rehm) Seaver, comb. nov.

Pezizella dakotensis Rehm, Ann. Myc. 11:396. 1913.

Apothecia scattered, subsessile, at first globose and closed, finally patelliform, $1-1.5 \mu$ in diameter; hymenium dilutely yellowish; asci clavate, reaching a length of $50-60 \mu$ and a diameter of $8 \mu, 8$-spored; spores clavate, straight, 1-seriate, $2 \times 12 \mu$; paraphyses filiform, $2 \mu$ in diameter, hyaline.

On branches of Symphoricarpos occidentalis.

Type locality: Kulm, North Dakota.

Distribution: Known only from the type locality. 
30. Helotium pallescens (Pers.) Fries, Summa Veg. Scand. 355. 1849.

Peziza pallescens Pers. Obs. Myc. 2: 85.1799.

Calycella pallescens Quél. Ench. Fung. 306. 1886.

Apothecia short-stipitate, waxy, white, pallid, or pale-yellow, .5-1 mm. in diameter; hymenium concave, or plane; stem short, .2-.6 mm. in diameter, whitish; asci clavate-cylindric, reaching a length of 85-120 $\mu$ and a diameter of 6-7 $\mu, 8$-spored; spores longfusiform, straight, or slightly curved, with two to four oil-drops, or occasionally pseudoseptate, $3-4 \times 10-15 \mu$; paraphyses filiform, enlarged slightly above.

On dead wood and bark of various trees.

Type locality: Europe.

Distribution: New Hampshire to California and Pennsylvania.

Specimens referable to this species have been frequently collected in North America.

31. Helotium amplum (Ellis \& Ev.) Seaver, comb. nov.

Phialea ampla Ellis \& Ev. Bull. Torrey Club 24: 135. 1897.

Apothecia gregarious, stipitate, or subsessile, obconic, or clavate at first, at length expanding, 3-4 mm. in diameter and shallow cup-shaped, externally pale-yellow, farinose-pubescent, or minutely striate, the margin involute; hymenium lemonyellow; asci clavate-cylindric, reaching a length of $110 \mu$ and a diameter of $6 \mu$; spores 1 -seriate, overlapping, narrow-ovoid, 3.5-4 $\times 11-12 \mu$; paraphyses filiform.

On decaying wood of Salix.

Type Locality: Mt. Paddo [Mt. Adams], Washington.

Distribution: Known only from the type locality.

Ellis states: "Differs from Helotium citrinum, in its involute margin and larger size." Type in The New York Botanical has been examined. While these are described as stipitate, mature plants appear to be sessile.

32. Helotium albopunctum Peck, Ann. Rep. N. Y. State Mus. 31: 47. 1879. Not Helotium albopunctum (Desm.) Bucknall, 1882.

Pezizella albopuncta Sacc. Syll. Fung. 8: 276. 1889.

Hymenoscyphus albopunctus Kuntze, Rev. Gen. Pl. 33: 485.1898. 
Apothecia scattered, solitary, punctiform, subsessile, when dry visible to the unaided eye only as dots, waxy-cartilaginous, the color to the unaided eye similar to that of the dried leaves on which they occur, when magnified pale-yellow to pale-orange; hymenium plane to slightly concave; asci clavate, reaching a length of $60-70 \mu$ and a diameter of $8-10 \mu$; spores straight, or slightly curved, clavate, the narrow end downward, 3.5-4 $\times 14-$ $16 \mu$; paraphyses simple, slightly enlarged above, reaching a diameter of $2.5-3.5 \mu$.

On fallen leaves of Fagus grandifolia.

Type locality : Adirondack Mountains, New York.

Distribution: New York; also reported from Michigan on leaves of Cormus. A portion of the type in The New York Botanical Garden has been examined.

Illustrations: Mycologia 34: 166, f. 13; Farlowia 1: 168, f. 10 .

33. Helotium puberulum (Lasch) Fuckel, Fungi Rhen. 1150. 1865 .

Peziza puberula Lasch in Klotzs. Herb. Viv. Myc. 1529; Flora 34: 566. 1851.

Not Berk. \& Curt. 1875.

Pseudohelotium puberulum Fuckel, Symb. Myc. 298. 1870.

Lachnella puberula Phill. Grevillea 18: 85. 1890.

Pezizella puberula Rehm in Rab. Krypt.-F1. 13: 665. 1892.

Dasyscypha puberula Massee, Brit. Fungus-Fl. 4: 355. 1895.

Belonium sulphureotinctum Rehm, Hedwigia 35: Beibl. (146). 1896.

Urceolella puberula Boud. Hist. Class. Discom. Eu. 129. 1907.

Niptera sulphureotincta Boud. Hist. Class. Discom. Eu. 141. 1907.

Phialina puberula Höhn. Mitt. Bot. Inst. Techn. Hochsch. Wein 3³:106. 1926.

Apothecia rather numerous on localized areas of the leaf surface, sometimes in groups of five to fifteen with occasional scattered ones, very small, appearing sessile but with a short, obscure stem, less than $1 \mathrm{~mm}$. in diameter, when fresh bright lemon-yellow, not contracting or changing color much on drying; stem very short and scarcely noticeable; hymenium convex when fresh and bright-yellow, on drying becoming plane and remaining yellow to pale-orange; asci short, clavate, reaching a length of 38 to $55 \mu$ and a diameter of $6-8 \mu, 8$-spored; spores 2 -seriate, or irregularly crowded, slightly irregular in outline, simple, $2-3 \times$ 12-18 $\mu$, often containing several small oil-drops; paraphyses rather stout, scarcely enlarged above, occasionally branched, $3-3.5 \mu$ in diameter at their apices. 


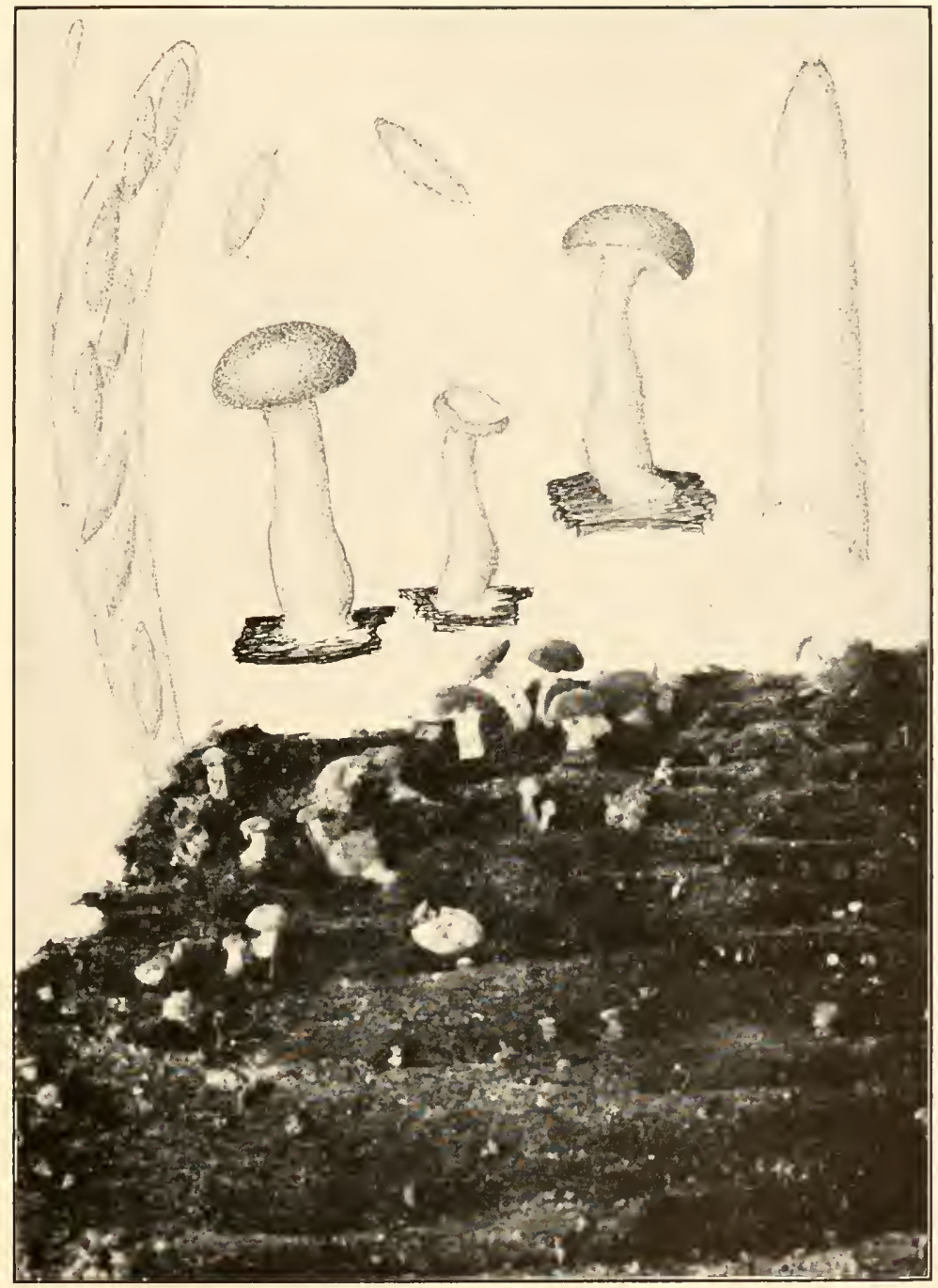

HELOTIUM CUDONIOIDES 

On decaying leaves of Quercus and occasionally on leaves of other kinds.

Type LOCAlity: Europe.

Distribution: New Hampshire, Massachusetts and New York; also in Europe.

Illustrations: Farlowia $1: 168, f .17$.

34. Helotium immutabile Fuckel, Symb. Myc. Nacht. 1: 50. 1871.

Pachydisca immutabilis Boud. Hist. Class. Discom. Eu. 94. 1907.

Apothecia scattered, short-stipitate, white when fresh, becoming yellow to orange when dry, .8 $-1.5 \mathrm{~mm}$. in diameter; stem $.2-.5 \mathrm{~mm}$. long, gradually expanding into the apothecium above, the color as above; hymenium when fresh white, becoming paleyellow or in old, dried specimens pale-orange to reddish-brown, plane to slightly convex; asci clavate, reaching a length of $80-$ $105 \mu$ and a diameter of $8-10 \mu, 8$-spored; spores 1 -seriate to 2 -seriate, simple, angular-obovoid, 3.8-4.6 $\times 10-13 \mu$, the contents granular, or with a few minute, scattered oil-drops; paraphyses once forked below the middle, scarcely enlarged above, reaching a diameter of $3-3.5 \mu$.

On decaying leaves, especially on the veins and petioles of various deciduous leaves.

Type locality: Europe.

Distribution: Massachusetts to New Jersey and Minnesota; also in Europe.

ILLustrations: Farlowia 1: 143, f. 3.

35. Helotium translucens White, Farlowia 1: 149. 1943.

Apothecia scattered, or subgregarious, stipitate, subfleshy, practically hyaline when fresh, drying to pale-ochraceous, reaching a diameter of $.4 \mathrm{~mm}$.; stem $.3 \mathrm{~mm}$. long, expanding abruptly into the apothecium; hymenium becoming plane and remaining so on drying; asci cylindric-clavate, abruptly narrowed below, reaching a length of 75-95 $\mu$ and a diameter of 10-11.5, 8-spored; spores 1 -seriate, or becoming partially 2-seriate, obovoid, the contents scarcely granular, $4-4.5 \times 12-15 \mu$; paraphyses clavate, $3-3.5 \mu$ in diameter above.

On the veins and parenchyma of leaves of Acer sp. and Quercus sp.

Type Locality: Blue Hills near Milton, Massachusetts. 
Distribution: Massachusetts.

Illustrations: Farlowia 1: 153, f. 6 .

36. Helotium populinum Fuckel, Symb. Myc. 316. 1869.

?Peziza punctiformis Grev. Scot. Crypt. F1. 2: 63. 1824.

?Helotium punctatum Fries, Summa Veg. Scand. 356. 1849.

Helotium Ilicis Phill. Brit. Discom. 164. 1887.

?Helotium punctiforme Phill. Brit. Discom. 168. 1887.

?Pseudohelotium punctiforme Sacc. Syll. Fung. 8: 295.1889.

?Pezizella punctiformis Rehm in Rab. Krypt.-F1. 133: 664. 1892.

Pezizella populina Rehm in Rab. Krypt.-Fl. 13: 668. 1892.

Calycina Ilicis Kuntze, Rev. Gen. Pl. $3^{3}: 448.1898$.

Calycina populina Kuntze, Rev. Gen. Pl. $3^{3}: 448.1898$.

Calycella Ilicis Boud. Hist. Class. Discom. Eu. 95. 1907.

Hyaloscypha punctiformis Boud. Hist. Class. Discom. Eu. 126. 1907.

Micropodia populina Boud. Hist. Class. Discom. Eu. 128. 1907.

Hymenoscypha punctiformis Schröt. Krypt.-Fl. Schles. 32: 71. 1893.

Calycellina populina Migula in Thome's Krypt.-F1. 10²: 1152. 1913.

Calycellina punctiformis Höhn. Sitz. Akad. Wissen. Wien 1271: 601. 1918.

Apothecia usually numerous, solitary, or more rarely in groups of two or three, unevenly distributed over large portions of the substratum, at first minute, globose, dirty yellowishwhite when fresh, narrowed toward the base, subsessile, opening with a pore, becoming cup-shaped, more shallow as the cup expands, reaching a diameter of $1 \mathrm{~mm}$., contracting on drying; hymenium creamy-white when fresh, plane, slightly concave, or convex, drying to dull-yellow; asci clavate, reaching a length of 50-70 $\mu$ and a diameter of $69 \mu, 8$-spored; spores 2-seriate or partially so, irregularly fusoid, slightly curved, or unequalsided, 2.7-3.4 × 10-13 $\mu$; paraphyses filiform, enlarged above.

On dead leaves of various kinds.

Týp Locality: Europe.

Distribution: Massachusetts, New York and Pennsylvania. Il.LUSTRATIONS: Farlowia 1: 168, f. 1 .

\section{Helotium erraticum White, Farlowia 1: 606. 1944.}

Apothecia scattered, or subgregarious, stipitate, when fresh white to creamy-yellow, reaching a diameter of $2.5 \mathrm{~mm}$. and a height of $1 \mathrm{~mm}$., when dry becoming yellow or reddish-yellow, cartilaginous; hymenium when fresh white or nearly so, plane, on drying becoming bright-yellow to reddish; stem stout, whitish to translucent-yellow; asci clavate, reaching a length of $90-120 \mu$ 
and a diameter of 9-11.5 $\mu, 8$-spored; spores 2-seriate above, 1 -seriate below, ellipsoid to ovoid, slightly curved, or flattened on one side, attenuated toward the ends, sometimes more or less slipper-shaped, 3.5-4 × 11-17 $\mu$; paraphyses long, straight, simple, or rarely once branched.

On much decayed leaves of various trees and on old pods of Robinia Pseudo-acacia.

Trpe locality: Coy Glen, New York.

Distribution: New York to Quebec.

Illustrations: Farlowia 1: 607, f. 14-18.

38. Helotium simulatum (Ellis) Seaver, comb. nov.

Peziza simulata Ellis, Bull. Torrey Club 8: 73. 1881.

Phialea simulata Sacc. Syll. Fung. 8: 254. 1889.

Apothecia gregarious, stipitate, dull watery-white, reaching a diameter of $3 \mathrm{~mm}$.; hỵmenium plane, or nearly so, sligntly umbilicate, becoming concave in drying; stem about $3 \mathrm{~mm}$. long, contracted and darker below; asci cylindric, 8-spored; spores ellipsoid, hyaline, $12 \mu$ long.

On decaying maple, Acer, leaves lying on the ground.

Trpe localitr: Newfield, New Jersey.

Distribution: Known only from the type locality.

Ellis states: "The stipe arises directly from the leaf, mostly from the veinlets, and is not attached to any sclerotium. When young the whole plant is milk white."

39. Helotium Conocarpi Seaver \& Waterston, Mycologia 34: 517. 1942. (Plate 107, Fig. 1.)

Apothecia gregarious, at first subglobose and subsessile, becoming expanded and short-stipitate, reaching an extreme diameter of $3 \mathrm{~mm}$., the hymenium usually remaining concave, the margin even or nearly so; hymenium with a delicate lilac tint, externally nearly the same, darker toward the base; stem scarcely exceeding $1 \mathrm{~mm}$. in length; asci clavate, reaching a length of $50-60 \mu$ and a diameter of $6 \mu, 8$-spored; spores ellipsoid, hyaline, $4 \times 10 \mu$ paraphyses filiform, scarcely enlarged above, about $2 \mu$ in diamater.

On dead leaves of Conocarpus erectus.

Type locality: Near Hamilton, Bermuda.

Distribution: Known only from the type locality. Illustrations: Mycologia 34: 518, $f$. I (upper figure). 
This fungus was found to be rather abundant on the fallen leaves of its host. However, the cups are often so small and, even when expanded, so nearly like the substratum in color that very close search is necessary to find them.

40. Helotium castaneum Sacc. \& Ellis; Sacc. Michelia 2: 572. 1882.

Apothecia thickly gregarious, on dead areas on the leaves of the host, occurring on the under side of the leaf, minute, brown, or reddish-brown with a slightly darker exterior, subsessile, scutellate, reaching a diameter of $.25 \mathrm{~mm}$.; asci short, stout, reaching a length of 40-50 $\mu$ and a diameter of 12-14 $\mu$; spores 2-seriate, or irregularly disposed, ellipsoid, 3-4 $\times 11-14 \mu$, densely granular within; paraphyses slender.

On leaves of Quercus laurifolia and Rhododendron maximum.

Type locality: Gree Cove Springs, Florida.

Distribution: Florida and IVest Virginia.

Exsiccatı: Ellis, N. Am. Fungi 994.

The spores are described as 1 -septate. The writer does not find them so. Specimen on Rhododendron appears to be identical.

41. Helotium destructor Peck; White, Mycologia 34: 163.1942.

Peziza subcarnea Cooke \& Peck; Cooke, Bull. Buffalo Soc. Nat. Sci. 2: 295.

1875. Not Peziza subcarnea Schum. 1803.

Phialea subcarnea Sacc. Syll. Fung. 8: 265. 1889.

Hymenoscyphus subcarneus Kuntze, Rev. Gen. Pl. 33: 486. 1899.

Apothecia minute, stipitate, scarcely visible to the unaided eye, solitary, or gregarious and occasionally rather numerous, reaching an extreme diameter of $.5 \mathrm{~mm}$. but of ten much smaller, gradually expanding and becoming subglobose; stem relatively long, reaching a length of .3 to $.5 \mathrm{~mm}$., slender and slightly broadened at the junction with the cup; hymenium similar in color to the outside of the apothecium, at maturity concave with upturned margin; asci clavate, reaching a length of 40-50 $\mu$ and a diameter of 5-6 $\mu, 8$-spored; spores clavate, 2-seriate, the narrow end directed downward, $2-2.5 \times 4.5-6 \mu$; paraphyses simple, or occasionally branched, scarcely enlarged above, 3-3.5 $\mu$ in diameter.

Growing on and apparently killing various species of liverworts and mosses: Jungermania sp. (type) and Dicranum fagellare. 
Type Locality: Indian Lake, New York.

Distribution: New York and New Hampshire to Michigan and Alberta, Canada.

Illustrations: Mycologia 34: 166, $f .8$.

Exsiccatr: Ellis \& Ev. N. Am. Fungi 2143.

42. Helotium episphaericum Peck, Ann. Rep. N. Y. State Mus. 40: 66. 1887.

Calycina episphaerica Kuntze, Rev. Gen. Pl. 333: 448. 1898.

Helotium parasiticum Ellis \& Ev. Jour. Myc. 9: 165. 1903.

Dermatea mycophaga Massee, Kew Bull. Misc. Inf. 1908: 218. 1908.

Apothecia minute, sessile, or subsessile, reaching a diameter of .2 to $.5 \mathrm{~mm}$., solitary, or gregarious, occasionally several crowded together, pale-yellow to bright-orange, or slightly rufous; stem-like base $\mathrm{V}$-shaped; hymenium concave, the color as above; asci clavate-cylindric, reaching a length of $48-65 \mu$ and a diameter of $5 \mu$; spores clavate, 1-seriate, or partially 2 -seriate, $1.8-2.5 \times 4.5-7 \mu$; paraphyses scarcely enlarged above, reaching a diameter of $2 \mu$.

On stromatic pyrenomycetous fungi: Hypoxylon, Diatrypella, Xylaria and Valsa?

Type locality: Elizabethtown, New York.

Distribution: New York and Ontario; also in Europe and Asia.

Illustrations: Mycologia $34: 166, f .15$.

43. Helotium laricinum (Ellis \& Ev.) Seaver, comb. nov.

Pseudohelotium laricinum Ellis \& Ev. Proc. Acad. Sci. Phila. 1894: 349. 1894.

Apothecia sessile or subsessile, thin, almost membranaceous, fleshy, orange-colored, flat-discoid, $3-5 \mathrm{~mm}$. in diameter, the margin slightly incurved when dry, externally minutely pubescent, darker outside; asci cylindric, reaching a length of $75 \mu$ and a diameter of $8 \mu, 8$-spored; spores 1-seriate, long-ellipsoid, 4-5 $\times 8-10 \mu$; paraphyses filiform, not thickened above.

On decaying needles of Larix in a tamarack swamp.

Type Locality: Northfield, Michigan.

Distributiox: Known only from the type locality.

The type in The New York Botanical Garden has been examined. As stated by Ellis the color in dried specimens is pale-orange. 


\section{Helotium aurantium Seaver, nom. nov.}

Pezizella aurantiaca Cash, Mycologia 28: 301. 1936. Not Helotium aurantiacum Cooke; Phill. Grevillea 19: 106. 1891.

Apothecia sessile, or subsessile, superficial, single, or cespitose, at first subglobose, then cup-shaped to applanate, contorted by mutual pressure, waxy-fleshy, salmon-orange to orange-brown, 1-2 $\mathrm{mm}$. in diameter, externally powdery, margin delicately fimbriate; hymenium concave, or plane, colored like the exterior; asci cylindric-clavate, gradually narrowed below, 8-spored, reaching a length of 38-45 $\mu$ and a diameter of 4-5 $\mu$; spores long-ellipsoid, straight, or curved, 1-2-seriate, hyaline, or palegreenish, usually with two oil-drops, 1.5-2 $\times 7-9 \mu$; paraphyses filiform, rarely branched, enlarged above to $1.5 \mu$.

On bark of Picea.

Type locality: Grand Mesa, Colorado.

Distribution: Known only from the type locality.

Illustrations: Mycologia 28: 302, f. 5.

The author of this species states that in general appearance it resembles the preceding, Ilelotium laricinum, from which it differs microscopically.

45. Helotium atrosubiculatum Seaver \& Waterston, Mycologia 32: 397. 1940. (Plate 107, Fig. 2.)

Apothecia thickly gregarious, occasionally forming congested masses, stipitate, gradually expanding above, becoming shallow cup-shaped, occasionally convoluted, 2-4 mm. in diameter and about $2 \mathrm{~mm}$. high, externally grayish-brown and pruinose; hymenium concave, whitish, even, or in larger specimens convoluted; asci clavate, reaching a length of $60 \mu$ and a diameter of $6 \mu$; spores ellipsoid, each containing two oil-drops, $2-2.5 \times 6-$ $7 \mu$; paraphyses filiform, about $1 \mu$ in diameter.

On the blackened surface of leaves of Archontophoenix Alexandrae rotting on the ground.

Type collected at Hungry Bay, Bermuda, December 2, 1938. The black subiculum seems to be a constant character in this species. The base of the stem of the fungus is also black and easily detached near the base leaving disc-like scars which themselves look like minute discomycetes.

Distribution: Bermuda and British Guiana.

Illustrations: Mycologia 34: 15, $f .1$, (lower figure). 
This fungus was collected in Bermuda by the writer and $\mathrm{Mr}$. Waterston in 1938 and again in 1940. It was also collected by D. H. Linder in British Guiana and Trinidad on palm leaves.

46. Helotium citrinulum Karst. Not. Soc. Fauna Fl. Fenn. 11: 238. 1871.

Pezizella citrinula Sacc. Syll. Fung. 8: 288.1889.

Helotium flexuosum Mlassee, Brit. Fungus-Fl. 4: 263. 1895.

Helotium citrinulum Seaveri Rehm, Ascom. 1637; Ann. Myc. 4: 67. 1906. Mollisiella citrinula Boud. Hist. Class. Discom. Eu. 142. 1907.

Apothecia scattered, sessile or subsessile, smooth, becoming discoid, lemon-yellow, reaching a diameter of $1 \mathrm{~mm}$.; hymenium plane, or slightly concave; asci reaching a length of 45-60 $\mu$ and a diameter of $6 \mu, 8$-spored; spores fusoid, straight, or curved, 1.5-2 $\times 6-9 \mu$; paraphyses very slender, slightly enlarged above.

On stems of grasses and sedges near the base. American specimen on Carex.

Type locality : Europe.

Distribution: Iowa and New York; also in Eirope.

Exsiccati: Rehm, Ascom. 1634.

Two collections of this fungus have been seen from North America. Rehm made a new variety on the Iowa material but it seems to us doubtful that it should be so regarded. The type of Helotium flexuosum in The New York Botanical Garden seems to be identical.

47. Helotium planodiscum (Peck \& Cooke) White, Mycologia 34: 171. 1942.

Periza planodisca Peck \& Cooke; Peck, Ann. Rep. N. Y. State Mus. 31: 46. 1879.

Pesizella planodisca Sacc. Syll. Fung. 8: 281. 1889.

Hymenoscypha planodisca Lindau in E. \& P. Nat. Pf. $1^{1}$ : 204. 1897.

Apothecia scattered, or subgregarious, pale-yellow, sessile or subsessile, attached by a relatively narrow basal portion with the margins free, reaching a diameter of $.4 \mathrm{~mm}$.; hymenium entirely plane from the beginning, pale-yellow; asci clavate, slightly narrowed to a thick stem-like base, reaching a length of 40-55 $\mu$ and a diameter of $5-7 \mu$; spores obliquely 1 -seriate with ends overlapping, straight, or slightly curved, fusoid, narrower below, not granular, $2-2.5 \times 7-9 \mu$; paraphyses simple, or sparingly branched, enlarged above, $2.5-3.5 \mu$ in diameter.

On dead leaves of Andropogon scoparius. 
Type Locality: Buffalo, New York.

Distribution: Known only from the type locality.

Illustrations: Mycologia 34: 166, $f$. 12.

This according to W. L. White is very close to Helotitum citrinulum Karst. (Helotium flexuosum Massee).

48. Helotium cyathoideum (Bull.) Karst. Fungi Fenn. 836; Not. Soc. Fauna Fl. Fenn. 11: 237. 1871.

?Peziza tenella Batsch, Elench. Fung. Cont. 1:215. 1786.

Peziza cyathoidea Bull. Hist. Champ. Fr. 250. 1791.

Peziza Solani Pers. Obs. Myc. 2: 80. 1799.

Peziza Urticae Pers. Myc. Eu. 1: 286. 1822.

Cyathicula vulgaris DeNot. Comm. Critt. Ital. 1: 381. 1864.

Helotium Lrticae Karst. Not. Soc. Fauna Fl. Fenn. 13: 234. 1873.

Helotium Limonium Cooke \& Peck; Peck, Ann. Rep. N. Y. State Mus. 26: 83. 1874.

Phialea cyathoidea Gill. Champ. Fr. Discom. 106. 1882.

Calycella cyathoidea Quél. Ench. Fung. 307. 1886.

?Calycella tenella Quél. Ench. Fung. 307. 1886.

Phialea Solani Sacc. Syll. Fung. 8: 252. 1889.

Hymenoscypha cyathoidea Phill. Brit. Discom. 140. 1887.

Hymenoscypha Urticae Phill. Brit. Discom. 141. 1887.

Hymenoscypha cyathoidea Solani Phill. Brit. Discom. 141. 1887.

Calycina Limonium Kuntze, Rev. Gen. Pl. $3^{3}: 448.1889$.

Apothecia gregarious, stipitate, at first closed, becoming expanded and shallow cup-shaped, reaching a diameter of .5 to $2 \mathrm{~mm}$; whitish, or slightly yellowish; hymenium concave, or nearly plane, a little darker than the outside of the apothecium; stem slender, nearly as long as the diameter of the cup, but occasionally much longer, similar in color to the outside of the apothecium; asci cylindric-clavate, reaching a length of $45-50 \mu$ and a diameter of 4.5-5 $\mu, 8$-spored; spores 2-seriate, elongated, fusoid, or subclavate, straight, or curved, usually with a small oil-drop in each end, 1.5-2 $\times 5-10 \mu$; paraphyses slender, clavate, reaching a diameter of $3 \mu$.

On herbaceous stems or more rarely on small twigs.

Type locality: Europe.

Distribution: New York to Pennsylvania, Alabama and California?; also in Europe.

Illustrations: Bull. Herb. Fr. pl. 416, f. 3; Batsch, Elench. Fung. Cont. 1:f. 151; Boud. Ic. Myc. pl. 494; Rab. Krypt.-Fl. $1^{3}: 703, f .1-5$.

Exsiccati: Ellis, N. Am. Fungi 986; Ellis \& Ev. N. Am. 
Fungi 2632 (as Helotium fumosum); Clements, Crypt. Form. Colo. 77; Brenckle, Fungi Dak. 537; Shear, N. Y. Fungi 325.

A form "graminicola" is distributed by Roumeguère, Fungi Selecti Exsiccati 7158, and ascribed to Lambotte (Mem. Soc. Sci. Liege 14: 310. 1888.) This would be Helotium cyathoideum f. graminicola.

49. Helotium consanguineum Ellis \& Ev. Fungi Columb. 1220. 1897.

Apothecia minute, about $.5 \mathrm{~mm}$. in diameter, thickly gregarious, often several confluent, subsessile, yellow; hymenium plane or nearly so, bright lemon-yellow, asci clavate, reaching a length of $45 \mu$ and a diameter of $6 \mu$; spores fusoid, indistinct, about $2 \times 6-7 \mu$; paraphyses filiform.

On old stems of Tephrosia virginiana.

Type locality: Newfield, New Jersey:

Distribution: Known only from the type locality.

Exsiccati: Ellis \& Ev. Fungi Columb. 1220.

Two collections of this species are in the herbarium of The New York Botanical Garden, one collected in February and one in September, 1879. While distributed in exsiccati the species was not previously published so far as we can find.

\section{Helotium rhizicola Seaver, sp. nov. (Plate 106.)}

Apothecia thickly gregarious, short-stipitate, or nearly sessile, yellowish, or with a tinge of salmon when moist, becoming shallow cup-shaped, or nearly discoid, pale yellowish-white, 1-2 mm. in diameter; hymenium nearly plane, yellowish, or with a tinge of salmon; stems whitish, of ten very short and again several $\mathrm{mm}$. in length depending upon the position of the substratum; asci clavate, reaching a length of $90-100 \mu$ and a diameter of 6-7 $\mu$, 8-spored; spores ellipsoid, or fusoid, 3-4 $\times 7-10 \mu$, granular within and often with a small oil-drop or group of oil-drops at either end; paraphyses filiform, about $2-3 \mu$ in diameter at their apices.

Apotheciis sessilis vel subsessilis, $1-1.5 \mathrm{~mm}$. diam., extus pilis brunneis vestitis; ascis clavatis, $5-6 \times 150 \mu$, 8 -sporis; sporis fusoideis, $+\times 13-15 \mu$, paraphysibus, clavatis, $4 \mu$ diam.

On exposed or partially submerged roots and hasal stems of Polygonum virginianum and Collinsonia canadensis.

Type Locality: The New York Botanical Garden. 
Distribution: Known only from the type locality.

This species was common and abundant during the month of September, 1930.

51. Helotium gemmarum Boud. Bull. Soc. Myc. Fr. 4: 81. 1881. Phialea gemmarum Sacc. Syll. Fung. 8: 271. 1889.

Apothecia scattered, or subgregarious, stipitate, white when fresh, reaching a diameter of $1.4 \mathrm{~mm}$., at first infundibuliform, then expanding; hymenium concave, or plane, same color as the outside of the apothecium; stem slender, slightly enlarged upward, white, reaching a length $1.5 \mathrm{~mm}$. (5 mm. according to Boudier); asci clavate, reaching a length of $45-50 \mu$ and a diameter of 5-7 $\mu, 8$-spored; spores pyriform, small, 2.5-3 3 6-9 $\mu$; paraphyses sparse, simple, or once branched below the middle, not enlarged above.

On the scales of buds of various species of Populus, in the early spring.

Type Locality : Europe.

Distribution: New York to Pennsylvania and Georgia; also in Europe.

Illustrations: Bull. Soc. Myc. Fr. 4: pl. 17, f. 2; Boud. Ic. Myc. pl. 493; Farlowia 1:615, f. 35-40.

The only specimen of this species seen was one sent, on request, the fungus collected on the campus of the Agricultural College, Athens, Georgia, by Dr. J. H. Miller.

52. Helotium Craginianum (Ellis \& Ev.) Seaver, comb. nov.

Phialea Craginiana Sacc. Syll. Fung. 8: 258. 1889.

Peziza Craginiana Ellis \& Ev. Jour. Myc. 1: 47. 1885.

Apothecia stipitate, discoid, pale waxy-white when fresh, darker when dry; stem slender, 2-3 mm. long; asci cylindric, reaching a length of $75 \mu$ and a diameter of $6 \mu, 8$-spored; spores ellipsoid, hyaline, 1 -seriate, or partially 2 -seriate, $2.5-3 \times 5-6 \mu$; paraphyses rather stout, often branched above, but scarcely thickened.

On very rotten wood.

Type locality: Topeka, Kansas.

Distribution: Known only from the type locality.

The type in The New York Botanical Garden is so fragmentary that nothing can be added to the above which has been compiled from the original description. 
53. Helotium lanceolato-paraphysatum (Relım) Seaver, comb. nov.

Pezizella lanceolato-paraphysata Rehm, Ann. Myc. 6: 316.1908.

Apothecia gregarious, sessile, or subsessile, at first globoseclosed, finally expanding and becoming plane, .3-.8 mm. in diameter, irregularly contracted when dry; hymenium yellowish with a whitish margin; asci clavate, reaching a length of $30 \mu$ and a diameter of 5-7 $\mu, 8$-spored; spores clavate, 2-seriate, $2 \times 6-8 \mu$; paraphyses lanceolate, acute, prominent.

On dried stems of Spiraea filipendula.

Type Locality: Lyndonville, New York.

Distribution: Known only from the type locality.

As indicated by the specific name this species is characterized by its lanceolate paraphyses, unusual in the plants of this genus.

54. Helotium albuminum (Cooke \& Peck) Sacc. Syll. Fung. 8: 214. 1889.

Pe iza albumina Cooke \& Peck; Peck, Ann. Rep. N. Y. State Mus. 26: 81. 1872.

Calycina albumina Kuntze, Rev. Gen. Pl. $3^{3}: 448.1898$.

Apothecia stipitate, or substipitate, solitary, more of ten gregarious, or sometimes crowded and showing a tendency to become confluent, whitish, pale-yellow when dry, expanding and becoming nearly plane in dried specimens, rather deeply concave, even, or slightly irregular, less than $1 \mathrm{~mm}$. in diameter; stem slender, often nearly lacking; hymenium similar in color to the outside of the apothecium, or yellowish; asci cylindric above and slightly narrowed below, reaching a length of $42-55 \mu$ and a diameter of $5 \mu, 8$-spored; spores allantoid, 1.2-1.8 $\times 7-9 \mu$; paraphyses simple, scarcely enlarged at their apices, about $2 \mu$ in diameter.

On wood and bark, reported on quince and maple, Acer.

Type locality: New York.

Distribution: New York to Ontario and Oregon.

Illustrations: Mycologia 34: 166, f. 5 .

55. Helotium ammoides (Sacc.) Seaver, comb. nov.

Pseudohelotium ammoides Sacc. Ann. Myc. 6: 564. 1908.

Apothecia densely or loosely gregarious, superficial, subsessile, minute, granuliform, whitish-honey-colored, waxy, at first cup- 
shaped, finally expanded, about $.3 \mathrm{~mm}$. in diameter, whitishpruinose; asci clavate, reaching a length of $60-80 \mu$ and a diameter of 8-9 $\mu, 8$-spored; spores 2 -seriate or partially so, ellipsoid, 2.5-3 $\times$ 8.5-9 $\mu$; paraphyses filiform, scarcely enlarged above.

On old bark of Carpinus.

Type Locality: Lyndonville, New York.

Distribution: Known only from the type locality.

56. Helotium propinquum Sacc. \& Ellis; Sacc. Michelia 2: 572. 1882.

Apothecia sparse, sessile or subsessile, patelliform, yellowish, $.5-.7 \mathrm{~mm}$. in diameter; hymenium concave to nearly plane; asci clavate, reaching a length of $50-60 \mu$ and a diameter of 6-7 $\mu$,

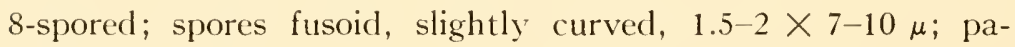
raphyses filiform.

On branches of Cornus.

Type Locality: Pennsylvania.

Distribution: Known only from the type locality.

Exsiccati: Ellis, N. Am. Fungi 995.

Type material in the herbarium is too scant to permit of satisfactory study and nothing can be added to the above.

57. Helotium Cassandrae (Kanouse) Seaver, comb. nov.

Phialea Cassandrae Kanouse, Papers Mich. Acad. Sci. 20: 71. 1935.

Apothecia solitary, scattered, stipitate, reaching a diameter of $.5 \mathrm{~mm}$., translucent-white; stem extremely long and thin, flexuous, the lower half or more black, the upper half like the apothecium, sub-bulbous at the base; hymenium similar in color to the outside of the apothecium; asci clavate, reaching a length of 30-42 $\mu$ and a diameter of 5-7 $\mu, 8$-spored; spores 2-seriate, elongated, attenuated below, $1.4-1.8 \times 6-8 \mu$; paraphyses simple, or sparingly branched, reaching a diameter of 3-4.5 $\mu$ above.

On fallen leaves of Chamaedaphne calyculata.

Type locality: Mud Lake Bog, Michigan.

Distribution: Michigan.

Illustrations: Farlowia $1: 168, f .13$.

The author of the species states: "This beautiful little fungus is distinguished by the small spores and by the contrasting black and white of the stipe." 
58. Helotium Friesii (Weinm.) Sacc. Syll. Fung. 8: 228. 1889.

Peziza Friesii Weinm. Hymeno-Gasteromycetes 469. 1836.

Apothecia short-stipitate, or nearly sessile, reaching a diameter of 1-2 mm.; hymenium plane, or convex, pale-yellow, when dry rather deep-ycllow; asci clavate, reaching a length of $65-70 \mu$ and a diameter of 5-6 $\mu, 8$-spored; spores slightly clavate, 3-4 $\times$ 8-9 $\mu$; paraphyses filiform, slender.

On decaying leaves of Populus.

Type locality: Europe.

Distribution: Iowa; also in Europe.

Illustrations: Bull. Lab. Nat. Hist. State Univ. Iowa 6: pl. $23, f .2$.

This was originally reported on dejected leaves of Populus Tremula and Betula alba but no spore measurements given. The above description is drawn from Iowa material. Rehm treats this as a doubtful synonym of Ilelotium foliicolum Schröt. (Schles. Crypt.-Fl. 32: 82. 1893.) but the spores of that species are $4-5 \times 20-24 \mu$.

59. Helotium midlandense White, Farlowia 1: 605. 1944.

Apothecia (described from dried specimens), scattered to subgregarious, usually solitary, more rarely in clusters of three to eight, stipitate, yellow, or yellow-orange, .3-.7 mm. in diameter and about the same height; hymenium plane to patelliform, more rarely slightly convex, yellow, or yellow-orange; stem about equal to the diameter of the apothecium; asci clavate, reaching a length of 45-65 $\mu$ and a diameter of 6-7 $\mu$; spores 2 -seriate or partially so, irregularly ovoid, $2.6-3.2 \times 7-10 \mu$; paraphyses filiform, septate.

On petioles and larger leaf veins of leaves of Quercus; also on old pods of Gleditsia triacanthos.

Type locality: Iowa.

Distribution: Ohio to Iowa and Kansas.

Illustrations: Farlowia 1: 607, f. 10-13.

60. Helotium umbrinum (Kanouse) Seaver, comb. nov.

Pseudociboria umbrina Kanouse, Mycologia 36: 460. 1941.

?Helotium contortum White, Farlowia 1: 147. 1943.

Apothecia foliicolous, stipitate, arising from leaf-blades or veins, externally longitudinally striate, dark-brown to brownishblack, reaching a diameter of $1 \mathrm{~mm}$, ; hymenium plane, similar in 
color to the outside of the apothecium; stem $1 \mathrm{~mm}$. long, expanding rather abruptly into the apothecium; asci cylindricclavate, reaching a length of 55-70 $\mu$ and a diameter of 6-7 $\mu$, 8 -spored; spores obliquely 1 -seriate, ellipsoid to subovoid, 3.5$4 \times 5-7 \mu$; paraphyses of two kinds, hyaline paraphyses $1 \mu$ in diameter and colored paraphyses, stout, $4-4.5 \mu$ in diameter and entirely filled with dark-brown coloring matter, the apices rounded.

On decaying leaves of Alnus.

Type Locality: Lake Crescent, Olympic National Forest, Washington.

Distribution: New York to Washington.

ILlustrations: Farlowia $1: 153, f .4$ ?

61. Helotium arenicola (Ellis \& Ev.) Seaver, comb. nov.

Phialea arenicola Ellis \& Ev. Am. Nat. 31: 426. 1897.

Apothecia stipitate, at first concave, becoming plane, or even slightly convex, externally light-yellow, subpruinose, 2-3 $\mathrm{mm}$. in diameter; hymenium dull-orange; stem stout, 2-4 mm. long, substriate, gradually enlarged above, same color as the hymenium; asci cylindric, or subcylindric, reaching a length of 60-65 $\mu$ and a diameter of $4 \mu, 8$-spored; spores 2-seriate, or partially so, long-ellipsoid, $1.5 \times 6-8 \mu$.

On sandy ground, probably attached to submerged roots or stems.

Type Locality: Blackbird Landing Bridge, Delaware.

Distribution: Known only from the type locality.

Type in The New York Botanical Garden has been examined. The material is scant.

\section{Doubtful and Excluded Species}

Helotium albovirens Cooke, Bull. Buffalo Soc. Nat. Sci. 2: 299. 1875. Apothecia scattered, or subgregarious, pale greenish-white, sessile, attached beneath by white, arachnoid threads, $1 \mathrm{~mm}$. in diameter; hymenium plane, or convex, darker when dry; asci cylindric, 8-spored; spores long-ellipsoid, straight, or curved, $3 \times 18 \mu$; paraphyses not observed. On woor of Acer, New Jersey.

Ifelotium alniellum (Ny1.) Karst. Not. Soc. Fauna Fl. Fenn. 11: 239. 1871; Peziza alniella Nyl. Not. Soc. Fauna Fl. Fenn. 10: 45. 1869; Phialea alniella Sacc. Syll. Fung. 8: 257. 1889. This species has been reported from Washington by Dr. B. Kanouse on maple seed. It has previously been reported on catkins of Alnus and would seem to belong to the genus Ciboria as defined by Whetzel. 
Helotium aurantiacum Cooke; Phill. Grevillea 19: 106. 1891. This orange-yellow species is described as having spores 4-5 $\times 14-18 \mu$, becoming pseudoseptate. On the under side of decaying leaves, United States. The species is in doubt.

Helotium brassicaecolum (Schw.) Sacc. Syll. Fung. 8: 226. 1889; Sarea brassicaecola Schw. Trans. Am. Phil. Soc. II. 4: 178. 1832. Saccardo places this doubrfully in the genus Helotium. Nothing more is known of it.

Helotium Buccina (Pers.) Fries, Summa Veg. Scand. 355. 1849; Peziza Buccina Pers. Syn. Fung. 659. 1801. This has been reported from North America by Saccardo on pine branches. It is usually regarded as a basidiomycete, Guepiniopsis.

Helotium caraborum Vel. Monog. Discom. Bohem. 1: 208. 1934. Apothecia less than $1 \mathrm{~mm}$. in diameter, milky-gray; spores $4-5 \times 8-10 \mu$. Reported from Lake Crescent, Washington on moss by 1)r. B. Kanouse. No material seen.

Phialea carneola Sacc.; Sacc. Peck, \& Trelease in Harriman Alaska Exped. 5: 25. 1904. This is said to be close to P. cyathoidea but differs slightly in color and size of spores, $3-3.5 \times 11-14 \mu$.

Helotium Cecropiae P. Henn. Hedwigia 41: 25. 1902; Phialea Cecropiae Seaver, Mycologia 17: 50. 1925. This species has been recorded from Porto Rico by the writer on leaves of Cecropia.

Helotium conformatum Karst. Not. Soc. Fauna Fl. Fen. 11: 236. 1871. Pesiza conformata Karst. Not. Soc. Fauna Fl. Fenn. 10: 149. 1869. This species has been reported from Michigan by Dr. B. Kanouse. No material has been seen.

Phialea crocea (Schw.) Sacc. Syll. Fung. 8: 261. 1889; Pesisa crocea Schw. Trans. Am. Phil. Soc. II. 4: 176. 1832. Saccardo suggests that this may be a Guepinia.

Helotium crocinum Berk. \& Curt.; Berk. Jour. Linn. Soc. 10: 369. 1868. Described as yellow, obconic, with a short, thick stem, crateriform, the margin inflexed. On dead twigs, Cuba. Drawings from the type by Massee in the herbarium of The New York Botanical Garden show the spores 1-septate which would make it a Calloria. Specimens in the herbarium of The New York Botanical Garden from Ohio are claimed by Massee, through whom the specimens came, to agree with the type of this species.

Helotium discretum Karst. Not. Soc. Fauna Fl. Fenn. 1: 235. 1871; Phialea discreta Rehm in Rab. Krypt.-Fl. 1 $1^{3}: 729.1893$. This species has been reported on gooseberry (Ribes) cane from Washington by Dr. B. Kanouse. No material seen.

Helotium ferrugineum (Schum.) Fries, Summa Veg. Scand. 356. 1849; Peziza ferruginea Schum. Pl. Saell. 2: 429 . 1803. This species on dead leaves of Quercus, has been reported from North America. No material has been seen.

Helotium fumigatum Sacc. \& Sacc. \& Speg. Michelia 2: 78.1880 ; Sacc. Syll. Fung. 8: 235. 1889. Reported from Alaska by Saccardo in Harriman Alaska Exped. 5: 26. 1904. On decaying herbaceous stems, Yakutat Bay, Alaska.

Helotium fumosum Ellis \& Ev. N. Am. Fungi 26.32; Sacc. Syll. Fung. 11: 403. 1895. No description has been seen and apparently it was never published. On stems of Leonurus Cardiaca, Lyndonville, New York, 
Helotium furfuraceum Phill. \& Hark. Bull. Calif. Acad. Sci. 1: 24. 1884. Scattererl, minute, short-stipitate, or sessile, cyathiform, alutaceous, furfuraceous; asci clavate, 8-spored; spores ellipsoid, slightly curverl, $5 \times 15 \mu$. On under side of dead leaves of Quercus agrifolia in California. Nothing more known of the species.

Helotium imberbe (Bull.) Fries, Summa leg. Scand. 356. 1849; Peziza imberbis Bull. Hist. Champ. Fr. 245, pl. 467, f. 2. 1791. This white species has been reported from Wisconsin and Michigan. The determinations are not at all certain.

Pseudohelotium isabellinum Clements, Bot. Surv. Nebr. 4: 15.1896. Reported on wet twigs from Rock (reek, Keyapaha County, Nebraska. No material seen.

Pezizella leguminum (Schw.) Sacc. Syll. Fung. 8: 290. 1889; Peziza leguminum Schw. Trans. Am. Phil. Soc. 11.4:176. 1832. A minute, scattered, emergent, brown species occurring on pods of Bignonia and Catalpa in Bethlehem, Pennsylvania. The fruit was not described and the species is in doubt.

Phialea leucopsis (Berk. \& Curt.) Sacc. Syll. Fung. 8: 264. 1889; Peziza leucopsis Berk. \& Curt.; Berk. Jour. Linn. Soc. 10: 368. 1868. Flesh-pallid, irregular, the margin erect, then reflexed, 3-6 $\mathrm{mm}$. in diameter; spores allantoid, $5 \mu$ long. On dead wood, Cuba.

Discinella lividopurpurea Boud. Bull. Soc. Nyc. Fr. 4: $79 . \quad$ 1888; Humaria lividopurpurea Sacc. Syll. Fung. 8: 124. 1889. This species has been reported from Michigan by Dr. B. Kanouse. Since this was described by Boudier as an inoperculate it should not have been placed in the genus Humaria as pointed out by Dr. Kanouse. Its position is uncertain.

Helotium microspis Karst. Myc. Fenn. 1: 152. 1871; Peziza microspis Karst. Not. Soc. Fauna Fl. Fenn. 10: 178. 1869; Pezizella microspis Sacc. Syll. Fung. 8: 281. 1889. Reported from Washington by Dr. B. Kanouse on sedges. The description would indicate that it is very close to Helotium citrinulum.

Phialea microspora Seaver, Mycologia 17: 50. 1925. Apothecia dullyellow, stipitate, $1 \mathrm{~mm}$. in diameter; spores $1.5-2 \times 6 \mu$. On leaves of uniclentified host in Porto Rico.

Rutstroemia microspora Kanouse, Mycologia 39: 684. 1947. This species is reported by its author as arising from a black stroma in old branches in Washington. The general description would indicate that it belongs with our genus Helotium.

IIelotium miserum Berk. \& Curt.; Berk. Jour. Linn. Soc. 10: 369. 1868. Minute, white, clavate, short-stipitate, subglobose; asci clavate; spores subclavate, contents finally four-parted, $12 \mu$ long. On bark among mosses in Cuba.

Helotium montaniense [montanense] Ellis \& Anders. Bot. Gaz. 16: 45. 1891. The type specimen in the herbarium of The New York Botanical Garden is too fragmentary to permit of study.

Helotium monticola Berk. Grevillea 4: 1. 1875. On dead wood, North Carolina. Described as "crowded, pale tawny, obovate; disc plane; sporidia biseriate, subfusiform." A minute specimen, apparently from the type, in the herbarium of The New York Botanical Garden is too meager for study.

Helotium nigripes (Pers.) Sacc. Syll. Fung. 8: 215 . 1889; Pesiza nigripes 
Pers. Syn. Fung. 661. 1801. This species has been recorded from North America and Cuba. No material has been seen.

Phialea olympiana Kanouse, Mycologia 39: 681. 1947. Apothecia described as stipitate, $1 \mathrm{~mm}$. in diameter, yellowish-citrine, drying black; spores $1 \times 6-8 \mu$; paraphyses filiform. Described from material collected in Washington. On herbaceous stems.

Phialea pallida Kanouse, Nycologia 39: 681. 1947. Apothecia described as pale olive-buff, $.5 \mathrm{~mm}$. in diameter, stipitate; spores $1.5 \times 6-9 \mu$; paraphyses filiform. Reported from Washington on old stems of Delphinium.

Pezizella Pastinacae (Schw.) Sacc. Syll. Fung. 8: 290. 1889; Peziza Pastinacae Schw. Trans. Am. Phil. Soc. II. 4: 176. 1832. The brief description suggests a Helotium. On Pastinaca. No material has been seen.

Helotium Phiala (Vahl.) Fries, Summa Veg. Scand. 355. 1849; Peziza Phiala Vahl. Fl. Dan. 18: 8, pl. 1078, f. 2. 1792. This has been reported from Washington on leaves of Sambucus callicarpa by Dr. B. Kanouse. Apothecia described as buff-yellow, stout with a stem $7 \mathrm{~mm}$. long; spores 7-8 $\times$ 14-16 $\mu$, finally becoming 1 -septate. No material has been seen.

Helotium pullatum Gerard; Cooke, Bull. Buffalo Soc. Nat. Sci. 2: 298. 1875. On stems of I'itis. No fruit was described and the identity of the species is uncertain. Looks like an Orbilia.

Helotium rhytidodes Berk. \& Curt.; Berk. Jour. Linn. Soc. 10: 369. 1868. Described as sessile, cup-shaped, below rugose-plicate; spores ellipsoid, smooth. Cuba. Habitat not given.

Helotium rubicolum (Fries) Fuckel, Symb. Myc. 314. 1869; Peziza fructigena rubicola Fries, Syst. Myc. 2: 119. 1822; Helotium virgultorum rubicolum Fries, Summa Veg. Scand. 355. 1849; Phialea rubicola Sacc. Syll. Fung. 8: 253. 1889. This has been reported from Michigan under the latter name but no American material seen.

Helotium scrupulosum Karst. Myc. Fenn. 1: 152. 1871; Peziza scrupulosa Karst. Not. Soc. Fauna FI. Fenn. 10: 178. 1869. This species is reported on old wood from Washington by Dr. B. Kanouse under the name of Unguicularia scrupulosa (Karst.) Höhn. Nothing more is known of it.

Helotium sordidatum Karst. \& Starb.; Karst. Hedwigia 26: 124. 1887; Phialea sordidata Sacc. Syll. Fung. 8: 271. 1889. This species has been recorded from Michigan on leaves and petioles of Quercus. The septate spores would place it in the genus Calloria.

Helotium sparsum Boud. Hist. Class. Discom. Eu. 111. 1907. Reported by Dr. B. Kanouse from Michigan on rotting leaves. Apothecia described as minute but the spores relatively large $7-8 \times 18 \mu$. See p. 124 .

Phialea subgalbula Rehm in Rab. Krypt.-Fl. 13: 711. 1892. Reported from Michigan by Dr. B. Kanouse and said to agree with Rehm, Ascom. 1981. No American material seen.

Helotium tumidulum (Rob.) Massee; Massee \& Crossl. Fungus Fl. Yorshire 285. 1905; Peziza tumidula Rob.; Desm. Ann. Sci. Nat. III. 16: 325. 1851; Pezizella tumidula Sacc. Syll. Fung. 8: 276. 1889. This species has been reported from Michigan by Dr. B. Kanouse but according to White (Farlowia 1: 167. 1943) is based on incorrect determination.

Helotium turgidellum Karst. Myc. Fenn. 1: 150. 1871; Pesiza turgidella Karst. Not. Soc. Fauna F1. Fenn. 10: 179. 1869; Pezizella turgidella Sacc. 
Syll. Fung. 8: 281. 1889. Reported from Michigan on Carex and Typha. No material seen.

Helotium vitigenum DeNot. Comm. Critt. Ital. 1: 377. 1864. This species originally recorded from Italy has been reported from Ann Arbor, Michigan, Spores described as $4-6 \times 17-20 \mu$. It would seem to be close to Helotium virgultorum.

\section{ORBILIA Fries, Summa Veg. Scand. 357. 1849.}

Pezizella Fuckel, Symb. Myc. 299. 1869. Myridium Clements, Gen. Fungi 174. 1909.

Apothecia sessile, membranous, subgelatinous, bright-colored, white, yellow, or red, typically smooth, subcorneous when dry; asci cylindric to clavate, usually 8-spored; spores bacilliform, or ellipsoid to subglobose; paraphyses filiform the apices of ten clavate to subglobose.

Type species, Peziza leucostigma Fries.

The plants of this genus are usually minute but because of their light or bright color they are more easily seen and consequently often collected. The apothecia are typically thin and membranous, the substance subcartilaginous and often translucent. The spores are minute and often difficult to diagnose. A number of the species have paraphyses with subglobose or pyriform apices.

Apothecia white to golden-yellow.

Color golden-yellow.

1. O. chrysocoma.

Color white or whitish when fresh.

Occurring on rotten wood.

Spores ellipsoid.

Spores large, $8 \times 17-20 \mu$.

2. O. diaphanula.

Spores small, $3 \times 6-7 \mu$.

3. O. Fairmani.

Spores bacilliform.

Spores 3-4 $\mu$ long.

4. O. leucostigma.

Spores 5-8 $\mu$ long.

5. O. inflatula.

Spores 10-15 $\mu$ long.

Not on rotten wood.

On rinds of squash, Cucurbita.

6. O. curatispora.

On old fungi, Polyporus.

7. O. Cucurbitae.

8. O. epispora.

Apothecia some shade of red, orange to scarlet.

Asci 8-spored.

Spores $12 \mu$ or more long.

Spores bacilliform, $1.5-2 \times 12-17 \mu$. 9 . vinosa.

Spores ellipsoid to fusoid.

On reeds in California.

10. O. phymatodes.

On bark of Gleditsia.

11. O. rubrococcinea. 
Spores mostly less than $12 \mu$ long.

Spores subglobose, or broad-ellipsoid.

Paraphyses with globose apices.

12. O. coccinella.

Paraphyses filiform.

Spores subglobose, $2-3 \mu$ in diameter. 13. O. rubinella.

Spores ellipsoid, $3 \times 5-7 \mu$. 14. O. Eucalypti.

Spores bacilliform.

Spores 4-5 $\mu$ long, on bark.

15. O. cruenta.

Spores 5-6 $\mu$ long, on Caulophyllum.

16. O. Caulophylli.

Spores 6-12 $\mu$ long.

Apothecia yellowish-red.

17. O. luteorubella.

Apothecia flesh-red to dark-red.

18. O. rubella.

Spores minute, spermatoid, on Phytolacca.

Asci many-spored.

19. O. pulviscula.

20. O. myriospora.

1. Orbilia chrysocoma (Bull.) Sacc. Syll. Fung. 8: 624. 1889.

Peziza chrysocoma Bull. Hist. Champ. Fr. 254. 1791.

Calloria chrysocoma Fries, Summa Veg. Scand. 359. 1849.

Dacryomyces chrysocomus Tul. Ann. Sci. Nat. JII. 19: 211.1853.

Guepiniopsis chrysocomus Brasfield, Am. Mid. Nat. 20: 226. 1938.

Apothecia gregarious, superficial, at first globose, soon expanded, golden-yellow, when dry subcorneous, flexuous, scarcely $.5 \mathrm{~mm}$. in diameter; asci cylindric, subsessile, reaching a length of $40-45 \mu$ and a diameter of $5 \mu$, 8-spored; spores bacilliform, curved, $1 \times 14-15 \mu$; paraphyses filiform, slightly enlarged above.

On old wood and pasteboard.

Type locality: Europe.

Distribution: Vermont to California, Porto Rico and Bermuda; probably throughout North America; also in Europe.

Illustrations: Bull. Herb. Fr. pl. $376, f$. 2; Cooke, Austr. Fungi pl. 20,f. 161.

2. Orbilia diaphanula (Cooke) Seaver, comb. nov.

Peziza diaphanula Cooke, Hedwigia 14: 84. 1875.

Apothecia gregarious, minute, transparent-white, at first hemispherical, then expanded, .1 $\mathrm{mm}$. in diameter; asci clavate; spores elongate-ellipsoid, $8 \times 17-20 \mu$; paraphyses filiform, scarcely enlarged above.

On old bark and wood of decaying Magnolia.

Type locality: Newfield, New Jersey.

Distribution: Known only from the type locality. 
3. Orbilia Fairmani (Rehm) Seaver, comb. nov.

Pezizella Fairmani Rehm, Ann. Myc. 5: 519. 1907.

Apothecia scattered, sessile, first globose, then expanded, externally smooth, .25 mm. in diameter, hyaline to slightly yellowish; asci clavate, reaching a length of $30-35 \mu$ and a diameter of 6-8 $\mu, 8$-spored; spores ovoid, 2 -seriate, $3 \times 6-7 \mu$; paraphyses filiform, $3 \mu$ in diameter.

On wood of Tsuga canadensis.

Type Locality: Lyndonville, New York.

Distribution: Known only from the type locality.

4. Orbilia leucostigma Fries, Summa. Veg. Scand. 357. 1849.

Peziza leucostigma Fries, Obs. Myc. 1: 165. 1815.

Peziza xanthostigna Fries, Syst. Myc. 2: 146. 1818.

Mollisia leucostigma Gill. Champ. Fr. Discom. 126. 1882.

Mollisia xanthostigma Gill. Champ. Fr. Discom. 125. 1882.

Calloria xanthostigma Phill. Brit. Discom. 329. 1887.

Calloria leucostigma Phill. Brit. Discom. 330. 1887.

Apothecia gregarious, or scattered, sessile, becoming plane, submembranaceous, whitish, becoming yellowish, translucent, reaching a diameter of .5 to $1 \mathrm{~mm}$.; asci cylindric to cylindricclavate, reaching a length of $30-35 \mu$ and a diameter of $3-3.5 \mu$, 8-spored; spores ellipsoid, 1-1.5 × 3-4 $\mu$; paraphyses slender with subglobose apices.

On dead wood.

Type LOCAlity: Europe.

Distribution: New Jersey to California and IVest Virginia; probably widely distributed in North America; also in Europe.

The writer can see no reason for separating Peziza leucostigma and Peziza xanthostigma. Rehm recognizes a varietal difference only.

5. Orbilia inflatula Karst. Not. Soc. Fauna Fl. Fenn. 11: 248. 1871.

Peziza inflatula Karst. Not. Soc. Fauna Fl. Fenn. 10: 175. 1869. Calloria inflatula Phill. Brit. Discom. 335. 1887.

Apothecia patellate, subtremelloid, 1-1.5 mm. in diameter, whitish-translucent, when dry becoming subglobose, or angular, sordid-yellowish, subcartilaginous; asci cylindric, or subcylindric, reaching a length of 18-24 $\mu$ and a diameter of 2-3 $\mu, 8$-spored; 
spores bacciliform, curved, .5-.7 $\times 5-8 \mu$ : paraphyses not observed.

On old wood and bark.

Type Locality: Europe.

Distribution: Toronto to Louisiana; also in Europe.

Illustrations: Massee, Brit. Fungus-Fl. 4: 156. f. 48-51.

6. Orbilia curvatispora Boud. Bull. Soc. Myc. Fr. 4: 80. 1888.

Apothecia reaching a diameter of $1 \mathrm{~mm}$. but often less, transparent-white, becoming slightly yellowish, fleshy; hymenium convex, rarely depressed in the center; asci reaching a length of 40-45 $\mu$ and a diameter of 3-3.5 $\mu$, 8-spored; spores slender, bacilliform, much curved, $1 \times 10-15 \mu$; paraphyses filiform, clavate at their apices, 4-5 $\mu$ thick.

On rotten wood and bark.

Type Locality: Europe.

Distribution: Michigan to Indiana and Ontario; also in Europe.

Illustrations: Bull. Soc. Myc. Fr. $4: p l .16, f .6$.

The only American specimens seen consists of four collections made in Michigan and Indiana, determined by Dr. Geo. B. Cummins. Also one specimen from Ontario determined by Dr. H. S. Jackson.

7. Orbilia Cucurbitae (Ger.) Seaver, comb. nov.

Peziza Cucurbitae Gerard, Bull. Torrey Club 5: 26. 1874.

Pezizella Cucurbitae Sacc. Syll. Fung. 8: 285. 1889.

Apothecia sessile, when moist waxy, scutellate; hymenium pale tan-colored, when dry somewhat horny and dark purplebrown; spores simple, ellipsoid, $10 \mu$ long.

On dead rinds of squash, Cucurbita.

Type Locality: Poughkeepsie, New York.

Distribution: known only from the type locality.

8. Orbilia epispora (Nyl.) Karst. Not. Soc. Fauna Fl. Fenn. 11: 248. 1871.

Peziza epispora Nyl. Not. Soc. Fauna Fl. Fenn. 10: 58. 1869.

Apothecia, gregarious, whitish-translucent, .3-.5 mm. in diameter; asci clavate, reaching a length of 16-19 $\mu$ and a diameter 2-2.5 $\mu$; spores bacilliform, .5 $\times 3-6 \mu$.

On Polyporus igniarius. 
Type locality : Europe.

Distribution: New Jersey to Wisconsin and Louisiana; also in Europe and South America.

Exsiccati: C. L. Smith, Centr. Am. Fungi 50.

The species is similar to Orbilia leucostigma but smaller.

9. Orbilia vinosa (Alb. \& Schw.) Karst. Myc. Fenn. 1: 101. 1871.

Peziza vinosa Alb. \& Schw. Consp. Fung. 308. 1805.

Calloria zinosa Fries, Summa Veg. Scand. 359. 1849.

Mollisia zinosa Gill. Champ. Fr. Discom. 125. 1882.

Apothecia scattered, more rarely crowded, sessile, at first rounded and closed, expanding and becoming plane, or slightly concave, flesh-colored to dark-red, .2-1 mm. in diameter; asci cylindric-clavate, reaching a length of $40-50 \mu$ and a diameter of 4-5 $\mu, 8$-spored; spores bacilliform to fusoid, $1.5-2 \times 12-17 \mu$; paraphyses filiform, subglobose above, $4 \mu$ in diameter.

On rotten wood of various kinds; also on fabric.

Type Locality: Europe.

Distribution: Massachusetts and New Jersey to Michigan, Iowa and South Carolina; also in Europe.

Illustrations: Bull. Soc. Myc. Fr. 4: pl. 22, f. 1-6; E. \& P. Nat. Pfl. $1^{1}: 217, f$. 169, D; Rab. Krypt.-Fl. $1^{3}: 447, f$. 1; Phill. Brit. Discom. pl. 10, f. 63.

Exsiccati: Rav. Fungi Car. 4: 19; Ellis, N. Am. Fungi 1+2, 1313.

A fine collection of this species was found on an old discarded bedtick in Woods Hole, Massachusetts during the summer of 1946.

10. Orbilia phymatodes (Phill.) Seaver, comb. nov.

Peziza phymatodes Phill. Grevillea 5: 117. 1877.

Pesizella phymatodes Sacc. Syll. Fung. 8: 285. 1889.

Apothecia scattered, at first spherical, then expanded and cup-shaped, reddish, or flesh-colored, smooth, faintly striate, the margin thin, paler; asci subclavate, 8 -spored; spores elongatefusoid, 3-4 $\times 13-16 \mu$; paraphyses filiform.

On reeds.

Type locality: Blue Canon, California.

Distribution: Known only from the type locality.

Illustrations: Grevillea 5: pl. $88, f$. 9. 
11. Orbilia rubrococcinea (Rehm) Sacc. Syll. Fung. 8: 622. 1889.

Calloria rubrococcinea Rehm; Winter, Hedwigia 22: 72. 1883.

Apothecia scattered, or gregarious, sessile, patelliform, scarlet-red, contracting when dry, expanding when moist, 1-3 mm. in diameter; asci clavate, reaching a length of 40-45 $\mu$ and a diameter of $5 \mu, 8$-spored; spores clavate, $3 \times 12-15 \mu$; paraphyses filiform $3 \mu$ in diameter above.

On bark of Gleditsia triacanthos.

Type Locality: Kentucky.

Distribution: Known only from the type locality.

12. Orbilia coccinella (Sommerf.) Fries, Summa Veg. Scand. 357. 1849.

Pesiza coccinella Sommerf. in Wahlenb. Fl. Lapp. 296.1826.

Mollisia coccinella Gill. Champ. Fr. Discom. 129. 1882.

Calloria coccinella Phill. Brit. Discom. 328. 1887.

Apothecia scattered, or gregarious, minute, subtremelloid, flesh-red, bright-red when dry, reaching a diameter of $1 \mathrm{~mm}$. but often much less; asci cylindric-clavate, reaching a length of $30-50 \mu$, and a diameter of 4-5 $\mu, 8$-spored; spores subglobose to cllipsoid, 2-2.5 $\times 3-5 \mu$; paraphyses very slender, with subglobose apices.

On wood and bark of various kinds, and occasionally on fungi Polyporus and Diatrype.

Type locality: Europe.

Distribution: Delaware to Wisconsin, probably common; also in Europe.

Illustrations: Boud. Ic. Myc. pl. 461; Rab. Krypt.-Fl. 13: 447,f. 6-8; E. \& P. Nat. Pfl. $1^{1}: 217, f .169, A, B$.

13. Orbilia rubinella (Nyl.) Karst. Myc. Fenn. 1:97. 1871.

Peziza rubinella Nyl. Not. Soc. Fauna Fl. Fenn. 10:56. 1869.

Apothecia scattered, subgelatinous, flesh-red, or nearly scarlet, about $.5 \mathrm{~mm}$. in diameter; asci clavate to pyriform, 8-12-spored, reaching a length of 39-46 $\mu$ and a diameter of 8-11 $\mu$; spores subglobose, about $2-3 \mu$ in diameter; paraphyses filiform, about $1 \mu$ thick, enlarged above to $1.5 \mu$.

On rotten wood and more rarely on woody fungi.

Type locality: Europe. 
Distribution: New Hampshire; also in Europe.

Exsiccati: Reliq. Farlow. 133.

The above cited specimen is the only one seen from North America.

14. Orbilia Eucalypti (Phill. \& Hark.) Sacc. Syll. Fung. 8: 628. 1889.

Calloria Encalypti Phill. \& Hark. Bull. Calif. Acad. Sci. 1: 23. 1884.

Apothecia minute, scattered, patellate, flesh-red, the margin paler, smooth; asci cylindric, 8-spored; spores ovoid-ellipsoid, 3-5 $\times 7 \mu$; paraphyses filiform and apices pyriform.

On decorticated wood of Eucalyptus; also reported on Salix.

Type locality: California.

Distribution: California and (Washington?).

15. Orbilia cruenta (Schw.) Seaver, comb. nov.

Peziza cruenta Schw. Trans. Am. Phil. Soc. II 4: 177. 1832.

Peziza rufula Schw. Trans. Am. Phil. Soc. II 4: 177. 1832.

Pesiza fibriseda Berk. \& Curt.; Berk. Grevillea 3: 157. 1875.

Peziza saccharifera Berk. \& Curt.; Berk. Grevillea 3: 157. 1875.

Peziza regalis Cooke \& Ellis, Grevillea 6: 91. 1878.

Calloria occulta Rehm, Hedwigia 24: 14. 1885.

Pesizella rufula Sacc. Syll. Fung. 8: 283. 1889.

Pezizella regalis Sacc. Syll. Fung. 8: 284. 1889.

Pezizella cruenta Sacc. Syll. Fung. 8: 284. 1889.

Pseudohelotium fibrisedum Sacc. Syll. Fung. 8: 298. 1889.

Orbilia occulta Sacc. Syll. Fung. 8: 623. 1889.

Apothecia gregarious, sometimes confluent, sessile, at first closed, then becoming widely open, the margin often wavy, reaching a diameter of $1 \mathrm{~mm}$., subgelatinous; hymenium slightly concave, crimson, or orange-red, brighter than the outside of the apothecium; asci narrowly clavate, with a long stem, 8-spored; spores irregularly 1 -seriate, or sometime 2 -seriate above, $1.5 \times 4-$ $5 \mu$; paraphyses slender clavate, or lanceolate at their tips.

On bark of various trees.

Type Locality: Bethlehem, Pennsylvania.

Distribution: New Jersey to Montana and New Mexico.

Exsiccati: Ellis, N. Am. Fungi 438 (as Peziza regalis), 848 (as Peziza occulta); Ellis \& Ev. N. Am. Fungi 2326 (as Peziza cruenta).

The above synonymy is based largely on the conclusions of George Massee (Grevillea 22: 99-100. 1894). 
16. Orbilia Caulophylli Ellis \& Ev. Proc. Acad. Sci. Phila. 1893: 145. 1893.

Apothecia scattered, or gregarious, sessile, subgelatinous, pale rose-colored when fresh, orange when dry, about $.5 \mathrm{~mm}$. in diameter; hymenium plane, or slightly concave when fresh, more strongly concave when dry, the margin thin, laciniately toothed when fresh, clothed with short, hair-like glandular structures; asci clavate-cylindric, reaching a length of $40-50 \mu$ and a diameter of 5-6 $\mu, 8$-spored; spores 2-seriate, clavate-ovoid, hyaline, $1.5 \times 5-6 \mu$; paraphyses filiform, not distinctly enlarged above.

On dead stems of Caulophyllum thalictroides.

Type locality: London, Canada.

Distribution: Ontario to Michigan.

Exsiccatı: Ellis \& Ev. N. Am. Fungi 2811.

17. Orbilia luteorubella (Nyl.) Karst. Not. Soc. Fauna Fl. Fenn. $11: 248 . \quad 1871$.

Pesiza luteorubella Nyl. Not. Soc. Fauna Fl. Fenn. 10: 55.1869. Calloria luteorubella Phill. Brit. Discom. 333. 1887.

Apothecia scattered, or gregarious, subtremelloid, plane or nearly so, often depressed in the center, pallid, then pale yellowish-red, or yellowish-brown, .5-1.5 mm. in diameter; asci cylindric-clavate, reaching a length of $30-40 \mu$ and a diameter of 4-4.5 $\mu$; spores fusoid-filiform, 1-1.5 $\times 6-12 \mu$; paraphyses filiform, $1.5 \mu$ thick, the apices clavate, or subsphacroid, $2-2.5 \mu$ thick.

On rotten wood of Populus, Alnus, Salix, etc.

Type locality: Europe.

Distribution: New York to Michigan and Louisiana and the Vest Indies; also in Europe.

18. Orbilia rubella (Pers.) Karst. Not. Soc. Fauna Fl. Fenn. 11: 248. 1871 .

Pesiza rubella Pers. Sỹn. Fung. 635. 1801.

Pesizella rubella Fuckel, Symb. Myc. 299. 1869.

Mollisia rubella Gill. Champ. Fr. Discom. 124. 1882.

Hyalinia rubella Nannf. Nova Acta Soc. Sci. U'psal. IV. 8: 252. 1932.

Apothecia gregarious, sessile, at first closed and subglobose, expanding and becoming plane or nearly so, flesh-red to darkred, waxy-gelatinous, .2-1.3 $\mathrm{mm}$. in diameter; asci cylindricclavate, reaching a length of $30-45 \mu$ and a diameter of $4-5 \mu$, 
8-spored; spores bacilliform, $1 \times 6-12 \mu, 2$-seriate; paraphyses filiform, gradually enlarged above, $3 \mu$ in diameter.

On rotten wood.

Type locality: Europe.

Distribution: New Jersey to Pennsylvania, and IVest Virginia; also in Europe.

19. Orbilia pulviscula (Cooke) Seaver, comb. nov.

Pesiza pulviscula Cooke, Hedwigia 14: 84. 1875.

Pesiza pulviscula Sacc. Syll. Fung. 8: 278.1889.

Apothecia gregarious, subtremelloid, at first globose, pallid to yellowish $.4 \mathrm{~mm}$. in diameter; asci cylindric, reaching a length of $30 \mu$ and a diameter of $5 \mu$; spores minute, spermatoid.

On stems of Phytolacca.

TyPe Locality: New York.

Distribution: New York and (New Jersey?).

While this species was placed in the subgenus Mollisia by its authors, the general description would indicate an Orbilia. This species was based on specimens collected by IV. R. Gerard. Specimen in The New York Botanical Garden is evidently a part of the type. A second specimen collected at Newfield, New Jersey has been referred to this species by J. B. Ellis.

20. Orbilia myriospora (Phill. \& Hark.) Sacc. Syll. Fung. 8: 631. 1889.

Calloria myriospora Phill. \& Hark. Bull. Calif. Acad. Sci. 1: 23.1884. Myridium myriosporum Clements, Gen. Fungi 174. 1909.

Apothecia minute, scattered, convex, pale rose-red; asci clavate; spores excessively minute, innumerable; paraphyses slender, abundant.

On dead stems of Psoralea macrostachya.

TyPe LOCAlity : California.

Distribution: Known only from the type locality.

Saccardo (Syll. Fung. 8: 631. 1889) founded a new subgenus Myriella on this species, but Clements had previously founded the genus Myridium on the same species.

\section{Doubtful and Excluded Species}

Orbilia assimilis (Cooke \& Peck) Sacc. Syll. Fung. 8: 629. 1889; Peziza assimilis Cooke \& Peck, Grevillea 1:5. 1872. Apothecia described as erumpent, dull-orange; spores $3 \times 39 \mu$. On stems of Aster puniceus, West Albany, New York. This looks like Calloria fusarioides. 
Pezizella carneorosea (Cooke \& Hark.) Sacc. Syll. Fung. 8: 284. 1889; Peziza carneorosea Cooke \& Hark. Grevillea 9: 130. 1881. Apothecia described as carneous-rosaceous, $.3 \mathrm{~mm}$. in diameter: spores ellipsoid, $3 \times 5 \mu$. On twigs of Eucalyptus in California. Nothing more is known of this species. Apparently an Orbilia.

Pezizella citrinella (Schw.) Sacc. Syll. Fung. 8: 287. 1889; Pesiza citrinella Schw. Trans. Am. Phil. Soc. II. 4: 177. 1832. This is probably an Orbilia. According to Schweinitz it is closely related to Orbilia chrysocoma.

Pesizella conchella (Schw.) Sacc. Syll. Fung. 8: 284. 1889; Peziza conchella Schw. Trans. Am. Phil. Soc. II. 4: 177. 1832. Apothecia minute, shellshaped, sessile, subpellucid, red, confluent. On dead branches of Morus alba, Bethlehem, Pennsylvania. This may be an Orbilia. No material has been seen.

Orbilia paradoxa V'el. Monog. Discom. Bohem. 1: 102. 1934. Reporterl by Dr. B. Kanouse from Washington, on $\log$ of Alnus. No material seen.

Orbilia rosella (Rehm) Sacc. Syll. Fung. 8: 623. 1889; Calloria rosella Rehm, Hedwigia 23: 56. 1884; Laetinaeria rosella Kanouse, Papers Mich. Acad. Sci. 21: 100. 1936. Reported from Michigan by Dr. B. Kanouse. No material seen.

Orbilia Sarraziniana Boud. Rev. Myc, 7: 221. 1885. This species has been reported from Michigan by Dr. B. Kanouse on decaying wood. No material has been seen.

26. TRICHOBELONIUM (Sacc.) Rehm in Rab. Krypt.-Fl. $1^{3}$ : 590. 1891.

Belonium subg. Trichobelonium Sacc. Syll. Fung. 8: 495.1889.

Apothecia sessile, gregarious, fleshy to subgelatinous, lightor dark-colored, seated on a white or colored mycelial subiculum; asci cylindric to clavate, usually 8 -spored; spores ellipsoid to fusoid, becoming 3-septate.

Type species, Peziza retincola Rab.

When Saccardo established the subgenus he described the apothecia as byssoid or pilose. When Rehm raised the subgenus to generic rank he described the apothecia as seated on a spreading white, or colored mycelium. He later included in the genus Trichobelonium albosuccineum Rehm, which in our opinion is a synonym Peziza leucorrhodina Mont., the only North American species of the genus seen.

1. Trichobelonium leucorrhodinum (Mont.) Seaver, comb. nov.

Peziza leucorrhodina Mont. in Sagra, Hist. Cuba Pl. Cell. 360. $18+2$.

Pesiza gelatinosa Ellis \& Mart. Am. Nat. 17: 1283. 1883.

Belonidium leucorrhodinum Sacc. Syll. Fung. 8: 501. 1889.

Scutula leucorrhodina Speg. Anal. Soc. Ci. Arg. 26: 58.1888.

Orbilia gelatinosa Sacc. Syll. Fung. 8: 624. 1889. 
Mollisia gelatinosa Sacc. Syll. Fung. 8: 624. 1889.

Trichobelonium albosuccineum Rehm, Hedwigia 39: 89. 1900.

Apothecia gregarious, sessile, subgelatinous, pinkish, .25 mm. in diameter, seated on a white mycelial subiculum; hymenium becoming plane, or slightly convex; asci broad-clavate to ovate, reaching a length of 35-40 $\mu$ and a diameter of 15-20 $\mu$, 8-spored; spores 2-3-seriate, fusoid, subhyaline, 3-3.5 $\times 12-16 \mu$; paraphyses thickened above, curved.

On the mycelium of species of Perisporiaceae (Meliola) on various hosts.

Type locality: Cuba.

Distribution: Southern United States, the West Indies and tropical South America.

Illustrations: Hedwigia 39: pl. 5, f. 24.

ExsiccAti: Rehm, Ascom. 1778.

\section{Dolbtful Species}

Trichobelonium hercynicum Lindau, Verh. Bot. Ver. Branden. 45: 154. 1904; Belonium hercynicum Boud. Hist. Class. Discom. Eu. 118. 1907. Reported from Michigan on old wood by Dr. B. Kanouse. No material seen.

27. CALloria Fries, Summa Veg. Scand. 359. 1849.

Niptera Fries, Summa V'eg. Scand. 359. 1849.

?Lansia Sacc. Bot. Cent. 18: 218.1884.

Beloniella Sacc,; Rehm in Rab. Krypt.-Fl. 1²: 638. 1892.

Eubelonis Clements, Gen. Fungi 175. 1909.

?Laetinaevia Nannf. Nova Acta Soc. Sci. Lpsal. IV. 8: 190. 1932.

Apothecia minute, usually less than $1 \mathrm{~mm}$. in diameter, sessile, or subsessile, occasionally with a short, stem-like base, superficial, or suberumpent, dark-grayish, greenish, or more frequently bright-colored, red, yellow, or purplish, externally smooth or nearly so; asci clavate, typically 8-spored; spores ellipsoid, or fusoid, normally 1 -septate (rarely 3-septate), hyaline; paraphyses filiform, simple, or branched, the ends either free, or agglutinated and forming an epithecium.

Type species, Peziza fusarioides Berk.

Most of the species originally included by Fries in this genus are now placed in Orbilia. The species here accepted as the type was the last one mentioned by Fries but has come to be regarded as the type. The spore characters were ignored by Fries.

Beloniella seems to have been established for species which are crumpent or a Pyrenopeziza with a septate spore. 
On phanerogams, wood, stems etc.

On dicotyledons.

On herbaceous stems.

Apothecia orange or orange-red.

Spores 9-1+ $\mu$ long.

1. C. fusarioides.

Spores 18-22 $\mu$ long.

2. C. oleosa.

Apothecia not orange.

Apothecia vermilion.

3. C. coccinea.

Apothecia not vermilion.

Spores 10-12 $\mu$ long, on Solidago.

t. C. Solidaginis.

Spores 12-20 $\mu$ long, on Lithospermum.

5. C. Lithospermi.

On woody plants.

Spores large, 12-18 $\mu$ long.

On cedar limbs and rubbish.

6. C. aurea.

On wood of Arctostaphylos.

7. C. nitens.

Spores less than $12 \mu$ long.

Apothecia purple.

8. C. oregonensis.

Apothecia yellow or orange.

Spores 3-4 4 9-10 $\mu$.

9. C. Fairmani.

Spores $4-5 \times 8-10 \mu$.

10. C. kansensis.

Spores $4 \times 12 \mu$.

On fallen leaf.

11. C. helotioides.

12. C. glagosa.

13. C. caricinella.

On monocotyledon, Carex.

On cryptogams.

On lichen, Peltigera.

14. C. Miilleri.

On fern stipe, Pteris.

15. C. cremea.

1. Calloria fusarioides (Berk.) Fries, Summa V'eg. Scand. 359. 1849.

Peziza fusarioides Berk. Mag. Zool. Bot. 1: 46. 1837.

Mollisia fusarioides Gill. Champ. Fr. Discom. 120. 1882.

Apothecia scattered, or gregarious, originating beneath the cuticle, often collected in patches and confluent, at first subglobose, gradually expanding and becoming superficial, orbicular, or elongated, bright-orange, .5-1.5 $\mathrm{mm}$. in diameter; hymenium slightly concave, or plane, orange-yellow; asci clavate, reaching a length of $70-95 \mu$ and a diameter of 8-10 $\mu$, 8-spored; spores long-ellipsoid, or fusiform, at first simple, finally becoming 1-septate (or occasionally 3 -septate) 3.5-4 49 -14 $\mu$; paraphyses filiform, gradually enlarged above to $3.5 \mu$.

On stems of Urtica and possibly on other herbaceous stems.

Type locality: Europe.

Distribution: New York and Delaware; probably widely distributed. 
Illustrations: Berk. Mag. Zool. Bot. 1: pl. 2, f. t; Gill Champ. Fr. Discom. pl. 81.f. 2; E. \& P. Nat. Pfl. 1':217,f. 169 E. G.; Rab. Krypt.-Fl. $1^{3}: 448, f .1-3$.

2. Calloria oleosa (Ellis) Sacc. Syll. Fung. 8: 639. 1889.

Peziza oleosa Ellis, Bull. Torrey Club 10: 52.1883.

Apothecia scattered, or gregarious, small, subglobose when fresh, orbicular and concave with a thick, obtuse margin when dry, oily-gelatinous; hymenium orange-red; asci fusoid, reaching a length of 75-90 $\mu$ and a diameter of 10-12 $\mu$, 8-spored; spores 2-seriate, fusiform-navicular, 1-septate, hyaline, 3-3.5 $\times 18-22 \mu$; paraphyses absent or not observed.

On dead herbaceous stems.

Type Locality: Pleasant Valley, Utah.

Distribution: Michigan to Utah.

Exsiccatr: Clements, Crypt. Form. Colo. 75.

Ellis states "Allied to P. fusarioides."

3. Calloria coccinea (Earle) Seaver, comb. nov.

Niptera coccinea Earle in Green, Pl. Baker. 2: 7. 1901.

Apothecia scattered, or gregarious, cup-shaped, .3-.5 mm. in diameter, soft, thin, subgelatinous, bright-vermilion throughout, or sometimes the margin bordered by a lighter, nearly white line; asci cylindric, reaching a length of $40-50 \mu$ and a diameter of 4-6 $\mu$; spores long-ellipsoid, becoming 1-septate, not constricted $3 \times 8 \mu$; paraphyses filiform, indistinct.

On dead stems of Corydalis.

Type locality: Pagosa Peak, Colorado, elevation 10,000 ft.

Distribution: Known only from the type locality.

4. Calloria Solidaginis Kanouse, Papers Mich. Acarl. Sci. 20: 66. 1935.

Apothecia erumpent through the epidermis of the host, solitary, or cespitose, often several appearing in rows, cupshaped, not expanding, .5-1 $\mathrm{mm}$. in diameter; hymenium dirtywhite with violet tints, or light-brown when fresh, rose-lilac when dry; asci cylindric-clavate, 4-spored, reaching a length of 45-65 $\mu$ and a diameter of 6-8 $\mu$; spores ellipsoid to subfusoid, straight, or slightly bent, with an oil-drop in each end, becoming 1-septate, 3-4 × 10-12 $\mu$; paraphyses filiform, scarcely thickened, above and forming an cpithecium. 
On wet mats of dead stems of Solidago sp.

TyPE LOCALITY: Bank of Huron River, near Dexter, Michigan.

Distribution: Known only from the type locality.

Illustrations: Papers Mich. Acad. Sci. 20: pl. 12, f. 2.

5. Calloria Lithospermi (Ellis \& Ev.) Seaver, comb. nov.

Niptera Lithospermi Ellis \& Ev. Proc. Acarl. Sci. Phila. 1893: 147. 1893.

Apothecia erumpent-superficial, scattered, sessile, $.75 \mathrm{~mm}$. in diameter, at first closed, finally opening, blackish-brown on the outside, granular; hymenium concave, livid-white, becoming darker with age; asci cylindric, reaching a length of $45-55 \mu$ and a diameter of $8-10 \mu$; spores 2 -seriate, long-ellipsoid, becoming 1-septate and mostly constricted in the center, 3-3.5 $\times 12-20 \mu$; paraphyses obscure.

On clead stems of Lithospermum canescens.

Type Locality: Mount Helena, Montana.

Distribution: Known only from the type locality.

6. Calloria aurea (Ellis) Sacc. Syll. Fung. 8: 640. 1889.

Ombrophila aurea Ellis, Bull. Torrey Club 8: 74. 1881.

Apothecia at first obconic and concave above, at length becoming plane, or convex, with a subundulated margin, reaching a diameter of 1-3 mm., soft, golden-yellow; asci cylindric, narrowed at the base, reaching a length of $100 \mu$ and a diameter of $10 \mu$; spores 1 -seriate, acutely cllipsoid, finally 1 -septate, $4 \times 12-14 \mu$; paraphyses filiform, yellow.

In swamps, mostly on decaying cedar limbs lying partly in the water; also on old leaves and rubbish.

Type locality: New Jersey.

Distribution: Known only from the type locality.

Exsiccatr: Ellis, N. Am. Fungi 395.

7. Calloria nitens (Cash) Seaver, comb. nov.

Helotium nitens Cash, Mycologia 28: 251. 1936.

Apothecia fleshy to subgelatinous, subsessile, pulvinate, convex, gregarious, sometimes confluent, reaching a diameter of $1.5 \mathrm{~mm}$., $1 \mathrm{~mm}$. high, pale yellow-orange to light salmon-orange; hymenium darker, even, smooth; asci clavate-cylindric, rounded with the wall slightly thickened at the apex, attenuated below into a long stem, reaching a length of $150-170 \mu$ and a diameter of 7-8 $\mu$; spores ellipsoid-clavate, at first simple, later becoming 
1-septate, 4-4.5 $\times 13-18 \mu$; paraphyses filiform, freely branched above, $1 \mu$ in diameter.

On wood of Arctostaphylos Tracyi.

Type locality: Spruce Cove, Trinidad, California.

Distribution: Known only from the type locality.

8. Calloria oregonensis Kanouse, Papers Mich. Acad. Sci. 24: 26. 1939.

Apothecia sessile, gregarious, $1 \mathrm{~mm}$. in diameter, soft and subgelatinous, purplish; hymenium plane, purple; asci cylindric, 8-spored, reaching a length of $120-150 \mu$ and a diameter of 7-8 $\mu$, spores ellipsoid, becoming 1 -septate and constricted at the septum, 5-6 6 10-12 $\mu$; paraphyses filiform, stiff, abruptly enlarged at their apices, the capitate apex reaching a diameter of $4 \mu$.

On coniferous wood.

Type Locality: Lake Tahkenitch, Oregon.

Distribution: Known only from the type locality.

9. Calloria Fairmani Rehm, Ann. Myc. 9: 366. 1911.

Belonium Fairmani Rehm, Ann. Myc. 9: 367. 1911.

Apothecia scattered, globose, finally discoid, externally smooth, .1-.2 mm. in diameter, subgelatinous, yellowish; asci clavate, reaching a length of $60 \mu$ and a diameter of 8-10 $\mu$, 8-spored; spores ellipsoid, or subclavate, 2-seriate, becoming 1-septate, 3-4 $\times$ 9-10 $\mu$; paraphyses filiform, yellowish above.

On decorticated wood.

Type Locality: Lyndonville, New York.

Distribution: Known only from the type locality.

10. Calloria kansensis Ellis \& Ev. Bull. Torrey Club 25: 507. 1898.

Apothecia gregarious, subgelatinous, pale-orange, globose, $.3 \mathrm{~mm}$. in diameter when fresh, of a deeper color and umbilicate when dry, with spreading, white hairs around the base; asci clavate-cylindric, reaching a length of $65-75 \mu$ and a diameter of 8-10 $\mu, 8$-spored; spores mostly 2-seriate, ellipsoid, with two large oil-drops, becoming 1 -septate, $4-5 \times 8-10 \mu$; paraphyses absent or not observed.

On rotten wood.

TyPE Locality: Kansas.

Distribution: Known only from the type locality. 
11. Calloria helotioides (Rehm) Seaver, comb. nov. Lanzia helotioides Rehm, Ann. Myc. 2: 36. 1904.

Apothecia gregarious, or rarely solitary, sessile, or subsessile, at first cyathiform, then more or less patelliform, $2 \mathrm{~mm}$. to $1 \mathrm{~cm}$. in diameter; hymenium dilutely yellowish-red; asci cylindric, reaching a length of $100-120 \mu$ and a diameter of $7-9 \mu, 8$-spored; spores ellipsoid, becoming 1 -septate, scarcely constricted, 2-seriate, $4 \times 12 \mu$; paraphyses filiform, hyaline, $2 \mu$ thick.

On decaying wood.

Type locality: United States.

Distribution: Known only from the type collection.

The specimens were sent to Dr. H. Rehm by G. F. Atkinson. No material has been seen.

\section{Calloria glagosa (Ellis \& Ev.) Seaver, comb. nov.}

Peziza glagosa Ellis \& Ev. Jour. Myc. 4: 56. 1888.

Pezizella glagosa Sacc. Syll. Fung. 8: 276. 1889.

Hymenoscyphus glagosus Kuntze, Rev. Gen. Pl. 3³: 485.1898.

Apothecia sessile, smooth, .25 mm. in diameter, milk-white when fresh, becoming subrufous, or amber-colored when dry; asci clavate, reaching a length of 70-75 $\mu$ and a diameter of $7-8 \mu$, gradually attenuated at the base, 8-spored; spores 2-seriate, or crowded above, long-ellipsoid, or clavate, 2.5-3 $\times 8-10 \mu$, becoming 1-septate; paraphyses abundant, filiform, not distinctly thickened above.

On a much-decayed, fallen leaf in swamp.

Type locality: Newfield, New Jersey.

Distribution: Known only from the type locality.

Ellis seemed a little uncertain about the septation of the spores which leaves the species somewhat in doubt. IV. L. White regards this as a Helotium.

13. Calloria caricinella (Peck) Seaver, comb. nov.

Helotium caricinellum Peck, Ann. Rep. N. Y. State Mus. 30: 61. 1878. Niptera caricinella Sacc. Syll. Fung. 8: 484. 1889.

Apothecia scattered, sessile, .5-.7 mm. in diameter, reddish, or ochraceous-brown when moist, black, or blackish when dry; hymenium plane, or slightly concave; asci clavate, 8-spored; spores crowded, ellipsoid, 1-septate, 20-25 $\mu$ long.

On dead leaves of Carex utriculata.

TYPE LOCality: Adirondack Mountains. 
Distribution: Known only from the type locality.

Illustrations: Ann. Rep. N. Y. State Mus. 30: pl. 1, f. 5-8.

14. Calloria Muilleri (Willey) Seaver, comb. nov.

Phacopsis Mülleri Willey, Enum. Lich. Massachusetts 34. 1892.

Niptera Mülleri Vouaux, Bull. Soc. Myc. Fr. 30: 182. 1914.

Apothecia adnate to the thallus of the lichen host, flat, or slightly convex, rounded, at length confluent, flesh-colored, becoming darker; asci cylindric, 8-spored; spores becoming 1-septate, 3.5-5.5 × 11-15 $\mu$.

On the thallus of Peltigera canina.

TyPe Locality: Massachusetts.

Distribution: Known only from the type locality.

No specimens seen.

15. Calloria cremea (Cash) Seaver, comb. nov.

Helotium cremeum Cash, Mycologia 28: 249. 1936.

Apothecia subsessile, waxy, patellate, occasionally lobate, reaching a diamater of $1 \mathrm{~mm}$., exterior cream-colored to creambuff, margin whitish-furfuraceous; asci clavate, reaching a length of 75-90 $\mu$ and a diameter of $10-12 \mu$, narrowed but rounded at the apex, gradually attenuated toward the base, 8-spored; spores 1-2-seriate, fusoid-clavate, 1-septate, slightly constricted at the septum, $4-5 \times 12-15 \mu$, upper cell slightly broader than the lower, containing many oil-clrops or granules; paraphyses filiform, septate, unbranched reaching a diameter of $2 \mu$ at the apex.

On stipes of Pteridium aquilinum pubescens.

TyPe locality: Spruce Cove, Trinidad, California.

Distribution: Known only from the type locality.

ILLUSTRATIONS: Mycologia 28: 250, f. 7 .

\section{Doubtful Species}

Calloria citrina A. L. Smith, Jour. Linn. Soc. 35: 15. 1901. Described from material collected in Dominica. No material seen.

Niptera discolor (Mont. \& Fries) Rehm in Rab. Krypt.-Fl. 133 552.1891 ; Patellaria discolor Mont. \& Fries, Ann. Sci. Nat. II. 5: 290. 1836; Mollisia discolor Phill. Brit. Discom. 175. 1887. Reported from Michigan by Dr. B. Kanouse. No material seen.

Solenopezia grisea A. L. Smith, Jour. Linn. Soc. 35: 14. 1901. Spores described as 1 -septate, $10 \times 15-17 \mu$. On stalks of some monocotyledon in Dominica. No material seen. Apparently a Calloria. 
Peziza mycogena Ellis, Bull. Torrey Club 6: 107. 1876. Apothecia minute, pale with a greenish tinge; spores ellipsoid, appearing to become 1 -septate, $7.5 \mu$ long. On old Polyporus igniarius buried in leaves, New Jersey. No material seen.

Niptera pella Clements, Crypt. Form. Colo. 88. 1906. On Streptopus amplexifolius, Jack Brook, Colorado. No other publication seen.

Niptera tyrolensis (Sacc.) Rehm in Rab. Krypt.-F1. 1 ${ }^{3}$ : 554. 1891; Mollisia tyolensis Sacc. Syll. Fung. 8: 333. 1889. This species has been reported from Michigan by Dr. B. Kanouse. No material has been seen.

Niptera uda (Pers.) Fuckel, Symb. Myc. 293. 1869; Peziza uda Pers. Syn. Fung. 634. 1801; Mollisia uda Gill. Champ. Fr. Discom. 127. 1882. Reported from Michigan by A. H. IV. Povah. No material seen.

28. BELONIUM Sacc. Bot. Cent. 18: 219.1884.

Belonidium Rehm in Rab. Krypt.-F1. 1³: 561. 1891. Not Mont. \& Dur. 1846.

Massea Sacc. Syll. Fung. 8: 488. 1889.

Harknessiella Sacc. Syll. Fung. 8: 845. 1889.

Apothecia sessile, or short-stipitate, cup-shaped to scutellate, black, brownish or occasionally yellowish, or reddish, usually smooth or not distinctly hairy; asci cylindric-clavate, 8-spored; spores fusiform to elongate, 2- to many-septate, hyaline; paraphyses filiform.

Type species, Peziza graminis Desm.

The presence of a short, stem-like base has been used to separate Belonidium from Belonium. The character is not regarded as a satisfactory one on which to separate the two genera.

On dicotyledonous plant tissues.

Spores very large, $35-40 \mu$ long.

Spores 3-septate, on Glyceria.

1. B. Glyceriae.

Spores more than 3 -septate.

Spores 4-8-septate.

Spores 36-40 $\mu$ long.

2. B. basitrichum.

Spores 40-50 $\mu$ long.

3. B. introspectum.

Spores many-septate, $40-60 \mu$ long.

4. B. tympanoides.

Spores not over $35 \mu$ long.

Spores $30-33 \mu$ long.

Apothecia greenish.

5. B. Parksi.

Apothecia not greenish.

On decaying Magnolia.

6. B. phlegmaceum.

On undetermined wood.

7. B. quisquiliarum.

Spores 10-20 $\mu$ long.

Spores 10-12 $\mu$ long.

8. B. atrosanguineum.

Spores 12-20 $\mu$ long. 
Spores 14-20 $\mu$ long, on Aralia.

Spores 12-15 $\mu$ long.

On twigs of Abies.

On Populus and Salix.

On monocotyledonous tissues.

On petioles of palms.

On grasses or sedges.

Spores not over $20 \mu$ long.

On culms of Spartina.

On Andropogon.

Spores $20 \mu$ or more long.

On Calamagrostis, spores 24-30 $\mu$ long.

On Carex, spores 18-24 $\mu$ long.

On Arundinaria, spores 20-24 $\mu$ long.

On various grasses, spores $21-40 \mu$ long.
9. B. minimum.

10. B. inconspicuum.

11. B. aggregatum.

12. B. sclerogenum.

13. B. heteromorphum.

14. B. Andropogonis.

15. B. intermedium.

16. B. caricincolum.

17. B. eustegiaeforme.

18. B. culmicola.

1. Belonium Glyceriae (Peck) Seaver, comb. nov.

Belonidium Glyceriae Peck, Bull. N. Y. State Mus. 139: 19. 1909.

Apothecia 1-1.5 $\mathrm{mm}$. in diameter, sessile, papillate on the under side; hymenium plane, or convex, pale-yellow; asci subclavate, or fusoid, reaching a length of 120-130 $\mu$ and a diameter of 14-18 $\mu, 8$-spored; spores elongate-ellipsoid, straight, or slightly curved, 2 -seriate, $4-5 \times 35-40 \mu$, becoming 3 -septate; paraphyses filiform.

On dead culns of Glyceria neviata.

Type Locality: Lyndonville, New York.

Distribution: Known only from the type locality.

2. Belonium basitrichum (Sacc.) Seaver, comb. nov.

Belonidium basitrichum Sacc. Atti Soc. Veneto Sci. Nat. Padova 4 ${ }^{1}: 35.1875$.

Apothecia gregarious, sessile, patelliform, soft, entirely white, finally sordid-white, $.25-.5 \mathrm{~mm}$. in diameter; hymenium concave, or plane, becoming yellowish; asci clavate, reaching a length of 100-120 $\mu$ and a diameter of $14 \mu$, short-stipitate, 8spored; spores 2-seriate, elongate-fusoid, curved, $3-4 \times 36-40 \mu$, becoming 6-8-septate, hyaline; paraphyses filiform, clavate.

On rotten wood Quercus, and Castanea, seated on a black mycelial growth.

Type locality : Europe.

Distribution: New York; also in Europe.

The only specimen seen of this species is one collected by C. L. Shear in Ringwood, New York and which seems to agree with the original description. 
3. Belonium introspectum (Cooke) Sacc. Syll. Fung. 8: 498. 1889.

Peziza introspecta Cooke, Hedwigia 14: 84. 1875.

Apothecia gregarious, or scattered, sessile, translucent, at first hemispherical, finally expanded and nearly plane, .3-.4 mm. in diameter; asci clavate, 8-spored; spores fusiform, straight, or curved, with four or five oil-drops, finally 5-septate, $8 \times 40-50 \mu$; paraphyses filiform.

On rotting wood.

Type Locality: New Jersey.

Distribution: Known only from the type locality.

4. Belonium tympanoides (Ellis \& Ev.) Seaver, comb. nov.

Belonidium tympanoides Ellis \& Ev. Proc. Acad. Sci. Phila. 1893: 149.1893.

Apothecia gregarious, fleshy, sessile, black, closed when dry, hemispherical when fresh, .3-.5 $\mathrm{mm}$. in diameter; hymenium concave, pallid; asci clavate-cylindric, reaching a length of 80 $100 \mu$ and a diameter of $12 \mu, 8$-spored; spores ellipsoid-cylindric, becoming many-septate, $2.5 \times 40-60 \mu$; paraphyses filiform, curved at their apices.

On rotten wood.

Type locality: London, Canada.

Distribution: Known only from the type locality.

5. Belonium Parksi (Cash) Seaver, comb. nov.

Belonidium Parksi Cash, Mycologia 28: 248. 1936.

Apothecia gregarious, cup-shaped, sessile, externally fuscous, furfuraceous, the margin inrolled, hysteroid, triangular, or irregularly folded; hymenium glaucous-green, drying chromiumgreen; asci clavate-cylindric, narrowed above, gradually tapering into a short stem, reaching a length of $65-80 \mu$ and a diameter of 6-8 $\mu, 8$-spored; spores fusoid, straight, or slightly curved, obliquely 1 -seriate below, 2 -seriate above, becoming 1 -3-septate, about $3 \times 13 \mu$; paraphyses filiform, slightly enlarged above, $1.5-2 \mu$ thick.

On decorticated stems of Vaccinium parvifolium, Rhamnus purshiana, Garrya elliptica, Physocarpus capitatus and Castanopsis chrysophylla.

Type locality: Humboldt Co., California.

Distribution: California.

Illustrations: Mycologia 28: 250, f. 2. 
6. Belonium phlegmaceum (Ellis) Seaver, comb. nov.

Pesiza phlegmacea Ellis, Bull. Torrey Club 9: 19. 1882.

Belonidium ? phlegmaceum Sacc. Syll. Fung. 8: 500. 1889.

Apothecia seated on a subiculum of delicate, creeping, white, loosely matted threads, gregarious, sessile, circular, thin, white, soft; asci cylindric-clavate, reaching a length of $60 \mu$ and a diameter of $12 \mu$; spores elongate-fusiform, attenuated below to a slender point, $2.5 \times 30-33 \mu$; paraphyses filiform, scarcely thickened above.

On decaying Magnolia.

Type locality: Newfield, New Jersey.

Distribution: Known only from the type locality.

7. Belonium quisquiliarum (Berk. \& Curt.) Seaver, comb. nov.

Pesiza quisquiliarum Berk. \& Curt.; Berk. Jour. Linn. Soc. 10: 366.1868. Massea quisquiliarum Sacc. Syll. Fung. 8: 488. 1889.

Apothecia yellow, crateriform, expanding, sessile, the margin inflexed, 2-5 mm. in diameter; asci clavate, 8-spored; spores fusiform, curved, becoming 3-septate, $6-7 \times 25 \mu$; paraphyses filiform.

On dead branches.

Type locality: Cuba.

Distribution: Known only from the type locality.

Illustrations: Cooke, Mycographia pl. 10, f. 37 .

8. Belonium atrosanguineum (Rehm) Seaver, comb. nov.

Calloria atrosanguinea Rehm, Ann. My'c. 5: 518. 1907.

Apothecia parasitic in the mycelium of a Stereum, gregarious, black when dry, when moist blackish-red, punctiform, irregularly hemispherical, $.15 \mathrm{~mm}$. in diameter; asci clavate, reaching a length of $40-50 \mu$ and a diameter of $10 \mu$, 8-spored; spores ellipsoid to clavate, becoming 1 -septate, finally 3 -septate, 3-3.5 $\times 10-12 \mu$; paraphyses filiform, $1 \mu$ thick, globose at their apices, $4 \mu$ in diameter.

On logs of conifers.

Type Locality: Sumner, Washington.

Distribution: Known only from the type locality.

9. Belonium minimum (Ellis \& Ev.) Seaver, comb. nov.

Belonidium minimum Ellis \& Ev. Proc. Acad. Sci. Phila. 1893: 452. 1893.

Apothecia scattered, erumpent, sessile, pale rose-colored, $.09-.11 \mathrm{~mm}$. in diameter, subdiscoid, subgelatinous, furfuraceous, 
pilose, or nearly smooth; asci clavate-cylindric, reaching a length of 45-55 $\mu$ and a diameter of 6-7 $\mu, 8$-spored; spores 2-seriate, fusoid, slightly curved, hyaline, 3-septate, $3-3.5 \times 14-20 \mu$; paraphyses not observed.

On dead stems of A ralia racemosa.

Type Locality: Granogue, Delaware.

Distribution: Known only from the type locality.

10. Belonium inconspicuum Cash, Mycologia 28: 304. 1936.

Apothecia superficial, sessile, occurring singly, smooth, patellate, thin-membranaceous, .3-.5 mm. in cliameter, brownishblack; hymenium drab; asci clavate, tapering into a short stem, reaching a length of 50-65 $\mu$ and a diameter of 8-10 $\mu, 8$-spored; spores ellipsoid to broad-clavate, obliquely 1 -seriate to irregularly 2-seriate, hyaline, 3-septate, not constricted, 4-5 × 12-15 $\mu$; paraphyses septate, branched with globose, olive-brown, glutinous tips $5 \mu$ in diameter, forming an agglutinated layer.

On decorticated twigs of Abies.

Type locality: Grand Mesa, Colorado.

Distribution: Known only from the type locality.

Illustrations: Mycologia 28: 302, f. 2.

\section{Belonium aggregatum Cash, Mycologia 28: 303. 1936.}

Apothecia sessile, urceolate to patellate, soft-fleshy, densely crowded on a more or less evident subiculum of pale-olivaceous hyphae, fuscous-black to olivaceous-black; hymenium of the same color with the margin paler and fimbriate, the entire fungus black when dry; asci cylindric-clavate, slightly narrowed at the apex, reaching a length of 50-65 $\mu$ and a diameter of 6-7 $\mu$, 8-spored; spores 1-2-seriate, clavate to cylindric, 1-3-septate, not constricted, 2.5-3 $\times 13-15 \mu$; paraphyses filiform, unbranched, septate, hyaline, slightly enlarged at the apex, $2 \mu$ in diameter.

On decorticated wood of Populus tremuloides and on Salix.

Type locality: Mesa Lakes, Colorado.

Distribution: Known only from the type locality.

Illustrations: Mycologia 28: 302, f. 5.

The subiculum would suggest a Trichobelonium.

12. Belonium sclerogenum (Berk. \& Curt.) Seaver, comb. nov. Peziza sclerogena Berk. \& Curt.; Berk. Jour. Linn. Soc. 10: 369. 1868.

Belonidium sclerogenum Sacc. Syll. Fung. 8: 497. 1889. 
Apothecia sessile, subhemispherical, yellowish, margin inflexed, finally applanate; asci clavate, 8-spored; spores 2-seriate, fusiform, curved, becoming 3-septate, 30-34 $\mu$ long.

On petioles of palms.

Type locality: Cuba.

Distribution: Known only from the type locality.

13. Belonium heteromorphum (Ellis \& Ev.) Seaver, comb. nov. Peziza heteromorpha Ellis \& Ev. Jour. Myc. 2: 88. 1889.

Belonidium heteromorphum Sacc. Syll. Fung. 8: 502. 1889.

Apothecia seated on a brownish-black, felt-like subiculum which extends for several inches along the culm, scattered, globose at first, with a small, round opening with a white margin, at length expanding to nearly plane, or even slightly convex, 2-3 $\mathrm{mm}$. in diameter; hymenium pallid-white to flesh-colored; asci clavate-cylindric, reaching a length of $70 \mu$ and a diameter of 6-7 $\mu, 8$-spored; spores fusoid, slightly curved, finally 3 -septate, or pseudoseptate, $2.5-3 \times 20 \mu$.

On the base of culms of Spartina polystachya.

Type Locality: Louisiana.

Distribution: Known only from the type locality.

The subiculum suggests a Trichobelonium.

14. Belonium Andropogonis (Berk. \& Curt.) Sacc. Syll. Fung. 8: 493. 1889.

Peziza Andropogonis Berk. \& Curt.; Berk. Grevillea 3: 158. 1875.

Peziza aberrans Peck, Bull. Torrey Club 6: 14. 1875.

Apothecia erumpent, at first elongated and hysteriform, gradually expanding and becoming elliptic in form, externally dark brownish-black, about $.5 \mathrm{~mm}$. long; hymenium concave, pale-yellowish; asci clavate, reaching a length of 60-70 $\mu$ and a diameter of $10-12 \mu, 8$-spored; spores irregularly 2-seriate, fusoid, $2-3 \times 18 \mu, 3$-septate; paraphyses filiform, about $2 \mu$ in diameter.

In Andropogon.

Type Locality: South Carolina.

Distribution: New Jersey to South Carolina.

Exsiccati: Ellis, N. Am. Fungi 61; Rab.-Winter, Fungi Eu. 3169 (from New Jersey). 
15. Belonium intermedium (Rehm) Seaver, comb. nov.

Belonidium intermedium Rehm, Ann. Myc. 6: 315. 1908.

Apothecia gregarious, sessile, at first closed, finally expanding and becoming patellate, brown, .2-.3 mm. in diameter; hymenium plane, yellow; asci clavate, reaching a length of $80 \mu$ and a diameter of $12 \mu, 8$-spored; spores elongate-fusoid, 2-seriate, mostly straight, 3 -septate, $5-5.5 \times 24-30 \mu$; paraplyses filiform $2 \mu$ in diameter, expanding above to 3.5 .

On dead culms of Calamagrostis canadensis.

Type Locality: Madison, Wisconsin.

Distribution: Known only from the type locality.

16. Belonium caricincolum (Rehm) Seaver, comb. nov.

Belonidium caricincolum Rehm in Rab. Krypt.-F1. 132: 564. 1891.

Apothecia gregarious, sessile, at first globose and closed, finally opening and becoming cup-shaped, externally brownishblack, .2-1 mm. in diameter; hymenium gray, or grayish-yellow to dark-olive; asci clavate, reaching a length of $60-70 \mu$ and a diameter of $7-8 \mu, 8$-spored; spores fusiform, straight, or somewhat curved, finally 3 -septate, $3 \times 18-24 \mu$; paraphyses filiform, $3 \mu$ thick.

On fallen leaves of Carex.

Type locality: Europe.

Distribution: Colorado; also in Europe.

Exsiccati : Clements, Crypt. Form. Colo. 28t. (as Belonidium caricincolum).

17. Belonium eustegiaeforme (Berk. \& Curt.) Sacc. Syll. Fung. 8: 494. 1889.

Peziza eustegiaeformis Berk. \& Curt.; Berk. Grevillea 3: 158.1875.

Peziza Arundinariae Berk. \& Curt.; Cooke, Bull. Buffalo Soc. Nat. Sci. 2: 297. 1875.

Pyrenopeziza Arundinariae Sacc. Syll. Fung. 8: 368. 1889.

Apothecia scattered, seated on a brownish spot, at first closed and rounded, or slightly elongated, expanding and becoming scutellate, externally dark brownish-black and furfuraceous; hymenium concave, lighter in color, pallid; asci clavate, reaching a length of $80 \mu$ and a diameter of $10-15 \mu, 8$-spored; spores fusoid, hyaline, $5 \times 20-24 \mu$, becoming 3-septate; paraphyses filiform.

On Arundinaria macrosperma.

TyPE locality: South Carolina. 
Distribution: South Carolina to Alabama and Georgia.

Exsiccati: Ellis, N. Am. Fungi 668; Rav. Fungi Am. 310.

18. Belonium culmicola (Desm.) Seaver, comb. nov.

Peziza culmicola Desm. Ann. Sci. Nat. II. 6: 244. 1836.

Belonium vexatum DeNot. Comm. Critt. Ital, 1:380. 1864.

Belonium Moliniae DeNot. Comm. Critt. Ital. 1: 380.1864.

Peziza vexata Karst. Not. Soc. Fauna. F1. Fenn. 10: 139. 1869.

Peziza subgibbosa Ellis, Bull. Torrey Club 6: 108. 1876.

Phialea culmicola Gill. Champ. Fr. Discom. 103. 1882.

Belonium subgibbosum Sacc. Syll. Fung. 8: 493. 1889.

Belonidium culmicolum Phill. Brit. Discom. 148. 1897.

Apothecia scattered, or gregarious, sessile, or with a very short, stem-like base, at first rounded, expanding and becoming cup-shaped, or saucer-shaped, .2-1 $\mathrm{mm}$. in diameter, externally yellowish, or slightly reddish; hymenium pallid, yellowish, or rosy; asci clavate-cylindric, reaching a length of $120-150 \mu$ and a diameter of 12-15 $\mu, 8$-spored; spores fusiform, straight, or curved, becoming 3-septate, 4-5 × 21-40 $\mu$ : paraphyses filiform, somewhat enlarged above, $6 \mu$ in diameter, brown.

On dead stems of $A$ ndropogon and various other grasses.

Type locality: Europe.

Distribution: New Jersey; also in Europe.

Illustrations: Phill. Brit. Discom. pl. 5, f. 29.

Exsiccati: Ellis, N. Am. Fungi 850 (as Peziza vexata DeNot.)

\section{Doubtful and Excluded Species}

Belonium arabicolum Ellis \& Ev. Proc. Acad. Sci. Phila. 1894: 352. 1894. On stems of Arabis furcata, Mt. Paddo, Washington. This is not a discomycete. It looks like a Lophodermium.

Belonidium aurantiacum Rehm in Rab. Krypt-Fl. 13: 564. 1891. Reported by A. H. W. Povah from Michigan on dead culms of Calamagrostis. No material seen.

Belonium bicolor Ellis \& Ev. Jour. Myc. 8: 69. 1902. Apothecia sessile, nearly black when dry, less than $1 \mathrm{~mm}$. in diameter; spores 6-8 $615-20 \mu$, becoming 3-septate. On Eupatorium, Tuskegee, Alabama.

Belonium consanguineum Ellis \& Ev. Jour. Myc. 8: 70. 1902. On Ilex, Tuskegee, Alabama. According to Ellis this is close to B. bicolor. Each is known only from the type collection. Both need further study.

Belonium Delitschianum (Auersw.) Rehm in Rab. Krypt.-Fl. 13: 689. 1892; Peziza Delitschiana Auersw. in Rab. Fungi Eu. 912. 1886; Coronellaria Delitschiana Karst. Myc. Fenn. 1: 183. 1871. This species has been reported from Michigan by Dr. B. Kanouse on rotten logs. The type was recorded on Scirpus lacustris. No American material has been seen. In spite of the difference in habitat Dr. Kanouse regards the American and European specimens as identical. The spores are described as 3-septate and 6-7 $\times 25-40 \mu$. 
Belonidium fuscopallidum, Bres. Verh. Zool.-Bot. Ges. Wien 52: 434. 1902. This species has been reported from Michigan by Dr. B. Kanouse on wood of Acer sp. The apothecia are described as olive-green and the hyphae projecting beyond the margin of the apothecium; spores $4-6 \times 18-21 \mu$. No material has been seen.

Belonium fuscum Phill. \& Hark. Bull. Calif. Acad. Sci. 1: 23. 1884. Apothecia short-stipitate, sooty-brown; spores 1-3-septate, 15-20 $\mu$ long. On dead stems of Sanicula Menziesii, California.

Belonidium hirtipes A. L. Smith, Jour. Linn. Soc. 35: 14. 1901. Apothecia stipitate, $2 \mathrm{~mm}$. in diameter with stem $2 \mathrm{~mm}$. long; spores 3-septate, $5 \times 20-25 \mu$. On wood in Dominica. No material seen.

Belonidium junciseảum (Karst.) Rehm in Rab. Krypt-Fl. 1³:568. 1891; Mollisia junciseda Karst. Myc. Fenn. 1: 198. 1871. Reported from Michigan by Dr. B. Kanouse. No material seen.

Harknessiella purpurea (Phill. \& Hark.) Sacc. Syll. Fung. 8: 845. 1889; Phillipsiella purpurea Phill. \& Hark. Bull. Calif. Acad. Sci, 1: 23. 1884. On leaves of Garrya elliptica, California. The 3 -septate spores would place this in the genus Belonium. Compare Belonium Parksi Cash which occurs on the same host.

Belonidium sclerotii A. L. Smith, Jour. Linn. Soc. 35: 14. 1901. Spores described as 3 -septate, $3 \times 20 \mu$. On decorticated branch in Dominica.

29. BELONIOSCYPHA Rehm in Rab. Krypt.-Fl. $1^{3}: 743.1893$.

Apothecia seattered, stipitate, at first rounded, expanding and becoming campanulate, or turbinate, light-colored, externally smooth; asci clavate, or cylindric, 4-8-spored; spores elongated fusoid, becoming 3-septate, hyaline; paraphyses filiform.

Type species, Peziza Campanula Nees.

Asci 4-spored.

1. B. lactea.

Asci 8-spored.

2. B. miniata.

1. Belonioscypha lactea (Ellis \& Ev.) Seaver, comb. nov. (Plate 109.)

Helotium lacteum Ellis \& Ev. Jour. Myc. 4: 56. 1888.

IIelotium lacteum Ellis \& Ev. Proc. Acad. Sci. Phila. 1893: 145.1893.

Helotiella lactea Sacc. Syll. Fung. 11: 415. 1895.

Apothecia thickly gregarious, or subconfluent, stipitate, less than $1 \mathrm{~mm}$. in diameter, at first closed, opening and becoming turbinate, white with a tinge of yellow, amber when dry; hymenium concave, or nearly plane; stem short, stout, the length less than the diameter of the apothecium; asci cylindric-clavate, reaching a length of $75-80 \mu$ and a diameter of $5 \mu$, tapering into a long, stem-like base, 4-spored; spores 1-seriate, or overlapping 
and beconing 2-seriate, fusoid, of ten curved, $2-3 \times 10-15 \mu$; paraphy'ses filiform.

On decorticated wood.

Type locality: Cazenovia, New York.

Distribution: New York and Pennsylvania.

Excellent specimens of this species were sent to the writer by L. O. Overholts Dec. 19, 1927 with the following note: "This was collected in abundance, and I can get enormous quantities of it, growing as thickly scattered as the sample, for $20 \mathrm{ft}$. or more along the side of an old Liriodendron log." His specimens agree perfectly with the type in the herbarium of The New York Botanical Garden.

This species was described twice as a new species both based on the same specimen. Ellis did not mention the 4-spored character of the asci but his material is apparently so.

2. Belonioscypha miniata Kanouse, Mycologia 39:640. 1947.

Apothecia stipitate, .2-.4 mm. in diameter, flat when moist with the margin slightly inrolled, delicately roughened by granules of an amorphous deposit outlining the cup, creamy-yellow when fresh, drying pale-yellow; stem very short; asci cylindricclavate, reaching a length of $50-70 \mu$ and a diameter of $69 \mu$, 8-spored; spores usually 2-seriate, fusoid, straight, or slightly curved, subhyaline, 3 -septate, $2-3 \times 10-12 \mu$; paraphyses filiform not enlarged above.

On old leaves of Carex.

Type Locality: Lake Tahkenitch, Oregon.

Distribution: Known only from the type locality

Illustrations: Mycologia 39: 649, $f .4-6$.

30. GORGONICEPS Karst. Myc. Fenn. 1: 15. 1871. Belonopsis Sacc. Syll. Fung. 16: 752. 1902.

Apothecia sessile, or short-stipitate, soft and waxy, yellowish, or ochraceous, turbinate to subdiscoid, or scutellate, seldom exceeding 2-3 $\mathrm{mm}$. in diameter and often less than $1 \mathrm{~mm}$.; asci cylindric to clavate, typically 8-spored; spores elongate, filiform, fusiform, or vermiform, usually becoming multiseptate, hyaline; paraphyses filiform, enlarged above and often branched.

Type species, Gorgoniceps aridula Karst.

The genus A postemidium which is usually treated with the Geoglossaceae is close to the present genus and some regard them as 


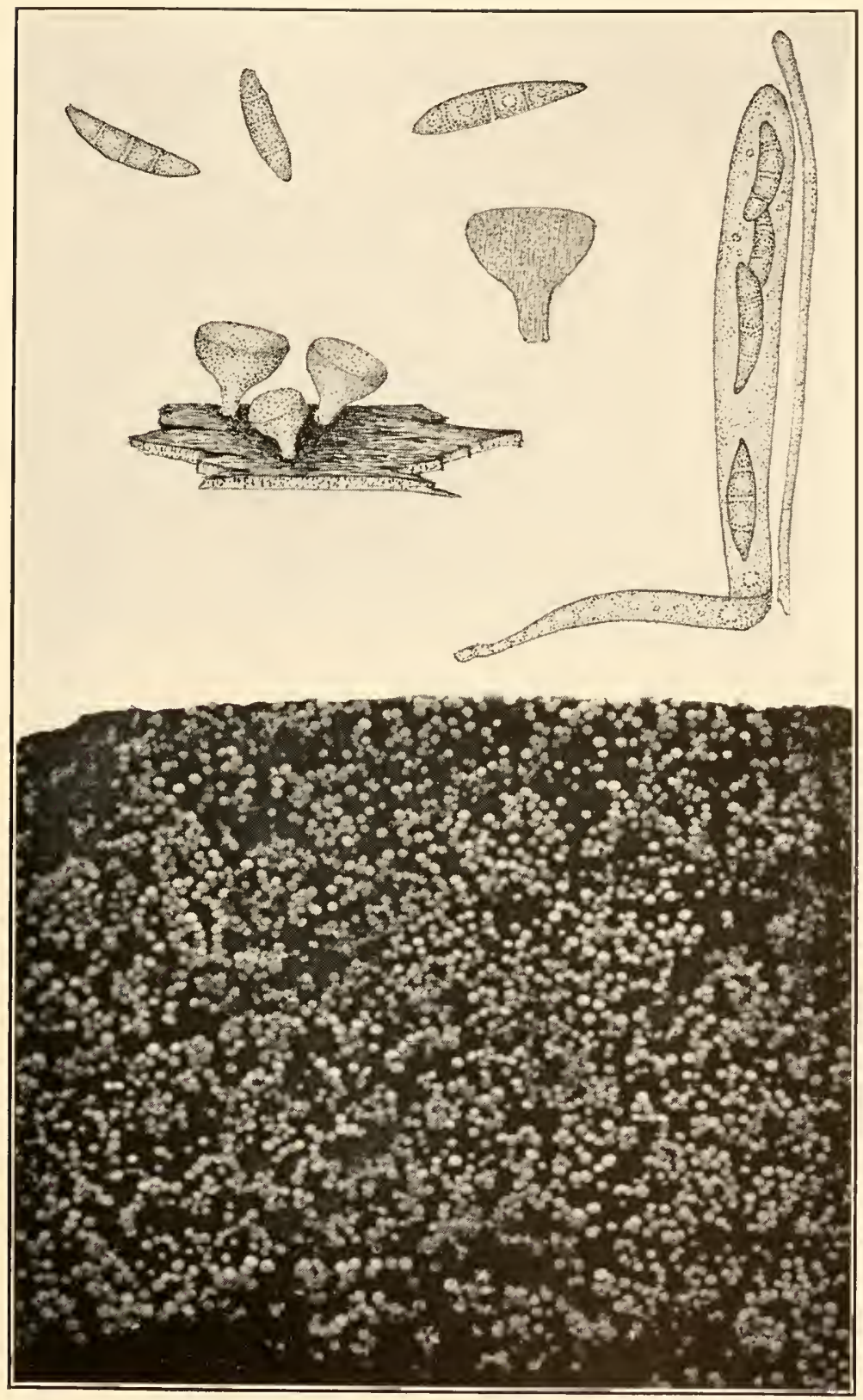

BELONIOSCYPHA LACTEA 

synonymous. Durand, however, treated them as distinct and retains the former with the Geoglossaceae because of its general resemblance to Vibrissea.

On coniferous plant tissues.

Spores 35-60 $\mu$ long.

On cones of conifers.

On bark and scales of Pinus.

1. G. Pumilionis.

2. G. aridula.

Spores 12-15 $\mu$ long, on pine needles.

3. G. ontariensis.

Not on coniferous plants.

Spores very slender, $1.5-2 \mu$ thick.

4. G. montanensis.

Spores stout, $3-10 \mu$ thick.
Spores 3-4 $\times$ 30-37 $\mu$, on rotten woorl.
5. G. iowensis.
Spores 5-7 $\times 40-45 \mu$, on wood and palms.
6. G. confluens.
Spores $9-10 \times 50-55 \mu$, on bamboo.
7. G. jamaicensis.

1. Gorgoniceps Pumilionis Rehm in Rab. Krypt-Fl. $1^{3}: 692$. 1892

Pezicula Pumilionis Rehm, Hedwigia 21: 115. 1882.

Dermatella Pumilionis Sacc. Sy.ll. Fung. 8: 490. 1889.

Apothecia gregarious, sessile, or contracted into a short, stem-like base, at first rounded, expanding and becoming scutellate, pale-cinereous, becoming brownish-yellow, reaching a diameter of .1-.3 mm.; asci clavate, reaching a length of 75-80 $\mu$ and a diameter of $6-7 \mu$, attenuated above and gradually tapering below into a stem-like base; spores filiform, becoming septate (the number of septa usually 3 or 4), 2-2.5 $\times 35-40 \mu$; paraphyses filiform, about $1.5 \mu$ in diameter.

On cones of conifers.

Type locality : Europe.

Distribution: Colorado; also in Europe.

Exsiccati: Clements, Crypt. Form. Colo. 290.

The only American specimen of this species seen is the Clements specimen referred to above on scales of Picea sp.

2. Gorgoniceps aridula Karst. Myc. Fenn. 1: 185. 1871. (Plate 110, Fig. 1.)

Apothecia gregarious, or scattered, sessile, or contracted into a very short, sten-like base, bluish-hyaline, when dry palebrownish, reaching a diameter of .3-.8 mm.; hymenium bluishhyaline, or pallid, plane, or convex; asci clavate, attenuated above and tapering below into a stem-like base, reaching a length of $100-125 \mu$ and a diameter of $15 \mu$; spores fasciculate, filiform, straight, or curved, becoming septate (the number 
difficult to determine but apparently 16 to 20 ), reaching a length of $65 \mu$ and a diameter of $2.5-3 \mu$; paraphyses filiform about $2 \mu$ in diameter.

On coniferous bark and scales of Pinus pungens.

Type locality: Europe.

Distribution: Pennsylvania; also in Europe.

Illustrations: E. \& P. Nat. Pfl. $1^{1}: 208, f .163$ A; Rab. Krypt.-Fl. $1^{3}$ : 652,f. 1-5; Mycologia 38: 551 (upper figure).

The only American specimen of this species seen is one collected by Dr. L. O. Overholts and P. Spaulding (No. 10795) in Pennsylvania. The plants are minute and the species is probably more common than indicated by the material at hand.

3. Gorgoniceps ontariensis (Rehm) Höhn. Mitt. Inst. Hochs. Wien 3: 106. 1926.

Pezizella ontariensis Rehm, Ann. Myc. 11: 167. 1913.

Apothecia scattered, sessile, at first globose, expanding becoming cup-shaped, finally discoid, contracted at the base, $.5-1.5 \mathrm{~mm}$. in diameter, pale ycllowish-white, externally floccose; hymenium plane or nearly so, pale rose-colored; asci clavate, reaching a length of $45 \mu$ and a diameter of 6-7 $\mu, 8$-spored; spores filiform, overlapping in the ascus, $1 \times 12-15 \mu$; paraphyses filiform, hyaline, $1.5 \mu$ in diameter below, enlarged above to $3 \mu$.

On needles of Pinus resinosa.

Type locality: East Shore of Lake Huron, Ontario.

Distribution: Known only from the type locality.

Exsiccati: Rehm, Ascom. 2030 (apparently part of type material).

4. Gorgoniceps montanensis (Kanouse) Seaver, comb. nov.

Belonopsis montanensis Kanouse, Mycologia 33: 461. 1941.

Apothecia superficial, $1.5-4.5 \mathrm{~mm}$. in diameter, at first globose and closed, finally expanding and becoming plane, or slightly convex, the margin irregular with patches of the remains of the hymenial covering, broadly sessile, soft-waxy, solitary, gray-brown; hymenium orange when dry, slightly paler when moist; asci cylindric-clavate, long-stemmed, 8-spored, reaching a length of 130-155 $\mu$ and a diameter of 9-12 $\mu$; spores needleshaped, straight, or slightly curved, $1.5-2 \times 38-50 \mu$, becoming about 7 -septate; paraphyses filiform, twisted into coils or spirals at the apices, forming a thin epithecium. 


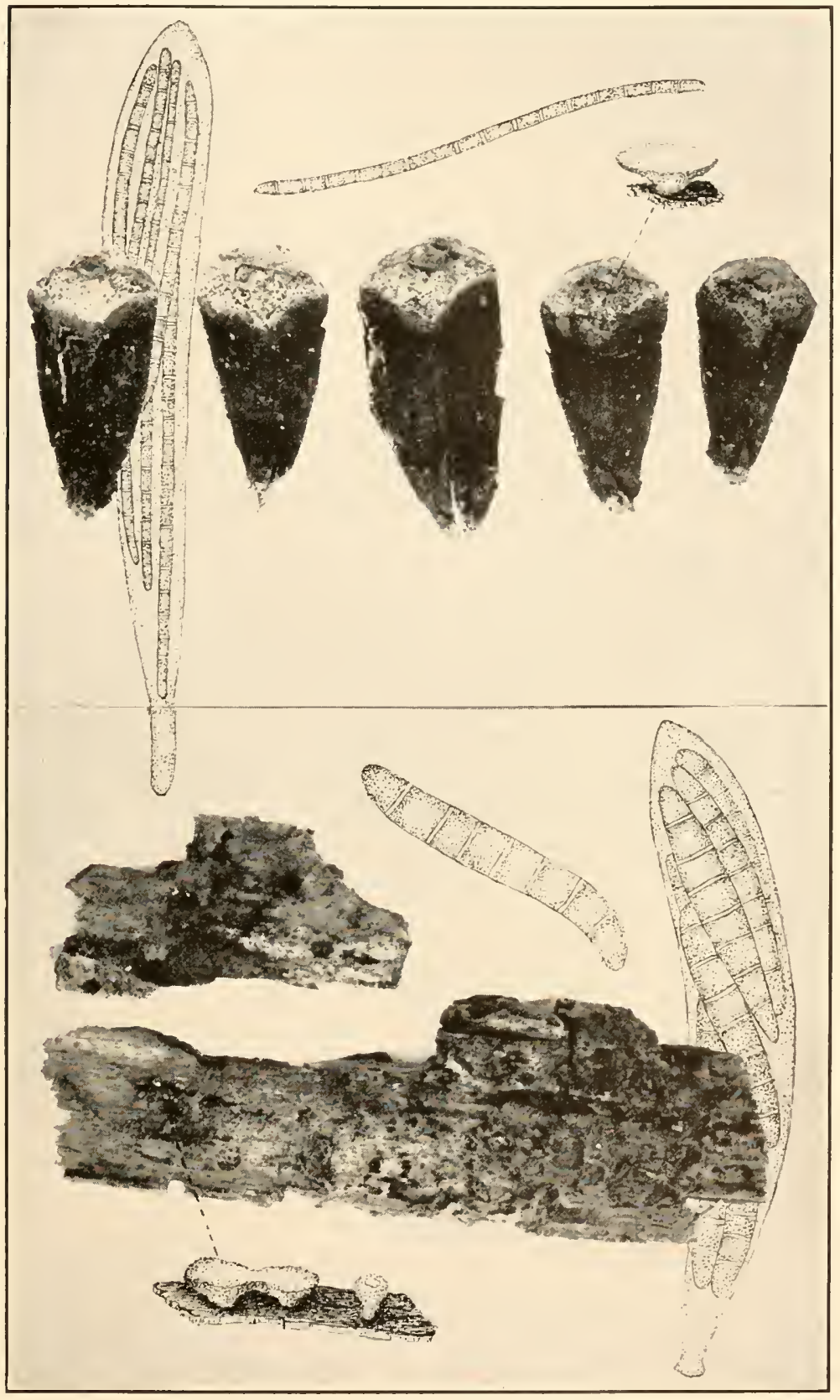

1. GORGONICEPS ARIDULA

2. GORGONICEPS CONFLUENS 

On fallen leaves of beech and on fir needles.

Type Locality: Echo Iake, Flathead National Forest, Montana.

Distribution: Known only from the type locality.

5. Gorgoniceps iowensis Rehm, Ann. Myc. 4: 338. 1906.

Apothecia scattered, at first subglobose, sessile, or contracted into a very short stem, expanding and becoming patellate, whitish, with a slight grayish-green tint when try, pale-brownish, reaching a diameter of .2-.5 mm.; asci clavate, reaching a length of $80-100 \mu$ and a diameter of $10-12 \mu$; spores subcylindric, or clavate, straight, or curved, becoming 7-septate, hyaline, 3-4 $\times$ 30-37 $\mu$; paraphyses filiform, slightly enlarged above.

On rotten wood.

Type locality: Mt. Pleasant, Iowa.

Distribution: New York and Iowa.

Illustration: Bull. Lab. Nat. Hist. State Univ. Iowa 6: pl. $26, f .2$.

6. Gorgoniceps confluens Seaver \& Waterston, Mycologia 32: 399. 1940. (Plate 110, Fig. 2.)

Apothecia gregarious, occasionally crowded and several fusing together, sessile, or contracted into a very short, stem-like base, whitish or bluish-white, remaining light-coloreel, or becoming darker when dried, reaching a diameter of $.5 \mathrm{~mm}$, soft and waxy; hymenium plane, or slightly convex, similar in color to the outside of the apothecium; asci broad-clavate, with a very short, stem-like base, attenuated at the apex, reaching a length of $100 \mu$ and a diameter of $14 \mu, 8$-spored; spores bunched together and overlapping, cylindric, fusoid, or subclavate, straight, or more often curved or double curved, becoming 7 -septate, $5-7 \times 40$ $45 \mu$; paraphy'ses filiform, about $2 \mu$ in diameter.

On rotten wood and on palm stems, Sabal.

TyPE LOCALITy: Bermuda.

Distribution: Known only from the type locality.

Illustrations: Mycologia 38: 551 (lower figure).

Type collected in Bermuda by Stewardson Brown, N. L. Britton and Fred J. Seaver (No. 1487) Nov. 29-Dec. 14, 1912. This is very similar to $G$. iowensis Rehm, which was described from material collected by the author in Iowa. The spores of the Bermuda specimens seem to be larger. Also collected in Paget Marsh on stems of native palm by Seaver \& Waterston. 
7. Gorgoniceps jamaicensis Seaver, Mycologia 38: 552. 1946.

Apothecia gregarious, or crowded, occasionally several coalescing, sessile or nearly so, becoming patellate, in dried specimens pale yellowish-amber, semitranslucent, reaching a diameter of $.5 \mathrm{~mm}$.; hymenium plane, or slightly concave; asci clavate, 8 spored, reaching a length of $140 \mu$ and a diameter of $20 \mu$, tapering below into a short, stem-like base; spores fasciculate, cylindric with the ends attenuated, reaching a length of $50-55 \mu$ and a diameter of $9-10 \mu$, becoming 7-septate; paraphyses filiform, about $2 \mu$ in diameter.

On bamboo, Bambusa vulgaris.

Type collected by W. A. and Edna Murrill in Chester Vale, Jamaica, December 21-24, 1908, altitude 3000-4000 ft. (No. 311).

This seems to differ from our Bermuda species in the much larger spores and asci.

\section{Doubtful Species}

Gorgoniceps dinemasporioides (Ellis \& Ev.) Sacc. Syll. Fung. 8: 506. 1889; Peziza dinemasporioides Ellis \& Ev. Jour. Myc. 1: 42. 1885. This was described as a Peziza by Ellis and placed in the genus Gorgoniceps by Saccardo because of the filiform spores. The spores are not filiform but fusoid and the asci appear to be borne in thin-walled perithecia, clothed with long Chaetomium-like hairs. In the opinion of the author this is not a cup-fungus at all.

31. POCILlUM DeNot. Conm. Critt. Ital. 1:361. 1864.

Apothecia stipitate, or substipitate, cup-shaped, or expanded; asci clavate-cylindric, 8-spored; spores filiform, hyaline.

Type species, Helotium Cesatii Mont.

This genus is close to Gorgoniceps apparently differing only in the stipitate, or substipitate character of the apothecia which ordinarily is not considered a very reliable one. So far as observed only one species has been reported within our range.

1. Pocillum hypophyllum (Berk. \& Curt.) Sacc. Syll. Fung. 8: 606. 1889.

Peziza hypophylla Berk. \& Curt.; Berk. Jour. Linn. Soc. 10: 369. 1868.

Apothecia hypophyllous, short-stipitate, externally brown, crateriform, the margin sinuate; hymenium livid; spores filiform.

On the under side of some leaf among the brown, velvety down.

Type locality: Cuba.

Distribution: Known only from the type locality. 
No material has been seen and the above is all that is known of this species. It was originally placed in the subgenus $\mathrm{Mol}$ lisia.

32. APOSTEMIDIUM Karst. Myc. Fenn. 1: 15, 186. 1871. Gorgoniceps Karst. Myc. Fenn. 1: 15, 185. (in part). 1871.

Vibrissea Phill. Trans. Linn. Soc. II. 2: 8. 1881.

Apothecia sessile, turbinate, or convex, soft-waxy, or subgelatinous; hymenium spread on the upper, convex, or plain surface, sterile below; asci narrowly cylindric, opening by a pore, 8-spored; spores in a parallel fascicle in the ascus, hyaline, filiform, many-septate, nearly as long as the ascus; paraphyses present.

Type species, Peziza fiscella Karst.

This genus is sometimes treated with the Geoglossaceae next to Vibrissea which it resembles in spore characters but in the opinion of the writer scarcely belongs there.

Paraphyses longer than the asci, repeatedly forked near the apices.

1. A. Guernisaci.

Paraphyses equaling or scarcely exceeding the asci, sinple or rarely forked.

2. A. vibrisseoides.

1. Apostemidium Guernisaci ( $\mathrm{Cr}$. ) Durand, Ann. Myc, 6: 456. 1908. (Plate 111.)

Iribrissea Guernisaci Crouan, Ann. Sci. Nat. IV. 7: 176. 1857.

Gorgoniceps Guernisaci Sacc. Syll. Fung. 8: 505. 1889.

Gorgoniceps turbinulata Rehm, Ann. Myc. 2: 353. 1904.

Apothecia solitary, or gregarious, sessile by a rather broad base, turbinate, or convex; hymenium plain to convex, bluishpallid to orange-ochraceous, $1-4 \mathrm{~mm}$. in diameter, even, or sometimes wrinkled, often with a dimple in the center, darkbrownish below, somewhat furfuraceous; asci long-cylindric, apex rounded, reaching a length of $225-300 \mu$ and a diameter of 5-6 $\mu$; 8-spored; spores in a parallel fascicle in the ascus, hyaline, slenderly filiform, multiseptate, $1 \times 200-250 \mu$; paraphyses numerous, filiform, hyaline, longer than the asci, the apical portion (about as much as projects beyond the asci) repeatedly forked or fasciculately branched, the tips abruptly pyriformthickened, hyaline, $4-5 \mu$ thick.

On dead sticks and wood in water.

Type Locality: Europe.

Distribution: New York and New England to Washington. 
Illustrations: Ann. Sci. Nat. IV. $7:$ pl. 4, f. 24-27; Pat. Tab. Fung.f. 369; Ann. Myc. 6: pl. 11, f. 115-118.

Exsiccati: Ellis \& Ev. N. Am. Fungi 2738.

The long, filiform spores often protrude at maturity, giving the hymenium a white, feathery appearance. This interesting species has been encountered by the writer but once in New York.

2. Apostemidium vibrisseoides (Peck) Boud. Ann. Myc. 4: 240. 1906.

Helotium vibrisseoides Peck, Ann. Rep. N. Y. State Mus. 32: 48. 1879.

?Vibrissea turbinata Phill. Trans. Linn. Soc. II. 2: 8. 1881.

?Gorgoniceps turbinata Sacc. Bot. Cent. 18: 219.1884.

Gorgoniceps vibrisseoides Sacc. Syll. Fung. 8: 505. 1889.

? A postemidium obconicum Kanouse, Papers Mich. Acad. Sci. 21: 97. 1936.

Apothecia gregarious, sessile, turbinate, $2-3 \mathrm{~mm}$. in diameter; hymenium plain to convex, varying in color from bluish-pallid to yellowish, or ochraceous; asci reaching a length of 275-300 and a diameter of 5-6 $\mu, 8$-spored; spores in a parallel fascicle in the ascus, long-filiform, hyaline, multiseptate, about $1 \times 250 \mu$; paraphyses not numerous, slender, $1-1.5 \mu$ thick below, simple, or occasionally forked, the apical portion clavate-thickened, colored, up to $6 \mu$ thick, about as long as the asci.

On decaying sticks lying in the water.

Type locality: New York.

Distribution: New Hampshire to New York.

Illustrations: Bull. N. Y. State Mus. $1^{2}:$ pl. 2,f. 7-9; Trans. Linn. Soc. II. 2: pl. 2, f. 14-18; Ann. Myc. 6: pl. 11,f. 119-120.

Apostemidium obconicum is said to differ in the color and more stipitate character of the apothecia. The writer doubts that the characters are dependable.

33. PhaEOHelotium Kanouse, Papers Mich. Acad. Sci. 20: 75.1935.

Apothecia superficial, sessile to stipitate, at first turbinate, opening to a disk, finally convex and slightly umbilicate, softwaxy, drying brittle to chalky, externally pulverulent, brightcolored; asci cylindric-clavate, 8-spored; spores ellipsoid to fusoid, straight, or slightly bent, 1-septate, brown; paraphyses filiform.

Type species, Pharohelotium flarum Kanouse. 


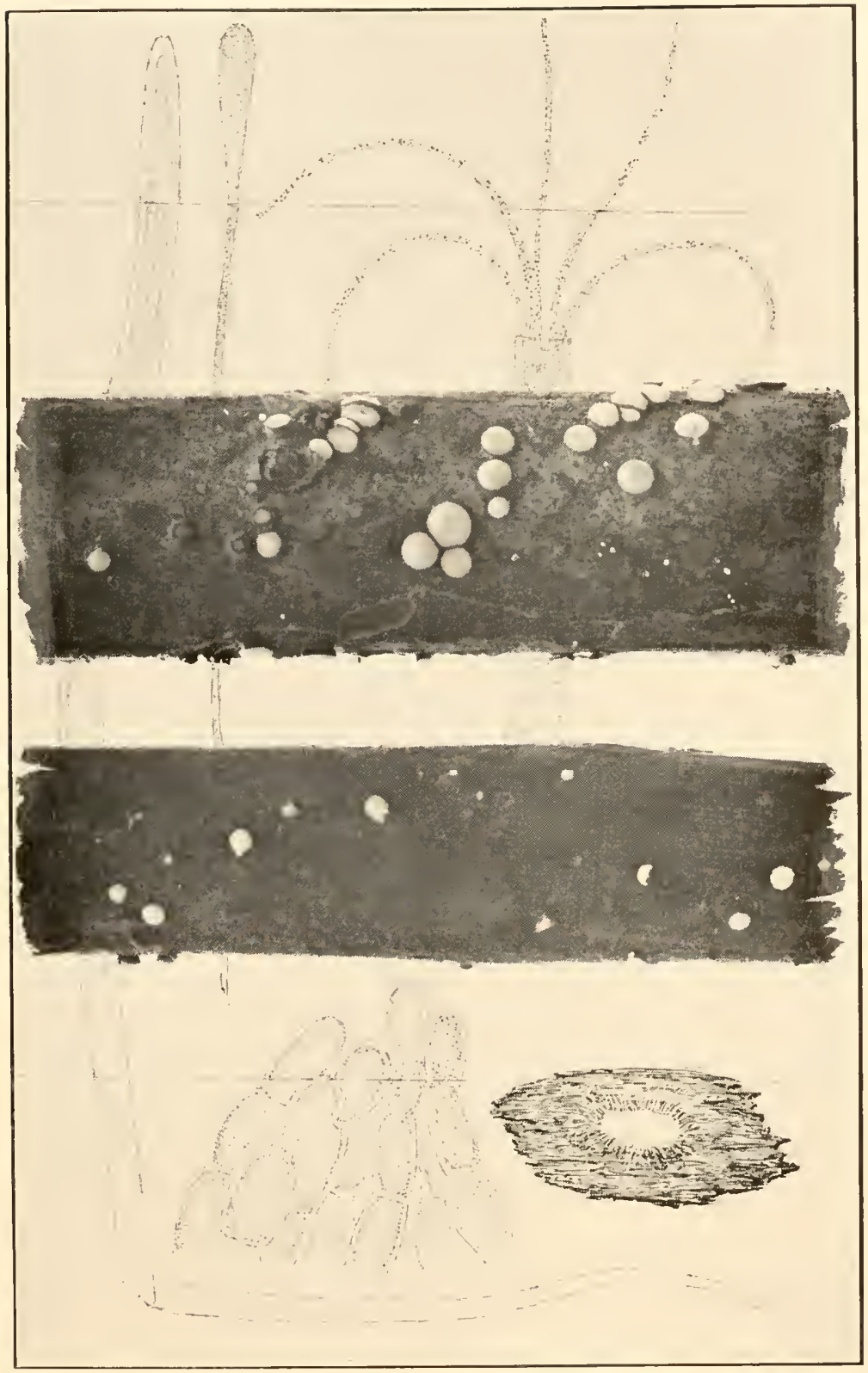

APOSTEMIDIUM VIBRISSEOIDES 

1. Phaeohelotium flavum Kanouse, Papers Mich. Acad. Sci. 20: 75. 1935.

Apothecia as above, 1-2 $\mathrm{mm}$. broad and 1-1.5 mm. high; hymenium bright-yellow to orange-yellow, margin white to paleyellow; asci reaching a length of $100-125 \mu$ and a diameter of 8-9 $\mu$; spores with two to four oil-drops, $4-5 \times 14-16 \mu$, brown when mature; paraphyses $2-3 \mu$ in diameter at their apices.

On decaying wood.

Type locality: Harbor Springs, Michigan.

Distribution: Michigan.

Illustrations: Papers Mich. Acad. Sci. 20 : pl. 15, f. 4.

34. PSEUDOPEZIZA Fuckel, Symb. Myc. 290. 1869.

Drepanopeziza (Kleb.) Höhn. Ann. Myc. 15: 332. 1917.

Pseudopesiza subg. Drepanopesiza Kleb. Zeitsch. Pflanzenkr. 16: 76. 1906.

Apothecia erumpent, usually on living leaves, gregarious, minute, soft and fleshy, the margin often crenulate; asci cylindricclavate, 4-8-spored; spores ovoid, simple, hyaline; paraphyses filiform and often much curved.

Type species, Ascobolus Trifolii Biv.-Bern.

On leguminose plants.

On leaves of Trifolium.

1. P. Trifolii.

On leaves of Medicago.

2. P. Medicaginis.

Not on leguminose plants.

On Ranunculus.

3. P. singularis.

On Gentiana.

4. P. Holwayi.

On Galium.

5. P. repanda.

On Ribes.

6. P. Ribis.

On Populus alba.

7. P. Populi-albae.

1. Pseudopeziza Trifolii (Biv.-Bern.) Fuckel, Symb. Myc. 290. 1869.

Ascobolus Trifolii Bivona-Bernardi, Stirp. Rar. Sic. 4: 27.1816.

Peziza Trifoliorum Lib. Pl. Crypt. Ard. 324. 1837.

Phyllachora Trifolii Sacc. Atti Soc. Veneto Sci. Nat. Padova 2: 145. 1873.

Phacidium Trifolii Gill. Champ. Fr. Discom. 170. 1886.

Trochilia Trifolii DeNot.; Rehm in Rab. Krypt.-Fl. 1³: 597. 1891.

Mollisia Trifolii Phill. Brit. Discom. 199. 1887.

Apothecia occurring on brown spots 1-3 mn. in diameter on living leaves, submerged, becoming erumpent, at first closed, opening and becoming nearly flat, .3-.5 mm. in diameter, brownish, waxy; asci clavate, reaching a length of $60-80 \mu$ and a diameter of 10-14 $\mu, 8$-spored; spores ellipsoid, or ovoid, simple, 
usually with one oil-rlrop, $5-7 \times 10-15 \mu$; paraphyses filiform, enlarged above, $3-4 \mu$ thick.

On living leaves of species of Trifolium.

Trpe locality: Europe.

Distribution: Probably throughout North America where clover grows; also in Europe.

Illustrations: Bivona-Bernardi, Stirp. Rar. Sic. 4: pl. 6 : f. 3; Rab. Krypt.-F1. 13: 594, f. 1-6; E. \& P. Nat. Pfl. 1': $216 . f$ 168. A-C; Briosi \& Cavara, Fung. Par. 68.

Exsiccati: Ellis \& Ev. N. Am. Fungi 2626; Rab.-IVinter-Paz. Fungi Eu. 3872 (from California); Barth. Fungi Columb. 1755, 3164; Clements, Crypt. Form. Colo. 285; Seym. \& Earle, Econ. Fungi 511; Rehm, Ascom. 61tc (from London, Canada).

Nannfeldt (Nova Acta Soc. Sci. Upsal. IV. 8: 179.) regards the form on Trifolium arvense as distinct and lists it under the name Pseudopeziza Trifolii-ariensis.

2. Pseudopeziza Medicaginis (Lib.) Sacr. Syll. Fung. 8: 724. 1889.

Phacidium Medicaginis I.ib. Pl. (rypt. Ard. 176. 1832.

?Pyrenopesiza . Medicaginis Fuckel, Symb. Myc. 295. 1869.

Phyllachora Medicaginis Sacc. Malpighia 1: 455. 1888.

Apothecia minute, expanded and subdiscoid, ochraceousbrown, seated on yellowish, suborbicular spots, opening with a laciniate aperture through the epiclermis, .5-1 mm. in diameter; asci stipitate, subcylindric, attenuated above, 8-spored, reaching a length of $75-80 \mu$ ancl a diameter of $10 \mu$; spores 2-seriate, ovoid, simple, hyaline, 4-6×8-11 $\mu$; paraphyses filiform-clavate.

On living or dying leaves of species, of Medicago, Trigonella and Melilotus.

Trye locality: Europe.

Distribution: Throughout North America or wherever the hosts are grown.

Ihustrations: Briosi \& Cavara, Fungi, Par. 262.

Exsiccati: Ellis, N. Am. Fung. 1319; Ellis \& Ev. N. Am. Fungi 1319, 2627, 3059, Fungi Columb. 533; Barth. Fungi Columb. 2554, 3050, 3927, 4250, 4345, 4551, Seaver, N. Dak. Fungi 18; Criff. West Am. Fungi 337; Seym. \& Earle, Econ. Fungi 506; Solh. Myc. Sax. Exsicc. 8.

Nannfeldt (Nova Arta Soc. Sci. Upsla. IV. 8: 179) regards Fuckel's material as distinct and assigns the new name Pseudopeziza Jonesii to it. 
Sydow (Ann. Myc. 34:396) regards the form on Melilotus alba as distinct and describes the species Psendopeziza Meliloti.

3. Pseudopeziza singularis (Peck) Davis, Trans. IVisc. Acad. Sci. $17: 863.1914$.

Pesiza singularis Peck, Ann. Rep. N. Y. State Mus. 35: 1+2. 1884. Mollisia singularis Sacc. Sy.ll. Fung. 8: 328, 1889.

Apothecia minute but often forming irregular, confluent patches $1 \mathrm{~mm}$. Or more in diameter, seated on pallid spots, dingy-gray, or pale amber-colored; lymenium plane, or convex; asci clavate, reaching a length of 50-70 $\mu$ and a diancter of $7-10 \mu$; spores 1-seriate or partially 2-seriate, clongate-ellipsoid, $45 \times 10-15 \mu$; paraphyses filiform.

On living leaves of species of Ranunculus.

Type Locality: East Berne, New York.

Distributios: New York and Wisconsin.

Exsiccati: Davis, Fungi Mise. 35.

4. Pseudopeziza Holwayi P. Henn. Hedwigia 41: Beibl. (64). 1902.

Apothecia bypophyllous, erumpent, at first subglobose. finally cup-shaped to discoid, sessile, the margin brownish-black, .3 to $.9 \mathrm{~mm}$. in diameter; hymenium plane or nearly so, cinereousviolet; asci clavate, or subfusoicl, 8-spored, reaching a length of 50-80 $\mu$ and a diameter of 10-14 $\mu$; spores 2-seriate, ellipsoid, or fusoid, $4-5 \times 15-21 \mu$; paraphyses simple, filiform, thickenerl above.

On living leaves of Gentiana.

Type Locality: Mexico.

Distribution: Known only from the type locality.

P. Hennings states that it is not minkely that at maturity the spores become 1 -septate which, if true, would place it in the genus Fabraea.

5. Pseudopeziza repanda (Fries) Karst. Acta Soc. Fauna Fl. Fenn. $2^{6}: 161.1885$.

Phacidium repandum Fries, Vet. Akad Handl. 1819: 108. 1819.

Leptotrochila repanda Karst. Myc. Fenn. I: 246. 1871.

Apothecia at first lightly submerged, soon becoming superficial but deep seated in the tissues of the host, opening with a laciniate margin, $.3 \mathrm{~mm}$. in diameter, externally greenish-black; 
hymenium concave, dingy-brown; asci clavate, reaching a length of 50-60 $\mu$ and a diameter of 6-7 $\mu, 8$-spored; spores 2-seriate, or partially so, fusoid, 3-4 $\times 16-12 \mu$; paraphyses filiform.

On living leaves of Galium and occasionally on other herbaceous plants.

Type locality: Europe.

Distribution: Oregon; also in Europe.

Illustrations: Alb. \& Schw. Consp. Fung. pl. 4, f. 6 (as Xyloma herbarum.)

The only American specimens seen are two collected in Oregon on Galium boreale and Galium triflorum. The fungus seems to agree well with European specimens.

6. Pseudopeziza Ribis Rehm; Kleb. Cent. Bakt. II. 15: 336. 1905.

Gloeosporium Ribis Kleb. Zeit. Pflanzenk. 16: 76. 1906. Drepanopeziza Ribis Höhn. Ann. Myc. 15: 332. 1917.

Apothecia erumpent, with a short, stout, stem-like base, becoming nearly plane, $.25 \mathrm{~mm}$. in diameter; asci clavate, reaching a length of $80-100 \mu$ and a diameter of 18-20 $\mu$, 8-spored; spores ovoid, $7-8 \times 12-17 \mu$; paraphyses filiform, branched, scarcely enlarged above.

On leaves of species of Ribes.

Type locality : Europe.

Distribution: Ontario and Oregon; also in Europe.

7. Pseudopeziza Populi-albae Kleb. Haupt.-Nebenfr. Ascom. 344. 1918.

Drepanopeziza Populi-albae Nannf. Nova Acta Soc. Sci. Upsal. IV. 8: 170. 1932.

Trochilia populorum Desm. Bull. Soc. Bot. Fr. 4: 858. 1857. Sensu Edgerton, Mycologia 2: 169.1910.

Apothecia at first somewhat globose, expanding and becoming plane, or slightly concave, surrounded by the upturned fragments of the ruptured epidermis, .1-.2 mm. in diameter; asci clavate, reaching a length of $60-80 \mu$ and a diameter of $12-14 \mu, 8$-spored; spores 1-2-seriate, ellipsoid, usually with two large oil-drops, hyaline, 5-7.2 × 12-16 $\mu$; paraphyses filiform, somewhat enlarged above.

On leaves of Populus alba.

Type locality: Europe.

Distribution: New York and Georgia; also in Europe. 
Illustrations: Mycologia 2: 170, f. 1 -5; 172, f. 6, 7.

The conidial stage Marsonia Castagnei (Desm. \& Mont.) Magn. is said to be widely distributed in the United States but the perfect stage rarely collected.

\section{Doubtful Species}

Pseudopeziza Bistortae (Lib.) Fuckel, Symb. Myc. 290. 1869. This species has been reported from Alaska in Harriman Alaska Exped. 5: 23, on Polygonum viviparum. No material seen.

Pseudopesiza Cerastiorum Arenariae Sacc.; Sacc. Peck, \& Trelease in Harriman Alaska Exped. 5: 23. 1904. This variety was described by Saccardo from material collected on Yakutat Bay, Alaska on dead leaves of Arenaria lateriflora. Said to differ from the species in its larger spores, $4-4.5 \times 1+-16 \mu$.

\section{FABRAEA Sacc. Michelia 2:331. 1881.}

Diplocarpon Wolf, Bot. Gaz. 54: 231. 1912.

Apothecia at first submerged, becoming superficial, sessile, becoming expanded and subdiscoid, soft and fleshy; asci cylindric to clavate, usually 8-spored; spores ellipsoid, or ovoid, becoming 1-septate; paraphyses filiform.

Type species, Phacidium congener Ces.

Occurring on herbaceous plants.

On Ranunculus.

1. F. Ranunculi.

On Fragaria.

2. F. Earliana.

On woody plants.

On Rosa.

3. F. Rosae.

On Pyrus, Amelanchier, and Cydonia.

4. F. maculata.

1. Fabraea Ranunculi (Fries) Karst. Acta Soc. Fauna Fl. Fenn. $2^{6}: 161.1885$.

Dothidea Ranunculi Fries, Syst. Myc. 2: 562. 1823.

Phlyctidium Ranunculi Wallr. Fl. Crypt. Germ. 2: 420. 1833.

Excipula Ranunculi Rab. Deutsch. Krypt.-F1. 1: 153. 1844.

Phacidium Ranunculi Lib. Pl. Crypt. Ard. 69. 1830.

Pseudopeziza Ranunculi Fuckel, Symb. Myc. 290. 1869.

Mollisia Ranunculi Phill. Brit. Discom. 200. 1887.

Phacidium litigiosum Rob. \& Desm. Ann. Sci Nat. 1II. 8: 181. 1847.

Fabraea litigiosa Sacc. Syll. Fung. 8: 735. 1889.

Apothecia occurring for the most part on discolored spots on the under side of the leaves, at first submerged, becoming erumpent and finally superficial, at first rounded, later cupshaped, then nearly plane, externally brown, or brownish-black; hymenium concave to plane, dull-gray, or brownish; asci clavate, 
reaching a length of 60-85 $\mu$ and a diameter of $12-14 \mu, 8$-spored; spores ellipsoid to ovoid, at first simple, becoming 1 -septate, 5-6 $\times 12-15 \mu$; paraphyses filiformı $3 \mu$ in diameter above.

On the under side of living leaves of Ranunculus.

Type locality: Europe.

Distribution: Maine to Toronto and Nebraska.

Exsiccati: Barth. Fungi Columb. 2625; Reliq. Farlow. 638.

2. Fabraea Earliana (Ellis \& Ev.) Seaver, comb. nov.

Leptothyrium Fragariae Lib. Pl. Crypt. Ard. 162. 1832.

Ascochyta colorata Peck, Ann. Rep. N. Y. State Mus. 38: 94. 1884.

Peziza Earliana Ellis \& Ev. Bull. Torrey Club 11: 74. 1884.

Marsonia Fragariae Sacc. Malpighia 10: 276. 1896.

Diplocarpon Earliana Wolf, Jour. Elisha Mitch. Sci. Soc. 39: 158. 1924.

Mollisia Earliana Sacc. Syll. Fung. 8: 328. 1889.

Conidial stage forming reddish, or purplish spots on the leaves of the host; acervuli black, usually epiphyllous; conidia unsymmetrical, 1-septate, the upper cell larger, constricted at the septum, 5-7 $\times 18-30 \mu$.

Apothecia discoid, mostly hypophyllous, dark-brown to black, reaching $.3 \mathrm{~mm}$. in diameter, at first submerged, becoming erumpent at maturity, splitting with an irregular margin, closing when dry; hymenium yellow to brown; asci clavate, reaching a length of 55-70 $\mu$ and a diameter of $15-20 \mu$; 8-spored; spores ellipsoid, curved, hyaline, unequally 2-celled, the upper larger, constricted at the septum, 4-6 × 18-28 $\mu$; paraphyses capitate.

On fallen leaves of Fragaria sp.

Type locality: Anna, Illinois.

Distribution: Widely distributed in eastern United States and Canada.

Illustrations: Ann. Rep. N. Y. State Mus. 38: pl. 2, f. 9 , 10; Jour. Elisha Mitch. Sci. Soc. 39: pl. 9-15; Tech. Bull. N. C. Agr. Exp. Sta. 28: pl. 7, f. 3-5; Ber. Deutsch. Bot. Ges. 42: 193, f. $9-13$.

Exsiccati: Ellis, N. Am. Fungi $20+3$.

\section{Fabraea Rosae (IVolf) Seaver, comb. nov.}

Asteroma Rosae Lib. Mem. Soc. Linn. Paris 5: 405. 1827.

Actinonema Rosae Fries, Summa Veg. Scand. 424. 1849.

Dicoccum Rosae Bonord. Bot. Zeit. 11: 282. 1853.

Marsonia Rosae Trail, Trans. Crypt. Soc. Scotland 14: 46. 1889.

Diplocarpon Rosae Wolf, Bot. Gaz. 54: 231. 1912.

Conidial stage forming large, dark-brown, or blackish spots, sometimes becoming confluent and involving the entire leaf; 
conidia formed on erumpent acervuli, 1-septate and constricted at the septum, 5-6 6 18-25 $\mu$.

Apothecia epiphyllous, sphaerical to discoid, $.25 \mathrm{~mm}$. in diameter, at first closed, opening with a stellate aperture; asci subclavate, reaching a length of $70-80 \mu$ and a diameter $15 \mu$, 8-spored; spores ellipsoid, hyaline, unequally 2-celled, constricted at the septum, 5-6 $\times 20-25 \mu$; paraphyses filiform, enlarged at their apices.

On leaves of Rosa sp.

Type locality: Auburn, Alabama.

Distribution: The conidial stage, black-spot of rose, is widely distributed wherever the rose is cultivated.

Illustrations: Mem. Soc. Limn. Paris 5: pl. 5, f. 3; Bot. Gaz. 54: pl. 13 .

4. Fabraea maculata (Lév.) Atkinson, Science N. S. 30:452. 1909.

Entomosporium maculatum Lév. in Moug. \& Nestl. Stirp. Crypt. 1457. 1860.

Apothecia minute, inconspicuous in dried specimens, when moist swelling up and making their appearance through the ruptured epidermis, often ellipsoid in form; asci 8 -spored; spores hyaline, 1-septate.

On leaves of Pyrus, Amelanchier and Cydonia.

Type locality: New York.

Distribution: Widely distributed in North America on cultivated pear and quince.

When Atkinson published a preliminary report of this he promiset a more complete description later but this apparently was never done.

\section{Doubtful Species}

Fabraea cincta Sacc. \& Scalia; Sacc. Peck, \& Trelease in Harriman Alaska Exped. 5: 23. 1904. On suborbicular or irregular spots 1-2 mm. in diameter; apothecia erumpent, $300-400 \mu$ in diameter; asci $18-20 \times 70-90 \mu$, 8spored; spores elongate-ellipsoid, 5-6.5 × 15-20 $\mu$; paraphyses filiform with capitate apices. On fading leaves of Rubus, Yakutat Bay, Alaska. No material has been seen.

36. PESTALOPEZIA Seaver, Mycologia 34:300. 1942.

Apothecia superficial, sessile, or subsessile, at first subglobose, becoming expanded and subdiscoid, externally pruinose, or tomentose, light-colored; hymenium becoming nearly plane, 
dark-colored, almost black; asci 8-spored, subcylindric; paraphyses filiform and rather strongly enlarged.

With a Pestalotin as its conidial stage.

Type species, Dermatea brunneopruinosa Zeller.

On leaves of Gaultheria Shallon in the far west.

On leaves of Rhododendron maximum in the east.
1. P. brunneopruinosa.

2. P. Rhododendri.

\section{Pestalopezia brunneopruinosa (Zeller) Seaver, Mycologia 34: 300. 1942.}

Pestalotia gibbosa Hark. Bull. Calif. Acad. Sci. 2: 439.1887.

Dermatea brunneopruinosa Zeller, Mycologia 26: 291. 1934.

Apothecia superficial, .6-2 mm. in diameter, closed at first, then cup-shaped, sessile to short-stipitate, externally powderyvillose, fawn-colored to wood-brown; hymenium fuscous-black due to the brownish tips of the paraphyses which form an epithecium; asci clavate-cylinctric, reaching a length of 120-140 $\mu$ and a diameter of $10-14 \mu$; spores cllipsoid, hyaline, 1-seriate, containing one or two oil-drops, $7-10 \times 14-20 \mu$; paraphyses slender, clavate, light-brown above, $4-6 \mu$ in diameter at their tips.

On large dead spots on leaves of Gaultheria Shallon associated with Pestalotia gibbosa which represents its coniclial stage.

Type locality: Coos County, Oregon.

Distribution: Washington to northern California.

2. Pestalopezia Rhododendri Seaver, Mycologia 34:300. 1942. (Plate 112.)

Apothecia sparingly scattered near the center of circular or subcircular dead spots apparently caused by the conidial or associated stage of the fungus, Pestalotia, the spots becoming brown and bordered with concentric rings of variegated colors from red to brownish the apothecia not exceeding $1 \mathrm{~mm}$. in diameter, appearing as minute, light-colored balls, gradually expanding and exposing the dark-colored discs; asci subcylindric to clavate, tapering into a short, stem-like base, reaching a length of $150 \mu$ and a diameter of $14 \mu, 8$-spored; spores 1-seriate, ellipsoid, hyaline, $8 \times 16 \mu$; paraphyses slightly enlarged above, pale-brown, reaching a diameter of $6 \mu$ at their apices.

Associated with what appears to be the Pestalotia stage on Rhododendron, the spores with three brown cells, $10 \times 20 \mu$, 


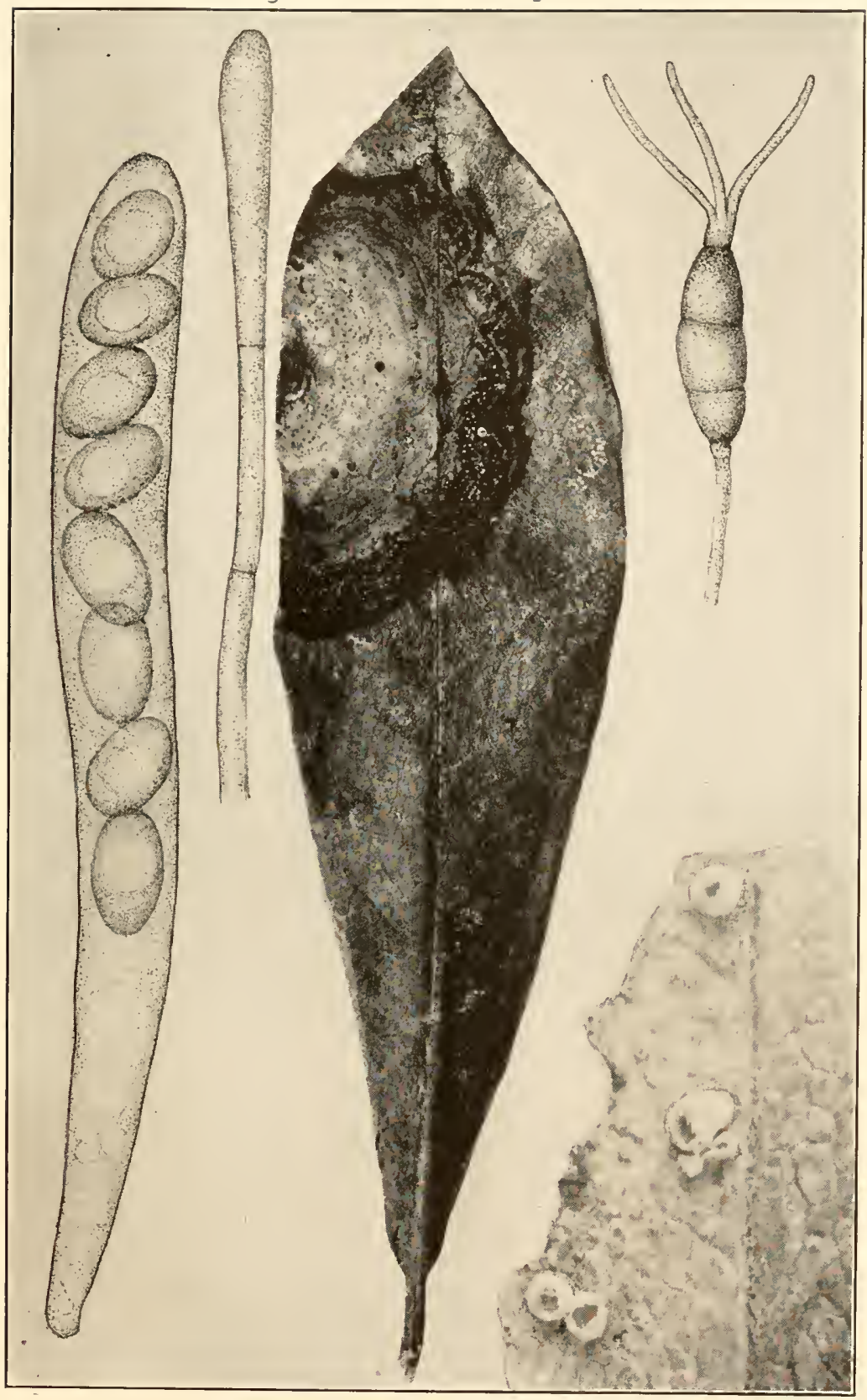

PESTALOPZIA RHODODENDRI 

exclusive of the basal cell and bearing three appendages at the opposite end.

Type Localitr: Pincola, North Carolina.

Distributiox: Known only from the type locality.

Ili.ustrations: Mycologia 34: 299, $f$. $I$.

Exsiccati: Ellis \& Ev. Fungi Columb. 331 (as Dermatea lobata).

\section{Doubtful Species}

Cenangella Ericae (Fries) Rehm in Rab. Krypt.-Fl. 1 ${ }^{3}$ : 232. 1889; Cenangium Ericae Fries, Sy'st. Myc. 2: 188. 1822. This species was described as the perfect stage of Pestalotia Callunae Ces. on Calluna. One specimen on Ledum groehlandicum seems to agree with the one reported on Calluna. This is the only North American specimen seen. If the reported connection is correct this species should be transferred to the genus Pestalopezia.

37. TAPESIA (Pers.) Rehm in Rab. Krypt.-F1. 13 : 574. 1891. Peziza [subg.] Tapesia Pers. Myc. Eu. 1: 270. 1822.

Apothecia superficial, seated on a conspicuous web of white, or dark-colored mycelium, minute, usually less than $1 \mathrm{~mm}$. in diameter, soft and waxy, scutellate, or discoid, the excipulum dark; hymenium often at first light-colored, becoming dark; asci cylindric, or clavate, 4-8-spored; spores ellipsoid, fusoid, or elongated, never or rarely septate, hyaline; paraphyses filiform.

Type species, Peziza fusca Pers.

This genus differs from Mollisia only in the presence of the subiculum.

Apothecia seated on a brown or black subiculum.

On wood or branches of various kinds.

Spores relatively large, $12-14 \mu$ long.

Spores mostly less than $12 \mu$ long.

On swollen branches of Bigeloria.

1. T. fusca.

Not on swollen branches.

On old decaying wood.

Hymenium white or yellow. 3. T. culcitella.

Hymenium brown.

2. T. tumefaciens.

On recently killed branches.

On stems of Rosa.

4. T. mollisioides.

On twigs of Ribes.

5. T. Rosae.

On branches of Sambucus.

6. T. ribicola.

On branches of Carpinus and Betula.

On leaves of Abies balsamea.

7. T. coloradensis.

8. T. lividofusca.

9. T. balsamicola.

Apothecia on a white mycelium.

Spores $2-3 \times 7-10 \mu$, on Betula.

10. T. secamenti.

Spores $7 \times 15 \mu$, on grass and old wood.

11. T. earina. 
1. Tapesia fusca (Pers.) Fuckel, Symb. Myc. 302. 1869.

Peziza fusca Pers. Obs. Myc. 1:29. 1796.

Peziza subiculata Schw. Trans. Am. Phil. Soc. II. 4: 174. 1832.

Peziza griseopulveracea Schw. Trans. Am. Phil. Soc. II. 4: 174.1832.

Mollisia fusca Karst. Myc. Fenn. 1: 207. 1871.

?Peziza vincta Cooke \& Peck, Grevillea 1: 6. 1872.

Tapesia cinerella Rehm, Hedwigia 21: 102. 1882.

Tapesia vincta Sacc. Syll. Fung. 8: 372. 1889.

Tapesia subiculata Sacc. Syll. Fung. 8: 380, 1889.

Tapesia griseopulveracea Sacc. Syll. Fung. 8: 380. 1889.

Tapesia Rhois Fairman, Proc. Rochester Acad. Sci. 3: 216.1900.

Apothecia seated on a widely, densely effused subiculum of brown filaments, scattered, or gregarious, at first urn-shaped, black, finally expanding and becoming cinereous-brown, or cinereous-yellow, reaching a diameter of $1 \mathrm{~mm}$; hymenium pallid-cinereous to pale-yellowish; asci fusoid-clavate, reaching a length of 55-68 $\mu$ and a diameter of 6-8 $\mu$, 8-spored; spores fusoid, usually simple, occasionally doubtfully 1 -septate, $2-3 \times$ 12-14 $\mu$; paraphyses filiform, 2-4 $\mu$ in diameter.

On wood and bark of various kinds.

Type locality : Europe.

Distribution: New York to Oregon and North Carolina; probably widely distributed.

Illustrations: Rab. Krypt.-Fl. $1^{3}$ : 573. f. 1-5: E. \& P. Nat. Pfl. 1' ${ }^{1}: 211 . f .165, A$. B.; Greville, Scot. Crypt. Fl. 4 : pl. 192.

No specimen of Peziza vincta Cooke \& Peck has been seen but the description suggests the above.

2. Tapesia tumefaciens Ellis \& Ev. Bull. Torrey Club 24: 281. 1897.

Apothecia densely gregarious, or in broad strips appearing through cracks in the bark, seated on a thick subiculum, when fresh about $2 \mathrm{~mm}$. in cliameter, mouse-colored, soft and fleshy, the margin fringed with olivaceous, straight hairs; hymenium slightly concave; asci clavate-cylindric, reaching a length of $70-75 \mu$ and a diameter of $8-10 \mu, 8$-spored; spores obliquely 1-seriate, ellipsoid, hyaline, 5-6 8-11 $\mu$; paraphyses stout, about $2 \mu$ thick.

On swollen dead stems of Bigelovia graveolens.

Type locality: Colorado.

Distribution: Known only from the type locality. 
Ellis states: "When dry the opposite sides of the ascomata are rolled together in a hysteriform manner. The habit is that of Angelina rufescens Duby." "The mycelium penetrates the wood and causes the stems to swell in the same manner as Montagnella tumefaciens E. \& M."

3. Tapesia culcitella (Cooke \& Ellis) Sacc. Syll. Fung. 8: 374. 1889.

Pesiza culcitella Cooke \& Ellis, Grevillea 6: 7. 1877.

Apothecia gregarious, about $1 \mathrm{~mm}$. broad, at first depressed urn-shaped, expanding to plane, seated on a sparse, brown, byssoid stratum, at first milk-white, pallid, or yellowish when dry, externally quite smooth; asci narrowly clavate-cylindric; spores narrow-ellipsoid, $2 \times 8 \mu$; paraphyses filiform.

Inside an old oak stump, Quercus.

Type Locality: Newfield, New Jersey.

Distribution: Newfoundland and New Jersey.

Exsiccati: Ellis, N. Am. Fungi 388 .

This looks like Mollisia melaleuca except for the subiculum.

4. Tapesia mollisioides (Schw.) Sacc. Michelia 2: 140. 1880.

Peziza mollisiaeoides Schw. Trans. Am. Phil. Soc. II. 4: 174.1832.

Apothecia seated on a brownish-black subiculum, minute, about $.12 \mathrm{~mm}$. in diameter, becoming plane, or slightly concave, sessile, brown; hymenium paler; asci clavate, reaching a length of $50-55 \mu$ and a diameter of $10 \mu, 8$-spored; spores ellipsoid to subfusoid, $3 \times 8-9 \mu$, slightly curved; paraphyses filiform.

On old wood.

Type locality: Pennsylvania.

Distribution: New England to Ohio and South Carolina.

5. Tapesia Rosae (Pers.) Fuckel, Symb. Myc. 301. 1869.

Pesiza Rosae Pers. Syst. Myc. 656. 1801.

Mollisia Rosae Karst. Myc. Fenn. 1: 208. 1871.

Lachnea Rosae Gill. Champ. Fr. Discom. 92. 1882.

Apothecia sparse, or gregarious, seated on a broadly effused subiculum of brown hyphae, subtomentose, or smooth, brown, slightly concave, coriaceous, contracted and deformed when dry, $1 \mathrm{~mm}$. in diameter; hymenium grayish-white; asci cylindricclavate, reaching a length of $45-60 \mu$ and a diameter of 6-8 $\mu$, 8-spored; spores, fusoid, $2-2.5 \times 7-9 \mu$; paraphyses filiform.

On stems of species of Rosa. 
Type locality : Europe.

Distribution: New York to Pennsylvania and Colorado; also in Europe.

Illustrations: Boud. Ic. Myc. pl. 539.

Exsiccati: Clements, Crypt. Form. Colo. 524.

6. Tapesia ribicola Cash, Mycologia 28: 300. 1936.

Apothecia sessile, superficial, depressed-globose, then patellate, irregularly contorted when dry, often hysteroid, or triangular, gregarious, soft-fleshy, reaching a diameter of $1.5 \mathrm{~mm}$., externally brownish-black to black and smooth near the base, dull-gray to white and fimbriate at the margin; hymenium lightgray; asci cylindiric-clavate, short-stipitate, narrowed at the apex, 8-spored, reaching a length of 35-50 $\mu$ and a diameter of 4.5-5 $\mu$; spores 2 -seriate, elongate-ellipsoid to clavate, hyaline, simple, straight, or slightly curved, 1.5-2 $\times 7-11 \mu$; paraphyses filiform, hyaline, septate, unbranched, not enlarged above.

On twigs of Ribes montigenum.

Type locality: Mesa Lakes, Colorado.

Distribution: Colorado.

Illustrations: Mycologia 28: 302, f. 3.

7. Tapesia coloradensis Ellis \& Ev. Proc. Acar. Sci. Phila. 1894 : 350.1894.

Apothecia scattered, or gregarious, sessile, seated on the epidermis or on the surface of the inner bark, surrounded by a thin, brown, subiculum composed of slender, pale-brown, sparingly septate hyphae, reaching a diameter of 1-2 mm., externally nearly black; hymenium glaucous-white, or livid-white at first, becoming nearly black when dry; asci clavate-cylindric, reaching a length of $45-55 \mu$ and a diameter of $8-10 \mu, 8$-spored; spores ellipsoid, 2-seriate, smoky-hyaline, often slightly curved, 2.5-3.5 $\times$ 8-11 $\mu$; paraphyses stout, evanescent.

On bark of Sambucus melanocarpa.

Type locality: Cameron Pass, Colorado, elevation 10,000 ft.

Distribution: Known only from the type locality.

8. Tapesia lividofusca (Fries) Rehm in Rab. Krypt.-F1. $1^{3}: 576$. 1891.

Peziza lividofusca Fries, Syst. Myc. 2: 147. 1822.

Niptera lividofusca Fuckel, Symb. Myc. Nacht. 2: 58.1873.

Mollisia lizidofusca Gill. Champ. Fr. Discom. 127. 1882. 
Apothecia for the most part gregarious, occasionally confluent, seated on a thick, brown, mycelial subiculum, at first globose and closed, opening and becoming cup-shaped, later expanded, shallow cup-shaped, externally brown, reaching a diameter of .2-2 mm., waxy; hymenium, gray, or yellowish-white; asci clavate, reaching a length of $50-60 \mu$ and a diameter of 5-6 $\mu$, 8-spored; spores fusiform, straight, or slightly curved, 2.5-3 $\times$ 9-12 $\mu$; paraphyses filiform $2 \mu$ in diameter.

On dead branches of Carpinus, Betula etc.

TrPE LOCALITY: Europe.

Distribution: Reported from Illinois and Nebraskil: also in Europe.

Dr. B. Kanouse (Papers Mich. Acad. Sci. 20: 69. 1935.) reports Tapesia lividofusca var. fallax (Desm.) Rehm on cones of Picea mariana from Michigan. No material has been seen.

9. Tapesia balsamicola (Peck) Sacc. Syll. Fung. 8: 376. 1889. Peziza balsamicola Peck, Ann. Rep. N. Y. State Mus. 34: 51. 1883.

Apothecia seated on a subiculum consisting of two kinds of mycelium one black, coarse and producing large, three- or fourlobed, spore-like bodies, the other hyaline, delicate, producing narrow-fusiform conidia, minute, less than $.5 \mathrm{~mm}$. in diameter, sessile, smooth, waxy, whitish; asci clavate, reaching a length of 40-50 $\mu$; spores, subfusoid, with three or four oil-drops, $5-7 \times$ 15-20 $\mu$; paraphyses filiform.

On dead or dying leaves of Abies balsamea.

Type Locality : Stony Clove, Catskill Mountains, New York.

Distribution: Known only from the type locality.

Illustrations: Ann. Rep. N. Y. State Mus. 34: pl. 1, $f$. $1+21$.

Part of the type collection is in the herbarium of The New York Botanical Garden.

10. Tapesia secamenti Fairman, Ann. Myc. 8: 329. 1910.

Apothecia seated on a white mycelium which is arachnoid and radiating from the cup bottom, later becoming extended and intricately interwoven and composed of simple, or sparingly branched, continuous, smooth, hyaline hyphae $3 \mu$ thick, globose, then expanded, brownish-olivaceous, sessile, about $1 \mathrm{~mm}$. in diameter; hymenium white at first, often becoming pale strawcolored; asci fusoid-cylindric, reaching a length of $57 \mu$ and a 
diameter of $6 \mu$; spores I-seriate, ellipsoid, or fusoirl, 2-3 $\times$ 7-10 $\mu$; paraphyses indistinct.

On old chips of Betula.

Type Locality: Lyndonville, New York.

Distribution: New York and Michigan.

\section{Tapesia earina (Ellis) Sacc. Syll. Fung. 8:377. 1889.}

Peziza earina Ellis, Bull. Torrey Club 8: 124. 1881.

Apothecia thin, soft, seated on a loose mycelium of dirtywhite, matted, cottony hairs, circular about $1 \mathrm{~mm}$. in diameter; hymenium brick-red when dry; asci cylindric, reaching a length of 100-125 $\mu$ and a diameter of $12 \mu, 8$-spored; spores 1-seriate, ellipsoid, usually with one oil-drop, $7 \times 15 \mu$; paraphyses rather stout, thickened above.

On dead stems and leaves of grasses and on weather-beaten wood, still partly covered with snow.

Type Locality: Pleasant Valley, Utah, elevation 6,000 feet.

Distribution: Known only from the type locality.

\section{Doubtful and Excluded Species}

Tapesia anomala (Pers.) Fuckel, Symb. Myc. 300. 1869; Peziza anomala Pers. Obs. Myc. 1: 29. 1796; Solenia anomala Fuckel, Symb. Myc. Nacht. 1: 290. 1871. This is now regarded as a Solenia. Widely distributed.

Tapesia arachnoidea (Schw.) Sacc. Syll. Fung. 8: 384. 1889; Peziza arachnoidea Schw. Trans. Am. Phil. Soc. II. 4: 174. 1832. The type of this species was examined by the writer on May 2, 1916, and no apothecia could be found. The description is brief and incomplete and the species must remain in doubt.

Tapesia atrofusca (Berk. \& Curt.) Sacc. Syll. Fung. 8: 373 . 1889; Peziza atrofusca Berk. \& Curt.; Berk. Grevillea 3: 156. 1875. The original description states "Cups dark brown, with an inflexed crenulated granulated margin springing from a pale ochre membranaceous stratum." This is all that is known of the species. No specimens seen. Probably Tapesia fusca.

Tapesia Bloxami (Berk. \& Curt.) Sacc. Syll. Fung. 8: 380. 1889; Peziza Bloxami Berk. \& Curt. Ann. Mag. Nat. Hist. II. 7: 181. 1851. This species has been rejected by Phillips (Brit. Discom. 408) since no fruit could be found.

Tapesia cinerella Rehm, Hedwigia 21:102. 1882. Reported on stems of Gaultheria Shallon from Washington by Dr. B. Kanouse. No naterial seen.

Tapesia daedalea (Schw.) Sacc. Syll. Fung. 8: 379. 1889; Pesiza daedalea Schw. Trans. Am. Phil. Soc. 11. 4: 174. 1832. Specimens distributed under this name (Rav. Fungi Car. 1: 37) are referred apparently by Ellis to Solenia poriaeformis. The type in the Schweinitz was examined by the writer May 2, 1916.

Tapesia derelicta Morgan, Jour. Myc. 8: 186. 1902. No specimen has been seen but the white subiculum and septate spores strongly suggest Arachnopeziza aurelia. 
Tapesia discincola (Schw.) Sacc. Syll. Fung. 8: 384. 1889; Pesiza discincola Schw. Trans. Am. I'hil. Soc. II. 4: 174. 1832. The type of this species in the Schweinitz Collection has been examined and found very unsatisfactory:

Tapesia megaloma (Schw.) Sacc. Syll. Fung. 8: 378. 1889; Peziza megaloma Schw. Trans. Am. Phil. Soc. 11. 4: 175. 1832. This was reported on rotten wood. No specimens have been seen and details of the fruits are unknown.

Tapesia melalencoides var. Vaccinii Rehm in Rab. Kirypt.-Fl. 13: 578. 1891. This species which was distributed by Rehm (Ascom, 153 b) as Tapesia fusca has been reported from Michigan by Dr. B. Kanouse. No American material has been seen.

Tapesia pruinata (Schw.) Sacc. Syll. Fung. 8: 379. 1889; Peziza pruinata Schw. Schr. Nat. Ges. Leipzig 1: 120. 1822. This is Solenia poriaeformis (Pers.) Fries.

Tapesia sanguinea (Pers.) Fuckel, Symb. Myc, 303. 1869; Peziza sanguinea Pers. Tent. Disp. Fung. 34. 1797; Patellaria sanguinea Karst. Myc. Fenn. 1: 231. 1871; Patellea sanguinea Rehm in Rab. Krypt.-Fl. 13: 284. 1889. This species belongs with the Patellariaceae which are not treated in this work.

Tapesia scariosa (Berk. \& Curt.) Sacc. Syll. Fung. 8: 375. 1889; Pesiza scariosa Berk. \& Curt.; Berk. Grevillea 3: 156. 1875. Original lescription reads: "Cups collapsing, confluent, black with a whitish margin springing from a black subiculum; sporidia slender, subfusiform. Allied to P. fusca." A small specimen and drawing by Massee are in the herbarium of the New York Botanical Garden. Nothing more is known of it.

Tapesia tela (Berk. \& Curt.) Sacc. Syll. Fung. 8: 373. 1889; Pesisa tela Berk. \& Curt.; Berk. Grevillea 3: 156. 1875. This is Cyphella tela (Berk. \& Curt.) Massee, Jour. Myc, 6: 179. 1891.

Tapesia tenebrosa (Karst.) Nannf. Nova Acta Soc. Sci. I'psal. IV. 8: 165. 1932. Reported from Michigan by Dr. B. Kanouse on oak bark. Characterized by the stroma-like base of coarse hyphae on which the apothecia are seated. Asci 5-6 6 30-40 $\mu$; spores 1.5-2 $\times 5-5.5 \mu$.

\section{MOLLISIA Karst. Myc. Fenn, 1: 187. 1871.}

Mollisiopsis Rehm, Ann. Myc. 6: 315. 1908.

Dibelon is Clements, Gen. Fungi 87, 175. 1909.

Apothecia usually dark-colored, sordid, the hymenium occasionally light-colored, externally smooth, or occasionally slightly roughened; asci clavate to cylindric, or curved, sometimes short and subglobose to ellipsoid, fusiform, or baciliform; paraphyses usually filiform, more rarely lanceolate, hyaline, or colored.

Type species, Peziza cinerea Batsch.

The genus Mollisiopsis was established for species with lanceolate paraphyses. 
This is a large and difficult genus, new species having been described on the flimsiest pretext and often based on a single specimen in many cases none too good. It is hoped that the following cnumeration may be of some assistance to the collector.

Occurring on phanerogams.

On dicotyledonous plant tissues.

On rotten wood.

Spores 2-5 $\mu$ thick.

Spores not exceeding $10 \mu$ long.

Hymenium cinereous or livil.

Spores 6-10 $\mu$ long.

Spores 3.5-4.5 $\mu$ long.

Hymenium whitish.

Hymenium pale-brown.

Spores $10 \mu$ or more long.

Hymenium orange-yellow.

Hymenium bluish-gray.

Hymenium horn-colored.

Hymenium sooty-black.

Hymenium whitish.

1. M. cinerea.

2. H. Fairmani.

3. M. melaleuca.

4. M. microcarpa.

5. M. aureofuliza.

6. M. caesia.

7. M. subcormea.

8. M. fumigata.

9. M. glenospora.

Spores slender, 1.5-2 $\mu$ thick.

Hymenium whitish.

Spores 6-9 $\mu$ long.

Spores $4-6 \mu$ long.

Hymenium leather-colored.

Hymenium lilac-colored.

On deacl herbaceous stems.

Spores 16-18 $\mu$ long.

Spores not exceeding $10 \mu \mathrm{long}$.

On dead stems of Polygonum.

On dead stems of Asclepias.

On dead stems of Thalictrum.

On compositae.

Spores scarcely $5 \mu$ long.

Spores $10 \mu$ long.

On stems of various kinds.

On living or recently killed leaves.

On living Potentilla.

On leaves of $A$ mophila.

On leaves of Angelica.

On leaves of Antennaria.

On leaves of Gaultheria.

On petioles of Juglans.

On a variety of herbaceous plants.

10. M. vulgaris.

11. M. caespiticia.

12. M. encoelioides.

13. M. lilacina.

14. M. apiophila.

15. M. Polygoni.

16. M. Asclepiadis.

17. M. subcinerea.

18. M. exigua.

19. M. erigeronata.

20. M. atrata.

21. M. Dehnii.

22. M. clavigera.

23. M. Angelicae.

24. M. lanaria.

25. M. Gaultheriae.

26. M. abdita.

27. M. Oenotherae.

On monocotyledonous plant tissues.

Spores 25-30 $\mu$ long.

On Andropogon.

On Scirpus.

28. M. atriella.

29. M. scirpina. 
Spores less than $25 \mu$ long.

Spores 15-21 $\mu$ long.

On Juncus.

30. M. stictoidea.

On leaves of Iris.

31. M. Iridis.

Spores 9-14 $\mu$ long.

On grasses of variou kincl.

32. M. hydrophila.

On Typha.

On Juncus alpints.

Spores 4-6 $\mu$ long.

On petioles of Sabal.

On dead stems of Smilax.

Occurring on cryptogams.

On fern stems, Osmunda.

33. M. epitypha.

34. M. alpina.

35. M. Sabalidis.

36. M. nipteroides

On fungi.

On Polyporus.

On Scoleconectria.

37. M. tenella.

38. M. incrustata.

39. M. Scoleconectriae.

1. Mollisia cinerea (Batsch) Karst. Myc. Fenn. 1: 189. 1871.

Pesiza cinerea Batsch, Elench. Fung. Cont. 1: 197. 1786.

Niplera cinerea Fuckel, Symb. Myc. 292. 1869.

Apothecia gregarious, or scattered, at first subglobose, then expanding and becoming nearly plane, or occasionally repand, cinereous, with a whitish margin; hymenium undulate, cincreous to yellowish, often becoming nearly black; asci cylindric-clavate, 8-spored, reaching a length of $45-60 \mu$ and a diameter of $5-7 \mu$, 8-spored; spores ellipsoid to fusoid, 2-seriate, straight, or curved, 2-3 3 6-10 $\mu$; paraphyses filiform, enlarged above to $3-5 \mu$ in diameter.

On decaying wood of many kinds.

Type locality: Europe.

Distribution: Throughout North America; also in Europe.

Illustrations: Batsch, Elench. Fung. pl. 26, f. 137; Bond. Ic. Myc. pl. 541; Phill. Brit. Discom. pl. 6, f. 32; E. \& P. Nat. Pfl. $1^{1}: 213, f .166, A, B$; Rab. Krypt.-F1. $1^{3}: 505, f .7,8$.

Exsiccati: Clements, Crypt. Form. Colo. 87; Wilson \& Seaver, Ascom. 39.

Numerous varieties of this species have been recorded by Saccardo, among them culmina and caricina. Mollisia culmina var. caricina (Sacc.) Rehm has been recorded from Michigan by Dr. B. Kanouse on Carex. No material has been seen.

2. Mollisia Fairmani (Ellis \& Ev.) Sacc. Syll. Fung. 8: 302. 1889.

Peziza Fairmani Ellis \& Ev. Jour. Myc. 4: 56. 1888.

Pseudohelotium Fairmani Sacc. Syll. Fung. 8: 302. 1889. 
Apothecia sessile, gregarious, concave with the margin subincurved, then expanding to plane, or slightly convex, reaching a diameter of $.75 \mathrm{~mm}$., externally clothed with glandular hair-like structures; hymenium livid, paler toward the margin; asci clavate-cylindric, reaching a length of $35-40 \mu$ and a diameter of 4-5 $\mu$; spores 2 -seriate or partially so, ellipsoid, the lower end often more acute, $2-2.5 \times 3.5-4.5 \mu$.

On inner bark lying on the ground.

Type locality: Lyndonville, New York.

Distribution: Known only from the type locality.

3. Mollisia melaleuca (Fries) Sacc. Syll. Fung. 8: 337. 1889.

Peziza melaleuca Fries, Syst. Myc. 2: 150. 1822.

Niptera melalenca Fuckel, Symb. Myc. 292. 1869.

Patellaria melaleuca Quél. Ench. Fung. 325. 1886.

Mollisia lignicola Phill. Grevillea 15: 113. 1887.

Pyrenopesiza lignicola Sacc. Syll. Fung. 8: 366. 1889.

Apothecia sessile, waxy, becoming patellate, externally rough, becoming black; hymenium whitish; asci cylindricclavate, acuminate, 8 -spored; spores 2 -seriate, cylindric, slightly curved, $2 \times 8 \mu$; paraphyses filiform, $2.5 \mu$ in diameter.

On old wood.

Type locality: Europe.

Distribution: Maine to Ontario and Michigan; also in Europe.

4. Mollisia microcarpa (Fuckel) Sacc. Syll. Fung. 8: 340. 1889. Niptera (?) microcarpa Fuckel, Symb. Myc. Nacht. 1: 46. 1871.

Apothecia gregarious, or scattered, sessile, $1 \mathrm{~mm}$. in diameter, watery-transparent, pale-brown, externally lightly strigose, at first closed, then opening; hymenium concave, flexuous, same color; asci clavate-cylindric, 8-spored, reaching a length of $30 \mu$ and a diameter of $8 \mu$; spores 2-seriate, fusoid, $2.5 \times 8 \mu$; paraphyses filiform.

On rotten wood.

TyPe locality: Europe.

Distribution: Michigan; also in Europe.

Reported from Michigan by Dr. B. Kanouse but no specimen seen. 
5. Mollisia aureofulva (Cooke) Sacc. Syll. Fung. 8: 339. 1889. Peziza aureofulva Cooke, Hedwigia 14: 83. 1875.

Apothecia subgregarious, soft-waxy, minute, at first hemispherical, then expanded, $.5 \mathrm{~mm}$. in diameter, contracted when dry; externally brown; hymenium convex, orange-yellow; asci clavate-cylindric; spores ellipsoid, with two oil-drops, $5 \times 8$ $15 \mu$; paraphyses enlarged above.

On old wood.

Type locality: New Jersey.

Distribution: Known only from the type locality.

6. Mollisia caesia (Fuckel) Sacc. Syll. Fung. 8: 340. 1889. Niptera caesia Fuckel, Symb. Myc. Nacht. 1:47. 1871.

Apothecia gregarious, sessile, reaching a diameter of $2 \mathrm{~mm}$, becoming plane, finally convex, externally smooth; hymenium bluish-gray; asci clavate-cylindric, reaching a length of $55 \mu$ and a diameter of $8 \mu$; spores fusiform, with two oil-drops, $3 \times 14$ $16 \mu$; paraphyses filiform, enlarged above to $3 \mu$ in diameter.

On rotting wood of Fagus.

Type locality: Europe.

Distribution: North Dakota; also in Europe.

Exsiccati: Brenckle, Fungi Dak. 533.

7. Mollisia subcornea Phill. \& Hark. Bull. Calif. Acad. Sci. 1: 22. 1884 .

Apothecia scattered, or crowded, occasionally coalescing, sessile, patellate, reddish horn-color, .5-1 mm. in diameter; asci clavate, 8 -spored; spores 2 -seriate, ellipsoid-fusoid, occasionally 1-septate, $3 \times 10-12 \mu$; paraphyses filiform.

On branches of Eucalyptus globulus.

TYPe locality: California.

Distributiox: Known only from the type locality.

No specimen has been seen.

8. Mollisia fumigata (Ellis \& Ev.) Sacc. Syll. Fung. 8: 343. 1889.

Pesiza fumigata Ellis \& Ev. Bull. Torrey Club 11:41. 1884.

Apothecia densely gregarious, minute, .13-.16 mm. in diameter, sooty-black; hymenium nearly plane, minutely papillose; asci subcylindric, reaching a length of $50 \mu$ and a diameter of $7 \mu$; 
spores obliquely arranged, or 2-seriate, with two or three oildrops, slightly curved, $3 \times 9-12 \mu$.

On rotten wood of Magnolia.

Type locality: New Jersey.

Distribution: Known only from the type locality.

No specimen found in New York Botanical Garden Herbarium.

9. Mollisia glenospora (Ellis \& Ev.) Sacc. Syll. Fung. 8: 343. 1889.

Pesiza glenospora Ellis \& Ev. Bull, Torrey Club 11:18. 1884.

Apothecia sessile, orbicular, .25-.5 mm. in diameter, clullwhite, becoming darker, the margin fringed with a row of erect, subcylindric, continuous, hair-like cells, $2 \times 8-10 \mu$; asci cylindric-clavate, reaching a length of $75-80 \mu$ and a diameter of 9-10 $\mu$; spores ellipsoid, or more acute at one end, with a single oil-drop, 7-8 $\times 12-15 \mu$; paraphyses curved and swollen at their apices.

On rotten Magnolia.

Type locality: New Jersey.

Distribution: Known only from the type locality.

10. Mollisia vulgaris (Fries) Gill. Champ. Fr. Discom. 119. 1882.

Peziza zulgaris Fries, Syst. Myc. 2: 146. 1822.

Pesizella r'ulgaris Sacc. Syll. Fung. 8: 278.1889.

Phialea vulgaris Rehm in Rab. Krypt.-Fl. 13: 709. 1892.

Apothecia subcespitose, membranaccous, sessile, $1 \mathrm{~mm}$. in diameter; hymenium concave, white, or pallid-white; asci cylindric-clavate, reaching a length of $35-45 \mu$ and a diameter of 5-6 $\mu, 8$-spored; spores elongate-ellipsoid, straight, or curved, 1.5-2 $\times 6-9 \mu$; paraphyses filiform.

On rotten wood.

Type locality: Europe.

Distribution: New Jersey and South Carolina; also in Europe.

Exsiccati: Rav. Fungi Car. 4: 18.

Berkeley (Grevillea 3: 159. 1875) records two varieties of this species: var. myceticola on decaying Polyporus, and on oak Santee River, South California; sanguinella with a pale-orange disc, on Liquidambar, from South Carolina and New England. 
Peziza albella With. (Arrang. Brit. Pl. 4:350. 1796) has been cited by various authors including Fries as a synonym. As pointed out by Phillips (Rev. Myc. 12:140. 1890) this was an error, apparently referring to Peziza albida. This species is described as having apothecia .25-.75 of an inch in diameter while the species listed under this name, Pesizella albella, is only $1 \mathrm{~mm}$. in diameter or less.

11. Mollisia caespiticia Karst. Myc. Fenn. 1: 188. 1871.

Pesiza caespiticia Karst. Not. Soc. Fauna. Fl. Fenn. 10: 159. 1869.

Apothecia for the most part occurring in cespitose clusters, at first globose and closed, finally opening and becoming cupshaped, at length nearly plane, externally brownish, .2-1.5 mm. in diameter, waxy; hymenium grayish-white; asci clavate, reaching a length of $30-45 \mu$ and a diameter of 3-4 $\mu$, 8-spored: spores elongated and somewhat fusoid, straight, or curved, 2seriate, $1-1.5 \times 4-6 \mu$; paraphyses filiform, $3 \mu$ in diameter.

On old wood, Salix, Ulmus etc.

Type locality: Europe.

Distribution: Michigan; also in Europe.

12. Mollisia encoelioides Rehm in Rab. Krypt.-Fl. $1^{3}: 522$. 1891.

Apothecia thickly gregarious, sessile but narrowed below, at first globose and closed, finally opening and becoming cup-shaped, .3-1.2 mm. in diameter, externally brownish and somewhat rough; hymenium leather-colored; asci clavate, reaching a length of $30-35 \mu$ and a diameter of $5 \mu, 8$-spored; spores cylindric, straight, or somewhat curved, 2-seriate, $1.5 \times 5-6 \mu$; paraphyses filiform, $2.5 \mu$ in diameter, above irregular, $5 \mu$ in diameter and brown.

On wood of Salix; also reported on spruce branches.

Type locality: Europe.

Distribution: Michigan; also in Europe.

13. Mollisia lilacina Clements, Bot. Surv. Nebr. 4: 15. 1896.

Apothecia gregarious, sessile, discoid, lilac, or pale-livid, testaceous when dry, paler beneath, margin elevated, whitecrenulate, reaching a diameter of $1 \mathrm{~mm}$.; asci small, clavate, reaching a length of $30-40 \mu$ and a diameter of $3-4 \mu$; spores cylindric, straight, or curved, with one to three oil-drops and 
pseudoseptate, 1-seriate, or becoming 2-seriate, 1.5-2 $\times$ 7-10 $\mu$; paraphyses cylindric, granular, $2 \mu$ in diameter.

On bark of Ulmus americana, and on stems of Itelianthus annuus.

Type Locality: Nebraska.

Distribution: Known only from the type locality.

Exsiccati: Rehm, Ascom. 1222 (from Lincoln, Nebraska).

14. Mollisia apiophila Dearness, Mycologia 8: 98.1916.

Apothecia minute, .3-1 $\mathrm{mm}$. in diameter when fresh, hardly visible to the naked eye when dry, flesh-colored, subsessile, turbinate, about as high as wide; asci reaching a length of 45-52 $\mu$ and a diameter of $10-12 \mu$; spores 2 -seriate, with two to four oildrops, 4-6 6 16-18 $\mu$; paraphyses forming a yellowish layer.

On old stems of A pios tuberosa.

Type locality: London, Ontario, Canada.

Distribution: Known only from the type locality.

While this was described as a Mollisia, the color and form would suggest that it might be a Helotium.

15. Mollisia Polygoni (Lasch.) Gill. Champ. Fr. Discom. 120. 1882.

Peziza Polygoni Lasch, in Rab. Herb. Myc. 1127. 1866.

Peziza lactuosa Cooke, Hedwigia 14: 83. 1875.

Niptera Polygoni Rehm, Ber. Naturh. Ver. Augsburg 26: 21.1881.

Apothecia gregarious, sessile, at first hemispherical, the margin incurved, crenulate, then expanding and becoming saucer-shaped, externally brownish, reaching a diameter of $1 \mathrm{~mm}$. though often less; hymenium dull-grayish, or slightly yellowish; asci clavate, reaching a length of 30-40 $\mu$ and a diameter of 5-6 $\mu$, 8-spored; spores ellipsoid to clavate, straight, or curved, $2 \times 7$ $9 \mu$; paraphyses filiform.

On stems of species of Polygonum.

Type locality: Europe.

Distribution: New Jersey to Iowa and probably widely distributed in North America; also in Europe.

Illustrations: Bull. Lab. Nat. Hist. State Univ. Iowa 5: pl. 23, f. 2 .

Exsiccati: Ellis, N. Am. Fungi $4+2$.

This was commonly collected by the writer in Iowa on old Polygonum stems. 
16. Mollisia Asclepiadis Ellis \& Ev. Proc. Acad. Sci. Phila. 1895 . 428. 1895.

Apothecia at first covered by the epiclermis, then erumpentsuperficial, circular, $.75 \mathrm{~mm}$. in diameter, pale slate-colored, the margin coarsely toothed, or subentire; hymenium plane to convex; asci cylindric, 8-spored, reaching a length of 55-60 $\mu$ and a diameter of $6 \mu$; spores for the most part 2-seriate, ellipsoid, or subinequilateral, with usually two oil-drops, $3 \times 8-10 \mu$; paraphyses slender.

On dead stems of Asclepias.

Type locality: London, Canada.

Distribution: Known only from the type locality.

Exsiccati: Ellis \& Ev. N. Am. Fungi 3334.

17. Mollisia subcinerea (Rehm) Seaver, comb. nov.

Mollisiopsis subcinerea Rehm, Ann. Myc. 6: 315. 1908.

Apothecia gregarious, sessile, at first globose-closed, then expanding, .3-1 $\mathrm{mm}$. in diameter, externally brownish, when dry margin inrolled; hymenium hyaline, yellowish when dry; asci clavate, reaching a length of $45-50 \mu$ and a diameter of $6-7 \mu$, 8 -spored; spores subclavate, straight, 2 -seriate, $2 \times 8-9 \mu$; paraphyses lanceolate, $4-5 \mu$ in diameter, prominent.

On dead stems of Thalictrum; also reported on aspen stems.

Type Locality: Lyndonville, New York.

Distribution: New York and Michigan.

Distinguished from Mollisia cinerea by its lanceolate paraphyses.

18. Mollisia exigua (Cooke) Seaver, comb. nov.

Peziza exigua Cooke, Hedwigia 14: 83. 1875.

Pesizella exigua Sacc. Syll. Fung. 8: 283. 1889.

Apothecia scattered, minute, scarcely visible to the unaided eye, sessile, subtremellose, cup-shaped, finally plane, or convex, the margin scarcely elevated; asci minute, lanceolate; spores linear scarcely $5 \mu$ long.

On stems of Erigeron.

Type locality: New Jersey.

Distribution: Known only from the type locality.

Cooke in describing the species states: "Oculo nudo inconspicua." Specimens in The New York Botanical Garden are 
apparently part of the type material. Several collections were made by Ellis.

19. Mollisia erigeronata (Cooke) Sacc. Syll. Fung. 8: 323. 1889.

Peziza erigeronata Cooke, Hedwigia 14: 83. 1875.

?Peziza astericola Cooke \& Ellis, Grevillea 6: 90. 1878.

? Mollisia astericola Sacc. Syll. Fung. 8: 323. 1889.

Apothecia gregarious, sessile, at first subglobose, expanding and becoming nearly plane, brownish-black, becoming black, $.5 \mathrm{~mm}$. in diameter; hymenium livid-cinereous, the margin slightly elevated; asci short-clavate; spores irregularly 2-seriate, long-ellipsoid, $2 \times 10 \mu$; paraphyses not observed.

On stems of Erigeron and Solidago.

Type locality: New Jersey.

Distribution: New Jersey to London, Canada.

Exsiccati: Ellis \& Ev. N. Am. Fungi ? 3335, 3040; Ellis \& Ev. Fungi Columb. 245, 1310.

20. Mollisia atrata (Pers.) Karst. Myc. Fenn. 1:200. 1871.

Peziza atrata Pers. Syn. Fung. 669. 1801.

Pyrenopeziza atrata Fuckel, Symb. Myc. 294. 1869.

Pesiza atrocinerea Cooke; Phill. Brit. Discom. 176. 1887.

Urceola atrata Quél. Ench. Fung. 322. 1886.

Mollisia atrocinerea Phill. Brit. Discom. 176. 1887.

Apothecia gregarious, or scattered, at first globose, expanding and becoming subdiscoid, cinereous, or brownish-black when dry, the margin white and more or less undulate, less than $1 \mathrm{~mm}$. in diameter; asci clavate-fusoid, reaching a length of 25-40 $\mu$ and a diameter of 5-6 $\mu$; spores elongate-ellipsoid, $1.5-2 \times 5-8 \mu$; paraphyses filiform.

On dead herbaceous stems of many kinds.

Type locality : Europe.

Distribution: New York to Ontario and California and south to Alabama; also in Europe.

Exsiccati: Ellis, N. Am. Fungi 443; Ellis \& Ev. N. Am. Fungi 2625; Fungi Columb. 409; Seaver, N. Dak. Fungi 14.

21. Mollisia Dehnii (Rab.) Karst. Myc. Fenn. 1: 206.1871. Peziza Dehnii Rab. Bot. Zeit. 1: 12.1843.

Beloniella Dehnii Rehm in Rab. Krypt.-Fl. 1²: 639. 1892.

Dibelonis Dehnii Clements, Gen. Fungi 175. 1909. 
Apothecia gregarious, innate, sessile, finally plane, brown, becoming black when dry, .5-1 $\mathrm{mm}$. in diameter; hymenium livid-cinereous, asci cylindric-clavate, reaching a length of $50-60 \mu$ and a diameter of $6-7.5 \mu$; spores 2 -seriate, fusoidelongate, simple, slightly curved, or nearly straight, $3 \times 10-16 \mu$; paraphyses filiform, $2 \mu$ thick.

On living leaves and stems of species of Potentilla.

Type locality: Europe.

Distribution: New York to Montana and lowa; also in Europe.

Illustrations: Alb. \& Schw. Consp. Fung. pl. 4, f. 6; Bull. Lab. Nat. Hist. State Univ. Iowa 5: pl. 23, f. 1.

Exsiccatr: Ellis \& Ev. N. Am. Fungi 2039; Fungi Columb. 531; Barth. Fungi Columb. 2237; Kellerm. Ohio Fungi 103; Seaver, N. Dak. Fungi 38; Brenckle, Fungi Dak. 5; Griff. West Am. Fungi 193; Wilson \& Seaver, Ascom. 15.

22. Mollisia clavigera (Ellis \& Ev.) Sacc. Syll. Fung. 8: 354. 1889.

Pesiza clavigera Ellis \& Ev. Jour. Myc. 4: 100. 1888.

Apothecia protruding when moist, contracted and hysteriform when dry, .25-.5 $\mathrm{mm}$. wide and .5-1 $\mathrm{mm}$. long, the margin fimbriate; hymenium cinereous, or livid-white; asci cylindricclavate, narrowed below into a stem-like base; spores 2-seriate, $4-4.5 \times 12-15 \mu$ with two or three oil-drops; paraphyses slender, enlarged above to $3-4 \mu$.

On leaves of Ammophila longifolia.

Type locality: Sand Coulee, Montana.

Distribution: Known only from the type locality.

No specimen seen.

23. Mollisia Angelicae Dearness, Mycologia 16: 145. 1924.

Apothecia dark-brown, superficial, mostly hypophyllous, occasionally epiphyllous, sessile, rugose-costate, urceolate, reaching a diameter of $.125 \mathrm{~mm}$.; asci cylindric to fusoid, 8-spored, reaching a length of $36-40 \mu$ and a diameter of $9 \mu$; spores 2 seriate, or obliquely 1 -seriate, narrowed at one end, 2.5-3 $\times 9$ $15 \mu$; paraphyses scant.

On dead parts of living leaves of Angelica atropurpurea.

Type locality: London, Canada. 
Distribution: Known only from the type locality.

Dearness states that more than 100 leaves were collected bearing this Mollisia.

24. Mollisia lanaria Fairman, Ann. Myc. 9: 150. 1911.

Apothecia hypophyllous, nestling in the woolly coating of the leaves, sessile, minute, $.25 \mathrm{~mm}$. in diameter, circular in outline, numerous, gregarious, brown; hymenium lighter, light-brown; asci clavate-cylindric, sessile or short-stipitate, narrowed slightly above, reaching a length of $40-45 \mu$ and a diameter of $6-7 \mu$; spores long-cylindric, 2-3 $\times 14-24 \mu$; paraphyses subcylindric.

On under side of leaves of Antennaria plantaginifolia.

Type Locality: Orchard Creek Road, Ridgway, New York.

Distribution: Known only from the type locality.

Illustrations: Ann. Myc. 9: 150. f. 1-2.

No specimens seen. Fariman states that on the same leaves is occasionally found a Septoria which might be connected with Mollisia lanaria.

25. Mollisia Gaultheriae Ellis \& Ev. Proc. Acad. Sci. Phila. 1894: 349.1894.

Apothecia occurring on large (1-2 cm. broad) orbicular, dirty-brown spots which are sometimes irregular in shape and occupying the greater part of the leaf, amphigenous but more numerous on the under side, $.5 \mathrm{~mm}$. in diameter, dark livercolored, nearly black when dry, the margin slightly dentate; hymenium concave; asci cylindric-clavate, reaching a length of 45-55 $\mu$ and a diameter of 10-12 $\mu$; spores 2-seriate, ellipsoid, 3-3.5 $\times 10-12 \mu$; paraphyses filiform, branched.

On living leaves of Gaultheria Shallon.

Type Locality: Seattle, Washington,

Distribution: Known only from the type locality.

26. Mollisia abdita (Ellis) Sacc. Syll. Fung. 8: 353.1889.

Peziza abdita Ellis, Bull. Torrey Club 9: 19. 1882.

Apothecia orbicular, pale, .6-.7 $\mathrm{mm}$. in diameter, with a narrow, jagged, membranaceous margin, protruding when fresh through a narrow slit in the epidermis from which it is again withdrawn and entirely disappears when dry; asci cylindricclavate, reaching a length of $40-45 \mu$ and a diameter of $4-5 \mu$; spores 2-seriate, clavate, $2-2.5 \times 10 \mu$; paraphyses clavate. 
On fallen petioles of Juglans regia.

Type locality: New Jersey.

Distribution: Known only from the type locality.

Exsiccati: Ellis, N. Am. Fungi 849.

When dry its presence is indicated only by a narrow slit in the epidermis, hence the name.

27. Mollisia Oenotherae (Cooke \& Ellis) Seaver, comb. nov.

Dacryomyces Lythri Desm. Pl. Crypt. Fr. 1545. 1846.

Peziza Oenotherae Cooke \& Ellis, Grevillea 6: 90. 1878.

Sphaeronema corneum Cooke \& Ellis, Grevillea 6: 84. 1878.

Gloeosporium ? tremellinum Sacc. Michelia 2: 168. 1880.

Gloeosporium ? rhoinum Sacc. Fungi Ital. f. 1035. 1881.

Hainesia rhoina Ellis \& Sacc. in Sacc. Syll. Fung. 3: 699. 1884.

Pezizella Oenotherae Sacc. Syll. Fung. 8: 278. 1889.

Tubercularia Rhois Halsted, Bull. Torrey Club 20: 251. 1893.

Patellina Fragariae Stevens \& Peterson, Phytopathology 6: 264. 1916.

Sporonema pulvinatum Shear, Bull. Torrey Club 34: 308. 1907.

Pezizella Lythri Shear \& Dodge, Mycologia 13: 161. 1921.

Apothecia scattered, with a short, stem-like base, externally light-brown to amber, .5-1 mm. in diameter; hymenium nearly plane, whitish especially when moist; asci cylindric, or clavate, reaching a length of $55-70 \mu$ and a diameter of $7-8 \mu, 8$-spored; spores straight, or slightly curved, 1 -seriate, or of ten becoming 2 -seriate, often enlarged at one end, $2 \times 8 \mu$; paraphyses filiform, branched, scarcely enlarged above, $1-1.5 \mu$ in diameter.

On dead spots on living or dead leaves, petioles and stems of Oenothera and a larger variety of other hosts.

Trpe locality: New Jersey.

Distribution: Widely distributed in North America; also in Europe.

Illustrations: Mycologia 13: 146, f. 1.; 148, f. 2.; 149, f. 3; 150, f. 4; 151, f. 5; pl. 8-10; Phy topathology 6: 267, f. 19-26.

Exsiccati: Ellis, N. Am. Fungi 733, 846; Ellis \& Ev. N. Am. Fungi 2074, 2278; Fungi Columb. 244, 287; Seym. \& Earle, Ecom. Fungi 273.

For a complete discussion of this species, its synonymy, morphology and hosts see Mycologia 13: 135-170.

28. Mollisia atriella (Cooke) Sacc. Syll. Fung. 8: 352.1889.

Pesiza atriella Cooke, Hedwigia 14: 83. 1875.

Apothecia gregarious, sessile, soft-waxy, .2 mm. in diameter, at first hemispherical, then expanded, smooth, black; hymenium 
cinereous-black; asci clavate-cylindric; spores narrowly fusiform, $2.5 \times 30 \mu$; paraphyses filiform.

On culms of Andropogon and Spartina.

Type Locality: New Jersey.

Distribution: New Jersey and Louisiana.

Exsiccati: Ellis \& Ev. N. Am. Fungi 1779 (on Spartina polystachya).

29. Mollisia scirpina (Peck) Sacc. Syll. Fung. 8: 348.1889. Pesiza scirpina Peck, Ann. Rep. N. Y. State Mus. 28: 67. 1876.

Apothecia minute, scattered, erumpent, smooth, externally black, grayish within; asci cylindric, 8-spored; spores crowded, fusiform, straight, or slightly curved, with two oil-drops, 20-25 $\mu$ long.

On dead stems of Scirpus caespitosus.

Type Locality: Adirondack Mountain, N. Y.

Distribution: Known only from the type locality.

30. Mollisia stictoidea (Cooke \& Ellis) Sacc. Syll. Fung. 8: 348. 1889.

Peziza stictoidea Cooke \& Ellis, Grevillea 6: 8. 1877.

Apothecia erumpent, sparse, .1-.12 mm. in diameter, becoming stictoid when dry, brownish-black; hymenium pallid; asci clavate; spores fusoid, $3 \times 16 \mu$.

On Juncus.

Type Locality: New Jersey.

Distribution: Known only from the type locality.

Illustrations: Grevillea 6: pl. 96, f. 37 .

The erumpent character of the apothecia would indicate a Pyrenopeziza. Cooke states: "Margin longitudinally connivent when dry, and retracted, hence it resembles a minute Stictis."

31. Mollisia Iridis (Rehm) Sacc. Syll. Fung. 8: 331. 1889. Micropesiza Iridis Rehm, Ascom. Lojk. 16. 1882.

Apothecia when dry oblongate, or rotundate, more or less hemispheric, finally expanded, sessile, gregarious, subfuscous, margin yellowish-green, $.3 \mathrm{~mm}$. in diameter; hymenium brownish : asci clavate, reaching a length of $50 \mu$ and a diameter of $9 \mu, 4-8$ spored; spores ellipsoid, 2-seriate, with one to four oil-drops, $4 \times 18-21 \mu$; paraphyses filiform, enlarged above to $3.5 \mu$. 
On stems of Iris.

TyPe LOCALITY: Europe.

Distribution: New York and Ontario; also in Europe.

Several collections of this species from Canada determined by H. S. Jackson are in The New York Botanical Garden. The apothecia are seated on large reddish discolored areas on the leaves.

32. Mollisia hydrophila Karst. Myc. Fenn. 1: 196. 1871.

Peziza hydrophila Karst. Not. Soc. Fauna Fl. Fenn. 10: 163. 1869.

Apothecia gregarious, entirely white, or pallid, finally sordidwhite to cinereous, becoming brown when dry, .7-1 $\mathrm{mm}$. in diameter; hymenium convex, concave when dry; asci fusoidcylindric, reaching a length of $50-70 \mu$ and a diameter of $5-7 \mu$; spores acicular, 1.5-2.5 $\times 9-12 \mu$; paraphỳses filiform, enlarged above.

On culms of grasses, Phragmites, Andropogon, Sorghum etc.

Type locality: Europe.

Distribution: New Jersey; also in Europe.

Exsiccati: Ellis, N. Am. Fungi 847.

33. Mollisia epitypha Karst. Myc. Fenn. 1: 197. 1871.

Niptera epitypha Karst. Not. Soc. Fauna. F1. Fenn. 11: 247. 1871.

Apothecia gregarious, sessile, at first globose, opening and becoming hemispherical, finally convex, at first entirely brownishcinereous, then cinereous-livid, .6-1 mm. in diameter, externally black when dry; hymenium grayish-pallid; asci fusoid-clavate, reaching a length of 50-60 $\mu$ and a diameter of 5-6 $\mu$; spores 2seriate, straight, $2 \times 10-14 \mu$; paraphyses filiform.

On stems of Typha latifolia; also reported on Carex.

TyPe locality: Europe.

Distributiox: Michigan; also in Europe.

The only American specimen of this species seen is one from Michigan collected and determined by Geo. B. Cummins.

34. Mollisia alpina Rostr. Medd. Grónl. 3: 609. 1891.

Apothecia gregarious, sessile, at first globose, then concave, brownish-black, reaching a diameter of $.25 \mu$; asci cylindricclavate, reaching a length of $40 \mu$ and a diameter of $6-8 \mu$; spores ellipsoid, $4 \times 10-21 \mu$, with two or three oil-drops. 
On dead stems of Juncus alpinus.

Trpe Locality: Greenland.

Distributiox: Known only from the type locality in Greenland.

35. Mollisia Sabalidis (Ellis \& Mart.) Seaver, comb. nov.

Dermatea Sabalidis Ellis \& Mart. Am. Nat. 18: 1147. 1884.

Cenangium Sabalidis Sacc. Syll. Fung. 8: 562. 1889.

Apothecia gregarious, or scattered, shallow cup-shaped, or scutellate, scarcely exceeding $.3 \mathrm{~mm}$. in diameter, externally tobacco-brown and clothed with very poorly developed hair-like structures which give the apothecium a powdery appearance; hymenium slightly concave, dark-brown; asci clavate, reaching a length of $35 \mu$ and a diameter of 6-7 $\mu, 8$-spored; spores 2seriate or irregularly crowded, ellipsoid, 1-1.3 $\times 4-6 \mu$; paraphyses filiform, slender, scarcely enlarged above.

On dead petioles of Sabal serrulata.

Type locality: Green Cove Springs, Florida.

Distribution: Known only from the type locality.

The apothecia do not appear to the writer to be erumpent. It is certainly not a Dermea.

36. Mollisia nipteroides Ellis \& Ev. Proc. Acad. Sci. Phila. 1893: 147. 1893.

Apothecia cup-shaped, substipitate, or almost sessile, reaching a diameter of 1-1.5 mm., umber-colored but whitened outside by a pruinose coat and a short, erect, glandular pubescence which is more abundant toward the margin; asci cylindric, reaching a length of 35-40 $\mu$ and a diameter of 5-6 $\mu$; spores 2seriate, with two or three oil-drops, straight, or slightly curved, 1-1.5 $\times 4-5 \mu$; paraphyses branched above and bearing minute, globose conidia.

On dead stems of Smilax.

Type locality: St. Martinville, Louisiana.

Distribution: Known only from the type locality.

The only specimen seen is the type collection in The New York Botanical Garden.

37. Mollisia tenella (Cooke \& Ellis) Sacc. Syll. Fung. 8: 349. 1889.

Peziza tenella Cooke \& Ellis, Grevillea 7: 40. 1878. 
Apothecia hypophyllous, scattered, at first hemispherical, finally expanded, .15-.2 mm. in diameter; hymenium pallicl; asci clavate; spores linear, straight, $5 \mu$ long.

On fronds of Osmunda.

Type locality: Newfield, New Jersey.

Distribution: Known only from the type locality.

Exsiccati: Ellis, N. Am. Fungi 669.

A part of the type collection is in The New York Botanical Garden.

38. Mollisia incrustata (Ellis) Seaver, comb. nov.

Pesisa incrustata Ellis, Am. Nat. 17: 192. 1883.

Mollisia trametis Ellis \& Ev. Proc. Acad. Sci. Phila. 1893: 147. 1893.

Pseudohelotium incrustatum Sacc. Syll. Fung. 8: 301. 1889.

Apothecia growing on the margin and inner surface of the pores of the host, obconic, .11-.15 $\mathrm{mm}$. in diameter, honeycolored, of fibrous structure, the ends of the fibers projecting so that the outer surface and margin appear granulose-pubescent, or as if covered with sharp-pointed granules, at first convexhemispheric, resembling a Nectria, soon becoming concave with a distinct subfimbriate margin; asci clavate, reaching a length of 20-23 $\mu$ and a diameter of $4-5 \mu$; spores 2 -seriate, or obliquely 1 -seriate, narrow-ellipsoid, or clavate, $1.5-2 \times 3.5-4.5 \mu$; paraphyses not observed.

Parasitic on Polyporus Stevensii and on a resupinate Polyporus.

Type locality: Newfield, New Jersey.

Distribution: Known only from the type locality.

The color of this species would suggest a IIelotium or Orbilia rather than a Mollisia. Should be more carefully studied.

39. Mollisia Scoleconectriae Cash \& Davidson, Mỵcologia 32: 733. 1940.

Apothecia cespitose on and sometimes completely covering stromata and perithecia of Scoleconectria scolecospora, .2-.4 mm. in diameter, brownish-black, sessile, soft-fleshy, globose with small circular opening, then cupulate with the margin fimbriate, incurved when dry; hymenium dark olive-gray; asci cylindric-

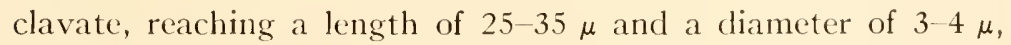
8-spored; spores 2-seriate, hyaline, simple, narrow-cylindric, straight, or slightly curved, $1 \times 5-7 \mu$; paraphyses filiform, hyaline, unbranched, $1 \mu$ in diameter. 
On stromata of Scoleconectria scolecospora on twigs of Pinus Strobus.

Type locality: Huntingdon County, Pennsylvania.

Distribution: Pennsylvania and New York.

Illustrations: Mycologia $32: 729, f .1, D$.

\section{DoubtFul Species}

Mollisia alabamensis Ellis \& Ev. Jour. Myc. 8: 69. 1902. Apothecia erumpent, pale rose-colored, becoming almost black; spores $6-7 \times 12-13 \mu$; paraphyses forming a brown epithecium. On canes of Rubus villosus, Alabama. May be a Cenangium.

Pezizella aquifoliae (Cooke \& Ellis) Sacc. Syll. Fung. 8: 288. 1889; Peziza aquifoliae Cooke \& Ellis, Grevillea 6: 91. 1878. Apothecia subaurantiaceous, attached by white, radiating mycelium; spores ovoid. On leaves of Ilex opaca. The type in The New York Botanical Garden is too scant to permit of critical study.

Mollisia benesuada (Tul.) Phill. Brit. Discom. 174. 1887; Pesisa benesuada Tul. Ann. Sci. Nat. III. 20: 169. 1853. This species has been reported from Michigan and Washington by Dr. B. Kanouse. No American specimens have been seen except one doubtfully determined from Pennsylvania. Also var. polyspora Kauff. has been recorded.

Pezizella brassicaecola (Berk.) Sacc. Syll. Fung. 8: 283. 1889; Peziza brassicaecola Berk. Grevillea 3: 157. 1875. Apothecia brownish; spores $10 \mu$ long. On cabbage stems, Brassica, New England. No material seen.

Peziza conorum Ellis, Bull. Torrey Club 6: 133. 1877. On cones of Pinus inops lying on the ground in New Jersey. Apothecia yellowish-brown sessile, convex; spores $7.5-10 \times 15-20 \mu$. No material seen.

Mollisia complicatula Rehm in Rab. Krypt.F1. 13 ${ }^{3}$ 520. 1891. Apothecia erumpent, brownish-black, .3-1 mm. in diameter; spores $2.5 \times 9-12 \mu$. On wood of Lonicera and Populus. Reported from Michigan and Washington. No material seen.

Mollisia euparaphysata Schröt. Krypt.-Fl. Schles. $3^{2}: 107$. 1908. This species is reported from Michigan on Carex by Dr. B. Kanouse under the name Mollisiopsis euparaphysata (Schröt.) Rehm. No material has been seen.

Pezizella exidiella (Berk. \& Curt.) Sacc. Syll. Fung. 8: $288 . \quad 1889$; Peziza exidiella Berk. \& Br.; Berk. Grevillea 3: 158. 1875. Berkeley places this in the subgenus Mollisia. The description is so brief as to mean little.

Pseudohelotium fibrisedum (Berk. \& Curt.) Sacc. Syll. Fung. 8: 298. 1889; Peziza fibriseda Berk. \& Curt.; Berk. Grevillea 3: 157. 1875. Apothecia irregular, orange, externally clothed with sugar-like granules, the margin broken, laciniate; hymenium concave. On Ulmus americana, Virginian Mountains. No specimen available and the description is too meager to enable it to be identified. See Orbilia cruenta.

Pezizella floriformis (Peck) Sacc. Syll. Fung. 8: 287. 1889; Peziza floriformis Peck, Ann. Rep. N. Y. State Mus. 33: 31. 1880. Apothecia at first subcyathiform, then floriform, with the margin wavy, hymenium creamcolored; spores spermatoid. On decaying wood of Acer, Verona, New York. No material seen. 
Peziza heterocarpa Ellis, Bull. Torrey Club 6: 134. 1877. Apothecia minute, stipitate, about $1 \mathrm{~mm}$. in diameter and high, pale-greenish; spores fusoid-ellipsoid, $20 \mu$ long. On dead stems of Bidens, in New Jersey. No material seen. This was placed in the subgenus Mollisia by Ellis.

Pesiza hypnicola Ellis, Bull. Torrey Club 6: 134. 1877. Apothecia sessile, pallid-orange, concave; asci subcylindric; spores 1 -septate, $2.5 \times 9$ $10 \mu$. On Hypmum syliaticum in Pennsylvania. This was placed in the subgenus Mollisia by Ellis.

Mollisia introviridis (Cooke \& Ellis) Sacc. Syll. Fung. 8: 339. 1889; Pesiza introviridis Cooke \& Ellis, Crevillea 7: 7. 1878; Ellis, N. Am. Fungi 566. The type of this species was first labeled Peziza sanguinea. What induced Ellis to change his mind is not apparent.

Mollisia leucostigma (Fuckel) Rehm in Rab. Krypt.-F1. 13: 516. 1891; Niptera leucostigma Fuckel, Symb. Myc. Nacht. 2: 59. 1873. This represents Fuckel's conception of Pesiza leucostigma Fries but does not agree with the usual interpretation of the species. See Orbilia leucostigma.

Peziza melichroa Cooke, Grevillea 7: 47. 1878; Psendohelotium melichroum Sacc. Syll. Fung. 8: 301. 1889. Apothecia described as minute, saccharine-granulated; spores ellipsoid, $5 \mu$ long.

Mollisia miltophthalma (Berk. \& Curt.) Sacc. Syll. Fung. 8: 33t. 1889; Pesiza miltophthalma Berk. \& Curt.; Berk. Grevillea 3: 158. 1875. Apothecia black with yellow hymenium; spores minute. On branches of Cornus florida, South Carolina. No material seen.

Mollisia papillata Earle, Bull. N. Y. Bot. Gard. 3: 290. 1905. Apothecia black, clothed with clavate papillae; spores $2 \times 8-10 \mu$, On old weathered chips, Stanford University, California. The papillate hairs would suggest a Lachnella. No material seen.

Mollisia paullopuncta (Cooke \& Ellis) Sacc. Syll. Fung. 8: 3+2. 1889; Peziza paulupuncta Cooke \& Ellis, Grevillea 7: 7. 1878. Apothecia brownishblack; hymenium cinereous; spores $1 \times 5 \mu$. On bark of Acer, New Jersey: No material seen. The spelling of the specific name was changed by Saccardo as indicated above.

Peziza regalis Cooke \& Ellis, Grevillea 6: 91. 1878. Apothecia $.1 \mathrm{~mm}$. in diameter, white; asci clavate; spores $7 \mu$ long. On apple bark, New Jersey: No material seen. This was originally placed in the subgenus Mollisia.

Pseudohelotium sacchariferm (Berk.) Sacc. Syll. Fung. 8: 298. 1889; Peziza saccharifera Berk. Grevillea 3: 157. 1875. Apothecia gregarious, pallid-orange, irregular, externally saccharine; disc concave. On Liquidambar, Alabama. Originally placed in the subgenus Mollisia. Its identity is uncertain. See Orbilia cruenta.

Mollisia stenostoma (Berk. \& Curt.) Sacc. Syll. Fung. 8: 35t. 1889; Peziza stenostoma Berk. \& Curt.; Berk. Grevillea 3: 159. 1875. Apothecia elongate; spores narrow-ellipsoid. Looks like a Hysterium. No specimen seen.

Mollisia Teucrii (Fuckel) Rehm in Rab. Krypt.-Fl. 13: 524. 1891; Niptera Teucrii Fuckel, Symb. Myc. Nacht. 1: 47. 1871; Psendohelotium Teucrii Sacc. Syll. Fung. 8: 294. 1889; Pezizella Teucrii Rehm in Rab. Krypt.F1. $1^{3}$ : 1264. 1896. Originally reporterl on stems of Teucrim. Reported from Michigan by Dr. B. Kanouse on wood of Almus. No specimens seen. 
39. MOLLiSIElla (Phill.) Massee, Brit. Fungus-F1. 4 : 221. 1895.

Mollisia subg. Mollisiella Phill. Brit. Discom. 193. 1887. Unguiculariopsis Rehm, Ann. Myc. 7: 400. 1909.

Apothecia small cupulate, becoming expanded, usually occurring on other fungi, externally dark-colored, brownish, tomentose, or clothed with poorly developed hairs; asci clavate, or cylindric, usually 8-spored; spores at maturity 1 -seriate, globose; paraphyses filiform, slightly enlarged above.

Type species, Peziza ilicincola Berk. \& Br.

Mollisiella ilicincola (Berk. \& Br.) Massee, Brit. Fungus-F1. 4 : 222. 1895. (Plate 113.)

Peziza ilicincola Berk. \& Br. Ann. Mag. Nat. Hist. III. 7: 450. 1859.

Peziza hysterigena Berk. \& Br. Jour. Linn. Soc. 14: 106. 1873.

Peziza Ravenelii Berk. \& Curt.; Berk. Grevillea 3: 152. 1875.

Pseudohelotium ilicincolum Sacc. Syll. Fung. 8: 304. 1889.

Lachnellula hysterigena Sacc. Syll. Fung. 8: 391. 1889.

Cenangium Ravenelii Sacc. Syll. Fung. 8: 568. 1889.

Mollisia ilicincola Phill. Brit. Discom. 193. 1887.

Unguiculariopsis ilicincola Rehm, Ann. Myc. 7: 400. 1909.

Apothecia occurring in fasciculate clusters 1-2 mm. in diameter, the individual apothecia irregularly cupulate often compressed from mutual pressure with the margins strongly incurved, externally furfuraceous, whitish, or brownish, with poorly developed hairs; hymenium concave, pallid-brown, or purplish to rosy; asci cylindric to clavate, 8-spored, reaching a length of $40-50 \mu$ and a diameter of 5-6 $\mu$, 8-spored; spores usually 1-seriate, 4-5 $\mu$ in diameter; paraphyses filiform, slightly enlarged above.

Usually on other fungi, Myrianginm, Patellaria, IIysterium and Tryblidiella.

Type localits: Europe.

Distribution: North Carolina to Florida; also in Europe.

Illuustrations: Ann. Mag. Nat. Hist. III. 7: pl. 16, f. 17. Jour. Linn. Soc. $31:$ pl. 18, f. 15-18; Mycologia 31: 94, f. 1 .

Exsiccati: Rav. Fungi Car. 2: $\$ 6$.

40. Catinella Boud. Hist. Class. Discom. Eu. 150. 1907. ?Bulgariella Karst. Acta Soc. Fauna Fl. Fenn. 2 ${ }^{\natural}: 142.1885$.

Apothecia patellate or nearly so, dark-greenish, subgelatinous; asci cylindric or subcylindric, 8-spored; spores simple, greenish; paraphyses filiform granular. 


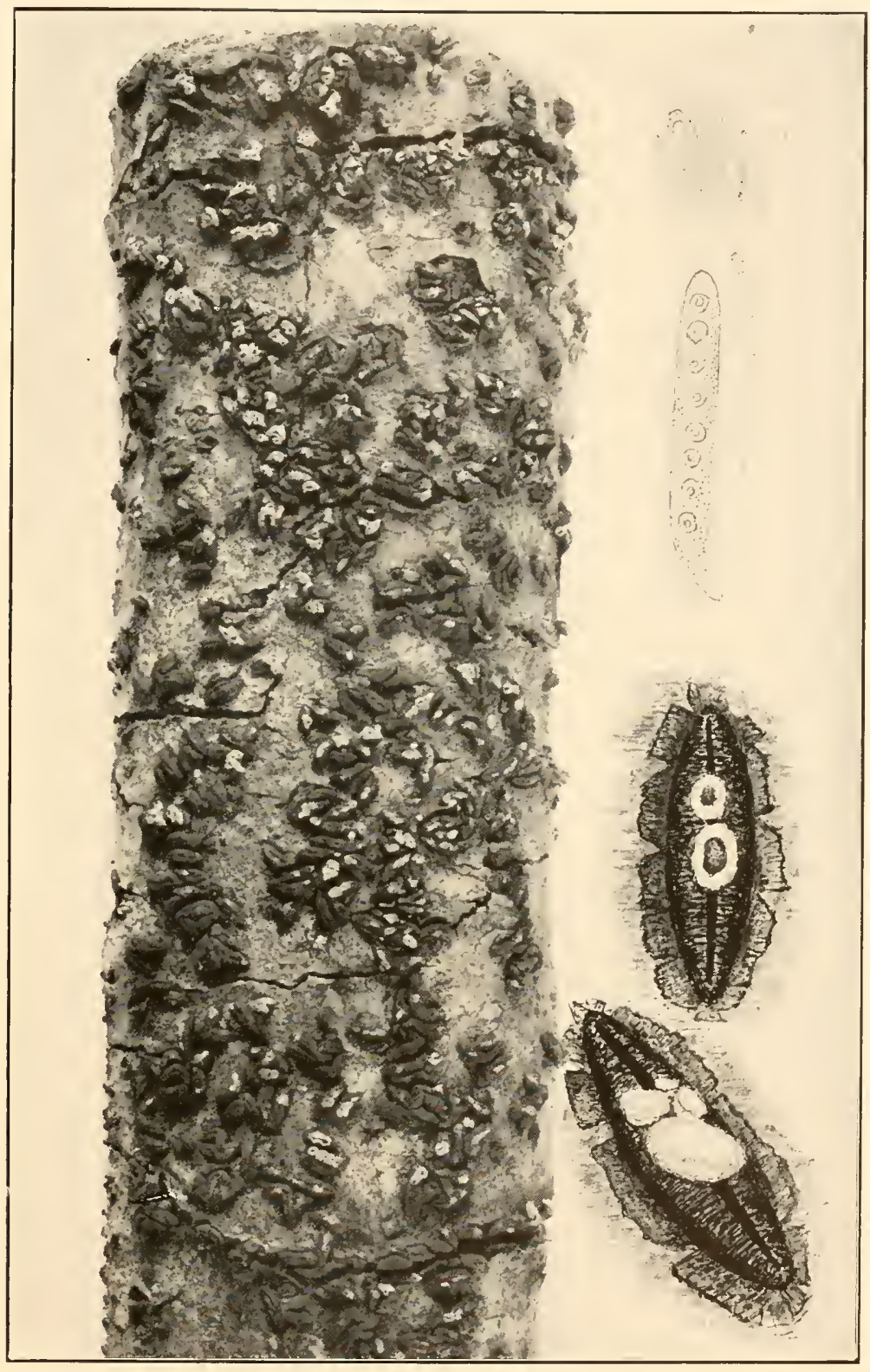

MOLLISIELLA ILICINCOLA 

Type species, Peziza olivacea Batsch.

1. Catinella nigroolivacea (Schw.) Durand, Bull. Torrey Club 49: 16. 1922. (PLATE 114.)

?Peziza olivacea Batsch, Elench. Fung. 127. 1783.

Peziza nigroolivacea Schw. Schr. Nat. Ges. Leipzig 1: 121. 1822.

Patellaria pulla nigroolivacea Fries, Syst. Myc. 2: 160.1822.

Bulgaria nigrita Fries, Elench. Fung. 2: 16. 1828.

Lemalis rufoolivacea Schw. Trans. Am. Phil. Soc. II. 4: 184. 1832.

Rhizina nigroolivacea Curr. Trans. Linn. Soc. 24: 493. 1864.

Peziza viridiatra Berk. \& Curt. Jour. Linn. Soc. 10: 369. 1868.

Patellaria violacea Berk. \& Br. Jour. Linn. Soc. 14: 108.1875.

Patellaria hirneola Berk. \& Br. Jour. Linn. Soc. 14: 108. 1875.

Patellaria applanata Berk. \& Br. Jour. Linn. Soc. 14: 108. 1875.

Peziza fuscocarpa Ellis \& Holw. Jour. Myc. 1: 5. 1885.

Patellaria olivacea Phill. Brit. Discom. 361. 1887.

?Humaria olivacea Sacc. Syll. Fung. 8: 148. 1889.

Pezicula viridiatra Sacc. Syll. Fung. 8: 315. 1889.

Phaeopezia fuscocarpa Sacc. Syll. Fung. 8: 474. 1889.

Bulgariella pulla nigroolivacea Sacc. Syll. Fung. 8: 638. 1889.

Bulgariella nigrita Sacc. Syll. Fung. 8: 638. 1889.

Patinella violacea Sacc. Syll. Fung. 8: 770. 1889.

Patinella olivacea Sacc. Syll. Fung. 8: 770. 1889.

Patinella hirneola Sacc. Syll. Fung. 8: 771. 1889.

Patinella applanata Sacc. Syll. Fung. 8: 771. 1889.

Humaria marchica Rehm in Rab. Krypt.-Fl. 1³:952. 1894.

Phaeopezia marchica Sacc. Syll. Fung. 11: 415.1895.

Aleuria marchica Sacc. \& Syd. in Sacc. Syll. Fung. 16: 739. 1902.

Humaria fuscocarpa Morgan, Jour. Myc, 8: 189. 1902.

Aleuria fuscocarpa Sacc. \& Syd. in Sacc. Syll. Fung. 16: 739. 1902.

Catinella olivacea Boud. Hist. Class. Discom. Eu. 150. 1907.

Apothecia sessile, solitary, or several crowded together, attached to the substratum by numerous radiating, dark-brown fibers more conspicuous in young plants, at first subglobose and closed, then expanding with a permanently upturned margin, at first entirely greenish-yellow, becoming dark-green, finally blackish with an olive tint, when old the exterior brownish and furfuraceous and vertically striate, fleshy and somewhat gelatinous when fresh, brittle when dry; reaching a diameter of $1 \mathrm{~cm}$. but usually much smaller, mycelial fibers about the base very coarse, straight, or strongly kinked, septate, dark-brown, reaching a diameter of $10 \mu$, radiating 2-3 $\mathrm{mm}$. beyond the base of the apothecium; asci narrowly cylindric-clavate, 8-spored, reaching a length of $75-90 \mu$ and a diameter of $5-6 \mu$; spores 1 -seriate, 
irregularly ellipsoid, often slightly constricted near the center so as to appear slipper-shaped, containing one or two oil-drops, paleolive, becoming brown, 4-5 × 7 10 ; paraphyses cylindric, simple or rarely branched.

On rotten wood of various kinds.

Type Locality: North Carolina.

Distribution: Throughout eastern North America, the West Indies and Ceylon; also in Europe.

Illustrations: Batsch, Elench. Fung. pl. 12, f. 51; Boud. Ic. Myc. pl. 452; Trans. Linn. Soc. $24:$ pl. 51, f. 10-12.

Exsiccati: N. Am. Fungi 2325: Seaver, N. Dak. Fungi 28.

The species is easily recognized by its greenish apothecia and peculiar shaped, greenish spores.

41. PYRENOPEZIZA Fuckel, Symb. Mỹc. 293. 1869. ?Phillipsiella Cooke \& Ellis; Cooke, Grevillea 7: 48. 1878.

Apothecia at first submerged in the plant tissues, then erumpent, sessile, at first rounded and closed, opening and becoming cup-shaped, or more or less expanded, externally darkcolored, usually brown, or brownish-black, and of ten roughened; hymenium usually concave, lighter than the outside of the apothecium; asci clavate, or subclavate, 4-8-spored; spores ellipsoid to fusiform, or elongate-ellipsoid, straight, or more rarely curved, simple; paraphyses filiform, usually enlarged above.

Type species, Peziza rugulosa Fuckel.

Distinguished from Mollisia by the erumpent character of the apothecia a character which is very difficult to recognize in mature plants. The two genera are, to say the least, very close together.

On dicotyledonous plant tissues.

On woody plants, trees or shrubs.

On canes of Rubus.

Spores $7-9 \mu$ long.

1. P. Rubi.

Spores 12-13 $\mu$ long.

2. P. lacerata.

On leaves.

Spores 10-15 $\mu$ long, on Quercus Primus.

3. P. prinicola.

Spores 7-8 $\mu$ long, on Magnolia.

Spores 5-7 $\mu$ long, on Acer.

4. P. protrusa.

Spores 4-5 $\mu$ long, on Tilia.

5. P. leucodermis.

6. P. minuta. 


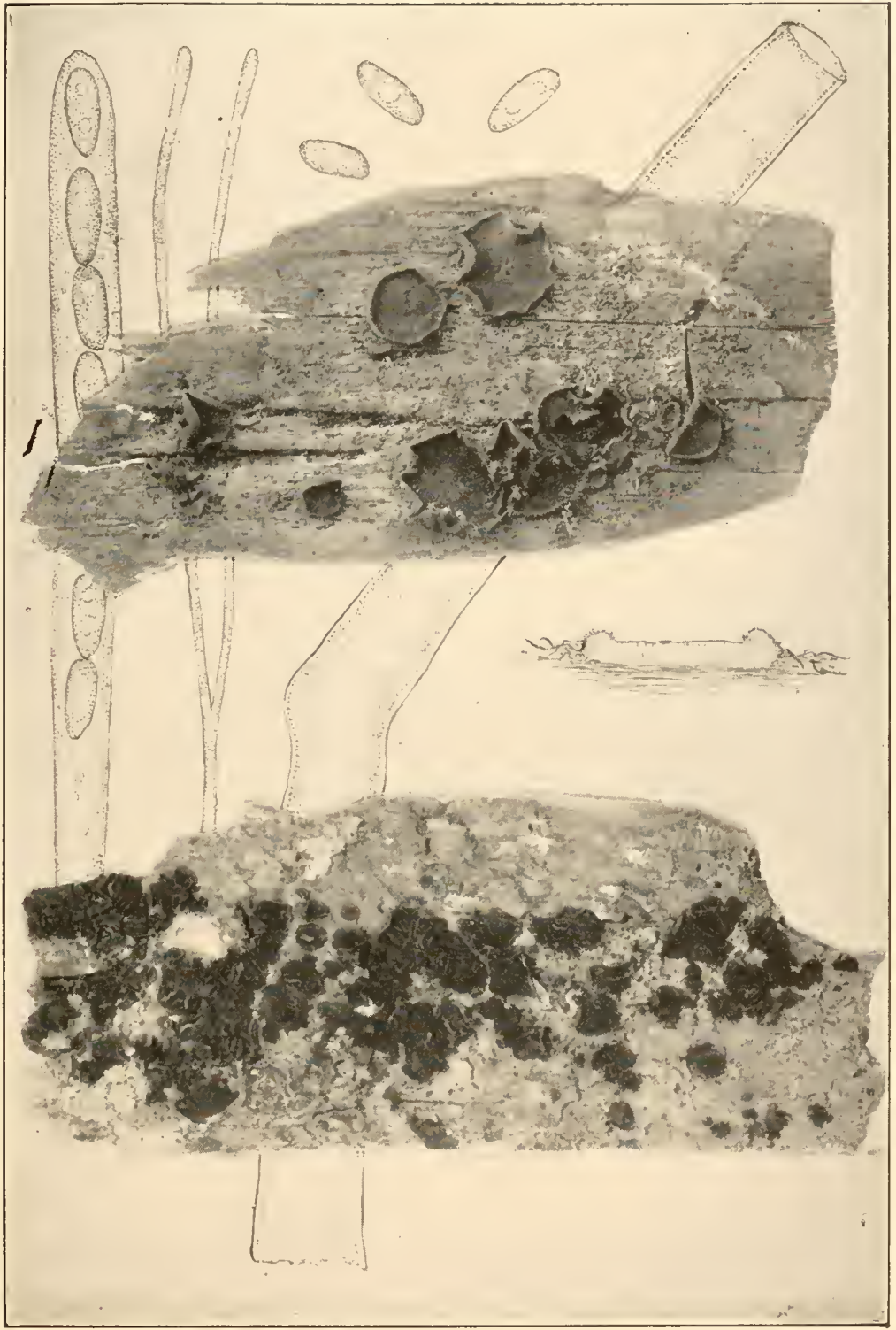

CATINELLA NIGROOLIVACEA 

On herbaceous plant tissues.

Spores 25-30 $\mu$ long, on Thalictrum.

7. P. Thalictri.

Spores less than $25 \mu$ long.

Spores mostly $10 \quad 12 \mu$ long.

Spores 14-16 $\mu$ long.

On Festuca.

On Solidago.

8. P. Ellisii.

On Potentilla.

9 P. subatra.

Spores 12-13 $\mu$ long, on Cephalanthus.

10. P. coloradensis.

Spores 8-12 $\mu$ long.

On stems of Linum.

On stems of various kinds.

11. P. Cephalanthi.

Hymenium gray or rose-colored. Hymenium reddish-yellow.

12. P. californica.

13. P. compressula.

14. P. Absinthii.

Spores $7-9 \mu$ long.

On Artemisia.

15. P. Artemisiac.

On Apocynum.

16. P. Dearnessii.

On Smilax herbacea.

17. P. smilacicola.

On monocotyledonous stems, Carex.

Spores 12-20 $\mu$ long.

Spores 18-20 $\mu$ long.

18. P. caricina.

Spores 12-15 $\mu$ long.

Spores 4-5 × 13-15 $\mu$.

19. P. yogoensis.

Spores $2 \times 12-14 \mu$.

20. P. cervinula.

Spores $10-12 \mu$ long.

Spores 5-7 $\mu$ long.

21. P. Caricis.

22. P. multipunctoidea.

1. Pyrenopeziza Rubi (Fries) Rehm, Ascom. 416. 1878.

Excipula Rubi Fries, Syst. Mỳc. 2: 190. 1822.

Mollisia Rubi Karst. Acta Soc. Fauna Fl. Fenn. $2^{6}$ : 136.1885.

Apothecia gregarious, or occasionally crowded, at first immersed, rounded, finally erumpent through the ruptured epidermis, sessile, expanding and becoming cup-shaped, .3-1 $\mathrm{mm}$. in diameter, the margin inrolled when dry; brownish-black; asci clavate, reaching a length of $45-55 \mu$ and a diameter of $6-8 \mu$, 8-spored, spores elongate-clavate, or almost cylindric, $1.5-2.5 \times$ 7-9 $\mu$; paraphyses filiform, $1.5 \mu$ in diameter.

On dead canes of Rubus.

Type Locality : Europe.

Distribution: Delaware to Oregon and Washington; also in Europe.

2. Pyrenopeziza lacerata (Cooke \& Peck) Sacc. Syll. Fung. 8: 361. 1889.

Pesiza lacerata Cooke \& Peck, Grevillea 1: 6. 1872. 
Apothecia gregarious, globose, then expanded, dark-brown, the margin coarsely lacerated into subtriangular, irregular teeth; hymenium cinereous, becoming blackish when dry; asci subcylindric; spores cylindric-clavate, $12-13 \mu$ long.

On Rubus odoratus.

Type Locality: Adirondack Mountains, New York.

Distribution: New York and IVest Virginia.

Exsiccati: Ellis \& Ev. N. Am. Fungi 20\%.

3. Pyrenopeziza prinicola (Ellis \& Ev.) Cash, Jour. Wash. Acad. Sci. 30:302. 1940.

Pesiza prinicola Ellis \& Ev. Jour. Myc. 4: 99.1888.

Mollisia prinicola Sacc. Syll. Fung. 8: 330. 1889.

Apothecia erumpent, becoming superficial, scattered rather thickly and evenly over the lower surface of the leaf, minute, $.15-.27 \mathrm{~mm}$. in diameter, subturbinate, then patellate, the entire apothecium black when dry; the margin slightly crenulate; hymenium alutaceous to dark-brown when fresh; asci clavate, narrowed below, reaching a length of 33-40 $\mu$ and a diameter of 6-8 $\mu$, 8-spored; spores irregularly 2-3-seriate, clavate, becoming pseudloseptate, $1-1.5 \times 10-15 \mu$; paraphy'ses filiform.

On dead leaves of Quercus Prinus and other species of Quercus. Type locality : Louisiana.

Distribution: Louisiana and Georgia.

4. Pyrenopeziza protrusa (Berk. \& Curt.) Sacc. Syll. Fung. 8: 364. 1889.

Peziza protrusa Berk. \& Curt.; Berk. Grevillea 3: 159. 1875.

Pseudopeziza protrusa Sacc. Syll. Fung. 8: 726. 1889.

Apothecia erumpent, dot-like, surrounded by the ruptured cuticle, externally granulated, chestnut; hymenium concave, white; asci clavate, reaching a length of $45-50 \mu$ and a diameter of $5 \mu$; spores ellipsoid-clavate, $1.5 \times 7-8 \mu$; paraphyses filiformclavate.

On the under side of the leaves of Magnolia glauca.

Type locality: South Carolina.

Distribution: New Jersey and South Carolina.

Exsiccati: Ellis, N. Am. Fungi 1+3; Rehm, Ascom. 310 (from New Jersey); Thüm. Myc. Univ. 519 (from New Jersey). 
5. Pyrenopeziza leucodermis Cash, Jour. Wash. Acad. Sci. 29: 49. 1939.

Apothecia hypophyllous, subepidermal, then superficial, sessile, scattered thickly over the leaf, at first nearly globose, then patellate, membranous-fleshy, pale-brown, .15-.25 mm. in diameter, externally furfuraceous, the margin even or slightly fimbriate, inrolled when dry; hymenium subhyaline; asci clavate, or narrow-ellipsoid, reaching a length of $28-35 \mu$ and a diameter

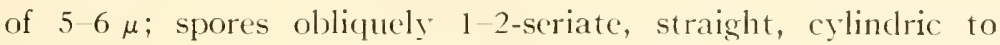
clavate, $.7-1 \times 5-7 \mu$; paraphyses filiform, slightly enlarged above.

On leaves of Acer leucoderme and Acer floridanum.

Type locality: Athens, Georgia.

Distribution: Georgia.

6. Pyrenopeziza minuta Cash, Jour. Mash. Acad. Sci. 30: 302. 1940.

Apothecia hypophyllous, subcuticular, becoming superficial, closely aggregated in pale spots on withering leaves, patellate, pale-brown when moist, entire fungus black when dry, .15-.17 $\mathrm{mm}$. in diameter, soft, fleshy to membranous; asci clavate to fusoid, rather abruptly narrowed above and below, reaching a length of 28-33 $\mu$ and a diameter of $4-5 \mu, 8$-spored; spores 2seriate, or irregularly 3 -seriate, clavate, .7-1 $\times 4-5 \mu$; paraphyses filiform, enlargerl above, $2-3 \mu$ in diameter.

On withering leaves of Tilia heterophylla var. Michauxii.

Type locality: Princeton, Georgia.

Distribution: Known only from the type locality.

7. Pyrenopeziza Thalictri (Peck) Sacc. Syll. Fung. 8: 360. 1889. Peziza Thalictri Peck, Ann. Rep. N. Y. State Mus. 29: 55. 1878.

Apothecia abundant, sessile, bursting through the epidermis, small, punctiform when dry, externally black, the margin usually whitish, or cinereous and subfimbriate; hymenium cinereous; asci cylindric; spores long-ellipsoid, $5 \times 25-30 \mu$ paraphyses not observed.

On dead stems of Thalictrum.

Type locality: Center, New York.

Distribution: New York to Ontario and South Dakota. 
8. Pyrenopeziza Ellisii (Rehm) Massee, Jour. Bot. 34: 149. 1896.

Niptera Ellisii Rehm; Ellis \& Ev. N. Am. Fungi 2329; Sacc. Syll. Fung. 11: 416. 1895. nom. nud.

Apothecia sparse, or gregarious, erumpent, at first subglobose and closed, then expanding, .5-.7 $\mathrm{mm}$. in diameter, grayishblack, externally brownish-black; asci clavate, reaching a length of 90-100 $\mu$ and a diameter of 10-12 $\mu, 8$-spored; spores 2-seriate, elongate-cylindric, usually curved, $3.5-4 \times 14-16 \mu$; paraphyses filiform, $3 \mu$ in diameter.

On dead stems of Festuca tenella; also reported ori Ammophila longifolia.

Type locality: Newfield, New Jersey.

Distribution: New Jersey and Montana.

Illustrations: Jour. Bot. 34: pl. 357, f. 6, 7 .

Exsiccati: Ellis, N. Am. Fungi 565 (as Peziza denigrata Kunze); Ellis \& Ev. N. Am. Fungi 2329.

9. Pyrenopeziza subatra (Cooke \& Peck) Sacc. Syll. Fung. 8: 359. 1889.

Peziza subatra Cooke \& Peck; Peck, Ann. Rep. N. Y. State Mus. 28: 66. 1876.

Apothecia erumpent, black, soft, or waxy, at first hemispherical, finally expanding, slightly rugose; hymenium fuliginous, the margin paler; asci subcylindric, 8-spored; spores narrow-ellipsoid, or fusoid, 15-16 $\mu$ long; paraphy'ses filiform.

On dead herbaceous stems.

Type Locality: North Greenbush, New lork.

Distribution: New York and New Jersey; also reported from Michigan.

Exsiccatı: Ellis, N. Am. Fungi 445; Ellis \& Ev. Fungi Columb. 21.

A portion of what appears to be the type of this species is in the collection of The New York Botanical Garden. A number of specimens have been doubtfully referred to this species. All should be more carefully studied.

10. Pyrenopeziza coloradensis Ellis \& Ev. Bull. Torrey Club 27 : 60. 1900.

Apothecia scattered, superficial, black, with a narrow, slightly incurved margin, reaching a diameter of $1 \mathrm{~mm}$; hymenium concave, or plane; asci clavate, reaching a length of 100-110 $\mu$ 
and a diameter of $15 \mu$; spores 2-seriate, ellipsoid, with two oildrops, $10 \times 20 \mu$; paraphyses stout.

On dead stems of Potentilla.

Type Locality: Red Mountain, Colorado, elevation 12,000 feet.

Distribution: Known only from the type locality.

11. Pyrenopeziza Cephalanthi Fairman, Jour. Myc. 10: 229. 1904.

Apothecia scattered, small, sessile, black outside, the margin occasionally white; hymenium white at first, growing yellowish, then black with age; asci clavate-cylindric, reaching a length of $60 \mu$ and a diameter of 6-7 $\mu$; spores cylindric, or elongatefusoid, $2-3 \times 10-13 \mu$ with several oil-drops; paraphyses filiform.

On dead limb of Cephalanthus occidentalis lying in a ditch.

Type Locality: Ridgway, New York.

Distribution: Known only from the type locality.

12. Pyrenopeziza californica Sacc. Ann. Mỹc. 2: 15. 1904.

Pezizella californica Rehm, Ann. Myc. 5: 520. 1907.

Apothecia superficial, gregarious, cyathiform, base contracted, black outside and inside, smooth, when dry mouth contracted, externally striate, .5-1 $\mathrm{mm}$. in diameter, the margin conspicuously laciniate; asci clavate, reaching a length of $50-68 \mu$ and a diameter of 5.5-6.5 $\mu, 8$-spored; spores 1-seriate, ellipsoid, $3.5-4.5 \times 9-12 \mu$; paraphyses filiform, enlarged above.

On dead stems of Linum Lewisii.

Type locality: Mt. Eddy, Siskiyou Co., California.

Distribution: Known only from the type locality.

Saccardo suggests that this might be the type of a new genus (Geasterina).

13. Pyrenopeziza compressula Rehm in Rab. Krypt.-Fl. $1^{3}: 618$. 1892.

Apothecia gregarious, at first globose and immersed, becoming erumpent and sessile, cup-shaped, externally brown to brownishblack, .1-.35 mm. in diameter; hymenium concave, gray, or slightly rose-colored; asci clavate, reaching a length of 45-60 $\mu$ and a diameter of $5-6 \mu, 8$-spored; spores fusoid, occasionally slightly curved, $1.5-3 \times 8-12 \mu$; paraphyses filiform, $2 \mu$ in diameter. 
On dead stems of various plants.

Type locality: Europe.

Distribution: Colorado, California and (Quebec?); also in Europe.

Exsiccati: Clements, Crypt. Form. Colo. 287.

14. Pyrenopeziza Absinthii (Lasch) Rehm in Rab. Krypt.-Fl. $1^{3}$ : 625. 1892.

Peziza Absinthii Lasch; Rab. in Klotzsch, Herb. Viv. Myc. 14: 17; Bot. Zeit.

8: 438.1850.

Pyrenopeziza fuscorubra Rehm; Winter, Flora 55: 526.1872.

Niptera fuscorubra Rehm, Ber. Naturh. Ver. Augsburg 26: 21. 1881.

Pseudohelotium Absinthii Sacc. Syll. Fung. 8: 297. 1889.

Mollisia fuscorubra Sacc. Syll. Fung. 8: 322. 1889.

Apothecia thickly gregarious, at first globose and closed, submerged, becoming erumpent and sessile, cup-shaped, finally expanded and saucer-shaped, externally reddish-brown, smooth, $.5-1.2 \mathrm{~mm}$. in diameter; hymenium reddish-yellow; asci cylindricclavate, reaching a length of $60-70 \mu$ and a diameter of $6-7 \mu$, 8 -spored; spores elongate-ellipsoid, $2.5 \times 8-10 \mu$; paraphyses sparse, filiform, $2 \mu$ in diameter.

On dead stems of various plants, Ira xanthiifolia, Erigeron, Bidens, Melianthus, Artemisia etc.

Type locality: Europe.

Distribution: New Jersey to Kansas and North Dakota.

Exsiccatı: Ellis, N. Am. Fungi 60; Brenckle, Fungi Dak. 215.

15. Pyrenopeziza Artemisiae (Lasch) Rehm, Ascom. 66. 1872. Peziza Artemisiae Lasch in Klotzsch, Herb. Viv. Myc. 335; Grevillea 1: 131. 1873.

Mollisia Artemisiae Phill. Brit. Discom. 188. 1887.

Apothecia erumpent, turbinate, substipitate, expanding and becoming flattened, brownish-black; hymenium concave to plane, whitish; asci cylindric, reaching a length of $50 \mu$ and a diameter of $5 \mu$; spores elongate-cylindric, $1.5-2 \times 7-9 \mu$; paraphyses filiform, $2 \mu$ thick, enlarged above to $3 \mu$.

On deat stems of Artemisia vulgaris.

Type locality: Europe.

Distribution: New York and New Jersey to Michigan and Ontario.

Exsiccat1: Barth. Fungi Columb. 3866. 
A variety, Solidaginis, on Solidago juncea, has been recognized by Rehm, Ascom. 1957 from material collected in Ontario, Canada by Dr. John Dearness.

16. Pyrenopeziza Dearnessii Rehm, Ann. Myc. 9: 286. 1911.

Apothecia gregarious, at first submerged, becoming erumpent through the laciniately splitting epidermis, at first globose, sessile, brownish, expanding, .2-.5 mm. in diameter, when dry more or less covered by the laciniate epidermis; asci clavate, reaching a length of $50 \mu$ and a diameter of $7-8 \mu$; spores elongate-ellipsoid, 2 -seriate, $3 \times 6-8 \mu$; paraphyses filiform $2 \mu$ thick, expanding to $3-3.5 \mu$ at their apices.

On dead stems of Apocynum androsaemifolium.

Type locality: London, Canada.

Distribution: Ontario, Canada.

17. Pyrenopeziza smilacicola Dearn. \& House, N. Y. State Mus. Circ. 24: 28. 1940.

Apothecia thickly scattered, subcorticular at first, then erumpent, and finally sessile-superficial, the margin inrolled when dry, .2-.35 mm. in diameter, externally brown; asci clavate, reaching a length of $48-55 \mu$ and a diameter of 6.5-9 $\mu$; spores 2 -seriate, subclavate, $2 \times 7-8.5 \mu$; paraphyses filiform, longer than the asci.

On the dead stems of Smilax herbacea.

Type locality: Essex Co., New York.

Distribution: Known only from the type locality.

18. Pyrenopeziza caricina (Lib.) Rehm in Rab. Krypt.-Fl. $1^{3}$ : 634. 1892.

Pesiza caricina Lib. Pl. Crypt. Ard. 230. 1834.

Pseudopeziza caricina Sacc. Sỵll. Fung. 8: 727. 1889.

Apothecia scattered, at first submerged, then erumpent, externally dark-brown, later black, waxy; hymenium grayishwhite; asci clavate, reaching a length of $100-110 \mu$ and a diameter of 15-20 $\mu, 8$-spored; spores elongated, slightly curved, 5-6 $\times 18-$ $20 \mu$; paraphyses filiform, slightly enlarged above.

On dead stems of Carex.

Type locality: Europe.

Distribution: Colorado; also in Europe.

Exsiccati: Clements, Crypt. Form. Colo. 286. 
19. Pyrenopeziza yogoensis (Ellis \& Gall.) Sacc. Syll. Fung. 10: 17.1892.

Peziza yogoensis Ellis \& Gall. Jour. Myc. 5: 65. 1889.

Apothecia erumpent, .2 $\mathrm{mm}$. in diameter, with an incurved, fimbriate margin, olivaceous within; hymenium pale; asci cylindric, reaching a length of 55-60 $\mu$ and a diameter of $15-18 \mu$; spores obliquely 1 -seriate, or 2-seriate, cllipsoid, a little narrower at one end, 4-5 × 13-15 $\mu$; paraphyses stout, not abundant.

On dead leaves of Carex.

Type Locality: Yogo, Belt Mountains, Montana.

Distribution: Known only from the type locality.

20. Pyrenopeziza cervinula (Cooke) Sacc. Syll. Fung. 8: 369. 1889.

Pesiza cervinula Cooke, Hedwigia 14: 84. 1875.

Pesiza multipuncta Peck; Thüm. Myc. Univ. 1+12. 1879.

Apothecia thickly scattered, crumpent, minute, .1-.2 mm. in diameter, at first subglobose, opening and becoming subhemispheric, externally deer-colored; hymenium white; asci clavate, reaching a length of $40 \mu$; spores cylindric, straight, or curved, $2 \times 12-14 \mu$; paraphyses not observed.

On culms of Carex.

Type Locality: New Jersey.

Distribution: New Jersey and New York.

Exsiccati: Ellis, N. Am. Fungi 440; Thüm. Myc. Univ. 1+12; Roum. Fungi Select. Exsicc. 4628 (as Peziza multipuncta).

21. Pyrenopeziza Caricis Rehm in Rab. Krypt.-Fl. $1^{3}: 633$. 1892.

Mollisia Karstenii var. Caricis Rehm, Hedwigia 23: 53. 1884.

Apothecia gregarious, at first globose and closed, immersed, then erumpent through the epidermis, expanding and becoming cup-shaped, or saucer-shaped, externally dark-colored, brownishblack, .2-.5 mm. in diameter; hymenium yellowish; asci clavate, reaching a length of $40-50 \mu$ and a diameter of $8-9 \mu, 8$-spored; spores, fusoid, straight, or slightly bent, $2-2.5 \times 10-12 \mu$; paraphyses filiform, $2 \mu$ in diameter above.

On dead stems of Carex.

Type locality: Europe.

Distribution: New York; also in Europe. 
22. Pyrenopeziza multipunctoidea Dearn. \& House, N. Y. State Mus. Circ. 24: 28. 1940.

Apothecia at first immersed, minute, thickly scattered, often in rows, emerging through a usually elliptic rupture of the cuticle, .15-.22 mm. in diameter; asci cylindric, or fusoid, reaching a length of $33-48 \mu$ and a diameter of $6-7.5 \mu, 8$-spored; spores partially 2-seriate, ellipsoid, 2.5-2.75 $\times 5-7 \mu$; paraphyses numerous, filiform.

On dead leaves of Carex lacustris.

Type locality: Newcomb, Essex Co., New York.

Distribution: Known only from the type locality.

Part of the type material is in The New York Botanical Garden.

\section{Doubtful And Excluned Species}

Pyrenopeziza cariosa (Peck) Sacc. Syll. Fung. 8: 367. 1889; Peziza cariosa Peck, Ann. Rep. N. Y. State Mus. 24: 95. 1872. On rotten wood, Catskill Mountains. Description incomplete.

Pyrenopesiza doryphora Clements, Crypt. Form. Colo. 28s. 1907. On dead stems of Carex, Colorado. A variety, Heleocharidis Clements, Crypt. Form. Colo. 525. 1908, has been listed. So far as known these have not been officially published.

Pyrenopeziza foliicola (Karst.) Sacc. Michelia 1: 65. 1877; Mollisia foliicola Karst. Myc. Fenn. 1: 201. 1871. This species has been reported from Georgia but on a doubtful determination.

Phillipsiella nigrella Cooke \& Hark. Bull. Calif. Acad. Sci. 1: 23. 1884. On leaves of Quercus agrifolia, California.

Pyrenopeziza nigrella Fuckel, Symb. Myc. Nacht. 3: 30. 1875. Reported from Michigan by Dr. B. Kanouse. On decaying stems. No material seen.

Pyrenopeziza nigritella (Phill. \& Hark.) Sacc. Syll. Fung. 8: 357.1889 ; Peziza nigritella Phill. \& Hark. Bull. Calif. Acad. Sci. 1:22. 1884. Apothecia blackish; spores $6 \times 15 \mu$. On dead stems of Galium.

\section{STAMNARIA Fuckel, Symb. Myc. 309. 1869.}

Apothecia erumpent-superficial, oecurring singly, or more often in cespitose clusters, more or less gelatinous, horny when dry, sessile, or short-stipitate; asci clavate, usually 8-spored; spores simple, ellipsoid, hyaline; paraphyses filiform, slightly enlarged above.

Type species, Peziza Persoonii Moug.

On species of Equisetum.

On foliage of Thuja.

1. S. americana.

2. S. Thujae. 
1. Stamnaria americana Massee \& Morgan, Jour. Myc. 8: 183. 1902. (Plate 115.)

Apothecia erumpent in clusters of three or four each, or in rows $6-7 \mathrm{~mm}$. long, the individual apothecia sessile, or subsessile, at first rounded, gradually expanding and becoming turbinate, reaching a diameter of .5-.7 mm., pale-orange; hymenium plane, or slightly concave, similar in color to the outside of the apothecium, whitish-pruinose from the ends of the protruding asci and paraphyses; asci clavate, 8-spored, reaching a length of $150-200 \mu$ and a diameter of $16 \mu$; spores 1 -seriate, or partially 2-seriate above, ellipsoid, straight, or curved, usually with one or two large oil-drops surrounded with a granular contents, hyaline, $7-9 \times 24-32 \mu$; paraphyses filiform, rather strongly enlarged above, pale-orange in mass.

On species of Equisetum, especially Equisetum robustum and Equisetum hyemale.

Type locality: Preston, Ohio.

Distribution: New York and New Jersey to Virginia, Indiana and (Oregon?).

Illustrations: Papers Mich. Acad. Sci. 19: pl. 8.

Exsiccati: Ellis, N. Am. Fungi $127+$ (as Peziza Personii); Ellis \& Ev. Fungi Columb. 333 (as Stamnaria Equiseti); Kellerm. Ohio Fungi 2: 18 .

2. Stamnaria Thujae Seaver, Mycologia 28: 186. 1936.

(Plate 116.)

Apothecia occurring singly, or more of ten in congested masses, erumpent through the epidermis on the under side of the foliage of the host, translucent with a slight yellowish or pinkish tint, exceedingly soft and gelatinous, shrinking much in drying, the individual apothecia small, not usually exceeding $.2 \mathrm{~mm}$. in diameter; asci clavate, reaching a length of $55 \mu$ and a diameter of $15 \mu, 8$-spored; spores irregularly disposed in the ascus, ellipsoid, hyaline, granular, $6-7 \times 10-12 \mu$; paraphyses very slender branched.

On foliage of Thuja occidentalis.

Type Locality: Baileys Harbor, Wisconsin.

Distribution: Known only from the type locality.

43. OMBROPHILA Fries, Summa Veg. Scand. 357. 1849. Neobulgaria Petrak, Ann. Myc. 19: 44. 1921. 


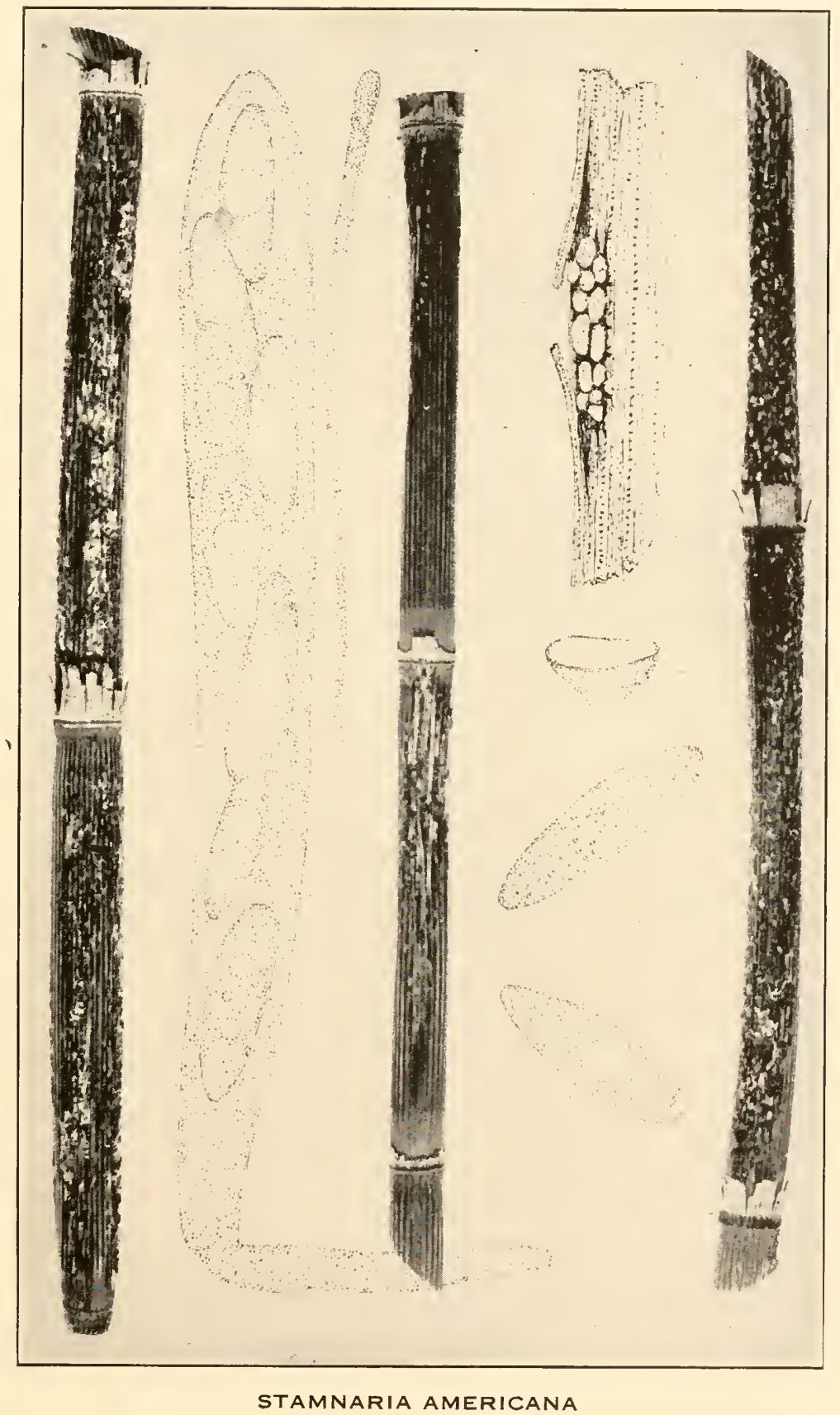



Apothecia fleshy to gelatinous, stipitate but the stem often much reduced in length, or $1 \mathrm{~cm}$. or more in length; asci clavate to cylindric, usually 8-spored; spores ellipsoid to fusoid, hyaline, simple; paraphyses variable.

Type species, Peziza Clavus Alb. \& Schw.

The genus has been used as a "waste basket" and most of the species placed here have been referred to other genera. However, the type species is very characteristic, widely distributed, and well known, so the genus is allowed to stand.

1. Ombrophila Clavus (Alb. \& Schw.) Cooke, Grevillea 8: 84. 1879. (Plate 76́.)

Peziza Claz'us Alb. \& Schw, Consp. Fung. 306. 1805.

Peziza Clavus violascens Alb. \& Schw. Consp. Fung. 306. 1805.

Helotium pileatum Peck, Ann. Rep. N. Y. State Mus. 28: 67. 1876.

?Helotium palustre Peck, Ann. Rep. N. Y. State Mus. 32: 48.1879.

Leotia aquatica Lib. Rev. Myc. 2: 18.1880.

Helotium Clavus Gill. Champ. Fr. Discom. 153. 1883.

Cudonia aquatica Quél. Ench. Fung. 267. 1886.

?Ombrophila albiceps Peck, Ann. Rep. N. Y. State Mus. 42: 34.1889.

Cudoniella fructigena Rostr. Medd. Gronl. 3: 605. 1891.

Cudoniella aquatica Sacc. Syll. Fung. 8: 42. 1889.

Apothecia scattered, fleshy, to subgelatinous, stipitate, or subsessile, pallid, or purplish; reaching a diameter of $1 \mathrm{~cm}$.; hymenium plane, or convex, same color; stem variable, short, or very long, gradually expanding into the apothecium, the whole subturbinate; asci cylindric-clavate, reaching a length of 70-90 $\mu$ and a diameter of 9-10 $\mu, 8$-spored; spores elongate-ellipsoid, or subfusoid, often unequal-sided, $4-5 \times 10-15 \mu$; paraphyses filiform.

On leaves and wood submerged in water or in very wet places.

Type locality: Europe.

Distribution: New England to Washington; probably widely distributed.

Illustrations: Alb. \& Schw. Consp. Fung. pl. 11,f. 5; Phill. Brit. Discom. pl. 10, f. 62; Boud. Ic. Myc. pl. 434.

When Albertini and Schweinitz described Peziza Clavus they listed two varieties: a. pallens and b. violascens. When Fries established the genus Ombrophila, he raised these forms to specific rank calling the first Ombrophila, purpurascens and the second Ombrophila violacea. Just why violascens was changed to violacea is not apparent. 
Ellis distributed specimens under these names (N. Am. Fungi 392 as Ombrophila violacea Fr. and 393 as Ombrophila purpurascens Fr.) He indicates that the two were collected together and so far as the writer can see they are identical. Whether these are identical with either of the forms listed by Fries is a question. Ellis and Everhart distributed this again (Fungi Columb. 22) as Ombrophila purpurascens Fr. One specimen in the Ellis collection is labeled Ombrophila purpurascens Fr. (stipitate var.). This is certainly Ombrophila Clavus and indicates that Ellis regarded the two as having a varietal relationship.

Dr. B. Kanouse lists for Michigan one collection of Ombrophila violacea (Hedw.) Fr. The small specimen examined seems to be entirely sessile although Octospora violacea Hedw. is illustrated (Hedw. Descr. 2: pl. $\delta, f . a$.) as being at first cylindric, expanding above and at maturity with a stout stem, closely resembling Tulasne's (Fung. Carp. 3: pl. 17, f. 1-8) figures of Coryne sarcoides. There is nothing to indicate that Ombrophila violacea Fries was based on Octospora violacea Hedw., although some have so regarded it. So it will be seen that there is much confusion over the identity of these forms.

Phillips (Brit. Discom. 325) states referring to Ombrophila Clavus: "A most variable species both in size and shape, the stem at one time absent, at another elongated to twice the diameter of the disc; sometimes very thick, at other times slender." The variability of this species doubtless is responsible for the confusion which has arisen concerning it.

\section{Doubtful And Excluded Species}

Ombrophila albofusca Ellis, Bull. Torrey Club 9: 73. 1882. The type of this species has been examined but no apothecia could be found.

Ombrophila aurata (Berk. \& Rav.) Phill. Grevillea 19: 74. 1891; Peziza aurata Berk. \& Rav. in Rav. Fung. Car. 3: 37. 1855. No specimen of this species is available but the description suggests Chlorociboria.

Ombrophila flavens Feltg. Vorst. Pilz-Fl. Luxenb. $1^{3}: 76.1903$. This species has been reported on wood of Salix from Washington by Dr. B. Kanouse. No material seen. Description suggests a Helotium.

Ombrophila hirtella Rehm, Ann. Myc. 6: 314. 1908. No material has been seen but from the description it would appear to be a Lachnella. It was described from material sent from Glenco, Illinois by E. T. and S. A. Harper.

Ombrophila lilacina (Wulf.) Karst. Myc. Fenn. 1: 90. 1871; Elvela lilacea Wulf. in Jacq. Coll. Bot. 1:347. 1786; Pesiza lilacina Fries, Syst. Myc. 2: 140. 1822. This species has been reported from Dominica by A. L. Smith, Jour. Linn. Soc. 35: 15. 1901. We have no other knowledge of the species. 


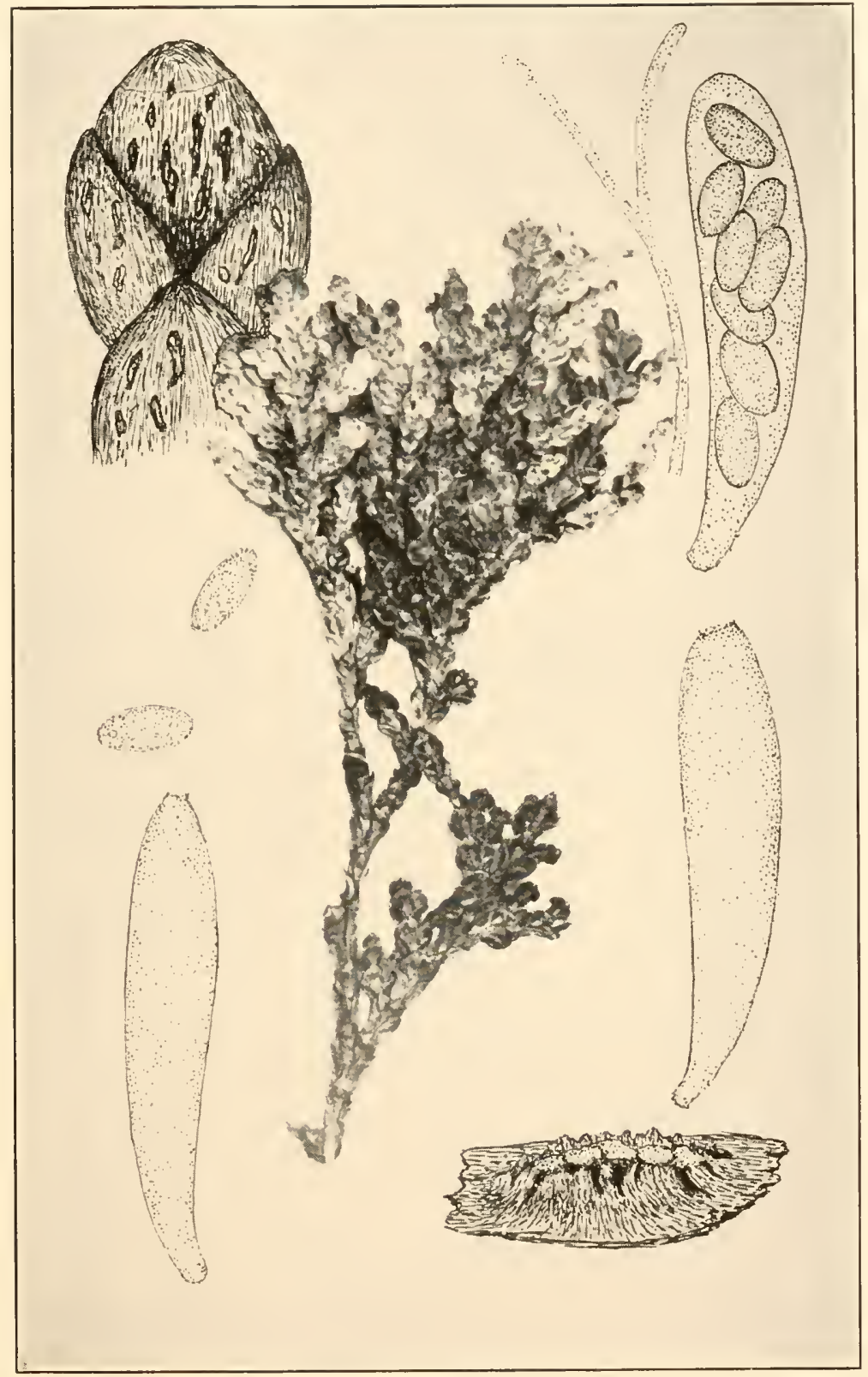

STAMNARIA THUJAE 

Ombrophila limosa Rehm, Ann. Myc. 11: 154. 1913. Described from material on dead leaves of Carex limosa from London, Canada. No specimens have been seen.

Ombrophila Lysichitonis Kanouse, Mycologia 39: 672. 1947. Reported on Lysichiton camtschatcense from Washington by Dr. B. Kanouse. The description strongly suggests Ombrophila Clavus.

Ombrophila limosella (Karst.) Rehm, Ascom. 508; Ber. Naturh. Ver. Augsburg 26: 122. 1881 ; Peziza limosella. Karst. Not. Soc. Fauna Fl. Fenn. 10: 152. 1869; Ombrophila violacea var. limosella Karst. Myc. Fenn. 1: 88. 1871. This species has been reported from Washington by Dr. B. Kanouse. As will be seen it was originally regarded as a variety of Ombrophila violacea, the identity of which is uncertain as indicated above.

Ombrophila pellucida A. L. Smith, Jour. Linn. Soc. 35: 14. 1901. Described from material collected in Dominica. No material seen.

Ombrophila similis (Berk. \& Curt.) Sacc. Syll. Fung. 8: 614. 1889; Bulgaria similis Berk. \& Curt.; Berk. Jour. Linn. Soc. 10: 370. 1868. On dead wood in Cuba. This is said to differ from Coryne sarcoides in its much smaller spores. Its identity is uncertain.

Ombrophila subsqualida Rehm in Rab. Krypt.-F1. 1 ${ }^{3}:$ 1226. 1896. This species has been reported from Michigan by Dr. B. Kanouse. No material has been seen.

Ombrophila subaurea Cooke, Bull. Buffalo Soc. Nat. Sci. 2: 300. 1875. Saccardo suggests that this is close to Ombrophila enterochroma (Kriegeria enterochroma) and the size of the spores, $5 \times 30 \mu$, would so indicate. Specimens distributed by Ellis (N. Am. Fungi 39-7) do not agree with Peck's description and are apparently small specimens of Coryne sarcoides.

\section{PHAEOBULGARIA Seaver, Mycologia 24: 253. 1932.}

Apothecia medium large, decidedly gelatinous within, distinguished from Bulgaria by its inoperculate asci and brown spores; asci clavate, 8-spored; paraphyses filiform.

'Type species, Peziza inquinans Pers.

Only one species of this genus known at the present time. Fries included this with Bulgaria since at that time no distinction was made between the operculates and the inoperculates.

Phaeobulgaria inquinans (Pers.) Nannf., Nova Acta Soc. Sci.

$$
\text { Upsal. IV. 8: 311. 1932. (Plate 117, FIG. 2.) }
$$

Peziza polymorpha Oeder, FI. Dan. 8: 8. 1769.

Tremella turbinata Hudson, FI. Angl. 2: 563. 1778.

Peziza nigra Bull. Hist. Champ. Fr. 238. 1791.

Peziza brunnea Batsch, Elench. Fung. 1: 125. 1783.

Octospora elastica Hedw. Descr. 2: 28.1789.

Burcardia turbinata Schmidel, Ic. Pl. 263. 1793.

Tremella agaricoides Retz. F1. Scand. 295. 1795.

Peziza inquinans Pers. Tent. Disp. Fung. 33. 1797.

A scobolus inquinans Nees, Syst. Pilze Schw, 268. 1817. 
Bulgaria inquinans Fries, Syst. Myc. 2: 167. 1822.

Coryne turbinata Bonord. Handh. Myk. 149. 1851.

Bulgaria polymorpha Wettst. Verh. Zool.-Bot. Ges. Wien 35: 595. 1886.

Apothecia occurring singly, or more of ten several from a common base in cespitose clumps, at first rounded, or short cylindric, finally expanding and becoming turbinate with the hymenium concave, becoming plane and finally convex with the margin repand, reaching a diameter of 1-4 cm., externally brownish; hymenium black, or bluish-black and shining; asci clavate, reaching a length of $150-200 \mu$ and a diameter of 9-10 $\mu$, 8spored; spores ellipsoid, unequal-sided and of ten narrower at one end, becoming pale-brown, 6-7 × 12-14 ; paraphyses slender yellow, or violet brown, $1 \mu$ in diameter.

On bark of trees, especially the various species of oak, Quercus; occasionally reported on other trees.

TyPe locality: Europe.

Distribution: New York to Alabama, Washington and California; also in Europe.

Illustrations: Fl. Dan. pl. 46t; Bull. Herb. Fr. pl. 116; Batsch. Elench. Fung. 1: pl. 11, f. 50; Schmidel, Ic. Pl. pl. 70; Schaeff. Fung. Bavar. pl. 158; Hedw. Descr. 2: pl. 6, E.; Bull. Lab. Nat. Hist. State Univ. Iowa 6: pl. 37, f. 2.

Exsiccati: Rav. Fungi Car. 5: 43 ; Ellis, N. Am. Fungi $4+8$; Reliq. Farlow. 100.

45. ASCOTREMELLA Seaver, Mýcologia 22: 53.1930.

Haematomyces Authors (in part) not Berk. \& Br. Jour. Linn. Soc. 14: 108. 1875.

Apothecia densely crowded, or cespitose, tremelloid, sessile, or substipitate; asci cylindric but often much swollen so that the spores appear relatively small, 8-spored; spores ellipsoid, or more or less irregular in form, usually containing two small oil-drops, hyaline; paraphyses slender, simple, or branched.

Type species, Haematomyces fagineus Peck.

Apothecia forming cerebriform masses.

1. A. faginea.

Apothecia cespitose, turbinate.

2. A. turbinata.

1. Ascotremella faginea (Peck) Seaver, Mycologia 22:53. 1930. (Plate 118.)

Ifaematomyces fagineus Peck, Ann. Rep. N. Y. State Mus. 43: 33. 1890.

Apothecia tremelloid, cerebriform, reaching a diameter of $2-4 \mathrm{~cm}$., or forming a continuous mass $8-10 \mathrm{~cm}$. in extent, gyrose- 


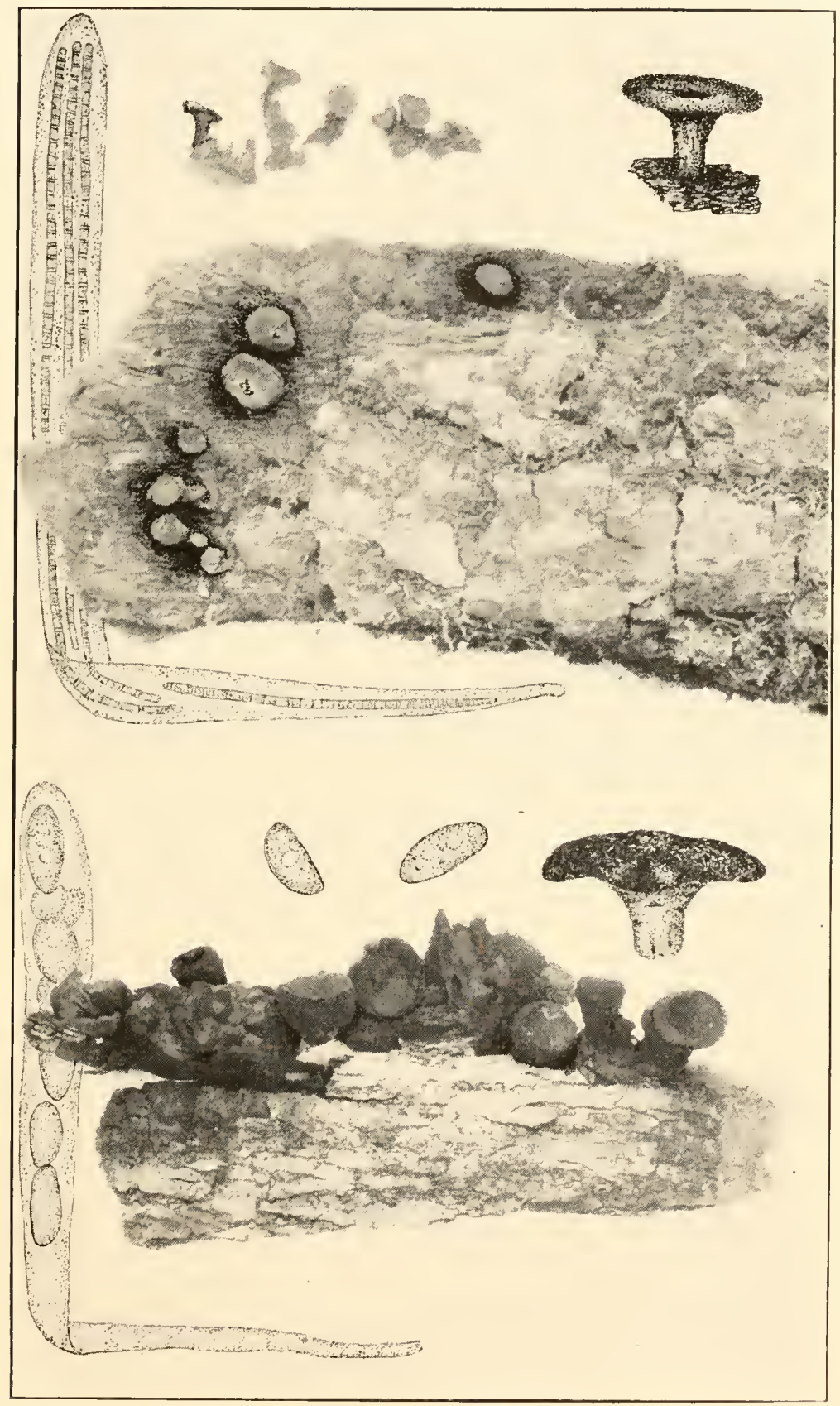

1. HOLWAYA giganteA

2. PHEUDOBULGARIA INQUINANS 

lobate, smooth, shining, raisin-colored without and within, the substance gelatinous, becoming horny when dry; asci subcylindric, reaching a length of $50 \mu$ and a diameter of $6-7 \mu$; spores usually 1 -seriate, narrow-ellipsoid, hyaline, $4-5 \times 7 \mu$; paraphyses slender, slightly enlarged above.

On trunks of beach, Fagus americana; also reported on Tilia.

Type Locality: Rainbow, Franklin Co., New York.

Distribution: New York to Ontario and Michigan; also reported from England.

Illustrations: Ann. Rep. N. Y. State Mus. 43 : pl. 4, f. 5-7; Mycologia 22: pl. 11; Trans. Brit. Mỵc. Soc. 29: 152, f. 13.

2. Ascotremella turbinata Seaver, Mycologia 22: 53. 1930. (Plate 119.)

Apothecia extremely gelatinous, closely crowded when young, giving rise to cespitose clusters as they mature, the individual apothecia at first rounded, becoming turbinate, or subturbinate, externally light-colored, reaching a diameter of about $2 \mathrm{~cm}$. and of about the same height, the substance shrinking to a thin film when dry; hymenium much darker than the outside of the apothecium, brownish, nearly circular in form, convex, plane, or very slightly concave, even or nearly so, occasionally with a few folds about the margin; asci cylindric, or subcylindric, of ten strongly swollen; spores small, ellipsoid, $3-4 \times 6-7 \mu$; paraphyses slender, often branched.

On rotten wood.

Type Locality: Ithaca, New York.

Illustration: Mycologia 22: pl. 12.

Distribution: New York.

\section{Excluded Siectes}

Peziza concrescens Schw. Schr. Nat. Ges. Leipzig 1: 118. 1822. This species which was described as a cartilaginous discomycete is a Tremella according to Burt.

46. CORYNE Tul. Fung. Carp. 3: 190. 1865.

Producing both conidial and ascigerous fruiting bodies from the same base, the structures occurring in cespitose clumps of similar purple color and both gelatinous, the conidial bodies clubshaped or tongue-shaped; apothecia turbinate, becoming expanded, sessile, or substipitate; asci clavate, 8-spored; spores fusoid, hyaline, becoming several-septate; paraphyses filiform. 
Type species, Peziza sarcoides Pers.

The name Coryne was first used by Nees (Syst. Pilze 157. 1817) for the conidial stage of this fungus. Later it was adopted by Tulasne for the ascigerous stage and would seem to be the tenable name for the genus.

Spores large, $10-30 \mu$ long.

Spores $4-6 \times 10-18 \mu$.

1. C. sarcoides.

Spores 6-7 $\times 24-30 \mu$.

2. C. urnalis.

Spores small, $2-3 \times 5-6 \mu$.

3. C. microspora.

1. Coryne sarcoides (Pers.) Bonord. Handb. Myk. 149.1851.

?Octospora violacea Hedw. Descr. 2: 32. 1789. Not Ombrophila violacea Fries. 1849.

Pesiza sarcoides Pers. Syn. Fung. 633. 1801.

Pesica janthina Fries, Syst. Myc. 2: 130. 1822.

Bulgaria sarcoides Fries, Syst. Myc. 2: 168.1822.

Tremella sarcoides Fries, Syst. Myc. 2: 217.1822.

Sarcodea sarcoides Karst. Not. Soc. Fauna Fl. Fenn. 11: 232.1871.

Bulgaria striata Ellis \& Ev. Jour. Myc. 1: 90. 1885.

?Coryne solitaria Rehm in Rab. Krypt.-Fl. 13: 488. 1891.

Ombrophila sarcoides Phill. Brit. Discom. 323. 1887.

Coryne striata Sacc. Syll. Fung. 8: 643. 1889.

?Orbilia atropurpurea Clements, Bot. Surv. Nebr. 4: 16. 1896.

Apothecia sessile, or substipitate, gelatinous, flesh-red to dark-purple, externally veined, turbinate, later expanding, $2 \mathrm{~mm}$. to $1 \mathrm{~cm}$. in diameter; hymenium at first concave, becoming plane, or repand, often irregularly deformed; asci clavate, reaching a length of $100-135 \mu$ and a diameter of $7-8 \mu, 8$-spored; spores ellipsoicl-fusoid, 4-6 $\times 10-18 \mu$, rarely larger, becoming severalseptate, the septa often indistinct; paraphyses filiform, often adhering.

On rotten wood.

TYPE LOCALITY: Europe.

Distribution: Maine to Oregon and probably throughout North America; also in Europe, and the West Indies.

Illustrations: Hedw. Descr. 2: pl. $8, f .1-7$; Bull. Herb. Fr. pl. +10, f. 1; (as Peziza tremelloidea) Gill. Champ. Fr. Discom. pl. 49 (as Aleuria purpurascens); E. \& P. Nat. Pfl. 1': 209, $f$. 164 E, F: Bull. Lab. Nat. Hist. State Univ. Iowa 5: pl. 22, f. 1; Tul. Fung. Carp. 3: pl. 17, f. 1-8.

Exsiccati: Ellis, N. Am. Fungi 1280 (as Bulgaria purpurea); Ellis \& Ev. N. Am. Fungi 2606 (as Tremella sarcoides). 


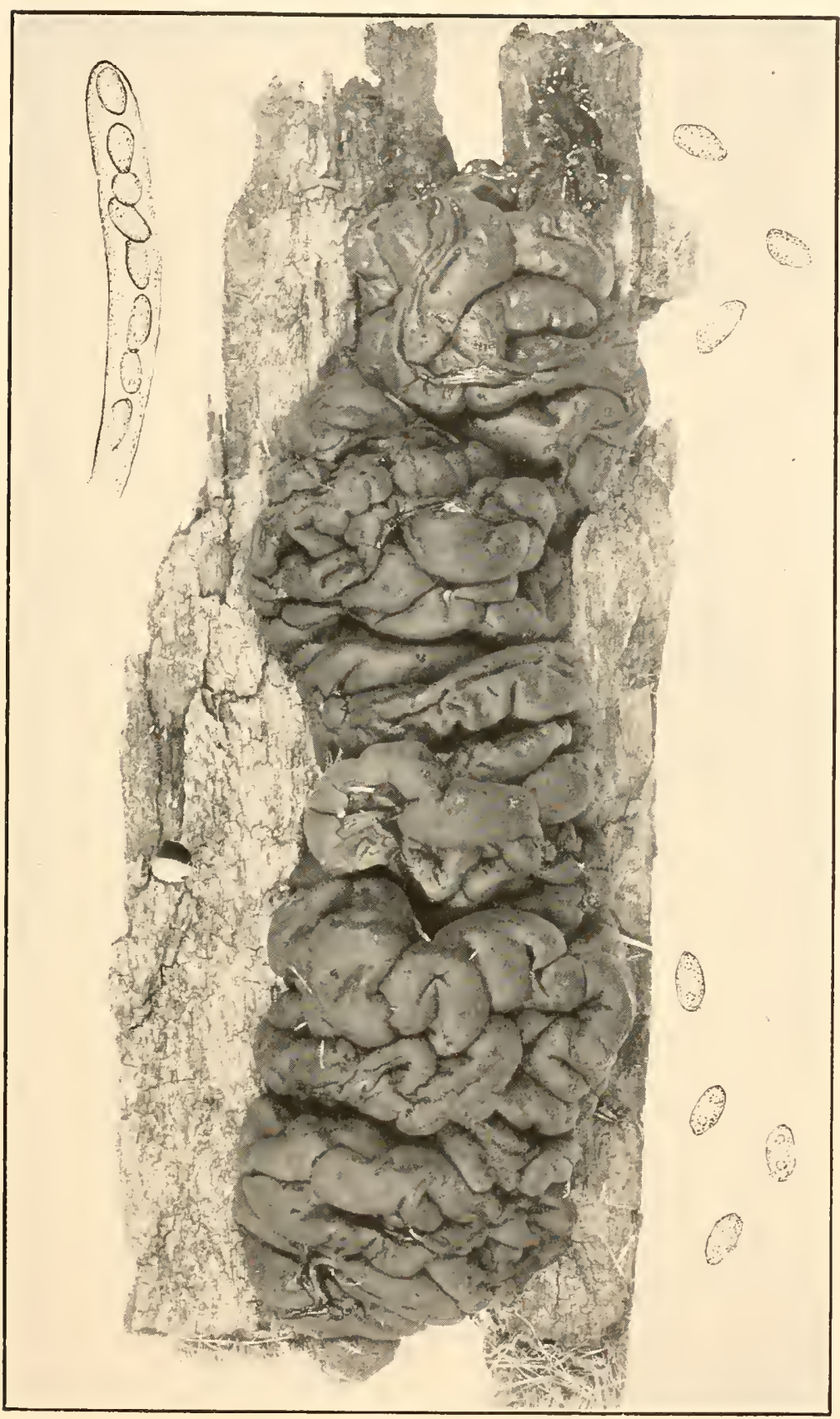

ASCOTREMELLA FAGINEA 

2. Coryne urnalis (Nyl.) Sacc. Atti Soc. Veneto Sci. Nat. Padova $4: 131.1875$.

Bulgaria urnalis Nyl. Not. Soc. Fauna Fl. Fenn. 10: 73. 1869.

Ombroplila urualis Karst. Myc. Fenn. 1: 87. 1871.

Coryne purpurea Fuckel, Symb. Myc. 284. 1869.

Apothecia similar to those of Coryne surcoides but much larger, reaching a diameter $2-3 \mathrm{~cm}$; asci clavate reaching a length of $160-190 \mu$ and a diameter of $10-15 \mu, 8$-spored; spores 2-seriate, elongate-fusoid, 6-7 $\times 24-30 \mu$, granular within, becoming 1-9-septate; paraphyses filiform, slightly enlarged above, the apices adbering.

On rotten wood of various kinds.

Týe locality: Europe.

Distribution: Same as that of Coryne sarcoides.

3. Coryne microspora Ellis \& Ev. Bull. Torrey Club 24: 282. 1897.

Ombrophila microspora Sacc. \& Syd. in Sacc. Syll. Fung. 14: 802. 1899.

Apothecia cespitose, fleshy-gelatinous, light liver-colored, reaching a diameter of $1 \mathrm{~cm}$., contracted below into a short, thick stem, wrinkled and folded; hymenium concave with a depression in the center, similar in color to the outside of the apothecium; asci cylindric-clavate, reaching a length of $70-75 \mu$ and a diameter of 5-6 $\mu, 8$-spored; spores 1-seriate, fusoid, 2-3 $\times$ 5-6 $\mu, 2$-nucleate (becoming septate?); paraphyses filiform.

On decaying logs.

Type locality: Canada.

Distribution: Canada; also reported from Washington.

The type has been examined and as stated by Ellis it looks exactly like Coryne urnalis except for the minute spores.

\section{Doubtful Species}

Coryne vinosa Berk. \& Curt.; Berk. Jour. Linn. Soc. 10: 341. 1868. Describerl as vinose, fusiform, compressed, rugose with a small head of similar color, about $+\mathrm{mm}$. high, single, or cespitose; conidia minute, abundant. On rotten wood in woods, Cuba. V'ery doubtful.

Coryne unicolor Berk. \& Curt.; Massee (as synonym) Jour. Myyc. 6: 182. 1891. This is Dacryopsis unicolor (Berk. \& Curt.) Massee, Jour. Myc. 6: 181.

47. HOLWAYA Sacc. Syll. Fung. 8: 646. 1889.

Apothecia stipitate, reaching a diameter of $1.5 \mathrm{~cm}$., darkcolored, brownish-black, or greenish; asci 8 -spored; spores septate, filiform, or vermiform, hyaline. 
Type species, Bulgaria Ophiobolus Ellis.

The position of the genus is uncertain. Durand (Bull. Torrey Club 28: 354 ) places it in the Patellariaceae because the paraphyses cling together above the asci forming an epithecium. This would hardly seem to the writer to be sufficient reason for placing it there since the consistency of the apothecia does not suggest such a relationship.

1. Holwaya gigantea (Peck) Durand, Bull. Torrey Club 28: 354. 1901. (Plate 117, Fig. 1.)

Stilbum giganteum Peck, Ann. Rep. N. Y. State Mus. 24: 93. 1872.

Coryne Ellisii Berk. Grevillea 2: 33.1873.

Patellaria leptosperma Peck, Ann. Rep. N. J. State Mus. 30: 62. 1878.

Bulgaria Ophiobolus Ellis, Am. Nat. 17: 193. 1883.

Graphium giganteum Sacc. Syll. Fung. 4: 611. 1886.

Holwaya Ophiobolus Sacc. Syll. Fung. 8: 646. 1889.

Lecanidion leptospermum Sacc. Syll. Fung. 8: 800. 1889.

Dacryopsis Ellisiana Massee, Jour. Myc. 6: 181. 1891.

Chlorosplenium canadense Ellis \& Ev. Proc. Acad. Sci. Phila. 1893: 146.1893. Holwaya tiliacea Ellis \& Ev. Am. Nat. 31: 427. 1897.

Conidial structures gregarious, or single, fleshy-gelatinous, consisting of a slender or tapering stem with a length of 3-10 $\mathrm{mm}$. and a diameter of $2 \mathrm{~mm}$. and an ellipsoid, soft, viscid head, 2-6 $\times$ 2-4 mm.; conidiophores very slender, branched; conidia hyaline, ellipsoid, $1 \times 3 \mu$.

Apothecia cespitose, or single, scattered, stipitate, cup-shaped, becoming expanded and plane, or with the margin reflexed and umbilicate, orbicular, or irregular from mutual pressure, reaching a diameter of $1.5 \mathrm{~cm}$., greenish-black, fleshy-gelatinous, shrinking much in drying; hymenium similar in color to the outside of the apothecium; stem tapering upward, covered with a greenishbrown tomentum which of ten disappears with age; asci narrowly clavate, reaching a length of $120-200 \mu$ and a diameter of $10-12 \mu$; spores more or less fasciculate, filiform-cylindric, or very narrowly clavate-cylindric with ends rounded or one end occasionally acute, straight, or curved, hyaline, 14-20-septate, 3-4 $\times 30-75 \mu$; paraphyses filiform, slender, longer than the asci, globose at their apices and clinging together.

On rotten logs of Tilia, Acer, Quercus, and Magnolia, in the crevices of the bark or on the bare wood.

Type Locality: Buffalo, New York.

Distribution : New York to Ontario, Iowa and West Virginia. 


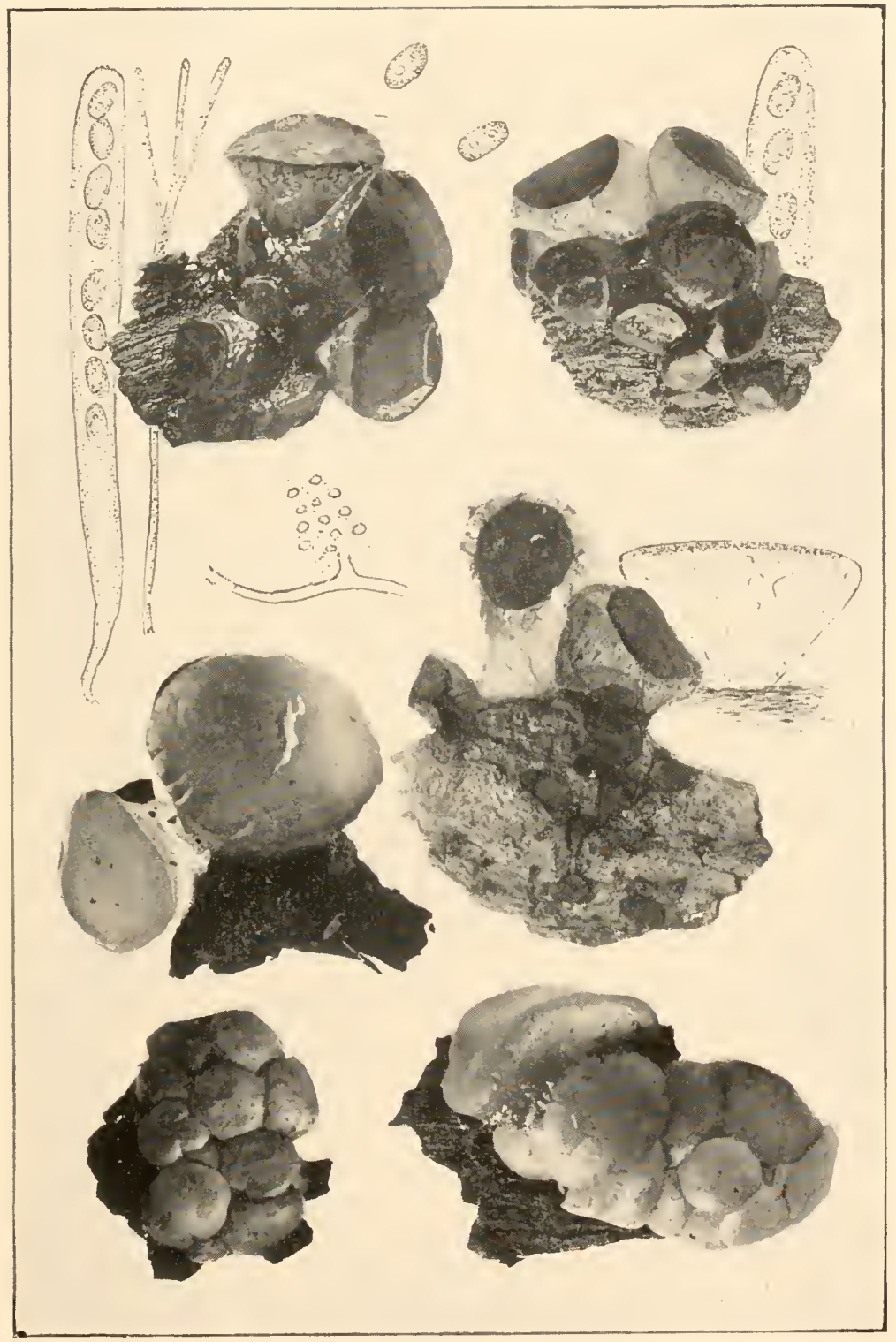

ASCOTREMELLA TURBINATA 

Illustrations: Ann. Rep. N. Y. State Mus. 24:pl. 3, f. 7-9; Bull. 'Torrey Club 28: pl. 26.

Exsiccati: Ellis, N. Am. Fungi 1383; Reliq. Farlow. $126 a$, $126 \mathrm{~b}$.

According to Nannfeldt. (Nova Acta Soc. Sci. Upsal. IV. 8: 306. 1932) Crinula caliciiformis Fries is identical with this species and would replace Graphium giganteum (Peck) Sacc. as had been pointed out by Von Höhnel.

48. ACERVUS Kanouse, Papers Mich. Acad. Sci. 23: 149.1938.

Apothecia sessile, densely cespitose in clusters varying from few to many, much contorted from mutual pressure, arising from a black, tough, rubbery sclerotiform base, reaching a diameter of $4 \mathrm{~cm}$, externally slightly verrucose, soft-leathery and pliant when fresh, somewhat friable when dry, orange-colored.

Type species, Acervus aurantiacus Kanouse.

1. Acervus aurantiacus Kanouse, Papers Mich. Acad. Sci. 23: 140. 1938.

Apothecia as above; hymenium orange-colored; asci cylindric, reaching a length of $100-140 \mu$ and a diameter of $7-10 \mu, 8-$ spored; spores ellipsoid, simple, usually with one oil-drop, smooth, 3.5-4 $46-8 \mu$; paraphyses clavate, curved, orangecolored, $9 \mu$ in diameter.

On soil at the base of an elm tree.

Type Locality: South Lyons, Michigan.

Distribution: Known only from the type locality.

Illustrations: Papers Mich. Acad. Sci. 23: 150, f. 1.

49. LACHNELLA Fries, Corpus F1. Prov. Suec. 1: 343.1835 ; Summa Veg. Scand. 365. 1849.

Lachnum Retz. Fl. Scand. Prodr. 256. 1779.

Dasyscyphus S. F. Gray, Nat. Arrang. Brit. Pl. 1: 670. 1821.

Peziza tribe Dasyscyphae Fries, Syst. Myc. 2: 89. 1822.

Trichopeziza Fuckel, Symb. Myc. 295. 1869.

Hyalopeziza Fuckel, Symb. Myc. 297. 1869.

Dasycypha Fuckel, Symb. Myc. 304. 1869.

Coronellaria Karst. Myc. Fenn. 1: 14. 1871.

Hyaloscypha Boud. Bull. Soc. Myc. Fr. 1: 118. 1885.

Erinella Quél. Ench. Fung. 301. 1886.

Cistella Quél. Ench. Fung. 319. 1886.

Solenopezia Sacc. Syll. Fung. 8: 477. 1889.

Atractobolus Tode; Kuntze, Rev. Gen. Pl. $3^{3}: 445.1898$. 
Unguicularia Höhn. Ann. Myc. 3: 404. 1905. Not Unguicularia D. C. 1825.

Helolachnum Torrend, Broteria 9: 53. 1910.

Apothecia sessile, or stipitate, externally densely clothed with hairs; hairs usually flexuose, smooth, or more often delicately roughened; asci cylindric to clavate, usually 8-spored; spores ellipsoid to fusoid, simple, or rarely pseudoseptate, paraphyses filiform to lanceolate.

Type species, Peziza corticalis Pers.

The genus Lachnella was founded by Fries (Fl. Corpus Prov. Sueciae 1: 343. 1835) on Peziza alboviolascens, a Cyphella, which he apparently mistook for a discomycete as indicated by the fact that a few years later (Summa Veg. Scand. 365. 1849) he used the name for a genus of Discomycetes. Six species were included, one of which Peziza flammea Alb. \& Schw. is an operculate and later became the type of the genus Perrotia (Boud. Bull. Soc. Myc. Fr. 17:24. 1901) and is included in our volume on the North American Cup-fungi (operculates). It is proposed that the name Lachnella be conserved for a genus of Discomycetes as originally intended by Fries, and that Peziza corticalis Pers. be adopted as the type since this is probably the most widely distributed and best known inoperculate species included by Fries in his genus. Although not mentioned by Fries, the spores of this species are much elongated, relatively large and occasionally become septate at maturity although this character is by no means a constant one.

Since Fries' time various interpretations have been placed on the genus by different workers. In 1887, William Phillips took up the genus and used it in the same sense as Fries (1849) including four of his six species, one species, Lachnella alboviolacens (Alb. \& Schw.) Fries, being ruled out as a Cyphella and one other Lachnella rhabarbarina (Berk.) Fries being transferred to Dermatea. Many other species were included in the genus by Phillips. No particular stress was placed on the spores but the genus was described as follows:

"Cups small, stipitate or sessile; flesh thin, firm, waxy; externally pilose or villous; asci cylindrical or subclavate; sporidia 8, colourless; paraphyses filiform or acerose."

In 1884, Saccardo (Bot. Cent. 18: 216) recognized the genus as follows: "(Lachnella et Helotium e. p. Erinella Quél. e. p. 


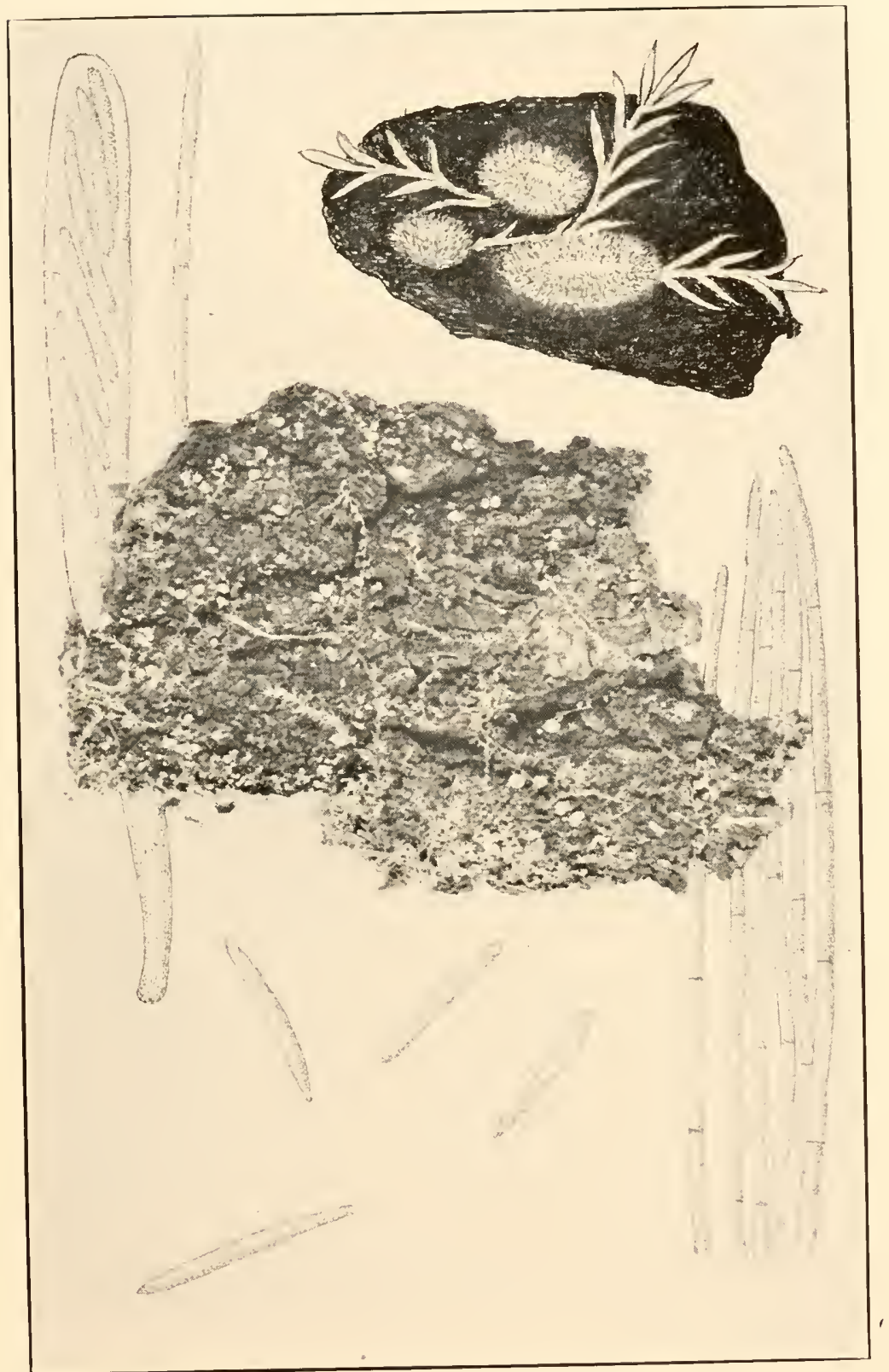

LACHNELLA CORTICALIS 

Velutaria Fuckel e. p.)" and treated Dasyscypha, Trichopeziza and Hyalopeziza as subgenera. In 1889 he used the genus Lachnella in a more restricted sense keeping it for those forms with filiform paraphyses. Those species with what he calls fusoid paraphyses, which is apparently another name for acerose are placed in two different genera Trichopeziza Fuckel (1849) with subsessile apothecia and Dasycypha with stipitate apothecia. Whether the form of the paraphyses is a good character on which to base a genus is a question. The presence or absence of a stem is scarcely more reliable here than in Helotium and Phialea. This is so variable in a given species that it is not regarded by us as a sound character on which to found a genus.

In 1897, Lindau, (Engler \& Prantl, Nat. Pfl. $\left.1^{1}: 201.1897.\right)$ also took up the genus Lachnum Retz (1770) treating Trichopeziza Fuckel (1849) as a synonym. If these two genera are synonyms, Trichopeziza would have priority as a post-Friesian genus. Lachnum (Trichopezisa) is distinguished by Lindau from Lachnella and Dasyscypha by its lanceolate paraphyses.

In 1931, Clements and Shear (Genera Fungi 327) used Lachnella with the Peziza flammea Alb. \& Schw. as the type placing it in the Helotiaceae which belong to the inoperculates and ignoring the fact that it had been made the type of the genus Perrotia founded by Boudier and placed in the operculates.

It will be seen from the above that no two authors have had exactly the same conception of this genus resulting in almost hopeless confusion. The writer is not presumptuous enough to think that he can straighten out this hopeless tangle, but he can at least present his own views. For the time being we are inclined to use Lachnella in much the same sense used by early workers, and include a number of the recent segregates.

Hairs hyaline, appearing white, or cinereous.

On coniderous plant tissues.

Spores ellipsoid to fusoid, not over $20 \mu$ long.

On species of Larix.

Spores 6-8 8 15-20 $\mu$.

1. L. H'illkommii.

Spores $4-7 \times 10-18 \mu$.

2. L. occidentalis.

Not restricted to Larix.

Spores 14-20 $\mu$ long.

3. L. Hahniana.

Spores 11-15 $\mu$ long.

4. L. oblongospora.

Spores usually less than $11 \mu$ long.

On Pseudotsuga taxifolia.

Forming cankers on branches.

Not forming cankers.

5. L. Psendotsugae.

6. L. ciliata. 
Not restricted to Pseudotsuga.

On resin on Abies balsamea.

On bark of various conifers.

7. L. resinaria.

8. L Agassizii.

Spores fusiform, sharp-pointed, 20-25 $\mu$ long.

9. L. Ellisiana.

Not restricted to coniferous plants.

On phanerogams.

Apothecia becoming shallow cup-shaped.

On dicotyledonous hosts.

On twigs and branches of woody plants.

Spores 15-20 $\mu$ long, on bark. 10. L. corticalis.

Spores less than $15 \mu$ long.

Hymenium orange-colored.

Hymenium ochraceous, on Rubus.

11. L. bicolor.

12. L. subochracea.

On rotten wood of various kinds.

Apothecia fasciculate, on olive.

Apothecia not fasciculate.

Paraphyses filiform.

Paraphyses lanceolate.

Hairs capped with crystals.

Hairs not capped with crystals.

13. L. fasciculata.

14. L. hyalina.

15. L. crucifera.

16. L. virginea.

On leaves, living or dead.

On leaves of Quercus.

Hairs capitate, spores 5-

$7 \mu$ long.

Hairs not capitate.

Spores 2.5-3 $\times 15-20 \mu$. 18. L. ciliaris.

Spores $1.5 \times 7-8 \mu$. 19. L. pollinaria.

Not on leaves of Quercus.

On leaves of Garraya.

20. L. tautilla.

On leaves of Vaccinium.

21. L. virginella.

On leaves of Gaultheria.

On leaves of Halesia.

22. L. Gaultheriae.

23. L. Halesiae.

On exposed roots and debris.

On monocotyledons.

On culms of Juncus.

On stems of Calamagrostis.

On leaves of Arundinaria.

Apothecia cylindric, soleniform.

24. L. pygmaea.

25. L. diminuta.

26. L. agrostina.

27. L. Arundinariae.

28. L. Solenia.

On cryptogams.

On rootstocks of Equisetum.

On ferns.

On stems of Pteris.

29. L. inquilina.

On stems of A spidium and Adiantum.

On fronds of Dicranopteris.

30. L. pteridicola.

31. L. aspidicola.

32. L. Dicranopteridis. 
On fungi.

On Rhytisma on Acer.

On stromata of Acanthonitschkia.

33. L. Rhytismatis.

34. L. Acanthonitschkeae.

Hairs pale-yellow to sulphur-yellow.

On phanerogams.

On lead wood.

Spores $3-5 \times 10-1+\mu$.

35. L. succina.

Spores $2 \times 7-8 \mu$.

36. L. albolutea.

On herbaceous stems.

Paraphyses lanceolate.

37. L. sulphurea.

Paraphyses filiform.

On stems of Arctium; spores 1.5-2 X 8-12 $\mu$.

38. L. canadensis.

On stems of $I v a$, spores; spores $3 \times$ 12-14 $\mu$.

39. L. Irae.

40. L. pulverulenta.

On fallen pine needles.

41. L. Gleicheniae.

42. L. atropurpurea.

43. L. viridicoma.

Spores large, $5-6 \times 12-15 \mu$.

Spores small, less than $10 \mu$ long.

Spores $1-1.5 \times 5-5.5 \mu$.

44. L. microspora.

Spores $2 \times 7-9 \mu$.

45. L. pulieracea.

llairs brown to blackish.

On phanerogams.

On dicotyledons.

On coniferous plants of various kinds.

Spores $4 \times 7 \mu$.

46. L. arida.

Spores $5 \times 12-15 \mu$.

47. L. fuscosanguinea.

Not on conifers.

On woody plant tissues.

On bark of Populus tremuloides.

Paraphyses lanceolate.

48. L. populicola.

Paraphyses clavate.

49. L. populina.

Not restricted to Populus.

Paraphyses lanceolate on leaves of Cornus.

50. L. Corni.

Paraphyses clavate, on rotten wood.

51. L. cerina.

On herbaceous stems; Eupatorium.

On monocotyledons, Fragmites, Andropogon etc.

52. L. Eupatorii.

53. L. albotestacea.

54. L. Pteridis.

On cryptogams, Pteris aquilina.

1. Lachnella Willkommii Hartig, Wicht. Krankh. Waldbäume 98. 1874. (Plate 123.)

?Peziza calycina Schum. Enum. Pl. Saell. 2: 424. 1803.

Peziza calycina Laricis Chaillet; Fries, Elench. Fung. 2: 8. 1828. 
Peziza Laricis Rehm, Grevillea 4: 169. 1876.

Lachnea calycina Gill. Champ. Fr. Discom. 71. 1880.

Helotium Willkommii Wettestein, Bot. Cent. 31: 285. 1887.

Trichoscypha Willkommii Boud. Hist. Class. Discom. Eu. 125. 1907.

Trichoscyphella Willkommii Namnf. Nova Acta Soc.Sci. Upsal. IV. 8:300. 1932.

Conidial stage which precedes the apothecial stage consists of waxy, whitish stromata with irregular labyrinthiform cavities in which the microconidia are abstricted from the tips of slender, subulate, simple, or verticillately-branched sporophores; microconidia hyaline, simple, ellipsoid, or allantoid, $1-2 \times 2-8 \mu$.

Apothecia sessile, or short-stipitate, scattered, or gregarious in small groups and occasionally several closely crowded together, at first closed and rounded, becoming expanded and finally scutellate, externally white and clothed with a dense covering of white hairs, reaching a diameter of $1-3 \mathrm{~mm}$., hymenium becoming nearly plane, yellow to orange; hairs flexuous, of nearly uniform thickness throughout their length, minutely roughened; asci cylindric-clavate, reaching a length of 100-120 $\mu$ and a diameter of 8-10 $\mu, 8$-spored; spores ellipsoid, often with the ends narrowed, hyaline, granular within, $6-8 \times 15-20 \mu$, or rarely as long as $25 \mu$; paraphyses slender, clavate, reaching a diameter of about $3 \mu$.

On branches of Larix europaea.

Type locality : Europe.

Distribution: Massachusetts to Idaho; also in Europe.

Illustrations: Hartig, Text-book Dis. Trees (trans.) 119, f. 58, 59; Boud. Ic. Myc. pl. 518 (in part); Mycologia 26: pl. 9, f. $1-5$, pl. 10 .

2. Lachnella occidentalis (Hahn \& Ayers) Seaver, comb. nov.

Dasyscypha occidentalis Hahn \& Ayers, Mycologia 26: 90.1934.

Conidial stage consisting of a fleshy stroma with irregular labyrinthiform cavities in which the microconidia are abstricted from the tips of slender, pointed, verticillately branched sporophores; microconidia ellipsoid, or allantoid, simple, $1-1.5 \times 2-5 \mu$.

Apothecia fleshy, abundant, scattered, or grouped, at first globose and closed, opening in a roundish form, the margin incurved, later expanding and becoming saucer-shaped under moist conditions, laterally compressed and closed when dry, short-stipitate, externally densely clothed with white hairs, reaching a diameter of 1-3 mm., salmon-orange; hairs long, 
flexuous, roughened on the outside, $3-4 \mu$ in diameter; asci clavate, reaching a length of $130 \mu$ and a diameter $12 \mu, 8$-spored; spores obliquely 1 -seriate, becoming 1 -septate on germination, ellipsoid, $4-7 \times 10-18 \mu$; paraphyses filiform, swollen at their apices, $1-2 \mu$ in diameter.

On species of Larix, L. europaea, L. Laricina, L. leptolepis, and L. occidentalis.

TyPE Locality: Hills, British Columbia.

Distribution: Vermont to Pennsylvania and British Cohimbia.

Illustrations: Mycologia 26: pl. 12, f. 6-10; pl. 13.

\section{Lachnella Hahniana Seaver, nom. nov.}

Dasyscypha calycina Fuckel, Symb. Myc. 305. 1869. Not Pesiza calycina Schum. 1803.

Conidial stage consisting of erumpent, fleshy, or waxy stromata containing simple, or labyrinthiform loculi in which microconidia are abstricted from the tips of short, subulate, simple, or verticillately branched sporophores; microconidia continuous, hyaline; ellipsoid, or allantoid, $1-2 \times 2-5 \mu$.

Apothecia abundant, solitary, or grouped, short-stipitate, at first globose and closed, opening with a rounded form and expanding to a saucer-shaped structure in moist weather, reaching a diameter of $3 \mathrm{~mm}$., externally densely clothed with white hairs; hymenium, concave, ochraceous to salmon-orange; hairs cylindric with slightly swollen extremities, $3-4 \mu$ thick, minutely roughened; asci clavate, reaching a length of $100-165 \mu$ and a diameter of 8-10 $\mu, 8$-spored; spores 1 -seriate, smooth, ellipsoid, simple, often becoming 1 -septate on germination, 5-8 $\times 14-20 \mu$; paraphyses filiform, intermixed with broader filaments with swollen extremities, rounded, or with subacute apices, occasionally spathulate, $1-4 \mu$ thick.

On Larix europaea, Larix leptolepis, and Pseudotsuga taxifolia.

TyPe locality: Europe.

Distribution: Massachusetts; also in Europe.

Illustrations: Mycologia 26: pl. 8; pl. 9, f. 6-10.

4. Lachnella oblongospora (Hahn \& Ayers) Seaver, comb. nov. Dasyscypha oblongospora Hahn \& Ayers, Mycologia 26: 88. 1934.

Conidial stage consisting of waxy, erumpent, stromata with irregular, labyrinthiform cavities in which the microconidia are 
abstricted from the tips of the slender, subulate, simple, or verticillately branched sporophores; microconidia hyaline, simple, ellipsoid, or allantoid, $1-1.5 \times 2-5 \mu$.

Apothecia erumpent, waxy, scattered, or grouped, at first globose, closed, opening and becoming urn-shaped, expanding under moist conditions, laterally compressed and closed when dry, short-stipitate, externally clothed with white, or grayishwhite hairs; reaching a diameter of $2 \mathrm{~mm}$.; hymenium salmonorange to orange-buff; hairs long, flexuous and minutely roughened, septate, 3-4 $\mu$ thick; asci clavate, reaching a length of 70-100 $\mu$ and a diameter of 7-10 $\mu, 8$-spored; spores 1-seriate, or irregularly disposed, ellipsoid, hyaline, smooth, at first simple, often becoming 1-septate before germination, $4-6 \times 11-15 \mu$; paraphyses filiform, scarcely swollen at their apices, $1-2 \mu$ in diameter.

On coniferous branches of Larix laricens, L. europaea, $L$. leptolepis, Picea pungens, Pinus pungens, Pimus virginiana and Pseudotsuga taxifolia.

Type Locality: Bethel, Vermont (On Larix laricina).

Distribution: Vermont to Pennsylvania and Michigan.

Illustrations: Mycologia 26: pl. 11; pl. 12, f. 1-5.

5. Lachnella Pseudotsugae (Hahn) Seaver, comb. nov.

Dasyscypha Pseudotsugae Hahn, Mycologia 32: 138. 1940.

Conidial stage consisting of waxy-fleshy, light-buff stromata with labyrinthiform cavities in which the conidia are borne and from which they exude in a droplet or tendril; conidia produced on the ends of simple, or branched conidiophores; hyaline ellipsoid, $1.8-3 \times 2.4-4 \mu$.

Apothecia waxy-fleshy, scattered, or closely grouped, at first globose and closed, opening in a roundish form, the margin incurved, urn-shaped, becoming widely expanded and discoid under moist conditions, laterally compressed when dry, 1-3.5 $\mathrm{mm}$. in diameter; hymenium light orange-yellow to orange; hairs minutely roughened, cylindrical with obtuse ends, 3-3.5 $\mu$ in diameter, hyaline-white; asci clavate, reaching a length of $50-60 \mu$ and a diameter of 4-5.4 $\mu, 8$-spored; spores 1-seriate, ellipsoid to fusoid, 2-4 $\times 4-7 \mu$; paraphyses filiform, slightly swollen above.

Forming cankers on living branches of Pseudotsuga taxifolia.

Type locality: Lokoya, Napa County, California.

Distribution: California to British Columbia.

Illustrations: Mycologia 32: 139. $f$. 1-6. 
6. Lachnella ciliata (Hahn) Seaver, comb. nov.

Dasyscypha ciliata Hahn, Mycologia 32: 141. 1940.

Conidial stage not observed.

Apothecia waxy-fleshy, short-stipitate, usually scattered, occasionally grouped, at first globose, expanding and becoming discoid, externally whitish, 1-2 mm. in diameter; hymenium concave, or plane, orange; hairs cylindric with acute ends, minutely roughened, giving rise to a fringe-like margin, $3 \mu$ thick; asci clavate, reaching a length of $70-80 \mu$ and a diameter of 7-10 $\mu, 8$-spored; spores obliquely 1 -seriate, ovoid to ellipsoid, $4-6 \times 8-12 \mu$; paraphyses filiform, slightly swollen at their apices.

On dead branches of Pseudotsuga taxifolia.

Type locality: Portland Heights, Oregon.

Distribution: Oregon and British Columbia.

Illustrations: Mycologia 32: 143.f. 2.

\section{Lachnella resinaria Phill. Brit. Discom. 242. 1887.}

Peziza resinaria Cooke \& Phill.; Cooke, Grevillea 3: 185.1875.

Dasyscypha resinaria Rehm, Ascom. Lojk. 11. 1882.

Lachnellula resinaria Rehm. in Rab. Krypt.-Fl. 1³: 864. 1893.

Apothecia short-stipitate, at first globose and closed, expanding and becoming shallow cup-shaped, externally densely clothed with white hairs, reaching a diameter of .5-1.5 mm.; hymenium concave, pale-orange; hairs hyaline-white, cylindric, flexuous, septate, reaching a diameter of 3-3.5 $\mu$; asci cylindric above, tapering below, 8 -spored; spores ellipsoid, $2.5 \times 5 \mu$; paraphy'ses filiform, slightly enlarged above.

On resin from the branches of balsam fir, Abies balsamea.

Type locality: Europe.

Distribution: Minnesota.

Illustrations: Bull. Torrey Club 29: pl. 1.

Reported from Minnesota, as causing canker growth on Abies balsamea (Bull. Torrey Club 29: 23. 1902.) While frequently reported from Europe, surprisingly little material has been encountered from this country.

8. Lachnella Agassizii (Berk. \& Curt.) Seaver, comb. nov. (Plate 121.)

?Elvela calyciformis Batsch, Elench. Fung. Cont. 1: 195. 1786.

PPeziza calyciformis Willd. Fl. Berol. 404. 1787.

?Octospora calyciformis Hedw. Descr. 2: 78. 1789. 
Peziza Agassizii Berk. \& Curt.; Cooke \& Peck, Grevillea 1: 5.1872.

Peziza subtilissima Cooke, Grevillea 3: 121. 1875.

Helotium calyciforme Wettstein, Bot. Cent. 31: 319. 1887.

Lachnella subtilissima Phill. Brit. Discom. 244. 1887.

Dasyscypha subtilissima Sacc. Syll. Fung. 8: 438. 1889.

Dasyscypha Agassizii Sacc. Syll. Fung. 8: 438. 1889.

Dasyscypha incarnata Clements, Bull. Torrey Club 30: 88. 1903.

Apothecia gregarious, short-stipitate, at first subglobose, becoming expanded and shallow cup-shaped, or nearly plane, externally clothed with flexuose, white hairs; hymenium bright orange-yellow, fringed about with marginal hairs, reaching a diameter of $4 \mathrm{~mm}$., but often much smaller; hairs hyaline, white to the unaided eye, blunt, or attenuated, externally covered with coarse granules, reaching a length of $100 \mu$ and a diameter of 2-3 $\mu$; asci cylindric or subcylindric, reaching a length of $6095 \mu$ and a diameter of 3-4 $\mu$; spores 1- or 2-seriate, narrow-ellipsoid, hyaline, 3-4 4 6-10 $\mu$; paraphyses clavate, reaching a diameter of $2-5 \mu$ at their apices.

On bark and wood of conifers, Abies balsamea, Picea Mariana, Picea rubra, Pinus monticola, Pinus Strobus, Psendotsuga taxifolia and Tsuga canadensis.

Type Locality: Lake Superior region (Calumet).

Distribution: Labrador to Pennsylvania, Montana and Colorado. Probably widely distributed in subboreal regions; ? also in Europe.

Illustrations: Hedw. Descr. 2: pl. 22, B; Grevillea 3: pl. 40 , f. 169; Mycologia 21: pl. 20; 35: 107,f. 2 .

Exsiccati: Ellis, N. Am. Fungi 1311; Barth. Fungi Columb. 4530; Clements, Crypt. Form. Colo. 82; $1 \mathrm{~T}$. B. Cooke, Mycobiota N. Am. 67. Rehm, Ascom. 185+ (from Misconsin).

Bingham and Ehrlich after an exhaustive study (Mycologia 35: 95-111. 1943) consider Dasyscypha A gassizii as distinct from Peziza calyciformis $\mathbf{W i l l d}$. of Europe, the differences based largely on spore measurements. The differences are so slight that it secms to the writer a question whether or not they should be separated.

9. Lachnella Ellisiana (Rehm) Seaver, comb. nov.

Peziza Ellisiana Rehm, Grevillea 4: 169. 1876.

Dasyscypha Ellisiana Sacc. Syll. Fung. 8: 459. 1889.

Imperfect stage abundant, yellowish-green, minute, consisting of an erumpent stroma, 106-132 $\mu$ diam., at first closed, then opening up with a single exposed chamber, or compound, with 


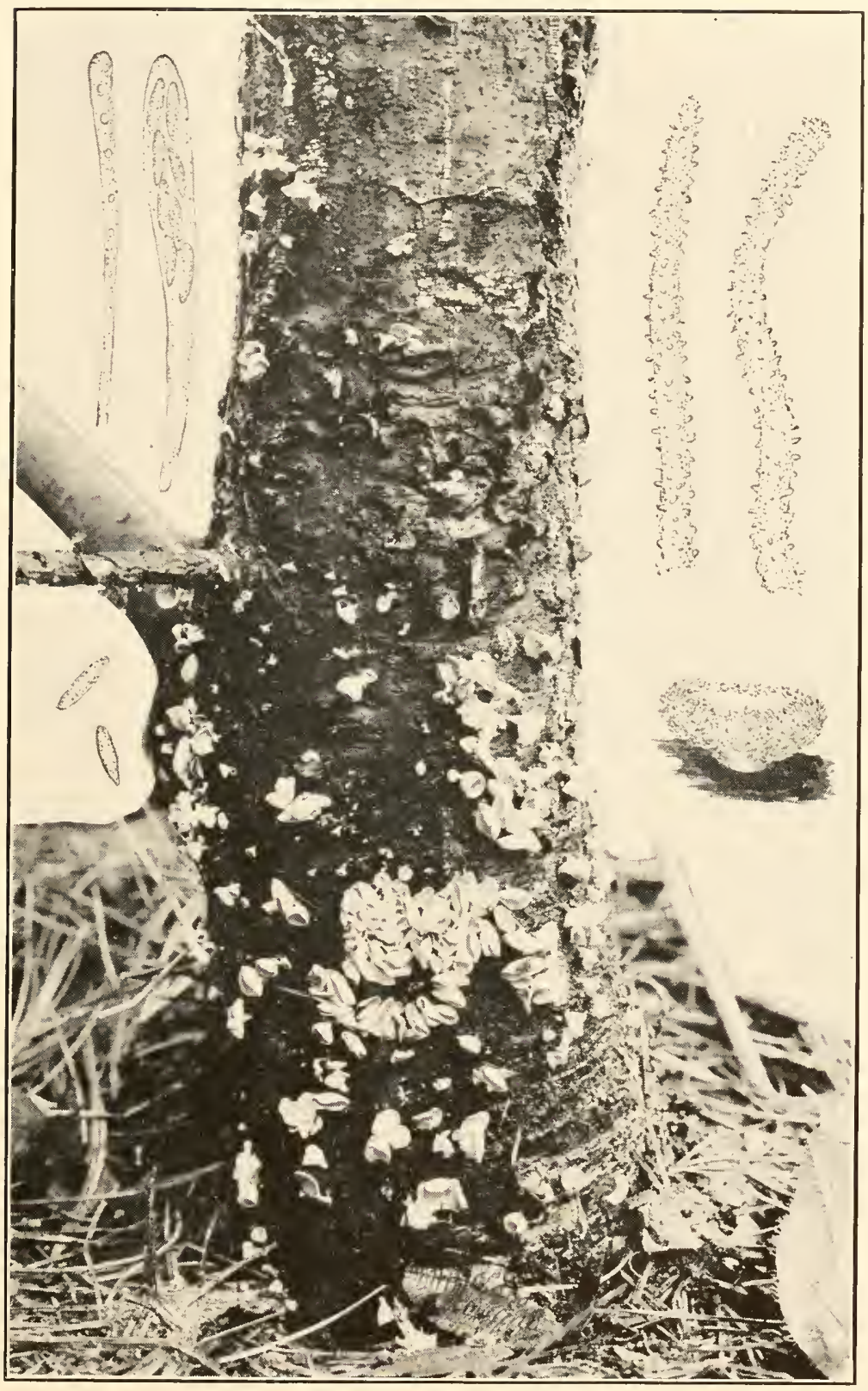

LACHNELLA AGASSIZII 

more than one locule, $243-433 \mu$ diam., microconidia fusiform, $.9-1.2 \times 5-5.8 \mu$ abstricted from the tips of short sporophores, subulate, acute, simple, or verticillately branched.

Apothecia scattered, or gregarious, sessile, or very shortstipitate, at first subglobose, expanding and becoming shallow cup-shaped, reaching a diameter of 1-2 mm., externally densely clothed with white or whitish hairs; hymenium plane, or slightly concave, bright-orange; hairs cylindric or subcylindric, septate, hyaline, minutely roughened on the outside, reaching a diameter of 4-6 $\mu$ and of variable length up to $200 \mu$; asci clavate, reaching a length of $65 \mu$ and a diameter of $6-7 \mu, 8$-spored; spores 2 seriate or partially so, fusiform and very sharp-pointed, $2-3 \times$ 20-25 $\mu$; paraphyses lanceolate, or sublanceolate, rather slender, about half the diameter of the ascus.

On bark of species of Pinus, Picea and Larix.

Trpe locality: New Jersey.

Distribution: Maine to Alabama and Texas.

Illustrations: Mycologia 26: pl. 21; pl. 22, f. 1-7.

Exsiccati: Rav. Fungi Am. 175; Ellis \& Ev. N. Am. Fungi 232t, 3231; Fungi Columb. 641, 122t; Rehm, Ascom. 303; Thüm. Myc. Univ. 716.

Resembling Lachnella bicolor but differing in the very long, sharply pointed spores. Dasyscypha lachnoderma (Berk.) Rehm, which was thought by Ellis to be identical with this species is quite distinct according to Ayers and Hahn (Mycologia 26: 157-180). Some of the above exsiccati were distributed under the latter name.

10. Lachnella corticalis (Pers.) Fries, Summa Veg. Scand. 365. 1849. (Plate 120.)

Peziza corticalis Pers. Tent. Disp. Fung. 33. 1797.

Helotium corticale Karst. Myc. Fenn. 1: 159. 1871.

Lachnea corticalis Gill. Champ. Fr. Discom. 84. 1880.

Peziza borealis Ellis \& Holw.; Arth. Bull. Geol. Nat. Hist. Surv. Minn. 3: 35. 1887.

Lachnella canescens Phill. Brit. Discom. 259. 1887.

Dasyscypha borealis Sacc. Syll. Fung. 8: 457. 1889.

Lachnella rhizophila Ellis \& Ev. Proc. Acad. Phila. 1894: 348.1894.

Dasyscypha canescens Massee, Brit. Fungus-F1. 4: 346. 1895.

Lachnum corticale Clements, Crypt. Form. Colo. 86. 1906.

Apothecia thickly gregarious, sessile, or short-stipitate, at first closed and subglobose, expanding and becoming shallow 
cup-shaped with the mouth constricted, reaching a diameter of $1 \mathrm{~mm}$., externally densely clothed with grayish hairs which may change to yellowish, or brownish with age, the hairs often tipped with masses of minute, rod-like bodies which give them a crystaline appearance; hymenium concave, cream-colored, or yellowish; hairs gradually attenuated, semiacute, septate, pale-yellow below, hyaline toward the tip, reaching a length of 100-150 $\mu$ and a cliameter of 3-4 $\mu$ at the base; asci clavate, reaching a length of $100 \mu$ and a diameter of $10 \mu$, tapering below; spores obliquely 2-seriate, fusoid, slightly curved, about $4 \times 15-20 \mu$ or rarely as long as $30 \mu$, often with a row of oil-drops, giving the spore a pseudoseptate appearance, or often 1-septate; paraphyses protruding far beyond the asci, cylindric below, semiacute at their apices, $2-3 \mu$ in diameter.

On bark of various deciduous trees.

TYPE LOCALITY: Europe.

Distribution: New York to Winnipeg, Washington and Colorado; also in Europe.

Illustrations: Boud. Ic. Myc. pl. 517; E. \& P. Nat. Pfl. $1^{1}: 202, f .159 \mathrm{II}$,

Exsiccati: Clements, Crypt. Form. Colo. 86.

11. Lachnella bicolor (Bull.) Phill. Brit. Discom. 249. 1887. (Plate 123, Fig. 2.)

Pesiza bicolor Bull. Hist. Champ. Fr. 243. 1791.

Dasyscypha bicolor Fuckel, Symb. Myc. 305. 1869.

Lachnum bicolor Karst. Myc. Fenn. 1: 172.1871.

Lachnea bicolor Gill. Champ. Fr. Discom. 70. 1880.

Erinella bicolor Quél. Ench. Fung. 303. 1886.

Apothecia closely gregarious, or scattered, sessile, or shortstipitate, at first closed, becoming expanded, extcrnally clothed with a dense covering of white hairs, reaching a cliameter of 1-2 mm.; hymenium nearly plane, orange-yellow; hairs hyaline, cylindric, septate, externally roughened with granules, reaching a length of $200 \mu$, and a diameter of $4 \mu$; often with crystaline caps, asci cylindric-clavate, reaching a length of $40-50 \mu$ and a diameter of $5-6 \mu$; spores fusiform, straight, or slightly curved, $1.5-2 \times 6-12 \mu$; paraphyses lanceolate, very sharp pointed.

On small twigs of various trees and shrubs.

Type locality: Europe.

Distribution: New York to Washington and Alaska to Mexico; also in Europe. Probably wiclely distributed. 
Illustrations: Bull. Herb. Fr. pl. H10, $f$. 3; Phill. Brit. Discom. pl. 8, f. 46; Gill. Champ. Discom. pl. 61, f. 3; Rab. Krypt.-F1. $1^{3}: 865, f .1-4$.

Exsiccatı: Ellis \& Ev. Fungi Columb. 1222; Barth. Fungi Columb. 3117.

During the summer of 1929 a fine collection of the species was made near the Alpine Laboratory on Pikes Peak, Colorado on dead stems of Rubus (Seaver \& Shope 443).

12. Lachnella subochracea (Cooke \& Peck) Seaver, comb. nov. Pesiza subochracea Cooke \& Peck, Grevillea 1: 6. 1872.

Trichopesiza subochracea Sacc. Syll. Fung. 8: 408. 1889.

Apothecia sessile, or substipitate, scattered, at first subglobose, then expanded and becoming discoid with the margin slightly elevated, yellowish, clothed with white hairs; hymenium ochraceous, nearly plane, or slightly concave with the margin slightly elevated; hairs poorly leveloped, hyaline; asci clavate, reaching a length of $80 \mu$ and a diameter of $8 \mu$; spores partially 2-seriate, or irregularly disposed, fusiform, hyaline, $3 \times 12-13 \mu$; paraphyses filiform, or slightly enlarged above.

On dead stems of Rubus.

Type Locality: Adirondack Mountains.

Distributions: New York and Newfoundland.

Illustrations: Grevillea 1: pl. 1, f. 4 .

Although this has been placed in the genus Trichoperiza by Saccardo, the apothecia are not conspicuously hairy as in most of the species of the genus. The apothecia are delicately pubescent but the hairs poorly developed.

13. Lachnella fasciculata (Seaver \& Waterston) Seaver, comb. nov.

Dasyscypha fasciculata Seaver \& Waterston, Mycolgia 32: 397. 1940.

Apothecia thickly gregarious, occurring singly, or more often in dense, fasciculate clumps, several apparently springing from the same base and so closely compact that they appear to be one componnd fruit body, short-stipitate, externally clothed with a dense covering of white hairs, the clumps scarcely exceeding $1 \mathrm{~mm}$. in diameter, the individual apothecia much less; hymenium concave, pale-orange; hairs flexuous, hyaline, externally roughened, about $2 \mu$ in diameter; asci clavate, reaching a length of 35-40 $\mu$ and a diameter of $4 \mu, 8$-spored; spores minute, fusoid, 
hyaline, $1.5 \times 6 \mu$; paraphyses filiform semiacute but scarcely lanceolate.

Type collected on rotten stumps of olive tree, Olea europaea, Walsingham, Bermuda, Nov. 30, 1938.

Distribution: Known only from the type locality.

14. Lachnella hyalina (Pers.) Phill. Brit. Discom. 267. 1887.

Peziza hyalina Pers. Syn. Fung. 655. 1801.

Helotium hyalinum Karst. Not. Soc. Fauna Fl. Fenn. 11: 240. 1871.

Lachnea hyalina Gill. Champ. Fr. Discom. 79. 1880.

Urceola hyalina Quél. Ench. Fung. 321. 1886.

Pseudohelotium hyalinum Fuckel, Symb. Myc. 298. 1869.

Hyaloscypha hyalina Boud. Ic. Myc. 4: 308. 1911.

Apothecia gregarious, sessile, at first globose and closed, opening and becoming cup-shaped, then expanded and saucershaped, soft and externally slightly downy, . $1-.5 \mathrm{~mm}$. in diameter; hymenium hyaline, occasionally slightly yellowish or rosy; hairs delicate, hyaline, or white; asci fusoid, reaching a length of 35$45 \mu$ and a diameter of $7-10 \mu, 8$-spored; spores elongated, or slightly fusiform, 2-seriate, straight, or slightly curved, $2-2.5 \times$ 6-10 $\mu$; paraphyses filiform, $2 \mu$ thick.

On dead wood and bark of various kinds.

Type locality: Europe.

Distribution: New Jersey to Washington, California and Louisiana; also in Europe.

Illustrations: Phill. Brit. Discom. pl. $8, f$. 48 ; Boud. Ic. Myc. pl. 525.

Exsiccati: Ellis \& Ev. N. Am. Fungi 2810.

15. Lachnella crucifera Phill. Brit. Discom. 250. 1887.

(Plate 122.)

Pesiza crucifera Phill. Gard. Chron. II. 10: 397. 1878.

Peziza sulphurella Peck, Ann. Rep. N. Y. State Mus. 30: 59. 1878.

Dasyscypha crucifera Sacc. Syll. Fung. 8: 440.1889.

Dasyscypha sulphurella Sacc. Syll. Fung. 8: 459. 1889.

Apothecia stipitate, reaching a diameter of .5-1 mm., shallow cup-shaped with hymenium pale-yellowish, externally clothed with hairs intermixed with crystals of calcium oxalate giving them a granular appearance; stem reaching a length of .5-1 $\mathrm{mm}$. and also clothed with hairs; hairs hyaline, clavate, septate, reaching a length of $80 \mu$ and a diameter of $4 \mu$; asci clavate, reaching a length of $40 \mu$ and a diameter of 5-6 $\mu, 8$-spored; spores minute, about $2 \times 5-6 \mu$; paraphyses lanceolate. 


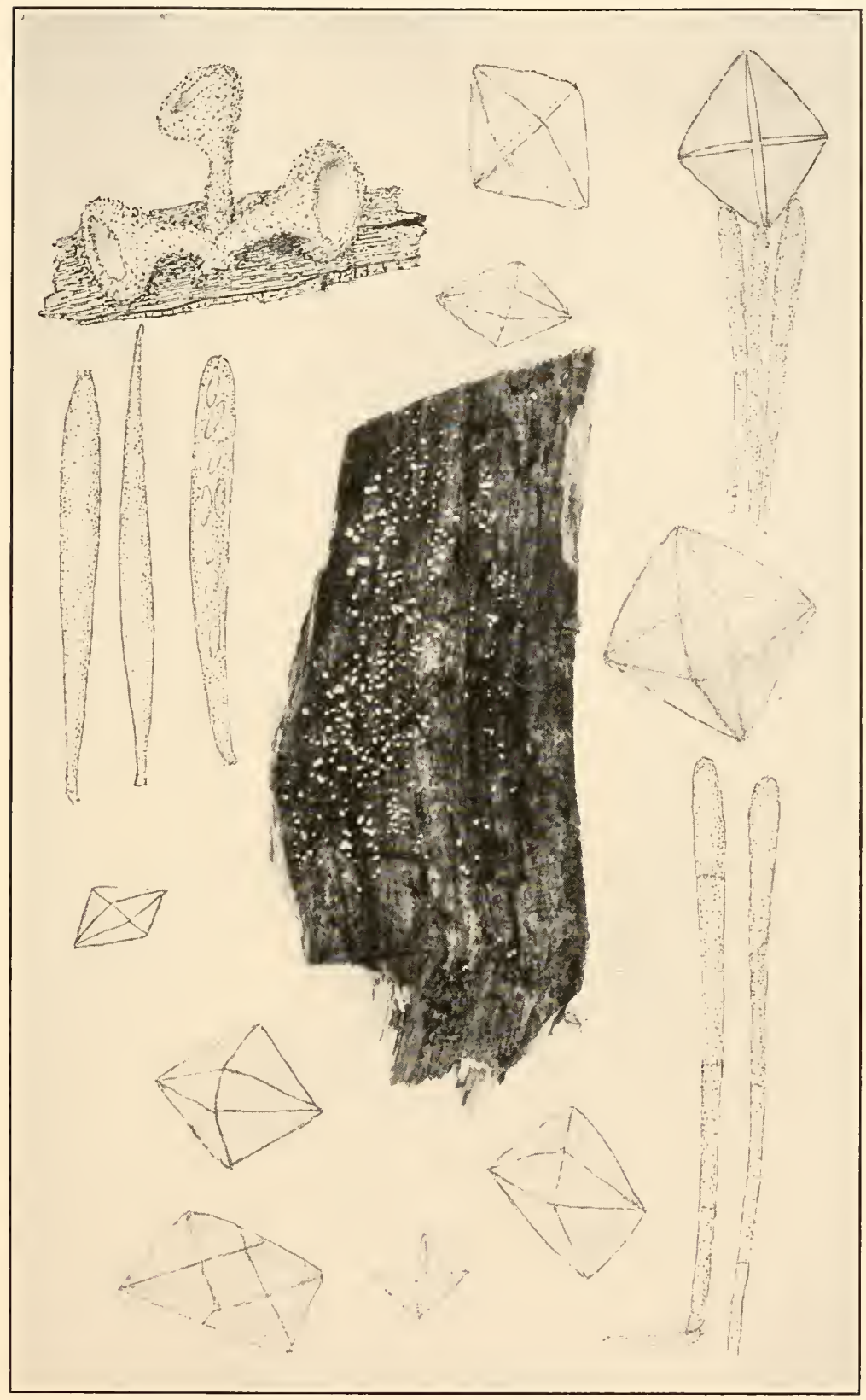

LACHNELLA CRUCIFERA 

On rotten wood.

Type locality: Europe.

Distribution: New York to Michigan; also in Europe.

Illustrations: Gard. Chron. II. 10: f. 71; Mycologia 28: 5, f. 1 .

In Papers of the Michigan Academy of Sciences (23: 153. 1938) Dr. B. Kanouse calls attention to the fact that Peziza sulphurella Peck and Peziza crucifera Phill. are identical. It is an interesting coincidence that both were described in the same month of the same year. Which name actually has priority it is difficult to say. The above synonymy is based on the conclusions of Dr. Kanouse.

16. Lachnella virginea (Batsch) Phill. Brit. Discom. 248. 1887.

Lachnum agaricinum Retz. F1. Scand. Prodr. 256. 1779.

Pesiza virginea Batsch, Elench. Fung. 125. 1783.

Octospora nivea Hedw. (fil.) Obs. Bot. 13. 1802.

Trichopeziza nivea Fuckel, Symb. Myc. 296. 1869.

Dasyscypha virginea Fuckel, Symb. Myc. 305. 1869.

Lachnum niveum Karst. Myc Fenn. 1: 168. 1971.

Lachnum virginèum Karst. Myc. Fenn. 1: 169. 1871.

Lachnea virginea Gill. Champ. Fr. Discom. 68. 1880.

?Peziza latebrosa Ellis, Bull. Torrey Club 9: 18. 1882.

Erinella virginea (Juél. Ench. Fung. 304. 1886.

Lachnella nivea Phill. Brit. Discom. 245. 1887.

?Dasyscypha latebrosa Sacc. Syll. Fung. 8: 434. 1889.

Dasyscypha nivea Sacc. Syll. Fung. 8: 437. 1889.

Lachnum niveum var. Fairmani Rehm, Ann. Myc. 6: 316.1908.

Apothecia gregarious, or scattered, at first globose and closed, becoming expanded and shallow cup-shaped, reaching a diameter of $1 \mathrm{~mm}$., contracted below into a short stem which reaches a length of 1-2 $\mathrm{mm}$., clothed with white hairs; hymenium nearly plane, white, or becoming slightly yellowish; hairs hyaline, septate, covered with minute granules, mostly clavate, reaching a diameter of $3 \mu$ below and about $6 \mu$ above, the length variable but up to $80 \mu$; asci clavate-cylindric, about $4-5 \times 45-60 \mu$, 8-spored; spores fusoid, $1.5-2.5 \times 6-10 \mu$; paraphyses lanceolate, extending far beyond the asci, hyaline, $4-6 \mu$ in diameter at the thickest point.

On wood of various kinds and on woody stems.

Type Locality: Europe.

Distribution: Widely distributed in North America; also in Europe. 
Illustrations: Hedw. (fil.) Obs. Bot. pl. $8, f$. B; Sow. Engl. Fungi, pl. 65; Gill Champ. Fr. Discom. pl. 59, f. 1-2; Bull. Lab. Nat. Hist. State Univ. Iowa 6: pl. 25, f. 3 (except paraphysis).

Exsiccatı: Ellis, N. Am. Fungi 387; Ellis \& Ev. N. Am. Fungi, 2912; Fungi Columb. 19, 2015.

This is a species concerning which there has been much confusion. Phillips in his British Discomycetes regards L. niveum and $L$. virgineum as distinct species and states that the latter can be distinguished from the former by its lanceolate paraphyses. Rehm treats them as distinct but assigns lanceolate paraphyses to both and seemed to know nothing of $L$. niveum as diagnosed by Phillips. Gillet in his Discomycetes of France treats them as distinct and attempts to draw a slight difference in the form of the cups or length of the hairs.

In his early work on the Discomycetes the writer encountered this species and figured it with clavate paraphyses which may have been due to faulty observation, for in going over all of the specimens in the herbarium of The New York Botanical Garden listed under these two names, he finds that all of them have lanceolate paraphyses. Since none of the diagnostic characters used by European authors, in separating these two species appear to have any particular value, they are here combined. One specimen examined seems to show two kinds paraphyses, lanceolate and filiform.

\section{Lachnella capitata (Peck) Seaver, comb. nov.}

?Pesiza crystallina Fuckel, Symb. Myc. 306. 1869.

Pesiza capitata Peck, Ann. Rep. N. Y. State Mus. 30: 60. 1878.

Trichopeziza capitata Sacc. Syll. Fung. 8: 417. 1889.

?Dasyscypha crystallina Sacc. Syll. Fung. 8: 440. 1889.

?Dasyscypha scintillans Massee, Brit. Fungus-Fl. 4: 328.1895.

Dasyscypha capitata Kanouse, Mycologia 39: 646. 1947.

Apothecia very minute, sessile, at first globose and closed, finally expanding, externally clothed with a dense coat of white hairs; hymenium white, or yellowish; hairs hyaline with transmitted light, often terminated with a crystalline cap; asci cylindric, or subcylindric, reaching a length of $30 \mu$; spores cylindric, slender 5-7 $\mu$ long; paraphyses thick, longer than the asci, lanceolate.

On leaves of Quercus.

Type Locality: Albany, New York, type on Quercus alba. 


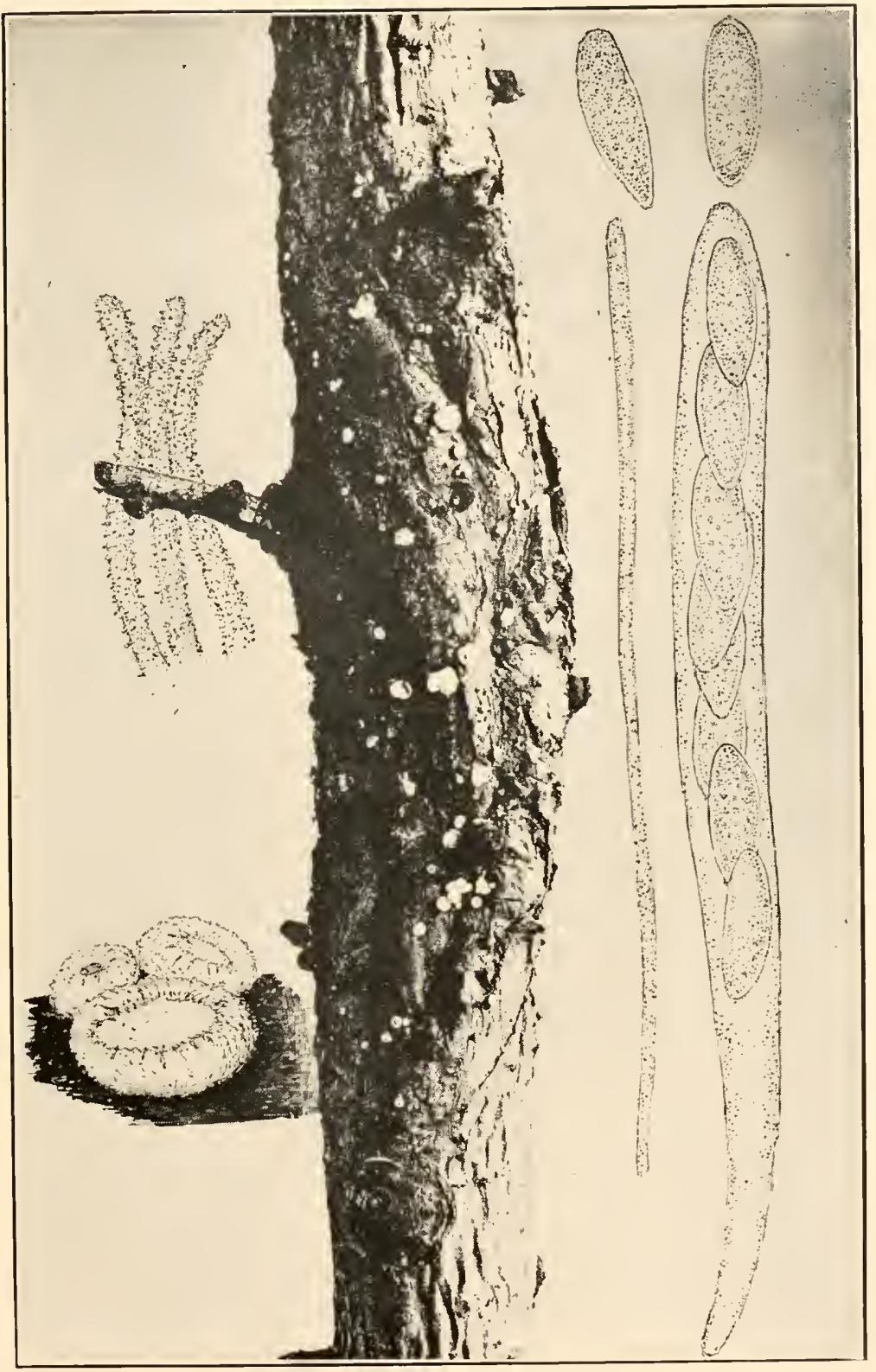

LACHNELLA WILLKOMMII 

Distribution: New York to Missouri, and Pennsylvania; also in Europe?

Exsiccatı: Rab.-Winter, Fungi Eu. 3168 (from Ohio); Thüm. Myc. Univ. 813 (from New York).

18. Lachnella ciliaris (Schrad.) Phill. Brit. Discom. 251. 1887.

Peziza ciliaris Schrad.; Gmel. Syst. Nat. 2: 1453. 1791.

Peziza chinulata Auersw. Hedwigia 7: 136. 1868.

Hyalopesiza ciliaris Fuckel, Symb. Myc. 298. 1869.

Lachnea ciliaris Gill. Champ. Fr. Discom. 68. 1880.

Erinella ciliaris Quél. Ench. Fung. 304. 1886.

Trichopeziza ciliaris Rehm, Ber. Naturh. Ver. Augsburg 26: 64. 1881.

Lachnella echinulata Phill. Brit. Discom. 249. 1887.

Dasyscypha ciliaris Sacc. Syll. Fung. 8: 443. 1889.

Lachnum echinulatum Rehm in Rab. Krypt.-F1. 1³: 876. 1893.

Apothecia minute, sessile, or very short-stipitate, subglobose and usually closed when dry, open when moist, white, densely clothed with white hairs; hymenium white; hairs hyaline with transmitted light, reaching a diameter of 6-7 $\mu$ and a length of 40-60 $\mu$; asci clavate, reaching a length of 50-60 $\mu$ and a diameter of 8-9 $\mu, 8$-spored; spores fusoid, partially 2 -seriate, $2.5-3 \times 15$ $20 \mu$; paraphyses sparse, filiform, reaching a diameter of $3 \mu$, lanceolate above.

On fallen leaves of Quercus.

Type locality: Europe.

Distrinution: Ohio; also in Europe.

Exsiccatı: Ellis, N. Am. Fungi 1312 (as Peziza chinulata Awd.).

19. Lachnella pollinaria (Cooke.) Scaver, comb. nov.

Peziza pollinaria Cooke, Bult. Buffalo Soc. Nat. Sci. 2: 292.1875.

Trichopeziza pollinaria Sacc. Syll. Fung. 8: 416.1889.

Lachnum pollinarium Cash, Jour. Wash. Acad. Nat. Sci. 29: 48. 1939.

Apothecia subgregarious, minute, sessile, at first globose, then expanding, clothed with short, white hairs; asci subcylindric, reaching a length of 35-40 $\mu$ and a diameter of $5 \mu$; spores irregularly 2-seriate, fusoid, $1.5 \times 7-8 \mu$; paraphyses stout, lanceolate, $3-4 \mu$ in diameter.

On old oak leaves.

Type locality: New Jersey.

Distribution: New Jersey to Georgia. 
The original description of this species is brief and unsatisfactory. The above description is based on material in the Ellis collection. The species will bear more investigation.

20. Lachnella tautilla (Phill. \& Hark.) Seaver, comb. nov.

Peziza tautilla Phill. \& Hark. Bull. Calif. Acad. Sci. 1: 21. 1884.

Dasyscypha tautilla Sacc. Syll. Fung. 8: 445. 1889.

Apothecia scattered, stipitate, minute, white, cup-shaped, clothed to the base with slender, hyaline-white hairs; asci broadclavate, 8 -spored; spores ovoid, $1 \times 4 \mu$; paraphyses filiform.

Among the hairs on the under side of living leaves of Garrya elliptica.

Type locality: Tamalpais, California.

Distribution: Known only from the type locality.

Exsiccatı: Ellis \& Ev. N. Am. Fungi 2041; Rab.-Winter, Fungi Eu. 3468 (from California).

21. Lachnella virginella (Cooke) Seaver, comb. nov.

Peziza virginella Cooke; Cooke \& Ellis, Grevillea 4: 178.1876.

Dasyscypha virginella Sacc. Syll. Fung. 8: 444. 1889.

Lachnum virginellum Zeller, Mycologia 26: 293. 1934.

Apothecia scattered, long-stipitate, externally white-tomentose; hymenium whitish; hairs hyaline, reaching a length of $40-$ $50 \mu$; asci clavate, reaching a length of $40 \mu$ and a diameter of 4-5 $\mu$, short-stipitate, 8-spored; spores fusoid, $1 \times 6-7 \mu$; paraphyses lanceolate.

On leaves of species of Vaccinium.

Type locality: New Jersey.

Distribution: New Jersey to Pennsylvania and Louisiana.

Exsiccatı: Ellis \& Ev. N. Am. Fungi 214 .

22. Lachnella Gaultheriae (Ellis \& Ev.) Seaver, comb. nov.

Dasyscypha Gaultheriae Ellis \& Ev. Erythea 1: 199. 1893.

Lachnum Gaultheriae Zeller, Mycologia 26: 292.1934.

Apothecia seated on large, semicircular, grayish to brownish spots with a dark-purple border, stipitate, nearly closed at first, then opening and becoming cup-shaped, pale-orange, clothed externally with a dense coat of short, white hairs; hymenium pale-orange, reaching a diameter of $1 \mathrm{~mm}$.; stem short, rather less than the diameter of the apothecium; asci clavate-cylindric, reaching a length of $40 \mu$ and a diameter of 3-4 $\mu$, 8-spored; spores 2 -seriate, ellipsoid, or clavate-ellipsoid, $1.25 \times 4-5 \mu$. 


\section{On leaves of Gaultheria Shallon.}

Type Locality: Seattle, Washington.

Distribution: Washington to Oregon and California.

According to Zeller (Mycologia 26: 293) this species is very closely related to Trichopeziza echinulata Rehm, Ascom. 259.

\section{Lachnella Halesiae Cash, Jour. Wash. Acad. Sci. 29: 48. 1939.}

Apothecia scattered over the lower surface of the host, sessile, or substipitate, at first subglobose with the margin inrolled and the hymenium hidden, then expanding and becoming subdiscoid, .2-.6 mm. in diameter, externally clothed with white hairs; hymenium translucent, apricot-colored; hairs hyaline, septate, delicately roughened, not enlarged above; asci broadcylindric, 8-spored, reaching a length of $47-50 \mu$ and a diameter of 7-8 $\mu$; spores obliquely 1 -seriate, fusoid, $1.5-2 \times 12-15 \mu$; paraphyses lanceolate, longer than the asci $2.5-4 \mu$ thick.

On leaves of IIalesia carolina.

Type Locality: Athens, Georgia.

Distribution: Known only from the type locality.

Illustrations: Jour. Wash. Acad. Sci. 29: 47, f. 2.

24. Lachnella pygmaea (Fries) Phill. Brit. Discom. 242. 1887. (Plate 125, Fig. 2.)

Pesiza pygmaea Fries, Syst. Myc. 2: 79. 1822.

Helotium luteolum Currey, Trans. Linn. Soc. 24: 153. 1864.

Helotium rhizophilum Fuckel, Fungi Rhen. 1598. 1865.

Ciboria rhizophila Fuckel, Symb. Myc. 312. 1869.

Ilelotium pygmaeum Karst. Not. Soc. Fauna Fl. Fenn. 11: 214. 1871.

Lachnea pygmaea Gill. Champ. Fr. Discom. 71. 1880.

Peziza nuda Phill. \& Plow. Grevillea 8: 101. 1880.

Helotium affinissinum Peck, Ann. Rep. N. Y. State Mlus. 33: 32. 1883.

Erinella pygmaea Quél. Ench. Fung. 303. 1886.

Hymenoscypha Hedwigii Phill. Brit. Discom. 130. 1887.

Hymenoscypha rhizophila Phill. Brit. Discom. 144. 1887.

Lachnella muda Phill. Brit. Discom. 247. 1887.

Lachnella luteola Phill. Brit. Discom. 247. 1887.

Helotium rhizogenum Ellis \& Ev. Jour. Myc. 4: 100. 1888.

Helotium Phillipsii Sacc. Syll. Fung. 8: 220.1889.

Phialea Hedwigii Sacc. Syll. Fung. 8: 260. 1889.

Phialea affinissima Sacc. Syll. Fung. 8: 272. 1889.

Dasyscypha pygmaea Sacc. Syll. Fung. 8: 436. 1889.

Dasyscypha luteola Sacc. Syll. Fung. 8: 440. 1889.

Hymenoscypha flexipes Cooke \& Phill. Grevillea 19: 106. 1891.

Phialea flexipes Sacc. Syll. Fung. 10: 9. 1892. 
Ciboria pygmaea Rehm in Rab. Kyypt.-Fl. 133: 760. 1893.

IIelotimm Hedwigii Massee, Brit. Fungus-Fl. 4: 243. 1895.

Helotinm nudum Massee, Brit. Fungus-F1. 4: 498. 1895.

Calycina rhizogena Kuntze, Rev. Gen. Pl. $3^{3}: 449.1898$.

Hymenoscyphus affinissimus Kuntze, Rev, Gen. Pl. 33: 485.1898.

Lachnum Hedwigii Bres. Ann. Myc. 1: 121. 1903.

Lachnum pygmaeum Bres. Ann. Myc. 1: 121. 1903.

Ciboria carbonaria Feltg. Vorst. Pilz-F1. Luxenb. 13: 44.1903.

Helotium carbonarium Boud. Hist. Class. Discom. Eu. 113. 1907.

Helotium flexipes Boud. Hist. Class. Discom. Eu. 114. 1907.

IIymenoscypha nuda Boud. Hist. Class. Discom. Eu. 122. 1907.

Helotium subrubescens Rehm, Ann. Myc. 7: 524. 1909.

Helolachnum aurantiacum Torrend, Broteria 9: 53. 1910.

Ciboria subrubescens Dodge, Trans. Wis. Acad. Sci. 17: 1033. 1914.

Lachnum rhisophilum Vel. Monog. Discom. Bohem. 1: 258. 1934.

Apothecia gregarious or cespitose, typically occurring in a few cespitose clusters of five to ten each, surrounded by a few growing singly, stipitate, 2-7 mm. high, 2-4 mm. in diameter, at first infundibuliform, then spreading and plane; stem slender, flexuous, usually somewhat thickened just below the disc, paleyellow to flesh-color, or dull-orange, more or less whitish-puberulent, often appearing smooth in the dried condition, the margin rather obtuse, when dried becoming somewhat elevated above the hymenium, finely and obscurely puberulent; hymenium paleyellow to deep-yellow, often varying toward orange, or apricot, retaining the color on drying, or becoming more ochraceous; hairs 20-50 $\mu$ long, clavate, rough, hyaline-white, 4-6 $\mu$ in dianeter, 1-2-septate; asci small, cylindric, 60-75 $\times$ 4.5-6 $\mu$; spores 2-seriate, 1-celled, narrow, broadest just above the middle, slightly tapering toward a point, at the lower end, round, or only slightly pointed above, straight, 1.9-2.4 × 7-11 more or less lance-pointed, protruding above the asci, septate, $3-4.5 \mu$ in diameter.

Apothecia arising at ground level on partly buried plant debris of all sorts, especially on roots and rhizomes of grasses and other herbaceous plants and on limbs of both frondose and coniferous trees.

Type locality: Europe.

Distribution: Throughout northern United States and southern Canada; also in Europe.

Illustrations: Trans. Linn. Soc. 24 : pl. 25, f. 11-12, 18; 25 : pl. 55, f. 7-18; Bull. Lab. Nat. Hist. State Univ. Iowa 6: pl. 24, f. $3 a-d$. 
Exsiccati: Rehm, Ascom. 1852 (from IVisconsin).

The synonymy is based largely on the studies of Dr. IV. L. White.

25. Lachnella diminuta (Rob.) Phill. Brit. Discom. 253. 1887.

Peziza diminuta Rob.; Desm. Pl. Crypt. Fr. 1538; Ann. Sci. Nat. III. 8: 185. 1847.

Lachnea diminuta Gill. Champ. Fr. Discom. 71. 1880.

Dasyscypha diminuta Sacc. Syll. Fung. 8: 449. 1889.

Apothecia scattered, or crowded, short-stipitate, at first globose, then expanded and hemispherical, minute, $.5 \mathrm{~mm}$. in diameter, whitish-tomentose; hymenium concave, yellowish, or orange; asci cylindric-clavate, 8-spored; spores long-ellipsoid, $2 \times 12 \mu$; paraphyses filiform.

On dry culms of Juncus and grass stems.

Type locality : Europe.

Distribution: Michigan and North Dakota; also in Europe.

Exsiccati: Brenckle, Fungi Dak. 527.

26. Lachnella agrostina (Peck) Seaver, comb. nov.

Peziza agrostina Peck, Ann. Rep. N. Y. State Mus. 29: 55.1878.

Trichopesiza agrostina Sacc. Syll. Fung. 8: 421.1889.

Apothecia scattered, minute, less than $1 \mathrm{~mm}$. in diameter, subsessile, subglobose, externally hairy, of a dull-pinkish color; hymenium pallid, or cream-colored; hairs about the margin bent inward when moist, usually with longer, subulate, whitish points, the others not subulate, often rough and septate; asci cylindric, 8-spored; spores elongated, $6-8 \mu$ in length; paraphyses longer than the asci, lanceolate.

On dead stems of Calamagrostis canadensis.

Type Locality: West Albany, New York.

Distributiox: Known only from the type locality.

Part of the type collection is in The New York Botanical Garden.

27. Lachnella Arundinariae (Cash) Seaver, comb. nov.

Lachnum Arundinariae Cash, Jour. Wash. Acad. Sci. 30: 301. 1940.

Apothecia sessile, scattered, minute, .1-.2 mm. in diameter, translucent when moist, clothed with white hairs, margin fimbriate, at first subglobose, then becoming discoid; hymenium plane or nearly so, hyaline to slightly pink; hairs slightly roughened, 
$3 \mu$ in diameter; asci cylindric, 8-spored, reaching a length of $27-33 \mu$ and a diameter of 3-3.5 $\mu$; spores narrow-clavate, 2-seriate, .7-1 $\times 5-6.5 \mu$; paraphyses lanceolate, about $3 \mu$ in diameter.

On leaves of Arundinaria tecta.

Type locality: Athens, Georgia.

Distribution: Known only from the type locality.

Illustrations: Jour. Wash. Acad. Sci. 30: 303. f. 2.

28. Lachnella Solenia (Peck) Seaver, comb. nov. (Plate 124.)

Pesiza Solenia Peck, Ann. Rep. N. Y. State Mus. 25: 99.1873.

Peziza soleniaeformis Ellis \& Ev. Jour. Myc. 4: 55. 1888. Not Berk. \& Curt. 1875.

Dasyscypha soleniiformis Sacc. Syll. Fung. 8: 436.1889.

Solenopezia Solenia Sacc. Syll. Fung. 8: 477. 1889.

Apothecia gregarious, sessile, minute, not exceeding $.3 \mathrm{~mm}$. in diameter, short-cylindric, a little longer than broad, constricted at the mouth, externally clothed with brown hairs but with a white margin around the mouth; hymenium not much exposed; hairs consisting of two kinds, those about the side of the apothecium dark-brown, clavate, septate, slightly roughened and knotted reaching a diameter of 5-6 $\mu$ and a length of $60-80 \mu$, the marginal hairs similar in size and form but hyaline tipped and covered with minute granules; asci clavate, reaching a length of $65 \mu$ and a diameter of $10 \mu$; spores 2-seriate, fusoid, hyaline, becoming 1 -septate, usually with four small oil-drops, about 3-4 $\times 12-13 \mu$; paraphyses filiform slightly enlarged above.

On dead stems of Eupatorium ageraloides, and on rotten wood. Type Locality: Watkins Glen, New York.

Distribution: New York.

Exsiccatr: Ellis, N. Am. Fungi 387; Thüm. Myc. Univ. 1117. The above description and accompanying illustrations were drawn from material in the herbarium of The New York Botanical Garden which is apparently part of the type collection.

29. Lachnella inquilina Karst. Acta Soc. Fauna Fl. Fenn. $2^{6}: 132$. 1885.

Helotium inquilinum Karst. Myc. Fenn. 1: 1+7. 1871.

Trichopesiza inquitina Sacc. Syll. Fung. 8: 424.1889.

Pezizella inquilina Rehm in Rab. Krypt.-Fl. 133:675. 1892.

Lachnum inquilinum Schröt. Krypt,-Fl. Schles, 3²: 96. 1893. 


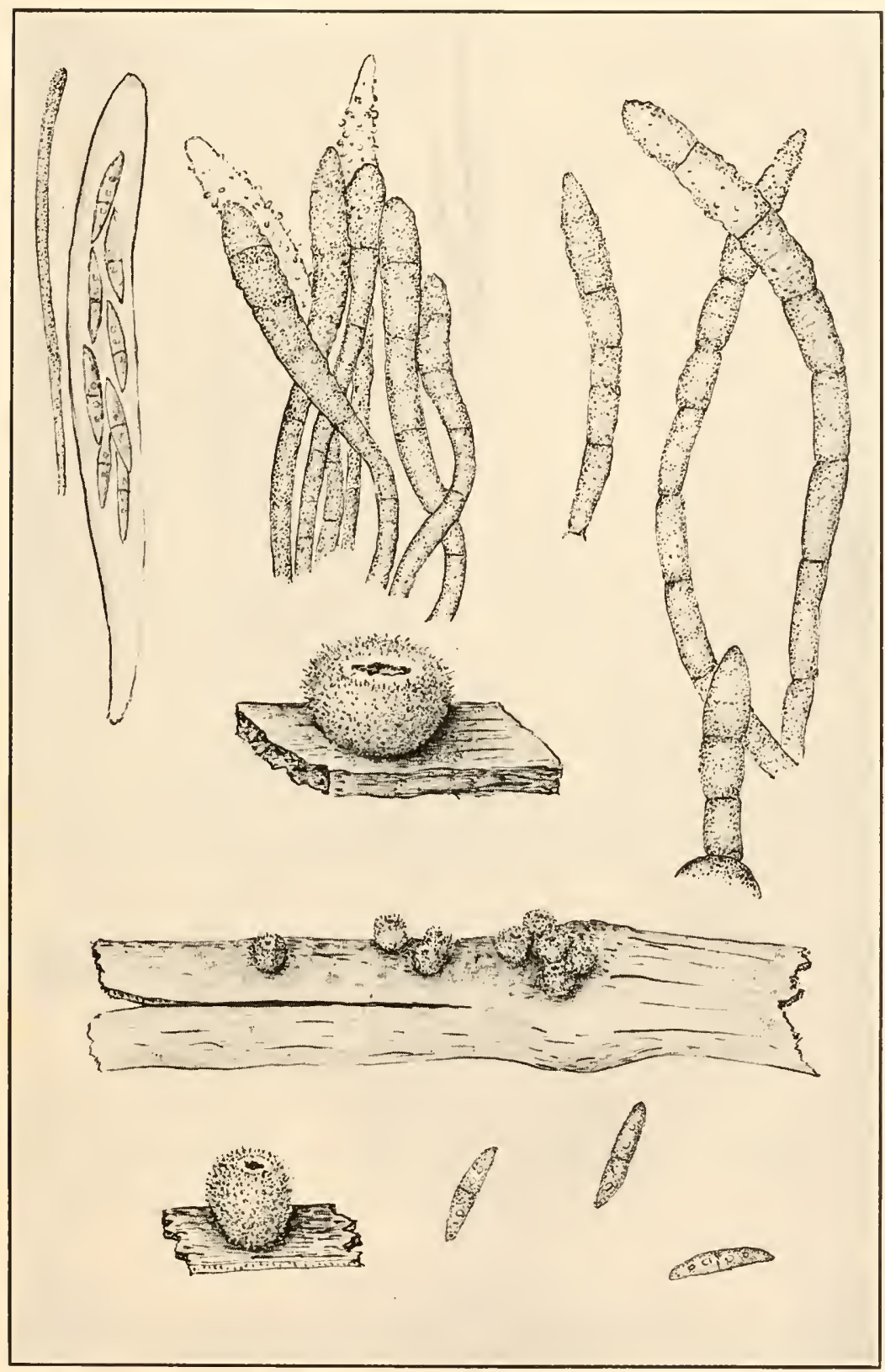

LACHNELLA SOLENIA 

Apothecia scattered, or gregarious, short-stipitate, at first globose and closed, later becoming expanded, reaching a diameter of .3-.5 mm., entirely white, or becoming brownish with age, clothed externally with white hairs; hymenium plane, or slightly concave; hairs short, not exceeding $50 \mu$ in length and reaching a diameter of $3-4 \mu$, hyaline, rarely septate, more or less irregularly curved, or flexuous, the tips obtuse, smooth, or granular; asci clavate, narrowed at the tips, reaching a length of 35-45 $\mu$ and a diameter of 5-6 $\mu, 8$-spored; spores 2-seriate, hyaline, clavate-cylindrical, $2 \times 8-10 \mu$; paraphyses lanceolateacute at their tips, $3 \mu$ thick.

On decaying rootstock of Equisetum hyemale, on the ground in wet places.

Type locality: Europe.

Distributions: New York and Ontario; also in Europe.

Our only knowledge of this is from Durand's report in Bull. Torrey Club 29: 464. 1902.

30. Lachnella pteridicola Seaver, nom. nov.

Hyalopeziza Pteridis Kanouse, Mycologia 39: 660. 1947. Not Lachnella Pteridis Phill. 1887.

Apothecia solitary, sessile to substipitate, about $.2 \mathrm{~mm}$. in diameter, cup-shaped, translucent-white; hairs hyaline-white, rough, reaching a length of $75 \mu$ and a diameter of $6 \mu$; asci cylindric-clavate, reaching a length of $30-35 \mu$ and a diameter of $4.5 \mu, 8$-spored; spores bacilloid, .75-1 $\times 4-5.5 \mu$; paraphyses filiform.

On stems of Pteris sp.

TyPe Locality: Lake Quinault, Washington.

Distributiox: Known only from the type locality.

31. Lachnella aspidicola (Berk. \& Br.) Phill. Brit. Discom. 245. 1887.

Pezisa aspidicola Berk. \& Br. Ann. Mag. Nat. Hist. II. 13: 465.1854.

Mollisia aspidicola Quél. Bull. Soc. Bot. Fr. 26: 234. 1879.

Dasyscypha aspidicola Sacc. Syll. Fung. 8: 451. 1889.

Helotium aspidicolum Rehm, Hedwigia 20: 35. 1881.

Apothecia scattered, or gregarious, sessile, or short-stipitate, at first rounded and closed, then expanded and cup-shaped, reaching a diameter of $.4 \mathrm{~mm}$. and about the same in height, white-floccose; hymenium white, or yellowish-white; asci clavate, reaching a length of $25-35 \mu$ and a diameter of 5-6 $\mu, 8$-spored; 
spores long-ellipsoid, or subclavate, $1-2 \times 5-8 \mu$; paraphyses filiform, $3 \mu$ in diameter.

On dead stems of ferns, Aspidium and Adiantum and undetermined species.

TyPE LOCAlity: Europe.

Distribution: Reported from Michigan and New Jersey; also in Europe.

32. Lachnella Dicranopteridis (Seaver \& Whetzel) Seaver, comb. nov.

Dasyscypha Dicranopteridis Seaver \& Whetzel, Sci. Sur. Porto Rico. 8: 74. 1926.

Apothecia scattered, shortly stipitate, or subsessile, externally reddish, densely clothed with white hairs, reaching a diameter of $.5 \mathrm{~mm}$.; hairs cylindric, roughened on the outside; asci clavate, 8-spored, reaching a length of $40-50 \mu$ and a diameter of $5 \mu$, tapering into a rather long, stem-like base; spores fusiform, the ends acute and almost bristle-like, not distinctly septate but often with suggestions of septa, $2 \times 8-10 \mu$; paraphyses not indicated.

On fronds of Dicranopteris pectinata.

Type locality: Porto Rico.

Distribution: Known only from the type locality.

33. Lachnella Rhytismatis Phill. Grevillea 8: 101. 1880.

Dasyscypha Rhytismatis Sacc. Syll. Fung. 8: 453. 1889.

Apothecia minute, gregarious, white, at first globose and closed, then expanding, clothed with white hairs; hymenium white; hairs short, hyaline with transmitted light, bearing at their tips globular or crystalline heads; stem rather long, hairy to the base; asci cylindric, 8-spored; spores fusoid, $1 \times 3-5 \mu$; paraphyses as broad as the asci but longer, lanceolate.

On Rhytisma acerinum, on leaves of Acer.

Type locality: Europe.

Distribution: Maryland; also in Europe.

Exsiccatr: Ellis \& Ev. Fungi Columb. 1819.

The original spelling of the specific name was "Rhytismae" but was corrected by Saccardo as indicated above.

34. Lachnella Acanthonitschkeae (Cash \& Davidson) Seaver, comb. nov.

Dasyscypha Acanthonitschkeae Cash \& Davidson, Mycologia 32: 730.1940. 
Apothecia scattered, one to eight on a single stroma of the host fungus, nearly globose at first, then cup-shaped to subglobose, with a circular opening, white, .1-.2 $\mathrm{mm}$. in diameter and beight, externally white-tomentose, the hymenium translucentwhite; asci cylindric, 8-spored, reaching a length of 22-24 $\mu$ and a diameter of 3-3.5 $\mu$; spores 1-seriate, ellipsoid, 1.5-2 $\times 3.5-4 \mu$; paraphyses filiform, hyaline, simple, not enlarged at their tips.

On stromata of Acanthonitschkea coloradensis.

Type locality: Grand Mesa, Colorado.

Distribution: Known only from the type locality.

Illuustrations: Mýcologia $32: 729, f .1, E, F$.

35. Lachnella succina (Phill.) Seaver, comb. nov.

Peziza succina Phill. Grevillea 5: 116. 1887.

Dasyscypha succina Sacc. Syll. Fung. 8: 458. 1889.

Apothecia stipitate, scattered, or crowded, at first globose, then expanded, concave, or nearly plane, reaching a diameter of $5 \mathrm{~mm}$, the stem short and brownish, externally clothed with a mass of rather poorly developed, sulphur-yellow hairs giving the whole exterior of the apothecium a decidedly yellow color, the individual hairs being yellow, or subhyaline; hymenium fleshcolored; asci clavate, reaching a length of $80 \mu$ and a diameter of $10-12 \mu$; spores ellipsoid, $3-5 \times 10^{-14 \mu}$; paraphyses cylindric, slightly enlarged above.

On dead wood of Quercus and (Celtis?).

Type locality: Blue Cannon, Sierra Nevada Mountains, California.

Distribution: California and Utah.

Illustrations: Grevillea 5: $p l .89, f .12$.

Exsiccatı: Ellis, N. Am. Fungi. 839.

36. Lachnella albolutea (Pers.) Karst. Acta Soc. Fauna Fl. Fenn. $2^{6}: 132.1885$.

Pesisa sulphurea albolutea Pers. Syn. Fung. 649. 1801.

Peziza variecolor Fries, Syst. Myc. 2: 100. 1822.

?Pesiza turbinulata Schw. Trans. Am. Phil. Soc. II. 4: 173. 1832.

Tapesia variecolor Fuckel, Symb. Nyc. Nacht. 1: 336. 1871.

Helotium alboluteum Karst. Myc. Fenn. 1: 160. 1871.

Lachnea variecolor Gill. Champ. Fr. Discom. 83. 1880.

Lachnella variecolor Phill. Brit. Discom. 259. 1887.

Dasyscypha turbinulata Sacc. Syll. Fung. 8: 456. 1889.

? Lachnella citrina Peck, Ann. Rep. N. Y. State Mus. 46: 35. 1893.

Dasyscypha sulphuricolor Peck, Bull. N. Y. State Mus. 157:25. 1911. 
Apothecia scattered, sessile, at first rounded, expanding and becoming subdiscoid, reaching a diameter of $2 \mathrm{~mm}$., externally clothed with sulphur-yellow hairs; hymenium slightly concave, whitish, or slightly yellowish; hairs when fresh sulphur-yellow, becoming darker with age, slightly roughened on the outside, often a little enlarged above; asci cylindric to clavate, reaching a length of $40-50 \mu$ and a diameter of $6 \mu, 8$-spored; spores ellipsoid to slightly clavate, straight, or curved, about $2 \times 7-8 \mu$; paraphyses filiform.

On old wood.

Type locality: Europe.

Distribution: Iowa to Missouri and Cuba; also in Europe.

Illustrations: Pers. Ic. \& Descr. pl. 8, f. 4-5.; Gill. Champ. Fr. Discom. pl. 67, f. 7 .

Exsiccati: Ellis, N. Am. Fungi $36+$ (as Peziza turbinulata Schw.).

37. Lachnella sulphurea (Pers.) Quél. Ench. Fung. 315. 1886. (Plate 125, Fig. 1.)

Peziza sulphurea Pers. Tent. Disp. Fung. 33. 1797.

Trichopesiza sulphurea Fuckel, Symb. Myc. 296. 1869.

Peziza sulphurea leucophaea Pers. Myc. Eu. 1: 250. 1871.

Lachmum leucophaeum Karst. Myc. Fenn. 1: 177. 1871.

Trichopeziza leucophaea Rehm, Ascom. 65. 1872.

Lachnea sulfurea Gill. Champ. Fr. Discom. 81. 1880.

Peziza cenangioides Ellis, Bull. Torrey Club 8: 123. 1881.

Lachnella cenangioides Sacc. Syll. Fung. 8: 396. 1889.

Lachnum sulfureum Rehm in Rab. Krypt-Fl. 13: 891. 1893.

Apothecia scattered, sessile but narrowed below approaching substipitate, at first closed, becoming expanded and plane, margin slightly raised, reaching a diameter of 1-1.5 mm., externally densely clothed with sulphur-yellow hairs; hymenium concave, or plane, whitish, or creamy-white; hairs straight, or slightly curved, septate, cylindric, either blunt, or gradually tapering with semiacute apices, minutely roughened, paleyellowish, or occasionally yellowish-brown; asci clavate, reaching a length of $50-75 \mu$ and a diameter of $5 \mu, 8$-spored; spores slender-ellipsoid, straight, or slightly curved, or fusoid, 2-seriate, $1.5-2 \times 8-10 \mu$ or rarely $15-16 \mu$ long; paraphyses lanceolate, about as thick as the ascus.

On dead herbaceous stems.

Type locality : Europe. 


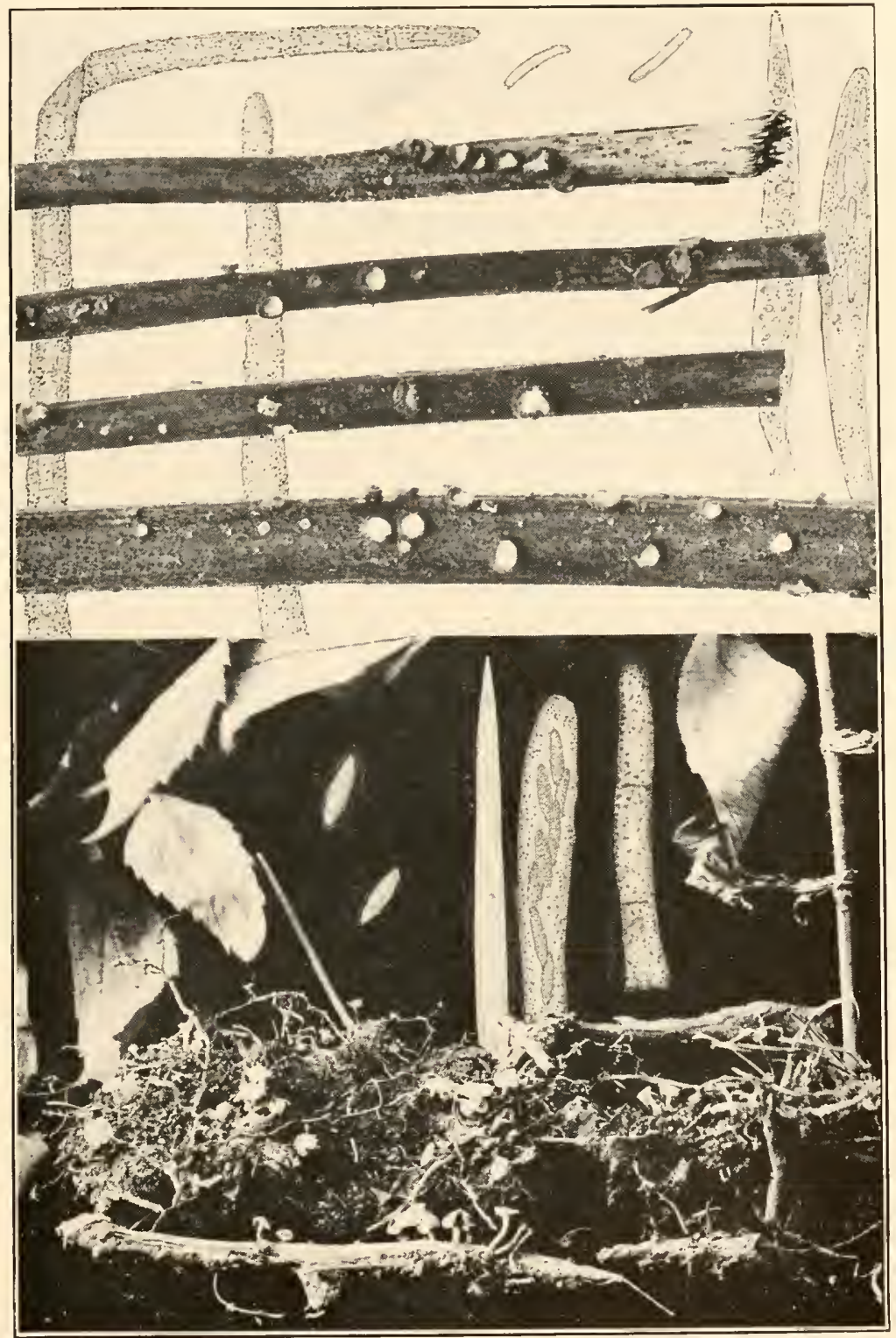

1. LACHNELLA SULPHUREA

2. LACHNELLA PYGMAEA 

Distribution: New York to Iowa; also in Europe. Probably widely distributed.

Illustrations: Boud. Ic. Myc. pl. 513; Bull. Torrey Club 27: pl. 31,f. 12 .

Exsiccati: Ellis \& Ev. N. Am. Fungi 2631; Brenckle, Fungi Dak. $66+$.

Phillips (Brit. Discom. 265.) treats leucophaea as a synonym of the above and states: "certainly not worthy of specific rank."

38. Lachnella canadensis (Ellis \& Dearn.) Seaver, comb. nov. Pseudohelotium canadense Ellis \& Dearn. Proc. Canad. Inst. 14: 89. 1897.

Apothecia scattered, short-stipitate, or subsessile, whitish, with a yellowish tinge, about $1 \mathrm{~mm}$. in diameter, pubescent, the margin fringed with tufts of short, pale hairs and when dry the opposite sides rolled together so as to become elliptical, or triangular in outline; hymenium concave, yellowish; asci cylindric-clavate, reaching a length of $40 \mu$ and a diameter of $4 \mu$; spores 2-seriate, long-ellipsoid, 1.5-2 $\times 8-12 \mu$; paraphyses filiform.

On dead stems of Arctium Lappa.

Type locality: London, Canada.

Distribution: Known only from the type locality.

39. Lachnella Ivae (Rehm) Seaver, comb. nov.

Dasyscypha Ivae Rehm, Ann. Myc. 11: 397. 1913.

Apothecia gregarious, sessile, at first globose and closed, then cup-shaped, finally expanded, constricted at the base, externally yellow, then brownish, . $5-1.3 \mathrm{~mm}$. in cliameter, the margin clothed with straight, septate, hyaline, then yellowish hairs $4-5 \times 150 \mu$; asci cylindric-clavate, reaching a length of $70 \mu$ and a diameter of $9 \mu, 8$-spored; spores ellipsoid, 2 -seriate, $3 \times 12-14 \mu$; paraphyses filiform, slightly enlarged above $4 \mu$ in diameter.

On dead stems of Ira xanthifolia.

Type locality: Kulm, N. Dakota.

Distribution: Known only from the type locality.

40. Lachnella pulverulenta (Lib.) Quél. Ench. Fung. 316. 1886.

Peziza pulverulenta Lib. Pl. Crypt. Ard. 125. 1832.

Trichopeziza pulverulenta Fuckel, Symb. Myc. 297. 1869.

Peziza solfalera Cooke \& Ellis, Grevillea 7: 7. 1878.

Lachnella solfatera Phill. Brit. Discom. 246. 1887.

Dasyscypha pulverulenta Sacc. Syll. Fung. 8: 462. 1889.

Dasyscypha solfatera Sacc. Syll. Fung. 8: 463. 1889. 
Apothecia scattered, sessile, or very short-stipitate, lemonyellow, at first globose, opening and becoming cup-shaped, .2-1 $\mathrm{mm}$. in diameter, externally clothed with hairs; hymenium concave, whitish to yellow; hairs reaching a length of 30-90 $\mu$ and a diameter of 4-5 $\mu$, rough, yellow, often with yellowish-brown masses at their apices; asci cylindric-clavate, reaching a length of $30-50 \mu$ and a diameter of $3-4 \mu, 8$-spored; spores fusoid, $1.5-2 \times 5-8 \mu$; paraphyses filiform, $2 \mu$ in diameter.

On fallen pine needles.

Type locality: Europe.

Distribution: New Jersey and Michigan; also in Europe.

Exsiccati: Ellis, N. Am. Fungi 439.

The variety purpurascens has been reported by Dr. B. Kanouse on fir needles from Olympic National Park (Mycologia 39: 647. 1947).

41. Lachnella Gleicheniae (Cash) Seaver, comb. nov.

Lachnum Gleicheniae Cash, Mycologia. 30: 105. 1938.

Apothecia developing in the sunken areas of the stems, sulphur-yellow to pale-orange, fading with age, stipitate, at first globose, then cup-shaped, .2-.7 mm. in diameter, clothed with yellow, strongly verrucose hairs $3-5 \mu$ in diameter; stem smooth, $.1 \mathrm{~mm}$. in diameter and .1-.4 $\mathrm{mm}$. high; asci cylindric, or subcylindric, reaching a length of $40-50 \mu$ and a diameter of 3-5 $\mu$, 8-spored; spores irregularly 2-seriate, fusiform, or fusoid, straight, or slightly unequal sided, $1-2 \times 9-11 \mu$; paraphyses extending beyond the asci, lanceolate, $3-3.5 \mu$ thick.

On stipes of Gleichenia, and stems of tree fern.

Type locality: Hawaii.

Distribution: Known only from the type locality.

Illustrations: Mycologia 30: 99, f. 2.

This is very close to L. Dicranopteridis (Seaver \& Whetzel) Seaver.

42. Lachnella atropurpurea (Durand) Seaver, comb. nov.

Lachnum atropurpureum Durand, Jour. Myc. 10: 100. 1904.

Apothecia gregarious, or scattered, stipitate, occasionally several apothecia at the summit of a common stem, pale-purple, reaching $1 \mathrm{~mm}$. in diameter, externally clothed with pale-purple hairs; hymenium concave, pale-purple; stem slender, the length equaling the diameter of the apothecium; hairs cylindrical, 
smooth, closely septate, reaching a length of $80 \mu$ and a diameter of $5 \mu$, pale-purple with transmitted light; asci clavate-cylindric, reaching a length of 40-50 $\mu$ and a diameter of 5-6 $\mu, 8$-spored; spores 1-seriate, hyaline, smooth, ellipsoid, $2-3 \times 6-8 \mu$; paraphyses narrowly lanceolate above, 3-4 $\mu$ thick.

On Eucalyptus.

TyPe Locality: Stanford University, California.

Distribution- Known only from the type locality.

\section{Lachnella viridicoma (Peck) Seaver, comb. nov.}

Peziza viridicoma Peck, Ann. Rep. N. Y. State Mus. 31:46. 1877.

Trichopesiza viridicoma Sacc. Syll. Fung. 8: 414. 1889.

Apothecia minute, reaching a diameter of .3 to $.5 \mathrm{~mm}$. sessile, or tapering below into a short, stem-like base, externally pale-green, clothed with a dense covering of hairs; hymenium becoming plane or nearly so, whitish, or slightly yellowish; hairs slender, reaching a length of $40 \mu$ and a diameter of $1.5-2 \mu$ at the base, gradually tapering above, subhyaline but more or less agglutinated in a greenish-yellow matrix; asci clavate, reaching a length of $80 \mu$ and a diameter of $10 \mu$; spores 2-seriate, ellipsoid, usually slightly curved, with two distinct oil-drops, 5-6 $\times 12-$ $15 \mu$; paraphyses very slender, hyaline.

On rotten wood.

Type Locality: Sandlake, New York.

Distribution: New York and Toronto.

\section{Lachnella microspora (Kanouse) Seaver, sp. nov.}

Lachnella tricolor var. microspora Kanouse, Papers Mich. Acad. Sci. 20: 73. 1935.

Apothecia gregarious, stipitate, externally pale-blue, or bluish-green, densely hairy, $.5 \mathrm{~mm}$. in diameter; hymenium concave, yellowish; hairs slender, nearly hyaline with transmitted light, bluish-green to the unaicled eye; asci clavate, 8-spored; spores $1-1.5 \times 5-5.5 \mu$; paraphyses filiform.

On decaying wood.

Type locality: Cascade Glen, Ann Arbor, Michigan.

Distribution: Known only from the type locality.

Dr. B. Kanouse recorded this variety as indicated above. The difference in size of the spores would, in the opinion of the writer, give it specific rank. It is one of the few species which has greenish hairs and in this is unique. 
45. Lachnella pulveracea (Alb. \& Schw.) Seaver, comb. nov.

Peziza pulveracea Alb. \& Schw. Consp. Fung. 342. 1805.

Cenangium pulveraceum Fries, Syst. Myc. 2: 181. 1822.

Tympanis seriata Schw. Trans. Am. Phil. Soc. I1. 4: 237. 1832.

Cenangium microspermum Sacc. \& Ellis; Sacc. Michelia 2: 571.1882.

Lachnum viridulum Massee \& Morgan; Morgan, Jour. Myc. 8: 187.1902.

Not Dasyscypha viridula (Schrad.) Sacc. Syll. Fung. 8: 437. 1889.

Dasyscypha chlorella Seaver, Mycologia 3: 63. 1911.

Apothecia gregarious, occasionally cespitose, at first rounded and closed, gradually expanding and becoming cup-shaped (mouth constricted in dried specimens), reaching a diameter of $.5 \mathrm{~mm}$., clothed with greenish hairs, narrowed into a short, stout stem the base of which is surrounded by a radiating mass of white mycelium, or nearly sessile, pale-greenish; hymenium concave, dark-green; hairs irregularly tapering above into a semiacute apex, reaching a length of $60-80 \mu$ and a diameter of 3-4 $\mu$; asci cylindric or subcylindric, 8-spored, reaching a length of 45-60 and a diameter of $6 \mu$; spores 2 -seriate, smooth, hyaline, cylindric, or slightly curved, $2 \times 7-9 \mu$; paraphyses filiform.

On Ilex opaca and old wood of various kinds.

Type locality: Europe.

Distribution: New Jersey to Alabama and Colorado; also in Europe.

Il.lustrations: Alb. \& Schw. Consp. Fung. pl. $8, f .2$.

While the hairs are greenish they fade in old specimens and become cinereous. It seems to us that our plants are identical with Peziza pulveracea although authentic material is lacking.

46. Lachnella arida (Phill.) Seaver, comb. nov. (Plate 126.)

Peziza arida Phill. Grevillea 5: 117. 1877.

Dasyscypha flavovirens Bres. Fungi Trid. 1: 92.1887.

Dasyscypha arida Sacc. Syll. Fung. 8: 455. 1889.

Lachnum Engelmani Earle in Greene, Pl. Baker. 1: 25. 1901.

Apothecia scattered, very short-stipitate, or apparently sessile, at first globose, then expanded but of ten irregularly angular, or subhysteriform, especially when dry, excipular cells dark-brown, giving rise to a dense covering of hairs, reaching a diameter of 4-8 mm.; hymenium concave, yellowish; hairs cylindrical, brown, septate, minutely roughened on the outside, the ends blunt or semiacute, reaching a length of $200-300 \mu$ and a diameter of $5 \mu$; asci clavate, 8 -spored, reaching a length of $50 \mu$ 


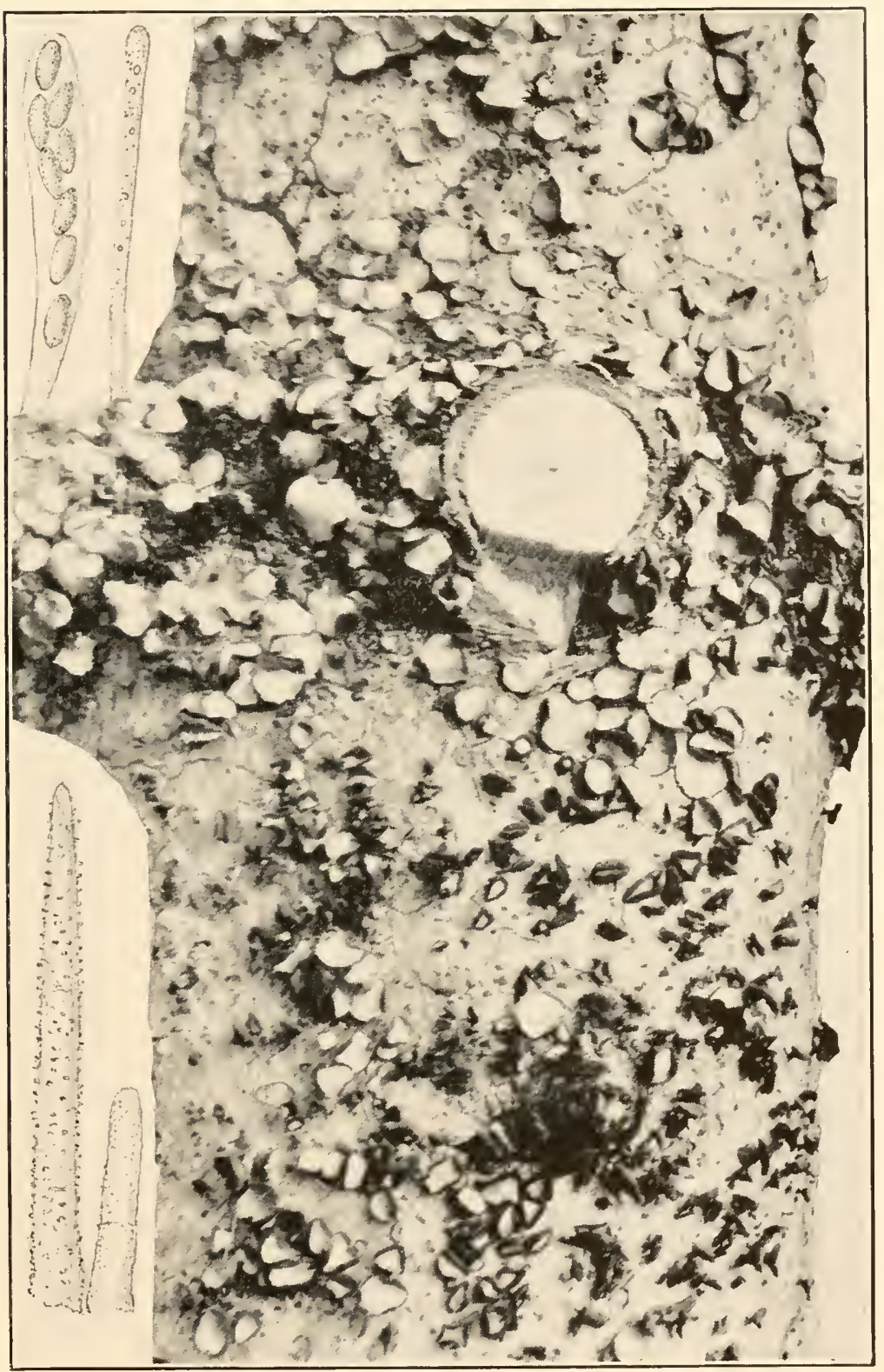

LACHNELLA ARIDA 

and a diameter of $5 \mu$; spores partially 2-seriate, ellipsoid, $4 \times 7 \mu$; paraphyses filiform.

On bark of conifers (Abies, Larix, Picea), or more rarely on the leaves.

Type Locality: Blue Canon, Sierra Nevada Mountains, California.

Distributiox: Newfoundland to Alberta and south to Colorado and California; also in Europe.

Illustrations: Grevillea 5: pl. 89, f. 13; Bres. Fungi. Trid. pl. $104, f .1$.

Exsiccati: Ellis \& Ev. N. Am. Fungi $21+6$ (as Peziza fuscosanguinea); Fungi Columb. 1223, 1311; 111t; Clements, Crypt. Form. Colo. 81 (as Dasyscypha cerina (Pers.) Fuckel); II. B. Cooke, Mycobiota N. Am. 66 .

One of the commonest species in the Rocky Mountains on spruces and firs, and conspicuous by reason of the bright-yellow color of the hymenium and distinguisherl from most other conifer-inhabiting species, by the darli exteriors of the apothecia.

47. Lachnella fuscosanguinea (Rehm) Karsı. Medd. Soc. Fauna Fl. Fenn. 16: 16. 1888.

Dasyscypha fuscosanguinea Rehm, Ascom. 112; Ber. Naturh. Ver. Augsburg 26: 30. 1881.

Lachnella Pini Brunch. Bergens Mus. Aarb. 18928: 8. 1892.

Dasyscypha Pini Hahn \& Ayers, Mycologia 26: 487. 1934.

Apothecia scattered, or occasionally several in close contact, short-stipitate, at first rounded, becoming shallow cup-shaped with the margin slightly upturned, reaching a diameter of 2-3 mm., becoming hysteriform, or angular when dry, excipular cells dark-brown, giving rise to a dense covering of brown hairs; hymenium bright-yellowish; hairs cylindrical, brown, septate, externally minutely roughened, reaching a diameter of $t-5 \mu$ and a length of 150-200 $\mu$; asci cylindric reaching a length of 90-100 $\mu$ and a diameter of $9 \mu$; spores 1-2-seriate, ellipsoid with the ends narrowed, $5 \times 12-15 \mu$; paraphyses clavate, reaching a diameter of $3 \mu$ at their apices.

On bark of Pinus Murrayana, and other species of Pinus.

Type Locality: Europe.

Distribution: Colorado and Michigan; also in Europe.

Illustrations: Rab. Krypt.-Fl. $1^{3}: 827, f .1$-4; Mỹcologia 26: pl. 53 . 
Our material agrees with Rehm's description except the color which is bright-yellow rather than rose-red. It differs from Lachnella arida with which it is thought by some to be identical, in its larger spores and asci. The two forms are casily confused.

\section{Lachnella populicola Seaver, sp. nov.}

Apothecia thickly gregarious, sessile, or subsessile, at first globose, becoming expanded with the margin incurved, reaching a diameter of 1-1.5 $\mathrm{mm}$., externally clothed with brown hairs; hymenium pale-yellow; hairs blunt, septate, pale-brown, externally minutely roughened, reaching a length of $80-90 \mu$ and a diameter of 5-6 $\mu$; asci clavate reaching a length of 50-55 $\mu$ and a diameter of 5-6 $\mu, 8$-spored; spores 2-seriate, fusoid, about $2 \times 8-9 \mu$; paraphyses lanceolate, reaching a diameter of $4 \mu$.

Apotheciis sessilis vel subsessilis, $1-1.5 \mathrm{~mm}$. diam., extus pilis brunneis vestitis; ascis clavatis, 5-6 $\times 80-90 \mu, 8$-sporis; sporis fusoideis, $2 \times 89 \mu$; paraphysibus lanceolatis.

On old wood of Populus tremuloides.

Type locality: Tolland, Colorado.

Distribution: Coloraclo.

This species closely resembles $L$. populina but differs in its smaller spores and asci and in having lanceolate paraphyses. From external characters the two can scarcely be distinguisheel.

\section{Lachnella populina Seaver, sp. nov.}

Apothecia thickly gregarious, sessile, or subsessile, at first globose, becoming expanded but with the margin incurved, when dry either rounded or hysteriform, reaching a diameter of 1-1.5 mm., externally densely clothed with brown hairs; hymenium yellowish-brown in dried specimens (the color in living material was not indicated); hairs cylindric, flexuous, reaching a diameter of 5-6 $\mu$ and a length of $150 \mu$, brown, roughened with minute granules; asci rather short and stubby, cylindric, scarcely narrowed at the base, reaching a length of $65-80 \mu$ and a diameter of $9-10 \mu$; spores obliquely 1 -seriate, or becoming 2 -seriate to irregularly clisposed, straight, or slightly curved, irregularly fusoid, $4 \times 13-15 \mu$, or occasionally as long as $18 \mu$; paraphyses clavate, rather strongly enlarged above where they reach a diameter of $4 \mu$.

Apotheciis dense gregariis, breve stipitatis vel subsessilis, pallide flavidis 1-2 mm. diam.; ascis clavatis, $7-10 \times 90-100 \mu$, 8 -sporis; sporis fusoideis, $3-4 \times 7-10 \mu$; paraphysibus filiformilus, $2-3 \mu$ diam. 
On bark and decorticated wood of Populus tremuloides.

Type locality: University of Colorado Summer Camp.

Distribution: Colorado and Montana to Oregon.

This species resembles in general appearance Lachnella fuscosanguinea but differs in habitat and in the longer more narrowly fusoid spores. Two collections were obtained by the writer and the late Ellsworth Bethel in 1910 and two collections during the summer of 1929 (Seaver and Shope 107 and 1+0). Also one specimen was received from Dr. J. R. Weir from Montana in 1917. All are on the same substratum Populus tremuloides.

50. Lachnella Corni (Cash.) Scaver, comb, nov.

Lachnum Corni Cash, Jour. Wash. Acad. Sci. 29: 47. 1939.

Apothecia stipitate, scattered, cup-shaped, brown, less than $1 \mathrm{~mm}$. in diameter, the margin inrolled when dry, often becoming triangular; externally clothed with hairs; hymenium whitish to pale olive-buff; stem cylindrical $.5 \mathrm{~mm}$. long and 1-.7 $\mathrm{mm}$. thick; hairs brown, non-septate, delicately roughened; asci narrowcylindric, 8-spored, reaching a length of 33-37 $\mu$ and a diameter of 3-3.5 $\mu$; spores 2-seriate, cllipsoid, .5-1 $\times 4-6 \mu$; paraphyses lanceolate, $3-3.5 \mu$ thick.

On leaves of Cornus Amomum.

Type locality: Clark County, Gcorgia.

Distribution: Known only from the type locality.

Illustrations: Jour. Wash. Acad. Sci. 29: 47, $f .1$.

51. Lachnella cerina Karst. Acta Soc. Fauna Fl. Fenn. $2^{6}: 131$. 1885.

Pesiza cerina Pers. Obs. Myc. 1: 43. 1796.

Dasyscypha cerina Fuckel, Symb. Myc. 305. 1869.

Helotium cerinum Karst. Myc. Fenn, 1: 156. 1877.

Lachnea cerina Gill. Champ. Fr. Discom. 70. 1880.

Erinella cerina Quél. Ench. Fung. 303. 1886.

Lachnella virginica Ellis \& Ev. Proc. Acad. Sci. Phila. 1894: 349.1894.

Apothecia gregarious, at first closed and subglobose, expanding and becoming shallow cup-shaped, with a short, dark stem, clothed externally with brown hairs, reaching a diameter of $1 \mathrm{~mm}$; hymenium becoming nearly plane, yellow; hairs brown, septate, roughened on the outsicle, reaching a length of $120 \mu$ and a diameter of $4-5 \mu$; asci cylindric, or subcylindric, reaching a length of $40-50 \mu$ and a diameter of $4-5 \mu, 8$-spored; 
spores ellipsoid, 1 - or 2 -seriate, $2.5-3 \times 5-6 \mu$; paraphyses filiform, extending far beyond the asci, reaching a diameter of $2 \mu$.

On wood of deciduous trees.

Type locality: Europe.

Distribution: West Virginia, Tennessee, Newfoundland, and Washington; also in Europe.

Illustrations: Boud. Ic. Myc. pl. 509; Gill. Champ. Fr. Discom. pl. 60, f. 1; Rab. Krypt.-Fl. 133: 826. f. 1-4; Phill. Brit. Discom. pl. $7, f .+4$.

52. Lachnella Eupatorii (Schw.) Seaver, comb. nov.

Peziza Eupatorii Schw. Trans. Am. Phil. Soc. II. 4: 174. 1832.

Trichopeziza Eupatorii Sacc. Syll. Fung. 8: 426. 1889.

Dasyscypha Eupatorii Massee, Jour. Bot. 34: 146. 1896.

Apothecia scattered, sessile, at first closed, then expanding and becoming plane, somewhat contorted when dry, $2-5 \mathrm{~mm}$. in diameter, externally clothed with hairs; hairs reaching a length of $70-120 \mu$ and a diameter of 5-7 $\mu, 3-7$-septate, externally sometimes roughened with particles of lime, dark-brown and translucent except near the apex which is paler, almost hyaline, or purple with potassium hydrate, often arranged in fascicles; asci clavate, reaching a length of $100 \mu$ and a diameter of 8-9 $\mu$, 8 -spored; spores 2 -seriate, straight, or slightly curved, finally becoming 1 -septate, $3 \times 12-20 \mu$; paraphyses $2-3 \mu$ thick, almost cylindric.

On dead stems of Eupatorium purpureum.

Type locality: Bethlehem, Pennsylvania.

Distribution: Known only from the type locality.

53. Lachnella albotestacea (Desm.) Phill. Brit. Discom. 273. 1887.

Peziza albotestacea Desm. PI. Crypt. Fr. 1415; Ann. Sci. Nat. II. 19: 368. 1843.

Lachnum albotestaceum Karst. Myc. Fenn. 1: 175. 1871.

Trichopesiza albotestacea Sacc. Atti Ist. Veneto V'I. 2: 491. 1884.

Apothecia scattered, sessile, or very short-stipitate, at first rounded, then expanding, externally brick-red, or reddish-brown, fading with age, $.5 \mathrm{~mm}$. in diameter; hymenium flesh-colored; hairs slender, flexuous, reddish, hyaline at their tips; asci cylindric-clavate, 8-spored; spores fusoid, $1-2 \times 7-10 \mu$; paraphyses lanceolate. 
On dead grasses, Phragmites, Andropogon and undetermined grasses.

Type Locality : Europe.

Distribution: New Jersey to Washington; also in Europe.

Exsiccati: Ellis \& Ev. N. Am. Fungi 2038, 2630.

54. Lachnella Pteridis (Alb. \& Schw.) Phill. Brit. Discom. 256. 1887.

Peziza Pteridis Alb. \& Schw. Consp. Fung. 338. 1805.

Urceola Pteridis Quél. Ench. Fung. 321. 1886.

Mollisia Pteridis Gill. Champ. Fr. Discom. 121. 1882.

Trichopeziza Pteridis Rehm, Ber. Naturh. Ver. Augsburg 26: 100. 1881.

Apothecia scattered, or gregarious, sessile, at first closed and rounded, finally expanding and becoming cup-shaped, externally dark olive-brown and clothed with adpressed, brown hairs; hymenium concave, dull-yellowish; hairs 30-50 $\mu$ long, $4 \mu$ thick, septate; asci clavate, 8 -spored, reaching a length of $35-55 \mu$ and a diameter of $6-7 \mu$; spores fusiform simple, $1.5-2.5 \times 6-9 \mu$; paraphyses filiform.

On dead stems of Pteridium aquilinum.

TyPe Locality: Europe.

Distribution: New York and New Jersey to Ontario, Canada; also in Europe.

Illustrations: Alb. \& Schw. Consp. Fung. pl. 12, f. 7; Phill. Brit. Discom. pl. 8, f. 47.

Exsiccati: Ellis, N. Am. Fungi $1+1$.

\section{Doubtful and Excluded Species}

Trichopesisa acerina (Cooke \& Ellis) Sacc. Syll. Fung. 8: 417. 1889; Pesiza acerina Cooke \& Ellis, Grevillea 7: 40. 1878. On leaves of Acer sp. Ellis, N. Am. Fungi 666 . Material unsatisfactory.

Dasyscypha acuum (Alb. \& Schw.) Sacc. Syll. Fung. 8: 443. 1889; Pesiza acuum Alb. \& Schw. Consp. Fung. 330. 1805; Helotiun acuum Karst. Myc. Fenn. 1: 147. 1871; Lachnella acuum Phill. Brit. Discom. 246. 1887. This is recorded from California on leaves of Sequoia.

Dasyscypha albocitrina (Cooke) Sacc. Syll. Fung. 8: 446 . 1889; Peziza albocitrina Cooke, Grevillea 7: 47. 1878. On I'accinium leaves. Cooke states "closely allied to $P$. virginella."

Lachnella albolabra Ellis \& Ev. Bull. Torrey Club 24: 467. 1897. On dead shoots of Ribes prostratum. Type specimen in The New York Botanical Garden needs further study.

Dasyscypha albopileata (Cooke) Sacc. Syll. Fung. 8: 445. 1889; Peziza albopileata Cooke, Hedwigia 14: 82. 1875. On fallen leaves of Magnolia. The description suggests Lachnella virginea. 
Lachnella albopileata var. subaurata Ellis, Grevillea 19: 107. 1891. On leaves of Clethra alnifolia.

Trichopesiza alboviridis (Cooke) Sacc. Syll. Fung. 8: 415. 1889; Pesiza alboviridis Cooke, Grevillea 7: 47. 1878. On decorticated Myrica or in fissures of the bark. Described as aeruginous-villose.

Lachnum alneum Vel. Monog. Discom. Bohem. 1: 247. 1934. This species has been reported from Washington on $\log$ of Alnus by Dr. B. Kanouse. It appears to be Lachnella virginea.

Hyaloscypha alniseda Vel. Monog. Discom. Bohem. 1:283. 1934. Apothecia described as .1-.3 mm. in diameter, sessile, watery-gray, fringed with a single row of simple hairs with bulbose bases; asci $30-40 \times 5 \mu$; spores $2 \times$ 5-7 $\mu$; paraphyses filiform. Reported on log of Alnus, from Washington by Dr. B. Kanouse. No material has been seen.

Dasyscypha A rundinariae (Berk.) Sacc. Syll. Fung. 8: 448. 1889; Peziza Arundinariae Berk. Grevillea 3: 155. 1875. Reported on stems of Arundinaria from South Carolina. No material seen. Peziza cannea Cooke is said to be identical. Compare Pyrenopeziza Arundinariae.

Lachnella ascoboloidea (Schw.) Sacc. Syll. Fung. 8: 400. 1889; Peziza ascoboloidea Schw. Trans. Am. Phil. Soc. 1I. 4: 175. 1832. Reported on I'itis labrusca. No material seen.

Trichopeziza Aspidii (1.ib.) Fuckel, Symb. Myc. 297. 1869; Pesiza Aspidii Lib. Pl. Crypt. Ard. 226. 1834; Lachnum Aspidii Karst. Medd. Soc. Fauna Fl. Fenn. 16:27. 1888. This species has been reported from Michigan, material determined by George B. Cummins.

Dasyscypha Bakeri Earle in Greene, Pl. Baker. 2: 6. 1901. On dead stems of Corydalis Brandegei. Clothed with brown hairs. Spores, $3 \times 12 \mu$.

Trichopeziza brevipila (Rob.) Sacc. Syll. Fung. 8: 404. 1889; Peziza brevipila Rob. in Desm. Pl. Crypt. Fr. 1742; Ann. Sci. Nat. III. 11:362. 1849; Lachnella brevipila Quél. Ench. Fung. 313. 1886; Beloniella brevipila Rehm in Rab. Krypt.-F1. 1 $1^{3}: 641$. 1892. Reported from Michigan on overwintering stems of $A$ ster sp. The spores are described as $27-32 \mu$ long and finally manyseptate which would place it in the genus Belonium as treated here.

Dasyscypha brunneola (Desm.) Sacc. Syll. Fung. 8: 460. 1889; Peziza brunneola Desm. PI. Crypt. Fr. 1156; Ann. Sci. Nat. II. 17:96. 1842; Lachnum brunneolum Karst. Myc. Fenn. 1: 180. 1871. This species has been reported from America but no American material has been seen.

Dasyscypha callochaetes (Ellis \& Ev.) Sacc. Syll. Fung. 8: 462. 1889; Lachnella callochaetes Ellis \& Ev. Jour. Myc. 4: 99. 1888. On fallen leaves of Myrica cerifera. About $1 \mathrm{~mm}$. in diameter, sparingly clothed with erect, black, bristle-like hairs. Spores $2-3 \times 12-14 \mu$.

Lachnum calyculaeforme (Schum.) Karst. Myc. Fenn. 1: 178. 1871; Pezisa calyculaeformis Schum. Enum. Pl. Saell. 2: 425. 1803; Dasyscypha calyculaeformis Sacc. Syll. Fung. 8: 454. 1889. This has been reported from Colorado (Mycologia 28: 304) and Washington but there seems to be some doubt as to its determination.

Peziza Campanula Ellis, Bull. Torrey Club 8: 73. 1881. This is apparently a Cyphella.

Trichopeziza candida Clements, Bot. Surv. Nebr. 4: 15. 1896. On bark and twigs of Tilia americana. Clements states "possibly Trichopesiza Tiliae (Peck) Sacc." which is a Cyphella. 
Lachnum carneolum (Sacc.) Rehm in Rab. Krypt.-Fl. 133: 881. 1893; I1yalopeziza carneola Sacc. Michelia 1:253. 1878. Dasyscypha carneola Sacc. Syll. Fung. 8: 447. 1889. Reported by Dr. B. Kanouse from Michigan on Eriophorum callitrix.

Trichopeziza carnearubra (Ellis) Sacc. Syll. Fung. 8: 405. 1889; Peziza carneorubra Ellis; Cooke, Bull. Buffalo Soc. Nat. Sci. 3: 22. 1877. On stems of Erigeron. "Sessile, rosy flesh-color, $1 \mathrm{~mm}$. broacl; sporidia linear binucleate." No material seen.

Coronellaria Castanopsidis Kanouse, Mycologia 33: 464. 1941. On leaves of Castanopsis chrysophylla, Mt. Hood, Oregon. The spores are described as $4 \times 14-16 \mu$ and spuriously septate. The apothecia are clothed with adpressed, hair-like hyphae. No material has been seen.

Dasyscypha chamacleontina (P'eck) Sacc. Syll. Fung. 8: 433. 1889; Peziza chamaeleontina Peck, Ann. Rep. N. Y. State Mus. 30: 60. 1878. On under surface of hemlock (Tsuga) wood lying on the ground. Described as white changing to yellow when bruised. Peck states "There is scarcely any appearance of hairiness on the cups." It is however placed in Dasyscypha by Saccardo.

Dasyscypha caulicola (Fries) Sacc. Syll. Fung. 8: 463. 1889; Periza caulicola Fries, Syst. Myc. 2: 94. 1822; Helotiun caulicola Karst. Myc. Fenn. 1: 134. 1871; Lachnella caulicola Phill. Brit. Discom. 236. 1887. Reported on Arundinaria in North America and palm stems in Cuba. Also on stems of L'rtica from Michigan.

Hyalopeziza ciliata Fuckel, Symb. Myc. 298. 1869. This species is reported by Dr. B. Kanouse from Washington on Delphinium. No material has been seen.

Lachnella cinereofusca (Schw.) Sacc. Syll. Fung. 8: 399. 1889; Peziza cinereofusca Schw. Schr. Nat. Ges. Leipzig 1: 119. 1822; Cyphella cinereofusca Sacc. Syll. Fung. 6: 674. 1888; Telutaria cinereofusca Bres.; Rehm in Rab. Krypt.-Fl. 1 ${ }^{3}: 645$. 1892. As will be seen, Saccardo treated this first as a Basidiomycete and later as a Discomycete. It is a Cyphella.

Dasyscypha clandestina (Bull.) Fuckel, Symb. Mỵc. 305. 1869; Pesiza clandestina Bull. Hist. Champ. Fr. 251, pl. H16, f. 5. 1791; Lachnum clandestinum Karst. Myc. Fenn. 1: 178. 1871. This species has been recorded for America. Characterized by its crystaline hairs.

Trichopeziza coarctata Ellis \& Ev. Am. Nat. 31: 427. 1897. On dead branches of Iaccinium myrtilloides. Type in The New York Botanical not very satisfactory.

Trichopeziza comata (Schw.) Sacc. Syll. Fung. 8: 431. 1889; Pesisa comata Schw. Trans. Am. Phil. Soc. II. 4: 173. 1832. On old leaves of Quercus. Minute, white-tomentose. Spores not described.

Dasyscypha crinella (Ellis \& Ev.) Sacc. Syll. Fung. 8: 450. 1889; Peaiza crinella Ellis \& Ev. Bull. Torrey Club 10: 76. 1883. On dead stems of Carex crinita lying in the water. Described as white, thin, and delicate. Spores $2 \times 9-12 \mu$. Ellis, N. Am. Fungi 1273 .

Trichopesiza crossota (Ellis) Sacc. Syll. Fung. 8: 413. 1889; Peziza crossota Ellis, Bull. Torrey Club 8: 124. 1881. According to Ellis this is closely related to Pesia Meleagris which is an old specimen of Perrotia fammea. Material very poor. 
Peziza digitalis Alb. \& Schw. Consp. Fung. 315. 1803. Reported from North America by Schweinitz. This is Cyphella pendula.

Trichopeziza distincta (Peck) Sacc. Syll. Fung. 8: 421. 1889; Peziza distincta Peck, Ann. Rep. N. Y. State Mus. 30: 60. 1878. On dead stems of Andropogon furcatus. Externally blackish, the margin tomentose-hairy, tawny, or olivaceous, the disk pink when moist. Spores fusiform, 20-25 $\mu$ long.

Trichopeziza earoleuca (Berk. \& Br.) Sacc. Syll. Fung. 8: 409. 1889; Peziza earoleuca Berk. \& Br. Jour. Linn. Soc. 14: 105. 1875. On herbaceous stems, sticks, and wood. Externally clothed with white hairs. Spores $4 \mu$ long. Reported from Ceylon. Also recorded from America (Rav. Fungi. Am. 631) and one doubtful specimen from Bermuda collected by the writer. Should be studied.

Dasyscypha epixantha (Cooke) Sacc. Syll. Fung. 8: 458. 1898; Peziza epixantha Cooke, Grevillea 7:3. 1878. On twigs of Quercus. Spores linear, $10 \mu$ long.

Dasyscypha eryngiicola Ellis \& Ev. Bull. Torrey Club 25: 506. 1898. On dead stens of Eryngium. White-tomentose, $1 \mathrm{~mm}$. in diameter. Spores $2.5-3 \times 12-15 \mu$.

Lachnella extricata (Berk \& Curt.) Sacc. Syll. Fung. 8: 401. 1889; Peziza extricata Berk. \& Curt.; Berk. Grevillea 3: 152. 1875. On dead stems of some umbelliferous plant. Specimens as stated by Berkeley not in very good condition.

Dasyscypha Fairmani Rehm, Ann. Myc. 7: 535. 1909. On decaying wood. Said to differ from $D$. albolutea in the larger spores which are $3 \times 12$ $14 \mu$.

Solenopesia fimbriata Ellis \& Barth. Jour. Myc. 8: 174. 1902. Type material of this species loaned the writer by Dr. Elam Bartholomew of Hays, Kansas shows it to be one of the Phacidiaceae and apparently a Diplonaeria. It is close to Diplonaevia melaleuca Ellis \& Ev. described from material occurring on decorticated wood of Populus tremuloides from Montana while the above species was described from material occurring on the same substratum in Colorado. The two species are very similar but appear to differ in spore measurements. Whether this difference will be found to be of specific inportance when more material has been studied remains to be seen.

Dasyscypha fimbriifera (Berk. \& Curt.) Sacc. Syll. Fung. 8: 452. 1889; Pesiza fimbriifera Berk. \& Curt.; Berk. Jour. Linn. Soc. 10:367. 1868. Apothecia white, short-stipitate, externally farinose-tomentose, toward the margin clothed with long, straight hairs. On stems of ferns in Cuba. Fruit not de scribed and no specimen seen.

Pseudohelotium fibrisedum Sacc. Syll. Fung. 8: 298. 1889; Peziza fibriseda Berk. \& Curt.; Berk. Grevillea 3: 157. 1875; Peziza saccharifera Berk. \& Curt.; Berk. Grevillea 3: 157. 1875; Pseudohelotium sacchariferum Sacc. Syll. Fung. 8: 298. 1889. Illustrations in the herbarium of The New York Botanical Garden, drawn by Geo. Massee show the exterior of the apothecia to be clothed with club-shaped hairs. Orbilia cruenta. 
Dasyscypha flavidula Rehm, Ann. Myc. 7: 542. 1909. Doubtfully reported on fern stems from Porto Rico by the writer.

Trichopeziza flarofuliginea (Alb. \& Schw.) Sacc. Syll. Fung. 8: 413. 1889; Pesiza flavofuliginea Alb. \& Schw. Consp. Fung. 319, pl. 11, f. 7. 1805; Dasyscypha flarofuliginea Fuckel, Symb. Myc. Nacht. 1: 337. 1871. Reported from America but material doubtful.

Peziza frondicola Ellis \& Ev. Jour. Myc. 4: 99. 1888; Pirottaea frondicola Sacc. Syll. Fung. 8: 388. 1889. On fallen leaves of Osmunda. Type specimen is very poor. Nannfeldt say's scarcely a Pirottaea.

Trichopesiza fulvocana (Schw.) Sacc. Syll. Fung. 8: 430. 1889; Peziza fulvocana Schw. Schr. Nat. Ges. Leipzig 1: 120. 1822. About 2 mm. in diameter, yellowish-brown-tomentose. Spores not described.

Dasyscypha fuscescens (Pers.) Rehm, Ascom. 457. 1878; Peziza fuscescens Pers. Syn. Fung. 654. 1801. On fallen leaves of Fagus. This species has been recorded for North America. American material has been reported on leaves of Andromeda.

Dasyscypha fuscidula (Cooke) Sacc. Syll. Fung. 8: 462. 1889; Peziza fuscidula Cooke, Bull. Buffalo Soc. Nat. Sci. 3: 22. 1877. On leaves of Andromeda.

Lachnella fuscobarbata (Schw.) Sacc. Syll. Fung. 8: 400. 1889; Pesiza fuscobarbata Schw. Trans. Am. Phil. Soc. II. 4: 173. 1832. No material seen and description inadequate.

Lachnum fuscofloccosum Rehm, Ann. Myc. 5: 520. 1907. Reported on sticks from Sumner, Washington. No material seen.

Lachnum hyalinellum Rehm in Rab. Krypt.-F1. 1 ${ }^{3}: 874$. 1893. This is reported from Michigan by Dr. B. Kanouse on cones of Picea Mariana. Also reported from Washington on Almus. No material has been seen.

Pirottaea ? Hydrangeae (Schw.) Sacc. Syll. Fung. 8: 390. 1889; Pesial IIydrangeae Schw. Schr. Nat. Ges. Leipzig. 1: 121. 1822. Apothecia described as cinereous-white, subglobose, clothed with long, black hairs. No specimen seen.

Dasyscypha hystricula (Ellis \& Ev.) Sacc. Syll. Fung. 8: 445. 1889; Lachnella hystricula Ellis \& Ev. Jour. Myc. 4: 99. 1888. On the under side of leaves of Magnolia grandiflora. Minute, white, clothed with rough hairs. Spores subfusoid, 3-septate, $2 \times 12 \mu$. Description suggests an Erinellina.

Dasyscypha illota (Berk. \& Curt.) Sacc. Syll. Fung. 8: 457. 1889; Peziza illota Berk. \& Curt.; Berk. Jour. Linn. Soc. 10: 368. 1868. Short-stipitate, solid, crateriform, fawn-colored, tomentose; hymenium brown. On bark. Cuba. No material seen.

Dasyscypha inspersa (Berk. \& Curt.) Sacc. Syll. Fung. 8: 437. 1889; Peziza inspersa Berk. \& Curt.; Berk. Jour. Linn. Soc. 10: 368. 1868. Cups subglobose, externally densely white-farinaceous; hymenium flesh-red. On rotten wood in Cuba. No material seen.

Lachnella incarnescens (Schw.) Sacc. Sy.ll. Fung. 8: 399. 1889; Peaiza incarnescens Schw. Trans. Am. Phil. Soc. II. 4: 173. 1832. Sessile, 2-5 mm. in diameter, externally brownish-black; hymenium flesh-colored. No fruit described. On rotten wood, Bethlehem, Pennsylvania. No material seen. 
Trichopeziza Kalmiae (Peck) Sacc. Syll. Fung. 8: 411. 1889; Peziza Kalmiae Peck, Ann. Rep. N. Y. State Mus. 25: 99. 1873. On dead stems of Kalmia angustifolia. Externally dull-gray, the hymenium pinkish-brown. Spores $5 \times 10 \mu$.

Trichopeziza labrosa (Phill. \& Jlark.) Sacc. Syll. Fung. 8: 419. 1889; Lachnella labrosa Phill. \& Hark. Bull. Calif. Acad. Sci. 1:21. 1884. On dead leaves of Arctostaphylos pungens. Olive-brown, clothed with brown hairs. Spores 3-6 $\times 10-1+\mu$.

Dasyscypha Lentaginis (Schw.) Sacc. Syll. Fung. 8: 458. 1889; Peziza Lentaginis Schw. Trans. Am. Phil. Soc. 11. 4: 175. 1832. On branches of Viburmum Lentago. Fruit not indicated.

Trichopeziza leonina (Schw.) Sacc. Syll. Fung. 8: 430. 1889; Peziza leonina Schw. Schr. Nat. Ges. Leipzig 1: 119. 1822. ()n wood of Clmus.

Dasyscypha longipila (l’eck) Sacc. Syll. Fung. 8: 463. 1889; Pesisa longipila Peck, Ann. Rep. N. Y. State Mus. 32: 20. 1879. On dead stems of Eupatorium maculatum. Clothel with long, tawny-brown hairs. Spores subfusoid, $2-3 \times 7-10 \mu$.

Dasyscypha luteoalba (Schw.) Sacc. Sỵll. Fung. 8: 457. 1889; Peziza luteoalba Schw. Trans. Am. Phil. Soc. 11. 4: 173. 1832. On bark. Hairs vellow; hymenium white.

Dasyscypha luteodisca (Peck) Sacc. Syll. Fung. 8: 449. 1889; Lachnella luteodisca Peck, Ann. Rep. N. Y. State Mus. 33: 31. 1880. On dead Scirpus ralidus. Hairs white; hymenium yellow.

Trichopesiza marginata (Cooke) Sacc. Syll. Fung. 8: 416. 1889; Peziza marginata Cooke, Hedwigia 14: 82. 1875. On fallen leaves of Quercus and Andromeda. Clothed with brown hairs. Spores minute, linear, spermatoid. See Ellis N. Am. Fungi 386. Should be studied.

Trichopeziza melaxantha (Fries) Sacc. Syll. Fung. 8: $428 . \quad 1889$; Peziza melaxantha Fries, Syst. Myc. 2: 150. 1822. On old wood. Externally black; hymenium yellowish.

Trichopeziza myricacea (Peck) Sacc. Syll. Fung. 8: 409. 1889; Pesiza myricacea Peck, Ann: Rep. N. Y. State Mlus. 30: 59. 1878. On dead stems of Myrica Gale. The type of this species in the herbarium is very scant and unsatisfactory.

Dasyscypha membranata (Schw.) Sacc. Syll. Fung. 8: 457. 1889; Pesiza membranata Schw. Trans. Am. Phil. Soc. II. 4: 175. 1832. On old wood. Clothed with adpressed hairs, entirely black. Fruit not indicated.

Lachnum Nardi Rehm in Rab. Krypt.-Fl. $1^{3}: 883$. 1893. This species originally reported on Nardus has been recorded by Dr. B. Kanouse on some sedge from Washington. No material seen.

Trichopeziza nigrocincta (Berk. \& Curt.) Sacc. Sỵll. Fung. 8: 421. 1889; Peziza nigrocincta Berk. \& Curt.; Berk. Grevillea 3: 155. 1875. On sheaths of grasses. "Minute dot-like, plane, scarlet, rough with short, black hairs externally; asci-clavate, sporidia oblong curved."

Trichopesiza obscura (Cooke) Sacc. Syll. Fung. 8: 410. 1889; Pesiza obscura Cooke, Grevillea 7:3. 1878. On twigs of Quercus. Sessile, blackishbrown. Spores linear, $10 \mu$ long. 
Dasyscypha ochracea (Schw.) Sacc. Syll. Fung. 8: 455. 1889; Peziza ochracea Schw. Trans. Am. Phil. Soc. 11. 4: 172. 1832. No specimen was found in the Schweinitz collection when examined May 22, 1931.

Trichopeziza Opulifoliae (Schw.) Sacc. Syll. Fung. 8: 429. 1889; Peziza Opulifoliae Schw. Trans. Am. Phil. Soc. 11. 4: 175. 1832. On dead branches of Spiraea opulifolia.

L'nguicularia oregonensis Kanouse, Mycologia 33: 467. 1941. The apothecia are described as less than $1 \mathrm{~mm}$. in diameter. The asci are $7-8 \times 35-$ $50 \mu$ and the spores $3-3.5 \times 7-8 \mu$; paraphyses curverl. No material seen.

Trichopeziza Osmundae (Cooke \& Ellis) Sacc. Syll. Fung. 8: 423. 1889; Pesiza Osmundae Cooke \& Ellis, Grevillea 6: 7. 1877; Ellis, N. Am. Fungi 136. On fronds of Osmunda. Minute, white. Spores $5 \mu$ long.

Lachnum pallideroseum (Saut.) Rehm in Rab. Krypt.-Fl. 132: 885. 1893; Peziza palliderosea Saut. Pilze Salzb. 2: 14. ?; Phialea palliderosea Sacc. Syll. Fung. 8: 264. 1889. Reported on grasses from Washington. No material seen. Said to become rose-red when dry. Spores $1.5 \times 7-10 \mu$.

Lachnella papillaris (Bull.) Karst. Acta Soc. Fauna Fl. Fenn. 26: 132. 1885; Peziza papillaris Bull. Hist. Champ. Fr. 244. 1791; Helotium papillare Karst. Myc. Fenn. 1: 160. 1871; Lachnea papillaris Gill. Champ. Fr. 1)iscom. 80. 1880. This species has been reported from Michigan by Dr. B. Kanouse. She states that the crystals at the ends of the hairs are a help in cletermining the species.

Dasyscypha patula (Pers.) Sacc. Syll. Fung. 8: 443. 1889; Peziza patula Pers. Syn. Fung. 654. 1801; Lachnella patula Phill. Brit. Discom. 251. 1887; Hyalopeziza patula Fuckel, Symb. Myc. 298. 1869. This species has been reported from America but no American material has been seen.

Trichopeziza penicillata (Schw.) Sacc. Syll. Fung. 8: 429. 1889; Peziza penicillata Schw. Schr. Nat. Ges. Leipzig. 1: 120. 1822. On bark of I'itis. No fruit described.

Trichopeziza pomicolor (Berk. \& Rav.) Sacc. Syll. Fung. 8: 429. 1889; Peziza pomicolor Berk \& Rav.; Cooke, Bull. Buffalo Soc. Nat. Sci. 2: 294. 1875; Berk. Grevillea 3: 157. 1875. On bark of Taxodium distichum. Externally pomicolor, the hymenium olivaceous. Spores not described. This species is listed by Saccardo twice; once under Trichopesiza and once as a Pseudohelotium. See Chlorosplenium chlora.

Dasyscypha prolificans (Schw.) Sacc. Syll. Fung. 8: 456. 1889; Peziza prolificans Schw. Trans. Am. Phil. Soc. II. 4: 172. 1832. On old trunks. No fruit described.

Dasyscypha puberula (Berk. \& Curt.) Sacc. Syll. Fung. 8: 461. 1889; Peziza puberula Berk. \& Curt.; Berk. Grevillea 3: 155. 1875. On fallen leaves of Fraxinus. "Cups, fawn-coloured, globose, furfuraceo-tomentose; stem short, pallid as is the hymenium, which becomes brighter with age." No fruit described.

Trichopeziza punctiformis (Fries) Fuckel, Symb. Myc. 296. 1869; Peziza punctiformis Fries, Syst. Myc. 2: 105. 1822. On leaves of Myrica, Alnus, and Quercus. Recorded for North America.

Trichopeziza relicina (Fries) Fuckel, Symb. Myc. 296. 1869; Peziza relicina Fries, Syst. Myc. 2: 103. 1822; Lachnum relicinum Karst. Myc. Fenn. 1: 182. 1871. Recorderl from Alaska. 
Trichopeziza roseoalba (Schw.) Sacc. Syll. Fung. 8: 428. 1889; Peziza roseoalba Schw. Schr. Nat. Ges. Leipzig 1: 122. 1822. On bark of Cornus florida. Type examined in 1931 and found unsatisfactory for study.

Trichopeziza rufiberbis (Schw.) Sacc. Syll. Fung. 8: 426. 1889; Peziza rufiberbis Schw. Trans. Am. Phil. Soc. II. 4: 173. 1832. On unidentified stems.

Dasyscypha scabrovillosa (Phill.) Sacc. Syll. Fung. 8: 458 . 1889; Peziza scabrozillosa Phill. Grevillea 7: 22. 1878. On Rubus mutkanus. This suggests Lachnella bicolor.

Trichopeziza setigera (Phill.) Sacc. Syll. Fung. 8: 407. 1889; Peziza setigera Phill. Grevillea 7:22. 1878; Lachnum setigerum Rehm, Ann. Myc. 3: 518. 1905. On dead stems of species of Aralia. Clothed with brown hairs; hymenium brown. Spores $3.5 \times 16 \mu$.

Pezizella soleniiformis (Berk. \& Curt.) Sacc. Syll. Fung. 8: 280. 1889; Peziza soleniiformis Berk. \& Curt.; Berk. Grevillea 3: 160. 1875. This is probably a Solenia.

Lachnella solitaria (Schw.) Sacc. Syll. Fung. 8: 401. 1889; Peziza solitaria Schw. Trans. Am. Phil. Soc. II. 4: 175. 1832. Solitary, 6 mm. in diameter, scantily clothed with white hairs. No fruit described.

Peziza sphaerincola Schw. Trans. Am. Phil. Soc. II. 4: 172. 1832. Described as minute, stipitate, externally brown, hairy. On some Sphaeria.

Dasyscypha spiraeicola (Karst.) Sacc. Syll. Fung. 8: 442. 1889; Peziza spiraeaecola Karst. Not. Soc. Fauna F1. Fenn. 10: 192. 1869; Lachnum spiraeaecolum Rehm in Rab. Krypt.-Fl. 13:880. 1893. Reported from Michigan from material collected by C. H. Kauffman and identified by Geo. B. Cummins.

Dasyscypha stipiticola (Schw.) Sacc. Syll. Fung. 8: 465. 1889; Peziza stipiticola Schw. Trans. Am. Phil. Soc. II. 4: 172. 1832. On old stems. No fruit indicated.

Lasiobelonium subfavidum Ellis \& Ev. Bull. Torrey Club 24: 136. 1897. The description of this species suggests Perrotia flammea.

Dasyscypha subhirta (Schw.) Sacc. Syll. Fung. 8: 462. 1889; Peziza subhirta Schw. Trans. Am. Phil. Soc. II. 4: 173 1832. On leaves. Described as yellow, minutely hirsute. Spores not described.

Dasyscypha subtilissima (Cooke) Sacc. Syll. Fung. 8: 438. 1889; Peziza subtilissima Cooke, Grevillea 3: 121. 1875. On bark of firs, Abies. Cooke states that this can scarcely be distinguished from Pesisa calycina Schum. but since its identity is in doubt it does not help much. See Lachnella Agassizii.

Dasyscypha sulphurella (Peck) Sacc. Syll. Fung. 8: 459. 1889; Peziza sulphurella Peck, Ann. Rep. N. Y. State Mus. 30: 59. 1878. The species is described as stipitate, pale-yellow, the hairs capitate; spores $7.5 \mu$ long; paraphyses lanceolate. On stems of Myrica Gale, Adirondack Mountains. The type in the herbarium of The New York Botanical Garden is too scant to permit of critical study. See Lachnella crncifera.

Solenopezia Symphoricarpi Ellis \& Ev. Jour. Myc. 9: 165. 1903. Described from material collected on Symphoricarpos at Steamboat Springs, Colorado. The apothecia are described as $1 \mathrm{~mm}$, in diameter and covered with a coat of dark-colored hairs; spores fusoid, or subclavate, septate. No material could be found in the Ellis Collection. Compare Lachnella Symphoricarpi Ellis \& Ev. Bull. Torrey Club 24: 467. 1897. The two may be the same. Material not satisfactory. 
Trichopeziza Tiliae (Peck) Sacc. Syll. Fung. 8: 428. 1889; Peziza Tiliae Peck, Ann. Rep. N. Y. State Mus. 24: 96. 1872; Cyphella Tiliae Cooke, Grevillea 20: 9. 1891. Cooke was undoubtedly correct in referring this species to Cyphella. Burt (Ann. Missouri Bot. Gard. 1:364) recognizes this combination. Frequently collected on Tilia.

Dasyscypha translucida (Berk. \& Curt.) Sacc. Syll. Fung. 8: 439. 1889; Peziza translucida Berk. \& Curt.; Berk, Grevillea 3: 155. 1875. On twigs of Castanea. Description very inadequate.

Dasyscypha tuberculiformis Ellis \& Ev. Bull. Torrey Club 27: 60. 1900. On dead stems of Aquilegia coerulea. Ellis states: "The specimens were not well matured so that the form and size of the sporidia will have to be more accurately ascertained hereafter."

Dasyscypha uncinata (Phill.) Sacc. Syll. Fung. 8: 456. 1889; Peziza uncinata Phill. Grevillea 5: 117. 1877. On pine needles, Pinus and oak wood, Quercus. Clothed with cinereous hairs. Spores $1 \times 6 \mu$. Specimens in The New York Botanical Garden meager.

Trichopeziza urticina (Peck) Sacc. Syll. Fung. 8: 403. 1889; Pesiza urticina Peck, Ann. Rep. N. Y. State Mus. 32: 46. 1879. On dead stems of nettle, Urtica canadensis. Peck states: "The plants are so small that to the naked eye they appear like mere white grains." A part of the type is in The New York Botanical Garden. The species should be investigated.

Trichopeziza venturioides (Ellis \& Ev.) Sacc. Syll. Fung. 8: 419.1889 ; Lachnella venturioides Ellis \& Ev. Jour. Myc. 4: 99. 1888. On fallen leaves of Gaylussacia dumosa. Minute, clothed with black bristles. Spores 1.5-2 $\times$ 10-12 $\mu$. See Ellis \& Ev. N. Am. Fungi 2145 .

Peziza rillosa Pers. Syn. Fung. 655. 1801. This is Cyphella rillosa (Pers.) Karst.

Trichopeziza Vitis (Schw.) Sacc. Syll. Fung. 8: 429. 1889; Peziza V'itis Schw. Trans. Am. Phil. Soc. II. 4: 173. 1832. Schweinitz's type examined Nay, 1931 shows only lichen apothecia.

Dasyscypha rixvisibilis (Schw.) Sacc. Syll. Fung. 8: 456. 1889; Peziza riveisibilis Schw. Trans. Am. Phil. Soc. II. 4: 175. 1832. On the bark of Castanea. Fruit not described.

Solenopezia a'ulpina (Cooke) Sacc. Syll. Fung. 8: 478. 1889; Peziza vulpina Cooke, Hedwigia 14: 82. 1875. As pointed out by the writer (Bull. Torrey Club 36: 202-203. 1909), this is a synonym of Nectria Peziza (Tode) Fries. Because of its resemblance to a cup-fungus, Cooke described it as a Peziza and Saccardo on the basis of his description placed it in the genus Solenopezia.

Pirottaea yakutatiana Sacc.; Sacc. Peck, \& Trelease in Harriman Alaska Exped. 5: 25. 1904. Apothecia $1 \mathrm{~mm}$. broad and high, externally hairy, black; asci $5.5-6 \times 40-45 \mu, 8$-spored; spores 1-seriate, fusoid, $2-2.5 \times 9 \mu$.

\section{DIPLOCARPA Massee, Brit. Fungus-Fl. 4: 307. 1895.}

Apothecia small, at first closed, finally expanding and becoming shallow cup-shaped, attenuated below into a short, stemlike base, densely clothed with short, septate, brown hairs giving the entire exterior a brown color; hymenium concave, olive- 
green; asci clavate, 8-spored; spores fusoid, containing several oil-drops and finally becoming septate; paraphyses filiform and surmounted with a fusiform conidium-like body.

Type species, Diplocarpa Curreyana Massee.

Diplocarpa Curreyana Massce, Brit. Fungus-Fl. 4: 307. 1895.

(Plate 127.)

Peziza diplocarpa Currey, Trans. Linn. Soc. 24: 153. 1864.

Lachnella diplocarpa Phill. Brit. Discom. 232. 1887.

Apothecia gregarious, or closely congested, appearing sessile but actually short-stipitate, at first closed, then expanding and becoming shallow cup-shaped, reaching a diameter of 1-2 mm. externally dark-brown, decidedly rough, tomentose, the roughening often vertically striated near the margin; hairs short, septate, brown, with the tips often sharp-pointed; stem 1-1.5 $\mathrm{mm}$. long, relatively thick, about half as thick as long; hymenium concave, olive-green, becoming brownish with age; asci clavate, reaching a length of $70 \mu$ and a diameter of $7 \mu$; spores partially 2-seriate, ellipsoid, with two or three small oil-drops, finally becoming 1 - or 2 -septate about $3 \times 9 \mu$; paraphyses slender, surmounted with fusoid, septate, spore-like tips which reach a length of $28-32 \mu$ and a diameter of $6-7 \mu$.

On much rotted wood, Wychwood, Wisconsin.

TyPe LOCality: England.

Distribution: Misconsin; also in Europe.

Illustrations: Trans. Linn. Soc. 24: pl. 25, f. 30, 32, 33; Phill. Brit. Discom. pl. 7, f. 43; Mycologia 29: 176, f. 1 .

For a full discussion of this species see Mycologia 29: 174-177. 1937.

51. LACHNEllula Karst. Medd. Soc. Famna Fl. Fenn. 11: 138. 1884.

Apothecia stipitate, or subsessile, bright-colored, yellowish, or orange, externally whitish and densely clothed with hairs which are white to the unaided eye, or in one species slightly rufous; asci cylindric, or clavate, 8-spored; spores globose, hyaline; paraphyses filiform, or subclavate.

Type species, Peziza chrysophthalma Pers.

Distinguished from Lachnella by its globose spores.

Spores reaching a diameter of 5-6 $\mu$. Spores reaching a diameter of $3.5 \mu$.

1. L. chrysophthalma.

2. L. microspora. 


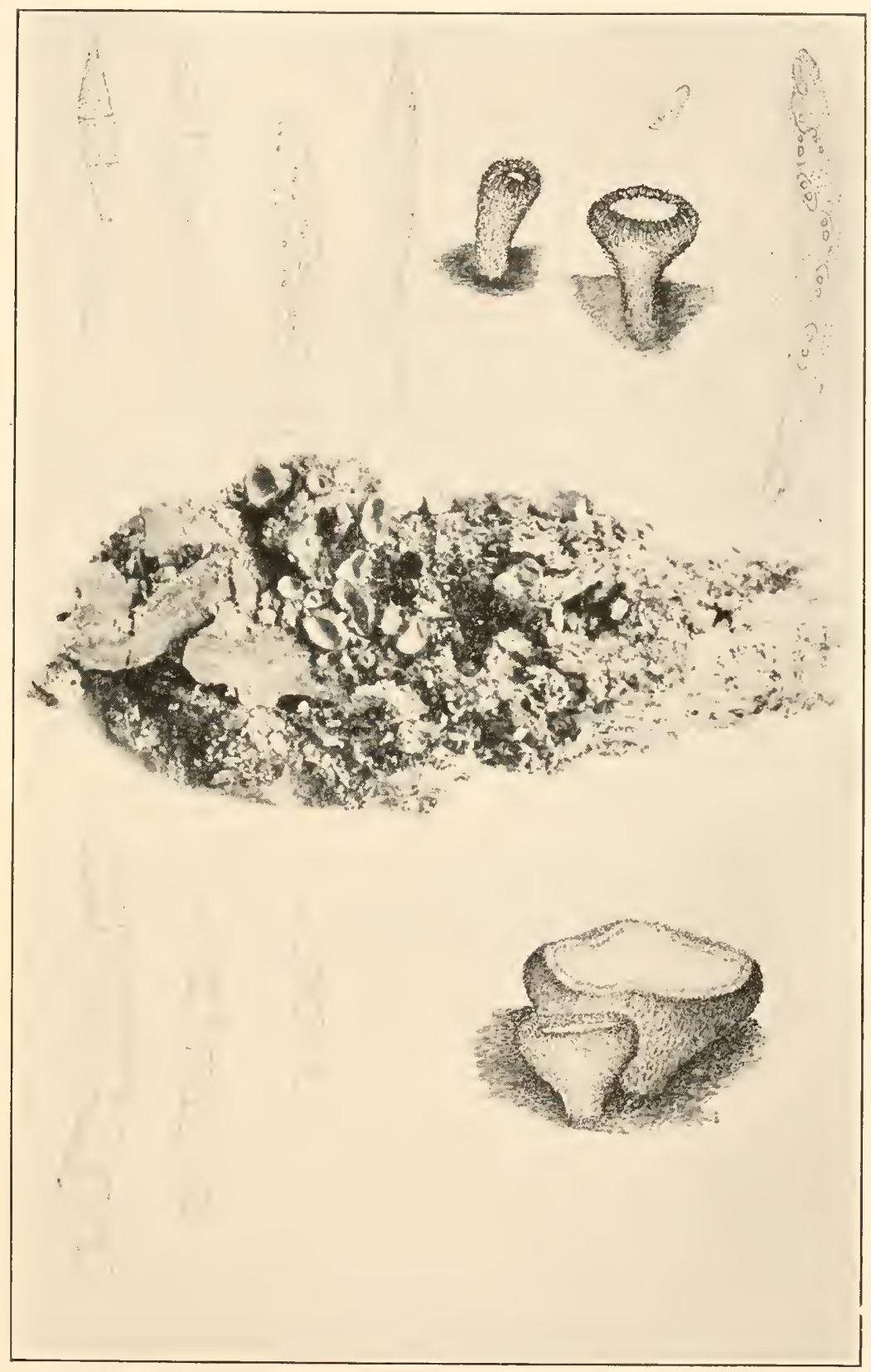

DIPLOCARPA CURREYANA 

1. Lachnellula chrysophthalma (Perз.) Karst. Medd. Soc. Fauna F1. Fenn. 11: 138. 18S4. (Plate 128, Fig. 1.)

Pesiza chrysophthalma Pers. Myc. Eu. 1: 259. 1822.

Peziza calycina Abietis Fries, Syst. My'c. 2: 91. 1822.

Helotium chrysophthalmum Karst. Fungi Fenn. 832. 1869.

Pithya suecica Fuckel, Symb. Myc. Nacht. 3: 32. 1875.

Apothecia gregarious, erumpent through the outer bark, short-stipitate, at first subglobose, expanding and becoming shallow cup-shaped and apparently sessile, reaching a diameter of 5-6 mm., clothed externally with a dense covering of white hairs; hymenium concave, or nearly plane, orange-red; hairs cylindric, reaching a diameter of $4 \mu$ and a length of 50-60 $\mu$, densely covered with minute granules, hyaline; asci cylindric, tapering below into a rather slender, stem-like base which is of ten forked, reaching a length of $80 \mu$ and a diameter of 5-6 $\mu$; spores 1-seriate, globose, reaching a diameter of 5-6 $\mu$; paraphyses filiform, slightly enlarged above, reaching a diameter of $2-2.5 \mu$, filled with oil-drops.

On bark of conifers.

Trpe locality: Europe.

Distribution: Ontario to Idaho, Montana and Colorado; also in Europe.

Illustrations: Rab. Krypt.-F1. $1^{3}: 828, f .1-5 ; E . \& . P$. Nat. Pfl. $1^{1}:$ 200, f. $138, A$.

Frequently collected in the Rocky Mountains on bark of Abies and Picea and occasionally on Pinus. Also reported by L. O. Overholts from Ontario on Pinus Banksiana (Mycologia 25: 420. 1933).

2. Lachnellula microspora Ellis \& Ev. Proc. Acad. Sci. Phila. 1893: 451 . 1893.

Apothecia sessile, or very short-stipitate, at first nearly closed, expanding and reaching a cliameter of $2-3 \mathrm{~mm}$, the margin fringed and the outside of the apothecium clothed with rufo-cinereous hairs; hymenium pale-orange when fresh, subrufous when dry; hairs stout, simple, or branched, subfasciculate, reaching a length of $70-80 \mu$ and a diameter of $3.5 \mu$; asci clavatecylindric, subsessile, reaching a length of 55-60 $\mu$ and a diameter of 6-7 $\mu$; spores 1-seriate, globose, hyaline, reaching a diameter of $3.5 \mu$; paraphyses present.

On bark of spruce trees, 
Type locality: New Harbor, Newfoundland.

Distribution: Known only from the type locality.

The type of this species has been examined in the herbarium of The New York Botanical Garden but unfortunately nothing remains but the shells of the apothecia and loose ascospores. The species seems to be clistinguished by its small spores.

\section{Doubtful Species}

Lachnellula cyphelloides (Ellis \& Ev.) Sacc. Syll. Fung. 8: 391. 1889; Peziza cyphelloides Ellis \& Ev. Jour. Myc. 1: 151. 1885. Although the writer has examined the type material, he is unable to find anything which would appear to belong to this genus.

Lachnellula theioidea (Cooke \& Ellis) Sacc. Syll. Fung. 8: 391. 1889; Peziza theioidea Cooke \& Ellis, Grevillea 7: 7. 1878. Reported from Michigan on material collected by A. H. Smith, determined by Geo. B. Cummins.

52. ERIOPEZIA (Sacc.) Rehm in Rab. Krypt.-Fl. 132:695. 1888. Tapesia subg. Eriopezia Sacc. Syll. Fung. 8: 381. 1889.

Apothecia sessile, seated on a spiderweb-like subiculum, at first globose and closed, opening and finally becoming subdiscoid, externally clothed with hairs; asci subcylindric, 8-spored; spores ellipsoid, or elongated, simple; paraphyses filiform.

Type species, Peziza caesia Pers.

Distinguished from Tapesia by the pilose exterior of the apothecia.

1. Eriopezia prolifica (Ellis) Sacc. Syll. Fung. 18: 73. 1906.

Pesiza prolifica Ellis, Bull. Torrey Club 8: 73.1881.

Tapesia prolifica Sacc. Syll. Fung. 8: 382. 1889.

Apothecia gregarious, sessile, minute, densely clothed with septate, coarse, spreading, cinereous hairs, cup-shaped; hymenium dark; asci clavate, reaching a length of $25 \mu, 8$-spored; spores 2 -seriate, cylindric, curved, subhyaline, $2.5 \times 7-8 \mu$.

On the end of a stick of white oak.

Type locality: Newfield, New Jersey.

Distribution: Known only from the type locality.

53. ARACHNOPEZIZA Fuckel, Symb. Myc. 303. 1869.

Apothecia gregarious, seated on a thin, spiderweb-like, white, or yellowish mycelial subiculum, at first closed and rounded, opening and becoming patellate, or scutellate, externally clothed 


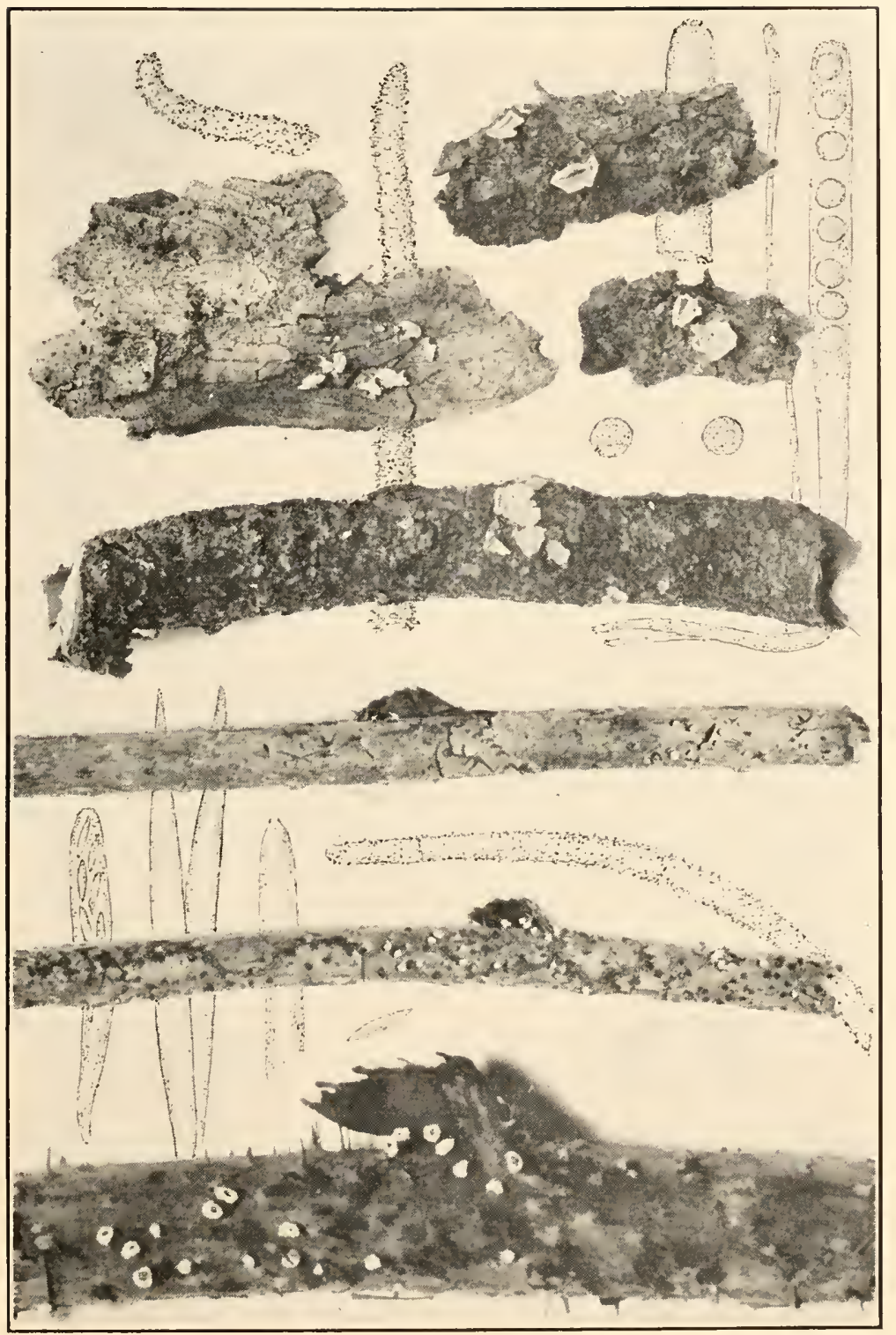

LACHNELLULA CHRYSOPHTHALMA

LACHNELLA BICOLOR 

with fine bristly hairs; asci clavate, 8 -spored; spores ellipsoid to fusoid, clavate, or filiform, becoming several-septate and often with an apiculus at each end, hyaline; paraphyses filiform, usually enlarged above.

Type species, Peziza aurelia Pers.

Spores, fusoid, apiculate $4-5 \times 15-20 \mu$.

1. A. aurelia.

Spores clavate or filiform.

Spores clavate, $3.5 \times 40 \mu$.

2. A. delicatula.

Spores filiform, $2.5-3 \times 65-75 \mu$.

On wood and bark.

3. A. aurata.

On stems of Arctostaphlos.

4. A. Arctostaphyli.

1. Arachnopeziza aurelia (Pers.) Fuckel, Sỵmb. Myc. 303. 1869. (Plate 129.)

Peziza aurelia Pers. Myc. Eu. 1: 270. 1822.

Pesisa Wrauchii Grev. Scot. Crypt. Fl. pl. 139. 1825.

Pesiza candidofulva Schw. Trans. Am. Phil. Soc. II. 4: 17t. 1832.

Belonidium aurelia DeNot. Comm. Critt. Ital. 1: 381. 1863.

Patellaria bicolor Curr. Trans. Linn. Soc. 24: 494. 1864.

Polynema aurelium Fuckel, Symb. Myc. Nachtr. 1: 49. 1871.

Lachnella aurelia Quél. Ench. Fung. 315. 1886.

Tapesia fulgens Hazsl. Zool.-Bot. Verh. 163. 1887.

Tapesia candidofulra Sacc. Syll. Fung. 8: 385. 1889.

Belonidium fulgens Sacc. Syll. Fung. 8: 500. 1889.

Apothecia gregarious, seated on a spreading, white, or yellowish mycelial web, sessile, at first rounded, then becoming scutellate, externally golden-yellow to pale-orange, clothed with fine hairs, reaching a diameter of 2-3 $\mathrm{mm}$; hymenium yellowish, a little paler than the outside of the apothecium; hairs slender, septate, reaching a length of $100 \mu$ and a diameter of $2 \mu$, tapering to a slender point, collected into conical tufts which stand up about the margin like teeth; asci clavate, attenuated above, reaching a length of 70-90 $\mu$ and a diameter of 8-10 $\mu, 8$-spored; spores fusoid, hyaline, becoming 3-septate, 4-5 $\times 15-20 \mu$, often with an apiculus at either end; paraphyses filiform, slightly enlarged above.

On leaves, soil, twigs and acorn-cups.

TyPe LOCALITY: Europe.

Distribution: New York to Pennsylvania, Iowa and Manitoba; also in Europe.

Illustrations: Fuckel, Symb. Myc. Nachtr. 1: $f$. 35; Grev. Scot. Crypt. Fl. pl. 139; Trans. Linn. Soc. 24: pl. 51, f. 15-16; Boud. Ic. Myc. pl. 520; Mycologia 30:660,f. 1.

Exsiccatı: Ellis, N. Am. Fungi 59; Rav. Fungi Car. 5: 41. 
2. Arachnopeziza delicatula Fuckel, Symb. Myc. 304. 1869.

Belonidium delicatulum Sacc. Syll. Fung. 8: 499. 1889.

Apothecia gregarious, or scattered, seated on a delicate, white, arachnoid subiculum, at first globose and closed, finally expanding, reaching a diameter of 1-2 mm.; hymenium concave, reddish-brown; asci clavate-cylindric, reaching a length of 80$100 \mu$ and a diameter of $8-10 \mu, 8$-spored; spores elongated, clavate, slightly curved, simple, or becoming sparingly septate, reaching a length of $40 \mu$ and a cliameter of 3.5-4 $\mu$; paraphyses filiform, slightly enlarged above, reaching a diameter of $3 \mu$.

On wood and bark.

Type LOCALity: Europe.

Distribution: Quebec and Michigan; also in Europe.

Illustrations: Papers Mich. Acad. Sci. 20: pl. 15, f. 1. (as Gorgoniceps delicatula (Fuckel) Höhn.).

3. Arachnopeziza aurata Fuckel, Symb. Myc. 304. 1869.

Belonidium auratum Sacc. Michelia 1: 66. 1879.

Tapesia aurata Massee, Brit. Fungus-F1. 4: 299. 1895.

Apothecia gregarious, sessile, at first closed, then expanding, externally yellowish, clothed with hairs, reaching a diameter of $.5 \mathrm{~mm}$., on a thin subiculum; hymenium a little darker than the outside of the apothecium; hairs long, cylindric, or tapering gradually toward the ends, septate, reaching a length of 60-85 $\mu$ and a diameter of $4 \mu$; asci clavate, the apex somewhat pointed, reaching a length of $96 \mu$ and a diameter of $7 \mu, 8$-spored; spores filiform, or slightly clavate, becoming multiseptate, slightly bent, 2.5-3 $\times 65-75 \mu$; paraphyses very slender, hyaline, occasionally branched.

On wood or the inside of bark.

Type locality: Europe.

Distribution: Ohio; also in Europe.

4. Arachnopeziza Arctostaphyli Cash, Mycologia 28: 247. 1936.

Apothecia sessile, on sparse subicle of hyaline mycelium, at first subglobose, becoming patellate, cream-colored to light-buff when dry, .4-.7 $\mathrm{mm}$. in diameter, attached at the margin by delicate, hyaline hairs; asci clavate, often arculate, narrowed above, attenuated toward the base, reaching a length of 100-115 $\mu$ and a diameter of 10-12 $\mu, 8$-spored; spores irregularly fasciculate, many-guttulate, straight, or curved, 7-septate, $2.5-3 \times 65-80 \mu$; 


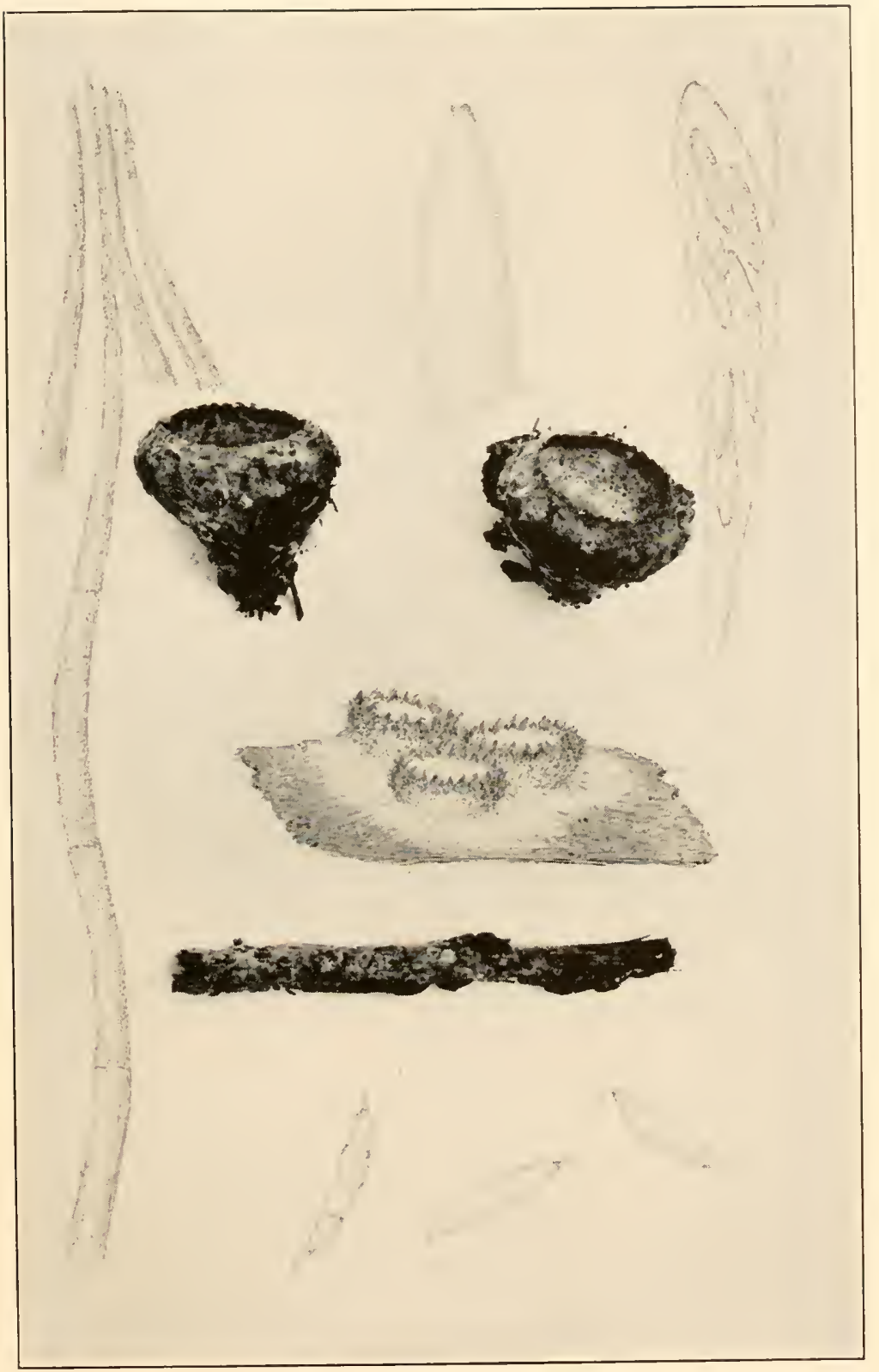

ARACHNOPEZIZA AURELIA 

paraphyses filiform, branched about half way from the base, granular, hyaline.

On decorticated stems of Arctostaphlos Tracyi.

Type locality: Trinidad, California.

Distribution: Known only from the type locality.

Illustrations: Mycologia 28: 250, f. 1 .

\section{Helotiella Sacc. Bot. Cent. 18: 218.1884.}

Apothecia minute, sessile, or subsessile, usually brightcolored as in Helotium, or occasionally dark, clothed with hairs; asci cylindric, or subcylindric, usually 8-spored; spores ellipsoid, or fusoid, becoming 1-septate; paraphyses filiform.

Type species, Helotium Citri Penz.

On monocotyledonous plant tissues.

On stems of Andropogon.

1. H. aureococcinea.

On old cornstocks, Zea.

2. H. pygmaea.

Not on monocotyledonous tissues.

On twigs of Lonicera.

3. H. Lonicerae.

On rotten wood.

Apothecia orange-colored.

4. H. trabinelloides.

Apothecia white or whitish.

Spores appendiculate.

5. H. cornuta.

Spores not appendiculate.

On old paper.

6. H. major.

7. H. papyricola.

1. Helotiella aureococcinea (Berk. \& Curt.) Massee, Jour. Linn. Soc. 35: 108. 190 I.

Solenopezia aureococcinea Rehm, Ann. Myc. 2: 352. 1904.

Patellaria aureococcinea Berk. \& Curt. in Ellis; N. Am. Fungi 63. 1878. nom. nud.

Apothecia scattered, sessile, at first closed and subglobose, finally expanded, externally brownish-black, densely clothed about the margin with yellow hairs; hairs hyaline with transmitted light, reaching a diameter $5-6 \mu$ and a length of $125 \mu$, blunt and slightly roughened; asci clavate, with the apex rounded, reaching a length of $60-70 \mu$ and a diameter of $7-8 \mu$; spores fusoid, straight, becoming 1-septate, 2-2.5 $\times 15 \mu$; paraphyses filiform with the apex obtuse, hyaline reaching a thickness of 2-3 $\mu$ at their apices.

On decaying stems of $A$ ndropogon.

Type locality: Newfield, New Jersey.

Distribution: Known only from the type locality. 
Illustrations: Jour. Linn. Soc. 35: pl. 4, f. 5-7.

Exsiccati: Ellis, N. Am. Fungi 63 (as Patellaria aureococcinea Berk. \& Curt. 1878).

2. Helotiella pygmaea Ellis \& Ev. Proc. Acad. Sci. Phila. 1894: 350. 1894.

Apothecia gregarious, minute, pallid, yellowish outside, sparingly clothed and the margin fringed with pale, slender hairs, convex-discoid when moist, .25-.35 mm. in diameter, when dry cup-shaped and yellowish, attached to the substratum by lightcolored hairs; asci cylindric, reaching a length of $30 \mu$ and a diameter of $6 \mu, 8$-spored; spores 2 -seriate, fusoid, becoming 1 -septate, and often slightly constricted, $3-3.5 \times 10-14 \mu$; paraphyses not observed.

On old cornstalks, Zea Mays.

Type locality: Ohio.

Distribution: Known only from the type locality.

3. Helotiella Lonicerae (Cash) Seaver, comb. nov.

Tapesia Lonicerae Cash, Mycologia 28: 299. 1936.

Apothecia sessile, superficial, soft-fleshy, becoming patelliform, irregularly contorted when dry, the margin crenulate, inrolled, 1-2.5 $\mathrm{mm}$. in diameter, exterior black, or dull lividpurple, densely setose at the margin; hairs brown, smooth, septate, 2.5-3 $\times 140-170 \mu$; hymenium pale-gray; asci cylindric, reaching a length of $65-75 \mu$ and a diameter of 7-9 $\mu$; spores obliquely 1-seriate, fusoid-clavate, 1-septate, 2-2.5 × 12-13.5 $\mu$; paraphyses filiform, slightly inflated above.

On twigs of Lonicera involucrata.

Type locality: Mesa Lakes, Colorado.

Distribution: Known only from the type locality.

Illustrations: Mycologia 28: 302, f. 1 .

$\mathrm{Mr}$. Richard Korf who is working on the genus Arachnopeziza regards this as a true Tapesia and believes that it should not be included with the present genus.

4. Helotiella trabinelloides Rehm, Ann. Myc. 2: 36. 1904.

Helotium trabinelloides Rehm, Hedwigia 26: 82. 1887.

Solenopezia trabinelloides Sacc. Syll. Fung. 8: 477.1889.

Helotiella Nuttallii Ellis \& Ev. Proc. Acad. Sci. Phila. 1894: 351. 1894.

Dasyscypha trabinelloides Massee, Jour. Bot. 34: 145. 1896. 
Apothecia gregarious, sessile, flat-hemispheric, .5-1.5 mm. in diameter, cup-shaped when fresh, contracted and subspherical when dry, with only a small, round apical opening, orangecolored throughout, the margin fringed with hairs; hymenium watery-orange; hairs pale-yellow, straight, roughish ; asci clavatecylindric, sessile, reaching a length of 50-60 $\mu$ and a diameter of 5-6 $\mu$, 8-spored; spores 2-seriate, ellipsoid, becoming 1-septate, 2.5-4 $\times 10-17 \mu$; paraphyses filiform, scarcely thickened above, with orange-colored granules.

On rotten wood.

Type Locality: Europe.

Distribution: Nest Virginia; also in Europe.

Illustrations: Jour. Bot. 34: pl. 357, f. 4.

Exsiccati: Ellis \& Ev. N. Am. Fungi 3233.

According to Massee (Jour. Bot. 34: 146) IIelotiella Nuttallii Ellis \& Ev. is identical with Helotium trabinelloides Rehm dis-. tributed in his Ascomycetes 853 .

5. Helotiella cornuta (Ellis) Sacc. Syll. Fung. 8: 474. 1889.

Pezisa cormuta Ellis, Bull. Torrey Club 9: 73. 1882.

Apothecia gregarious, minute, dull-white, flesh-colored when dry, sessile, thin, membranaceous, the margin sparingly fringed with straight, 4-5-septate, white, spreading hairs; asci clavatecylindric, reaching a length of $50-60 \mu$ and a diameter of $8-10 \mu$; spores 2-seriate, fusiform, becoming 1-septate, with a short, bristle-like appendage at either end, $3-4 \times 12 \mu$; paraphyses filiform.

On decaying chestnut wood.

Type Locality: Westchester, Pennsylvania.

Distributios: Known only from the type locality.

Ellis writes: "I have not seen $P$. arachnoidea Schw. but that is said to be 'white villous,' while this in only ciliate."

6. Helotiella major Ellis \& Ev. Proc. Acad. Sci. Phila. 1894: 351. 1894.

Apothecia gregarious, often confluent, sessile, 1-2 $\mathrm{mm}$. in diameter, externally dull-white, and densely clothed, especially about the margin, with short, pale, glandular hairs, expanded when fresh, the margin incurved when dry, attached by spreading, white filaments; asci cylindric or subcylindric, reaching a length of $65-70 \mu$ and a diameter of $7-8 \mu, 8$-spored; spores mostly 2- 
seriate, elongate-ellipsoid, slightly curved, becoming 1-septate, or occasionally 3 -septate, $2.5-3 \times 12-16 \mu$; paraphyses not observed.

On rotten wood.

Type locality: Ann Arbor, Michigan.

Distribution: Known only from the type locality.

7. Helotiella papyricola Ellis \& Ev. Proc. Acad. Sci. Phila. 1894 : 351. 1894.

Apothecia gregarious, sessile, or contracted below into a very short stipe, pale-orange, of a soft-waxy consistency, discoid when fresh, .2-.3 $\mathrm{mm}$. in diameter, subspherical and nearly closed when dry, outside sparingly furfuraceous, margin fringed with short, spreading hairs; asci cylindric, very short-stipitate, reaching a length of $50-60 \mu$ and a diameter of $12 \mu, 8$-spored; spores 2 -seriate, fusoid, slightly curved, with two to four oildrops, finally 1 -septate, $3 \times 12-15 \mu$; paraphyses filiform.

On old paper on the ground.

Type locality: Ann Arbor, Michigan.

Distribution: Michigan and New Jersey.

\section{Excluded Species}

Helotiella Russellii (Berk. \& Curt.) Sacc. Syli. Fung. 8: 476. 1889; Pesiza Russellii Berk. \& Curt.; Berk. Grevillea 3: 158. 1875. This is undoubtedly a Nectria. No material has been seen.

\section{ERINELLINA Seaver, nom. nov.}

Erinella Sacc. Syll. Fung. 8: 507. 1889. Not Erinella Quél. 1886.

?Dasyscyphella Tranz. Hedwigia 38: Beibl. (11). 1899.

Apothecia cup-shaped, or subdiscoid, externally clothed with hyaline, or subhyaline hairs; hymenium plane, or concave, variously colored; hairs rigid, or more often flexuous, smooth, or rough; asci cylindric to clavate, usually 8-spored; spores much elongated, fusiform to filiform, hyaline, or subhyaline, 3-manyseptate; paraphyses filiform, clavate, or lanceolate.

Type species, Peziza simillima Berk. \& Br.

The genus Erinella was established by Quélet and is a straight synonym of Lachnella as used here. Saccardo took up the name but used it in an entirely different sense thus creating a homonym. The new name above is proposed for the genus as treated by Saccardo. 
Spores 100-120 $\mu$ long.

Apothecia sessile, on Pinus.

1. E. rhaphidospora.

Apothecia stipitate, on undetermined bark.

2. E. calospora.

Spores 40-65 $\mu$ long.

Hymenium orange to scarlet.

3. E. miniopsis.

Hymenium pallid to brown.

Apothecia sessile.

4. E. cervina.

Apothecia short-stipitate.

5. E. appressa.

Spores 16-40 $\mu$ long.

On living leaves of Persea.

6. E. maculosa.

On dead herbaceous stems or wood.

Hairs yellowish, on herbaceous stems. 7. E. Nylanderi.

Hairs white, on bark.

8. E. longispora.

1. Erinellina rhaphidospora (Ellis) Seaver, comb. nov.

Pesiza rhaphidospora Ellis, Bull. Torrey Club 6: 107. 1876.

Erinella rhaphidospora Sacc. Syll. Fung. 8: 509. 1889.

Apothecia gregarious, sessile, minute, subconfluent, whitetomentose; hymenium plane, or slightly convex; asci cylindricclavate, reaching a length of $100-140 \mu$ and a diameter of 12-20 $\mu$, 8-spored; spores nearly as long as the ascus (multiseptate?).

On trunks of Pinus.

Type locality: Newfield, New Jersey.

Distribution: New Jersey to Pennsylvania, and Bermuda. Exsiccati: Ellis, N. Am. Fungi $8+2$.

2. Erinellina calospora (Pat.) Seaver, comb. nov.

Erinella calospora Pat. Bull. Soc. Myc. Fr. 4: 101. 1888.

Apothecia scattered, turbinate, short-stipitate, 2-3 mm. in diameter, externally white-tomentose; hymenium orange-yellow; hairs long, cylindric, flexuous; asci cylindric, substipitate, reaching a length of $120-150 \mu$ and a diameter of 12-15 $\mu$; spores nearly as long as the ascus, 2-3 $\times 90-120 \mu$, 6-14-septate, subhyaline; paraphyses simple, or branched, thickened above, septate, hyaline.

On bark of some tree.

Type locality: Venezuela.

Distribution: South America and the West Indies.

Illustrations: Bull. Soc. Myc. Fr. 4: pl. 18, f. 7 .

3. Erinellina miniopsis (Ellis) Seaver, comb. nov.

Peziza miniopsis Ellis, Bull. Torrey Club 8: 66. 1881.

Erinella miniopsis Sacc. Syll. Fung. 8: 510. 1889.

Dasyscyphella miniopsis Kanouse, Papers Mich. Acarl. Sci. 23: 151. 1938. 
Apothecia gregarious, sessile, minute, less than $1 \mathrm{~mm}$. in diameter, clothed with a white-tomentose coat of crisped hairs; hymenium concave, orange to scarlet; asci clavate-cylindric, reaching a length of $95 \mu$ and a diameter of $12 \mu$, 8-spored; spores crowded, linear-lanceolate, $50-65 \mu$ long, becoming multiseptate; paraphyses filiform, not thickened above.

On the outer bark of Acer rubrum.

Type locality : Newfield, New Jersey.

Distribution: New Jersey to New Hampshire.

Exsiccati: Ellis, N. Am. Fungi 563; Barth. Fungi Columb. 2428; Reliq. Farlow. 115.

4. Erinellina cervina (Ellis \& Ev.) Seaver, comb. nov.

Erinella cervina Ellis \& Ev. Bull. Torrey Club 24: 468. 1897.

Apothecia gregarious, sessile, at first subglobose, becoming urceolate, the margin incurved leaving only a small rounded opening, stag-colored; short-tomentose; hymenium concave, pallid; asci cylindric, or subcylindric, with a short, stem-like base, reaching a length of $75-85 \mu$ and a diameter of $7-9 \mu, 8$-spored; spores fasciculate, acicular, attenuated toward each end, $2-2.5 \times$ 50-60 $\mu$; paraphyses stout, rather longer than the asci, scarcely enlarged above, $2-2.5 \mu$ thick.

On decaying birch limbs.

Type locality: Dillon, Colorado.

Distribution: Known only from the type locality.

The type specimen is in the herbarium of The New York Botanical Garden.

5. Erinellina appressa (Cash) Seaver, comb. nov.

Dasyscyphella appressa Cash, Univ. Iowa Stud. Nat. Hist. 17: 217. 1937.

Apothecia obconic to infundibuliform, short-stipitate, .2-1 $\mathrm{mm}$. in diameter $.5 \mathrm{~mm}$. high, waxy-membranous, ochraceoustawny, pilose; hairs pale-brown, verrucose; hymenium cinnamonbrown; asci cylindric, narrowed above, reaching a length of 90$110 \mu$ and a diameter of $7-9 \mu$, short-stipitate, 8-spored; spores fasciculate, filiform, 2-2.5 $\times 40-55 \mu$, subhyaline 1-5-septate; paraphyses filiform, $1.5 \mu$ thick.

On woody stem.

Type Locality: Panama.

Distribution: Panama and Colombia.

Illustrations: Univ. Iowa Stud. Nat. Hist. 17: pl. 1H, f. 2. 
This scarcely differs from Erinella cervina Ellis \& Ev. so far as we can judge from the descriptions.

6. Erinellina maculosa (Ellis \& Martin) Seaver, comb. nov.

Helotium maculosum Ellis \& Martin, Am. Nat. 17: 1284. 1883.

Apothecia sessile, $.16 \mathrm{~mm}$. in diameter, externally clothed with a few brown, bristle-like, faintly septate hairs arising from near the base; hymenium dull flesh-colored; asci clavate, reaching a length of $55 \mu$ and a diameter of $12 \mu, 8$-spored; spores 2-seriate,

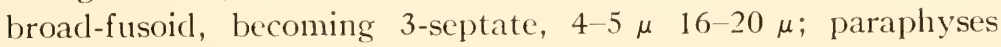
rather stout.

On pale-brown spots on living leaves of Persea palustris.

Type locality: Green Cove, Florida.

Distribution: Known only from the type locality.

Exsiccatı: Ellis. N. Am. Fungi 1276.

\section{Erinellina Nylanderi (Rehm) Seaver, comb. nov.}

Erinella Nylanderi Rehm in Rab. Krypt.-Fl. 133:910. 1893.

Apothecia gregarious, sessile, globose, at first closed, expanding and becoming cup-shaped, externally yellow, or yellowishbrown, densely hairy, .3-2 $\mathrm{mm}$. in diameter; hymenium faintly bluish, or reddish-gray; hairs pointed, septate, rough, greenishyellow, reaching a length of $150 \mu$ and a diameter of $4-5 \mu$; asci cylindric-clavate, slightly attenuated above, reaching a length of 80-90 $\mu$ and a diameter of 5-6 $\mu, 8$-spored; spores elongated, fusiform, straight, or somewhat curved, becoming 3-5-septate, hyaline, $2 \times 25-33 \mu$; paraphyses sparse, not strongly pointed, 3-4 $\mu$ in diameter.

On dead stems of herbaceous plants Urtica and Impatiens.

Type Locality: Europe and Michigan.

Distribution: New York; also in Europe.

Resembling and often confused with Lachnella sulphurea.

8. Erinellina longispora (Karst.) Seaver, comb. nov.

Lachnum longisporum Karst. Hedwigia 28: 191. 1889.

?Erinella subcorticalis Pat. in Duss, Enum. Meth. Champ. Guadeloupe and Martin. 67. 1903.

?Dasyscyphella subcorticalis Cash, Mycologia 35: 601. 1943.

Apothecia gregarious, or subsparse, sessile, or short-stipitate, white-tomentose, at first subglobose, then cup-shaped, $.5 \mathrm{~mm}$. in diameter; hymenium yellowish; asci cylindric-clavate, reaching 
a length of $60 \mu$ and a diameter of $6-7 \mu, 8$-spored; spores fasciculate, fusoid-filiform, usually 3 -septate, subhyaline, $2 \times 18$ $40 \mu$; paraphyses $2 \mu$ in diameter, acute at their apices.

On bark of some tree.

TyPe LOCALITY: Brazil.

Distribution: Central to South America and the West Indies.

\section{DoubtFul Species}

Dasyscyphella acutipila Cash, Univ. Iowa Stud. Nat. Hist. 17:216. 1937. On woody stems in Panama. Spores $1 \times 33-45 \mu$. No specimens have been seen.

Erinella borealis Povah, Mycologia 24: 241. 1932. Described from material collected on dead stems of Chamaedaphne calyculata on Isle Royale, Michigan. Later reported by Dr. B. Kanouse (Papers Mich. Acarl. Sci. 20: 74. 1935) as synonymous with Dasyscyphella Cassandrae Tranz.; Erinella Cassandrae Sacc. \& Syd. in Sacc. Syll. Fung. 16: 757. 1902. No material has been seen.

Erinella raphidophora (Berk. \& Curt.) Sacc. Syll. Fung. 8: 509. 1889; Peziza raphidophora Berk. \& Curt.; Berk. Jour Linn. Soc, 10: 368.1868. First globose, then expanded, clothed with short, white hairs, the margin inflexed; asci elongate; spores linear, variable in length, but about $25 \mu$ long. On rotten wood, Cuba and Venezuela.

Erinella similis Bres. Hedwigia 35: 296. 1896. This species has been doubtfully reported from Porto Rico by the writer. Spores $2-3 \times 35-4 \mu$.

56. ECHINELLA Massee, Brit. Fungus-Fl. 4: 304. 1895.

Apothecia sessile, at first closed, then expanding and becoming cup-shaped; for some distance down the sides clothed with black, or brown hyphae; asci clavate, 8-spored; spores irregularly 2-seriate, hyaline, narrowly fusiform, becoming 3-manyseptate; paraphyses filiform or slightly clavate.

Type species, Peziza Vectis Berk. \& Br.

Distinguished from Pirottaea Sacc. by the elongated spores, and from Erinellina by the dark-colored hairs.

Echinella rhabdocarpa (Ellis) Seaver, comb. nov.

Peziza rhabdocarpa Ellis, Bull. Torrey Club 9: 19. 1882.

Erinella rhabdocarpa Sacc. Syll. Fung. 8: 510. 1889.

Apothecia scattered, sessile, $.5 \mathrm{~mm}$. in diameter, the margin clothed with short, black, fasciculate, obtusely clavate hairs; asci clavate-cylindric, reaching a length of $65-75 \mu$ and a diameter of $10 \mu$; spores linear, multi-septate?, nearly as long as the ascus. 
On branches of Comptonin asplenifolia.

Type locality: Newfield, New Jersey.

Distribution: New Jersey and Ontario, Canada.

Exsiccati: Ellis, N. Am. Fungi 8tt.

\section{Family 5. CENANGIACEAE}

Conidial stage present, variable in form, or unknown.

Apothecia usually occurring on woody plants, at first immersed and bursting through the outer bark, singly, or more of ten in cespitose clusters, cup-shaped, often opening with an irregular aperture, or discoiel to patellate, pale to dark brownish-black, fleshy, waxy, or leathery, becoming horny when dry; asci usually broad-clavate, 4-8-sporeel; spores simple, ellipsoid, allantoid, rarely subglobose, or fusiform to filiform, then usually severalseptate, hyaline, or colored; paraphyses filiform, often strongly enlarged above, the ends free or glued together forming an epithecium, hyaline, or colored.

Asci containing $4-8$ ascospores.

Ascospores simple.

Apothecia tomentose.

Apothecia not tomentose.

1. Velutaria.

Ascospores remaining hyaline.

Spores not over $14-20 \mu$ long.

Spores $30 \mu$ or more long.

Apothecia hysteriform when young.

Apothecia not hysteriform.

Ascospores becoming brown.

2. Cenanglum.

3. Dermateopsis.

4. Godroniopsis.

5. Sphaerangitu.

Ascospores becoming septate, with cross walls only.

Asci with ascospores only.

Spores 1-septate.

Spores hyaline.

Spores becoming brown.

Spores more than 1-septate.

Spores long fusoid to filiform.

Spores ellipsoid, becoming tardily septate.

Apothecia light-colored; conidia ellipsoid.

Apothecia dark-colored; conidia fusiform.

Asci with both ascospores, and spermatoid bodies.

6. Cenangella.

7. DERMATELLA.

8. Godronil.

9. Pezicula.

10. Dermed.

11. Durandiella.

Ascospores with cross and longitudinal walls (muriform).

12. MURANGIUM.

13. Tympanis.

Asci containing only spermatoid borlies. 
1. VELUTARIA Fuckel, Symb. Myc. 300. 1869. Schweinitzia Massee, Brit. Fungus-Fl. 4: 134. 1895.

Apothecia erumpent, becoming apparently superficial, for the most part single, or in dense, cespitose clusters, at first closed, opening but remaining cupulate, externally clothed with a dense woolly growth, tan-colored, or light-brown; hymenium concave, or nearly plane; asci subcylindric, 8-spored; spores ellipsoid. simple, hyaline, or slightly colored; paraphyses filiform to clavate.

Type species, Peziza rufoolivacea Alb. \& Schw.

The genus Schweinitzia was proposed by Massee based on Cenangium phaeosporum Cooke. No authentic material of this species is available but the original drawings and notes of Massee are in the herbarium of The New York Botanical Garden. In these notes he states "belongs to same genus as P. rufoolivacea." Except for the brown spores the two species would seem to be identical. The globose cells at the tips of the hairs in Cenangium phaeosporum have been noted in $P$. rufoolivacea, or material so determined.

Nannfeldt (Nova Acta Soc. Sci. Upsal. IV. 8: 302) treats Schweinitzia as a doubtful synonym of Velutaria. The present author would agree but would remove the doubt. In fact, if as admitted by Massee, the two species are congeneric there was no reason for the founding of the genus Schweinitzia in the first place.

1. Velutaria rufoolivacea (Alb. \& Schw.) Fuckel, Symb. Myc. 300. 1869.

Peziza rufoolivacea Alb. \& Schw. Consp. Fung. 320. 1805.

Lachnea rufoolivacea Gill. Champ. Fr. Discom. 85. 1882.

Humaria rufoolivacea Quél. Ench. Fung. 291. 1886.

Lachnella rufoolizacea Phill. Brit. Discom. 275. 1887.

Schweinitzia rufoolivacea Massee, Brit. Fungus-FI. 4: 135.1895.

Cenangium Rubi Bäumler, Ann. Nat. Hofmus. Wien 13: 440. 1898.

Phaeangium Rubi Sacc. \& Syd.; Sacc. Syll. Fung. 16: 764. 1902.

Apothecia erumpent, either occurring singly, or several together in dense clusters and soon becoming apparently superficial, externally clothed with a dense coat of poorly developed and more or less disjuncted hairs of ten each with a large, globose apex which gives a dense mealy appearance, reaching a diameter of 1-3 mm.; hymenium concave, or nearly plane, dark-colored, slightly olivaceous to black; asci subcylindric, reaching a length of $110-120 \mu$ and a diameter of 12-14 $\mu, 8$-spored; spores 1-seriate, 
ellipsoid, 6-8 $\times 12-15 \mu$; hyaline, or faintly colored; paraphyses filiform, rather strongly enlarged above.

On dead branches of various kinds: Quercus, Betula, Andromeda, Acer, Sassafras and Rubus.

Type locality : Europe.

Distribution: New Jersey to Oregon; also in Europe.

Illustrations: Alb. \& Schw. Consp. Fung. pl. 11, f. t; Phill. Brit. Discom. pl. 8, f. 49.

Exsiccati: Ellis, N. Am. Fungi 69 (as Dermated lobata Ell.)

\section{Doubtful and Excluded Species}

Velutaria cinereofusca (Schw.) Bres, has been regarded as a synonym of this species but is now regarded as a Cyplella. For details see page 275.

Velutaria griseovitellina Fuckel, Symb. Myc. 300. 1869. This species has been reported from Washington under the name of Tapesina griseovitellina Höhn. The 3 -septate spores would place it in the genus Belonium as treated here.

Schweinitzia phaeospora (Cooke) Massee, Brit. Fungus-Fl. 4: 135. 1895; Cenangium phaeosporum Cooke, Grevillea 12: 44. 1883; Phaeangium phaeosporum Sacc. Syll. Fung. 16: 765. 1902. No material available but apparently scarcely distinct from the preceding.

\section{CENANGIUM Fries, Summa Veg. Scand. 364. 1849.}

Apothecia occurring singly, or more often in cespitose clusters of variable number, erumpent, usually light-colored not black, at first closed, finally opening, deep cup-shaped, or becoming more shallow when expanded, the margin often incurved; asci usually 8 -spored, of variable form; spores ellipsoid, or elongated, often allantoid, hyaline, simple; paraphyses filiform, simple, or branched, scarcely enlarged above, hyaline or subhyaline.

Type species, Cenangium ferruginosum Fries.

Occurring on coniferous trees.

On branches of various conifers.

Apothecia $1-1.5 \mathrm{~mm}$. in diameter, reddishbrown.

1. C. Abietis.

Apothecia 2-5 $\mathrm{mm}$. in diameter, purplishbrown.

On needles of species of Pinus.

2. C. atropurpureum.

3. C. acuum.

Not on coniferous trees.

Apothecia medium large; $5 \mathrm{~mm}$. to $1 \mathrm{~cm}$. in diameter.

On branches of Alnus.

4. C. furfuraceum. 
On branches of Populus, more rarely on Fraxinus.

Apothecia scattered, densely whitepruinose.

Apothecia cespitose, not pruinose.

5. C. pruinosum.

6. C. populneum.

Apothecia small, less than $5 \mathrm{~mm}$. in diameter.

Spores medium large, $7-10 \mu$ long.

On branches of Ceanothus.

7. C. aureum.

On leaves of Iucca.

8. C. Yuccae.

Spores small $4-6 \mu$ long.

Apothecia accompanied by flask-shaped conidial bodies.

Apothecia not as above, forming tubercular masses.

9. C. dimorphum.

10. C. tuberculiforme.

1. Cenangium Abietis (Pers.) Rehm in Rab. Krypt.-Fl. $1^{3}: 227$. 1889.

Peziza Abietis Pers. Syn. Fung. 671. 1801.

Cenangium ferruginosum Fries, Vet. Akad. Handl. 1818. 361. 1818.

Dermatea Pini Phill. \& Hark. Grevillea 13: 22. 1884.

Apothecia gregarious, usually occurring in cespitose clusters, subsessile, at first nearly globose, later opening irregularly, expanding and becoming subturbinate, often irregular from mutual pressure, the margin inflexed when dry, coated externally with a reddish-brown powder, 1-1.5 mm. broad; hymenium concave, yellowish to olive-brown; asci cylindric-clavate, reaching a length $100-120 \mu$ and a diameter 12-18 $\mu$, 8-spored; spores ellipsoid, 5-7 $\times 10-14 \mu$, 1-seriate, or partially 2-seriate; paraphyses stout, simple, about $2 \mu$ in diameter, slightly enlarged above, pale-yellowish.

On branches of various species of Pinus, Abies, Picea and probably other conifers.

Type locality: Europe.

Distribution: New England to Oregon, California and Alabama; also in Europe.

Illustrations: E. \& P. Nat. Pfl. $1^{1}$ : 233, f. E-G; Grev. Scot. Crypt. Fl. 4: pl. 197; Cooke, Handb. Brit. Fungi 2: f. 337.

Exsiccati: Ellis \& Ev. N. Am. Fungi 2050, 2050 (B), Fungi Columb. 1416, 1514; Clements, Crypt. Form. Colo. 517.

2. Cenangium atropurpureum Cash \& Davidson, Mycologia 32: 734. 1940.

Apothecia erumpent, occurring singly, or two or three together from a stroma beneath the bark, subglobose, then cupulate, 
reaching a diameter of $2-5 \mathrm{~mm}$. and of equal height, fleshyleathery, substipitate, exterior furfuraceous, dull purplishblack to brownish-black when moist, darker when dry, margin lacerate, becoming inrolled when dry and triangular or hysteroid; hymenium light ochraceous-buff; asci cylindric, reaching a length of 70-85 $\mu$ and a diameter of 9-12 $\mu, 8$-spored; spores broad-ellipsoid, irregularly 1 -seriate, hyaline, simple, containing several granules, 5-8 $\times$ 9.5-11 $\mu$; paraphyses hyaline, unbranched, enlarged at their apices, 3-5 $\mu$ in diameter.

On dead twigs Pinus nigra, $P$. Mugho, $P$. pungens, $P$. rigida, $P$. virginiana, $P$. Taeda and $P$. sylvestris.

Type Locality: Sugar Loaf Mountain, Maryland, on Pinus nigra.

Distribution: Maryland to Pennsylvania and Georgia.

Illustrations: Mycologia 32: 729, f. 1, $A, B$.

3. Cenangium acuum Cooke \& Peck; Cooke \& Ellis, Grevillea $7: 40.1878$.

Peziza Pinastri Cooke \& Peck; Cooke, Bull. Buffalo Soc. Nat. Sci. 1: 297.

1875. Not Cenangium Pinastri Hazsl. 1887.

Mollisia Pinastri Sacc. Syll. Fung. 8: 327. 1889.

Apothecia erumpent through the epidermis of the host, at first closed, soon opening with an irregular aperture leaving the margin irregularly toothed, externally reddish-brown, reaching $1 \mathrm{~mm}$. in diameter; hymenium concave or nearly plane, lighter than the outside of the apothecium; asci clavate, reaching a length of $80-100 \mu$ and a diameter of $8-10 \mu$, tapering into an abrupt, stem-like base, 8-spored; spores fusoid, 3-4 $312-14 \mu$; paraphyses filiform, enlarged above, reaching a diameter of 2-3 $\mu$.

On needles of Pinus Strobus and other species of Pinus.

Type locality: Albany County, New York.

Distribution: New York and New Jersey to British Columbia; also in Europe.

Exsiccati: Ellis, N. Am. Fungi 367; Rehm, Ascom. 822 (from Newfield, N. J.), $822 b$ (from Lake Huron, Ontario); Sydow, Fungi Exotici Exsicc. 275 (from Lake Huron, Ontario); Rab.-Winter, Fungi Eu. 3365 (from Newfield, N. J.); Ellis \& Ev. Fungi Columb. 642; Barth. Fungi Columb. 4705.

Pezizella ontariensis seems to differ in the color and size of the spores. However, it is suggestive of this species. 
4. Cenangium furfuraceum (Roth) Sacc. Syll. Fung. 8: 565. 1889.

Peziza furfuracea Roth, Catal. Bot. 3: 257. 1806.

Phibalis furfuracea Wallr. Fl. Crypt. Germ. 2: 447. 1833.

Dermatea furfuracea Fries, Summa Veg. Scand. 362.1849.

Encoelia furfuracea Karst. Myc. Fenn. 1: 218. 1871.

Apothecia erumpent in cespitose clusters of five or six each, or more rarely occurring singly, at first entirely closed, finally opening rather irregularly and expanded but with the margin usually incurved, externally whitish-furfuraceous, the individual apothecia reaching a diameter of $1 \mathrm{~cm}$. or more; asci narrowly clavate, reaching a length of $80 \mu$ and a diameter of 6-7 $\mu$, 8-spored; spores narrow-ellipsoid, or allantoid, often with two small oil-drops, 2-4 $\times 8-10 \mu$; paraphyses filiform slightly enlarged above.

On branches of species of Alnus.

Type locality: Europe.

Distribution: Newfoundland to Idaho, California, south to Iowa, and Pennsylvania; also in Europe.

Illustrations: Roth, Catal. Bot. pl. 9, f. 2 (as "Thelephora fimbriata").

Exsiccati: Shear, N. I. Fungi 327; Brenckle, Fungi Dak. 426. Wilson \& Seaver, Ascom. 52.

5. Cenangium pruinosum (Ellis \& Ev.) Seaver, comb. nov. (Plate 130.)

Peziza pruinosa Ellis \& Ev. Jour. Myc. 4: 100. 1888.

Dermatea pruinosa Sacc. Syll. Fung. 8: 555.1889.

Apothecia gregarious, occurring in large numbers underneath the outer bark of the host, which rolls back exposing large blackened areas on which the apothecia are seated, the individual apothecia deep cup-shaped with the mouth at first constricted, expanding and reaching a diameter of 3-4 mm., externally covered with a white, granular coat, brown to brownish-black inside and out, the margin slightly crenate, when dry becoming boat-shaped or angular; asci narrow-clavate, reaching a length of $55 \mu$ and a diameter of 4-5 $\mu, 8$-spored; spores minute, allantoid, $2 \times 8-10 \mu$; paraphyses filiform, very slender, enlarged above, with dark-brown tips.

On trunks of Populus. 


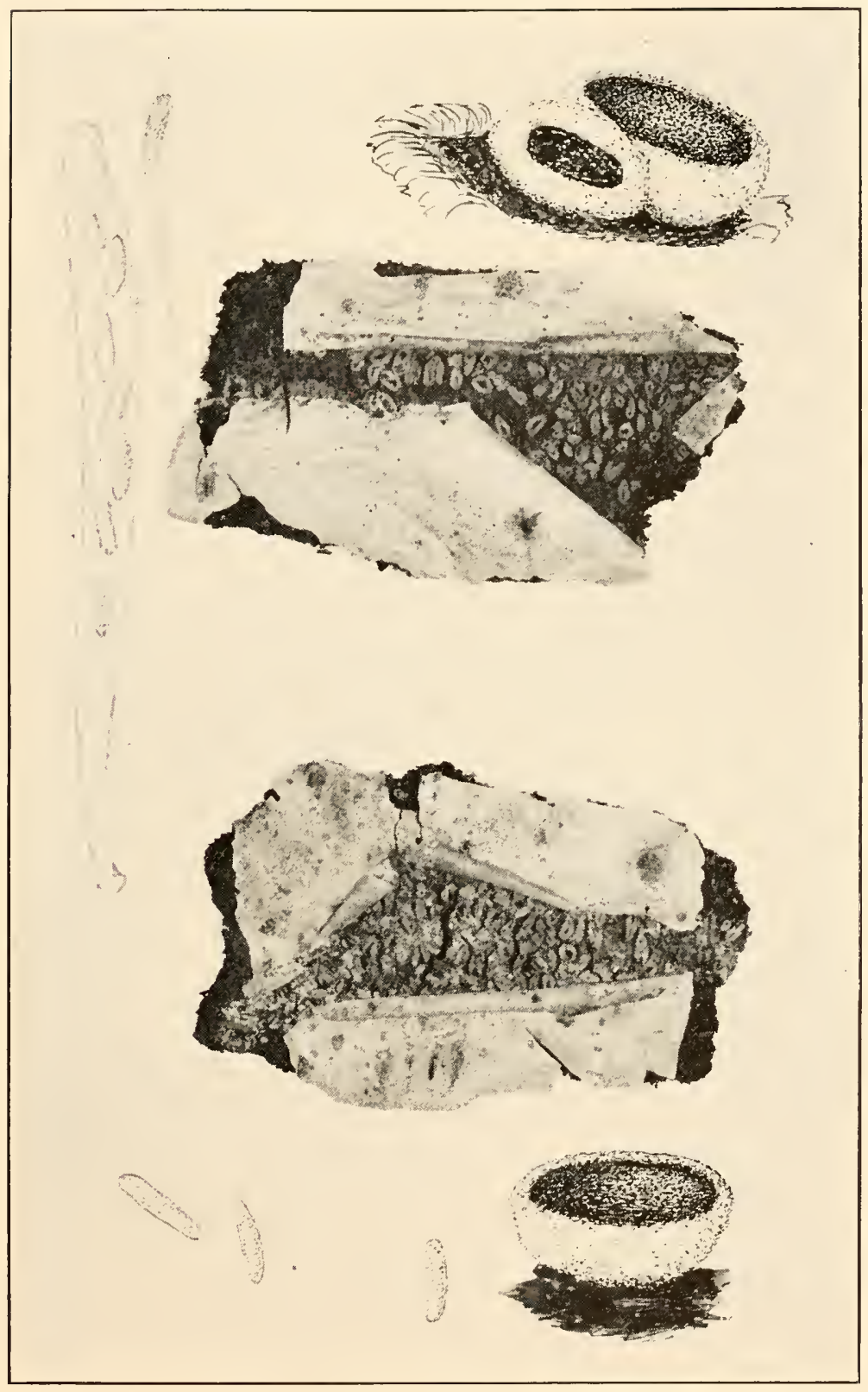

CENANGIUM PRUINOSUM 

Type localit Y: Colorado.

Distribution: Colorado and Toronto, Canada.

The illustration accompanying this description was made from material collected by the writer and Mr. Bethel in 1910. A note in the herbarium of The New York Botanical Garden on a Bethel label 1898 states "this is abundant everywhere in the Mts. where aspen (Populus tremuloides) is found." It was apparently confused by Mr. Ellis with Cenungium populneum, although Ellis, himself, described it ten years before under the name indicated above.

6. Cenangium populneum (Pers.) Rehm in Rab. Krypt.-Fl. $1^{3}: 220$. 1889. (Plate 131.)

Peziza populnea Pers. Tent. Disp. Fung. 35. 1797.

Peiiza fascicularis Alb. \& Schw. Consp. Fung. 315. 1805.

Peziza crispa Sow. Engl. Fungi pl. 425. 1814.

?Cenangium populinum Schw. Trans. Am. Phil. Soc. II. 4: 239. 1832.

Dermatea fascicularis Fries, Summa Veg. Scand. 362. 1849.

Encoelia fascicularis Karst. Myc. Fenn. 1: 217. 1871.

Cenangium fasciculare Karst. Acta Soc. Fauna Fl. Fenn. $2^{6}: 145.1885$.

Encoelia populnea Kirsch. Ann. Myc. 33: 222. 1935.

Apothecia erumpent through the outer bark in cespitose clusters of six to twelve each, the clusters often $5 \mathrm{~mm}$. or more in diameter, or more rarely solitary, the individual apothecia at first closed, finally opening and usually deep cup-shaped, often much contorted and twisted from mutual pressure, grayishbrown, reaching a diameter of $3-5 \mathrm{~mm}$.; asci narrowly clavate, reaching a length of 75-90 $\mu$ and a diameter of $8-9 \mu, 8$-spored; spores narrowly ellipsoid, or allantoid, $3-4 \times 12-14 \mu$; paraphyses slender, slightly enlarged above, reaching a diameter of $3 \mu$.

On dead branches of Populus tremuloides and Populus grandidentata; also reported on Fraxinus.

Type locality: Europe.

Distribution: Massachusetts to Colorado, Iowa and Kansas; also Europe.

Illustrations: Alb. \& Schw. Consp. Fung. pl. 12, f. 2; Rab. Krypt.-Fl. $1^{3}: 215, f .2$; Bull. Lab. Nat. Hist. State Univ. Iowa 5: pl. 25, f. 1; Sow. Engl. Fungi pl. 425, f. 1 .

Exsiccati: Ellis, N. Am. Fungi 1314; Barth. Fungi Columb. 2209; Brenckle, Fungi Dak. 209 (as var. prunicolum Rehm); Reliq. Farlow. $10 t$. 
While this species usually occurs on Populus tremuloides one specimen from Canada was reported on Populus grandidentata. Albertini and Schweinitz (Consp. Fung. 315) report this species on Salix alba and on Fraxinus. A specimen in the Ellis collection is accompanied by the following unsigned note: "Dermatea fascicularis A. \& S. Have found this again on ash; (you questioned its being an ash) when 120 was sent. Can this be a different species?" Apparently Ellis questioned the host. However we have in the herbarium of The New York Botanical Garden two other specimens reported on ash both by reliable collectors, one by S. H. Burnham at Hudson Falls, New York the fungus determined by the writer and one by R. F. Cain from Ontario, Canada, the fungus determinated by J. IV. Groves. The spores in those specimens on ash agree with those from poplar so apparently this fungus is not restricted to Populus.

7. Cenangium aureum Ellis \& Ev. Bull. Torrey Club 24: 468. 1897.

Apothecia erumpent through transverse crevices in the bark, occurring singly, or two or three together, short-stipitate, cupshaped, golden-yellow, externally flocose-furfuraceous, becoming nearly smooth, margin slightly incurved, $2-3 \mu$ in diameter; stem short, stout, about $1 \mathrm{~mm}$. long; asci clavate-cylindric, reaching a length of $90-110 \mu$ and a diameter of $7-8 \mu, 8$-spored, gradually narrowed below; spores 1-seriate, ovoid to pyriform, $3.5 \times 7-10 \mu$; paraphyses filiform, about as long as the ascus, scarcely thickened above.

On dead branches of Ceanothus velutinus.

Type locality: Bear Valley, Colorado (alt. $7000 \mathrm{ft}$.).

Distribution: Known only from the type locality.

Type material in The New York Botanical Garden has been examined, and is in excellent condition.

8. Cenangium Yuccae Clements, Crypt. Form. Colo. 518.1907.

Apothecia erumpent, scattered, at first closed, opening and becoming cup-shaped, externally densely furfuraceous, brown, reaching a diameter of $1 \mathrm{~mm}$.; hymenium lighter, creamy; asci cylindric, reaching a length of $100-120 \mu$ and a diameter of 16-12 $\mu, 8$-spored; spores 1-seriate, ellipsoid, not granular within, about $8 \times 10 \mu$ paraphyses $2 \mu$ in diameter, scarcely enlarged above, granular within, slightly yellowish. 


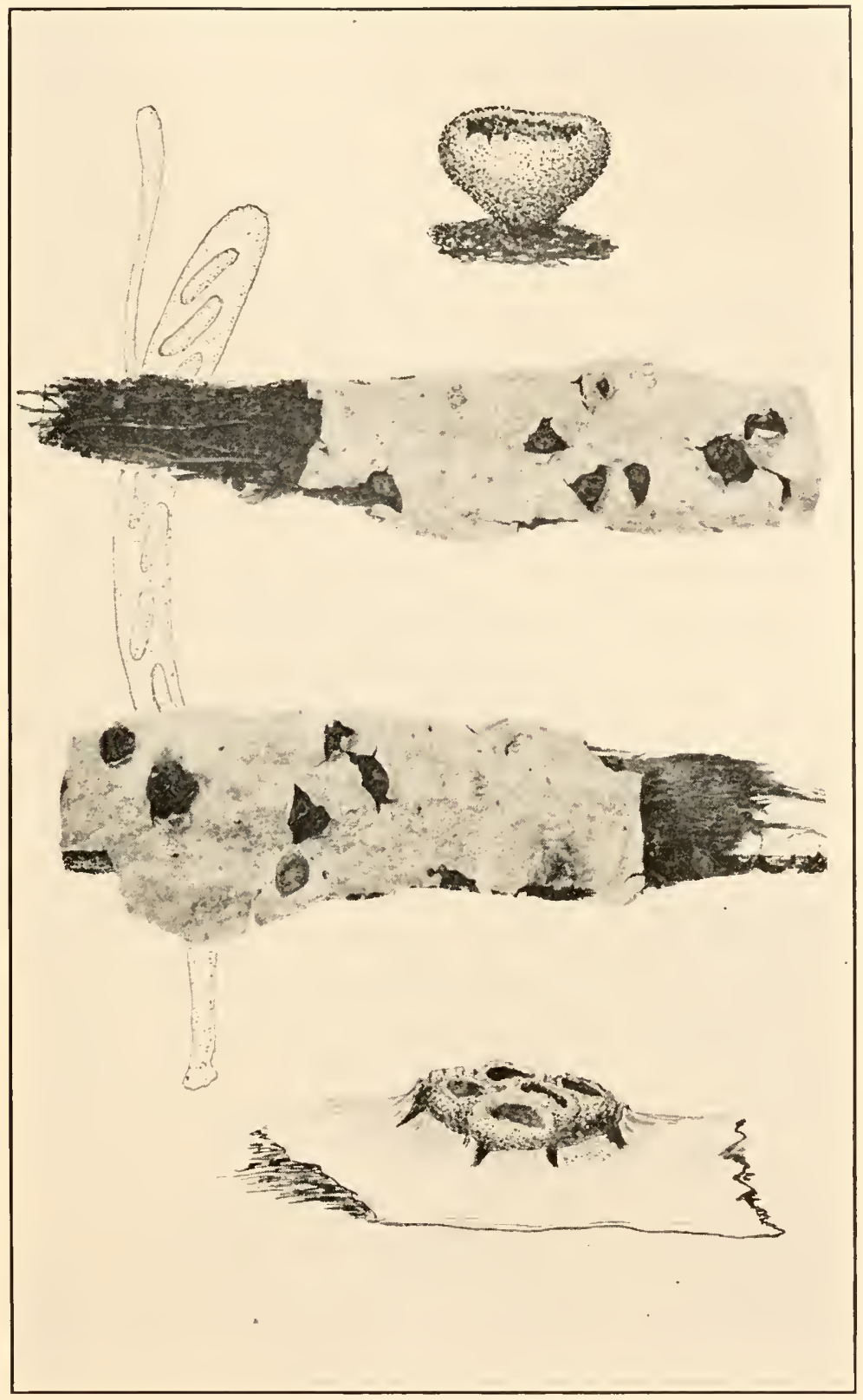

CENANGIUM POPULNEUM 

Apotheciis sparsis, erumpentibus, primo clausis dein scutellatis, extus furfuraceis, brunneis, $1 \mathrm{~mm}$. diam.; hymenio cremeo; ascis cylindraceis, 8sporis; sporis ellipsoideis, $8 \times 10 \mu$; paraphysibus filiformibus, $2 \mu$ diam.

On leaves of Yucca.

Type locality: Mesa Verda, Colorado.

Distribution: Colorado and California.

Exsiccati: Clements, Crypt. Form. Colo. 518.

A second collection of this species was obtained by the writer and Ellsworth Bethel in 1910. A third collection from Santa Anita Canyon, California was sent to the writer in 1939. This was at first thought to be an undescribed species but it was later found that Clements had distributed it in 1907 under the above name as a new species, without diagnosis.

\section{Cenangium dimorphum Seaver, comb. nov.}

Dermatea dimorpha Seaver, Mycologia 16: 8. 1924.

Conidial stage described as consisting of club-shaped or flaskshaped bodies 1-2 mm. high, either occurring separately, or associated with and often fused to the base of the apothecia; pycnidia minute, more or less angular, about $2 \mu$ in diameter.

Apothecia usually cespitose, sessile, or substipitate, apparently erumpent through the outer bark and becoming subsuperficial, shallow cup-shaped, with a purplish tint, furfuraceous, the hymenium somewhat darker, reddish, reaching a diameter of 1-2 mm.; asci clavate, reaching a length of $40 \mu$ and a diameter of $4 \mu, 8$-spored; spores usually 1 -seriate, ellipsoid, of ten with two small oil-drops; $2 \times 4 \mu$; paraphyses very slender.

On the bark of some undetermined shrub or vine.

Type Locality: Louisenhoj Estate on the island of St. Thomas.

Distribution: St. Thomas of the Virgin Islands and Porto Rico; also in Venezuela and Brazil.

Illustrations: Mycologia 16: pl. 2, f. $1-4$.

In addition to the type, one specimen collected in Porto Rico by John Stevenson in February 1914 has been referred to this species, with which it agrees perfectly. Also one specimen collected by Dr. Carlos F. Chardon in Venezuela has been examined. The latter is said to have been collected on some dead Citrus. It was collected on a coffee plantation near San Cristobal. One specimen from the Farlow Herbarium collected by Rick in Brazil labeled "Dermatea episphaeria" Schw. is identical 
with our species but no authentic material of Cenangium episphaeria Schw. has been seen.

10. Cenangium tuberculiforme Ellis \& Ev. Proc. Acad. Sci. Phila. 1893: 452. 1893.

Apothecia erumpent in dense clumps forming tubercular masses up to $1 \mathrm{~cm}$. in diameter, individual apothecia lightyellow, furfuraceous-squamulose outside, irregularly cup-shaped with the margin incurved, reaching a diameter of 2-3 $\mathrm{mm}$.; hymenium pale brick-red, contracted below into a short, stemlike base; asci cylindric-clavate, reaching a length of 40-50 $\mu$ and a diameter of 4-5 $\mu, 8$-spored; spores obliquely 1 -seriate, ellipsoid, hyaline, with two small oil-drops, 2-2.5 $\times 5-6 \mu$; paraphyses filiform, branched, scarcely enlarged above.

On dead twigs of Ilex glabra.

Type locality: Newfield, New Jersey.

Distribution: New Jersey and Massachusetts.

Exsiccati: Reliq. Farlow. 105.

Excellent type material is in the herbarium at The New York Botanical Garden. The only other specimen seen is the one distributed by the Farlow Herbarium collected at East Billerica, Massachusetts by J. B. Rorer. This is a very conspicuous and interesting fungus.

\section{Doubtful and Excluded Species}

Many species of Cenangium have been reported from North America with meager descriptions and in numerous cases based on sterile material. Some of these are not ascomycetes at all. The names are recorded with the hosts, hoping that future collectors may be able to tie them up with something concrete.

Cenangium aeruginosum Schw. Trans. Am. Phil. Soc. II. 4: 239. 1832. On decorticated wood. Asci and spores unknown.

Cenangium alboatrum Ellis \& Ev. Bull. Torrey Club 24: 136. 1897. On decorticated, decaying chestnut log. This does not appear to be a Cenangium; material very poor.

Cenangium alpinum Ellis \& Ev. Bull. Torrey Club 24: 468. 1897. On decorticated limbs of Abies. Spores described as allantoid, $2.5 \times 10-14 \mu$.

Cenanginm Andromedae (Schw.) Fries, Syst, Myc. 2: 182. 1822; Peziza Andromedae Schw. Schr. Nat. Ges. Leipzig 1: 123. 1822. Asci and spores unknown.

Cenangium apertum Schw. Trans. Am. Phil. Soc. II. 4: 239. 1832. On dead branches of Hydrangea. Nothing is known of this species.

Cenangium asterinosporum Ellis \& Ev. Bull. Torrey Club 10: 76. 1883. Apothecia erumpent in cespitose cluster 2-3 mm. in diameter, individuals $.5-1 \mathrm{~mm}$. in diameter; spores ellipsoid or subpyriform, subhyaline, constricted 
in the center, becoming 3 -septate and submuriform, 6-8 $\times 15-20 \mu$. New Jersey. A Pezicula?

Cenangium Cassandrae Peck, Ann. Rep. N. Y. State Mus. 31: 48.1879.

On Cassandra calyculata. Spores described as linear, 28-30 $\mu$ long. Compare Godronia Cassandrae.

Cenangium Castaneae Schw. Trans. Am. Phil. Soc. II. 4: 239. 1832. On young branches of Castanea. Asci and spores unknown.

Cenangium clavatum Schw. Trans. Am. Phil. Soc. II. 4: 238. 1832. No spores found. See Dermea Cerasi.

Cenangium compressum Schw. Trans. Am. Phil. Soc. II. 4: 238. 1832. On Betula. Asci and spores unknown.

Cenangium conglobatum Ellis \& Ev. Proc. Acad. Sci. Phila. 1895: 428. 1895. On dead branches of some deciduous tree or shrub. Spores described as allantoid, $2-2.5 \times 5-6.5 \mu$.

Cenangium contortum Berk. \& Curt.; Cooke, Grevillea 21:75. 1893. On Cornus. Description inadequate. No material seen.

Cenangium confusum Schw. Trans. Am. Phil. Soc. II. 4: 238. 1832. No specimen of this species could be found in the Schweinitz collection. Two specimens in the herbarium of The New York Botanical Garden under this name have 3 -septate ascospores $3-4 \times \cdot 35-45 \mu$ and curved. Whether these are correctly named we do not know.

Cenangium Crataegi Schw. Trans. Am. Phil. Soc. II. 4: 239. 1832. No material found in the Schweinitz collection at Philadelphia.

Cenangium Ellisii Sacc. Syll. Fung. 8: 566. 1889; Dermatea purpurea Ellis, Bull. Torrey Club 6: 108. 1875. Not Dermatea purpurea (Hedw.) Fries. 1849. Said to resemble Dermatea furfuracea but smaller. Ellis states "unfortunately the insects have nearly destroyed my spec." No specimens have been seen.

Cenangium enteroxanthum Schw. Trans. Am. Phil. Soc. II. 4: 240.1832. Asci and spores unknown. Description indicates that it may be one of the Hysteriales.

Cenangium episphaeria Schw. Trans. Am. Phil. Soc. II. 4: 238.1832. On Diatrype Stigma and other sphaeriaceous fungi. Asci and spores unknown, very doubtful. See Cenangium dimorphum.

Cenangium fatiscens Schw. Trans. Am. Phil. Soc. II. 4: 239. 1832. On bark of Syringa and Morus alba. No asci or spores indicated. It may not be a Discomycete at all.

Cenangitm fibrisedum Schw. Trans. Am. Phil. Soc. II. 4: 239. 1832. On Castanea. Asci and spores unknown.

Cenangium Juglandis Berk. \& Curt.; Berk. Grevillea 4: 5. 1875. On Juglans. Description inadequate.

Cenangium leptospermum Berk. \& Curt.; Berk. Grevillea 4: 5. 1875. On Abies. Description inadequate.

Cenangium nigrofuscum Schw. Trans. Am. Phil. Soc. II. 4: 239. 1832. On old wood. Asci and spores unknown.

Cenangium palmatum Schw. Trans. Am. Phil. Soc. II. 4: 238. 1832. On bark of Rhododendron maximum. Asci and spores unknown. Very doubtful. 
Cenangium patellatum Cooke, Grevillea 21: 75. 1892. On Acer. Spores described as ellipsoid, tawny-brown, or amber, 5-6 $\times 18-20 \mu$. No material available.

Cenangium pesizoides Peck, Ann. Rep. N. Y. State Mus. 31: 48. 1879. The spores suggest a Dermea but no septa observed.

Cenangium pyrinum Schw. Trans. Am. Phil. Soc. II. 4: 239. 1832. Asci and spores unknown. Description indicates one of the Hysteriales. On Pyrus.

Cenangium punctoideum (Cooke) Sacc. Syll. Fung. 8: 570. 1889; Tympanis punctoidea Cooke, Bull. Buffalo Soc. Nat. Sci. 3: 30 . 1875; Phaeangium punctoideum Sacc. \& Syd. in Sacc. Syll. Fung. 16: 765. 1902. No asci could be found in the type specimen.

Cenangium quercinum Schw. Trans. Am. Phil. Soc. II. 4: 239. 1832; Hysterium quercinum Schw. Schr. Nat. Ges. Leipzig 1: 49. 1822. Not a Cenangium.

Cenangium Rhois Schw. Trans. Am. Phil. Soc. II. 4: 238.1832. On branches of Rhus glabra. Asci and spores unknown.

Cenangium rigidum Schw. Trans. Am. Phil. Soc. II. 4: 238. 1832. No apothecia found in the Schweinitz specimen. See Dermea Prunastri.

Cenangium Rosae Schw. Trans. Am. Phil. Soc. II. 4: 239. 1832. On bark of Rosa. Asci and spores unknown.

Cenangium rubiginellum Sacc. Syll. Fung. 8: 560. 1889. Cenangium rubiginosum Cooke; Rav. Fungi Am. 635. Not Pesiza rubiginosa Fries.

Cenangium sphaeriaemorphum Schw. Trans. Am. Phil. Soc. II. 4: 238. 1832. On Quercus alba. Asci and spores unknown. Nay be a lichen.

Cenangium Spiraeae (Schw.) Sacc. Syll. Fung. 8: 574. 1889. Dermea Spiraeae Schw. Trans. Am. Phil. Soc. I1. 4:237. 1832. Schweinitz specimens examined May 21, 1931 and found worthless.

Cenanginim Staphyleae Schw. Trans. Am. Phil. Soc. II. 4: 238. 1832. On Staphylea. Asci and spores not known. Species very doubtful.

Cenangium sticticum (Berk. \& Curt.) Sacc. Syll. Fung. 8: 559. 1889; Tympanis stictica Berk. \& Curt.; Peck, Grevillea 4: 3. 1875. On Salix babylonica. Asci described as clavate; spores fusiform, curved, quadrinucleate. The species was also reported on Prinus verticillata and on Quercus tinctoria. The description is inadequate and material not available.

Cenangium tryblidioides Ellis \& Ev. Bull. Torrey Club 4: 136. 1897. On decorticated willow, Salix. Material weathered and unsatisfactory.

Cenangium triangulare Schw. Trans. Am. Phil. Soc. II. 4: 238. 1832; Coccomyces triangnlaris Sacc. Syll. Fung. 8: 750. 1889.

Cenangium tumorum Schw. Trans. Am. Phil. Soc. II. 4: 239. 1832. On old wood. Asci and spores unknown.

Cenangium ustale (Berk. \& Curt.) Sacc. Syll. Fung. 8: 568. 1889; Peziza ustalis Berk. \& Curt.; Berk. Grevillea 3: 152. 1875. Description inadequate. No material available.

Cenangium Viburni (Schw.) Fries, Syst. Myc. 2: 185. 1822; Peziza Viburni Schw. Schr. Nat. Ges. Leipzig 1: 123. 1822. This may be a Tympanis. On I'iburnum. 
3. DERMATEOPSIS Nannf. Nova Acta Soc. Sci. Upsal. IV. 8: 89. 1932.

Apothecia erumpent, thickly gregarious, or closely crowded, often cespitose, when young bilaterally compressed, hysteriform, opening with an irregular aperture leaving the margin often notched, or occasionally toothed, externally yellowish; hymenium darker, reaching a diameter of less than $1 \mathrm{~mm}$.; asci 8-spored; spores long-fusoid; paraphyses filiform.

Type species, Dermatea tabacina Cooke.

1. Dermateopsis tabacina (Cooke) Nannf. Nova Acta Soc. Sci. Upsal. IV. 8: 89. 1932.

Dermatea tabacina Cooke, Bull. Buffalo Soc. Nat. Sci. 3: 24. 1877.

Godronia tabacina Seaver, Mycologia 37: 350. 1945.

Apothecia as above; asci broad-clavate, reaching a length of $100 \mu$ and a diameter of $30 \mu, 8$-spored; spores irregularly 2seriate, very long, fusoid, straight, or curved, granular within, 8-10 × 60-75 $\mu$; paraphyses filiform, enlarged above.

On branches of Quercus alba and Quercus coccinea.

Type locality: Newfield, New Jersey.

Distribution: Known only from the type locality.

Exsiccati: Ellis, N. Am. Fungi 146; Rehm, Ascom. 359 (from Newfield, New Jersey); Roum. Fungi Selecti Exsicc. 1712 (from Newfield, New Jersey); Thün. Myc. Univ. 1560 (from Newfield, New Jersey).

4. GODRONIOPSIS Diehl \& Cash, Mycologia 21: 243. 1929.

Apothecia sessile, or subsessile, seated on a black, blister-like subiculum which seems to be erumpent through the outer bark, at first closed, later cup-shaped, or subdiscoid, corky-leathery; asci clavate, 8-spored; spores simple, hyaline, fusiform; paraphyses filiform, slightly enlarged above, forming an epithecium.

Type species, Peziza quernea Schw.

1. Godroniopsis quernea (Schw.) Diehl \& Cash, Mycologia 21: 244. 1929.

Peziza quernea Schw. Schr. Nat. Ges. Leipzig 1: 124.1822.

Cenangium turgidum Fries, Syst. Myc. 2; 186. 1822. Not Cenangium turgidum Duby. 1830.

Patellaria cenangiicola Ellis \& Ev. Jour. Myc. 4: 56. 1888.

Patellea cenangicola Sacc. Syll. Fung. 8: 784. 1889.

Cenangium querneum Seymour; Thaxter, Mycologia 14: 101. 1922. 
Apothecia as described above, reaching a diameter of $1 \mathrm{~mm}$., externally ridged the ends of the ridges giving rise to a toothed margin; hymenium brown; asci clavate to cylindric-clavate, reaching a length of $150 \mu$ and a diameter of 13-16 $\mu, 8$-spored; spores irregularly 2 -seriate, simple, hyaline, subfusiform to fusiform, at first symmetrical and larger at one end, 6-10 $\times 30-47 \mu$; paraphyses filiform, hyaline at the base, enlarged above and light chestnut brown, 3-5.5 $\mu$ in diameter, the ends forming an epithecium.

On various species of Quercus.

Type locality: North Carolina.

Distribution: New Hampshire to Missouri, Florida and Alabania.

Illustrations: Mycologia 21:245. $f .1,2$.

Exsiccati: Rav. Fungi Car. 4:24; Ellis \& Ev. N. Am. Fungi 2148 .

\section{SPHAERANGIUM Seaver, nom. nov.}

Phaeangium Sacc. Syll. Fung. 16: 764. 1902 (in part). Not Phaeangium Pat. 1894.

Apothecia as in Cenangium; asci clavate, 4-8-spored; spores large subglobose, or ellipsoid, at first hyaline, becoming brown; paraphyses forming an epithecium.

Type species, Dermatea tetraspora Ellis.

A note in the herbarium of The New York Botanical Garden by $\mathrm{H}$. Rehm states that this species might be the type of a new genus, although no name was suggested. While the genus Phaeangium Sacc. was not founded on this species, it was included.

Asci 4-spored.

1. S. tetrasporum.

Asci 8-spored.

Spores $19-22 \times 40-50 \mu$.

2. S. magnisporum.

Spores $20 \times 26 \mu$.

3. S. Tiliae.

1. Sphaerangium tetrasporum (Ellis) Seaver, comb. nov. (Plate 132.)

Dermatea tetraspora Ellis, Bull. Torrey Club 6: 108. 1876.

Cenangium tetrasporum Sacc. Syll. Fung. 8: 570. 1889.

Phaeangium tetrasporum Sacc. Syll. Fung. 16: 765. 1902.

Apothecia crumpent but scarcely rising above the surface of the bark, occurring singly, or in cespitose clusters, externally 


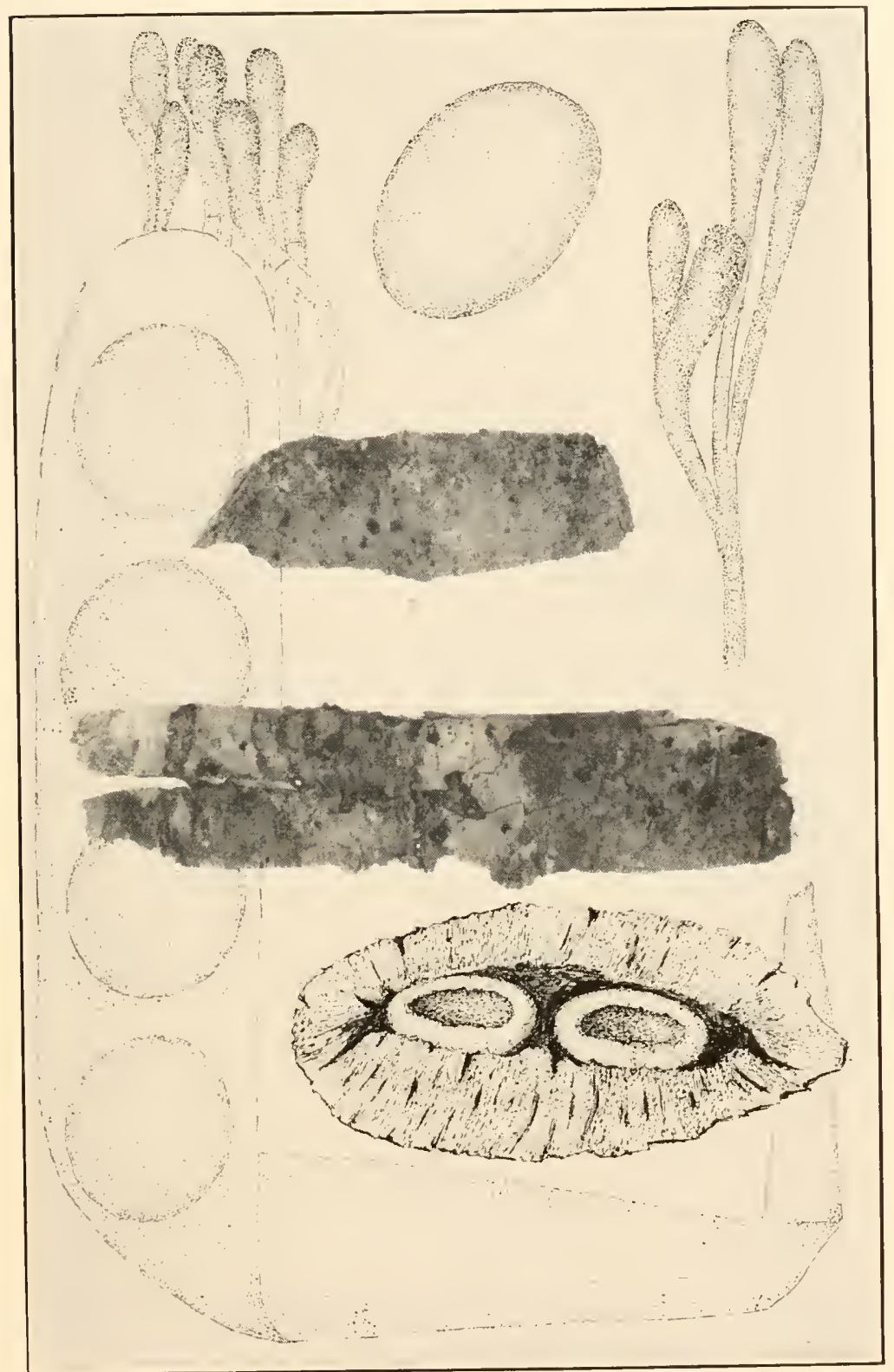

SPHAERANGIUP TETRASPORUM 

light-brown, reaching a diameter of $2 \mathrm{~mm}$; hymenium concave, darker than the outside of the apothecium; asci clavate, reaching a length of 200-225 $\mu$ and a diameter of $25 \mu$, 4-spored; spores 1 -seriate, very large and broad-ellipsoid to subglobose, 15-20 $\times$ $20-25 \mu$, becoming brown and very granular, often with several oil-drops; paraphyses slender, hyaline below, brown above, the ends adhering in an epithecium.

On dead limbs of Quercus coccinea.

Type locality: Newfield, New Jersey.

Distribution: Known only from the type locality.

Exsiccati: Ellis, N. Am. Fungi 70.

2. Sphaerangium magnisporum (Cash \& Stevenson) Seaver, comb. nov.

Phaeangium magnisporum Cash \& Stevenson, Jour. Wash. Acad. Sci. 30: 304. 1940.

Apothecia erumpent, occurring singly, or in groups of two or three each, closely surrounded by fragments of the ruptured bark, reaching a diameter of 1-1.5 mm., fleshy, subturbinate, or obconic, black, often contorted from mutual pressure, often falling out leaving cavities; hymenium brownish-black, rough; asci broad-clavate, abruptly narrowed at the base, reaching a length of $175-200 \mu$, and a diameter of $25-30 \mu$, 4-spored; spores 1seriate, broad-ellipsoid, with one large oil-drop when young, surrounded by a thick, hyaline, gelatinous envelope, 19-22 $\times$ 40-50 $\mu$ (exclusive of the envelope); paraphyses numerous, branched and interwoven at their tips.

On branches of Betula nigra.

Type Locality: Agricultural College Campus, Athens, Georgia.

Distribution: Known only from the type locality.

Illustrations: Jour. Wash. Acad. Sci. $30:$ 303. f. t.

3. Sphaerangium Tiliae Seaver, sp. nov. (Plate 133.)

Apothecia erumpent through the outer bark which breaks irregularly, at first closed and clothed externally with white, furfuraceous granules, finally opening irregularly, of ten stellately, expanding and exposing the black hymenium; hymenium plane or nearly so, with a rough appearance apparently due to the exucled spores, reaching a diameter of 1-2 mm.; asci subcylindric, reaching a length of $240 \mu$, and a diameter of about $25 \mu$, with no 
extended base, 8 -spored; spores 1 -seriate, broad-ellipsoid, very granular within, at first hyaline, becoming dark-brown, $20 \times$ $26 \mu$; paraphyses very slender, hyaline, about $2 \mu$ thick.

Apotheciis erumpentibus, extus albido-furfuraceis, primo clausis dein apertis; hymenio nigro; ascis subcylindraceis, 8 -sporis, 20-26 $\times 240 \mu$; sporis ellipsoideis, brunneis, $20 \times 26 \mu$; paraphysibus filiformibus, $2 \mu$ diam.

On branches of Tilia heterophylla.

Type locality: Agricultural College Campus, Athens, Georgia.

Distribution: Known only from the type locality.

6. Cenangella Sacc. Bot. Cent. 18: 248. 1884; Syil. Fung. 8: 587.1889.

Apothecia erumpent, urceolate to patellate, dark-colored, brown, or black, coriaceous; asci clavate, 4-8-spored; spores ellipsoid to fusoid, definitely 1-septate, hyaline; paraphyses filiform to clavate.

Type species, Tympanis Ravenelii Berk.

This genus was established by Saccardo in 1884 including two species Cenangium Fraxini Tul., based on Tympanis Fraxini Fries, which was based on Peziza Fraxini Schw. and Cenangium dolosum Sacc. The first, which would be the type, was apparently included through a misconception of the Schweinitz species since the spores do not agree at all with the above description (see Rehm, Ann. Myc. 11: 166). The second is poorly known and we, therefore, suggest as the type of the genus Tympanis Ravenelii Berk. which was treated by Saccardo as Cenangella Ravenelii in 1889.

Spores very large, $14 \times 40 \mu$.

Spores relatively small $3-4 \times 12-15 \mu$.

1. C. Ravenelii.

2. C. oricostata.

1. Cenangella Ravenelii (Berk.) Sacc. Syll. Fung. 8: 589.1889. Tympanis Ravenelii Berk. Grevillea 4: 3. 1875.

Apothecia erumpent, single, or several together, dark-brown to black, scarcely exceeding $1 \mathrm{~mm}$. in diameter; hymenium at first concave, becoming nearly plane; asci very broad-clavate, reaching a length of $130 \mu$ and a diameter of 30-35 $\mu$, tapering abruptly below, 8 -spored; spores irregularly 2 -seriate, ellipsoid, or fusoid, 1-septate and strongly constricted at the septum, densely filled with coarse granules, $14 \times 40 \mu$, hyaline; paraphyses stout, reaching a diameter of $5-6 \mu$ at their apices. 


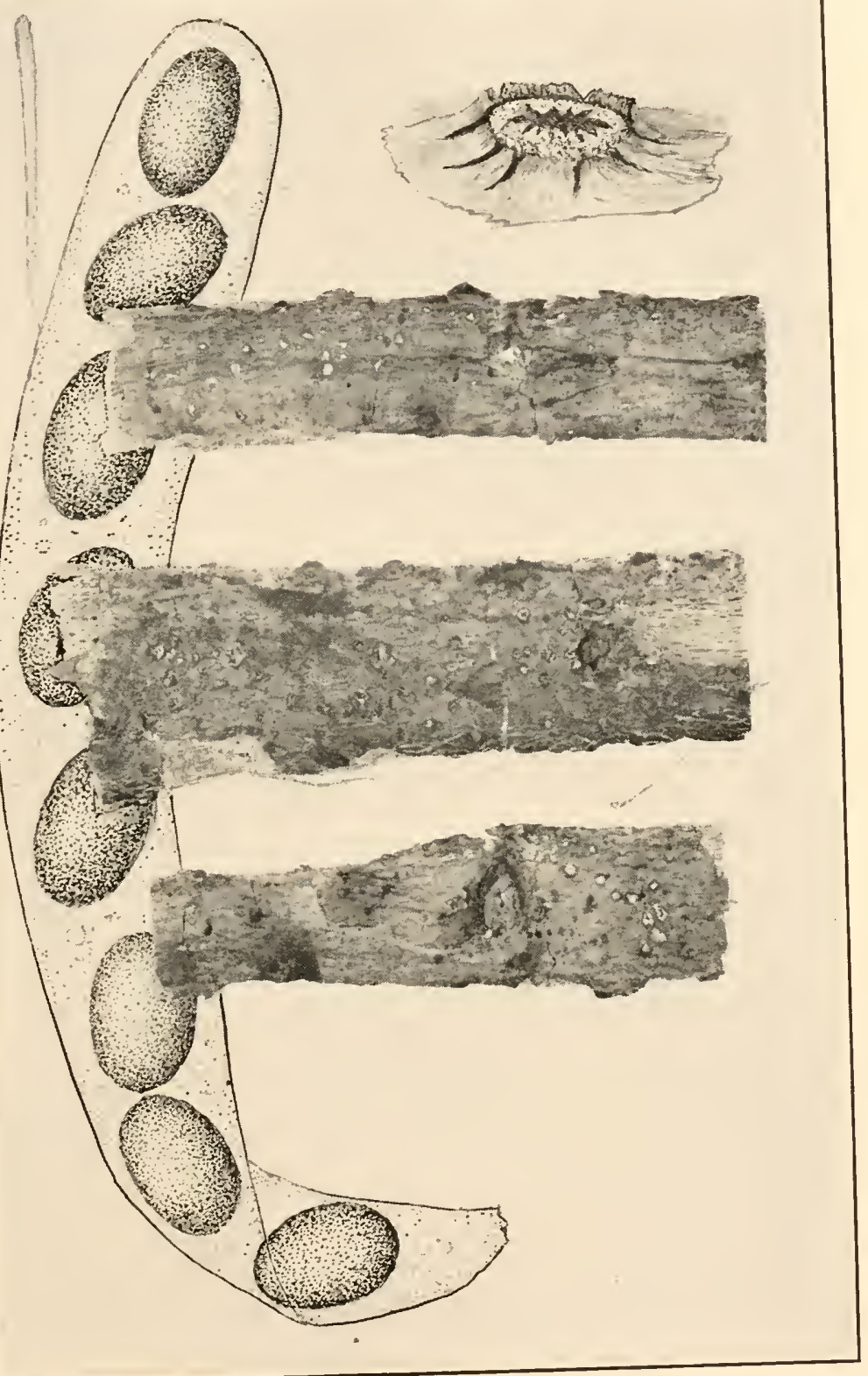

SPHAERANGIUM TILIAE 

On branches of Carpinus and Ilex.

Type Locality: South Carolina.

Distribution: Pennsylvania to Missouri and Alabama.

Exsiccati: Rav. Fungi Car. 4: 66; Rab.-Winter, Fungi Eu. $3+6+$ (from Perryville, Missouri).

2. Cenangella oricostata Cash, Mycologia 28:298. 1936.

Apothecia coriaceous, subglobose, sessile, depressed, and radiately ridged at the apex, collapsing when old, emerging sometimes singly, more often in groups from cracks in the bark, on a thin, sclerotic layer, dark grayish-olive, olivaceous-black when dry, 1-2 mm. in cliameter, not quite so high, slightly furfuraccous; hymenium pallid-grayish; asci cylindric, or subcylindric, short-stipitate, reaching a length of $130 \mu$ and a diameter of 6-8 $\mu$; spores fusoid-clavate, 1-seriate, or 2-seriate, hyaline, 1-septate, not constricted, upper cell broader, lower cell acute, 3-4 $\times 12-$ $15 \mu$; paraphyses filiform, slightly swollen above and often curved at their apices.

On twigs of Ribes Wolfi.

Type locality: Mesa Lakes, Colorado.

Distribution: Known only from the type locality.

Illustrations: Mycologia 28: 302, f. 4.

\section{Doubtful and Excluded Species}

Cenangella abietina Ellis \& Ev. Proc. Acad. Sci. Phila. 1895: 429. 1895; Phaeangella abietina Sacc. \& D. Sacc.; Sacc. Syll. Fung. 18: 128.1906. Based on material collected by Waghorn in Newfoundland. Identity uncertain.

Cenangella favocinerea (Phill.) Sacc. Syll. Fung. 8: 591. 1889; Dermatea favocinerea Phill. Grevillea 7:23. 1878. No material has been seen.

Cenangella Hartii Rostr. Medd. Gronl. 3: 611. 1891. Apothecia densely gregarious, discoid, margin brown, reaching a diameter of .25-.5 mm.; hymenium black; asci clavate, reaching a length of $35-40 \mu$ and a diameter of 7-9 $\mu, 8$-spored; spores 2-seriate, ellipsoid, olivaceous, 1-septate, 4-5 $\times$ 7-9 $\mu$. On decorticated branches of Betula. Known only from the type locality in Greenland.

Cenangella pruinosa Rostr. Medd. Grónl. 18: 59. 1894. No material has been seen. On Vaccinium uliginosum.

Cenangella Rhododendri (Cesati) Rehm in Rab. Krypt.-Fl.1 ${ }^{3}: 230.1889$; Peziza Rhododendri Cesati; Rab. Bot. Zeit. 12: 186. 1854; Velutaria Rhododendri Rehm, Ber. Naturh. Ver. Angsburg 26: 63. 1881. Reported from Oregon. No material has been seen.

Cenangella thujina!Ellis \& Barth. in Ellis \& Ev. N. Am. Fungi 3132. 1894. This belongs with the Hysteriaceae and may be a Glonium. 
Cenangella violacea Ellis \& Ev. Proc. Acad. Sci. Phila. 1893: 149. 1893. This belongs with the Hysteriaceae and may be a Glonium. Cenangella thujina appears to be identical.

7. DERMATELla Karst. Myc. Fenn. 1: 209. 1871. Phaeangella Sacc. Syll. Fung. 18: 128. 1906.

Apothecia erumpent, cupulate to discoid as in Dermea; asci cylindric to clavate, 4-8-spored; spores ellipsoid to fusoid, at first hyaline, becoming yellow, green, or brown, and 1-5-septate; paraphyses filiform to clavate.

Type species, Peziza Frangulae Pers.

Asci 4-spored.

1. D. Frangulae.

Asci 8-spored.

Occurring on conifers, Juniperus.

Occurring on deciduous trees.

2. D. deformata.

Spores $10-12 \times 24-35 \mu$.

On Fraxinus.

On Magnolia.

Spores $6-8 \times 12-24 \mu$.

On branches of Carya.

On unidentified branches.

3. D. Fraxini.

4. D. Magnoliae.

5. D. caryigena.

6. D. montanensis.

1. Dermatella Frangulae (Pers.) Karst. Myc. Fenn. 1: 209. 1871.

Peziza Frangulae Pers. Myc. Eu. 1: 324, 1822.

Tympanis Frangulae Fries, Syst. Myc. 2: 174. 1822.

Cenangium Frangulae Tul. Ann. Sci. Nat. III. 20: 136. 1853.

Dermatea Frangulae Tul. Fung. Carp. 3: 161. 1865.

Pesicula Frangulae Fuckel, Symb. Myc. 279. 1869.

Apothecia erumpent, usually occurring singly, or often several together, turbinate and prominent, at first closed, opening with an irregular margin, dark brownish-black, less than $1 \mathrm{~mm}$. in diameter; hymenium lighter than the outside of the apothecium, becoming dark with age; asci clavate, reaching a length of $80-85 \mu$ and a diameter of $12-14 \mu$, 4-spored; spores usually 1 -seriate, ellipsoid, becoming 3 -septate, at first hyaline, becoming brown, $8-10 \times 20-22 \mu$; paraphyses rather stout, enlarged above to about $4 \mu$ in diameter.

On branches of Rhammus purshiana.

Type Locality: Europe (on Rhammus frangula).

Distribution: Trinidad, California; also in Europe.

Illustrations: Fuckel, Symb. Myc. pl. 4, f. 46; Ann. Sci. Nat. III. $20:$ pl. 16, f. 1-8. 


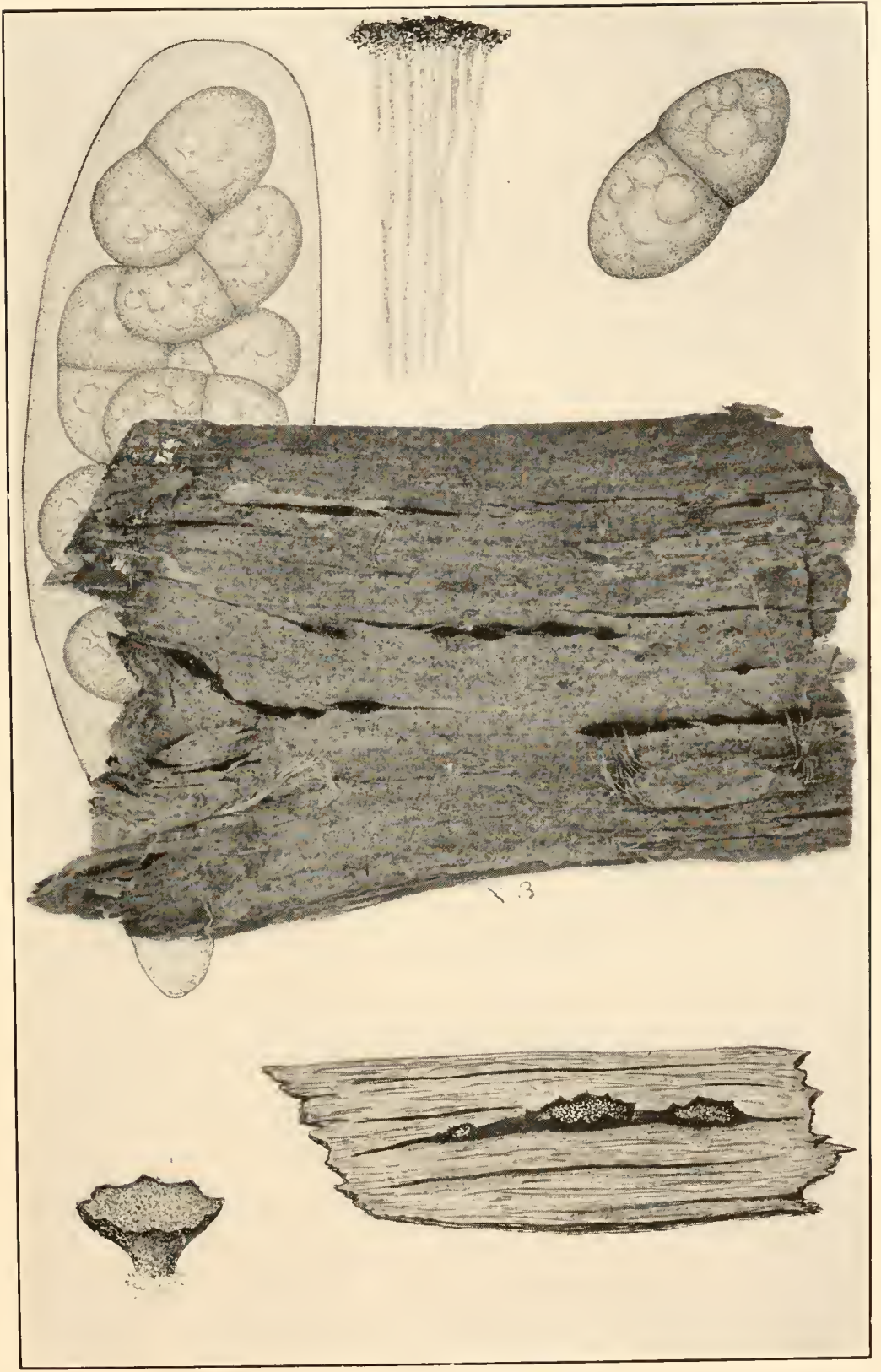

DERMATELLA DEFORMATA 

Only one North American specimen of this species has been seen, collected by Harold E. Parks in California. American specimens agree well with European but the spores are a little larger than indicated in most descriptions. The spores are only pale-brown in our specimens. Fuckel describes and illustrates the spores as muriform but this has not been noted by other authors.

2. Dermatella deformata (Peck) Seaver, comb. nov. (Plate 134.)

Cenangium deformatum Peck, Ann. Rep. N. Y. State Mus. 28: 68. 1876. Cenangella deformata Sacc. Syll. Fung. 8: 593. 1889.

Phaeangella deformata Sacc. \& D. Sacc.; Sacc. Syll. Fung. 18: 128. 1906.

Apothecia erumpent, occurring singly, in small cespitose clusters, or with a serial arrangement, the individual apothecia at first rounded, gradually opening leaving the margin irregularly split and ragged, black and coarsely granular, reaching a diameter of $1.5 \mathrm{~mm}$; hymenium concave, lighter than the outside of the apothecium; asci broad-clavate, about $120 \mu$ long and 35-45 $\mu$ broad, normally 8-spored, but often with part of the spores undeveloped; spores irregularly 2-seriate, broad-ellipsoid, 1 -septate and deeply constricted at the septum, becoming darkbrown, 14-16 $\times$ 30-35 $\mu$; paraphyses filiform, profusely branched, dark-brown with a greenish matrix.

On Juniperus virginiana, Jumiperus communis and Juniperus scopulorum.

Type Locality: Greenbush, New York.

Distribution: New York, Montana and Wyoming and Bermuda.

Illustrations: Mycologia 34: 520, f. 2.

Exsiccati: Ellis \& Ev. Fungi Columb. 1225.

Excellent material of this species was collected by the writer and J. M. Waterston in Bermuda on Bermuda cedar, Juniperus bermudiana.

3. Dermatella Fraxini Ellis \& Ev. Proc. Acad. Sci. Phila. 1893: 149. 1893.

Apothecia gregarious, erumpent-superficial, occurring singly or with two or three grouped together, flesh-colored, reaching a diameter of .75-1 mm., contracted below and slightly turbinate; hymenium plane, or convex, similar in color to the outside of the apothecium; asci clavate, cylindric, reaching a length of 125- 
$150 \mu$ and a diameter of $12-15 \mu$; spores partially 2 -seriate, longellipsoid, becoming 1 -septate, later $3-5$-septate, $10-12 \times 25$ $35 \mu$, at first hyaline, becoming brown; paraphyses filiform.

On bark of Fraxinus.

Type locality: London, Canada.

Distribution: Known only from the type locality.

Exsiccati: Ellis \& Ev. N. Am. Fungi 2633.

Type material has been examined and agrees with the above except that no asci were found in good condition, although spores were present in abundance. This may be due to the age of the material. Measurements were based on the original description. This looks like a Pezicula with a colored spore.

4. Dermatella Magnoliae (Berk. \& Curt.) Seaver, comb. nov.

Cenangium Magnoliae Berk. \& Curt.; Berk. Grevillea 4: 5. 1875.

Apothecia erumpent in cespitose clusters $2-3 \mathrm{~mm}$. in diameter, the individual apothecia turbinate, black, reaching a diameter of $1 \mathrm{~mm}$; hymenium concave, or nearly plane, black, or brownishblack; asci broad-clavate, reaching a length of $120 \mu$ and a diameter of $26 \mu$, 8-spored; spores irregularly 2-seriate, broadellipsoid, often curved, or sausage-shaped, denscly granular within, becoming 1 -septate and brown, 9-12 $\times 24-30 \mu$; paraphyses filiform, slightly enlarged above, reaching a diameter of $3 \mu$.

On branches of Magnolia glauca, Persea and Sassafras.

Type Locality: South Carolina.

Distribution: South Carolina to Florida and Texas.

ExsicCati: Rav. Fungi Am. 70.

This was placed in the doubtful list by Groves. The brown 1-septate spores would place in the genus Dermatella as here treated.

5. Dermatella caryigena (Ellis \& Ev.) Seaver, comb. nov.

Dermatea caryigena Ellis \& Ev. Proc. Acad. Sci. Phila. 1893: 148. 1893.

Apothecia erumpent in cespitose clumps of four to eight each, nearly black, reaching a diameter of $.5-.75 \mu$, patelliform when fresh, collapsing when dry; hymenium plane, or slightly convex when fresh, similar in color to the outside of the apothecium; asci narrow-clavate, reaching a length of 75-90 $\mu$ and a diameter of $10 \mu, 8$-spored; spores 1-seriate, or irregularly crowded, ellipsoid, distinctly 3 -septate, greenish-yellow to pale-brown, $6 \times$ 12-15 $\mu$; paraphyses filiform, profusely branched, olivaceousbrown. 
On dead limbs of Carya (Hickoria).

Type Locality: West Chester, Pennsylvania.

Distribution: Known only from the type locality.

The only specimen seen is the type collection in the herbarium of The New York Botanical Garden.

6. Dermatella montanensis Ellis \& Ev. Proc. Acad. Sci. Phila. 1893: 148.1893.

Apothecia erumpent-superficial, discoid, or subdiscoid, reaching a diameter of $1 \mathrm{~mm}$., livid, subgelatinous when fresh; hymenium concave, black, with a thin, upturned margin when dry; asci broad-clavate, reaching a length of $72-80 \mu$ and a diameter of 18-22 $\mu, 8$-spored; spores irregularly 2-seriate, ellipsoid to clavate-ellipsoid, becoming 3 -septate, slightly constricted at the septa, at first hyaline, becoming yellowish-brown, $7-8 \times 24 \mu$; paraphyses, branched, enlarged at their apices, forming a darkbrown epithecium.

On small, dead limbs among driftwood.

Type Locality: Sheridan, Montana.

Distribution: Known only from the type locality.

\section{Doubtful and Excluded Species}

Dermatella populina Petrak, Ann. Myc. 20: 196. 1922. On bark of Populus tremuloides from Idaho, Weir No. 18002. Specimen of cotype material shows no apothecia.

Dermatella viticola Ellis \& Ev. Proc. Acad. Sci. Phila. 1894: 352. 1894. Apothecia convex-discoid and pale when moist, concave and flesh-colored when dry, then scarcely projecting above the surface of the bark, .5-.75 $\mathrm{mm}$. in diameter; asci clavate-cylindric, reaching a length of $70 \mu$ and a diameter of $12 \mu, 8$-spored; spores 2 -seriate or partially so, ellipsoid, becoming 1-3-septate, 6-6.5 $\times 15-18 \mu$; paraphyses filiform. On dead shoots of Vitis, Nuttallburg, West Virginia. No material has been seen. It is probably not a Dermatella as used here.

8. GODRONIA Moug. Consid. Gen. Veg. Vosges 355. 1845.

Crumenula DeNot. Comm. Critt. Ital. 1: 365.1864.

Scleroderris (Fries) DeNot. Comm. Critt. Ital. 1: 383.1864.

A scocalyx Naumov, Bolesni Rast. 14: 138. 1925.

Atropellis Zeller \& Goodding, Phytopathology 20: 561. 1930.

Mougeot describes the genus as having apothecia which are coriaceous, or gelatinous like Bulgaria, and with the spores of a Stictis. The genus Godronia and the genus Stictis are strikingly 
similar and might easily be confused, notwithstanding the fact that they are placed in different orders. The genus is characterized by the erumpent apothecia and the very much elongated, or filiform spores which usually become 1-several-septate, although they may be for a long time without septa, as in other species of Cenangiaceae.

Type species, Godronia Muhlenbeckii Moug. \& Lév.

On deciduous, woody plants.

Spores relatively short, less than half the length of the ascus.

On stems of Ribes.

In congested masses; spores clavate.

Spores becoming 3-septate.

Spores 20-38 $\mu$ long.

1. G. Ribis.

Spores 18-20 $\mu$ long.

2. G. lobata.

Spores simple, in specimens studied.

3. G. tumoricola.

Occurring singly; spores fusoid.

4. G. Daridsoni.

Not on Ribes.

Spores fusoid.

Spores 11-17 $\mu$ long; on Lantana.

Spores 20-24 $\mu$ long.

Apothecia turbinate; hymenium concave.

Apothecia patellate; hymenium plane or nearly so.

Spores $25-40 \mu$ long.

Apothecia with a laciniate border, on Spiraea; spores 3-4 × 25-25 $\mu$.

Apothecia not laciniate on Vitis; spores 3-4 $\times 35-40 \mu$.

5. G. Lantanae.

6. G. turbinata.

7. G. fusispora.

8. G. Spiraeae.

9. G. riticola.

Spores slender, rod-like; 1.5-2 $\times 10-12 \mu$.

10. G. Lonicerae.

Spores relatively long, more than half as long as the ascus.

On stems of woody plants.

Spores long-fusoid.

Apothecia deeply concave; on Salix.

Apothecia slightly concave; on Betula.

Spores filiform or vermiform.

Spores short, 25-30 $\mu$ long; on Kalmia.

Spores $40-75 \mu$ long.

Spores slender, $1.5-2 \mu$ thick.

Apothecia cespitose, discoid.

Apothecia scattered, urceolate.

11. G. fuliginosa.

12. G. seriata.

13. G. Kalmiae.

Spores 3-4 $\mu$ in diameter, nearly as long as the ascus.

Apothecia scattered; on sage brush.

14. G. Nemopanthis.

15. G. L'rceolus.

16. G. montanensis. 
Apothecia in cespitose clusters.

Spores $3 \times 65-70 \mu$; on Cephalanthus.

17. G. Cephalanthi.

Spores 3-4 $485-100 \mu$; on $\mathrm{l}^{r} i$ burnum.

18. G. viburnicola.

Spores very long, nearly as long as the ascus.

On leaves of Tetrazygia; spores $250 \mu$ long.

On branches of Castanopsis.

19. G. parasitica.

20. G. Castanopsidis

()n coniferous branches.

Paraphyses blue with transmitted light.

Spores 1-3-septate.

21. G. pinicola.

Spores simple or doubtfully septate.

Spores $1.5-3.5 \times 32-63 \mu$.

22. G. Zelleri.

Spores 5-6 $\times 15-22 \mu$.

23. G. sororia.

Paraphyses not blue.

Hymenium light-colored.

Hymenium pink to brown; on Picea in Alaska.

24. G. Treleasei.

Hymenium pale-yellow or whitish; on Juniperus in Jamaica.

Hymenium grayish or black; on Abies.

Spores 8-12 $\mu$ long.

Spores $40-60 \mu$ long.

On cankers on living branches.

On bleached bark.

25. G. jamaicensis.

26. G. Abietis.

27. G. abieticola.

28. G. abietina.

1. Godronia Ribis (Fries) Seaver, Mycologia 37:339. 1945.

Peziza ribesia Pers. Tent. Disp. Fung. 35. 1797.

Cenangium Ribis Fries, Syst. Myc. 2: 179. 1822.

Tympanis Ribis Wallr. Fl. Crypt. Germ. 2: 430.1833.

Crumenula Ribis Karst. Fungi Fenn. 929. 1870.

Scleroderris ribesia Karst. Myc. Fenn. 1: 215. 1871.

Apothecia erumpent in cespitose clusters, $1-3 \mathrm{~mm}$. in cliameter from a stromatic base, each cluster consisting of four to twelve apothecia, individual apothecia at first globose, or subglobose, short-stipitate, gradually expanding and becoming shallow cup-shaped, with a notched, or fimbriate margin, reaching a diameter of 1-2 mm., blackish-brown; hymenium concave pale-cincreous; asci clavate-cylindric, reaching a length of $90-$ $100 \mu$ and a diameter of 7-8 $\mu, 8$-spored; spores much elongated, clavate, $3-4 \times 20-38 \mu$, becoming 3 -septate; paraphyses filiform, slightly enlarged above.

Pycnidia, Fuckelia Ribis, present; pycnospores elongateclavate, $3-4 \times 7-11 \mu$, usually containing two oil-drops.

On branches of species of Ribes. 
Type Locality: Europe.

Distribution: Toronto, Canada; also in Europe.

lleustrations: Boud. Ic. Myc. pl. 563; Ann. Sci. Nat. III. 20: pl. 16, f. 9-11; Tul. Fung. Carp. 3: pl. 19, f. 1-9; Rab. Krypt.Fl. $1^{3}: 200, f .1-2 ; 201, f .6,7$; E. \& P. Nat. Pfl. $1^{1}: 255, f .187, G$.

2. Godronia lobata (Cash) Seaver, Mycologia 37: 340. 1945.

Scleroderris lobata Cash, Mycologia 28: 248. 1936.

Apothecia breaking through the bark, usually in clusters of two to four, or rarely single, subglobose to cupulate, opening by splitting into 4-6 lobes which fold over one another on drying, reaching $1 \mathrm{~mm}$. in diameter and height, externally blackishbrown, smooth; hymenium concave, light olive-gray; asci cylindric, short-stipitate, rounded and slightly narrowed above, reaching a length of $90-115 \mu$ and a diameter of 7-9; spores 1 -seriate below, 2 -seriate above, clavate, usually 3 -septate, $3-4 \times 18-20 \mu$; paraphyses filiform, simple, or branched near the tip, slightly enlarged above.

On twigs of Ribes Menziesii.

Type locality: Spruce Cove, Trinidad, California.

Distribution: Known only from the type locality.

Illustrations: Mỹcologia 28: 250, f. 3.

3. Godronia tumoricola (Cash) Seaver, Mycologia 37: 340. 1945.

Scleroderris tumoricola Cash, Mycologia 26: 270. 1934.

Apothecia sessile, usually cespitose, or rarely single, cupshaped to nearly plane, triangular, or irregularly contorted when dry, coriaceous, blackish-brown to black, .5-2 $\mathrm{mm}$. in diameter; hymenium concave to plane, drab, drying nearly black; asci cylindric, narrowed above, reaching a length of $90-110 \mu$ and a diameter of 5-8 $\mu, 8$-spored; spores 2-seriate, or irregularly 1seriate, clavate with the acute end below, first simple, later septate?, $1.5-2 \times 10-15 \mu$; paraphyses filiform, hyaline, simple, or branched near the middle, enlarged above to $2 \mu$ in diameter.

On swollen canker-like areas on twigs of Ribes montigenum.

Type locality: Mesa Lakes, Colorado.

Distribution: Known only from the type locality.

Illustrations: Mycologia 26: pl. 32, f.. . 


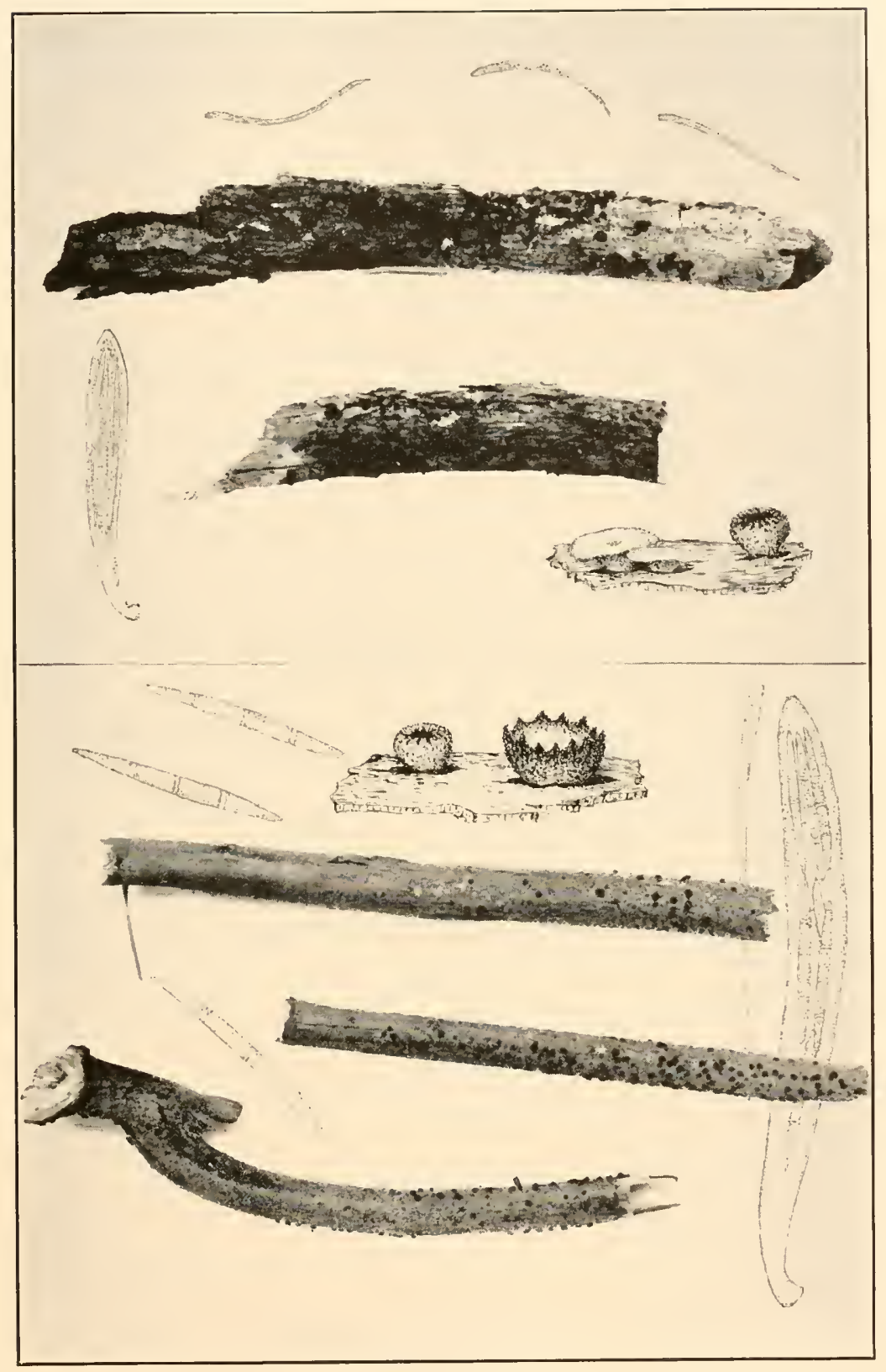

1. GODRONIA KALMIAE

2. GODRONIA SPIRAEAE 

4. Godronia Davidsoni Cash, Mycologia 26: 269. 1934.

Apothecia sessile, or substipitate, single, depressed-globose to urceolate, not exceeding $1 \mathrm{~mm}$. in diameter and height, darkcolored, greenish-olive, opening with a circular opening, with a fimbriate margin; hymenium concave, smoky-gray; asci cylindric, gradually narrowed toward the base and above, 8-spored, reaching a length of $90-120 \mu$ and a diameter of 5-7 $\mu$; spores acicular-fusoid, parallel, or slightly twisted in the ascus, becoming 3-septate, 2.5-3 3 33-45 $\mu$; paraphyses filiform, simple, hyaline, gradually enlarged above, reaching a diameter of $2-2.5 \mu$, often curved at the tips.

On stems of Ribes Wolfi, $R$. bracteosum $\times R$. nigrum.

Type lochlity: Near Mesa Lakes, Colorado.

Distribution: Colorado and Alaska.

Illustrations: Mycologia 26: $269, f . A ; p l .32, f .3$.

5. Godronia Lantanae (Cash) Seaver, Mycologia 37:341. 1945. Scleroderris Lantanae Cash, Mycologia 30: 100. 1938.

Apothecia cespitose, sessile, cupulate to discoid, contorted by mutual pressure, reaching a diameter of $1-1.5 \mathrm{~mm}$., furfuraceous, brown, the margin inrolled when dry, sometimes becoming hysteroid; hymenium concave to plane, brownish-black; asci clavate, rounded above, gradually narrowed toward the base, 8-spored, reaching a length of $50-55 \mu$ and a diameter of $5 \mu$; spores 2-seriate, fusoid, straight, or slightly curved, becoming 1-septate, hyaline to pale-brownish, 1.5-2 × 11-17 $\mu$; paraphyses simple, $2.5 \mu$ in diameter at their apices.

On fallen branches of Lantana Camara.

Type Localitx: Kaluaaha Valley, Molokai, Hawaii.

Distribution: Known only from the type locality.

Illustration: Mycologia 30: 99, f. $九$.

6. Godronia turbinata (Schw.) Farlow; Thaxter, Mycologia 14: 101. 1922.

Tympanis turbinata Schw. Trans. Am. Phil. Soc. II. 4: 237. 1832.

Apothecia erumpent, turbinate, with the mouth strongly constricted, brownish-black, furfuraceous, reaching a diameter of $1 \mathrm{~mm}$; hymenium deeply concave, pallid; asci clavate, reaching a length of $110 \mu$ and a diameter of 6-7 $\mu$, apparently 8 - 
spored; spores often indistinct, fusiform, about $2 \times 20 \mu, 3$ septate.

On twigs of Diervilla.

Type locality: Bethlehem, Pennsylvania.

Distribution: Pennsylvania and Maine.

Exsiccati: Reliq. Farlow. 122.

This description is based on material collected by Dr. R. Thaxter at Kittery Point, Maine. Material in the Schweinitz collection in Philadelphia is scant and uncertain.

7. Godronia fusispora (Ellis \& Ev.) Seaver, Mycologia 37: 342. 1945.

Dermatea fusispora Ellis \& Ev. Proc. Acad. Sci. Phila. 1893: 148. 1893.

Apothecia scattered, occurring singly, or occasionally two or three crowded together, externally subolivaceous, reaching a diameter of $1 \mathrm{~mm}$.; hymenium plane or nearly so, with a slightly elevated margin, reddish; asci clavate, 8-spored, reaching a length of $70-75 \mu$ and a diameter of $6-7 \mu$; spores narrow-fusoid, $2-3 \times$ 20-24 $\mu$; paraphyses filiform, slightly enlarged above, reaching a diameter of $2-3 \mu$.

On dead branches of Betula sp.

Type locality: Orono, Maine.

Distribution: Known only from the type locality.

8. Godronia Spiraeae (Rehm) Seaver, Mycologia 37:342. 1945. (Plate 135, Fig. 2.)

Scleroderris Spiraeae Rehm in Rab. Krypt.-Fl. 13: 1220. 1896.

?Belonidium Macounii Dearness, Mycologia 8: 98. 1916.

Apothecia subsessile, thickly gregarious, occurring singly or rarely with two or three crowded together, subglobose, with the mouth constricted (in dried specimens) and laciniate, dark brownish-black, of ten with a greenish tint, reaching a diameter of $1 \mathrm{~mm}$; hymenium concave, obscured when dry by the incurved margin, freely exposed when moist, light-brown; asci cylindric-clavate, reaching a length of $80-85 \mu$ and a diameter of 6-7 $\mu, 8$-spored; spores fusoid, overlapping and subfasciculate, 3-4 $\times 25-35 \mu$, becoming 3-septate; paraphyses slender, slightly enlarged above.

On branches of Spiraea salicifolia.

Type locality : Europe.

Distribution: New York and Toronto, Canada; also in Europe. 


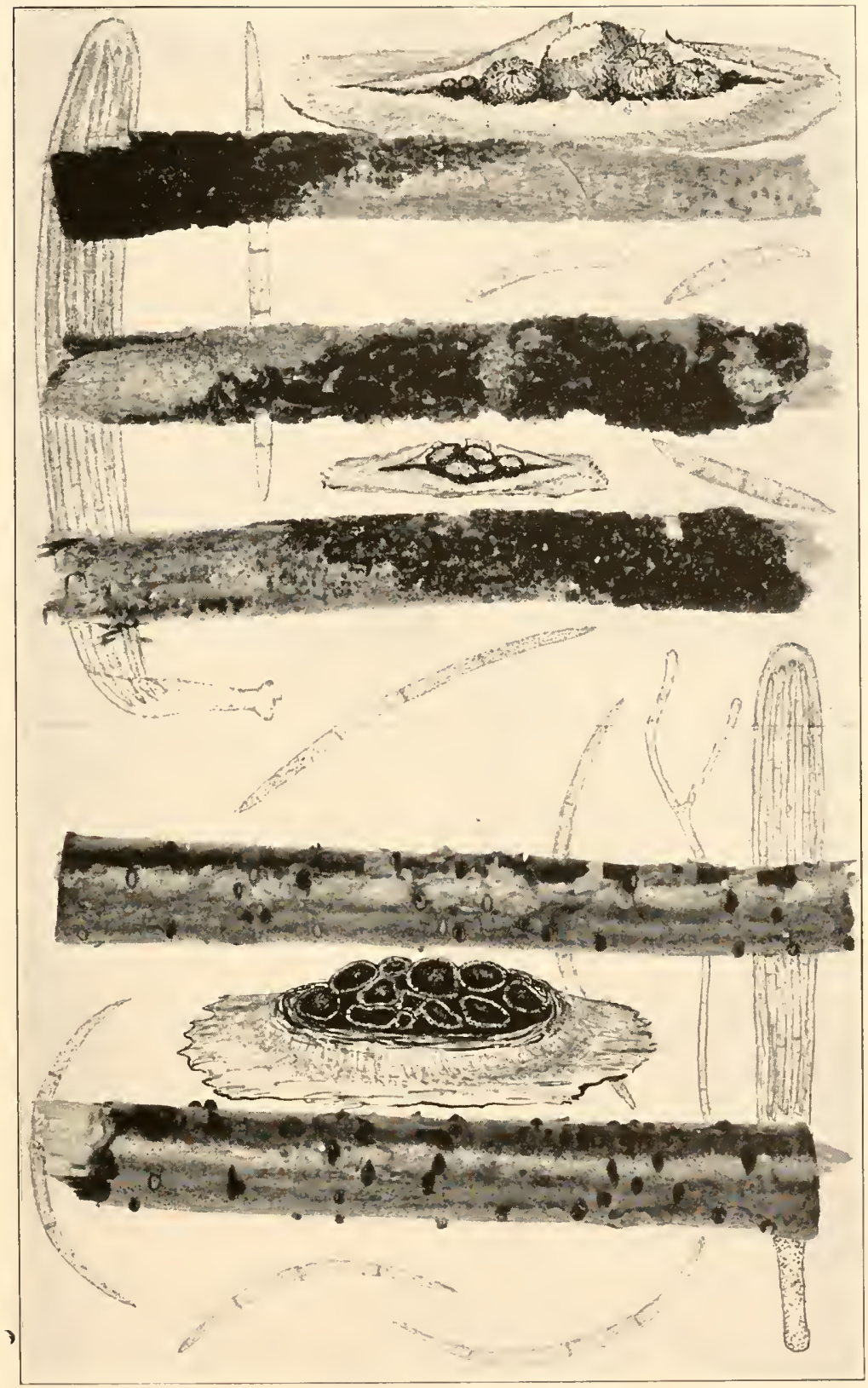

1. GODRONIA FULIGINOSA

2. GODRONIA SERIATA 

Illustrations: Mycologia 37: 337 (lower figure).

Described from the material in the herbarium of The New York Botanical Garden, collected by C. H. Peck at Hewitt's Pond in July (the year not indicated), at first thought to be new but later found to be as above.

Belonidium Macounii was described from material collected on dead stems of Spiraea Mensiesii in Vancouver Island by John Macoun. Through the kindness of Dr. Dearness a portion of the type has been examined. It is a Godronia. The description of the spores fits this species but from the specimen examined they resemble more closely those of Godronia Urceolus.

9. Godronia viticola (Schw.) Seaver, Mycologia 37:343. 1945.

Peziza viticola Schw. Schr. Nat. Ges. Leipzig 1: 123. 1822.

Tympanis viticola Fries, Syst. Myc. 2: 176. 1822.

Peziza Schweinitziana Spreng. in L. Syst. Veg. ed. 16. 4': 515. 1827.

Cenangium viticolum Sacc. Syll. Fung. 8: 572. 1889.

Apothecia scattered, or gregarious, scutellate to subdiscoid, black, or blackish, soft and subgelatinous when moist, reaching a diameter of $.15 \mathrm{~mm}$; asci clavate, tapering below into a slender, stem-like base, reaching a length of $85 \mu$ and a diameter of $12 \mu$, 8-spored; spores fusoid, 1-3-septate, $4 \times 35-40 \mu$; paraphyses filiform.

On bark of living grape vine, Vitis sp.

TyPe locality: North Carolina.

Distribution: North Carolina to New Jersey.

Exsiccati: Ellis, N. Am. Fungi 1317.

10. Godronia Lonicerae Seaver, Mycologia 37: 343. 1945.

Apothecia sessile, or subsessile, attenuated below, at first closed, externally dark-colored, striated near the margin and clothed with poorly developed, adpressed hairs, gradually expanding but with the margin constricted, $.3 \mathrm{~mm}$. diameter; hymenium dull but lighter than the outside of the apothecium; asci clavate, reaching a length of $40-45 \mu$ and a diameter of 6-7 $\mu$, 8-spored; spores slender, rod-like, 1.5-2 × 10-12 $\mu$, containing several oil-drops; paraphyses filiform, $1.5-2 \mu$ in diameter, slightly enlarged above, hyaline.

On branches of Lonicera canadensis.

Type locality: Iake Temagami, Toronto, Canada.

Distribution: Known only from the type locality. 
11. Godronia fuliginosa (Pers.) Seaver, Mycologia 37: 344. 1945. (Plate 136, Fig. 1.)

Sphaeria fuliginosa Pers. Obs. Myc. 2: 68. 1799.

Cenangium difforme Fries; Moug. \& Nest. Stirp. Crypt. 889. 1826.

Cenangium fuliginosum Fries, Elench. Fung. 2: 23. 1828.

Tryblidium difforme Pers;; Tul. Fung. Carp. 3: 166. 1865.

Scleroderris fuliginosa Karst. Myc. Fenn. 1: 216. 1871.

Lasiosphaeria striata Ellis \& Ev. Proc. Acad. Sci. Phila. 1893: 443. 1893. Godronia Betheli Seaver, Mycologia 3: 6t. 1911.

Godronia striata Seaver, Mycologia 4: 123.1912.

Apothecia erumpent through the outer bark of the host, single, or occurring in clusters, often so numerous as to form congested masses many cm. in extent and often almost entirely surrounding the branches on which they grow, the individual apothecia at first nearly globose, opening at the top so as to leave an irregular margin, at maturity about $1 \mathrm{~mm}$. broad and the same in height, brownish, furfuraceous externally and longitudinally striated; hymenium whitish, or bluish-white; asci clavate, reaching a length of $130 \mu$ and a diameter of 7-8 $\mu$, 8-spored; spores fasciculate in the ascus, subfiliform, tapering toward either end, sharp-pointed, 3-4 × 65-85 $\mu$, becoming 7-septate at maturity and often slightly constricted at the septa, hyaline; paraphyses abundant, filiform.

Pycnidia often accompanying the apothecia, at first closed, becoming shallow cup-shaped, usually black; pycnospores fusiform, straight, or slightly curved, 3-septate, 3-4 $\times 28-30 \mu$.

On branches of Sulix.

Type locality : Europe.

Distribution: Ontario and Colorado; also in Europe.

Illustrations: Tul. Fung. Carp. 3: pl. 20, f. 1-4; E. \& P. Nat. Pfl. $1^{1}$ : 255, f. 187, H-J; Rab. Krypt.-Fl. $1^{3}$ : 201, f. 3-7; Mycologia 25: pl. 15 (upper figure).

This species was collected in abundance on willow at Tolland, Colorado by the author in company with Ellsworth Bethel in 1910 and described as a new species, Godronia Betheli. Later study revealed the fact that Lasiosphaeria striata Ellis \& Ev. is identical but owing to the fact that it had been placed in the Sphaeriales it had been overlooked. The young apothecia are strongly constricted which doubtless accounts for the fact that Ellis placed it in that group. Later study has revealed the fact that both Ellis and Everhart's species and the species of the writer are identical with Cenangium fuliginosum of Fries. 


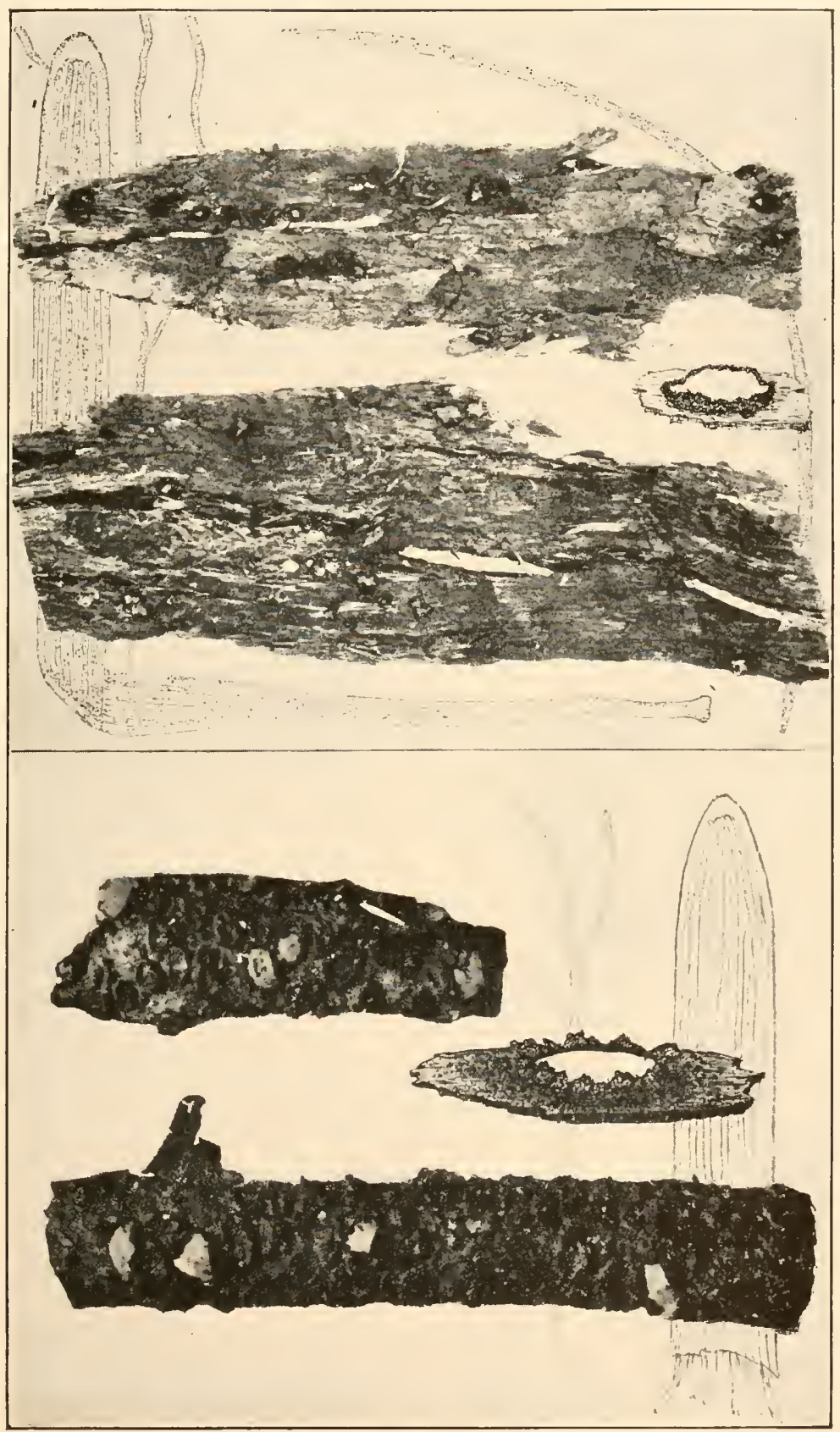

1. GODRONIA JAMAICENSIS

2. GODRONIA CEPHALANTHI 

Specimens erroneously reported on Alnus by Kauffman (Papers Michigan Acad. Sci. 1: 109. 1923) have been examined and proved to be Cyphella fasciculata (Schw.) Berk. \& Curt.

12. Godronia seriata (Fries) Seaver, Mycologia 37: 345.1945. (Plate 136, Fig. 2.)

Cenangium seriatum Fries, Syst. Myc. 2: 185. 1822.

Phacidium seriatum Fries, Elench. Fung. 2: 131. 1828.

Tryblidium seriatum Fries, Sclerom. Suec. 161.

Dermatea seriata Tul. Fung. Carp. 3: 160. 1865.

Gelatinosporium betulinum Peck, Ann. Rep. N. Y. State Mus. 25: 84. 1873.

Apothecia occurring in elongated clumps 3-4 $\mathrm{mm}$. long and about $2 \mathrm{~mm}$. broad, closely compressed together and often slightly irregular from mutual pressure, entirely black, reaching a diameter of $.5 \mathrm{~mm}$. ; hymenium slightly concave, bordered by a slightly upturned margin, black; asci clavate, reaching a length of $95-110 \mu$ and a diameter of $10-12 \mu, 8$-spored; spores long, fusiform and usually slightly curved when free, reaching a length of 45-60 $\mu$ and a diameter of 2-3 $\mu, 3$-septate; paraphyses slender, branched, hyaline, or subhyaline.

The conidial stage accompanies the ascigerous and consists of a blackish stroma in which the pycnospores are produced; pycnospores fusiform, strongly curved and 3-septate, reaching a length of $40-45 \mu$ from tip to tip and a diameter of $2-3 \mu$.

On Betula lutea and Betula fontinalis.

Type locality: Europe.

Distribution: New York to Pennsylvania and Colorado; also in Europe.

Illustrations: Mycologia 25: pl. 15 (lower figure).

Exsiccatr: Ellis, N. Am. Fungi 5.37-5.37b; Ellis \& Ev. Fungi Columb. 853; Shear, N. Y. Fungi 200.

A fine collection of this species was obtained in Coal Creek Cañon, Colorado, by the writer and Paul F. Shope, in the summer of 1929 (No. 495), and determined by Mr. II. IV. Diehl as, Scleroderris seriata (Fries) Rehm. This is the only perfect specimen of this in the herbarium of The New York Botanical Garden from America.

Material which seems to be a part of the type collection of Gelatinosporium betulinum Peck is found in our collection. A note apparently in the handwriting of C. H. Peck reads as follows: "Perhaps the same as Sphaeronema seriatum B. \& C. possibly a condition of Cenangium seriatum Fr." This conclusion is un- 
doubtedly correct since our material collected in Colorado shows both stages on the same stroma. The pycnospores agree very closely with those from Peck's type. No definite pycnidia could be detected.

13. Godronia Kalmiae (Rehm) Seaver, Mycologia 37: 346. 1945. (Plate 135, Fig. 1.)

Gorgoniceps Kalmiae Rehm, Ann. Myc. 2: 353. 1904.

Apothecia gregarious, erumpent, at first cyathoid, shortstipitate, finally becoming irregularly discoid, externally reddishbrown, reaching a diameter of $1 \mathrm{~mm}$.; hymenium at first concave, becoming plane, or convex, sordid-yellow; stem very short and stout, gradually expanding into the apothecium; asci cylindricclavate, reaching a length of $40-50 \mu$ and a diameter of 5-8 $\mu$, 8-spored; spores filiform, straight, or curved when freed from the ascus, no septa apparent, $1 \times 25-30 \mu$; paraphyses filiform, slightly enlarged above, $1-1.5 \mu$ in diameter.

On decaying branches of Vaccinium corymbosum.

Type locality: North America (exact locality not given).

Distribution: Known only from the type locality.

Illustrations: Mycologia 37: 337 ((upper figure).

Exsiccatr: Ellis, N. Am. Fungi 147 (as Dermatea Kalmiae Peck). This material which was incorrectly named by Ellis was made the type of a new species by Rehm.

14. Godronia Nemopanthis (Peck) Sacc. Syll. Fung. 8: 603. 1889.

Tympanis Nemopanthis Peck, Ann. Rep. N. Y. State Mus. 35: 142. 1884. Durandiella Nemopanthis Groves, Mycologia 29: 75. 1937.

Apothecia occurring in cespitose clusters, or occasionally single, sessile, slightly narrowed below, reaching a diameter of $1 \mathrm{~mm}$. and a height of $1.5 \mathrm{~mm}$., circular in form, or becoming irregular from mutual pressure, dull-black, the consistency leathery to cartilaginous, or horny when dry; hymenium at first concave, becoming plane, or convex, black, or olivaceous when moist; asci cylindric to clavate-cylindric, tapering below into a stem-like base, reaching a length of $80-125 \mu$ and a diameter of 7-9 $\mu$; spores hyaline, filiform, septate, attenuated at the ends, straight, or variously curved, intertwined in the ascus, $1.5-2 \times$ 50-85 $\mu$; paraphyses hyaline, filiform, septate, branched, $1.5-2 \mu$ 
in diameter, scarcely enlarged above, forming a yellowish hymenium.

On tead stems of Nemopanthes canadensis (Nemopanthes mucronata).

Type Locality: Grafton, Rensselaer County, New lork.

Distribution: New York to Maine and Ontario.

Illustrations: Mycologia 29: 76, f. 3; 77, f. +9.

Exsiccati: Ellis \& Ev. N. Am. Fungi 2330; Fungi Columb. 332; Barth. Fungi Columb. 4530; Reliq. Farlow. 121.

15. Godronia Urceolus (Alb. \& Schw.) Karst. Acta Soc. Fauna Fl. Fenn. $2^{6}: 144.1885$.

Pesiza L'rceolus Alb. \& Schw. Consp. Fung. 332. 1805.

Peziza globularis Pers. Myc. Eu. 1: 326. 1822.

Cenangium Urceolus Fries, Syst. Myc. 2: 182. 1822.

Sphaeria uberiformis Fries, Syst. Myc. 2: 491. 1823.

Tympanis Urceolus Wallr. Fl. Crypt. Germ. 2: 425.183.

Mastomyces Friesii Mont. Ann. Sci. Nat. III. 10: 135. 1848.

Cenangium globulare Fries, Summa Veg. Scand. 364. 1849.

Crumenula L'rceolus DeNot. Comm. Critt. Ital. 1: 363.1863.

Cenangium urceolatum Ellis; Cooke \& Ellis, Grevillea 6: 9. 1877.

Godronia Cassandrae Peck, Ann. Rep. N. Y. State Mus. 39: 50. 1886.

Cenangella urceolata Sacc. Syll. Fung. 8: 591. 1889.

Apothecia scattered, or rarely five to seven closely croweled together, erumpent through the bark, ustally with a short, thick stem, urceolate, reaching a diameter of .5-1.5 mm., externally brownish, or brownish-black; hymenium grayish, or pallid; stem very short and inconspicuous; asci clavate-cylindric, reaching a length of 90-125 $\mu$ and a diameter of 6-7 $\mu$, 8-spored; spores filiform, many'septate, $1.5 \times 50-75 \mu$; paraphyses filiform, $2 \mu$ in diameter.

Reported on twigs of various kinds, Alnus, Betula, Cassandra and Clethra. American specimen on Ribes seems to agree.

Type locality: Europe.

Distribution: Newfoundland to Alaska and Michigan; also in Europe.

Illustrations: Alb. \& Schw. Consp. Fung. pl. 3, f. f; E. \& P. Nat. Pfl. $1^{1}: 234, f .178, G-J$; Rab. Krypt.-Fl. $1^{3}: 217, f .1-5$; Peck, Ann. Rep. N. Y. State Mus. 39: pl. 1, f. 16-20.

Exsiccati: Ellis, N. Am. Fungi 990 (as Cenangium urceolatum); Ellis \& Ev. Fungi Columb. $7+2$. 
Miss Daisy S. Hone in her Minnesota work (Minn. Bot. Studies 4: 111. 1909) describes a variety Godronia urceolata conferta which was said to differ in the habitat on Prunus pumila as well as in the clustered habit of the apothecia and the slightly shorter spores.

Godronia Cassandrae described by Peck from material collected on Cassandra calyculata appears to be identical with the above.

Cenangium urceolatum Ellis is identical. The spores are described by Ellis as fusoid, 1-septate and $4 \times 15 \mu$. These were apparently conidia or pycnospores. Such spores have been found in connection with other specimens. The ascospores in this species are typical.

16. Godronia montanensis Seaver, Mycologia 37:348. 1945.

Apothecia scattered, erumpent, superficial, at first urceolate, later expanding and becoming subdiscoid, blackish and minutely verrucose, reaching a diameter of $1 \mathrm{~mm}$; hymenium concave, or nearly plane, pale-yellowish; asci cylindric, reaching a length of $175-185 \mu$ and a diameter of 10-11 $\mu$, probably 8-spored; spores filiform, nearly as long as the ascus, about $3 \mu$ in diameter, manyseptate and apparently breaking up into segments in the ascus, the segments about as long as broad; paraphyses filiform, about 1.5 in diameter.

On sage brush.

Type Locality: Sheridan, Montana.

Distribution: Known only from the type locality.

This interesting species was found sparingly associated with Dermatella montanensis Ellis \& Ev. and was probably overlooked by Ellis. The species differs from others examined in the spores becoming disjuncted in the ascus as well as in the size of the spores and asci.

17. Godronia Cephalanthi (Schw.) Seaver, Mycologia 37: 349. 1945. (Plate 137, Fig. 2.)

Peziza Cephalanthi Schw. Schr. Nat. Gez. Leipzig 1: 123. 1822.

Cenangium Cephalanthi Fries, Syst. Myc. 2: 188. 1822.

Scleroderris Cephalanthi Farlow; Thaxter, Mycologia 14: 102.1922.

Apothecia erumpent, usually in congested clusters several mm. long, the individual apothecia scutellate with the margin, dark brownish-black, reaching a diameter of $2 \mathrm{~mm}$.; hymenium 
concave, pale-yellowish; asci cylindric, reaching a length of 65$70 \mu$ and a diameter of 10-12 $\mu, 8$-spored; spores filiform, about $3 \times 65-70 \mu$, hyaline, becoming 5-7-septate; paraphyses filiform slender.

On Cephalanthus occidentalis.

Type Locality: South Carolina.

Distribution: New York and New Hampshire to South Carolina.

Exsiccati: Reliq. Farlow. 103, 144.

The description is drawn from material identified by $\mathrm{C}$. $\mathrm{H}$. Peck and $\mathrm{I}$. G. Farlow. Specimens in the Schweinitz collection are immature and the spore characters therefore uncertain.

18. Godronia viburnicola Seaver, Mycologia 37: 349. 1945.

Apothecia erumpent in cespitose clusters of two to ten each, the individual apothecia black, reaching a diameter of $1 \mathrm{~mm}$., tapering below into a stem-like base; hymenium slightly concave, or nearly plane, similar in color to the outside of the apothecium; asci cylindric-clavate, reaching a length of $110 \mu$ and a diameter of 10-12 $\mu$, 8-spored; spores filiform, 3-4 4 85-100 $\mu$; paraphyses slender, branched, slightly enlarged above, and brownish.

On Viburnum cassinoides and Viburnum dentatum.

Type Locality: New Hampshire.

Distribution: Known only from the type locality.

Exsiccati: Reliq. Farlow. $154 a, 154 b$.

19. Godronia parasitica Seaver, Mycologia 24: 354. 1932. (Plate 138.)

Apothecia scattered on the under side of the living leaf, especially along the midrib, erumpent, at first globose, becoming expanded but with the mouth constricted, black, reaching a diameter of .3-.5 mm.; hymenium dingy, more or less concealed; asci clavate, reaching a length of 250-300 $\mu$ and a diameter of $27 \mu$; spores filiform, nearly as long as the ascus and about $4 \mu$ thick, many-septate, the number of the septa difficult to determine but more than 50 have been counted, reaching a length of $250 \mu$; paraphyses slender and rather freely branched.

On leaves of Tetrazygia longicollis.

Type Locality: Marmelade, Republic of Hayti.

Distribution: Known only from the type locality.

Illustrations: Mycologia 24: pl. 9. 
This is described from inaterial collected by Mr. George V. Nash, August 25, 1903. The species is distinguished by its huge asci and spores.

20. Godronia Castanopsidis Seaver, Mycologia 37: 351. 1945.

Apothecia thickly gregarious, erumpent through the bark, sessile, usually occurring singly, irregularly rounded, externally blackish, reaching a diameter of $2-3 \mathrm{~mm}$.; hymenium plane with a dark, elevated margin, pale-yellowish, or nearly white; asci subcylindric, tapering below into a stem-like base, attenuated above, reaching a length of $300 \mu$ and a diameter of $16-18 \mu$, 8 -spored; spores filiform, nearly as long as the ascus, hyaline, septate, $2 \mu$ in diameter; paraphyses filiform, branched, paleyellowish, scarcely enlarged above, $2-3 \mu$ in diameter.

On dead branches of Castanopsis chrysophylla.

Type Locality: Mount Shasta, California.

Distribution: Known only from the type locality.

Illustrations: Mycologia 37: 353 (lower figure).

21. Godronia pinicola (Reb.) Karst. Acta Soc. Fauna Fl. Fenn. $2^{6}: 144$. 1885. (Plate 139, Fig. 1.)

Pesiza pinicola Reb. Fl. Neom. 385. 1804.

Peziza pinicola solitaria Fries, Syst. My'c. 2: 113. 1822.

Heterosphaeria pinicola Fries, Summa Veg. Scand. 365. 1849.

Crumenula pinicola Karst. Myc. Fenn. 1: 210. 1871.

Apothecia erumpent-superficial, at first rounded, expanding and becoming shallow cup-shaped to scutellate, black with a purplish tinge (purple by transmitted light) furfuraceous, or slightly hairy, reaching a diameter of 2-3 $\mathrm{mm}$., sessile, or shortstipitate; hymenium concave, or nearly plane, similar in color to the outside of the apothecium; asci clavate, reaching a length of $120 \mu$ and a diameter of $12 \mu, 8$-spored; spores in a fascicle near the end of the ascus or irregularly disposed, fusiform, hyaline, 3-4 $\times 24-36 \mu$, becoming 1-3-septate; paraphyses slender, branched and forming a purplish epithecium.

On living branches of Pinus rigida, $P$. pungens and $P$. resinosa.

Type locality: Europe.

Distribution: New Hampshire to Pennsylvania; also in Europe.

Illustrations: Not. Soc. Fauna Fl. Fenn. 10: pl. 2, f. e; Mycologia 18: 182, f. 1, $B-C ; 37: 357$ (upper figure); Rab. Krypt.Fl. $1^{3}: 217, f$. 1-5; E. \& P. Nat. Pfl. $1^{1}: 234, f .178, A-C$. 


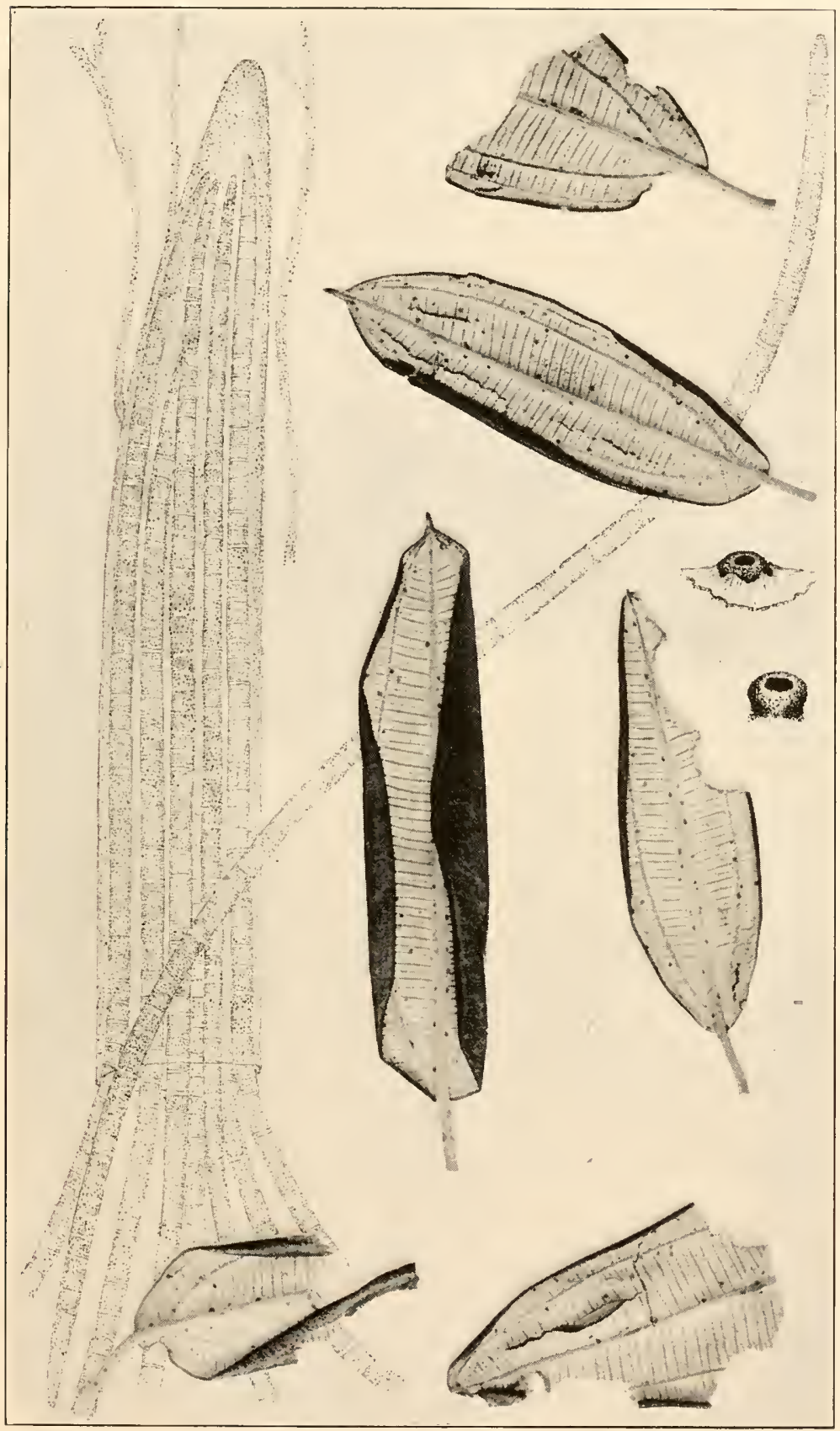

GODRONIA PARASITICA 

This was listed by L. O. Overholts as a Crumenula and possibly Crumenula pinicola (Reb.) Karst. in Mycologia 18: 181. It agrees reasonably well with the descriptions of that species except for the purplish color which was not mentioned by Karsten. It is, however, thought best to refer American specimens to that species.

\section{Godronia Zelleri Seaver, Mycologia 37:354. 1945.}

Atropellis pinicola Zeller \& Goodding, Phytopathology 20: 563. 1930. Not Godronia pinicola (Reb.) Karst. 1882.

Apothecia solitary, or gregarious, erumpent from outer cortical layers of bark, sessile, or on very short, central stalk, 2-4 $\mathrm{mm}$. in diameter, at first closed, opening by stellate or irregular clefts, leaving rather fimbriate margins, expanding discoid, usually rolling up from two sides when drying, externally pruinose, black to fuscous-black; hymenium pruinose, black; asci clavate, hyaline, staining brown with iodine, 8-spored, $8-13 \times 74-178 \mu$; spores filiform to acicular-clavate, hyaline continuous, guttulate, $1.5-3.5 \times 36-63 \mu$; paraphyses hyaline, hair-like, flexuous, exceeding the length of the asci by 32-38 $\mu$, tips slender, agglutinated, forming a dense epithecium with rosy and purplish tints in section.

Imperfect stage Neofuckelia pinicola Zeller \& Goodding (Mycologia 27: 464), usually associated with A. pinicola. Stromata erumpent, sometimes scattered, mostly gregarious, blackpulvinulate, sessile to short-stipitate, $.8-1.2 \mathrm{~mm}$. in diameter, containing 16-35 locules (pycnidia); conidiophores from entire inner surface of pycnidia, hair-like, simple, or branched; conidia hyaline, continuous, narrowly ellipsoid to bacillar, $1.7-3 \times 8^{-}$ $11 \mu$.

On living branches and trunks of Pinus lambertiana, Pinus monticola, Pinus Strobus, and P. contorta.

Type Locality: Oregon.

Distribution: Oregon to California, Montana and British Columbia.

Illustrations: Phytopathology 20: pl. $1, f . G-M$.

23. Godronia sororia Karst. Acta Soc. Fauna Fl. Fenn. $2^{6}: 145$. 1885. (Plate 139, Fig. 2.)

Crumenula sororia Karst. Myc. Fenn. 1: 211. 1871.

?Cenangium piniphilum Weir, Phytopathology 11: 295. 1921.

Atropellis pinicola Lohman \& Cash, Jour. Wash. Acad. Sci. 30: 357. 1940. 
Apothecia erumpent in congested masses $1 \mathrm{~cm}$. or more in diameter, the individual apothecia black, or with a purplish tinge (decidedly purple when teased out), irregularly cup-shaped, closing when dry and often irregularly hysteriform, externally furfuraceous; reaching a diameter of 2-4 mm.; hymenium concave, similar in color to the outside of the apothecium; asci clavate, tapering very gradually into a long, stem-like base, reaching a length of $135 \mu$ and a diameter of $12 \mu$, 8-spored; spores irregularly 2 -seriate above, fusoid, granular within, often slightly constricted near the center and appearing pseudoseptate, 5-6 $\times 15-22 \mu$; paraphyses very slender, branched above and forming a purplish epithecium.

Forming cankers on trunks of Pinus ponderosa.

Type locality: Europe.

Distribution: Idaho; also in Europe.

Illustrations: Phytopathology 11: 294, f. 1; 295, f. 2; Mycologia 37: 357,f. 3 (lower figure).

The only American material seen was collected in Idaho by J. R. Weir who writes: "forming cankers on 16-year old pine, causing a black deposit to form." As pointed out by Karsten that species is similar to $G$. pinicola so far as apothecial characters are concerned. The specific name selected by Karsten doubtless indicates that it is a sister species to that one which was listed in the same paper. Both have the blue character with transmitted light which, however, was not mentioned by Karsten. Examination of authentic material of both species shows it to be present. The spores in this species are shorter and broader than in that one. It also has a black subiculum not noted in $G$. pinicola.

\section{Godronia Treleasei (Sacc.) Seaver, Mycologia 37: 355. 1945.}

Scleroderris Treleasei Sacc. in Harriman Alaska Exped. 5: 24. 1904. Atropellis Treleasei Zeller \& Goodding, Phytopathology 20: 562. 1930.

Apothecia solitary, or gregarious, at first erumpent then entirely superficial, mostly sessile, at first pitcher-shaped, closed then scutellate, laciniately-dehiscent, $2.5-4 \mathrm{~mm}$. in diameter, expanding to 3-5 $\mathrm{mm}$. when moistened, outside and margins torn, dusky purplish-gray, carbonaceous, rugose; hymenium flatly-concave to convexly expanded, waxy, pinkish-cinnamon; asci clavate with obtusely acute apices, long-stipitate, 8-14 $\times$ 


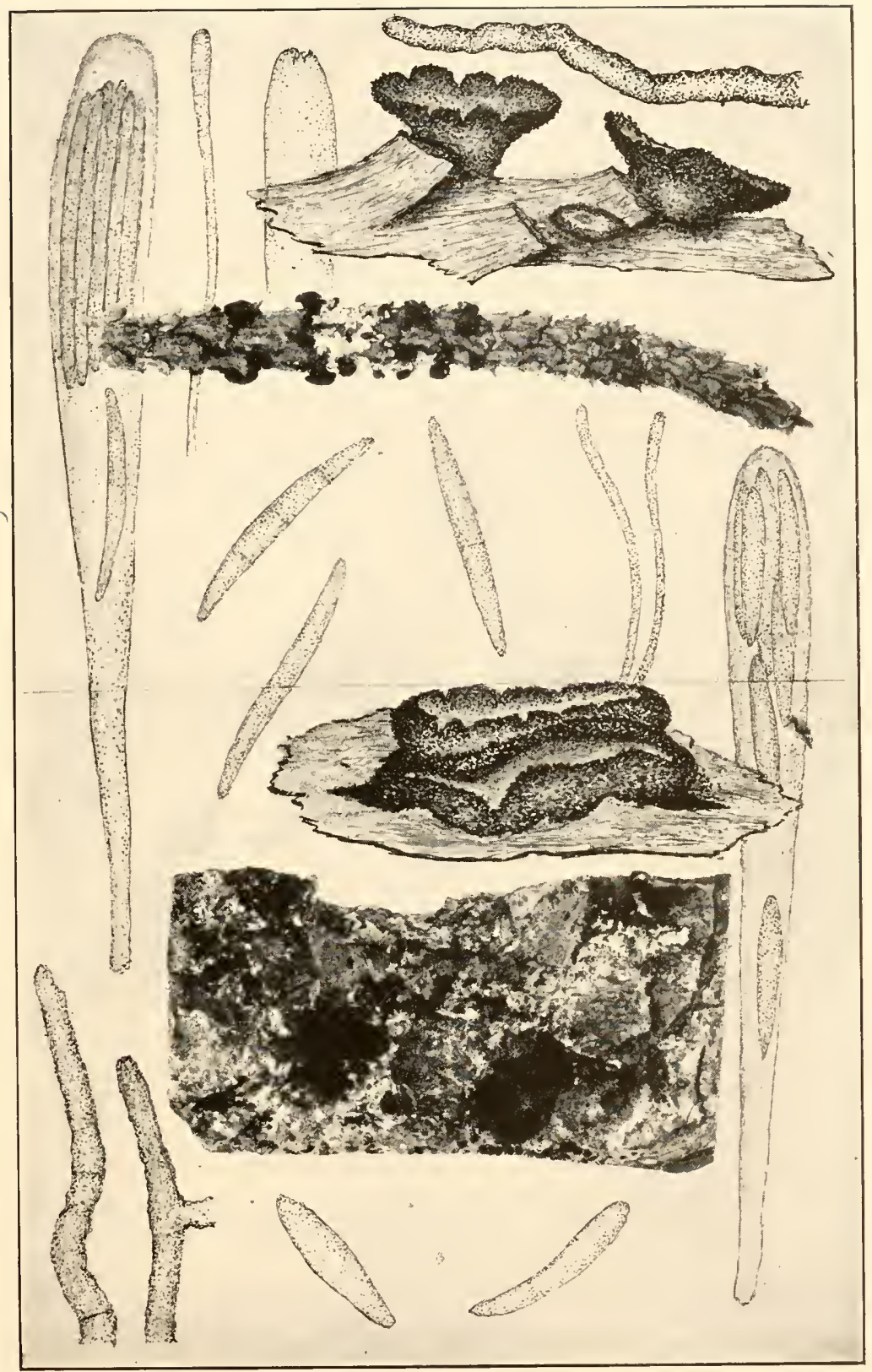

1. GODRONIA PINICOLA

2. GODRONIA SORORIA 

$178 \mu$, spores fasciculate in the upper part of the ascus, mostly filiform, often somewhat clavate, hyaline, continuous, $2-2.5 \times$ 42-60 $\mu$; paraphyses filiform, with simple, or incurved, furcate tips which very slightly exceed tips of asci, hyaline.

On bark of Picea sitchensis.

TyPe locality: Alaska.

Distribution: Known only from the type locality.

Illustrations: Harriman Alaska Exped. 5: pl. 3, f. 7 a-g; Phytopathology 20: pl. $1, f . A-E$.

25. Godronia jamaicensis Seaver, Mycologia 37: 356. 1945. (Plate 137, Fig. 1.)

Apothecia scattered, erumpent through the outer bark, finally appearing quite superficial, sessile, becoming expanded and scutellate with a wavy margin, externally brownish-black and verrucose, or wrinkled, reaching a diameter of $2 \mathrm{~mm}$.; hymenium plane, or slightly concave, surrounded by the upturned, blackish margin, pale-yellowish, or whitish; asci clavate, reaching a length of $175 \mu$ and a diameter of $10-12 \mu$, 8-spored; spores filiform, nearly as long as the ascus, $1.5-2 \mu$ in diameter, no septa apparent; paraphyses filiform, freely branched.

On bark of Juniperus.

Type Locality: Cinchona, Jamaica, altitude 4500-5400 feet. Distribution: Known only from the type locality.

Illustrations: Mycologia 37:353 (upper figure).

A liberal quantity of this material was collected by W. A. Murrill in 1908-1909. The host species was not named but since only one species of Jumiperus occurs in Jamaica it must have been that, Juniperus lucayana.

26. Godronia Abietis (Naumov) Seaver, Mycologia 37: 356. 1945.

Fusisporium Berenice Berk. \& Curt.; Berk. Grevillea 3: 147. 1875.

Cenangium pithyum Berk. \& Curt.; Berk. Grevillea 4: 4. 1875.

Scleroderris pitya Sacc. Syll. Fung. 8: 596. 1889.

Botryodiscus pinicola Shear, Bull. Torrey Club 34: 313. 1907.

Pycnocalyx Abietis Naumov, Bull. Soc. Oural. Sci. Nat. Trud. Bur. Mykol. 35:

34. 1915. (Citation from Groves.)

Ascocalyx Abietis Naumov, Bolesni Rast. 14: 138. 1925. (Citation from Groves.)

Apothecia erumpent, usually in clusters of three to six arising from a rounded, black, basal stroma, circular, or slightly wavy in 
outline, narrowed below, .3-1 $\mathrm{mm}$. in diameter, dull-black externally leathery to horny, becoming softer when moist; hymenium concave, becoming plane, smooth, gray to blackish, the margin infolded when dry; asci cylindric-clavate, shortstemmed, 8-spored, 9-11 $\times 65-100 \mu$; spores hyaline, ellipsoid to subclavate, irregularly 2-seriate, simple, becoming 1-3-septate, 4-5 $\times 14-22 \mu$; paraphyses hyaline, filiform, branched, $1.5-2 \mu$ in diameter, scarcely enlarged above.

Pycnidia often arising from the stroma, at first almost globose, opening and becoming cup-shaped, reaching $2 \mathrm{~mm}$. in diameter; pycniclial cavities immersed in the disc, ovoid, about 25-75 $\times 75-100 \mu$; conidiophores hyaline, tapering above, 1.5$2.5 \times 8-12 \mu$; conidia hyaline, elongated to subfiliform, straight, or curved, simple, becoming 1-5-septate, 3-5 × 16-24 $\mu$.

On species of Abies.

Type locality: Europe.

Distribution: New Hampshire to Michigan and North Carolina; also in Europe.

Illustrations: Mycologia 28: 452, f. $1 ; 454, f .2 ; 457, f .3-6$.

27. Godronia abieticola (Zeller \& Goodding) Seaver, comb. nov. Scleroderris abieticola Zeller \& Goodding, Phytopathology 20: 565. 1930.

Apothecia single, or gregarious, from an erumpent stroma, short-stipitate, or subsessile, .5-1.2 $\mathrm{mm}$. in diameter, at first closed, spherical, or ellipsoid, opening by a stellate, or irregular cleft, then cup-shaped to expanded, externally smooth to flaky, grayish-black to shiny-black; hymenium shiny-slate to shinyblack; asci clavate, reaching a length of 118-135 $\mu$ and a diameter of 9-14 $\mu, 8$-spored, or rarely 4-spored; spores filiform with many oil-drops, finally distinctly 5-8-septate, 3.5-4.5 $\times 40-67 \mu$; paraphyses filiform, slightly enlarged above, somewhat agglutinated but not forming an epithecium.

On cankers on living branches and twigs of Abies grandis and Abies amabilis.

TyPE LOCALITY: Oregon.

Distribution: Oregon.

Illustrations: Phytopathology 20: pl. $1, N-R$.

28. Godronia abietina (Ellis \& Ev.) Seaver, comb. nov.

Scleroderris abietina Ellis \& Ev. Am. Nat. 31: 427. 1897.

Apothecia erumpent-superficial, black, subconical, about .5 $\mathrm{mm}$. in diameter; hymenium plane, or convex, black; asci 
clavate-cylindric, reaching a length of $70 \mu$ and a diameter of $15 \mu, 8$-spored; spores fasciculate, clavate-cylindric, containing numerous oil-drops, finally beconing multiseptate, $3-4 \times 50-$ $65 \mu$; paraphyses filiform.

On bleached bark of fir trees, Abies sp.

Type locality: Newfoundland.

Distribution: Known only from the type locality.

Two fine specimens of this species are in The New York Botanical Garden both collected by Rev. A. C. Waghorne in Newfoundland and both apparently a part of the type specimen.

\section{Doubtful And Excluded Species}

Godronia rugosa Ellis \& Ev. Jour. Mỵc. 8: 70. 1902. This species was described by Ellis from material collected at Tuskegee, Alabama, August, 1900 (G. IV. Carver 779). The spores are described as fusoid, arcuate, $45-55 \times$ 3-3.5 $\mu$. Examination of the Ellis material showed such spores but no trace of asci. It is probably not an ascomycete.

Godronia Juniperi Rostr. Medd. Grónl. 3: 611. 1891. Apothecia scattered, sessile, hard, black, reaching a diameter 1-2 mm.; asci reaching a length of 75-85 $\mu$ and a diameter of 7-8 $\mu$; spores filiform, $2 \times 35-40 \mu$; paraphyses filiform. On wood of Juniperus. Known only from the type locality in Greenland.

Godronia rhabdospora (Berk. \& Curt.) Sacc. Sy.ll. Fung. 8: 602. 1889; Tympanis rhabdospora Berk. \& Curt.; Berk. Grevillea 4: 3. 1875. Spores said to be filiform. Reported on Acer from New England. No material seen.

Atropellis apiculata Lohman, Cash \& Davidson, Jour. Wash. Acad. Sci. 32: 297. 1942. Said to differ from other species on Pinus in that the apothecia are chocolate brown rather than blue as in other specimens on Pinus. No specimens have been seen.

Atropellis arizonica Lohman \& Cash, Jour. Wash. Acarl. Sci. 30: 261. 1940. On stems of Pinus ponderosa. Said to differ from other species or Pinus mainly in the size of the spores.

Atropellis tingens Lohman \& Cash, Jour. Wash. Acad. Sci. 30: 257. 1940. On various species of Pinus. Said to be suggestive of Atropellis pinicola but differing mainly in spore size. No material has been seen.

9. PEZICULA Tul. Fung. Carp. $3: 182.1865$.

Neofabraea Jackson, Oregon Agr. Exp. Station, Bienn. Crop. Pest and Hort. Rep. 1911-1912: 187. 1913.

Conidial stage consisting of a basal fleshy stroma of the Myxosporium type on the surface of which the conidia are produced, or with definite conical, or flask-shaped pycnidia of the Sphaeronema form in which the conidia are produced; conidiophores variable in form and length, often very long; conidia broad-ellipsoid, usually granular and hyaline; microconidia of ten present. 
Apothecia usually occurring in cespitose clusters on a stromatic base, sessile, or with a short, thick, stem-like base, usually light-colored, whitish, or yellowish, rarely exceeding $1 \mathrm{~mm}$. in diameter, tubercular, or discoid, usually soft and fleshy; asci broad-clavate, usually 8-spored; spores ellipsoid, simple, or becoming tardily several-septate; paraphyses hyaline, or subhyaline and usually free, not agglutinated and not usually forming an epithecium.

Type species, Peziza carpinea Pers.

On non-coniferous hosts.

On Betulaceae.

On Carpinus caroliniana.

1. P. carpinea.

On Corylus rostrata.

2. P. corylina.

On Alnus or Betula.

Spores small, fusoid.

3. P. alnicola.

Spores large ellipsoid or ovoid.

Spores 8-12 12 18-32 $\mu$.

4. P. aurantiaca.

Spores 7-10 10 15-20 $\mu$.

5. P. Alni.

On Rosaceae.

On Crataegus.

Spores 15-17 17 35-48 $\mu$.

Spores $10-12 \times 20-25 \mu$.

6. P. crataegicola.

7. P. olivascens.

Not on Crataegus.

Apothecia at first club-shaped, on Amelanchier.

8. P. pruinosa.

Apothecia at first subglobose.

On Rubus spp.

On Rosa sp.

9. P. Rubi.

10. P. Brenckleana.

On Aceraceae.

Spores ellipsoid 20-27 $\mu$ long.

Conidial stage spike-like.

11. P. spiculata.

Conidial stage not spike-like.

12. P. acericola.

Spores subglobose $6-8 \times 7-10 \mu$.

13. P. spicata.

On Cornaceae.

Spores 7-8 $820 \mu$.

14. P. cormicola.

Spores $10-13 \times 28-34 \mu$.

15. P. Corni.

On Salicaceae.

Spores $10-12 \times 25-30 \mu$.

16. P. ocellata.

Spores 5-6 6 18-20 $\mu$.

17. P. Populi.

On various other hosts.

Apothecia reddish-purple, on Castanea.

18. P. purpurascens.

Apothecia ochraceous.

On Viburnum.

19. P. minuta.

On Hamamelis.

20. P. Hamamelidis.

On Rhammus.

21. P. Morthieri.

On coniferous hosts.

On branches of Pinus and Abies.

22. P. livida.

On leaves of Abies. 
1. Pezicula carpinea (Pers.) Tul. Fung. Carp. 3: 183.1865. (Plate 140.)

? Tubercularia fasciculata Tode, Fungi Meckl. 1:20. 1790.

Pesiza carpinea Pers. Syn. Fung. 673. 1801.

Octospara paradoxa Hedwig, Obs. Bot. 1: 13. 1802.

Peziza Betuli Alb. \& Schw. Consp. Fung. 309. 1805.

Ditiola paradoxa Fries, Syst. Myc. 2: 171. 1822.

Stictis Betuli Fries, Syst. Myc. 2: 193. 1822.

Cycledum Carpini Wallr. Fl. Crypt. Germ. 2: 512. 1833.

Dermatea carpinea Fries, Summa Veg. Scand. 362. 1849.

Discella discoidea Cooke \& Peck; Peck, Ann. Rep. N. Y. State Mus. 28: 58. 1876.

Discula Peckiana Sacc. Syll. Fung. 3: 675. 1884.

Ombrophila paradoxa Sacc. Syll. Fung. 8: 620. 1889.

Ocellaria Betuli Rehm in Rab. Krypt.-Fl. ${ }^{3}$ : 136. 1888.

?Dermatella scatinus Morgan, Jour. Myc. 10: 98.1904.

Pezicula fasciculata Dearn. \& House, Bull. N. Y. State Mus. 243: 95.1923.

Cryptosporiopsis fasciculata Petrak, Ann. Myc. 21: 187. 1923.

Conidial stage consisting of a soft, fleshy, erumpent stroma on the surface of which the coniclia are produced; conidiophores slender, often several times the length of the spore, strongly swollen just below the point of attachment; conidia broadellipsoid, simple, 10-12 $\times 20-24 \mu$.

Apothecia thickly gregarious, springing in cespitose clusters from an immersed, fleshy stromatic base, the indiviclual apothecia tuberculate, or expanderl and subdiscoid, with a short, stem-like base, often distorted by mutual pressure, reaching a diameter of 1-3 mm., pale-yellowish; hymenium plane, or convex, similar in color to the outside of the apothecium; asci clavate, reaching a length of 150-200 $\mu$ and a diameter of 15-20 $\mu$, 8-spored; spores ellipsoid, straight, or slightly curved, granular within, for a long time simple but often becoming 1-3-septate, $10-12 \times 18-30 \mu$; paraphyses slender, branched, enlarged above, reaching a diameter of $5 \mu$, not forming an epithecium.

On trunks and branches of Carpinus caroliniana.

Type Locality: Europe.

Distribution: Massachusetts to Missouri and Pennsylvania; also in Europe.

Illustrations: Tode, Fungi Meckl. pl. 4, f. 32; Hedwig, Obs. Bot. 1: pl. 8; Rab. Krypt.-Fl. 13: 243, f. 1-6; Ann. Sci. Nat. III. 20 : pl. 16, f. 17, 18; Mycologia 25: pl. 22.

Exsiccati: Ellis, N. Am. Fungi 67, 67 (b) (as Dermatea cornea); Ellis \& Ev. N. Am. Fungi 2623, 27+1, 3333; Shear, N. Y. 
Fungi 93; Rav. Fungi Car. 5: 38; Rab.-Winter, Fungi Eu. 3463 (From Missouri); Wilson \& Seaver, Ascom. 91.

\section{Pezicula corylina Groves, Mycologia 30:47. 1938.}

Excipula turgida Fries, Syst. Myc. 2: 189. 1822.

Cenangium turgidum Duby, Bot. Gall. 2: 736. I 830.

Catinula turgida Desm. Ann. Sci. Nat. III. 18: 37t. 1852.

Sphaeronema Coryli Peck, Ann. Rep. N. Y. State Mus. 24: 85. 1872.

Conidial fruiting bodies erumpent, thickly scattered, or more or less in rows, mostly separate, sometimes two or three together, cylindric to cylindric-conic, or compressed when dry and subhysteriform, opening out widely when moist, .2-.5 mm. in diameter, .3-.5 mm. in height, black, or dark-olivaceous, hard, brittle, fleshy-leathery when moist; conidia ellipsoid, $8-10 \times 17-28 \mu$.

Apothecia erumpent, scattered, or more or less in rows, separate, or cespitose, circular, sometimes crowded, sessile, narrowed below, pale-yellow, slightly pruinose when dry, much brighter when moist, close to sulphur-yellow, minute, .2-.5 mm. in diameter, .2-.4 mm. in height, soft-waxy in consistency, more fleshy when moist; hymenium at first concave, then plane to convex, slightly pruinose, pale-yellow to slightly reddish, margin at first forming a delicate lighter border, later disappearing; asci cylindric-clavate, short-stalked, usually 8-spored, occasionally 4-spored, 15-20 × 85-125 $\mu$; spores oblong-ellipsoid, hyaline, straight, or slightly curved, simple, or 1 -septate, irregularly biseriate, $6-10 \times 15-27 \mu$; paraphyses hyaline, filiform, simple, or branched, septate, $2-2.5 \mu$ in diameter, the tips swollen to $3.5 \mu$, forming a slight epithecium.

On Corylus rostrata.

Type Locality: Bear Mountain, Temagami Forest Reserve, Ontario, Canada.

Distribution: Pennsylvania to Washington and Canada; also in Europe.

Illustrations: Mycologia 30:48, f. 1; 49, f. 2.

Exsiccati: Reliq. Farlow. 106 (as Cenangium turgidum); Ellis, N. Am. Fungi 949; Ellis \& Ev. N. Am. Fungi 1622.

3. Pezicula alnicola Groves, Mycologia 32: 120.1940.

?Cenangium tennesseense Kanouse, Mycologia 33: 462. 1941.

Conidial stage inconspicuous, developing beneath the outer bark splitting it but scarcely breaking through, the conidia 


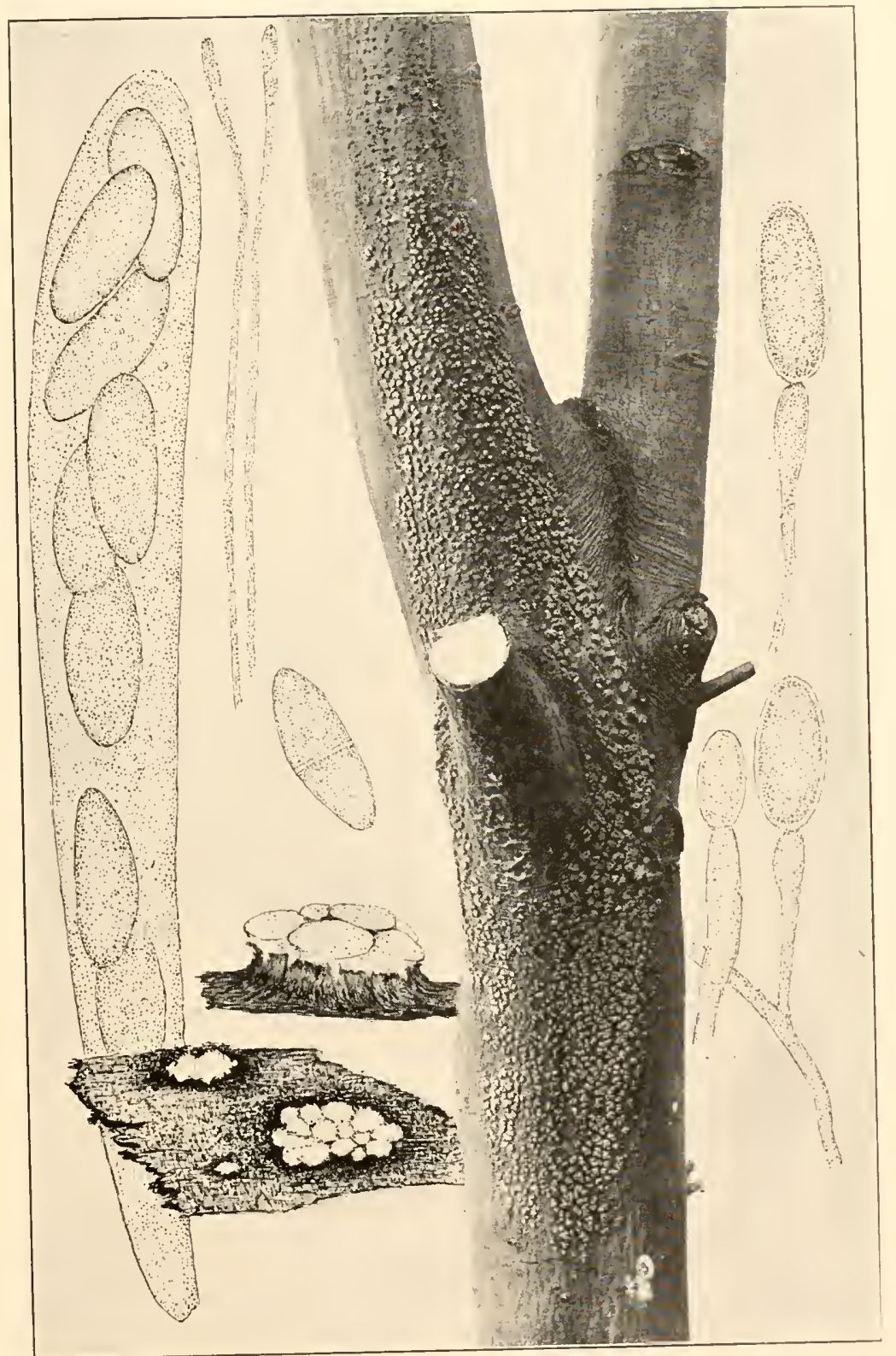

PEZICULA CARPINEA 

emerging in whitish masses, the stroma usually circular, reaching a diameter of .6 mm., slightly conical to cushion-shaped; conidiophores exposed on the upper surface, or in widely opening cavities, hyaline, cylindric, pointed, simple, or septate, not branched, $1.5-2.5 \times 10-30 \mu$; conidia elongate-fusiform to subfiliform, hyaline, 5-7-septate, almost straight, sickle-shaped, or sigmoid, $4-5 \times 35-53 \mu$.

Apothecia erumpent, scattered, or more often in clusters of five to ten or occasionally more, circular, or irregular from crowding, sessile, narrowed below, reaching a diameter of $1 \mathrm{~mm}$., and half as high; hymenium concave to plane, or slightly convex, pinkish-cinnamon, slightly pruinose; asci cylindric to cylindricclavate, short-stalked, 8-spored, reaching a length of 70-110 $\mu$ and a diameter of 8-12 $\mu$; spores ellipsoid-fusoid, hyaline, simple, becoming 1-3-septate, straight, or slightly curved, 1seriate, or becoming irregularly 2-seriate, 3.5-5 × 15-20 $\mu$, rarely larger; paraphyses filiform, simple, or branched, 1.5-2 $\mu$ in diameter, swollen above to $5 \mu$ and forming a slight epithecium.

On twigs and branches of Alnus incana and Betula lutea.

Type locality: Temagami Forest Reserve, Ontario, Canarla.

Distribution: Ontario to Quebec; also in Europe (as Pezicula $A \ln i)$.

Illustrations: Mycologia 32: 114, f. 3; 116, f. 8,9,

4. Pezicula aurantiaca Rehm, Ber. Bayer. Bot. Ges. 13: 198. 1912.

Habrostictis aurantiaca Rehm, Ber. Naturh. Ver. Augsburg 26: 67. 1881.

Ocellaria aurantiaca Rehm in Rab. Krypt.-Fl. 1²: 135. 1888.

Conidial stage forming beneath the outer bark raising and splitting it but scarcely breaking through but the conidia emerging in whitish masses, the stromata circular, or slightly elongated, reaching a diameter of $1 \mathrm{~mm}$., obtusely conical, or cushionshaped to discoid; conidiophores borne more or less exposed over the upper surface, or in widely open cavities, hyaline, cylindric to subclavate, simple, or occasionally branched, reaching a length of $15-25 \mu$ (rarely more) and a diameter of 3-5 $\mu$, sometimes swollen below the point of attachment to $7 \mu$; conidia ellipsoid to ovoid, hyaline, simple, or occasionally 1 -3-septate, straight, or slightly curved, one end with a truncate apiculus, $12-16 \times 25-40 \mu$; microconidia (in culture) filiform, straight, or curved, $1.5-2 \times 6-14 \mu$. 
Apothecia erumpent or subimmersed, occurring singly, or occasionally two or three in a cluster, circular, or somewhat irregular, sessile, scarcely narrowed below, 1-2 mm. in diameter and scarcely half as high; hymenium concave to plane, or slightly convex, brownish, or olive-brown, slightly pruinose; asci cylindric-clavate, reaching a length of $100-140 \mu$ and a diameter of 15-20 $\mu$, short-stalked; spores ellipsoid to ovoid, hyaline, straight, or slightly curved, simple, or occasionally 1-3-septate, irregularly 2-seriate, 8-12 × 18-32 $\mu$; paraphyses filiform, hyaline, simple, or branched $1.5-2 \mu$ in diameter, enlarged above to $5 \mu$.

On Almus crispa var. mollis.

Type locality: Europe.

Distribution: Toronto, Canada; also in Europe.

Illustrations: Mycologia 32: 114, f. 1-3; 116, $f .5$.

5. Pezicula Alni Rehm, Ber. Bayer. Bot. Ges. 13: 199. 1912.

Dermatella quercina var. Alni Sacc. Syll. Fung. 8: 490. 1889.

Dermatea Alni Rehm in Rab. Krypt.-Fl. 1³: 252. 1889.

Conidial stage forming beneath the outer bark and splitting it but scarcely breaking through, slightly conical, or cushionshaped, less than $1 \mathrm{~mm}$. in diameter, blackish; conidiophores cylindric to clavate, simple, or branched, 2.5-4 $\times 12-30 \mu$, produced on the outer surface of the stroma; conidia ovoid to ellipsoid, or subfusiform, hyaline, simple, one end with a small, truncate apiculus, 5-7 $\times 14-18 \mu$.

Apothecia erumpent, mostly scattered, occasionally with two or three in a cluster, circular, or slightly elongated, sessile but narrowed below, reaching a diameter of $1 \mathrm{~mm}$. and half as high; hymenium plane to convex, slightly pruinose, brownish-ochraceous; asci broad-clavate, 4-8-spored, mostly 8-spored, reaching a length of $100-130 \mu$ and a diameter of $18-20 \mu$; spores ellipsoid, irregularly 2-seriate, at first simple, becoming 1-3-septate, 7-10 $\times 15-25 \mu$; paraphyses filiform 2-2.5 $\mu$ in diameter.

On species of Almus, Alnus crispa var.mollis, A. incana.

Type locality: Europe.

Distribution: Nova Scotia to Michigan and South Carolina; also in Europe.

Illustrations: Mycologia 32: 114, f. 2; 116, f. 6, 7 .

Exsiccatr: Rav. Fungi Car. 5: 46 (as Patellaria rhabarbarina). 


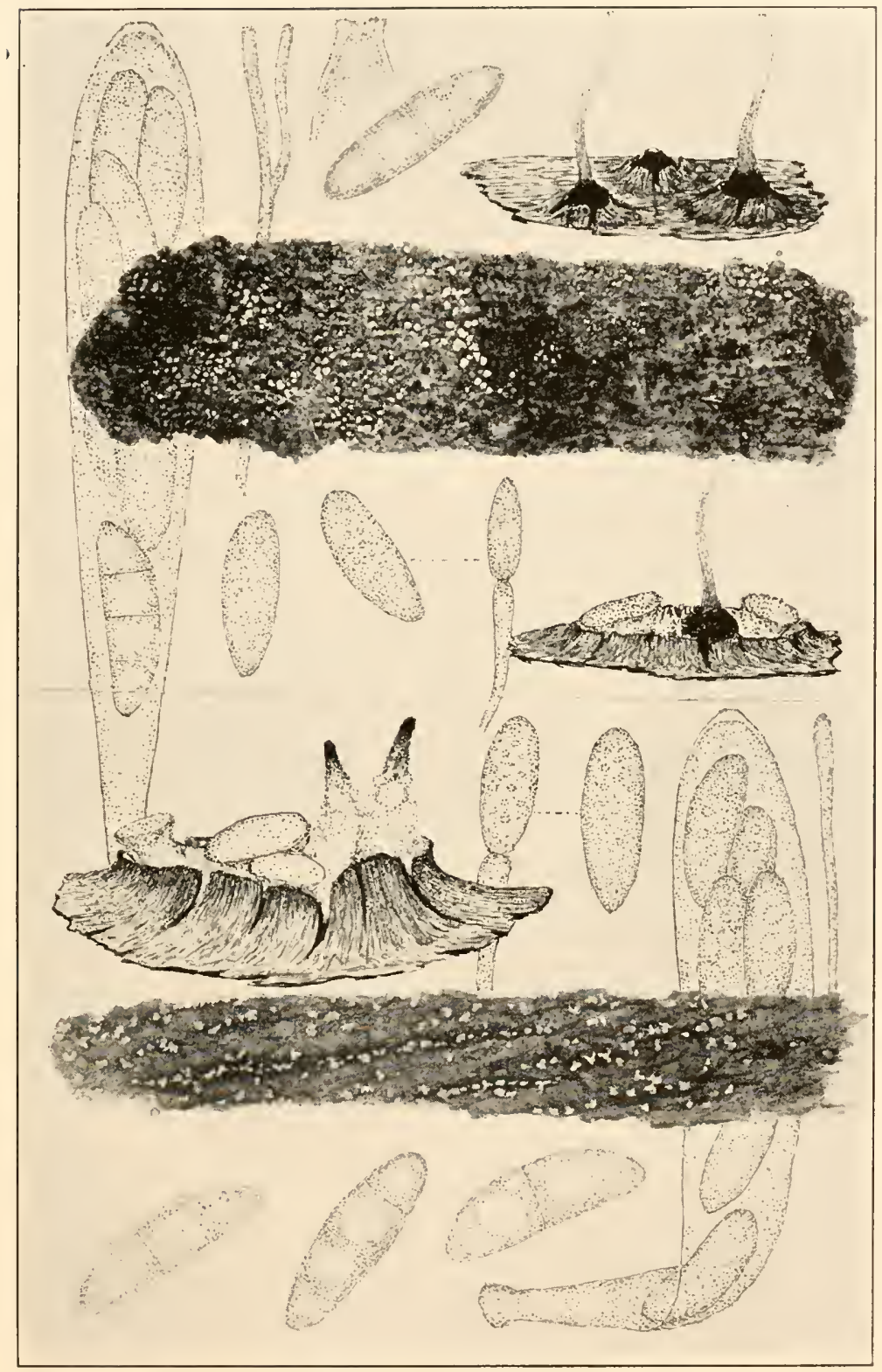

1. PEZICULA ACERICOLA

2. PEZICULA SPICULATA 

6. Pezicula crataegicola (Durand) Groves, Mycologia 38: 414. 1946.

Dermatea crataegicola Durand, Jour. Myc. 10: 100. 1904.

Apothecia erumpent, occurring singly, or two to four together arising from a common stroma, sessile, or narrowed into a stemlike base .5-1 $\mathrm{mm}$. in diameter, externally mealy-pruinose, rhubarb-color; hymenium plane or nearly so, or even slightly convex, yellowish-olivaceous; asci broad-clavate, attenuated into a short stem, at first filled with a homogeneous, granular protoplasm, reaching a length of $150-165 \mu$ and a diameter of 25-30 $\mu$, 8-spored; spores irregularly 2 -seriate, or obliquely 1 seriate, hyaline, smooth, simple, oblong-ellipsoid, with a central oil-drop, $15-17 \times 35-48 \mu$; paraphyses filiform, branched, enlarged above, olivaceous-yellow, $6-8 \mu$ in diameter above, the ends free, not glued together to form an epithecium.

On branches of Crataegus.

Type locality: London, Ontario, Canada.

Distribution: Known only from the type locality.

Exsiccatı: Ellis \& Ev. Fungi Columb. 1917.

This differs from Pezicula olivascens mainly in the size of the spores. This may be due to the immaturity of the material in $P$. olivascens which was collected very early in the season and the spores seemed poorly developed.

7. Pezicula olivascens (Rehm) Seaver, comb. nov.

Dermatea olivascens Rehm, Ann. Myc. 5: 80. 1907.

Apothecia scattered, occurring singly, or two or three together, erumpent, subglobose becoming expanded, sessile, or with a very short, stem-like base, yellowish with an olivaceous tinge, $.5-1.5 \mathrm{~mm}$. in diameter; asci broad-clavate, at first densely granular within, reaching a length of $150 \mu$ and a diameter of 20-25 $\mu, 8$-spored; spores broad-ellipsoid, simple (in the specimens examined), irregularly 2 -seriate, $10-12 \times 20-25 \mu$, surrounded with much granular material, hyaline; paraphyses filiform, $2 \mu$ in diameter, branched, slightly enlarged above, the ends free, not glued together into a distinct epithecium.

On dead branches of Crataegus still on the tree.

Type locality: Mt. Pleasant, Iowa.

Distribution: Known only from the type locality.

Illustrations: Bull. Lab. Nat. Hist. State Univ. Iowa 6: pl. $38, f .1$. 
Exsiccati: Rehm, Ascom. 1686; Wilson \& Seaver, Ascom. 2.

This species was described from material collected in $\mathrm{Mt}$. Pleasant, Iowa in February. The ascospores appear to be more or less immature. Whether they later became septate is uncertain. The species is very close to Pezicula crataegicola (Durand) Groves but seems to differ in its smaller ascospores. This apparent difference may be due to the immaturity of the spores. Other characters seem to conform very closely with that species.

8. Pezicula pruinosa (Peck) Farlow; Thaxter, Mycologia 14: 102. 1922.

Sphaeronema pruinosum Peck, Ann. Rep. N. Y. State Mus. 24: 85. 1875.

Dermatea pruinosa Petrak, Ann. Myc. 20: 196. 1922. Not D. pruinosa (Ellis \& Ev.) Sacc. 1889.

Lagynodella pruinosa Petrak, Ann. Myc. 20: 207. 1922.

Conidial stage (Sphaeronema) consisting of conical, or spinulose, black, pruinose pycnidia which spring from a stromatic base, reaching a length of $1 \mathrm{~mm}$.; conidia broad-ellipsoid, 8-9 $\times$ 20-24 $\mu$.

Apothecia scattered, erumpent, short-stipitate, occurring singly or in cespitose clusters of three to five apothecia each springing from a stromatic base, at first club-shaped, expanding and becoming discoid, or subdiscoid above, pale cinnamonbrown, reaching a diameter of $1 \mathrm{~mm}$; hymenium plane, or concave, similar in color to the outside of the apothecium; stem short, almost as thick as the diameter of the apothecium, densely albopruinose, reaching a length of $2 \mathrm{~mm}$.; asci clavate, reaching a length of 95-110 $\mu$ and a diameter of 18-21 $\mu, 8$-spored; spores 1-2-seriate, subellipsoid, usually slightly curved, simple, or becoming 1-3-septate, $8-9 \times 22-25 \mu$; paraphyses filiform, simple, or branched, reaching a diameter of $1 \mu$.

On Amelanchier canadensis, A. alnifolia and unnamed species of Amelanchier.

Type Locality: Sharon, Massachusetts.

Distribution: New York,- Massachusetts, North Dakota, Idaho, and Montana.

Exsiccati : Reliq. Farlow. 135 a.b.; Brenckle, Fungi Dak. 450.

9. Pezicula Rubi (Libert) Rab. in Fungi Eu. 2122. 1876.

Patellaria Rubi Lib. Pl. Crypt. Ard. 231. 1834.

Peziza ardennensis Mont. Ann. Sci. Nat. II. 5: 287. 1836. 


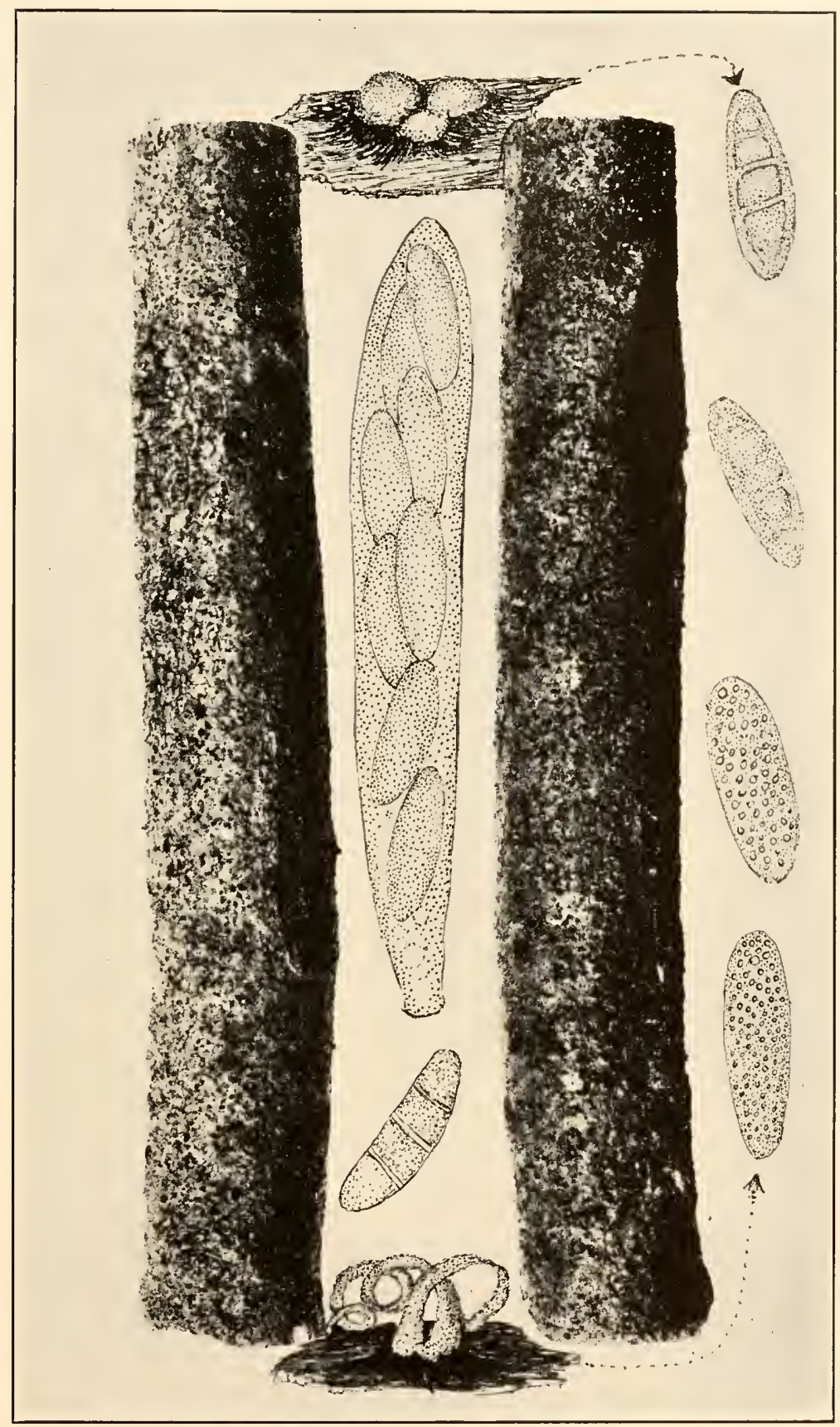

PEZICULA CORNICOLA 

Peziza rhabarbarina Berk. in Hooker, Engl. Fl. 52: 197. 1836.

Lachnella rhabarbarina Fries, Summa Veg. Scand. 365. 1849.

Helotium Rubi Spree in Rab. Fungi Eu. 717. 1865.

Pezicula rhabarbarina Tul.; Fuckel, Symb. Myc. 278. 1869.

Dermatea rhabarbarina Phill. Brit. Discom. 343. 1887.

Dermatea Rubi Rehm in Rab. Krypt.-F1. 1³: 258. 1889.

Apothecia usually occurring singly, at first subglobose, then expanding and becoming shallow cup-shaped, finally discoid, reaching a diameter of $1 \mathrm{~mm}$.; hymenium plane, or convex, with a yellowish-brown, mealy coating; asci clavate, reaching a length of $90-110 \mu$ and a diameter of $16-20 \mu, 8$-spored; spores irregularly 2 -seriate, long-ellipsoid, becoming 1 -2-septate, $6-7 \times 18-$ $24 \mu$; paraphyses slender, branched, the enlarged ends forming an epithecium and agglutinated together with a yellow matrix.

On Rubus idaeus and other species of Rubus.

Type locality: Europe.

Distribution: Maine to West Virginia and Ohio; also in Europe.

Illustrations: Ann. Sci. Nat. II. 5: pl. 13, f. 5; Boud. Ic. Myc. pl. 560.

Exsiccati: Shear, N. Y. Fungi 95; Reliq. Farlow. 114, 858.

10. Pezicula Brenckleana Seaver, nom. nov.

Cenangium Rosae Sacc. Atti Soc. Veneto Sci. Nat. Padova 2²: 160.1873.

Not Cenangium Rosae Schw. 1832.

Pezicula Rosae Sacc, Michelia 2: 332. 1881.

Dermatea Rosae Rehm in Rab. Krypt.FI. 1²: 259. 1889.

Apothecia occurring singly, or several in cespitose groups, at first rounded, opening and becoming shallow cup-shaped, then discoid, at first yellowish, becoming brown, reaching a diameter of .5-1 mm.; hymenium concave, plane, or slightly convex, yellowish-brown; asci clavate, reaching a length of 90-120 $\mu$ and a diameter of 16-18 $\mu, 8$-spored; spores irregularly 2-seriate, ellipsoid, 7-9 $\times 20-24 \mu$, finally becoming $1-3$-septate; paraphyses slender, enlarged above, the tips surrounded with a yellowish matrix.

On species of Rosa.

Type locality: Europe.

Distribution: North Dakota; also in Europe.

Illustrations: Sacc. Atti Soc. Veneto Sci. Nat. Padova $2^{2}$ : pl. 16, f. 19-22.

Exsiccati: Brenckle, Fungi Dak. 392. 
Only one specimen of this species has been seen from North America. While the spores and asci are slightly smaller than indicated in European descriptions, the specimens appear to be otherwise identical. While placed in the genus Pezicula by Saccardo, the conidial stage has not been observed. Since the name given this species is untenable we dedicate the species to Dr. Brenckle who collected the only specimen seen from America.

11. Pezicula spiculata Seaver, Mycologia 25: 146. 1933. (Plate 141, Fig. 2.)

The conidial stage (Sphaeronema) accompanies the apothecial both springing from a floccose stroma; pycnidia large and spikelike, black but covered with white flakes, reaching a length of $1.5 \mathrm{~mm}$., swollen below; macroconidia $10 \times 20-24 \mu$ and borne on sporophores equalling or exceeding the length of the spore.

Apothecia cespitose in rounded or elongated clusters, or rarely occurring singly, reaching a diameter of $1 \mathrm{~mm}$., paleyellowish, sessile, or tapering into a short, stem-like base; hymenium slightly concave, or plane, not darker than the outside of the apothecium; asci broad-clavate, reaching a length of $120 \mu$ and a diameter of 16-18 $\mu, 8$-spored; spores irregularly 2-seriate, ellipsoid and often slightly curved, $8 \times 24-27 \mu$, becoming 1-3-septate; paraphyses slender, slightly enlarged above, the ends free, branched, hyaline, about $2 \mu$ in diameter.

On Acer (spicatum?).

Type Locality: Near Ithaca, New York.

Distribution: Known only from the type locality.

Illustrations: Mycologia 25: pl. 23 (lower figure).

So far as the ascigerous stage of this species is concerned it can scarcely be distinguished from Pezicula acericola. However, the two are apparently entirely distinct in their conidial stages.

12. Pezicula acericola (Peck) Sacc. Atti Ist. Veneto VI. 3: 725. 1885. (Plate 141, Fig. 1.)

?Peziza cinnamomea D. C. in Pers. Myc. Eu. 1: 268. 1822.

Nodularia acericola Peck, Ann. Rep. N. Y. Mus. 25: 98. 1873.

Dermatea carnea Cooke, \& Ellis, Grevillea 5: 32. 1876.

?Dermatea cinnamomea Phill. Brit. Discom. 342. 1887. Not Cooke \& Peck 1875.

Dermatea simillima Ellis \& Ev. Proc. Acad. Sci. Phila. 1893: 451. 1893.

Dermatea Alni f. Aceris Rehm in Rab. Krypt-Fl. 13 ${ }^{3}: 252.1889$. 
Apothecia erumpent in cespitose clusters of three to eight each, the individuals seldom exceeding $1 \mathrm{~mm}$. in diameter, sessile or subsessile, pale-yellow at least when young; hymenium plane, or slightly convex, the margin rather indistinct, similar in color to the outside of the apothecium, becoming concave with age; asci clavate, reaching a length of 90-130 $\mu$ and a diameter of 15-20 $\mu, 4-8$-spored, gradually tapering below into a slender, stem-like base; spores irregularly 2-seriate above, ellipsoid, straight, or curved, at first simple, often becoming 3-4-septate, $8 \times 20-26 \mu$, hyaline, or subhyaline; paraphyses slender, enlarged above and often flexuose, hyaline, or slightly colored with age.

On dead branches of Acer spicatum and Acer rubrum.

Type locality: North Elba, New York.

Distribution: New York to Newfoundland and Ontario, Canada.

Illustrations: Grevillea 5: pl.75,f. 9 (as Dermatea carnea); Mycologia 25: pl. 23 (upper figure in part).

Exsiccati: Ellis, Nova-Caesar, 56; N. Am. Fungi 67; Ellis \& Ev. N. Am. Fungi 246; Barth. Fungi Columb. 3+20; Reliq. Farlow. $112 a, b$; Thüm. Myc. Univ. 978 (from New York); Rehm, Ascom. 1901 (from Ontario, Canada).

In a previous paper (Mycologia 25: 145. 1933) the writer concluded from herbarium observations that Nodularia acerciola Peck and Tympanis acerina Peck were identical, the latter being aged, discolored specimens of the former. The two were often found growing in the same clump; the ascospores were identical and both were accompanied by the Sphaeronema stage.

J. W. Groves, however, disagrees and regards Tympanis acerina Peck and Nodularia acericola Peck as two distinct species and treats Sphaeronema acerinum as the coniclial stage of the former. He states that the conidial stage of Pezicula acericola is a very inconspicuous fleshy stroma developing beneath the outer bark.

Groves further states that the oblong-ellipsoid conidia of Tympanis acerina are similar in form to conidia of species of the related genus Pezicula and this has led to confusion regarding the specific identity and conidial relations of this species and of species of Pezicula occurring on Acer. This also suggests that Dermea acerina may be a discolored Pezicula. 
13. Pezicula spicata Ellis \& Ev. Bull. Torrey Club 25: 506. 1898.

Apothecia scattered, usually occurring singly, erumpent, through the ruptured epidermis but scarcely protruding above its surface, . $35-.5 \mathrm{~mm}$. in diameter, dull watery-white, yellowish when dry; hymenium slightly concave when dry, the margin a little darker undulated; asci broad-clavate, reaching a length of 60-70 $\mu$ and a diameter of $12-15 \mu$, with a short, abrupt, stemlike base, 8-spored; spores irregularly 2-seriate, subglobose, 6-8 $\times 7-10 \mu$; paraphyses filiform, enlarged above, reaching a diameter of $3 \mu$.

On dead twigs of Acer spicatum.

Type locality: Near Ottawa, Canada.

Distribution: Known only from the type locality.

14. Pezicula cornicola Seaver, Mycologia 29: 337.1937. (Plate 142.)

Apothecia usually in cespitose clusters, individual apothecia sessile, reaching $1 \mathrm{~mm}$. in diameter, pale-yellow; hymenium plane, or slightly convex; asci clavate, reaching a length of $100-120 \mu$ and a diameter of $12-15 \mu$; spores partially 2-seriate, ellipsoid, straight, or slightly curved, about $7-8 \times 20 \mu$, becoming tardily 1-3-septate; paraphyses filiform, slightly enlarged at their apices.

On bark of Cornus sp.

Type locality: East Hampton, New York.

Distribution: Known only from the type locality.

Illustrations: Mycologia 29: 336, $f .2$.

This is associated with a Myxosporium which appears to be its conidial stage. The spores ooze out from the pycnidia in sausage-like streams, whitish in color. The conidia are ellipsoid, or slightly narrowed at one end, quite variable in size but often reaching a length of $40 \mu$ and a diameter of $15 \mu$, densely filled with minute granules.

15. Pezicula Corni Petrak, Ann. Myc. 20: 197. 1922. (Plate 143.)

?Dermatea Corni Phill. \& Hark. Grevillea 13: 22. 1884.

Pezicula rhabarbarina f. Corni Ellis in Herb.

Apothecia solitary, or cespitose, at first rounded, becoming expanded and subdiscoid, with a mealy, brown covering, reaching a diameter of about .5-1 mm.; hymenium plane or nearly so. 


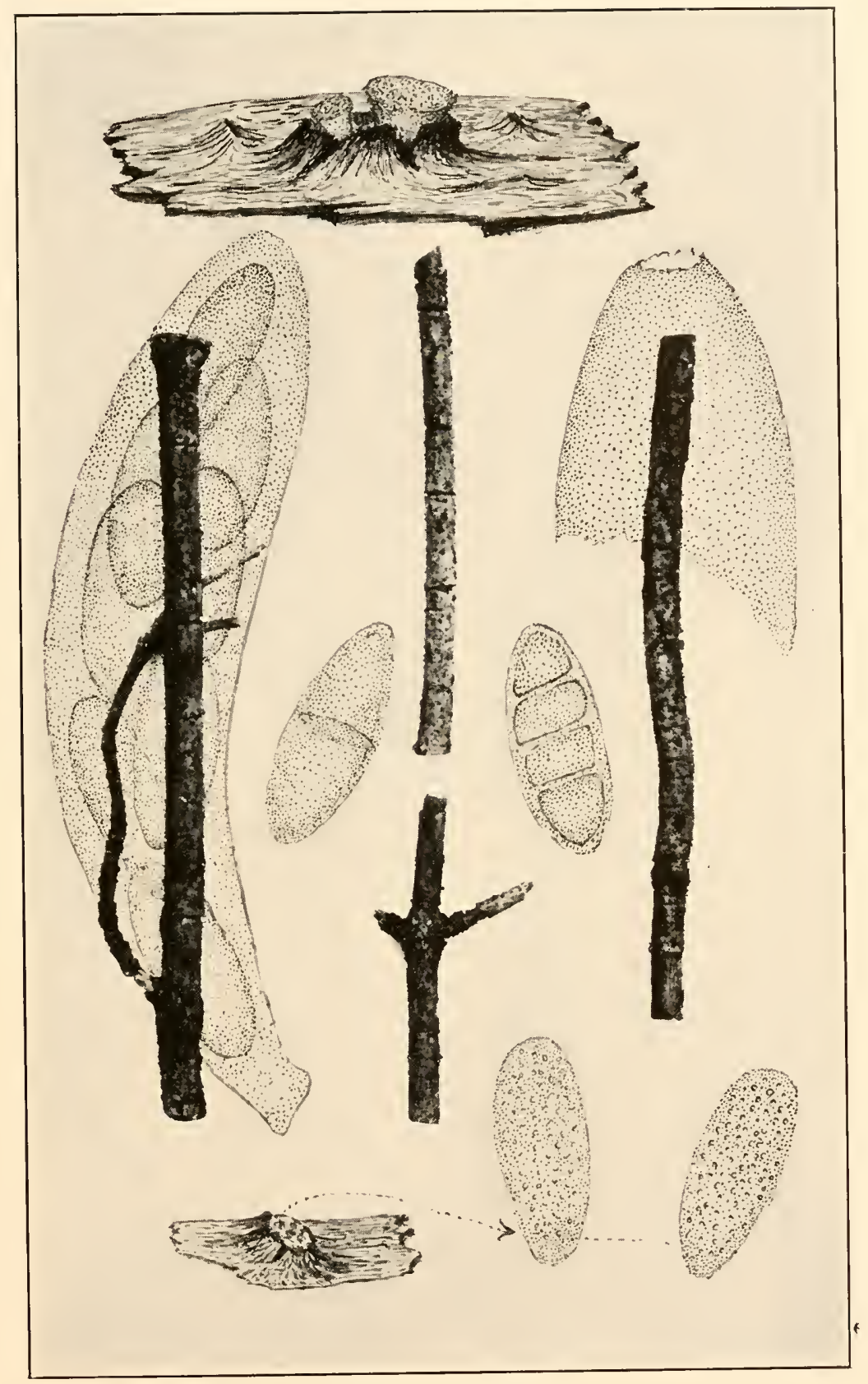

PEZICULA CORNI 

yellowish to dark brownish-black; asci clavate, reaching a length of $120 \mu$ and a diameter of $27 \mu, 8$-spored; spores ellipsoid, irregularly crowded in the ascus, $10-13 \times 28-34 \mu$; paraphyses filiform, slightly enlarged above.

On Cornus alternifolia, C. stolonifera, and unnamed species of Cormus.

Type locality: Idaho.

Distribution: California to Oregon and Ontario.

Illustrations: Mycologia 29:335, f. 1 .

Exsiccati: Ellis \& Ev. N. Am. Fungi 2809 (as Pezicula rhabarbarina); Reliq. Farlow. 857.

This is accompanied by a Myxosporium which appears to be its conidial stage. The pycnospores are ellipsoid and densely filled with granules, $13-15 \mu \times 33-36 \mu$.

16. Pezicula ocellata (Pers.) Seaver, comb. nov. (Plate 144, FIG. 1.)

Peziza ocellata Pers. Syn. Fung. 667. 1801.

Stictis ocellata Fries, Syst. Myc. 2: 193.1822.

Pesiza Lecanora Schm. \& Kunze, Deuts Schw. 17t. 1817.

Stictis Lecanora Fries, Syst. Myc. 2: 193. 1822.

Phacidium Populi Lasch in Rab. Herb. Myc. ed. 2. 519.1857.

Ocellaria aurea Tul. Fung. Carp. 3: 129. 1865.

Habrastictis ocellata Fuckel, Symb. Myc. Nacht. 1:38. 1871.

Dermatea cinnamomea Cooke \& Peck; Cooke, Bull. Buffalo Soc. Nat. Sci. 3:

24. 1875.

Dermatea inclusa Peck, Ann. Rep. N. Y. State Mus. 30: 62. 1878.

Propolis acellata Gill. Champ. Fr. Discom. 214. 1887.

Dermatea macrospara Clements, Bull. Torrey Club 30: 87. 1903.

Ocellaria ocellata Seaver, Mycologia 3: 65. 1911.

Pesicula eximia Rehm, Ann. Myc. 11: 154. 1913.

Conidia borne on the surface of a fleshy, submerged stroma, large, ellipsoid, densely filled with granular matter, reaching a length of $30-35 \mu$ and a diameter of $10-12 \mu$ borne on a conidiophore about the length of the spore itself and strongly swollen just below the point of attachment.

Apothecia occurring singly, breaking through the bark, the broken edges of which form a ragged margin often extending above the margin of the cup, reaching a diameter of 1-2 mm., yellowish, with an irregularly notched margin which is often whitish; hymenium concave, or nearly plane, surrounded by the upturned margin of the apothecium, yellowish, or dull-orange; asci broad-clavate, reaching a length of $120 \mu$ and a diameter of 
$24 \mu$, terminated abruptly at the base; spores ellipsoid, granular within, 10-12 $\times 25-30 \mu$, irregularly 2 -seriate, hyaline, simple, or 1-3-septate; paraphyses enlarged above, reaching a diameter of $5-6 \mu$.

On branches of Salix petiolaris, Salix discolor and other species of Salix and Populus.

Type locality: Europe.

Distribution: New York to Winnipeg, Washington and Colorado; also in Europe.

Illustrations: Tul. Fung. Carp. 3: pl. 18, f. 1-11; Gill. Champ. Fr. Discom. pl. 98; E, \& P. Nat. Pfl. $1^{1}: 247$, f. 182. A-C; Massee, Brit. Fungus-Fl. 4: 22, f. 34-35.

Exsiccati: Schm. \& Kunze, Deuts. Schw. 174 (as Peziza Lecanora); Barth. Fungi Columb. 1918; Brenckle, Fungi Dak. 535.

This species has been placed in various genera and made the type of the genus Ocellaria by Tulasne which genus is usually treated with the Phacidiales. The writer can see no reason for treating it with that group. It has been collected in abundance by the writer in Colorado on some species of willow around Tolland at an altitude of 8,000 to 10,000 feet.

Through the kindness of John Dearness, the writer has been permitted to examine a part of the type collection of Pezicula eximia Rehm and finds it identical with the above.

\section{Pezicula Populi (Thompson) Seaver, comb. nov.}

Neofabraea Populi Thompson, Mycologia 31: 458. 1939.

Apothecia thickly gregarious, usually occurring singly, or rarely two or three crowded together, entirely sessile, erumpent but scarcely rising above the surface of the substratum, surrounded with the upturned edges of the ruptured outer bark, scarcely exceeding $.5 \mathrm{~mm}$. in diameter, dark brownish-black; hymenium concave, or nearly plane, reddish-brown, with a slightly elevated, darker center which gives the hymenium an umbilicate appearance; asci clavate, apparently normally 8spored but of ten with only 5 or 6 of the spores developed, reaching a length of $80 \mu$ and a diameter of $12 \mu$; spores 2 -seriate above, ellipsoid, usually with two oil-drops, hyaline, 5-6 618 $20 \mu$, becoming indistinctly 3 -septate; paraphyses enlarged above, hyaline. 


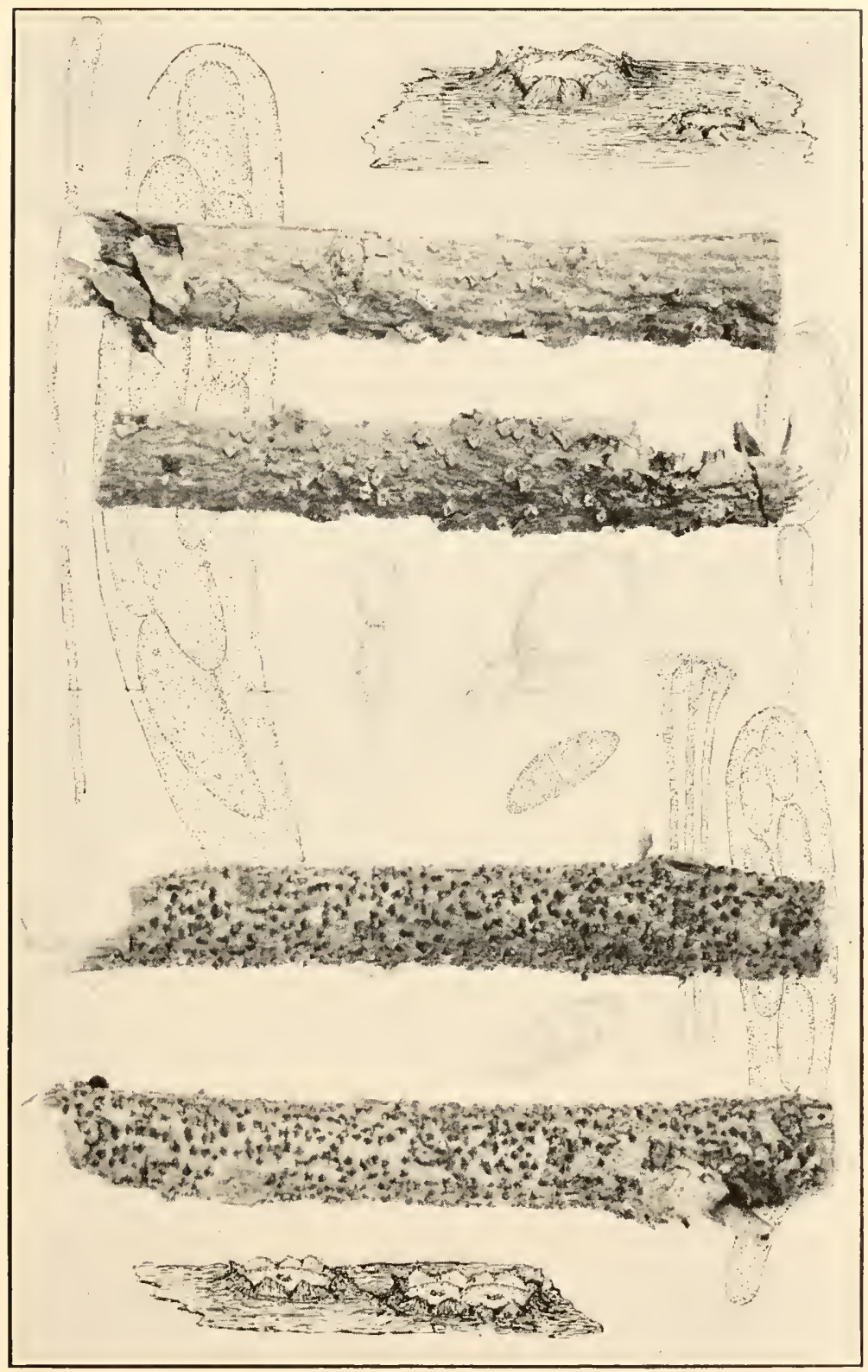

1. PEZICULA OCELLATA

2. PEZICULA POPULI 

On Populus grandidentata and Populus tremuloides.

Type locality: Ontario, Canada.

Distribution: Known only from the type locality.

Illustrations: Mycologia $31: 457, f .1 ; 460, f .2 ; 462, f .3$.

This species is known from two collections by G. E. Thompson and communicated by H. S. Jackson, University of Toronto, Cryptogamic Herbarium 2054 and 2046. Said to cause canker on living trees.

The conidial stage is reported by Thompson as a Myxosporium which forms definite cankers on young Populus branches.

18. Pezicula purpurascens (Ellis \& Ev.) Seaver, Mycologia 34: 414. 1942. (Plate 145.)

Dermatea purpurascens Ellis \& Ev. Jour. Myc. 4: 100. 1888. Ascoconidium Castaneae Seaver, Mycologia 34: 414. 1942.

Conidia found associated with this species and possibly representing its perfect stage. Ascoconidiophores club-shaped reaching a length of $90 \mu$ and a diameter of $12 \mu$, pale-brown, each containing one ascoconidium; ascoconidia broad-ellipsoid, reaching a length of 30-40 $\mu$ and a diameter of 9-10 $\mu$, borne on slender stalk within the conidiophore, becoming disconnected, and finally discharged through the ruptured conidiophore, 3-septate, appearing brownish within the conidiophore but hyaline or subhyaline when discharged.

Apothecia scattered, erumpent, occurring singly, or two or three crowded together, sessile, or subsessile, externally reddishpurple, reaching a diameter of .75-1 mm.; hymenium plane, or slightly concave, dirty-white, becoming reddish-purple but lighter than the outside of the apothecium; asci cylindricclavate, reaching a length of 120-140 $\mu$ and a diameter of 25-30 $\mu$, 8-spored but some often undeveloped, 8-11 $\times 30-36 \mu$, hyaline or nearly so, ellipsoid with the ends strongly narrowed, becoming distinctly 3-septate, 9-11 $\times$ 30-36 $\mu$; paraphyses slender, slightly enlarged above, reaching a diameter of 2-3 $\mu$, often slightly colored.

The exterior of the apothecium is clothed with a palisade of appressed, poorly developed hairs which are dilutely purplish. It is this character which has suggested the specific name.

On dead limbs of chestnut, Castanea dentata.

Trpe locality: West Chester, Pennsylvania.

Distribution: Pennsylvania and Massachusetts. 
Illustrations: Mycologia 34:413, f. 1 .

Exsiccati: Ellis \& Ev. N. Am. Fungi 2147.

19. Pezicula minuta Peck, Bull. N. Y. State Mus. $1^{2}: 21.1887$.

Dermatea minuta Peck, Ann. Rep. N. Y. State Mus. 32: 48.1879.

Apothecia thickly scattered, occurring singly, or two or three together, rounded, becoming more or less turbinate, subochraccous, reaching a diameter of .25-.5 mm.; hymenium at first concave, becoming plane, similar in color to the outside of the apothecium; asci broad-clavate, 8-spored, reaching a length of $90 \mu$ and a diameter of 20-22 $\mu$; spores broad-ellipsoid, granular within, $10-12 \times 20-25 \mu$; paraphyses filiform, slender.

On Viburnum lantanoides.

Type Locality: Catskill Mountains, New York.

Distribution: New York and Ontario, Canada.

Specimens in the herbarium of The New York Botanical Garden, a part of the type collection, have been examined. In this material it is very difficult to find mature spores. Whether they become septate could not be determined.

One specimen collected by Roy Cain, in Canada, No. 7162, has been compared with the type and found identical.

20. Pezicula Hamamelidis Groves \& Scaver, Canadian Jour. Res. 17: 140. 1939. (Plate 146.)

Conidial fruiting bodies minute, about .3-.4 mm. in diameter, crumpent, cushion-shaped, and containing one or more cavities lined with conidiophores $2.5-3 \times 15-30 \mu$, swollen just below the point of attachment to $4 \mu$; conidia oblong-ellipsoid, hyaline, simple, straight, or slightly curved, $12-14 \times 30-45 \mu$; microconidia borne in the same fruiting body, hyaline, filiform, straight, or curved, simple, $1.5-2 \times 10-18 \mu$.

Apothecia erumpent, scattered, or more or less in rows, usually single, sometimes cespitose with two to six in a cluster, sessile, narrowed below, circular .3-1 $\mathrm{mm}$. in diameter .2-.4 $\mathrm{mm}$. high, pale ochraccous-yellowish, darker when dry, waxy; hymenium plane to convex, slightly pruinose; asci oblong-clavate, broad, short-stalked, 8-spored, reaching a length of 90-120 $\mu$ and diameter of 20-30 $\mu$; ascospores oblong-ellipsoid to ovoid, hyaline, straight, or curved, irregularly 2-seriate, becoming 1-3septate, $9-13 \times 25-37 \mu$; paraphyses hyaline, filiform, simple, or 


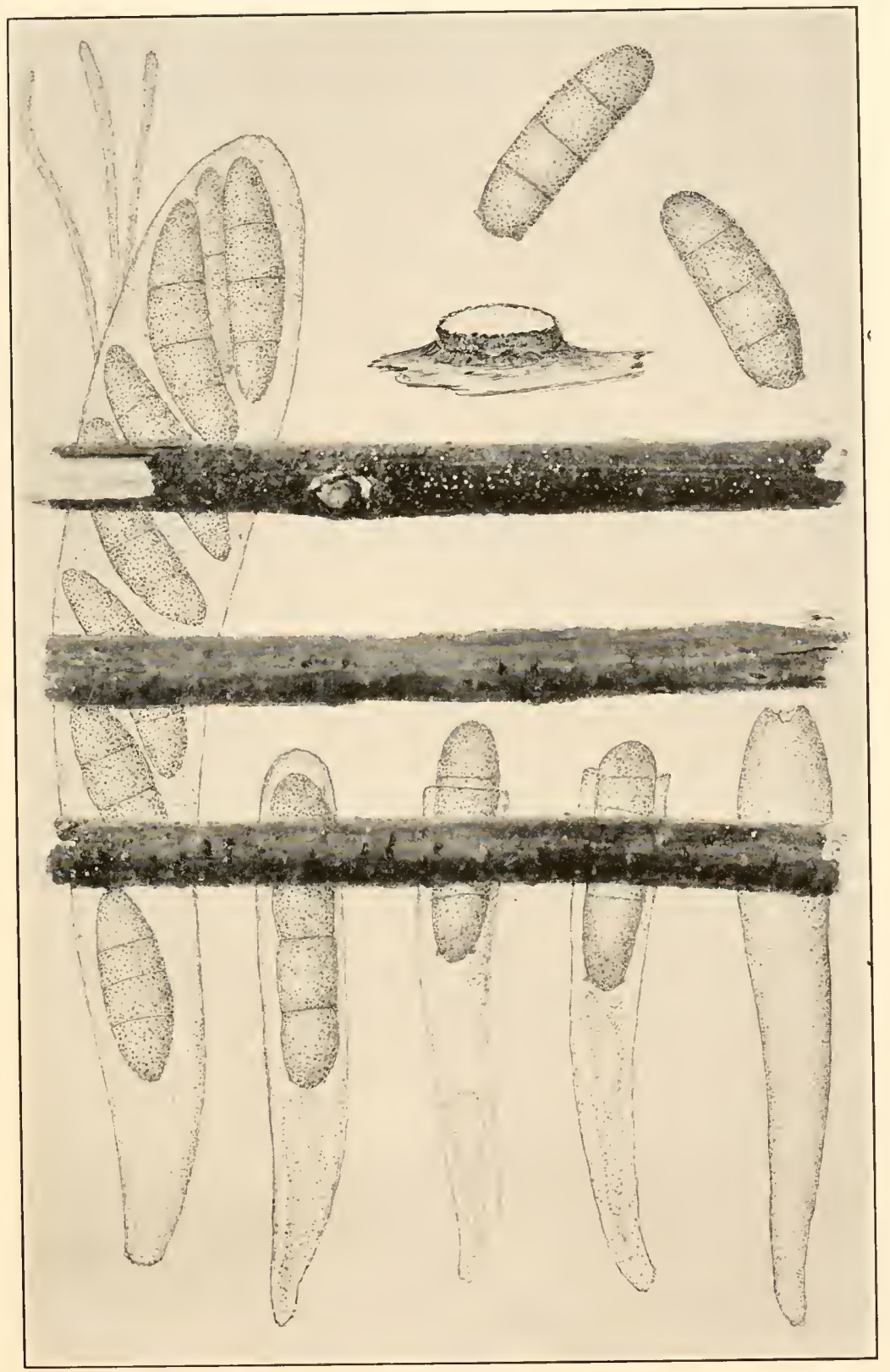

PEZICULA PURPURASCENS 

occasionally branched, $2-3 \mu$ in diameter, the tips swollen to $8 \mu$ in diameter, forming a yellowish epithecium.

On branches of Hamamelis virginiana.

Type locality: Don Valley, Toronto, Canada.

Distribution: Canada.

Illustrations: Canadian Jour. Res. 17: 129, $f .3,1-2, f .4$, $5 a, b$.

Exsiccati: Sydow, Fungi Exotici Exsicc, 423 (as Dermatea Rubi).

The type specimen is intimately associated with a Coryneum which the writer took to be its conidial stage, but Groves decided that the conidial stage was a Cryptosporiopsis and not the Coryneum which often occurred in the same pustule with the Pezicula.

21. Pezicula Morthieri (Fuckel) Groves, Mycologia 39: 329. 1947.

Sphaeria micula Fries, Elench. Fung. 2: 101.1828.

Micula Mougeotii Klotzs. Herb. Viv. Myc. 636. 1844.

Cenangium Morthieri Fuckel, Symb. Myc. 272. 1869.

Atractium Therryanum Sacc. Michelia 1: 535. 1879.

Cenangella Morthieri Sacc. Syll. Fung. 8: 592. 1889.

Dermatea micula Rehm in Rab. Krypt.-Fl. 13: 261. 1889.

Phaeangella Morthieri Sacc \& D. Sacc; Sacc Syll. Fung. 18: 128. 1906.

Sphaerographium niveum Dearn. \& House, Bull. N. Y. State Mus. 266: 89. 1925.

Conidial stage erumpent from the same stroma which produces the apothecia, cylindric-conic, reaching a height of $1 \mathrm{~mm}$. and less than half as broad at the base, usually white, sometimes darkened; conidiophores septate, branched, 2-2.5 $\times 25-40 \mu$; conidia hyaline, filiform, straight, or curved, pointed at the ends, 3-4 $\times$ 45-65 $\mu, 1-3$-septate.

Apothecia erumpent, occurring singly or two or three together, sessile, narrowed below, less than $1 \mathrm{~mm}$. in diameter and height, yellowish-brown to reddish-brown; hymenium at first concave, becoming plane, or slightly convex, darker than the outside of the apothecium; asci cylindric-clavate, 8-spored, reaching a length of $65-100 \mu$ and a diameter of 8-14 $\mu$; spores ellipsoid-fusoid, hyaline, or pale-yellowish, straight, or slightly curved, 4-6 $\times 15-20 \mu$; paraphyses filiform, very slightly enlarged above, $1.5-3.5 \mu$ in diameter.

On branches of Rhamnus alnifolia. 
Type locality: Europe.

Distributiox: Quebec; also in Europe.

Illustrations: Mycologia 39:330, f. 1, 2 .

Grove states that the position of this species is uncertain but places it in Pezicula.

22. Pezicula livida (Berk. \& Br.) Rehm, Ascom. 462. 1878.

Patellaria livida Berk. \& Br. Ann. Mag. Nat. Hist. II. 13: 466.1854.

Dermatea abietina Auersw. in Rab. Fungi Eu. 1027; Hedwigia 6: 46. 1866. Peziza eucrita Karst.; Nylander, Not. Soc. Fauna Fl. Fenn. 10: 47. 1869. Dermatea livida Phill. Brit. Discom. 340. 1887.

Dermatella livida Sacc. Syll. Fung. 8: 490. 1889.

Dermatella eucrita Sacc. Syll. Fung. 8: 491.1889.

Durella livida Sacc. Syll. Fung. 8: 795. 1889.

Myxosporium abietinum Rostr. Tids. Skow. 13: 89. 1901.

Coniclial stage consisting of a stroma on which the conidia are produced; conidia ellipsoid, $5 \times 12-16 \mu$; microconidia present, $1.5-2.5 \times 10-17 \mu$.

Apothecia occurring singly, or in small, cespitose clusters of usually three to six each, the clusters thickly gregarious, individual perithecia reaching a diameter of .5-1 mm., pale-ycllowish; hymenium plane, or convex, similar in color to the outside of the apothecium, minutely roughened with the ends of the paraphyses; asci clavate, reaching a length of $100 \mu$ and a diameter of $20 \mu$, 8-spored; spores partially 2-seriate, ellipsoid, straight, or more commonly curved, at first simple, often becoming 3-5-septate, 6-7 $\times 20-31 \mu$; paraphyses slender below, strongly enlarged above, reaching a diameter of $5-7 \mu$.

On bark of Pinus Strobus; also reported on other species of Pinus and Abies.

Type locality: Europe.

Distribution: New York and New England; also in Europe.

Illustrations: Not. Soc. Fauna Fl. Fenn. 10: pl. 1, f. 12: Ann. Bot. 45:f. 1-5. (pp. 77-80); Mycologia 24:424, f. 1 .

According to Mary J. F. Gregor (Ann. Bot. 45: 73. 1931) the above indicated species are synonyms.

23. Pezicula phyllophila (Peck) Seaver, comb. nov.

Dermatea phyllophila Peck, Ann. Rep. N. Y. State Mus. 31: 47. 1879.

Apothecia minute, erumpent but of ten partially concealed by the epidermis which has a blistered appearance, yellowish-brown; hymenium pallid, or dingy-white, nearly plane; asci clavate, 


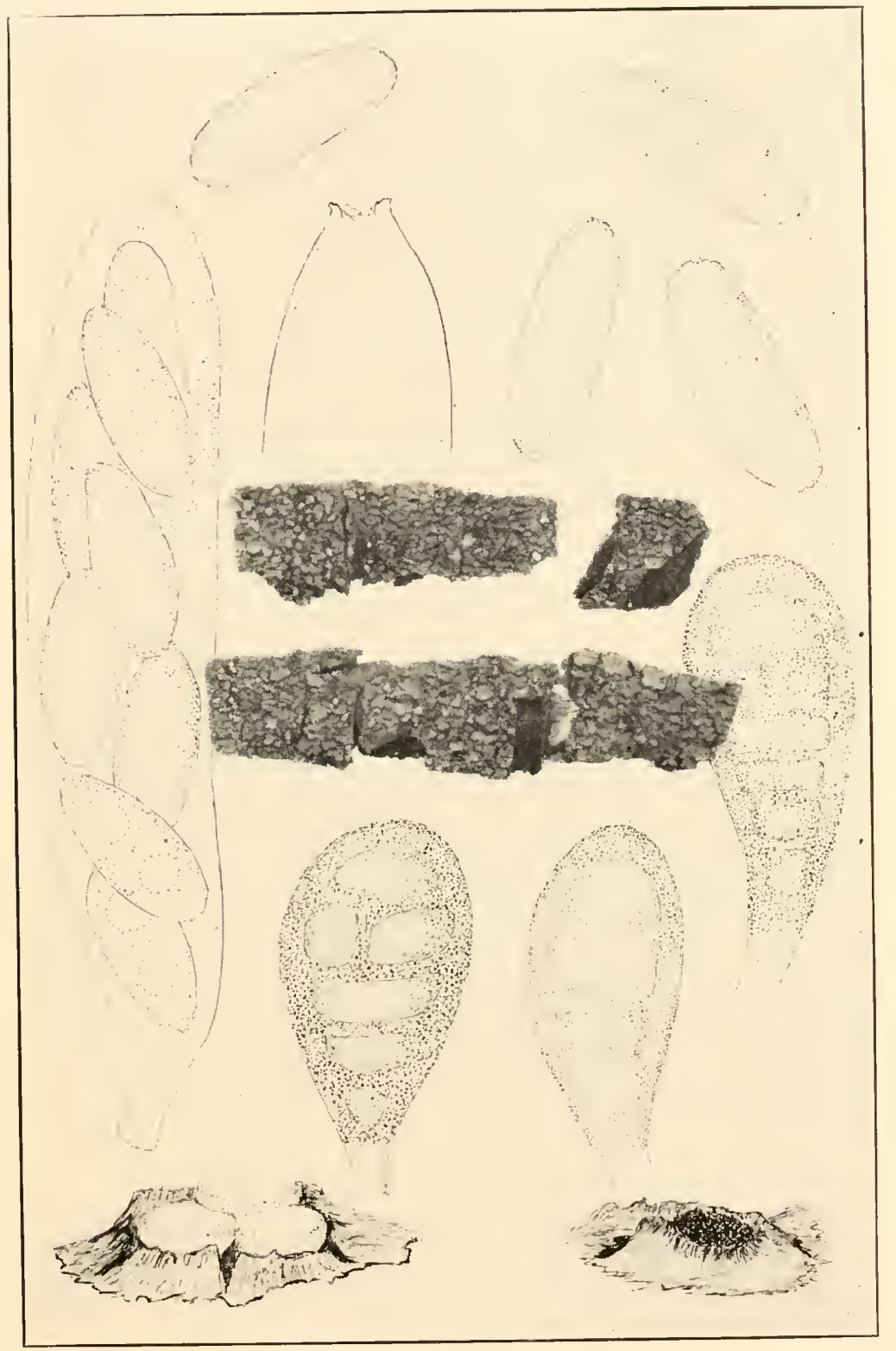

PEZICULA HAMAMELIDIS 

8-spored, reaching a length of $80-90 \mu$ and a diameter of 10-12 $\mu$; spores broad-ellipsoid, 5-6 6 -7-8 $\mu$, usually containing one large oil-drop; paraphyses filiform, thickened above.

On lowe surface of balsam leaves, Abies balsamea, while still on the tree; also on leaves of Pinus rigida.

Type locality: Summit, New York.

Distribution: New York and (New Jersey?).

Exsiccati: Ellis, N. Am. Fungi. 385.

Type material of this species has been examined. It has all the appearance of a Pezicula except that the spores are small with no indication of septa. The type material is abundant.

\section{Doubtful ANd Excluded Species}

Pesicula atroviolacea Bres. Ic. Myc. 25: pl. 12.37. 1933; Peziza atroviolacea Bres. Fungi. Trid. 1: 24. 1881; Humaria atroviolacea Sacc. Syll. Fung. 8: 150. 1889; Pachyella atroviolacea Boud. Hist. Class. Discom. Eu. 51. 1907. This is certainly Peziza clypeata Schw. and not a Pezicula.

Pezicula Kalmiae (Peck) Sacc. Syll. Fung. 8: 314. 1889; Peziza Kalmiae Peck, Ann. Rep. N. Y. State Mus. 25: 99. 1873. No material seen. See Trichopeziza Kalmiae.

Beloniella marcyensis Kanouse, Papers Mich. Acad. Sci. 24: 25. 1939. The erumpent habits, general description, and spores becoming tardily severalseptate would indicate a Pezicula. No material has been seen.

Pesicula pallidula (Cooke) Rehm, Ber. Bayer. Bot. Ges. 13: 199. 1912; Dermatea pallidula Cooke, Grevillea 16: 70. 1888; Scleroderris pallidula Sacc. Syll. Fung. 8: 598. 1889. Reported on branches of Rhus venenata from New Jersey. No material seen.

Pesicula Philadelphi (Schw.) Sacc. Syll. Fung. 8: 315. 1889; Peziza Philadelphi Schw. Trans. Am. Phil. Soc. II. 4: 177. 1832. Reported on Philadelphus inodorus. No material seen.

Pesicula viridiatra (Berk. \& Curt.) Sacc. Syll. Fung. 8: 315. 1889; Peziza viridiatra Berk. \& Curt.; Berk. Jour. Linn. Soc. 10: 369.1868. Sessile, greenish-black, underneath granular, irregularly undulate; spores ellipsoid, finally subfuscous; spores ellipsoid, $5 \mu$ long. This has been made a synonym of catinella nigroolivacea by Durand. On dead wood with Polyporus, Cuba.

10. DERMEA Fries, Syst. Orbis Veg. 114. 1825. Dermatea Fries, Summa Veg. Scand. 362. 1849.

Apothecia occurring singly, or more often in cespitose clusters, often on a stromatic base, tubercular in form or discoid, more rarely scutellate, usually dark-colored, comparatively small, rarely exceeding $2 \mathrm{~mm}$. and usually $1 \mathrm{~mm}$. or less in diameter, coriaceous to subcarbonaceous; asci usually broad-clavate and 
8-spored; spores usually comparatively large, occasionally minute, simple, or becoming tardily several-septate, the septation often erratic even in the same species; paraphyses colored and their tips agglutinated into a dark-brown or blackish epithecium.

Type species, Peziza Cerasi Pers.

This genus grades rather closely into Cenangium but usually has smaller discoid apothecia and large often septate spores. The macroconiclia in the various species which are produced in irregular pycnidial cavities in a fleshy stroma are fusiform, usually curved and septate. The conidial stage so far as observed belongs to the form genus Micropera (Gelatinosporium).

These studies are based partly on the work of Dr. J. IV. Groves (Mycologia 38: 351-431. 1946).

Apothecia $1.5 \mathrm{~mm}$. or more in diameter.

Not on coniferous hosts.

On Prunus, apothecia distinct.

On Betula, apothecia of ten coalesced.

On coniferous hosts, Abies and Tsuga. Apothecia mostly less than $1.5 \mathrm{~mm}$. in diameter.

Ascospores less than $5 \mu$ in diameter.

Conidia in beaked pycnidia, on triburnum.

Conidia not in beaked pycnidlia.

Asci more than $10 \mu$ broad; on Nemopanthes.

Asci less than $10 \mu$ broad.

On Amelanchier, apothecia black.

On Sorbus, apothecia brownish.

1. D. Cerasi.

2. D. molliuscula.

3. D. balsamea.

4. D. Tiburni.

5. D. Peckiana.

6. D. bicolor.

7. D. Ariae.

Ascospores more than $5 \mu$ in diameter.

Conidia in beaked pycnidia.

Conidia elongate-ellipsoid; on Acer.

Conidia elongate-fusiform; on Prunus.

Pycnidia usually single.

Pycnidia usually cespitose.

8. D. acerina.

9. D. Padi.

10. D. Prunastri.

Conidia not in beaked pycnidia.

On coniferous hosts.

Ascospores less than $14 \mu$ long; on Picea.

Ascospores usually more than $14 \mu$ long.

On Pinus.

On Libocedrus.

11. D. piceina.

12. D. pinicola.

13. D. Libocedri.

Not on coniferous hosts.

Asci usually less than $15 \mu$ in diameter.

On Hamamelis.

Asci usually more than $15 \mu$ in diameter.

On Fraxinus.

On Chionanthus.

On Morus.

14. D. Hamamelidis.

15. D. Tulasnei.

16. D. Chionanthi.

17. D. Mori. 


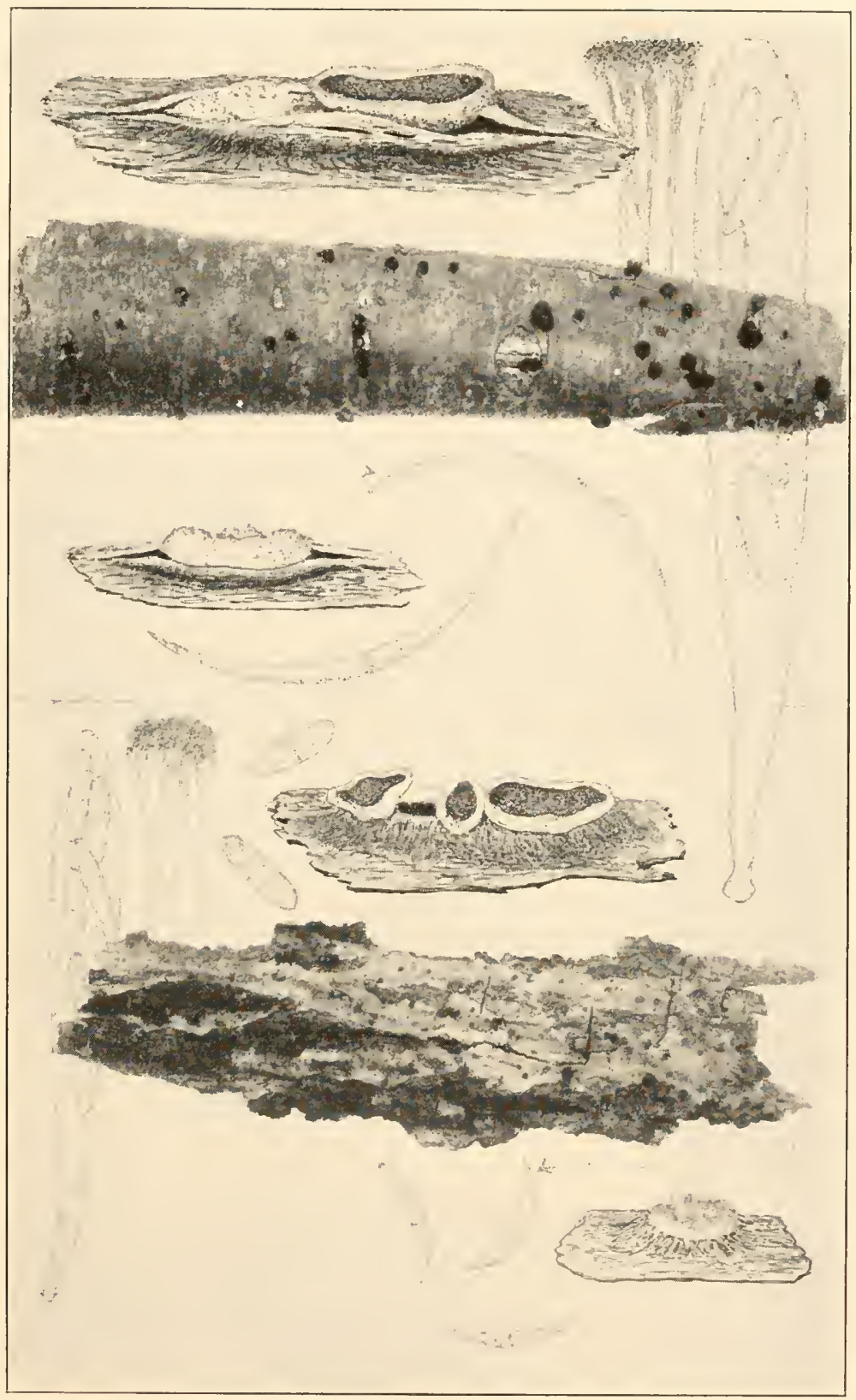

DERMEA CERASI

DERMEA BICOLOR 

1. Dermea Cerasi (Pers.) Fries, Syst. Orb. Veg. 115. 1825. (Plate 147, Fig. 1.)

Pezisa Cerasi Pers. Tent. Disp. Fung. 35. 1797.

Sphaeria dujia Pers. Ic. Pict. Fung. 4: 48.1806.

Cenangium Cerasi Fries, Syst. Myc. 2: 179. 1822.

?Cenangium cerasorum Schw. Schr. Nat. Ges. Leipzig 1: 118. 1822.

?Cenangium claratum Fries, Syst. Myc. 2: 179. 1822.

Cycledum Cerasi Wallr. Fl. Crypt. Germ. 2: 512. 1833.

Micropera roseola Lév. Ann. Sci. Nat. III. 5: 283. 1846.

Micropera drupacearum Lév. Ann. Sci. Nat. III. 5: 283. 1846.

Micropera Cerasi Sacc. Atti Soc. V'eneto Sci. Nat. Padova 2²:160. 1873.

Tympanis Cerasi Quél. Ench. Fung. 330. 1886.

Conidial stage erumpent, irregular in form, circular, or elongated to conical, usually with several flask-shaped bodies which open irregularly, reaching a height of $1 \mathrm{~mm}$., whitish to yellowish, soft-waxy; conidiophores simple, or branched, tapering to a slender tip, $2-2.5 \times 10-25 \mu$; conidia sickle-shaped, or almost straight, fusiform, hyaline to faintly yellowish, simple, or 1-septate, 2.5-4.5 $\times 35-65 \mu$; microconidia hyaline, filiform, straight, or curved, simple, $1-1.5 \times 12-23 \mu$.

Apothecia accompanying the conidial stage, single, or more often cespitose, narrowed below, 1-3 mm. in diameter and 1.5 $\mathrm{mm}$. high, at first brownish, finally black, leathery to horny; hymenium at first concave, becoming plane, or convex, of ten slightly umbilicate, black, or slightly olivaceous; asci cylindricclavate, tapering below into a stem-like base, reaching a length of 100-150 $\mu$ and a diameter of 10-15 $\mu, 8$-spored; spores ellipsoidfusoid, hyaline to yellowish, straight, or slightly curved, simple, becoming 3 -septate, $5-7 \times 15-25 \mu$; paraphyses simple, or branched, the tips swollen and forming a yellowish epithecium.

On branches of various species of Prunus.

Type locality: Europe.

Distribution: Maine to Washington and South Carolina; probably widely distributed throughout North America; also in Europe.

Illustrations: Pers. Ic. Pict. Fung. pl. 20, f. 1-2; Tul. Fung. Carp. 3: pl. 19, f. 13-17; E. \& P. Nat. Pfl. 1': 237, f. 179 $A-D$; Rab. Krypt.-Fl. 133: 242. f. 1-6; Mycologia 25: pl. 20, (upper figure); 38: 366, f. 1, 2; 383, f. 27; 395, f. 42.

Exsiccatr: Ellis, N. Am. Fungi 40, 989, 2812; Ellis \& Ev. N. Am. Fungi 2555; Shear, N. Y. Fungi 97; Barth. Fungi Columb. 4942; Reliq. Farlow. 113; Rav. Fungi Am. 246; Fung. Car. 4: 71. 
2. Dermea molliuscula (Schw.) Cash, Mycologia 29: 304. 1937. (Plate 148.)

Cenangium mollinsculum Schw. Trans. Am. Phil. Soc. II. 4: 239. 1832. Gelatinosporium fulvum Peck, Ann. Rep. N. Y. State Mus. 38: 97.1885.

Conidial stage, erumpent, circular, or transversely elongated, 1-4 mm. in diameter, .5-1 mm. high, blackish, waxy, usually containing several lobed, or flask-shaped cavities; conidiophores hyaline, simple, or branched, 1.5-2 × 15-30 $\mu$; conidia hyaline, or pale-yellowish, subfiliform, ends pointed, sickle-shaped, or almost straight, simple, $1-1.5 \times 7-12 \mu$.

Apothecia accompanying the conidial stage, erumpent, single, or cespitose in clusters of two to six, often crowded and sometimes fused, sessile, or substipitate, $1-3 \mathrm{~mm}$. in diameter and 1-2 $\mathrm{mm}$. high, tawny to almost black, leathery to horny; hymenium at first concave, becoming strongly convex, olivaceousbrown to black; asci cylindric-clavate, attenuated below, 8spored, reaching a length of $100-150 \mu$ and a diameter of $12-15 \mu$; spores narrow-ellipsoid to subfusiform, hyaline, becoming yellowish, straight, or slightly curved, 1-seriate, or irregularly 2seriate, often becoming 1-3-septate, 4-7 × 15-22 $\mu$; paraphyses filiform, simple, or branched, $1.5-2 \mu$ in diameter, the tips swollen and embedded in a yellowish matrix forming a dark epithecium.

On branches of species of Betula.

Type Locality: Mauch Chunk, Pennsylvania.

Distribution: New Hampshire to Pennsylvania and Canada. Illustrations: Mycologia 25: pl. 21 (as Dermea Betulae); $32: 742, f .2,12,13 ; 38: 379, f .21 ; 386, f .39 ; 395, f .47$.

3. Dermea balsamea (Peck) Seaver; Dodge, Mycologia 24: 427. 1932. (Plate 149.)

Cenangium balsameum Peck, Ann. Rep. N. Y. State Mus. 38: 101. 1885.

Cenangium balsameum var. abietinum Peck, Ann. Rep. N. Y. State Mus. 43: 40. 1889.

Gelatinosporium abietinum Peck, Ann. Rep. N. Y. State Mus. 25: 84. 1873. Micropera erumpens Ellis \& Ev. Proc. Acad. Sci. Phila. 1894: 386. 1894. Micropera abietina Höhn. Mitt. Bot. Inst. Wien 3: 32. 1926.

Conidial stage erumpent to subimmersed, rounded to cylindric, or subconic, .5-1 mm. in diameter, .2-.5 mm. high, yellowish, or olivaceous to black, waxy, opening with one or more irregular cavities; conidiophores hyaline, simple, or branched, tapering 


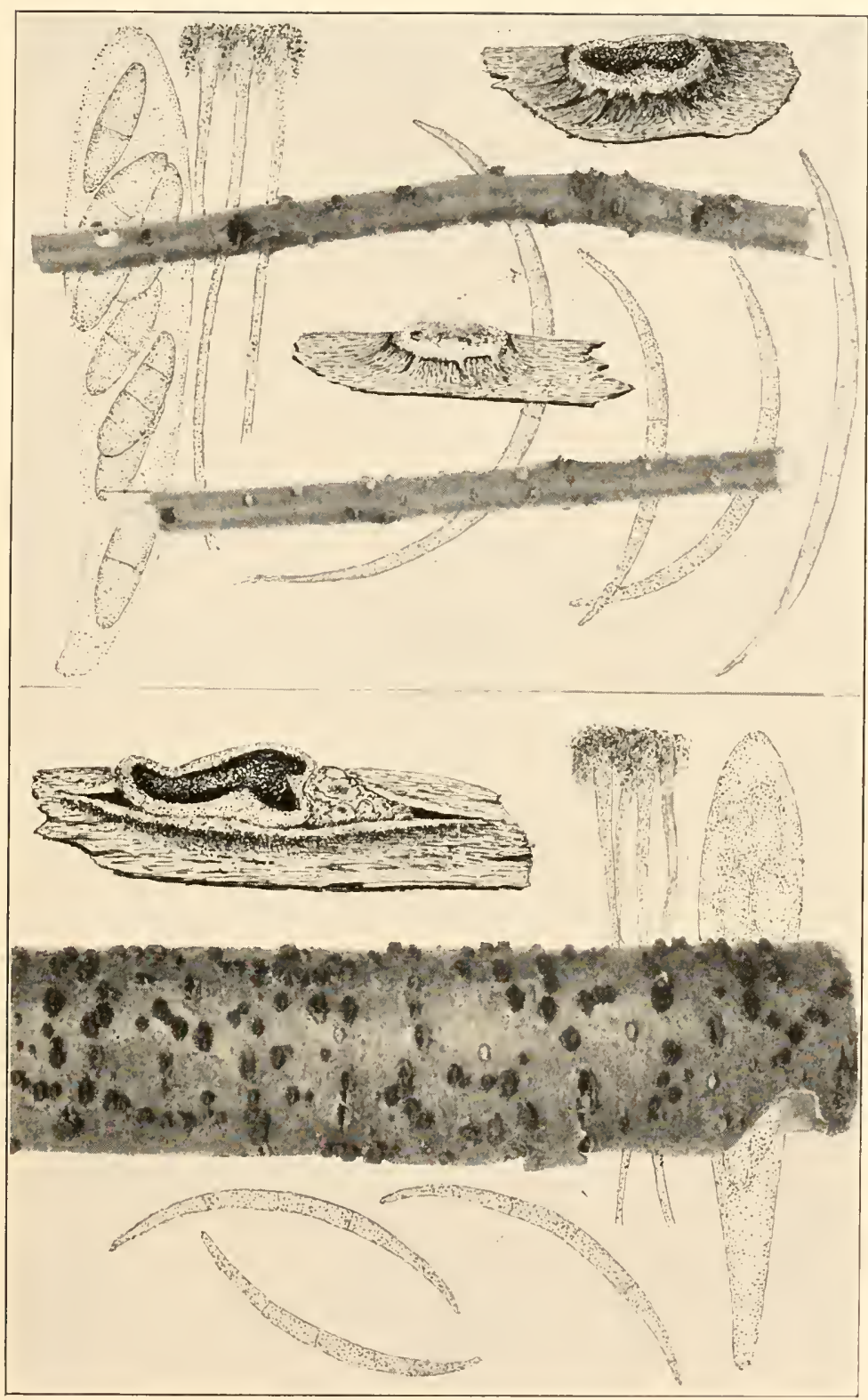

DERMEA MOLLIUSCULA 

above, $2-2.5 \times 15-25 \mu$; conidia elongate-filiform, pointed at the ends, hyaline to pale greenish-yellow, becoming 1-3-septate, sickle-shaped, or nearly straight, $4-5 \times 50-90 \mu$; microconidia filiform, straight, or curved, $1-1.5 \times 11-22 \mu$.

Apothecia erumpent, mostly single, sometimes cespitose, two to four in a cluster, sessile, or substipitate, circular, or undulated, 1-2.5 $\mathrm{mm}$. in diameter .4-.8 $\mathrm{mm}$. high, at first yellowish, or brownish, finally black, leathery to horny when dry; hymenium at first concave, then plane, or slightly convex, often umbilicate, light-brown to olivaceous-brown, or black; asci cylindric-clavate, tapering below, 8-spored, reaching a length of $90-150 \mu$ and a diameter of 14-16 $\mu$; spores ellipsoid-fusiform, hyaline or slightly yellowish, becoming 1-3-septate, straight, or curved, irregularly 2-seriate, $6-10 \times 20-35 \mu$; paraphyses filiform, usually much branched, $1.5-2 \mu$ in diameter, the tips very slightly swollen and glued together forming a yellowish epithecium.

On branches of Abies balsamea and Tsuga canadensis.

Type locality: Caroga Lake, New York.

Distribution: Maine to Virginia and Canada.

Illustrations: Mycologia 24: 424, f. 1, pl. 10, pl. 11, e. f.; 38: 366, f. 8, 9; 383, f. 30; 400, f. 54 .

Exsiccatı: Shear, N. Y. Fungi 328; Reliq. Farlow. 102.

\section{Dermea Viburni Groves, Mycologia 32: 745. 1940.}

Sphaeronema hystricinum Ellis, Bull. Torrey Club 6: 106. 1876.

Sphaerographium hystricinum Sacc. Syll. Fung. 3: 597. 1884.

Sphaerographium hystricinum var. Triburni Dearn. \& House; House, Bull. N. Y.

State. Mus. 197: 35.1917.

Conidial fruiting bodies erumpent, scattered, or more or less in rows, single, or two or three arising from the same basal stroma, cylindric-subulate, dark-brown to black, of ten with a reddish tinge, $.3-.5 \mathrm{~mm}$. in diameter at the base, and the beaks about $1 \mathrm{~mm}$. long, leathery to horny, basal stroma containing a single more or less elongated cavity about $150-200 \mu$ in diameter; conidiophores cylindric, occasionally branched, tapering above to a slender tip, 2-2.5 $\times 15-30 \mu$; conidia elongate-fusiform, to subfiliform, hyaline, sickle-shaped, or almost straight, one end more attenuated than the other, 1-3-septate, 2.5-4 $\times 30-45 \mu$; microconidia not observed.

Apothecia erumpent, separate, or in small clusters of two to six each, sessile, slightly narrowed below, circular, or slightly undulated, .3-1 $\mathrm{mm}$. in diameter, .2-.5 mm. high, dark-brown to 
black, leathery to horny, softer when moist; hymenium black, at first concave, becoming plane to convex; asci cylindric-clavate, short-stalked, 8-spored, reaching a length of 50-75 $\mu$, and a diameter of 8-12 $\mu$; spores ellipsoid fusoid, hyaline, becoming slightly yellowish, straight, or slightly curved; simple, or 1septate, 3.5-5.5 $\times 14-18 \mu$; paraphyses, hyaline, filiform, much branched, 1.5-2 $\mu$ in diameter, the tips swollen to $3 \mu$ and glued together, forming a yellowish epithecium.

On various species of Viburnum.

Type locality: Hatchley, Ontario.

Distribution: Vermont and Ontario, Canada.

Illustrations: Mycologia 32: 737. f. G, II; 38: 379, f. 27; 386, f. 38; 398, f. 49.

Exsiccatr: Ellis, N. Am. Fungi 3.37 (as Sphaeronema hystricinum); Reliq. Farlow. $198 a, 198 b$ (as Sphaerographium hystricinum).

5. Dermea Peckiana (Rehm) Groves, Mycologia 29: 67. 1937.

Cenangium Peckianum Rehm, Ann. Myc. 13: 3. 1915.

Sphaeronema stellatum Ellis, Bull. Torrey Club 6: 107. 1876.

Sphaerographium stellatum Sacc. Syll. Fung. 3: 598. 1884.

Micropera Nemopanthis Peck, Ann. Rep. N. Y. State Mus. 46: 31. 1893. Micropera stellata Jacz. Nouv. Mem. Soc. Imp. Nat. Moscow 15: 366.1898.

Conidial stage erumpent, rounded, of ten somewhat capitate, circular to more or less transversely elongated, .5-2 $\mathrm{mm}$. in diameter, $1 \mathrm{~mm}$. high, upper surface uneven and wrinkled around the openings of the cavities, pale-yellowish to black, of ten with a greenish cast, subfleshy, softer than the apothecia; conidiophores hyaline, cylindric, sometimes branched, tapering above, 2-2.5 $\times$ $20-40 \mu$; coniclia hyaline, elongate-fusiform to subfiliform, sickle-shaped, ends pointed, becoming 1-3-septate, 2.5-4.5 $\times$ $40-60 \mu$; microconidia hyaline, filiform, straight, or curved, simple, $1.5 \times 8-13 \mu$.

Apothecia arising from the old conidial stroma, cespitose in clusters up to fifteen each, .3-.8 $\mathrm{mm}$. in diameter, circular, or undulated, narrowed below, dark-brown to black; asci cylindricclavate, tapering below, 8-spored, reaching a length of 75-110 $\mu$ and a diameter of 9-12 $\mu$; spores ellipsoid-fusiform, hyaline to pale-ycllow, straight, or slightly curved, becoming 1-3-septate, 3-4 $\times 12-18 \mu$; paraphyses hyaline, filiform, simple, or branched 1.5-2 $\mu$ in diameter, the tips swollen to $3-5 \mu$ and glued together forming a yellowish epithecium. 


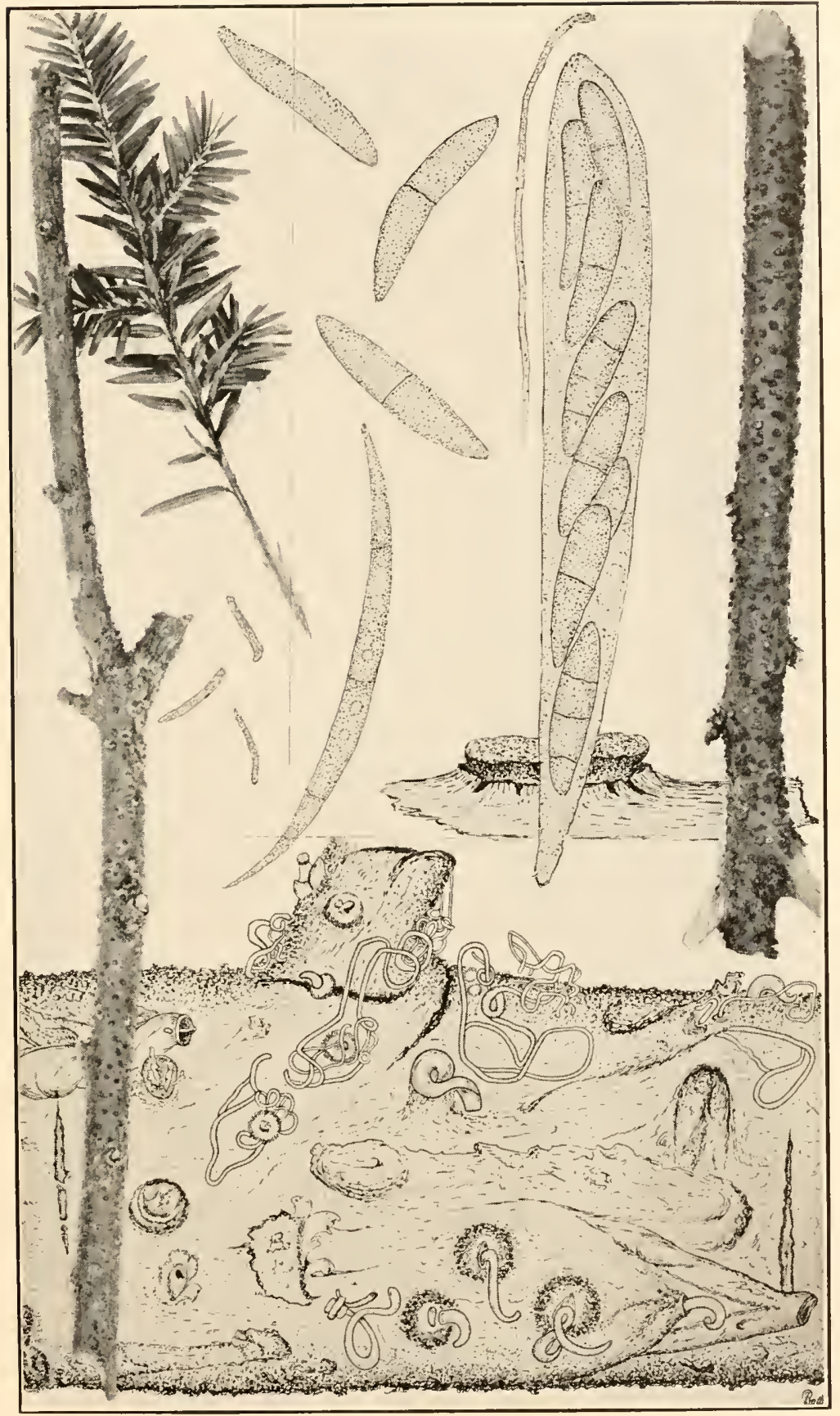

DERMEA BALSAMEA 

On branches of Nemopanthes mucronata and Ilex verticillala.

Type Locality: Munith, Michigan.

Distribution: Michigan and Canada.

Illustrations: Mycologia 29: 68, f. 1, 77, f. +9; 38: 379, $f$. 18,$25 ; 386, f .35 ; 400, f .56$.

Exsiccati: Ellis \& Ev. N. Am. Fungi 3042; Ellis \& Ev. Fungi Columb. 332 .

6. Dermea bicolor (Ellis) Groves, Mycologia 35: 460. 1943.

Tympanis bicolor Ellis, Am. Nat. 17: 193. 1883.

Cenangium bicolor Sacc. Syll. Fung. 8: 572.1889.

Cenangium dichroum Sacc. Syll. Fung. 8: 1143. 1889.

Patinella Brenckleana Sacc. Mycologia 12: 203. 1920.

Dermea Brenckleana Seaver, Mycologia 25: 142. 1933.

Conidial fruiting bodies more or less immersed, splitting the bark and slightly erumpent, circular to elongated, or angular, $.2-.8 \mathrm{~mm}$. in diameter, .2-.4 $\mathrm{mm}$. high, yellowish, soft-waxy, containing one to several lobed cavities which open irregularly exposing the greenish to yellowish spore masses; conidiophores lining the cavity, hyaline, cylindric, unbranched, tapering above, $1.5-2.5 \times 15-30 \mu$; coniclia hyaline fusiform, sickleshaped, or almost straight, pointed at the ends, simple, or 1septate, 2.5-4 × 15-25 $\mu$; microconidia not observed.

Apothecia erumpent, usually single, sometimes in more or less elongated clusters, circular, or undulated, sessile, narrowed below, .5-1.5 mm. in diameter, .5-1 mm. high, yellowish or greenish when moist, finally dark-brown to black, leathery to horny, softer when moist; hymenium concave to plane, or slightly convex, greenish when young, becoming dark-brown to black on drying; asci cylindric-clavate, tapering below to a short stalk, 8-spored, reaching a length of $60-80 \mu$ and a diameter of 8-10 $\mu$; spores ellipsoid-fusiform, straight, or slightly curved, simple, or 1-septate, hyaline, becoming yellowish brown, irregularly 2 -seriate, $3-4.5 \times 12-16 \mu$; paraphyses filiform, simple, or branched, $1.5-2 \mu$ in diameter, the tips scarcely swollen but more or less glued together forming an epithecium.

On branches of Amelanchier.

Type locality: Decorah, Iowa.

Distribution: Iowa to North Dakota.

Illustrations: Mycologia 25: pl. 20 (lower figure); 35: 460, f. 1,$2 ; 462, f .3 ; 38: 379$, f. 19,$20 ; 383, f .33 ; 395$, f. 45 . 
7. Dermea Ariae (Pers.) Tul.; Karst. Myc. Fenn. 1: 224.1871.

Pesiza Ariae Pers. Myc. Eu. 1: 325. 1822.

Tympanis Ariae Fries, Syst. Myc. 2: 175. 1822.

Sphaeria Cotoneastri Fries in Kunze \& Schm. Myk. Hefte 2: 46. 1823.

Sphaeria Cotoneastri Sorbi Fries, Syst. Myc. 2: 494. 1823.

Tympanis inconstans Fries, Summa Veg. Scand. 400. 1849.

Cenangium Ariae Tul. Ann. Sci. Nat. III. 20: 136. 1853.

Cenangium inconstans Fuckel, Symb. Myc. 268. 1869.

Sphaeronema pallidum Peck, Ann. Rep. N. Y. State Mus. 25: 85. 1873.

Cenanginm subnitidum Cooke \& Phill.; Cooke, Grevillea 3: 186. 1875.

Micropera Sorbi Sacc. Michelia 2: 628. 1882.

Micropera Cotoneastri Sacc. Syll. Fung. 3: 605. 1884.

Phaeangella subnitida Massee, Brit. Fungus.F1. 4: 137. 1895.

Conidial fruiting bodies erumpent, usually single, occasionally two or three together, bluntly conical, about .25-.35 $\mathrm{mm}$. in diameter and .25-.5 $\mathrm{mm}$. high, reddish-brown to olivaceous, or black, horny, becoming softer when moist, containing a single ovoid cavity; conidiophores hyaline, cylindric, simple, or branched, attenuated at the tips, $1.5-2 \times 20-40 \mu$; conidia hyaline to pale yellowish-green, fusiform, sickle-shaped, or occasionally almost straight, ends pointed, simple, or 1-septate, $2-4 \times$ 15-25 $\mu$; microconidia not observed.

Apothecia erumpent, single, or in clusters of two to four, circular to undulated, sessile, narrowed below, .4-1 mm. in diameter, .2-.4 mm. high, dark reddish-brown to black, leathery to horny, softer when moist; hymenium concave to plane, black; asci cylindric-clavate, narrowed into a short stalk, 8-spored, reaching a length of $70-100 \mu$ and a diameter of $8-10 \mu$; spores ellipsoid-fusoid, hyaline to pale-yellowish, simple, or becoming 1-3-septate, straight, or slightly curved, irregularly 2-seriate, 3-5 $\times 12-18 \mu$; paraphyses hyaline, filiform, simple, or branched, $1.5-2.5 \mu$ in diameter, the tips swollen to $5 \mu$ and glued together forming a yellowish epithecium.

On various species of Sorbus.

Type locality: Europe.

Distribution: Quebec to Ontario, Canada; also in Europe.

Illustrations: Mycologia 38: 379, f. 22, 23; 383, f. 34; 398, f. 53 .

Exsiccati: Ellis \& Ev. Fungi Columb. 571 (conidia only). 
8. Dermea acerina (Peck) Rehm, Ber. Bayer. Bot. Ges. 13: 197. 1912.

Sphaeronema acerinum Peck, Ann. Rep. N. Y. State Mus. 24: 86. 1872.

Sphaeronema nigripes Ellis, Bull. Torrey Club 6: 107. 1876.

Tympanis acerina Peck, Ann. Rep. N. Y. State Mus. 31: 48.1879.

Scleroderris acerina Sacc. Syll. Fung. 8: 599. 1889.

?Lecanidion acericolum Atk.; Peck, Ann. Rep. N. Yr. State Mus. 49: 24.1896.

?Patellaria acericola Atk.; Butler, My'cologia 32: 810. 1940.

Conidial bodies erumpent, single, or cespitose in small clusters, or more often in long rows, subulate, basal stroma subglobose to ovoid .2-.5 $\mathrm{mm}$. in diameter, dark-brown to black, leathery to horny, softer when moist, the beak slender, tapering, straight, or curved, reaching a length of $1.5 \mathrm{~mm}$. and $100-150 \mu$ in diameter at the base, paler and sometimes translucent toward the tip; conidiophores hyaline, cylindric, simple, $2 \times 20-40 \mu$, swollen below the point of attachment; conidia ellipsoid, hyaline, straight, or sometimes slightly curved, one end with a truncate apiculus, 5-8 × 15-25 $\mu$; microconidia hyaline, filiform, simple, straight, or curved, $1-2 \times 6-10 \mu$.

Apothecia erumpent, single, or in rows, circular, or undulate, .4-1 mm. in diameter, .2-.5 $\mathrm{mm}$. high, sessile, narrowed below, black, or dark-brownish, leathery to horny, softer when moist; hymenium at first concave, becoming plane, or slightly convex, slightly paler than the outside of the apothecium; asci cylindricclavate, short-stalked, 8-spored, reaching a length of 85-125 $\mu$ and a diameter of 13-16 $\mu$; spores ellipsoid-fusiform, hyaline, becoming yellowish, simple, or 1-3-septate, straight, or sometimes slightly curved, irregularly 2-seriate, 5-6 × 13-20 $\mu$; paraphyses hyaline, filiform, simple, or branched, 1.5-2 $\mu$ in diameter, the tips slightly swollen and glued together forming a yellowish epithecium.

On various species of Acer, $A$. Saccharum, A. saccharinum, $A$. rubrum.

Type Locality: Greenbush, New York.

Distribution: New York to Michigan and Virginia.

Illustrations: Mycologia 38: 379, f. 16;386, f. 36; 398, f. 50.

Exsiccati: Ellis, N. Am. Fungi 9.77; Ellis \& Ev. Fungi Columb. 2086, 3585; Relic. Farlow. 143a, $b$. 
9. Dermea Padi (Alb. \& Schw.) Fries, Summa, Veg. Scand. 362. 1849.

Peziza Cerasi Padi Alb. \& Schw. Consp. Fung. 345. 1805.

Cenangium Cerasi Padi Fries, Syst. Myc. 2: 180. 1827.

Tympanis Padi Quél. Ench. Fung. 330. 1886.

Cenangium Padi Sacc. Michelia 2: 84. 1880.

Sphaeria padina Sacc. Michelia 2: 84. 1880.

Sphaeronema brunneoviride Auersw.; Sacc. Syll. Fung. 3: 186. 1884.

Cryptosporium brunneoviride Jacq. Nouv. Mem. Soc. Imp. Moscow 15: 369. 1898.

Conidial fruiting bodies erumpent, mostly single, occasionally two or three in a cluster, cylindric to conic, .5-1.3 mm. in height and .2-.5 mm. in diameter, opening at the tip, dark reddishbrown to black, leathery to horny, softer when moist, the basal stroma containing one cavity in which the conidiophores are produced; conidiophores cylindric, tapering to a slender point, 2-3 $\times 25-50 \mu$; conidia elongate, fusiform to subfiliform, pointed at the ends, sickle-shaped to almost straight, simple, or 1-septate, hyaline, $2.5-4 \times 20-35 \mu$; microconidia hyaline, bacilliform, straight, or slightly curved, simple.

Apothecia erumpent, single, or cespitose in clusters of two to six, sessile, narrowed below, circular, or undulated, .5-1.5 mm. in diameter and about .3-1 $\mathrm{mm}$. high, dark reddish-brown to black, leathery to horny, softer when moist, hymenium at first concave, then plane to convex, black, or dark-brown; asci cylindric-clavate, tapering to a short stalk, 8-spored, reaching a length of $85-100 \mu$ and a diameter of 15-15 $\mu$; spores ellipsoidfusoid, hyaline, becoming yellowish, straight, or slightly curved, simple, or 1-3-septate, 5-7 $\times 15-20 \mu$; paraphyses hyaline, filiform, simple, or branched, 1.5-2 $\mu$ in diameter, the tips swollen to $3 \mu$ and glued together forming a yellowish epithecium.

On species of Prunus, P. domestica, P. Padus, P. spinosa, P. virginiana.

Type locality: Europe.

Distribution: New York, also in Europe.

Illustrations: Mycologia 38: 366, f. 3, f; 383, f. 29; 395, f. 74 .

10. Dermea Prunastri (Pers.) Fries, Summa Veg. Scand. 362. 1849.

Peziza Prunastri Pers. Tent. Disp. Fung. 35. 1797.

Ceratostoma spurium Fries, Obs. My'c. 2: 338. 1818. 
Cenangium Prunastri Fries, Syst. Myc. 2: 180.1822.

Cenangium Prunastri rigida Fries, Syst. Myc. 2: 180. 1822.

?Cenangium rigidum Schw. Trans. Am. Phil. Soc. II. 4: 238. 1832.

Tympanis Prunastri Wallr. Fl. Crypt. Germ. 2: 427. 1833.

Sphaeronema spurium Sacc. Syll. Fung. 3: 186. 1884.

Phaeangella Prunastri Massee, Brit. Fungus-F1. 4: 137. 1895.

Dermatella Prunastri Dowson, New Phytologist 12: 207. 1913.

Conidial bodies erumpent, occasionally single, more often cespitose, cylindric, or cylindric-conic to subulate, 1-2 $\mathrm{mm}$. in height, .2-.4 mm. in cliameter at the base, arising from a more or less circular, or transversely elongated basal stroma, black to greenish, or olivaceous when moist, hard, horny, brittle, softer when moist, with a single, ovoid cavity which is frequently in the tip of the beak only but may extend into the basal stroma also; conidiophores hyaline, cylindric, tapering to a slender point, simple, $2.5-3 \times 20-35 \mu$; coniclia elongate-fusiform, hyaline, slightly greenish, simple, almost straight, or slightly sickleshaped, the ends acute, 5-7 $\times 20-35 \mu$; microconidia hyaline to yellowish, filiform, straight, or slightly curved, simple, ends rounded, $1.5 \times 7-10 \mu$.

Apothecia erumpent, single, or cespitose, sessile, narrowed below, circular, or undulated, .5-1 mm. in diameter .2-1 $\mathrm{mm}$. high, dark-brown to black, leathery to horny, fleshy when moist; hymenium concave to plane, or slightly convex, black; asci cylindric-clavate, short-stalked, 8-spored, reaching a length of 90-125 $\mu$ and a diameter of 12-15 $\mu$; spores ellipsoid-fusiform, hyaline, becoming yellowish, simple, or 1-3-septate, straight, or slightly curved, irregularly 2 -seriate, $5-7.5 \times 15-25 \mu$; paraphyses hyaline, filiform, simple, or branched, $1.5-2 \mu$ in diameter, the tips swollen to $2.5-3 \mu$ and glued together forming a vellowish epithecium.

On various species of Prunus.

Type locality: Europe.

Distribution: New Hampshire to Washington and South Carolina.

Illustrations: Phill. Brit. Discom. pl. 10, f. 66; New Phytologist 12:209, f. 1, 2; 211, f. 3; Mycologia 38: 366, f. 5, 6; 383, f. 28, 395; f. 43.

Exsiccati: Ellis \& Ev. Fungi Columb. 3118 (as Dermatea Cer(asi). 


\section{Dermea piceina Groves, Mycologia 38: 404. 1946.}

Conidial bodies erumpent, mostly single, minute, black, or greenish-black, .1-.3 mm. in diameter, almost globose, opening above and the spores emerging in a whitish, or pale-greenish mass or cirrhus; conidiophores lining the cavity, hyaline, cylindric, tapering to a tip, simple, or 1-3-septate; microconidia hyaline, filiform, simple, strongly curved, ends rounded, $1-1.5 \times 9-15 \mu$.

Apothecia erumpent, single, or cespitose in clusters of two to six, circular, or slightly undulated, sessile, narrowed below and substipitate, .5-1.5 mm. in diameter, .5-1 mm. high, dark recldishbrown to almost black; asci cylindric-clavate, short-stalked, 8spored, reaching a length of 75-100 $\mu$ and a diameter of 14-16 $\mu$; spores ellipsoid, or ovoid, hyaline, becoming brownish, simple, or 1-3-septate, irregularly 2-seriate, $6-8 \times 12-18 \mu$; paraphyses hyaline, filiform, simple, or branched, 1.5-2 $\mu$ in diameter, the tips swollen to $3 \mu$, forming a slight epithecium.

On branches of Picea glauca.

Type Locality: Petawawa Forest Experiment Station, Ontario, Canada.

Distribution: Known only from the type locality.

IlLustrations: Mycologia 38: 375, f. 11, 12; 383, f. 32; 398, f. 52 .

\section{Dermea pinicola Groves, Mycologia 38: 403. 1946.}

Conidial stage a rounded, fleshy stroma about $.5 \mathrm{~mm}$. in diameter, containing a single cavity; conidiophores, hyaline, cylindric, simple, or branched, 3-4 $420-45 \mu$; coniclia elongatefusiform, to subfiliform, 1-3-septate, hyaline, sometimes yellowish, mostly sickle-shaped, or nearly straight, one end more acute than the other, $4-6 \times 30-50 \mu$.

Apothecia erumpent, single, or cespitose in clusters of two to six each, circular, or slightly undulate, sessile, narrowed below, $.3-.8 \mathrm{~mm}$. in diameter, .2-.4 mm. high, dark reddish-brown to black, leathery to horny, softer when moist; hymenium concave, becoming plane, or slightly convex, the margin slightly raised; asci cylindric-clavate, short-stalked, 8-spored, reaching a length of 70-100 $\mu$ and a diameter of 14-20 $\mu$; spores ellipsoid-fusiform, hyaline, straight, or slightly curved, simple, or 1-septate, irregularly 2-seriate, 5-7.5 $\times 18-20 \mu$; paraphyses hyaline, filiform, simple, or branched, $1.5-2 \mu$ in cliameter, the tips swollen to $3 \mu$ and glued together forming an epithecium. 
On branches of Pinus Strobus.

Type Locality: West mainland, Lake Temagami, Ontario, Canada.

Distribution: Vermont to Ontario.

Illustrations: Mycologia 38: 375, f. 15; 398, f. $51 a-b$.

\section{Dermea Libocedri Groves, Mycologia 38: 382. 1946.}

Conidial fruiting bodies erumpent, separate, black, minute, $.2-.3 \mathrm{~mm}$. in diameter and about the same in height, rounded to subcylindric, opening at the tip, containing a single ovoid, or slightly lobed cavity lined with the conidiophores; conidiophores hyaline, cylindric, pointed at the tip, simple, or branched near the base, occasionally septate, $2.5-3.5 \times 20-30 \mu$; conidia elongate-filiform, hyaline, sickle-shaped, pointed at the ends, 1-3septate, 4-6 $\times 42-65 \mu$; microconidia hyaline, filiform, simple, straight, or curved, ends not pointed, $1-1.5 \times 10-18 \mu$.

Apothecia erumpent, single, or in clusters of two to four each, sessile, slightly narrowed below, circular, or slightly undulated, .3-.5 mm. in diameter, .2-.3 mm. high, dark brownish-black, fleshy-leathery when moist; hymenium concave to plane, black; asci cylindric-clavate, short-stalked, 8 -spored, reaching a length of $75-100 \mu$ and a diameter of $12-17 \mu$; spores ellipsoid-fusoid, hyaline, 1-3-septate, straight, or slightly curved, irregularly 2-seriate, $68 \times 15-20 \mu$; paraphyses hyaline, filiform, simple, or branched, $1.5-2 \mu$ in diameter, the tips swollen to $3-4 \mu$ and forming an epithecium.

On Libocedrus decurrens.

Type Locality: Darlingtonia, California.

Distribution: Known only from the type locality.

Illustrations: Mycologia 38: 366, f. 7; 383, f. 31; 400, f. 57.

14. Dermea Hamamelidis (Peck) Groves, Mycologia 32: 743. 1940.

Patellaria Hamamelidis Peck, Ann. Rep. N. Y. State Mus. 33: 32. 1880.

Lecanidion IIamamelidis Sacc. Syll. Fung. 8: 800. 1889.

Dermatella Hamamelidis Ellis \& Ev. Proc. Acad. Sci. Phila. 45: 149. 1893. (as a new species).

Dermatella Hamamelidis Durand, Bull. Torrey Club 29: 464. 1902.

Conidial fruiting bodies, minute, about .15-.20 mm. in diameter, erumpent through and splitting the outer bark, appearing as thickly scattered, blister-like elevations in the bark, the spores emerging through the cracks in the bark when moist; conidio- 
phores simple, hyaline, tapering above to a slender tip, $2 \times 10-$ $25 \mu$; conidia elongate-fusiform to subfiliform, hyaline, simple, or 1 -septate, straight, or curved, one end often narrower than the other, 4.5-6 × 18-25 $\mu$; no microconidia observed.

Apothecia erumpent, more or less in rows, single, or in small clusters, circular, or somewhat undulated, sessile, narrowed below, .3-.8 mm. in diameter, .2-.4 mm. high, dark reddishbrown to black, leathery to horny, softer when moist; hymenium concave to plane, or finally convex; asci cylindric-clavate, shortstalked, 8-spored, reaching a length of $80-120 \mu$ and a diameter of $12-15 \mu$; spores ellipsoid-fusiform, hyaline to yellowish, straight, or slightly curved, irregularly 2 -seriate, simple, or 1-3septate, 5-7.5 × 15-20 $\mu$; paraphyses filiform, hyaline, simple, or branched, 1.5-2 $\mu$ in diameter, the tips slightly swollen and glued together, forming a yellowish epithecium.

On branches of Hamamelis virginiana.

Type Locality: Clinton, Catskill Mountains.

Distribution: New Hampshire to Pennsylvania and Canada. Illustrations: Mycologia 32: 737,f. 1, E, F; 742, f. 6-8; 38 : 379, f. 17,$25 ; 386$, f. $41 ; 395$, f. 46.

Exsiccatr: Ellis \& Ev. N. Am. Fungi 2634; Ellis \& Ev. Fungi Columb. 2016.

15. Dermea Tulasnei Groves, Mycologia 38: 399. 1946.

Cenangium Fraxini Tul. Ann. Sci. Nat. III. 20: 140. 1853. Not Peziza Fraxini Schw. 1822.

Cenangella Fraxini Sacc. Syll. Fung. 8: 590. 1889.

Dermea Fraxini Rehm, Ber. Bayer. Bot. Ges. 13: 196. 1912.

Coniclial bodies erumpent, rounded to short-conical, .15-.50 $\mathrm{mm}$. in diameter and .2-.4 mm. high, in clongated clusters up to $1 \mathrm{~mm}$. in length, dark reddish-brown to black, softer than the apothecia, containing one, or sometimes several, more or less ovoid, simple to slightly chambered cavities which open irregularly at the top; conidiophores cylindric, simple, or branched, attenuated above, $4-5 \times 25-50 \mu$; conidia hyaline to yellowishgreen, fusiform, or subfiliform, simple, or occasionally septate, strongly curved to almost straight, 6-8 $\times 40-50 \mu$.

Apothecia erumpent, single, or in small clusters, circular, or slightly undulate, sessile, slightly narrowed below, .5-1 mm. in diameter, .2-.6 $\mathrm{mm}$. high, waxy-leathery to horny, softer when moist; hymenium concave to plane, or slightly convex, dark 
reddish-brown to almost black; asci cylindric-clavate, tapering into a short stalk, 8-spored, reaching a length of 85-115 $\mu$ and a diameter of 14-20 $\mu$; spores hyaline to pale yellowish-green, ellipsoid-fusiform, straight, or slightly curved, simple, or 1-3septate, irregularly 2-seriate, 6-10 $\times 15-22 \mu$; paraphyses hyaline, filiform, usually branched, the tips swollen and glued together forming a yellowish epithecium.

On species of Fraxinus, Fraxinus nigra.

Type locality: Europe.

Distribution: Canada; also in Europe.

Illustrations: Mýcologia 38: 375, f. 13, 1.7; 386, f. 37; 400, f. 55 .

16. Dermea Chionanthi Ellis \& Ev. Proc. Acad. Sci. Phila. 45: 148. 1893.

Conidial fruiting bodies erumpent, single, black, about .2$.4 \mathrm{~mm}$. in diameter and $.2 \mathrm{~mm}$. high, irregularly rounded to slightly conical, opening widely at the top, fleshy-membranous, containing a single cavity on the base of which the conidiophores are borne; conidiophores hyaline, cylindric, simple, or occasionally branched, tapering above to a tip on which the conidia are borne, $3.4 \times 12-20 \mu$; conidia elongate-fusiform to subfiliform hyaline, curved, sickle-shaped to almost straight, simple, or 1 septate, bluntly pointed at the ends, 5-7 $\times 25-35 \mu$; no microconidia observed.

Apothecia erumpent, gregarious, often more or less in rows, single, or cespitose, sessile, slightly narrowed below, circular, or undulated, .4-1 mm. in diameter, .2-.4 mm. high, dark-reddish, or olivaceous-brown to black, leathery, or horny, softer when moist; hymenium at first concave, becoming plane to slightly convex, reddish-brown to black; asci cylindric-clavate, narrowed below into a rather short stalk, 8-spored, reaching a length of 90-110 $\mu$ and a diameter of 15-20 $\mu$; spores ellipsoid to ellipsoidfusoid, hyaline, becoming yellowish, simple, often becoming 1-3septate, straight, or slightly curver, irregularly 2 -seriate, $6-7 \times$ 18-25 $\mu$; paraphyses hyaline, filiform, simple, or occasionally branched, $1.5-2.5 \mu$ in diameter, the tips swollen to 3-4 $\mu$ in diameter and forming an epithecium.

On branches of Chionanthus virginica.

Type Locality: Wilmington, Delaware.

Distribution : Delaware and Maryland. 
Illustrations: Mycologia 38: 375, f. 10; 398, $f .48$.

Exsiccati: Ellis, N. Am. Fungi 2635; Ellis \& Ev. Fungi Columb. 2423.

17. Dermea Mori Peck, Bull. N. Y. State Mus. 157: 46. 1912.

Apothecia erumpent and usually occurring singly, patellate, reaching a diameter of 1-2 mm., black, or blackish; hymenium plane or nearly so, similar in color to the outside of the apothecium; asci broad-clavate, reaching a length of $80-90 \mu$ and a diameter of 20-25 $\mu, 8$-spored; spores irregularly 2-seriate, hyaline, apparently simple, ellipsoid, or slipper-shaped, $8-10 \times 20$ $30 \mu$; paraphyses slender, hyaline below but ends forming a brown epithecium.

On dead twigs of Russian mulberry, Morus alba tartarica.

Type locality: Concordia, Kansas.

Distribution: Known only from the type locality.

Description drawn from part of original collection sent from Albany by Dr. H. D. House. From the material examined it seems to be properly placed in the genus.

\section{Doubtful and Excluded Species}

Dermatea crypta Cooke, Grevillea 16: 70. 1888. Ellis states: "This appears to be the same thing I have published in Torr. Bull. as Dermatea olivacea on Ilex glabra Newfield, N. J. 1875".

Dermatea cucurbitaria Cooke; Ellis, N. Am. Fungi 68; Tryblidium cucurbitaria Rehm, Ber. Naturh. Ver. Augsburg 26: 78. 1881. This is regarled as a Tryblidium.

Dermatea Cydoniae Schw. Trans. Am. Phil. Soc. II. 4: 237. 1832. On Cydonia. According to Groves, this is not a discomycete.

Dermatea Eucalypti Cooke \& Hark.; Cooke, Grevillea 9: 130. 1881. This according to Groves is apparently not a Dermea but it is impossible to place it.

Dermatea ferruginea (Cooke \& Ellis) Rehm, Ann. Myc. 2: 353.1904 ; Patellaria ferruginea Cooke \& Ellis, Grevillea 5: 91. 1877. Groves states that this is probably a Pesicula but its identity is uncertain. Ellis, N. Am. Fungi 148 under this name is on stems of Desmodium.

Dermatea olvacea Ellis, Bull. Torrey Club 6: 133. 1876. According to Groves this is probably a Pezicula. The species, however, needs more study. from fresh material. It was originally reported on Ilex glabra. See N. Am. Fungi 851 . The name as pointed out by Groves is invalid having been previously used.

Dermatea puberula Durand, Jour. Myc. 10: 101. 1904. This according to Groves is not a Dermea and its position is uncertain.

Dermatea Xanthoxyli Peck, Ann. Rep. N. Y. State Mus. 31: 47. 1877. This is Thyronectria pyrrhochlora (Auersw.) Sacc. 
11. DURANDIELLA Seaver, Mycologia 24:261. 1932. Durandia Rehm, Ann. Myc. 11: 166. 1913. Not Durandia Bockel, 1896.

Apothecia erumpent, coriaceous, black as in Tympanis; asci clavate, containing many minute, spermatoid, spore-like bodies as in Tympanis and in addition normal ascospores; paraphyses filiform.

Type species, Peziza Fraxini Schw.

In a previous paper (Mycologia 37: 336) this genus was regarded as a synonym of Godronia. Groves (Mycologia 29: 79) believes that this should be retained as a distinct genus. It might be characterized as a Tympanis with ascospores.

We have a similar situation in Scoleconectria of the Hypocreales in which the normal spores are often obscured by the numerous spermatoid, spore-like bodies.

1. Durandiella Fraxini (Schw.) Seaver, comb. nov.

Peziza Fraxini Schw. Schr. Nat. Ges. Leipzig 1: 123. 1822.

Tympanis Fraxini Fries, Syst. Myc. 2: 174. 1822.

?Sphaeronema Fraxini Peck, Ann. Rep. N. Y. State Mus. 29: 71. 1878.

?Sphaerographium Fraxini Sacc. Syll. Fung. 3: 598. 1884.

Durandia Fraxini Groves, Mycologia 29: 78. 1937.

Godronia Fraxini Seaver, Mycologia 37: 350. 1945.

Apothecia erumpent in clusters of three to ten, or rarely occurring singly, black, or blackish, reaching a diameter of $1 \mathrm{~mm}$., circular, or irregular from mutual pressure; hymenium plane or nearly so, similar in color to the outside of the apothecium; asci clavate, reaching a length of $120-150 \mu$ and a diameter of $10-12 \mu$, 8-spored; spores filiform, attenuated at either end, septate, 2.5-3 $\times$ 50-90 $\mu$, accompanied by minute sprematoid, spore-like bodies; paraphyses filiform.

The apothecia often accompanicd with Sphaerographium Fraxini which appears to be its conidial stage.

On branches of Fraxinus americana.

Type Locality : North Carolina.

Distribution: North Carolina to Massachusetts, Ontario and Ohio.

Exsiccati: Barth. Fungi Columb. 3885; Rehm, Ascom. 2027 (from Canada); Reliq. Farlow. $155 a-b$.

12. MURANGIUM Seaver, gen. nov.

Apothecia as in Cenanginm, gregarious, or congested; asci broad-clavate, 8-spored; spores very large, ellipsoid, hyaline, or brown, becoming muriform. 
Apotheciis erumpentibus; ascis clavatis; sporis muriformibus.

Type species, Cenangium Sequoiae Plow.

\section{Murangium Sequoiae (Plow.) Seaver, comb. nov.}

Cenangium Sequoiae Plow.; Phill. Grevillea 7: 23. 1878.

Scleroderris Sequoiae Sacc. Syll. Fung. 8: 596. 1889.

Apothecia erumpent through the crevices of the bark, usually in linear groups, often congested, turbinate, at first closed, opening with an irregular aperture; hymenium concave, or nearly plane; asci very broad-clavate, reaching a length of $140 \mu$ and a diameter of 30-40 $\mu, 8$-spored, tapering abruptly into a stem-like base; spores irregularly disposed in the ascus, broad-ellipsoid, the contents granular, becoming 1-3-septate, then muriform, $16 \times 33-36 \mu$; paraphyses filiform.

On bark of Sequoia gigantea and Juniperus virginiana.

Type locality: California.

Distribution: South Carolina and California.

Exsiccati: Ellis, N. Am. Fungi 671; Rav. Fungi Am. 634.

13. TYMPANIS Tode, Fungi Meckl. 1:23. 1790; Fries, Syst. Myc. 2: 173. 1822.

Apothecia erumpent as in Dermea, single, or cespitose, usually hard and coriaceous, dark-brown, or black; hymenium concave to plane at maturity; asci clavate, filled with numerous spermatoid, spore-like bodies; paraphyses filiform.

Type species, Tympanis saligna Tode.

The genus Tympanis comprises a number of species in which normal ascospores are absent or undeveloped. Ascospores sometimes develop in addition to the spermatoid bodies in which case the species is transferred to some other genus depending upon the nature of the ascospores (see Durandiella Fraximi); the species listed here are those in which no definite ascospores have been observed.

On coniferous hosts, Pinus, Abies.

1. T. Pinastri.

On nonconiferous hosts.

On species of Alnus.

2. T. alnea.

On species of Populus.

3. T. spermatiospora.

On Oxydendrum.

4. T. Oxydendri.

On miscellaneous hosts.

Spermatoid bodies . $5 \times 1-2 \mu$.

5. T. conspersa.

Spermatoid bodies $1.5 \times 4-5 \mu$.

6. T. fasciculata. 
1. Tympanis Pinastri (Pers.) Tul. Fung. Carp. 3: 151. 1865.

Cenangium Pinastri Pers. Obs. Myc. 2: 83. 1799.

Phacidium Pinastri Fries, Scler. Suec. 55. 1820.

Cenangium Pinastri Fries, Syst. Myc. 2: 184. 1822.

Tryblidium Pinastri Fries, Summa Veg. Scand. 369. 1849.

Cenangium laricinum Fuckel, Symb. Myc. 270. 1869.

Tryblidiopsis Pinastri Karst. Myc. Fenn. 1: 262. 1871.

Micropera Pinastri Sacc. Michelia 2: 104. 1880.

Cenangella Pinastri Sacc. Syll. Fung. 8: 588. 1889.

Apothecia scattered, erumpent, occurring either singly, or in cespitose clusters on a stroma, short-stipitate, at first closed, expanding and becoming turbinate, black, or blackish, reaching a diameter of $1 \mathrm{~mm}$; hymenium concave, becoming plane, or convex, lighter than the outside of the apothecium, cinereous; asci clavate, reaching a length of $120-130 \mu$ and a diameter of $12 \mu$, filled with minute, spore-like bodies, $1 \times 2-2.5 \mu$; paraphyses filiform, branched at their apices, reaching a diameter of $3 \mu$.

The pycnidial stage, Micropera Pinastri, is described with pycnospores fusoid-falcate, 5-7 $\times 50-60 \mu$.

On Abies balsamea, Pinus rigida and Pinus Strobus.

Type locality: Europe.

Distribution: Newfoundland to Washington and Colorado.

Illustrations: Tul. Fung. Carp. 3: pl. 19, f. 10-12; Rab. Krypt.-F]. $\mathbf{1}^{3}: 245, f .1$.

Exsiccatr: Reliq. Farlow. $156 a-b$; Rav. Fungi Car. 3: 63.

2. Tympanis alnea (Pers.) Fries, Syst. Myc. 2: 174. 1822.

Peziza alnea Pers. Sỵn. Fung. 673. 1801.

Tympanis conspersa alnea Karst. Myc. Fenn. 1:227. 1871.

Apothecia erumpent in cespitose clusters of three to twenty each, on a rounded, black stroma $3-4 \mathrm{~mm}$. in diameter, the individual apothecia short-stipitate, reaching a diameter of .3-.5 mm., black but often covered with a whitish, powdery coat; asci cylindrical-clavate, reaching a length of $150-160 \mu$ and a diameter of $15-20 \mu$, filled with numerous spore-like bodies; paraphyses branched enlarged at their tips where they reach a diameter of $6 \mu$, brown, forming a brown epithecium.

On branches of Alnus, Alnus tenuifolia and Alnus incana.

Type locality: Europe.

Distribution: Newfoundland to New York and Montana.

This species is very similar to Tympanis cespitosa and was regarded as a variety by Karsten. The specimen in Schweinitz, 
North American Fungi 1961 is a Godronia. Other specimens, however, do not show the Godronia type of spore so the species is allowed to remain in the present genus.

3. Tympanis spermatiospora (Nyl.) Nyl. Not. Soc. Fauna Fl. Fenn. 10: 70. 1869.

?Dermea populnea Schw. Trans. Am. Phil. Soc. II. 4: 237. 1832. Not Peziza populnea Pers. 1797.

Patellaria spermatiospora Nyl. Not. Soc. Fauna Fl. Fenn. 4: 125. 1858.

Cenangium populinum Fuckel, Symb. Myc. 268. 1869.

Tympanis populina Sacc. Bot. Cent. 18: 247. 1884.

Cenangium spermatiosporum Sacc. Syll. Fung. 8: 560. 1889.

?Cenangium Schweinitzii Sacc. Syll. Fung. 8: 576. 1889.

Apothecia erumpent, occurring either singly, or more of ten in dense, cespitose clusters, the individual apothecia short-stipitate, at first closed and knob-like, opening and gradually expanding and becoming shallow cup-shaped, or turbinate, black, reaching a diameter of $1 \mathrm{~mm}$; hymenium concave, or nearly plane, brownish-black; asci clavate, reaching a length of 75-80 $\mu$ and a diameter of $12 \mu$, densely filled with spore-like bodies $1 \times 3$ $3.5 \mu$; paraphyses slender, enlarged above, the ends adhering and forming a brown epithecium.

On dead branches of Populus, especially Populus tremuloides.

Type locality: Europe.

Distribution: Newfoundland to New York, Idaho, Colorado and Iowa; also in Europe.

4. Tympanis Oxydendri Ellis \& Ev. Proc. Acad. Sci. Phila. 1894: 352. 1894.

Apothecia erumpent in cespitose clusters of three to five each, the individual apothecia expanding and becoming subturbinate, reaching a diameter of .5-.75 mm. ; hymenium becoming plane, or convex, lighter than the outside of the apothecium, greenishblack when dry; asci cylindrical-clavate, reaching a length of 110-130 $\mu$ and a diameter of $15-18 \mu$, filled with minute sporelike bodies $1 \times 2.5-3 \mu$; paraphyses slender, abundant, freely branched, hyaline.

On dead limbs of Oxydendrum arboreum.

Type Locality: Nuttalburg, IVest Virginia.

Distribution: Known only from the type locality.

Exsiccati: Ellis \& Ev. N. Am. Fungi 30+3; Fungi Columb. $2+7$. 
This closely resembles Tympanis fasciculata but is distinguished by the greenish hymenium.

5. Tympanis conspersa Fries Syst. Myc. 2: 175. 1822.

Sphaeria cespitosa Tode, Fungi Meckl. 2: 41. 1791.

Sphaeria Aucupariae Pers. Syn. Fung. 51. 1801.

Peziza Pyri Pers. Syn. Fung. 671. 1801.

Sphaeria conspersa Fries, let. Akad, Handl, 1817: 112. 1817.

Cenangium A ucupariae Fries, Syst. Myc. 2: 181. 1822.

Tympanis Aucupariae Vallr. Fl. Crypt. Germ. 2: 427. 1833.

Peziza Aucupariae Pers. Myc. Eu. 1: 327. 1822.

Apothecia erumpent in cespitose clusters of ten to twenty each, seated on a fleshy stroma, at first closed, gradually expanding and becoming turbinate, with a short, thick stem, reaching a diameter of .5-1 mm., black but of ten covered with a whitish mealy coat, semicartilaginous when fresh, horny when dry; hymenium plane, or slightly concave, blackish; asci cylindric-clavate, reaching a length of $175 \mu$ and a diameter of 18-20 $\mu$, filled with minute, spore-like bodies .5 $\times 1-2 \mu$; paraphyses slender, branched, brown above and forming a brown epithecium.

On branches of various kinds, Malus, Tilia and Prumus.

Type locality: Europe.

Distribution: New York and New Jersey to Massachusetts, also in Europe.

Illustrations: Tode, Fungi Meckl. 2: pl. 1t, f. 113; Grev. Scot. Crypt. Fl. pl. 338; Phill. Brit. Discom. pl. 11, f. 67; Rab. Crypt.-Fl. $1^{3}: 245, f .2$.

Exsiccati: Ellis, N. Am. Fungi 66; Barth. Fungi Columb. 4588; Reliq. Farlow. 153.

6. Tympanis fasciculata Schw. Trans. Am. Phil. Soc. II. 4: 237. 1832.

Apothecia erumpent in fascicles of two to six apothecia each, the individual apothecia becoming expanded and subturbinate, black, reaching a diameter of $.5 \mathrm{~mm}$.; hymenium concave, or nearly plane, similar in color to the outside of the apothecium; asci cylindric-clavate, reaching a length of $130 \mu$ and a diameter of $15 \mu$, filled with minute, spore-like bodies $1.5 \times 4-5 \mu$; paraphyses very slender, branched.

On branches of Viburnum Lentago; also on Rhus and Cormus.

Type locality: Bethlehem, Pennsylvania. 
Distribution: New Jersey and Pennsylvania to Ontario.

Exsiccati: Ellis, N. Am. Fungi 65; Rehm, Ascom. 423 (from Newfield, New Jersey).

For additional information on Tympanis see Groves, Mycologia $41: 59-76.1949$.

\section{Doubtful and Excluded Species}

Tympanis cinerascens Schw. Trans. Am. Phil. Soc. II. 4: 237. 1832. On unidentified branches, Easton [Pennsylvania].

Tympanis gyrosa Berk. \& Curt.; Berk. Grevillea 4:3. 1875. The species was described from sterile specimens. No authentic material has been seen.

Tympanis plicatocrenulata (Schw.) Sacc. Syll. Fung. 8: 580. 1889; Pesiza plicato crenata Schw. Schr. Nat. Ges. Leipzig 1: 123. 1822. Material in the Schweinitz collection was very scant and looked more like a Tapesia.

Tympanis saligna Tode, Fungi Meckl. 1: 24, pl. 4,f.37. 1790. Reported on very scant material.

Tympanis pithya Karst. Myc. Fenn. 1:228. 1871. This species has been reported on Pinus albicaulis at Horse Camp on Mt. Shasta. See Groves.

\section{Position Doubtful}

HAEMATOMYXA Sacc. Bot. Cent. 18: 250. 1884.

Apothecia subglobose, finally subpatellate, irregularly subcerebriform, gelatinous; asci broadly clavate, 8-spored; spores becoming muriform, brown.

Type species, Ilaematomyces vinosus Cooke \& Ellis.

Spores large 8-10 × 25-30 $\mu$.

Spores small $8-10 \times 18-20 \mu$.
1. II. rinosa.

2. H. ascoboloides.

1. Haematomyxa vinosa (Cooke \& Ellis) Sacc. Bot. Cent. 18: 250. 1884. (Plate 150, Fig. 1.)

Haematomyces vinosus Cooke \& Ellis, Grevillea 4: 179. 1876.

Dothiora rufa (Ellis \& Ev. in herb.); Rehm, Ann. Myc. 10: 397. 1912.

Haematomyxa rufa Rehm, Ann. Myc. 10: 397. 1912.

Apothecia at first subglobose, becoming patellate and irregularly gyrose, wine-colored to blackish; less than $1 \mathrm{~mm}$. in diameter; asci broad-clavate, 8-spored; spores broad-ellipsoid, slightly constricted in the middle, becoming muriform; paraphyses sparse.

On decorticated oak.

Type locality: Newfield, New Jersey.

Distribution: Known only from the type locality.

The species shows some affinity with the Patellariaceae. 


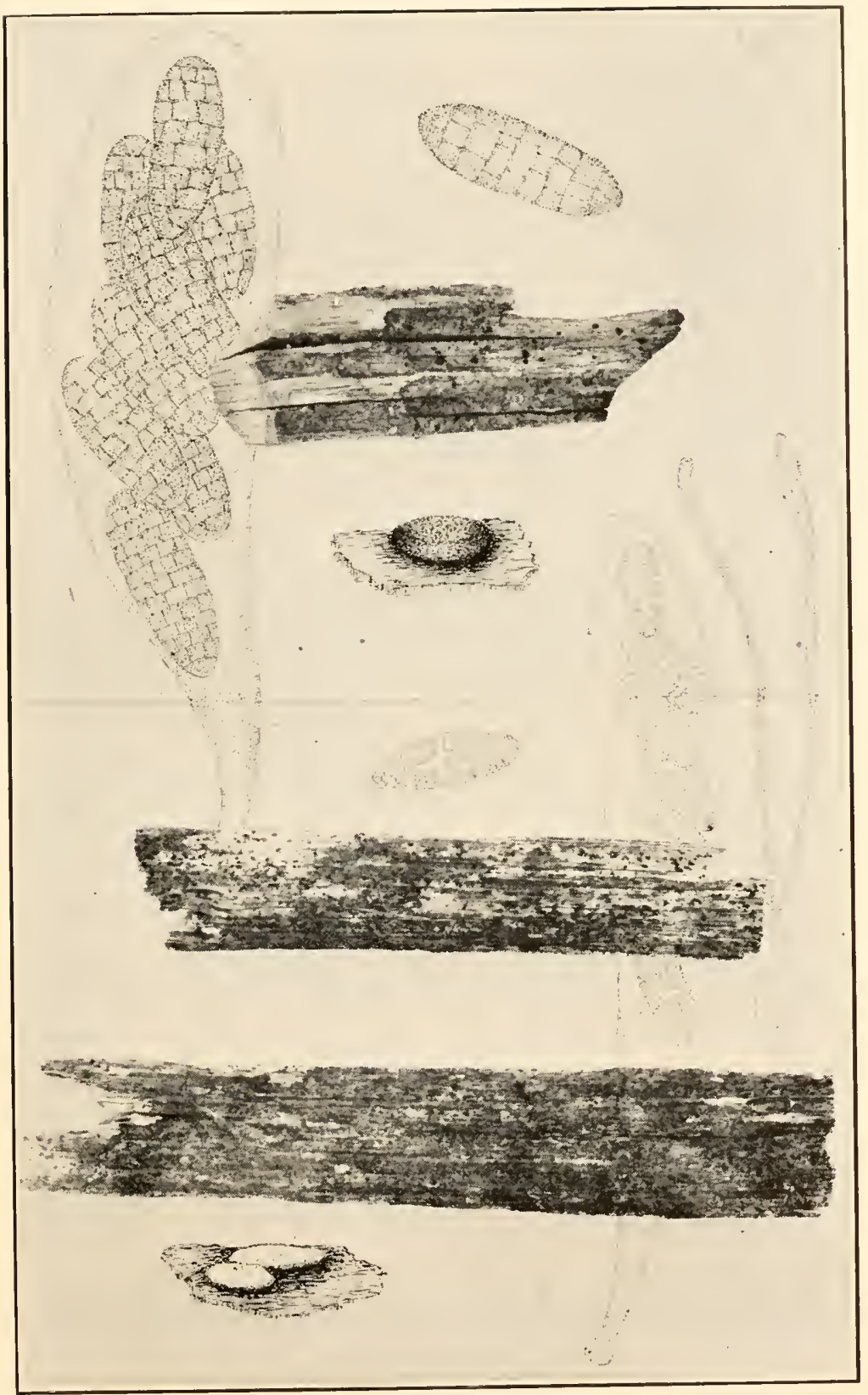

1. HAEMATOMYXA VINOSA

2. HAEMATOMYXA ASCOBOLOIDES 

2. Haematomyxa ascoboloides Ellis \& Ev. Bull. Torrey Club 27 : 60. 1900. (Plate 150, Fig. 2.)

Apothecia orbicular, fleshy-tremelloid, convex-discoid and wine-colored when fresh, concave and nearly black when dry, $.5-.75 \mathrm{~mm}$. in diameter; asci clavate-cylindric, reaching a length of $80-100 \mu$ and a diameter of 12-15 $\mu$. 8-spored; spores 1-seriate, ellipsoid, becoming 3 -septate and muriform, $8-10 \times 18-20 \mu$; paraphyses filiform, branched.

On weathered oak.

TyPe LOCALITY: Kansas.

Distribution: Known only from the type locality.

SARCOMYCES Massee, Jour. Myc. 6: 178. 1891.

Apothecia subgelatinous, subsessile, occurring singly, or several in a cluster, reaching a diameter of $2.5 \mathrm{~cm}$.; asci cylindric, 8-spored; spores becoming muriform and brown.

Type species, Tremella vinosa Berk. \& Curt.

1. Sarcomyces vinosa (Berk. \& Curt.) Massee, Grevillea 20: 14. 1891.

Tremella vinosa Berk. \& Curt. in herb.; Massee, Jour. Myc. 6: 179. 1891.

Apothecia as above; spores 1-seriate, becoming 3-septate and muriform, 8-10 × 21-24 $\mu$; paraphyses numerous, not thickened above, $2-5 \mu$ thick.

Type Locality: Venezuela.

Distribution: Venezuela and South Carolina.

Massee states that this species has much the appearance and habitat of Bulgaria inquinans but of a dark-purple color. It is recorded from South Carolina but no material has been seen. It would doubtless belong with our Ascotremelleae. 


\section{EXPLANATION OF PLATES}

(Continued from previous volume)

\section{Plate 75}

(frontispiece)

Ciborinia bifrons. A branch of Populus tremuloides showing healthy and infected leaves. Below, photograph of three sclerotia somewhat reduced; also enlarged photographs of two sclerotia with apothecia. The enlarged photographs were made by Paul F. Shope from fresh material collected in Colorado.

\section{Plate 76 (P. 10)}

Mitrula phalloides. Upper figure, habitat from leaves submerged in water. Center, Ombrophila Clavis on oak leaf. Lower figure, several ascophores, about natural size. Photographs furnished by L. R. Hesler (in part).

\section{Plate 77 (P. 28)}

Trichoglossum velutipes. Photographs of a group of ascophores, about natural size with drawings of an ascus with spores, tips of paraphyses and tip of a ruptured ascus; also one of the setae from the ascophore. Photographed from material collected in New Jersey by Mr. Fred R. Lewis.

\section{Plate 78 (P. 30)}

Trichoglossum hirsutum. This is regarded as a capitate form of the above. Photograph of a clump of sporophores, about natural size or slightly enlarged. Drawings of an ascus with spores, the end of a ruptured ascus, the tip of a paraphysis, one spore removed from the ascus and one of the setae. From material collected near Arden, New York, by Fred R. Lewis.

\section{Plate 79 (P. 32)}

Trichoglossum Wrightii. Photograph of ascophores from material collected in Bermuda by H. H. Whetzel, F. J. Seaver, and L. Ogilvie, Jan. 1926, about natural size, with drawings of portion of ascus with spores and tip of seta. Setting improvised from Bermuda limestone and soil.

$$
\text { Plate } 80 \text { (P. 34) }
$$

Trichoglossum Farlowii. Photograph of ascophores, about natural size, with drawings of ascus with spores and paraphyses; also one of the setae. Photographed from material collected during foray at Ithaca, August, 1931.

\section{Plate 81 (P. 36)}

UTPER FIgURE (1). Spathularia velutipes. Photograph of ascophores, about natural size, with drawings of spores.

LOWER FIGURE (2). Spathularia clavata. Photograph of ascophores, about natural size, with drawings of ascus with spores and paraphysis. Photographs furnished by the Dominion National Museum, Canada.

$$
\text { Plate } 82 \text { (P. 38) }
$$

Upper figure (1). Leotia lubrica. Photographed from material collected in The New York Botanical Garden, about natural size, with drawings of ascus, spores, and paraphysis. 
Lower figure (2). Cudonia circinans. Photographed by Paul F. Shope from material collected in Colorado in 1929, about natural size, with drawings portion of ascus, spores, and paraphysis.

\section{Plate 83 (P. 50)}

Monilinia fructicola. Above, mummified fruits with conidia and young apothecia; also drawings of conidia. Below, mummified fruits with mature apothecia, about natural size; also drawings of ascus with spores and paraphyses. Photographs furnished by Edwin E. Honey.

\section{Plate 84 (P. 5t)}

Monilinia Seaveri. Center, branches of wild cherry showing leaves infected with the conidial stage of the fungus Monilia Seaveri. Above, drawing of the conidia. Below, several seeds with the apothecial stage, about natural size. Left, ascus with spores and paraphysis.

\section{Plate 85 (P. 58)}

UPPER figure (I). Seazerinia Geranii. Photograph of the rootstocks of wild Geranium with growth of Botrytis. Center, drawing of a cluster of conidia with some immature at the extreme left.

Lower figure (2). Seaverinia Geranii. Photograph of a clump of apothecia. Left, drawing of ascus with spores. Below, three spores germinating.

\section{Plate 86 (P. 60)}

Streptotinia Arisaemae. 21, concentrically arranged sclerotia from conidia on potato agar, natural size; 22 , conidia with typically twisted branches; 23 , upper surface of leaf of Arisaema triphyllum, natural size; 24, Botrytis streptothrix on Orontium aquaticum, structure of sclerotium. From H. H. Whetzel.

\section{Plate 87 (P. 68)}

Martinia panamaensis. 1, conidia, developed on potato dextrose agar; 2 , two plantings of sclerotia showing tendency to aggregate and coalesce; 3 , stick with apothecia developed from sclerotia on bark in moist chamber, twice enlarged; 4 , apothecia developed from sclerotia grown on potato dextrose agar. From H. H. Whetzel.

\section{PLATE 88 (P. 70)}

Ciborinia bifrons. Above, photograph of poplar leaves, showing shotholes, where the sclerotia had dropped out. Below, photograph of a number of sclerotia producing apothecia. Photographs made from dried specimens, about natural size.

\section{Plate 89 (P. 72)}

Ciborinia Whetzelii. Above, sclerotia on leaf of Populus tremuloides. Below, apothecia arising from sclerotia, natural size. From H. H. Whetzel.

\section{Plate 90 (P. 74)}

Sclerotinia tuberosa. Above, photograph of several apothecia from New York City, about natural size. Below, several apothecia removed from the ground, with diagram showing position of sclerotia in the soil. Left, drawing of ascus with spores and paraphysis. 


\section{Plate 9I (P. 76)}

Sclerotinia Caricis-ampullaceae. Upper figure, left, part of the type specimen in Carex inflata from Finland. Center, clump of apothecia attached to a sclerotium, part of which is broken off, from specimen collected by Dr. C. L. Porter in Medicine Bow Mt. Swamp, Myoming. Right, apothecia on sclerotium attached to leaves of Carex aquatilis, from Sweden. Lower figure, apothecia in natural setting in Medicine Bow Mountains. Photographed by Dr. C. L. Porter, one-half natural size. From H. H. Whetzel.

\section{Plate 92 (P. 78)}

Sclerotinia Duriaeana. Upper left-hand corner, photographs of host with several sclerotia. Upper right-hand corner, drawings of ascus with spores and paraphysis. Below, photographs of apothecia, about natural size. Photographs furnished by H. H. Whetzel.

\section{Plate 93 (P. 84)}

Ciboria amentacea. Photograph of alder catkins bearing apothecia, about natural size. At the left, drawing of an ascus with spores and paraphysis. Below, drawing of one apothecium, much enlarged. Above, portion of ascus showing pore and three spores isolated. Photographed from material collected in Oregon by J. R. Keinholz in 1932.

\section{Plate 94 (P. 86)}

UPPER Figure (1). Ciboria pseudotuberosa. Photograph of apothecia on old acorns, with drawing of an ascus with spores and paraphyses.

Lower figure (2). Ciboria Caucus. Several apothecia on catkins of Salix, collected in Hood River region, Oregon by J. R. Keinholz.

\section{Plate 95 (P. 88)}

Ciboria carunculoides. Upper figure, stromatized fruits of mulberry, Morns, the sclerotial stage. Below, photographs of apothecia arising from sclerotia, about natural size. From H. H. Whetzel and F. A. Wolf.

\section{Plate 96 (P. 90)}

Sclerotinia Smilacinae. Photographs of two clumps of apothecia, about natural size. Photographs furnished by H. H. Whetzel. Above, drawing of an ascus with spores and paraphyses.

$$
\text { Plate } 97 \text { (P. 92) }
$$

Midot is Westii. Center, photograph of several clumps of apothecia, about twice natural size. Above, drawing of an apothecium, several times enlarged with ascus and spores. Below, several apothecia in different stages of development.

$$
\text { Plate } 98 \text { (P. 96) }
$$

Podophacidium xanthomelum. Center, photograph of apothecia showing habitat, somewhat enlarged. Left, ascus with spores and tip of paraphysis. Right, portion of empty ascus. Above, three spores. Below, drawing of $t$ wo apothecia much enlarged. Photographed from material collected at the Mycological Foray in Quebec during the summer of 1938. 


\section{Plate 99 (P. 98)}

UPPER FIGURE (1). Midotis versiformis. Photographs of apothecia in various stages of development, about natural size; also drawings of ascus with spores and paraphysis. Photographs furnished by the Dominion National Museum, Canada.

LOWER FIguRE (2). Chlorociboria strobilina. Photographs of spruce cone with apothecia, about natural size; also one scale removed with apothecia. Upper right-hand corner, drawings of two a pothecia, enlarged about two diameters; also drawing of ascus with spores and paraphysis. Photographed from material collected in Michigan by Dow V. Baxter.

\section{Plate 100 (P. 100)}

Kriegeria Seaveri. Photograph of type material collected in Montana by J. R. Weir, somewhat enlarged. At the right, drawings of branches bearing apothecia, much enlarged; also several apothecia removed. At the left, drawing of ascus with spores and paraphyses. Below, two spores removed from the ascus.

\section{Plate 101 (P. 102)}

Kriegeria enterochroma. Near center, photograph of branch, much enlarged, showing apothecia. Below, drawings of apothecia removed. At the left, drawing of an ascus with spores and paraphysis. At the right, drawings of three spores removed from the ascus. Below, drawings of apothecia, much enlarged. Photographed from material collected by H. S. Jackson in Ontario, Canada.

\section{Plate 102 (P. 104)}

Kriegeria cedrina. Center, photograph of two branches of cedar with apothecia, from material collected by F. A. Wolf in North Carolina. Below, three apothecia, very much enlarged. Left, drawing of ascus with spores and tips of paraphyses. Right, tip of ruptured ascus showing ascostome and below two mature spores.

\section{Plate 103 (P. 108)}

UpPer figure (1). Calycina bolaris. Photographs of several apothecia, about natural size. At the left, drawing of ascus with spores and paraphysis. At the right, several spores. Photographs furnished by $\mathrm{H}$. H. Whetzel.

Lower figure (2). Calycina macrospora. Photograph of several apothecia, about natural size, with drawings of ascus with spores and paraphysis. Photograph furnished by the Dominion National Museum, Canada.

\section{Plate 104 (P. 112)}

UPPER figure (1). Helotium rirgultorum. Photographs of apothecia on alder roots, about natural size. Lower right-hand corner, one apothecium enlarged. Near center, drawing of ascus with spores and paraphysis. Above, three isolated spores.

Lower figure (2). Helotium citrinum. Photographs of dead wood with the often confluent, apothecia, about natural size. At the left, drawing of ascus with spores and paraphysis; also two isolated spores and one apothecium enlarged. Photographed from material collected in Colorado by F. J. Seaver and Paul F. Shope in 1929. 


\section{Plate 105 (P. 120)}

Helotium nyssicola. Above, photographs of a number of seeds of Nyssa syliatica with apothecia, removed from the soil, about natural size. Below, photographs of apothecia as they appear above the soil. At the left, drawing of ascus with spores and paraphysis. Near center, drawings of three spores isolated. Photographed from type material collected near the Museum building of The New York Botanical Garden.

\section{Plate 106 (P. 124)}

Helotium rhizicola. Photographs of roots of Polygonum and Collinsonia with apothecia, about natural size. At the right, drawing of ascus with spores and paraphysis; also three isolated spores. Photographed from type material collected in The New York Botanical Garden.

\section{Plate 107 (P. 128)}

UPPER figure (1). Helotium Conocarpi. Photograph of part of leaf with apothecia, about four times enlarged. Right, ascus with spores and paraphysis, portion of empty ascus and free spores. Below, drawings of two apothecia, much enlarged.

LOWER FIGURE (2). Helotium atrosubiculatum. Several apothecia on portion of leaf, about three times enlarged. Below, drawing of apothecium and spores. Left, ascus with spores and paraphysis.

\section{Plate 108 (P. 134)}

Helotium cudonioides. Below, photograph of a group of apothecia on rotten wood, about two and one-half times enlarged. Above, drawings of three apothecia in different stages and from different angles. Left, ascus with spores and paraphysis. Right, empty ascus showing ascostome.

$$
\text { Plate } 109 \text { (P. 178) }
$$

Belonioscypha lactea. Photograph of apothecia on Liriodendron much enlarged. Photograph furnished by L. O. Overholts from Pennsylvania. Above, drawings of several apothecia, enlarged, also an ascus with spores and paraphysis and three spores isolated.

\section{Plate 110 (P. 180)}

UPPER figure (1). Gorgoniceps aridula. Photographs of several scales from cones of Pinus pungens collected in Pennsylvania by L. O. Overholts. At the left, drawing of an ascus with spores. Above, drawing of one apothecium, enlarged; also one spore isolated.

LOWER Figure (2). Gorgoniceps confuens. Photographs of rotten wood bearing apothecia, with drawings of three apothecia below, much enlarged. At the right, an ascus with spores. Above, one spore, isolated. Photographed from type material collected in Bermuda by Stewardson Brown, N. L. Britton, and F. J. Seaver in the winter of 1912.

\section{Plate 111 (P. 184)}

A postemidium vibrisseoides. Photograph of sticks bearing apothecia, about natural size. Below, drawing of one apothecium with protruding spores; also clump of cells from outside of apothecium. At the left, drawing 
of an ascus with spores and paraphysis. Above, portion of ascus with protruding spores. Photograph furnished by F. L. Drayton, from material collected in New York State.

$$
\text { Plate } 112 \text { (P. 192) }
$$

Pestalopezia Rhododendri. Center, photograph of leaf of Rhododendron maximum infected with Pestalotia sp. and the apothecia of Pestalopesia Rhododendri. Lower right corner, photograph of several apothecia, much enlarged. Left, an ascus and paraphysis. Upper right-hand corner, one spore of the Pestalotia associate.

\section{Plate 113 (P. 218)}

Mollisiella ilicincola. Left, photograph of a stick bearing apothecia of Mollisiella ilicincola on the hysterothecia of Tryblidiella rufula, much enlarged. Lower right, two hysterothecia, much enlarged, bearing apothecia. Above, drawing of an ascus with paraphysis and a clump of short hairs from the outside of the apothecium of the Mollisiella.

$$
\text { Plate } 114 \text { (P. 220) }
$$

Catinella nigroolizacea. Above, photograph of apothecia on rotten wood, collected by $\mathrm{IV}$. A. Murrill in the island of Jamaica, about natural size. Below photograph of rotten wood with spothecia from material collected in Nebraska by Leva B. Walker, about natural size. Left, drawing of ascus with spores and paraphysis. Right, diagram of a section of an apothecium. Center, drawing of a portion of hair from substratum.

\section{Plate 115 (P. 230)}

Stamnaria americana. Photograph of stems of Equisetum with apothecia, about natural size. At the left, drawing of ascus with spores and paraphysis. At the right, drawing of a clump of apothecia; also one apothecium removed and two spores isolated. Photographed from material collected in Ohio by J. H. Schaffner.

\section{Plate 116 (P. 232)}

Stamnaria Thujae. Photograph of infected branch of Thuja. Upper right, drawing of ascus with spores and paraphysis. Upper left, drawing of infection on leaves. Below, two empty asci and isolated spores. Also drawing of a clump of apothecia, much enlarged.

$$
\text { Plate } 117 \text { (P. 234) }
$$

LPPER Figure (1). Holwaya gigantea. Photograph of bark bearing apothecia, about natural size. Above, several apothecia removed, also drawing of one apothecium, enlarged. At the left, an ascus with spores. Photographed from material collected in New Jersey by B. O. Dodge in 1909.

Lower Figure (2). Phaeobulgaria inquinans. Photograph of apothecia on bark from dried specimen in herbarium collected by F. S. Earle at Reading, Connecticut in 1902. At the left, drawing of an ascus with spores. Above, two spores isolated and drawing of one apothecium, enlarged.

\section{Plate 118 (P. 236)}

Ascotremella faginea. Photograph of apothecial mass, about natural size. Upper left-hand corner, an ascus with spores. At the right, several spores isolated. I'hotograph furnished by the Dominion National Museum, Canada. 


\section{Plate 119 (P. 238)}

Ascotremella turbinata. Photographs of apothecia in various positions and stages, about natural size. Upper left-hand corner, an ascus with spores and paraphysis. Upper right-hand corner, portion of ascus with spores; also two spores, isolated. At the right, diagram of section of an apothecium. Near center, sketch of a cluster of spore-like bodies observed in the tissue of the apothecium. Photographs supplied by H. M. Fitzpatrick from material collected at Ithaca, New York.

\section{Plate 120 (P. 240)}

Lachnella corticalis. Center, photograph of a piece of bark of Populus tremuloides with apothecia, twice enlarged. Above, drawing of apothecia, much enlarged. Left, ascus with spores and paraphysis. Right, cluster of hairs. Below, four spores, isolated.

\section{Plate 121 (P. 248)}

Lachnella Agassizii. Photograph of apothecia on a blister-rust canker on Pinus Strobus, taken during moist weather at Dannemora, New York, about natural size. Photograph furnished by Walter $H$. Snell. At the right, drawing of an apothecium much enlarged; also hairs from the outside of the apothecium. At the left, drawing of an ascus with spores and paraphysis; also two spores isolated.

\section{Plate 122 (P. 252)}

Lachnella crucifera. Center, photograph of apothecia, about natural size. I pper left, drawing of three apothecia, much enlarged. Left, asci and paraphyses. Right and below, hairs and crystals from the outside of the apot hecium.

\section{Plate 123 (P. 254)}

Lachnella IVillkommii. Photograph of Japanese larch branch with apothecia, about natural size. At the right, ascus with spores and paraphysis and two spores, isolated. At the left, drawing of three apothecia, enlarged; also hairs from the outside of the apothecium. Photograph furnished by Walter $\mathrm{H}$. Snell from Rhode Island.

$$
\text { Plate } 124 \text { (P. 260) }
$$

Lachnella Solenia. Drawing of a cluster of apothecia, several times enlarged and two isolated apothecia, greatly magnified. Also drawings of ascus with spores and paraphysis and hairs from the outside of the apothecium. Cluster near center showing the two kinds, the hyaline tipped and the brown. Drawn from material in the herbarium of The New York Botanical Garden which is apparently part of the type.

$$
\text { Plate } 125 \text { (P. 264) }
$$

UPPER FIgURE (1). Lachnella sulphurea. Photograph of stems showing apothecia, somewhat enlarged. Photograph furnished by H. H. Whetzel. At the right, ascus with spores and paraphysis. At the left, drawings of hairs from outside of apothecium.

LOWER FIGURE (2). Lachnella pygmaea. Photograph of roots bearing apothecia, about natural size, from material collected in New York City. Near center, drawings of ascus with spores and paraphysis; also hair from outside of the apothecium. 
Plate 126 (P. 268)

Lachnella arida. Photograph of apothecia on coniferous trunk, about natural size. Photograph by Paul F. Shope from fresh material in the field at Middle Boulder Canon, Colorado, summer, 1929. Upper left-hand corner, drawing of an ascus with spores and paraphysis. Lower left-hand corner, drawing of portion of hairs from outside of apothecium.

\section{Plate 127 (P. 282)}

Diplocarpa Curreyana. Center, photograph of a group of apothecia, four times enlarged. Above, drawings of two apothecia enlarged, also asci with spores and paraphy'ses with their conidium-like apices. Below, two apothecia, much enlarged, and hairs from the outside of the apothecium.

\section{Plate 128 (P. 284)}

UPPER FIGURE (1). Lachnellula chrysophthalma. Photographs of apothecia from dried material collected in Wyoming during the summer meeting of Botanical Society of America, 1929, about natural size. At the right, drawing of ascus with spores and paraphysis; also portion of ascus. Near center, drawing of poritions of hairs from apothecium.

Lower figure (2). Lachnella bicolor. Photographs of Rubus bearing apothecia, both natural size and enlarged. At the left, drawings of ascus with spores and paraphy'ses; also ascus showing pore. At the right, drawing of hair from apothecium; also apothecium enlarged. Photographed from material collected on Pikes Peak, Colorado by F. J. Seaver, Paul F. Shope and F. E. Clements in 1929.

\section{Plate 129 (P. 286)}

Arachnopesiza aurelia. Photograph of two acorns and a twig with apothecia, about natural size and drawing of three apothecia, much enlarged. Upper right, an ascus with spores and paraphy'ses, and portion of empty ascus. I.eft, clump of hairs from apothecia. Below three spores.

\section{Plate 130 (P. 300)}

Cenangium pruinostm. Photograph of two clumps of apothecia, about natural size. Below and above, drawings of apothecia greatly enlarged. Left, ascus with spores and paraphysis and loose spores below.

\section{Plite 131 (P. 302)}

Cenangium populneum. Photograph of several clumps of apothecia, somewhat enlarged. Below, clump of apothecia bursting through the bark, much enlarged. Above, one apothecium, much enlarged. Left, drawing of ascus with spores and paraphysis.

\section{Plate 132 (P. 308)}

Sphaerangium tetrasporum. Center, photographs of branches with apothecia, somewhat enlarged. Below, two apothecia, much enlarged. Left, ascus with spores and paraphyses. Above, one spore, isolated, and branching paraphyses.

$$
\text { Plate } 133 \text { (P. 310) }
$$

Sphaerangium Tiliae. Center, photograph of portion of three branches, about natural size. Above, one apothecium, much enlarged. Left, drawing of ascus with spores and paraphysis. 


\section{Plate 134 (P. 312)}

Dermatella deformata. Center, photograph of wood with apothecia, about three times natural size. Below, drawing of apothecia on wood with one isolated, much enlarged. Upper left, ascus with spores. Above one spore, isolated; also tips of paraphyses.

\section{Plate 135 (P. 318)}

UpPer figure (1). Godronia Kalmiae. Photograph of branches showing apothecia. Below, drawing of apothecia in various stages of development; also an ascus with spores. Above, three spores removed. Photographs and drawings from material distributed in North American Fungi $1+7$.

Lower figure (2). Godronia Spiraeae. Photographs of branches bearing apothecia. Above, two apothecia, enlarged. At the right, drawing of ascus with spores and paraphysis. Above, drawing of two apothecia, enlarged. At the left, three ascospores, isolated. Photographed and drawn from material collected by C. H. Peck (no date) and listed as Godronia urceolata.

\section{Plate 136 (P. 320)}

UPPER Figure (1). Godronia fuliginosa. Photograph of willow branches bearing apothecia and conidia. Above, drawing of clump of apothecia, enlarged. At the left, drawing of one ascus with spores; also one ascospore, isolated. Near the center, conidia producing bodies. At the right, three conidia, isolated. Photographed and drawn from material collected in Coloado by F. J. Seaver and Ellsworth Bethel in 1910.

Lower figure (2). Godronia seriata. Photograph of branches of Betula fontinalis bearing apothecia and conidia, about natural size. Near center, drawing of clump of apothecia nuch enlarged. At the right, drawing of an ascus with spores and paraphysis. Above, two ascospores, isolated. Photographed and drawn from material collected in Coal Creek Canon, Colorado by F. J. Seaver and Paul F. Shope in 1929.

$$
\text { Plate } 137 \text { (P. 322) }
$$

UPPER fIGURE (1). Godronia jamaicensis. Photograph of two fragments of wood with apothecia, about natural size; also one apothecium much enlarged. Left, an ascus with spores and paraphysis. Also one loose spore.

Lower figure (2). Godronia Cephalanthi. Photograph of branch with apothecia, somewhat enlarged. Right, one apothecium, much enlarged; also portion of ascus with spores and paraphysis.

\section{Plate 138 (P. 328)}

Godronia parasitica. Photographs of several leaves with apothecia, about natural size. At the right, two apothecia enlarged. At the left, portion of an ascus with spores and paraphyses. Diagonally across the plate, one spore. Photographed from type collected in the island of Hayti, by George V. Nash, in 1903.

$$
\text { Plate } 139 \text { (P. 330) }
$$

UPPER figure (1). Godronia pinicola. Photographs of a piece of branch with apothecia, about natural size. Above, drawing of apothecia, much enlarged. Left, ascus with spores, paraphysis, tip of ascus and hair from apothecium. Below three loose spores. 
Lower FIGURe (2). Godronia sororia. Photograph of piece of bark with apothecia, about natural size. Above, two apothecia, much enlarged. Right, ascus with spores. Below, two loose spores and portion of two hairs from apothecium.

$$
\text { Plate } 140 \text { (P. 336) }
$$

Pezicula carpinea. Photograph of branch showing apothecia, considerably reduced. To the left, sketch of apothecia with an ascus with spores and paraphyses. To the left, pycnospores in various stages of development.

\section{Plate 141 (P. 338)}

LPper figure (1). Pesicula acericola. Near the center photograph of bark showing apothecia, about natural size. To the left, an ascus with spores and paraphysis and the end of a ruptured ascus. Upper right-hand corner, sketch of Sphaeronema acericola. Lower right-hand corner, stroma showing both apothecial and conidial stages produced on the same stroma.

Lower figure (2). Pezicula spiculata. Near the center, photograph of bark showing apothecia and pycnidia, about natural size. L'pper left-hand corner, sketch of stroma showing apothecia and pycnidia and pycnospores. Right-hand side, an ascus with spores and paraphysis. Below, drawing of mature ascospores.

\section{Plate 142 (P. 340)}

Pezicula cornicola. Photograph of two branches showing apothecia. Above, sketch of apothecium, much enlarged. Center, an ascus with spores. Above right, two ascospores. Below, a stroma with exuding conidiospores. Below right, two conidia.

\section{Plate 143 (P. 344)}

Pezicula Corni. Center, photographs of several $\mathrm{t}$ wigs showing apothecia. Above, sketch of two apothecia, much enlarged. Background, drawings of an ascus with spores; also two spores removed and the end of a ruptured ascus. Below, drawing of a sorus and two conidia.

\section{Plate 144 (P. 346)}

Upper figure (1). Pezicula ocellata. Photograph of willow branches showing apothecia, enlarged about one-third. Above, drawing of two apothecia, enlarged. At the left, an ascus with spores and paraphysis. Below, drawing of conidia in various stages. Photographed from material collected in Colorado by F. J. Seaver and Ellsworth Bethel in 1910.

Lower figure (2). Pezicula Populi. Photograph of branches of poplar bearing apothecia, enlarged about one-third. Below, drawing of several apothecia, enlarged. At the right, drawing of an ascus with spores and paraphyses; also two ascospores, isolated. Photographed and drawn from type material collected in Ontario, Canada, by G. E. Thompson in 1930.

\section{Plate 145 (P. 348)}

Pezicula purpurascens. Photograph of chestnut branches bearing apothecia and conidia, about natural size. At the left, drawing of an ascus with spores and paraphyses. Above, drawing of one apothecium, enlarged; also two ascoconidia. Below, several ascoconidiophores showing stages in the 
development and discharge of the ascoconidium. Photographed and drawn from type material collected at W'est Chester, Pennsylvania in 1888.

\section{Plate 146 (P. 350)}

Pezicula Hamamelidis. Photograph of bark of Hamamelis bearing apothecia and conidia, natural size. Below at the left, drawing of three apothecia, enlarged. At the right, cluster of conidia; also three conidia isolated. Above, tip of ascus showing rupture; also four ascospores at different stages. Photographed from type collected in Ontario by H. S. Jackson.

\section{Plate 147 (P. 352)}

UpPer figure (1). Dermea Cerasi. In the center, photograph of branch showing apothecia about natural size, with enlarged sketch of an apothecium; also stromata, and pycnospores.

Lower Figure (2). Dermea bicolor. In the center, photograph of branch showing apothecia from type material, about natural size. Above, large drawing of apothecia. To the left, an ascus with spores and paraphyses. Below, sketch of stroma and pycnospores.

\section{PlATE 148 (P. 354)}

UPPER FIgURE (1). Dermea molliuscula. Photograph of twigs of Betula lutea showing apothecia, about natural size. Above, enlarged sketch of apothecia. To the left, an ascus with spores and paraphyses. In the center, sketch of a stroma and pycnospores.

Lower Figure (2). Dermea mollinscula. In the center, photograph of branch of Alnus showing apothecia, about natural size. Above, enlarged sketch of an apothecium and stromata. To the right, an ascus with spores and paraphyses. Below pycnospores.

\section{Plate 149 (P. 356)}

Dermea balsamea. Photographs of branches of hemlock bearing a pothecia and conidia. Below, drawing of portion of branch, enlarged, showing cirrhi of exuding conidia. Above, drawing of one apothecium, enlarged; also ascus with spores and paraphysis, three isolated ascospores, one conidiospore and three microconidia. Photographs and drawing of branch furnished by B. O. Dodge from material collected at Scarsdale, New York.

\section{Plate 150 (P. 372)}

UPPer figure (1). Haematomyxa vinosa. Photograph of wood bearing apothecia, enlarged about one-half. At the left, drawing of an ascus with spores. Below, one apothecium, enlarged. Above, one spore, isolated. Photographed from material in the Ellis herbarium, collected at Newfield, New Jersey.

Lower Figure (2). Haematomyxa ascoboloides. Photograph of herbaceous stems bearing apothecia, enlarged about one-third. Below, drawing of two apothecia, enlarged. At the right, an ascus with spores and paraphysis. Above, one spore, enlarged. Photographed from type material collected at Tacoma Park, Maryland in 1889. 


\section{HOST INDEX}

\section{Abies amabilis}

Godronia abieticola

Abies balsamea

Dermea balsamea

Lachnella Agassizii

Lachnella resinaria

Pezicula phyllophila

Tapesia balsamicola

Tympanis Pinastri

Abies grandis

Godronia abieticola

Abies sp.

Cenangium Abiet is

Cenangium alpinum

Cenangium leptospermum

Belonium inconspicuum

Ciboria rufofusca

Godronia abietina

Godronia Abiet is

Helotium fumosellum

Lachnella arida

Lachnellula chrysophthalna

Pezicula livida

Acanthonitschkea coloradensis

Lachnella Acanthonitschkeae

Acer floridanum

Pyrenopeziza leucodermis

Acer leucoderme

Pyrenopeziza leucodermis

Acer rubrum

Ciboria acerina

Dermea acerina

Erinellina miniopsis

Pezicula acericola

Pycnopeziza sympodialis

\section{Acer saccharinum}

Ciboria acerina

Dermea acerina

Acer Saccharum

Dermea acerina

Acer spicatum

Pezicula acericola

Pezicula spicata

Pezicula spiculata
Acer sp.

Belonidium fuscopallidum

Godronia rhabdospora

Helotium albovirens

Helotium albuminum

Helotium fraternum

Helotium luteovirescens

Helotium naviculasporum

Helotium translucens

Holwaya gigantea

Lachnella Rhytismatis

Mollisia paullopuncta

Pezizella floriformis

Velutaria rufoolivacea

Adiantum sp.

Lachnella aspidicola

Alnus crispa mollis

Pezicula Alni

Pezicula a urantiaca

Alnus incana

Ciboria a mentacea

Pezicula Alni

Tympanis alnea

\section{Alnus oregona}

Helotium seminicola

\section{Alnus tenuifolia}

Tympanis alnea

Alnus sp.

Cenangium furfuraceum

Ciboriella rufescens

Godronia Urceolus

Helotium alniellum

Helotium fastidiosum

Helotium umbrinum

Hyaloscypha alniseda

Lachnum alneum

Lachnum hyalinellum

Mollisia Teucrii

Orbilia luteorubella

Trichopeziza punctiformis

Amelanchier alnifolia

Pezicula pruinosa 
Amelanchier canadensis

Monilinia Amelancheris

Pezicula pruinosa

Amelanchier Cusickii

Monilinia gregaria

Amelanchier intermedia

Monilinia Amelanchieris

Amelanchier oblongifolia

Monilinia Amelanchicris

Amelanchier sp.

Dermea bicolor

Fabraea maculata

Monilinia Amelanchieris

Ammophila longifolia

Pyrenopeziza Ellisii

Andromeda sp.

Dasyscypha fuscidula

Trichopeziza marginata

Velutaria rufoolivacea

Andropogon furcatus

Trichopeziza distincta

Andropogon scoparius

Helotium planodiscum

Andropogon sp.

Belonium Andropogonis

Belonium culmicola

Helotiella aureococcinea

Lachnella albotestacea

Mollisia atriella

Anemone nemorosa

Sclerotinia tuberosa

Angelica atropurpurea

Mollisia Angelicae

Antennaria plantaginifolia

Mollisia lanaria

Apios tuberosa

Mollisia apiophila

Apium sp.

Sclerotinia minor

Apocynum androsaemifolium

Pyrenopeziza Dearnessii

Aquilegia coerulea

Dasyscypha tuberculiformis

Arabis furcata

Belonium arabicolum

Aralia racemosa

Helotium minimum

Aralia sp.

Trichopeziza setigera
Archontophoenix Alexandrae

Helotium atrosubiculatum

Arctium Lappa

Lachnella canadensis

Arctostaphylos pungens

Trichopeziza labrosa

Arctostaphylos Tracyi

Arachnopeziza Arctostaphyli

Calloria nitens

Arisaema triphyllum

Streptotinia Arisaemae

Aronia sp.

Monilinia Aroniae

Artemisia vulgaris

Pyrenopeziza Artemisiae

Artemisia sp.

Pyrenopeziza Absinthii

Arundinaria macrosperma

Dasyscypha Arundinariae

Dasyscypha caulicola

Asclepias sp.

Mollisia Asclepiadis

Aspidium sp.

Lachnella aspidicola

Aster puniceus

Orbilia assimilis

Aster sp.

Trichopeziza brevipila

Azalea sp.

Ovulinia Azaleac

Bambusa vulgaris

Gorgoniceps jamaicensis

Betula alba

Helotium Friesii

Betula fontinalis

Godronia seriata

Betula lutea

Godronia seriata

Verpatinia duchesnayensis

Betula nigra

Sphaerangium magnisporum

Betula sp.

Cenangella Hartzii

Cenangium compressum

Dermea molliuscula

Godronia fusispora

Godronia Urceolus

Helotium Linderi

Tapesia lividof usca 
Tapesia secamenti

Veltutaria rufoolivacea

Bidens sp.

Peziza heterocarpa

Pyrenopeziza Absinthii

Bigelovia graveolens

Tapesia tumefaciens

Bignonia sp.

Pezizella leguminum

Brassica sp.

Helotium brassicaccolum

Pezizella brassicaccola

Bryum sp.

Hclotium turbinat um

Calamagrostis canadensis

Lachnella agrostina

Calamagrostis sp.

Belonidium aurantiacum

Belonium intermedium

Calluna sp.

Cenangella Ericae

Caltha palustris

Verpatinia calthicola

Camellia japonica

Sclerotinia Camelliae

Carex ampullacea

Sclerotinia Caricis-ampullaceac

Carex aquatilis

Sclerotinia Caricis-ampullaceae

Carex crinita

Dasyscypha crinella

Sclerotinia Duriaeana

Sclerotinia longisclerotialis

Carex exsiccata

Sclcrotinia paludosa

Carex flava

Sclcrotinia Duriacana

Carex hystericina

Sclerotinia Duriaeana

Carex inflata

Sclerotinia Caricis-ampullaceae

Carex interior

Sclerotinia longisclerotialis

Carex lacustris

Pyrenopeziza multipunctoidea

Carex limosa

Ombrophila limosa

Carex nebraskensis

Sclerotinia Duriacana
Carex prairea

Sclerotinia Duriaeana

Sclerotonia longisclerotialis

Carex retrorsa

Sclerotinia Caricis-ampullaceae

Sclerotinia Duriacana

Sclerotinia longisclerotialis

Carex riparia lacustris

Sclerotinia Duriaeana

Carex stricta

Sclerotinia Duriacana

Carex utriculata

Calloria caricinella

Carex vesicaria

Sclerotinia longisclerotialis

Carex sp.

Belonioscypha miniata

Belonium caricincolum

Helotium citrinulum

Helotium turgidellum

Mollisia epitypha

Mollisa euparaphysata

Pyrenopeziza caricina

Pyrenopeziza Caricis

Pyrenopeziza cervinula

Pyrenopeziza doryphora

Pyrenopeziza yogoensis

Carpinus caroliniana

Pezicula carpinea

Carpinus sp.

Cenangella Ravenelii

Helotium ammoides

Tapesia lividof usca

Carya ovata

Lambertella Hicoriae

Carya sp.

Dermatella caryigena

Helotium fructigenum

Cassandra calyculata

Cenangium Cassandrac

Godronia Urccolus

Castanea dentata

Pezicula purpurascens

Castanea vesca

Ciboria americana

Castanea sp.

Belonium basitrichum

Dasyscypha translucida

Dasyscypha vixvisibilis 
Castanopsis chrysophylla

Belonium Parksi

Coronellaria Castanopsidis

Godronia Castanopsidis

Catalpa sp.

Pezizella leguminum

Caulophyllum thalictroides

Orbilia Caulophylli

Ceanothus velutinus

Cenangium aureum

Cecropia sp.

Helotium Cecropiae

Celtis sp.

Lachnella succina

Cephalanthus occidentalis

Godronia Cephalanthi

Lambertella Cephalanthi

Cephalanthus sp.

Pyrenopeziza Cephalanthi

Chamaedaphne calyculata

See Cassandra

Erinella borealis

Helotium Cassandrae

Chionanthus virginica

Dermea Chionanthi

Citharexylum spinosum

Lambertella Jasmini

Clethra alnifolia

Godronia Urceolus

Lachnella albopileata subauata

Coccoloba sp.

Lambertella tropicalis

Collinsonia canadensis

Helotium rhizicola

Comptonia asplenifolia

Echinella rhabdocarpa

Conocarpus erectus

Helotium Conocarpi

Cornus alternifolia

Pezicula Corni

Cornus Amomum

Lachnella Corni

Cornus florida

Mollisia miltophthalıa

Trichopeziza roseoalba

Cornus stolonifera

Pezicula Corni

Cornus sp.

Cenangium contortum

Helotium propinquum
Monilinia Corni

Pezicula cornicola

Tympanis fasciculata

Corydalis Brandegei

Dasyscypha Bakeri

Corydalis sp.

Calloria coccinea

Corylus rostrata

Pezicula corylina

Corylus sp.

Helotium epiphyllum

Crataegus punctata

Monilinia Johnsoni

Crataegus sp.

Cenangium confusum

Pezicula crataegicola

Pezicula olivascens

Crocus sp.

Stromatinia Gladioli

Cucurbita sp.

Orbilia Cucurbitae

Cydonia sp.

Dermea Cydoniae

Fabraea maculata

Daucus Carota

Sclerotinia intermedia

Delphinium sp.

Hyalopeziza ciliata

Phialea pallida

Desmodium sp.

Dermea ferruginea

Diatrype Stigma

Cenangium episphaeria

Diatrype sp.

Orbilia coccinella

Diatrypella sp.

Helotium episphaericum

Dichaena sp.

Helotium strumosum

Dicranopteris pectinata

Lachnella Dicranopteridis

Dicranum flagellare

Helotium destruct or

Diervilla sp.

Godronia turbinata

Elymus canadensis

Cyathicula alpina

Equisetum hyemale

Lachnella inquilina 
Equisetum robustum

Stamnaria americana

Equisetum sp.

Stamnaria americana

Erigeron sp.

Helotium nigrescens

Mollisia erigeronata

Mollisia exigua

Pyrenopeziza Absinthii

Trichopeziza carneorubra

Eriophorum callitrix

Lachnum carneolum

Eryngium sp.

Dasyscypha eryngiicola

Erythronium americanum

Ciborinia Erythronii

Eschscholtzia californica

Helotium Eschscholtziae

Eucalyptus globulus

Mollisia subcornea

Eucalyptus sp.

Lachnella atropurpurea

Orbilia Eucalypti

Pezizella carneorosea

Eupatorium ageratoides

Lachnella Solenia

Eupatorium maculatum

Dasyscypha longipila

Eupatorium purpureum Lachnella Eupatorii

Eupatorium sp.

Belonium bicolor

Helotium herbarum

Fagus americana

Ascotremella faginea

Fagus grandifolia

Helotium albopunctum

Fagus sp.

Calycina petiolorum

Helotium naviculasporum

Mollisia caesia

Festuca tenella

Pyrenopeziza Ellisii

Fomes fomentarius

Helotium mycetophilum

Fragaria sp.

Fabraea Earliana

Fraxinus americana

Durandiella Fraxini
Fraxinus nigra

Dermea Tulasnei

Fraxinus sp.

Cenangium populneum

Dasyscypha puberula

Dermatella Fraxini

Dermea Tulasnei

Ilelotium lut eovirescens

Freesia sp.

Stromatinia Gladioli

Galium sp.

Pyrenopeziza nigritella

Pseudopeziza repanda

Garrya elliptica

Belonium Parksi

Harknessiella purpurea

Lachnella tautilla

Gaultheria Shallon

Cyathicula aquilina

Lachnella Gaultheriae

Mollisia Gaultheriae

Pestalopezia brunneopruinosa

Gaylussacia dumosa

Trichopeziza venturioides

Gentiana sp.

Pseudopeziza Holwayi

Geranium maculatum

Seaverinia Geranii

Gladiolus sp.

Botryotinia Draytoni

Stromatinia Gladioli

Gleditsia triacanthos

Helotium midlandense

Orbilia rubrococcinea

Gleichenia sp.

Lachnella Gleicheniae

Glyceria nervata

Belonium Glyceriae

Halesia carolina

Lachnella Halesiae

Hamamelis virginiana

Dermea Hamamelidis

Pezicula Hamameliclis

Helianthus annuus

Mollisia lilacina

Helianthus sp.

Pyrenopeziza Absinthii

Hydrangea sp.

Cenangium apertum 
Hypnum sylvaticum

Peziza hypnicola

Hypoxylon sp.

Helotium episphaericum

Hysterium sp.

Mollisiella ilicincola

Ilex glabra

Cenangium tuberculiforme

Dermea crypta

Dermea olivacea

Ilex opaca

Lachnella pulveracea

Pezizella aquifoliae

Ilex verticillata

Cenangium sticticum

Dermea Peckiana

Ilex sp.

Cenangella Ravenelii

Impatiens sp.

Erinellina Nylanderi

Helotium herbarum

Iris sp.

Botryotinia convoluta

Helotium nigromaculatum

Mollisia Iridis

Iva xanthifolia

Lachnella Ivae

Pyrenopeziza Absinthii

Jasminum gracile

Lambertella Jasmini

Juglans regia

Mollisia abdita

Juglans sp.

Cenangium Juglandis

Juncus alpinus

Mollisia alpina

Juncus effusus californica

Sclerotinia juncigena

Juncus sp.

Lachnella diminuta

Mollisia stictoidea

Jungermania sp.

Helotium destructor

Juniperus bermudiana

Dermatella deformata

Juniperus communis

Dermatella deformata

Kriegeria juniperina

Juniperus lucayana

Godronia jamaicensis
Juniperus scopulorum

Dermatella deformata

Juniperus virginiana

Murangium Sequoiae

Juniperus sp.

Godronia Juniperi

Kalmia angustifolia

Trichopeziza Kalmiae

Kalmia sp.

Ovulinia Azaleae

Pezicula Kalmiae

Lactuca sp.

Sclerotinia minor

Lantana camara

Godronia Lantanae

Larix europaea

Lachnella Hahniana

Lachnella oblongospora

Lachnella occidentalis

Lachnella Willkommii

Larix laricina

Lachnella oblongospora

Lachnella occidentalis

Larix leptolepis

Lachnella occidentalis

Larix sp.

Helotium laricinum

Lachnella arida

Lachnella occidentalis

Ledum groenlandicum

Cenangella Ericae

Leonurus cardiaca

Helotium fumosum

Libocedrus decurrens

Dermea Libocedri

Kriegeria alutipes

Linum Lewisii

Pyrenopeziza californica

Liquidambar sp.

Mollisia vulgaris sanguinella

Pseudohelotium sacchariferum

Lithospermum canescens

Calloria Lithospermi

Lonicera canadensis

Godronia Lonicerae

Lonicera involucrata

Helotiella Lonicerae

Lonicera sp.

Mollisia complicatula 
Lysichiton camtschatcense

Ombrophila Lysichitonis

Magnolia glauca

Ciborinia gracilipes

Dermatella Magnoliae

Pyrenopeziza protrusa

Magnolia grandiflora

Dasyscypha hystricula

Magnolia sp.

Belonium phlegmaceum

Dasyscypha albopileata

Holwaya gigantea

Mollisia fumigata

Mollisia glenospora

Orbilia diaphanula

Malus sp.

Ciboria aestivalis

Tympanis conspersa

Marchantia polymorpha

Cyathicula Marchantiae

\section{Medicago sativa}

Sclerotinia sativa

Medicago sp.

Pseudopeziza Jonesii

Pseudopeziza Medicagnis

Melilotus alba

Sclerotinia sativa

Melilotus officinalis

Sclerotinia sativa

Melilotus sp.

Pseudopeziza Medicaginis

Pseudopeziza Meliloti

Meliola sp.

Trichobelonium leucorrhorlinum

Morus alba

Cenangium fatiscens

Ciboria carunculoides

Pezizella conchella

Morus alba tatarica

Dermea Mori

Myirangium sp.

Mollisiella ilicincola

Myrica cerifera

Dasyscypha callochaetes

\section{Myrica Gale}

Ciboria acerina

Dasyscypha sulphurella

Trichopeziza myricacea
Myrica sp.

Trichopeziza alboviridis

Trichopeziza punctiformis

Narcissus

Botryotinia narcissicola

Nardus sp.

Lachnum Nardi

Nemopanthes canadensis

Godronia Nemopanthis

Nemopanthes mucronata

Dermea Peckiana

Godronia Nemopanthis

Nyssa sylvatica

Helotium nyssicola

Sclerotinia nyssaegena

Oenothera sp.

Mollisia Oenotherae

Olea europaea

Lachnella fasciculata

Osmunda sp.

Mollisia tenella

Peziza frondicola

Trichopeziza Osmundae

Ostrya virginiana

Ciboria acerina

Ostrya sp.

Midot is Westii

Oxydendrum arboreum

Tympanis Oxydendri

Paludella squarrosa

Mitrula gracilis

Panax quinquefolium

Sclerotinia Panacis

Pastinaca sp.

Pezizella Pastinacae

Patellaria sp.

Mollisiella ilicincola

Pedicularis bracteosa

Sclerotinia coloradensis

Pedicularis groenlandica

Sclerotinia coloradensis

Pedicularis sp.

Cyathicula alpina

Peltigera canina

Calloria Mülleri

Persea palustris

Erinellina maculosa

Persea sp.

Dermatella Magnoliae 


\section{Philadelphus inodorus}

Pezicula Philadelphi

Phragmites sp.

Lachnella albot estacea

Mollisia hydrophila

Physocarpus capitatus

Belonium Parksi

Phytolacca sp.

Orbilia pulviscula

Picea glauca

Dermea piceina

Picea Mariana

Lachnella Agassizii

Lachnum hyalinellum

Tapesia lividof usca fallax

Picea pungens

Lachnella oblongospora

Picea rubra

Lachnella Agassizii

Picea sitchensis

Godronia Treleasei

Picea sp.

Cenangium Abietis

Chlorociboria strobilina

Gorgoniceps Pumilionis

Helotium aurantium

Helotium sulphuratum

Lachnella arida

Lachnella Ellisiana

Lachnellula chrysophthalma

Pinus Banksiana

Lachnellula chrysophthalma

Pinus contorta

Godronia Zelleri

Pinus inops

Peziza conorum

Pinus Lambertiana

Godronia Zelleri

Pinus monticola

Godronia Zelleri

Lachnella Agassizii

Pinus Mugho

Cenangium atropurpureum

Pinus Murrayana

Lachnella fuscosanguinea

Pinus nigra

Cenangium atropurpureum

Pinus ponderosa

Atropellis arizonica

Godronia sororia
Pinus pungens

Cenangium atropurpureum

Godronia pinicola

Gorgoniceps aridula

Lachnella oblongospora

Pinus resinosa

Godronia pinicola

Gorgoniceps ontariensis

Pinus rigida

Cenangium atropurpureum

Godronia pinicola

Pezicula phyllophila

Tympanis Pinastri

Pinus Strobus

Cenangium acuum

Dermea pinicola

Godronia Zelleri

Lachnella Agassizii

Mollisia Scoleconectriae

Pezicula livida

Tympanis Pinastri

Pinus sylvestris

Cenangium atropurpureum

Pinus Taeda

Cenangium atropurpureum

Pinus virginiana

Lachnella oblongospora

Pinus sp.

Atropellis apiculata

Atropellis tingens

Cenangium Abiet is

Cenangium acuum

Erinellina rhaphidospora

Lachnella Ellisiana

Lachnella pulverulenta

Pezicula livida

Platanus sp.

Helotium luteovirescens

Podophyllum peltatum

Septotinia podophyllina

Polycodium stamineum

Monilinia Polycodii

Polygonum sp.

Stromatinia Rapulum

Polygonum virginianum

Helotium rhizicola

Polygonum viviparum

Pseudopeziza Bistortae

Polygonum sp.

Mollisia Polygoni 
Polyporus igniarius

Peziza mycogena

Polyporus Stevensii

Mollisia incrustata

Polyporus sp.

Mollisia incrustata

Mollisia vulgaris myceticola

Orbilia coccinella

Orbilia epispora

Populus alba

Pseudopeziza Populi-albae

Populus canadensis

Pycnopeziza sympodialis

Populus grandidentata

Cenangium populneum

Pezicula Populi

Populus Tremula

Helotium Friesii

Populus tremuloides

Belonium aggregatum

Cenangium populneum

Cenangium pruinosum

Ciboria Caucus

Ciborinia bifrons

Dermatella populina

Lachnella populicola

Pezicula Populi

Pycnopeziza sympodialis

Tympanis spermatiospora

Populus sp.

Helotium Friesii

Helotium gemmarum

Mollisia complicatula

Orbilia luteorubella

Pezicula ocellata

Tympanis spermatiospora

Potentilla sp.

Mollisia Dehnii

Pyrenopeziza coloradnsis

Sclerotinia fallax

Prinus verticillata

See Ilex

Cenangium sticticum

Prunus avium

Lambertella Pruni

Prunus demissa

Monilinia demissa

Prunus domestica

Dermea Padi
Prunus emarginata

Monilinia emarginata

Prunus Padus

Dermea Padi

Prunus serotina

Monilinia Seaveri

Prunus spinosa

Dermea Padi

Prunus virginiana

Dermea Padi

Monilinia Padi

Prunus spp.

Dermea Cerasi

Dermea Prunastri

Monilinia fructicola

Monilinia laxa

Tympanis conspersa

Pseudotsuga taxifolia

Lachnella Agassizii

Lachnella ciliata

Lachnella oblongospora

Lachnella Pseudotsugae

Pseudotsuga sp.

Lachnella Hahniana

Psoralea macrostachya

Orbilia myriospora

Pteridium aquilinum

Lachnaster miniatus

Pteridium aquilinum pubescens

Calloria cremea

Pteris sp.

Lachnella pteridicola

Lachnella Pteridis

Pyrus sp.

Cenangium pyrinum

Fabraea maculata

Quercus agrifolia

Helotium furfuraceum

Phillipsia nigrella

Quercus alba

Dermateopsis tabacina

Lachnella capitata

Quercus coccinea

Dermateopsis tabacina

Helotium strumosum

Sphaerangium tetrasporum

Quercus laurifolia

Helotium castaneum

Quercus Prinus

Pyrenopeziza prinicola 
Quercus tinctoria

Cenangium sticticum

Quercus sp.

Belonium basitrichum

Calycina petiolorum

Chlorosplenium olivaceum

Ciboria pseudotuberosa

Dasyscypha epixantha

Dasyscypha uncinata

Godroniopsis quernea

Helotium ferrugineum

Helotium midlandense

Helotium puberulum

Helotium sordidat um

Helotium translucens

Holwaya gigantea

Lachnella capitata

Lachnella ciliaris

Lachnella pollinaria

Lachnella succina

Phaeobulgaria inquinans

Pyrenopeziza prinicola

Tapesia culcitella

Trichopeziza comata

Trichopeziza obscura

Trichopeziza punct if ormis

Velutaria rufoolivacea

Ranunculus sp.

Fabraea Ranunculi

Pseudopeziza singularis

Rhamnus alnifolia

Pezicula Morthieri

Rhamnus purshiana

Belonium Parksi

Dermatella Frangulae

Rhododendron maximum

Cenangium palmatum

Helotium castaneum

Rhododendron roseum

Monilinia Azaleae

Rhododendron sp.

Cenangella Rhododendri

Monilinia Azaleae

Ovulinia Azaleae

Pestalopezia Rhododendri

Rhus venenata

Pezicula pallidula

Rhus sp.

Tympanis fasciculata
Ribes bracteosum $\mathrm{x}$ nigrum

Godronia Davidsoni

Ribes Menziesii

Godronia lobata

Ribes montigenum

Godronia tumoricola

Tapesia ribicola

Ribes prostratum

Lachnella albolabra

Ribes Wolfii

Cenangella oricostata

Godronia Davidsoni

Ribes sp.

Godronia Ribis

Godronia Urceolus

Helotium discretum

Pseudopeziza Ribis

Ricinus communis

Botryotinia Ricini

Robinia Pseudo-acacia

Helotium erraticum

Rosa sp.

Cenangium Rosae

Fabraea Rosae

Pezicula Brenckleana

Tapesia Rosae

Rubus idaeus

Pezicula Rubi

Rubus nutkanus

Dasyscypha scabrovillosa

Rubus odoratus

Pyrenopeziza lacerata

Rubus villosus

Mollisia alabamensis

Rubus sp.

Lachnella subochracea

Pezicula Rubi

Pyrenopeziza Rubi

Velutaria rufoolivacea

Sabal serrulata

Mollisia Sabalidis

Sabal sp.

Gorgoniceps confluens

Salix alba

Cenangium populneum

Salix babylonica

Cenangium st icticum

Salix discolor

Ciboria amentaceae

Ciboria amenti 
Salix sp.

Belonium aggregatum

Cenangium tryblidioides

Ciboria amenti

Ciboria Caucus

Ciborinia foliicola

Godronia fuliginosa

Helotium amplum

Helotium salicellum

Mollisia caespiticia

Mollisia encoelioides

Ombrophila flavens

Orbilia Eucalypti

Orbilia luteorubella

Pezicula ocellata

Sambucus callicarpa

Helotium Phiala

Sambucus melanocarpa

Tapesia coloradensis

Sanicula Menziesii

Belonium fuscum

Sassafras sp.

Dermatella Magnoliae

Velutaria rufoolivacea

Scirpus caespitosus

Mollisia scirpina

Scirpus lacustris

Belonium Delitschianum

Scirpus validus

Dasyscypha luteodisca

Scoleconectria scolecospora

Mollisia Scoleconectriae

Secale cereale

Sclerotinia temulenta

Sequoia gigantea

Murangium Sequoiae

Sequoia sempervirens

Kriegeria chloromela

Sequoia sp.

Dasyscypha acuum

Smilacina racemosa

Stromatinia Smilacinae

Smilax herbacea

Pyrenopeziza smilacicola

Smilax sp.

Mollisia nipteroides

Solidago sp.

Calloria Solidaginis

Mollisia erigeronata
Sorbus sp.

Dermea Ariae

Sorghum sp.

Mollisia hydrophila

Spartina polystachya

Belonium heteromorphum

Mollisia atriella

Sphagnum sp.

Mitrula phalloides

Spiraea Menziesii

Godronia Spiraeae

Spiraea opulifolia

Trichopeziza Opulifoliae

Spiraea salicifolia

Godronia Spiraeae

Spiraea sp.

Cenangium Spiraeae

Helotium lanceolatoparaphysatum

Staphylea sp.

Cenangium Staphyleae

Steironema ciliatum

Helotium Dearnessii

Streptopus amplexifolius

Niptera pella

Symphoricarpos occidentalis

Helotium dakotense

Symphoricarpos sp.

Solenopezia Symphoricarpi

Syringa sp.

Cenangium fatiscens

Taxodium distichum

Trichopeziza pomicolor

Tephrosia virginiana

Helotium consanguineum

Tetrazygia longicollis

Godronia parasitica

Teucrium sp.

Mollisia Teucrii

Thalictrum sp.

Mollisia subcinerea

Pyrenopeziza Thalictri

Thuja occidentalis

Kriegeria enterochroma

Stamnaria Thujae

Thuja plicata

Kriegeria Seaveri

Tilia americana

Sclerotinia Tiliae

Trichopeziza candida 
Tilia heterophylla

Pyrenopeziza minuta

Sphaerangium Tiliae

Tilia sp.

Ascotremella faginea

Helotium luteovirescens

Helotium naviculasporum

Holwaya gigantea

Trichopeziza Tiliae

Tympanis conspersa

Tragopogon porrifolius

Sclerotinia intermedia

Trifolium arvense

Pseudopeziza Trifolii-arvensis

Trifolium sp.

Pseudopeziza Trifolii

Trigonella sp.

Pseudopeziza Medicaginis

Tryblidiella sp.

Mollisiella ilicincola

Tsuga canadensis

Dermea balsamea

Lachnella Agassizii

Orbilia Fairmani

Tsuga sp.

Dasyscypha chamaeleontina

Tulipa sp.

Sclerotinia sativa

Typha latifolia

Mollisia epitypha

Typha sp.

Helotium turgidellum

Ulmus americana

Mollisia lilacina

Pseudohelotium fibrisedum

Ulmus sp.

Mollisia caespiticia

Trichopeziza leonia

Umbellularia californica

Midot is plicata

Urtica canadensis

Trichopeziza urticina

Urtica sp.

Calloria fusarioides

Dasyscypha caulicola

Erinellina Nylanderi
Vaccinium corymbosum

Godronia Kalmiae

Monilinia Vaccinii-corymbosi

Vaccinium myrtilloides

Trichopeziza coarctata

Vaccinium Oxycoccos

Monilinia Oxycocci

Vaccinium parvifolium

Belonium Parksi

Vaccinium uliginosum

Cenangella pruinosa

Vaccinium sp.

Monilinia Urnula

Valsa sp.

Helotium episphaericum

Veratrum californicum

Sclerotinia Veratri

Viburnum cassinoides

Godronia viburnicola

Lambertella Viburni

Viburnum dentatum

Godronia viburnicola

Viburnum lantanoides

Pezicula minuta

Viburnum Lentago

Dasyscypha Lentaginis

Tympanis fasciculata

Viburnum sp.

Cenangium Viburni

Dermea Viburni

Vitis vulpina

Chlorosplenium salviicolor

Vitis sp.

Dermatella viticola

Godronia viticola

Helotium pullatum

Lachnella ascoboloidea

Trichopeziza penicillata

Webera nutans

Mitrula muscicola

Xylaria sp.

Helotium episphaericum

Yucca sp.

Cenangium Yuccae

Zea Mays

Helotiella pygmaea 


\section{INDEX TO ILLUSTRATIONS}

The following species are illustrated in this volume. The colored frontispiece is in bold face type.

Apostemidium vibrissioides, pl. 111

Arachnopeziza aurelia, pl. 129

Ascotremella faginea, pl. 118

turbinata, pl. 119

Belonioscypha lactea, pl. 109

Botryt is Geranii, pl. 85

streptothrix, pl. 86

Calycina bolaris, pl. 103

Calycina macrospora, pl. 103

Catinella nigroolivacea, pl. 114

Cenangium populneum, pl. 131 pruinosum, pl. 130

Chlorociboria strobilina, pl. 99

Ciboria amentacea, pl. 93

carunculoides, pl. 95

Caucus, pl. 94

pseudot uberosa, pl. 94

Ciborinia bifrons, (front ispiece)

bifrons, pl. 88

Whetzelii, pl. 89

Cudonia circinans, pl. 82

Dermatella deformata, pl. 134

Dermea balsamea, pl. 149

bicolor, pl. $1+7$

Cerasi, pl. 147

molliuscula, pl. 148

Diplocarpa Curreyana, pl. 127

Godronia Cephalanthi, pl. 137

fuliginosa, pl. 136

jamaicensis, pl. 137

Kalmiae, pl. 135

parasitica, pl. 138

pinicola, pl. 139

seriata, pl. 136

sororia, pl. 139

Spiraeae, pl. 135

Gorgoniceps aridula, pl. 110

confluens, pl. 110

Haematomyxa ascoboloides, pl. 150

vinosa, pl. 150
Helotium atrosubiculatum, pl. 107

citrinum, pl. 104

Conocarpi, pl. 107

cudonioides, pl. 108

nyssicola, pl. 105

rhizicola, pl. 106

virgultorum, pl. 104

Holwaya gigantea, pl. 117

Kriegeria cedrina, pl. 102

enterochroma, pl. i01

Seaveri, pl. 100

Lachnella Agassizii, pl. 121

arida, pl. 126

bicolor, pl. 128

corticalis, pl. 120

crucifera, pl. 122

pygmaea, pl. 125

Solenia, pl. 124

sulphurea, pl. 125

Willkommii, pl. 123

Lachnellula chrysophthalma, pl. 128

Leotia lubrica, p]. 82

Martinia panamaensis, pl. 87

Midot is versiformis, pl. 99

Westii, pl. 97

Mitrula phalloides, pl. 76

Mollisiella ilicincola, pl. 113

Monilia Seaveri, pl. 84

Monilinia fructicola, pl. 83

Seaveri, pl. 84

Ombrophila Clavus, pl. 76

Pestalopezia Rhododendri, pl. 112

Pezicula acericola, pl. 141

carpinea, pl. 140

Corni, pl. 143

cornicola, pl. 142

Hamamelidis, pl. 146

ocellata, pl. 144

Populi, pl. $1+4$

purpurascens, $\mathrm{pl} .145$

spiculata, pl. 1+1 
Phaeobulgaria inquinans, pl. 117

Podophacidium xanthomelum, pl. 98

Sclerotinia Caricis-ampullaceae, pl. 91

Duriaeana, pl. 92

Smilacinae, pl. 96

tuberosa, pl. 90

Seaverinia Geranii, pl. 85

Spathularia clavata, pl. 81

velutipes, pl. 81
Sphaerangium tetrasporum, pl. 132

Tiliae, pl. 133

Sphaeronema acericola, pl. 141

Stamnaria americana, pl. 115

Thujae, pl. 116

Streptotinia Arisaemae, pl. 86

Trichoglossum Farlowii, pl. 80 hirsutum, pl. 78

velutipes, pl. 77

Wrightii, pl. 79 


\section{INDEX TO RECOGNIZED GENERA}

Acervus 239

Apostemidium 183

Arachnopeziza 284

Ascotremella 234

Belonioscypha 177

Belonium 169

Botryotinia 61

Calloria 162

Calycina 108

Catinella 218

Cenangella 310

Cenangium 297

Chlorociboria 98

Chlorosplenium 104

Ciboria 84

Ciboriella 107

Ciborinia 70

Coprotinia 90

Coryne 235

Corynetes 17

Cudonia 41

Cyathicula 111

Dermatella 312

Dermateopsis 307

Dermea 351

Diplocarpa 281

Durandiella 367

Echinella 294

Eriopezia 284

Erinellina 290

Fabraea 189

Geoglossum 23

Gloeglossum 20

Godronia 315

Godroniopsis 307

Gorgoniceps 178

Haematomyxa 372

Helotiella 287

Helotium 113

Holwaya 237

Kriegeria 100
Lachnella 239

Lachnellula 282

Lambertella 66

Leotia 36

Martinia 69

Microglossum 13

Midotis 91

Mitrula 8

Mollisia 199

Mollisiella 218

Monilinia 48

Murangium 367

Ombrophila 230

Orbilia 152

Ovulinia 64

Pestalopezia 191

Pezicula 333

Phaeobulgaria 233

Phaeohelotium 184

Pocillum 182

Podophacidium 97

Pseudopeziza 185

Pycnopeziza 106

Pyrenopeziza 220

Sarcomyces 373

Sclerotinia 74

Seaverinia 59

Septotinia 63

Spathularia 3 t

Sphaerangium 308

Stamnaria 229

Streptotinia 60

Stromatinia 89

Tapesia 193

Trichobelonium 161

Trichoglossum 29

Tympanis 368

Velutaria 296

Verpatinia 73

Vibrissea 39 


\title{
INDEX TO GENERA AND SPECIES
}

\author{
(Synonyms in italics)
}

Acervus 47, 239

aurantiacus 239

Acarosporium 46, 106

laxum 51

quisquilaris 107

sympodiale 106, 107

Actinonema Rosae 190

Aleuria

fuscocarpa 219

marchica 219

purpurascens 236

xanthomela 97

Allophylaria fumosella 126

Angelina rufescens 195

Apostemidium 46, 178, 183

Guernisaci 183

obconicum 184

vibrisseoides 183,184

Arachnopeziza 48, 284

Arctostaphyli 285, 286

aurata 285, 286

aurelia 198, 285

delicatula 285, 286

Ascobolus 100

epimyces 100

inquinans 233

striisporus 100

Trifolii 185

Ascocalyx 315

Abietis 331

Ascochyta colorata 190

Ascoconidium Castancae 347

Ascotremella 47, 234

faginea 234

turbinata 234, 235

Asteroma Rosae 190

Atractium Therryannm 349

Atractobolus 239

Atropellis 315

apiculata 333

arizonica 333

pinicola 329, 333 tingens 333

Treleasei 330

Belonidium 169

aurantiacum 176

auratum 286

aurelia 285

basitrichum 170

caricincolum 175

culmicolum 176

delicatulum 286

fulgens 285

fuscopallidum 177

Glyceriae 170

heteromorphum 174

hirtipes 177

intermediun 175

juncisedum 177

lencorrhodinum 161

Maconnii 320, 321

minimum 172

Parksi 171

phlegmaceum 172

sclerogenum 173

sclerotii 177

tympanoides 171

Beloniella 162

brevipila 274

Dehnii 208

marcyensis 352

Belonioscypha 46, 177

ciliatospora 119

lactea 177

miniata 177,178

Belonium 46, 47, 161, 169, 177, 274, 297

aggregatum 170, 173

Andropogonis 170, 174

arabicolum 176

atrosanguineum 169,172

basitrichum 169,170

bicolor 176

bryogenum 122 
caricincolum 170, 175

consanguineum 176

culmicola 170, 176

Delitschianum 176

eust egiaeforme 170,175

Fairmani 166

fuscum 177

Glyceriae 169, 170

hercynicum 162

heteromorphum 170,174

inconspicuum 170, 173

intermedium 170,175

introspectum 169, 171

minimum 170,172

Moliniae 176

Parksi 169, 171, 177

phlegmaceum 169, 172

quisquiliarum 169, 172

sclerogenum 170,173

subgibbosum 176

sulphureotinctum 134

tympanoides 169,171

vexatum 176

Belonopsis 178

montanensis 180

Belospora ciliatospora 119

Botryodiscus pinicola 331

Botryotinia 45, 61

convoluta 61

Draytoni 61, 62

narcissicola 61,63

Ricini 61, 62

Botrytis 3, 4, 45, 59-63

cinerea 4

convoluta 61

narcissicola 63

Bulgaria 233, 315

decolorans 110

inquinans 234, 373

nigrita 219

Ophiobolus 238

polymorpha 234

purpurea 236

sarcoides 236

similis 233

striata 236

urnalis 237

Bulgariella 218

nigrita 219

pulla nigroolivacea 219
Burcardia turbinata 233

Calloria 46, 149, 151, 162, 168

atrosanguinea 172

atrovirens 106

aurea 163,165

caricinella 163, 167

chrysocoma 153

citrina 168

coccinea 163,164

coccinella 157

cremea 163,168

dentata 113

Eucalypti 158

Fairmani 163, 166

fusarioides 160,163

glagosa 163,167

helotioides 163, 167

inflatula 154

kansensis 163, 166

leucostigma 154

Lithospermi 163, 165

luteor ubella 159

Mülleri 163, 168

myriospora 160

nitens 163, 165

occulta 158

oleosa 163,164

oregonensis 163,166

rosella 161

rubrococcinea 157

Solidaginis 163,164

vinosa 156

xanthostigma 154

Calycella 111

acicularum 127

citrina 132

cyathoidea 142

pallescens 133

petiolorum 110

Scutula 119

tenella $1+2$

turbinata 122

Calycellina 136

populina 136

punctiformis 136

Calycina 46, 108

albumina 145

aurantiaca 125

bolaris 108, 109

bryogena 122 


\author{
episphaerica 139 \\ fastidiosa 117 \\ firma 108, 110 \\ Ilicis 136 \\ Limonium 142 \\ macrosporum 108, 110 \\ mycetophila 122 \\ naviculaspora 124 \\ petiolorum 108, 110 \\ populina 136 \\ rhizogena 258 \\ saprophylla 124 \\ Cantharellus viridis 98 \\ Catinella 47, 218 \\ nigroolivacea 219 \\ olivacea 219
}

Catinula turgida 336

Cenangella 295, 310

abietina 311

deformata 313

Ericae 193

flavocinerea 311

Fraxini 364

Hartzii, 311

Morthieri 349

oricostata 310,311

Pinastri 369

pruinosa 311

Ravenelii 310

Rhododendri 311

thujina 311,312

urceolata 325

violacea 312

Cenangium 295, 297, 304, 306, 308, 352,367

Abiet is 297, 298

acuum 297, 299

aeruginosum 304

alboatrum 304

alpinum 304

Andromedae 304

apertum 304

Ariae 358

asterinosporum 304

atropurpureum 297, 298

Aucupariae 371

aureum 298, 302

balsameum 354

balsameum abietinum 354

bicolor 357
Cassandrae 305

Castaneae 305

Cephalanthi 326

Cerasi 353

Cerasi Padi 360

cerasorum 353

clavatum 305,353

compressum 305

confusum 305

conglobatum 305

contortum 305

Crataegi 305

deformatum 313

dichroum 357

difforme 322

dimorphum 298, 303, 305

dolosum 310

Ellisii 305

enteroxanthum 305

episphaeria 304,305

Ericae 193

fasciculare 301

fatiscens 305

ferruginosum 297, 298

fibrisedum 305

Frangulae 312

Fraxini 310, 364

fuliginosum 322

fulvotingens 97

furfuraceum 297, 300

globulare 325

inconstans 358

Juglandis 305

laricinum 369

leptospermum 305

Magnoliae 314

microspermum 268

molliusculum 354

Morthieri 349

nigrofuscum 305

Padi 360

palmatum 305

patellatum 306

Peckianum 356

pezizoides 306

phaeosporum 296

Pinastri 369

piniphilum 329

pithyum 331

populinum 301, 370 
populneum 298, 301

populneum prunicolum 301

pruinosum 298, 300

Prunastri 361

Prunastri rigida 361

pulveraceum 268

punctoideum 306

pyrinum 306

quercinum 306

querneum 307

Ravenelii 218

Rhois 306

Ribis 317

rigidum 306, 361

Rosae $306,3+1$

Rubi 296

rubiginellum 306

rubiginosum 306

Sabilidis 214

Schweinitzii 370

Sequoiae 368

seriatum 323

spermatiosporum 370

sphaeriaemorphum 306

Spiraeae 306

Staphyleae 306

sticticum 306

strobilinum 99

subnitidum 358

tennesseense 336

tetrasporum 308

triangulare 306

tryblidioides 306

tuberculiforme 298, 304

tumorum 306

turgidum 307,336

urceolatum 325, 326

Urceolus 325

ustale 306

Viburni 306

viticolum 321

Yuccae 298, 302

Ceratostoma spurium 360

Chaetonium 182

Chlorociboria 46, 98, 232

aeruginescens 98

aeruginosa 98

strobilina 98, 99

iersiformis 94
Chloroscypha 100

cedrina 103

chloromela 102

Jacksoni 101

juniperina 102

Seareri 100

Chlorosplenium 46, 98, 104, 106

aeruginescens 98, 99

aeruginosum 98, 99

atrovirens 106

canadense 100,238

chlora 104, 279

chloromelum 102

elatinum 104

epimyces 100

lividum 99

olivaceum 104, 105

salviicolor 104,105

Schweinitzii 104

striisporum 100

tortum 106

versiforme 94

versiforme nigrescenteolizacea 99

viride 98

Ciboria 45, 84, 89, 98, 107, 108, 148

acerina 85

aestivalis 85,88

amentaceae 85,86

amenti 85

americana 85,88

bolaris 109

caespitosa 93

carbonaria 258

carunculoides 85,87

Caucus 85, 86

ciliatospora 119

Dallasiana 111

firma 108

fructicola 48,50

fuscocinerea 111

Johnsoni 55

juncigena 76

Liquidambaris 89

luteovirescens 131

nyssaegena 80

ochroleuca 108

petiolorum 110

pseudotuberosa 85,87

pygmaea 258

renispora 130 
rhizophila 257

rufescens 107

rufof usca 89

strobilina Bresadolae 99

subrubescens 258

sulfurella 131

Sydowiana 130, 131

tabacina 131

tropicalis 67

Ciboriella 46,107

rufescens 107

Ciborinia 45, 70, 73

bifrons 70,71

confundens 71

Erythronii 70, 72

foliicola 70,71

gracilipes 70,72

gracilis 72

Whetzelii 70

Cistella 239

dentata 113

Clavaria

contorta 13

mitrata 18

mitrata viridis 16

nigrita 24

ophioglossoides 24

phalloides 10

viridis 16

Claviceps 79

Coccomyces triangulare 306

Coniocybe pallida $4+$

Coprotinia 45,90

minutula 90

Cordierites irregularis 92

Coronellaria 239

Aquilinae 113

Castanopsidis 275

Delitschiana 176

Coryne 47, 235, 236

atrovirens 106

Ellisii 238

microspora 236, 237

purpurea 237

sarcoides 232, 233, 236, 237

solitaria 236

striata 236

turbinata 234

unicolor 237 urnalis 236,237

versiformis 94

vinosa 237

virescens 106

Corynetes 8,17

arenarius 18,20

atropurpureus 18,19

purpurascens 18

robustus 18,19

Coryneum 349

Crinula caliciiformis 239

Crumenula 315, 329

pinicola 328, 329

Ribis 317

sororia 329

Urceolus 325

Cryptosporiopsis 349

fasciculata 335

Cryptosporium brunneoviride 360

Cudonia 8, 34, 41, 126

aquatica 231

circinans 41

grisea 41,43

lutea 41,42

monticola 41,43

ochroleuca $+1,43$

Cudoniella $36,37,44$

acicularis $4 t$

aquatica 231

fructigena $4+, 231$

Cyathicula 46, 110,111, 113

alpina 113

aquilina 113

coronata 112

dentata 113

Marchantiae 112

petiolorum 110

quisquiliaris, 107

vulgaris 142

Cycledum

Carpini 335

Cerasi 353

Cyphella 240,274, 275, 281, 297

cinereofusca 275

fasciculata 323

pendula 276

tela 199

Tiliae 281

villosa 281 
Dacryomyces

chrysocomus 153

Lythri 211

Dacryopsis

Ellisiana 238

unicolor 237

Dasyscypha 239, 241, 275

Acanthonitschkeae 262

acuum 273

Agassizii 248

albocitrina 273

albolutea 276

albopileata 273

arida 268

Arundinariae 274

aspidicola 261

Bakeri 274

bicolor 250

boreal is 249

brunneola 274

callochaetes 274

calycina 245

calyculaeformis 274

canescens 249

capitata 254

carneola 275

caulicola 275

cerina 269, 271

chamaeleontina 275

chlorella 268

ciliaris 255

ciliata 247

clandestina 275

crinella 275

crucifera 252

crystallina 254

Dicranopteridis 262

diminuta 259

Ellisiana 248

epixantha 276

eryngiicola 276

Eupatorii 272

Fairmani 276

fasciculata 251

fimbriifera 276

flavidula 276

flavofuliginea 277

flavovirens 268

fuscescens 277

fuscidula 277 fuscosanguinea 269

Gaultheriae 256

hystricula 277

illota 277

incarnata 248

inspersa 277

Ivae 265

lachnoderma 249

latebrosa 253

lentaginis 278

longipila 278

luteoalba 278

luteodisca 278

luteola 257

membranata 278

nivea 253

oblongospora 245

occidentalis $24+4$

ochracea 279

patula 279

Pini 269

prolificans 279

Pseudotsugae 246

puberula 134, 279

pulverulenta 265

pygmaea 257

resinaria 247

Rhytismatis 262

scabrovillosa 280

scintillans 254

soleniiformis 260

solfatera 265

spiraeicola 280

stipiticola 280

subhirta 280

subtilissima 248, 280

succina 263

sulphurella 252, 280

sulphuricolor 263

tautilla 256

trabinelloides 288

translucida 281

tuberculif ormis 281

turbinulata 263

uncinata 281

virginea 253

virginella 256

viridula 268

vixvisibilis 281 
Dasyscyphella 290

acutipila 294

appressa 292

Cassandrae 294

miniopsis 291

subcorticalis 293

Dasyscyphus 239

Dermatea see Dermea

Dermatella 295, 312,314, 315

caryigena 312,314

deformata 312,313

eucrita 350

Frangulae 312

Fraxini 312, 313

Hamamelidis 363

livida 350

Magnoliae 312,314

montanensis $312,315,326$

populina 315

Prunastri 361

Pumilionis 179

quercina Alni 338

scotinus 335

viticola 315

Dermateopsis 295, 307

tabacina 307

Dermea $214,240,295,351,366,368$ abietina 350

acerina $343,352,359$

Alni 338

Alni Aceris 342

Ariae 352, 358

balsamea 352,354

bicolor 352,357

Brenckleana 357

brunneopruinosa 192

carnea 342,343

carpinea 335

caryigena 314

Cerasi 352, 353, 361

Chionanthi 352,365

cinnamomea $3+2,345$

cornea 335

Corni 344

crataegicola 339

crypta 366

cucurbitaria 366

Cydoniae 366

dimorpha 303

episphaeria 303
Eucalypti 366

fascicularis 301, 302

ferruginea 366

flavocinerea 311

Frangulae 312

Fraxini 364

furfuracea 300, 305

fusispora 320

Hamamelidis 352, 363

inclusa 345

juniperina 102

Kalmiae 324

Libocedri 352, 363

livida 350

lobata 297

macrospora 345

micula 349

minuta 348

molliuscula 352,354

Mori 352, 366

mycophaga 139

olivacea 366

olivascens 339

Padi 352, 360

pallidula 351

Peckiana 352, 356

phyllophila 350

piceina 352,362

Pini 298

pinicola 352,362

populnea 370

pruinosa 300, 340

Prunastri 352,360

puberula 366

purpurascens 347

purpurea 305

rhabarbarina $3+1$

Rosae 341

Rubi 341, 349

Sabilidis 214

seriata 323

simillima $3+2$

Spiraeae 306

tabacina 307

tetraspora 308

Tulasnei 352, 364

Viburni 352, 355

Yanthoxyli 366

Dibelonis 199

Dehnii 208 
Dicoccum Rosae 190

Diplocarpa 48, 281

Curreyana 282

tinctoria 92

Diplocarpon 189

Earliana 190

Rosae 190

Diplonaevia 276

melaleuca 276

Discella discoidea 335

Discinella 113

lividopurpurea 150

washingtonensis 108

Discula Peckiana 335

Ditiola paradoxa 335

Dothidea Ranunculi 189

Dothiora rufa 372

Drepanopesiza 185

Populi-albae 188

Ribis 188

Durandia 367

Fraxini 367

Durandiella 295, 367

Fraxini 367, 368

Nemopanthis 324

Durella livida 350

Echinella 48, 294

rhabdocarpa 294

Elvela

aeruginosa 98

calyciformis 247

clazata 34

cucullata 11

infundibuliformis 39

lilacina 232

lubrica 36,37

Encoelia

fascicularis 301

furfuracea 300

populnea 301

Endoconidium 76

temulentum 76

Entomosporium maculatum 191

Epidochium

affine 79

ambiens 79

Erinella 48, 239, 240, 290

bicolor 250

borealis 294

calospora 291
Cassandrae 294

cervina 292

ciliaris 255

miniopsis 291

Nylanderi 293

pygmaea 257

raphidophora 294

rhabdocarpa 294

rhaphidospora 291

similis 294

subcorticalis 293

virginea 253

Erinellina 48, 277, 290, 294

appressa 291, 292

calospora 291

cervina 291, 292

longispora 291, 293

maculosa 291, 293

miniopsis 291

Nylanderi 291, 293

rhapidospora 291

Eriopezia 48, 284

prolifica 284

Eubelonis 162

Excipula

Ranunculi 189

Rubi 221

turgida 336

Fabraea 47, 189

cincta 191

Earliana 189, 190

litigiosa 189

maculata 189,191

Ranunculi 189

Rosae 189, 190

Fuckelia Ribis 317

Fusisporium Berenice 331

Geaster 106

Geasterina 225

Gelatinosporium 352

abietinum 354

betulinum 323

fulvum 354

Geoglossum 8, 13, 17, 20, 23, 29

album 28

alveolatum 23,27

americanum 29

atropurpureum 18, 19

capitatum 30

cohaerens 23, 26 
difforme 21, 22, 24

fallax 23, 25

farinaceum 29

Farlowi 32

glabrum 23, 24, 27

glabrum paludosum 25

glutinosum 21

glutinosum lubricum 21

hirsutum 29, 30

hirsutum americanum 29

intermedium 23, 27

irregulare 9

luteum 13

microsporum 17, 19

microsporum tremellosum 19

nigritum 23, 24

olivaceum 16

Peckianum 22

pistillare 13

pumilum 23, 28

purpurascens 18

pygmaeum 23, 26

Rehmianum 33

rufum 13

simile 24

sphagnophilum 24

tremellosum 19

velutipes 29,32

viride 13, 16

viscosum 21

vitellinum 10

Walteri 33

Geopyxis nebulosa 111

Gioeoglossum 8, 20, 45

affine 21,22

difforme 21, 22

glutinosum 21

Gloeosporium

podophyllinum 64

rhoinum 211

Ribis 188

tremellinum 211

Glonium 312

Godronia 295, 315, 321, 367, 370

abieticola 317,332

abietina 317,332

Abietis 317,331

Betheli 322

Cassandrae 305, 325, 326

Castanopsidis 317,328
Cephalanthi 317,326

Davidsoni 316, 319

Fraxini 367

fuliginosa 316,322

fusispora 316,320

jamaicensis 317,331

Juniperi 333

Kalmiae 316, 324

Lantanae 316,319

lobata 316,318

Lonicerae 316,321

montanensis 316,326

Nuhlenbeckii 316

Nemopanthis 316,324

parasitica 317,327

pinicola $317,328,339,330$

rhabdospora 333

Ribis 316,317

rugosa 333

seriata 316,323

sororia 317,329

Spiraeae 316, 320

striata 322

tabacina 307

Treleasei 317,330

tumoricola 316,318

turbinata 316,319

urceolata conferta 326

Urceolus 316, 321, 325

viburnicola 317,327

viticola 316,321

Zelleri 317,329

Godroniopsis 295, 307

quernea 307

Gorgoniceps 46, 178, 182, 183

aridula 178,179

confluens 179,181

delicatula 286

dinemasporioides 182

Guernisaci 183

iowensis 179,181

jamaicensis 179,182

Kalmiae 324

montanensis 179,180

ontariensis $179, \mathbf{1 8 0}$

Pumilionis $\mathbf{1 7 9}$

turbinata 184

turbinulata 183

vibrisseoides 181 
Graphitu giganteum 238, 239

Guepinia 149

Guepiniopsis 149

chrysocomus 153

Habrostictis

aurantiaca 337

ocellata 345

Haematomyces 234

fagineus 234

vinosus 372

Haematomyxa 372

ascoboloides 372,373

rufa 372

vinos $a 312$

Hainesia rhoina 211

Harknessiella 169

purpurea 177

Helolachnum 240

aurantiacum 258

Helote 13, 16

viridis 16

Helotiella 48, 287

aureococcinea 287

cornuta 287,289

lactea 177

Lonicerae 287, 288

major 287, 289

Nuttallii 288, 289

papyricola 287,290

pygmaea 287,288

Russellii 290

trabinelloides 287, 288

Helotium 46, 113, 149, 150, 167, 206, $215,232,240,241,287$

aciculare 44

acicularum 115, 127

acuum 273

aeruginosum 98

affinissimum 257

alaskae 132

alboluteum 263

albopunctum 115, 133

albovirens 148

albuminum 117,145

alniellum $1+8$

amenti 85

ammoides 117,145

amplum 115, 133

appendiculatum 119

arenicola 117, 148 aspidicolum 261

atrosubiculatum 116, 140

aurantiacum 140,149

aurantium 116, 140

brassicaecolum 149

bryogenum 122

Buccina 149

calyciforme 248

caraborum 149

carbonarium 258

caricinellum 167

Cassandrae 117, 146

castaneum 116, 138

caudatum 124

caulicola 275

Cecropiae 149

cerinum 271

Cesatii 182

chrysophthalmum 283

ciliatosporum 119

Citri 287

citrinulum 116, 141, 142, 150

citrinulum Seaveri $1+1$

citrinum 115, 131

citrinum sublenticulare 132

Clavus 231

confluens 132

conformatum 149

Conocarpi 116, 137

consanguineum 116, 143

contortum 147

coronatum 112

corticale 249

Craginianum 117, 144

cremeum 168

crocinum 149

cudonioides 115,125

cyathoideum 116, 129, 142

cyathoideum graminicola 143

dakotense 115,132

Dearnessii 114,118

destructor 116, 138

discretum 149

epiphyllum 115, 125

episphaericum 116, 139

erraticum 116, 136

Eschscholtziae 115, 129

fastidiosum 114, 117

ferrugineum $1+9$

firmum 108 
flexipes 258

flexuosum 141, 1+2

foliicolum $1+7$

fraternum 114, 123

Friesii 117,147

fructigenum $114,120,126$

fumigatum 149

fumosellum 115. 126

fumosum $1+3,1+9$

furfuraceum 150

gemmarum 117,144

gracile 119

Hedwigii 258

herbarum 115, 129

herbarum Rubi 130

hyalinum 252

Ilicis 136

imberbe 150

immutabile 116, 135

inquilinum 260

lacteum 177

lanceolato-paraphysatum 117, 145

laricinum 116, 139, 140

lenticulare 132

limonicolor 101

Limonium 142

Linderi 115,123

luteolum 257

luteovirescens 115,131

macrosporum 110

maculosum 293

microspis 150

midlandense 117,147

miserum 150

montanense 150

monticola 150

mycetophilum 114, 122

naviculasporum 115,124

nigrescens 115,128

nigripes 150

nigromaculatum 114, 123

nitens 165

mudum 258

nyssaegenum 80

nyssicola 80,1 I 4,121

pallescens 115, 133

palustre 231

papillare 279

parasiticum 139

petiolorum 110

phaeoconium 115,129

Phiala 151

Phillipsii 257

Piceae 127

pileatum 231

planodiscum 116, 141

populinum 116, 136

propinquum 117,146

puberulum 116, 134

pullatum 151

punctatum 136

punctiforme 136

pygmaetm 257

renisporum 115, 130, 131

rhizicola 117,143

rhizogenum 257

rhizophilum 257

rhytidodes 151

Rubi 3+1

rubicolum 151

rugipes 94

salicellum 114, 120

saprophyllum 124

scrupulosum 151

Scutula 114, 119, 126

Scutula caudatum 179

Scutula Lysimachiae 119

Scutula Rubi 119

Scutula Rudbeckiae 119

Scutula vitellina 119

Seaveri 100

seminicola 115,127

serotinum 114,118

simulatum 116, 137

sordidatum 151

sparsum 124

sphaerophoroides 102

strumosum 115, 128

sublenticulare 132

subrubescens 258

sulfurellum 131

sulphuratum 115, 127

trabinelloides 288, 289

translucens 116,135

tumidulum 151

turbinatum 114, 122

turgidellum 151

umbrinum 117,147

Urticae $1+2$

I'erbenae 119 
versiforme 94

vibrisseoides 184

virgultorum $115,120,126,152$

virgultorum fructigenum 121

virgultorum rubicolum 151

virgultorum Scutula 119

vitellinum 119

vitellinum pallidostriatum 119

vitigenum 152

ITillkommii 244

Helvella 39 see also Elvela

acicularis 4t, 114

elastica 39

gelatinosa 37

laricina 10

Heterosphaeria pinicola 328

Heyderia 8

Holwaya 47,237

gigantea 100, 238

Opliobolus 238

tiliacea 238

Humaria 150

atroviolacea 351

fuscocarpa 219

lividopurpurea 150

marchica 219

olivacea 219

rufoolizacea 296

turbinata 122

xanthomela 97

Ityalinia 111

rubella 159

Iyalopeziza 239, 241

carneola 275

ciliaris 255

ciliata 275

patula 279

Pteridis 261

Hyaloscypha 239

alnesida 274

liyalina 252

punctiformis 136

Hygromitra 36

Hymenoscypha

amentaceae 86

amenti 85

bolaris 109

Caucus 86

coronata 112

cyathoidea 142 cyathoidea Solani $1+2$

Dearnessii 118

Duriaeana 79

epiphylla 125

firma 108

flexipes 257

fructigena 120

Hedwigii 257

nigromaculata 123

nuda 258

petiolorum 110

planodisca $1+1$

pseudotuberosa 87

punctiformis 136

renispora 130

rhisophila 257

Scutula 119

Scutula Grossulariae 119

Scutula Lysimachiae 119

Scutula Rudbeckiae 119

serotina 118

tuberosa 75

Urticae 142

virgultorum 126

IIymenoscyphus

affinissimus 258

albopunctus 133

Dearnessii 118

glagosus 167

gracilis 119

subcarneus 138

IIymenula fumosa 126

Hysterium 217

quercinum 306

Ionomidotis 91

fulvotingens 97

irregularis 92

nicaraguensis 93

olivascens 94

plicata 93

portoricensis 93

Kriegeria 46, 100

alutipes 100,103

cedrina 100,103

chloromela 106, 102

enterochroma 100, 101, 233

Jacksoni 10 I

juniperina 100, 102

Seaveri 100,103

lachnaster miniat us 113 
Lachnea

bicolor 250

calycina $2+4$

cerina 271

ciliaris 255

corticalis 249

diminuta 259

hyalina 252

papillaris 279

pygmaea 257

Rosae 195

rufoolivacea 296

sulphurea $26+$

rariecolor 263

virginea 253

l.achnella 48, 232, 239, 240, 241, 282, 290

Acanthonitschkeae 243, 262

acuum 273

Agassizii 242, 247, 280

agrostina 242,259

albolabra 273

albolutea 243, 263

albopileata subaurata 274

albotestacea 243,272

alboviolascens 240

arida $243,268,270$

Arundinariae 242, 259

ascoboloidea 274

aspidicola 242,261

at ropurpurea 243, 266

aurelia 285

bicolor $242,249,250,280$

brevipila 274

callochaetes 274

canadensis 243,265

canescens 249

capitata 242, 254

caulicola 275

cedrina 103

cenangioides 264

cerina 243,271

ciliaris 242,255

ciliata 241,237

cinereof usca 275

citrina 263

Corni 243, 271

corticalis $2+2,249$

crucifera $242,252,280$

Dicranopteridis 242,262 diminuta 242, 259

diplocarpa 282

echinulata 255

Ellisiana 242, 248

Eupatorii 243,272

extricata 276

fasciculata 242,251

fuscobarbata 277

fuscosanguipea 243, 269, 271

Gaultheriae 242, 256

Gleicheniae 243, 266

Hahniana 241, 245

Halesiae 242, 257

hyalina 242,252

hystricula 277

incarnescens 277

inquilina 242,260

I vae 243,265

labrosa 278

luteodisca 278

luteola 257

microspora 243,267

nivea 253, 254

nuda 257

oblongospora 241,245

occidentalis 241,244

papillaris 279

patula 279

Pini 269

pollinaria 242,255

populicola 243,270

populina 243,270

Pseudotsugae 241, 246

pteridicola 242,261

Pteridis 243, 261, 273

puberula 134

pulveracea 243,268

pulverulenta 243,265

pulverulenta purpurascens 266

pygmaea 242,257

resinaria 242,247

rhabarbarina 240,341

rhizophila 249

Rhytismatis 243,262

rufoolivacea 296

Solenia 242, 260

solfatera 265

solitaria 280

subochracea 242, 251

subtilissima 248 
succina $2+3,263$

sulphurea 2+3, 264, 293

Symphoricarpi 280

tautilla $2+2,256$

iricolor microspora 267

ariecolor 263

venturioides 281

virginea $242,253,273,274$

virginella $2+2,256$

'irginica 271

viridicoma 243,267

Willkommii 241,243

I achnellula 48,282

chrysophthalma 282, 283

cyphelloides 284

hysterigena 218

microspora 282, 283

resinaria 247

theioidea 284

Lachnum 239, 241

agaricinum 253

albotestacenm 272

alneum $27+$

Arundinariae 259

Aspidii 274

atropurpureum 266

bicolor 250

brunneolum 274

calyculaeforme $27+$

carneolum 275

clandestinum 275

Corni 271

corticale 249

echinulatum 255

Engelmani 268

fuscofloccosum 277

Gaultheriae 256

Gleicheniae 266

Hedwigii 258

hyalinellum 277

inquilinum 260

leucophaenm 264

longisporum 293

Nardi 278

nireum 253

nivenm Fairmani 253

pallideroseum 279

pollinarium 255

pygmaeum 258

reclinatum 279 rhisophilum 258

setigerum 280

spiraeaecolum 280

sulfurenm 264

virginellum 256

virginenm 253, 254

viridulum 268

Laetinaevia 162

rosella 161

Lagynodella pruinosa 340

1. ambertella $+5,66$

Cephalanthi 66,69

Corni-maris 66

Hicoriae 66

Jasmini 66,67

Pruni 66, 68

tropicalis 66,67

Viburni 66, 68

Lanzia 162

helotioides 167

rugipes 94

Lasiobelonium subflavidum 280

Lasiosphaeria striata 322

Lecanidion

acericolum 359

Hamamelidis 363

leptospermum 238

Lemalis rufoolizacea 219

l.eotia $8,36,37$

aquatica 231

atropurpurea 18

chlorocephala 37,38

chlorocephala Stevensoni 39

circinans 41

Clavus 40

elegans 10

exigua 39

infundibuliformis 39

lubrica 37, 39

lutea 42

marcida 39

Mitrula 11

ochrolenca 43

rufa 39

Steven soni 39

stipitata 37,38

truncorum 40

uliginosa 10

viscosa 38 
Leptoglossum 13, 17 alabamense 16 fumosum 14 latum 20 lutescens mitruloides 13 luteum 13 luteum fumosum it microsporum 19

Leptothyrium Fragariae 190

Leptotrachila repanda 187

Lencoloma turbinata 122

Macroscyphus tuberosus 75

Marsonia

Castagnei 189

Fragariae 190

Rosae 190

Martinia 45,69 panamaensis 69

Massea 169 quisquiliarum 172

Mastomyces Friesii 325

Melachroia 97 terrestris 97 xanthomela 97

Microglossum 8, 13, 17 album 28 arenarium 20 atropurpureum 18, 19 contortum 16 fumosum 13, 14 longisporum 13,15 obscurum 16 olivaceum 13, 16 rufum 13 viride 13,16 vitellinum 10

Micropera 352 abietina 354 Cerasi 353

Cotoneastri 358 drupacearum 353 erumpens 354 Nemopanthis 356 Pinastri 369 roseola 353 Sorbi 358 stellata 356

Micropesiza Iridis 212 Micropodia populina 1.36 Micula Mougeotii 349
Midotis 46, 91, 98 floridana 92, 95 heteromera 92, 95 irregularis 91, 92 Lingua 91 nicaraguensis 92,93 occidentalis 92, 96 olivascens 92, 94 plicata 92, 93 v'erruculosa 95 versiformis 92,94 Westii 92, 96

Mitrula 7,8 alba 28

arenaria 20

crispata 9

cucullata 9,11

elegans 10

exigua 39

glabra 19

gracilis $9,12,13$

gracilis flavipes 12

Heyderi 8, 11

inflata 13

irregularis 9

Johnsonii 28

laricina 10

luteola 9

lutescens 13

microspora 19

muscicola 9, 12

olivacea 16

paludosa 10

phalloides 9, 10

pistillaris 13

purpurascens 18

roseola 13

rufa 13

viridis 16

vitellina 9,10

vitellina irregularis 9

Mitruliopsis flavida 34

Mollisia 47, 160, 193, 199, 206, 210 , $215-218,220$

abdita 200,210

alabamensis 216

alpina 201, 213

Angelicae 200, 209

apiophila 200, 206

Artemisiae 226 
Asclepiadis 200, 207

aspidicola 261

astericola 208

atrata 200,208

atriella 200,211

atrocinerea 208

aureofulva 200, 203

benesuada 216

benesuada polyspora 216

caesia 200, 203

caespiticia 200, 205

cinerea $200,201,207$

clavigera 200, 209

coccinella 157

complicatula 216

culmina caricina 201

Dehnii 200, 208

dentata 113

discolor 168

Earliana 190

encoelioides 200, 205

epitypha 201, 213

erigeronata 200, 208

euparaphysata 216

exigua 200, 207

Fairmani 200, 201

foliicola 229

fumigata 200, 203

fusarioides 163

fusca 194

fuscorubra 226

Gaultheriae 200, 210

gelatinosa 162

glenospora 200, 204

hydrophila 201, 213

ilicincola 218

incrustata 201, 215

introviridis 217

Iridis 201,212

junciseda 177

Karstenii Caricis 228

lanaria 200, 210

leucastigma 154, 217

lignicola 202

lilacina 200, 205

lividofusca 196

melaleuca 195, 200, 202

microcarpa 200, 202

miltophthalma 217

nipteroides 201, 214
Oenotherae 200, 211

papillata 217

paullopuncta 217

Pinastri 299

Polygoni 200, 206

prinicola 222

pteridina 11.3

Pteridis 27.3

Ramunculi 189

Rosae 195

rubella 159

Rubi 221

Sabalidis 201, 214

scirpina 200, 212

Scoleconectriae 201, 215

singularis 187

sterostoma 217

stictoidea 201, 212

subcinerea 200, 207

subcornea 200, 203

tenella 201, 214

Teucrii 217

trametis 215

Trifolii 185

tyrolensis 169

uda 169

rinosa 156

vulgaris 200, 204

vulgaris myceticola 204

vulgaris sanguinella 204

xanthostigma 154

Mollisiella 47, 218

citrinula $1+1$

ilicincola 218

Mollisiopsis 199

euparaphysata 216

subcinerea 207

Monilia $45,48,51-57$

angustior 52

cinerea 51

cinerea americana 50

Corni 58

Crataegi 55

laxa 51

aregonensis 51

Peckiana angustior 52

Polycodii 56

Seaveri 53

Vaccinii-corymbosi 57

Monilinia 45, 48, 49 
Amelanchieris 50, 54

Aroniae 59

Azaleae 50, 58

Corni 58

demissa 50,54

emarginata 59

fructicola $\mathbf{5 0}$

gregaria 50,56

Johnsonii 50,55

laxa 50,51

Ledi 49

Oxycocci 50, 57

Padi 50, 52

Polycodii 50, 56

Rhododendri 49

Seaveri $50,52,53$

Urnula 59

Vaccinii-corymbosi 50, 57

Montagnella tumefaciens 195

Morchella 12

Murangium 295, 367

Sequoiae 368

Myridium 152, 160

myriosporum 160

Myriella 160

Myxosporium 333, 345, $3+7$

abietinum 350

Nectria 290

Peziza 281

Neobulgaria 230

Neofabraea 333

Populi $3+6$

Neofuckelia

pinicola 329

Niptera 162

caesia 203

caricinella 167

cinerea 201

coccinea $16+$

dentata 113

discolor 168

Ellisii 224

epitypha 213

fuscorubra 226

leucostigma 217

Lithospermi 165

lividofusca 196

melaleuca 202

microcarpa 202

Mulleri 168 pella 169

Polygoni 206

sulphureotincta 134

Teucrii 217

tyrolensis 169

uda 169

Nodularia acericola $3+2,343$

Ocellaria 346

aurantiaca 337

aurea $3+5$

Betuli 335

ocellata $3+5$

Octospora

calyciformis 247

citrina 131

elastica 233

nirea 253

paradoxa 335

tuberosa 75

violacea 236

Oidium laxum 51

Ombrophila 47, 230, 231

albiceps 231

albof usca 232

aurata 232

aurea 165

Clavus 231, 232, 233

decolorans 111

enterochroma 101, 233

flavens 232

hirtella 232

Kriegeriana 100, 104

lilacina 232

limosa 233

limosella 233

Ly'sichitonis 233

microspora 237

paradoxa 335

pellucida 233

purpurascens 231, 232

sarcoides 236

similis 233

strobilina 99

subaurea 233

subsqualida 233

thujina 100, 101

urnalis 237

violacea $231-233,236$

violacea limosella 23.3

Oospora laxa 51 
Orbilia 46, 151, 152, 160-162, 215 assimilis 160

atropurpurea 236

Caulophylli 153, 159

chrysocoma 152, 153, 161

coccinella 153,157

cruenta 153,158

Cucurbitae 152, 155

curvatispora 152,155

diaphanula 152,153

epispora 152,155

Eucalypti 153,158

Fairmani 152, 154

gelatinosa 161

inflatula 152,154

leucostigma $152, \mathbf{1 5 4}, 156,157$

lut eorubella 153,159

myriospora 153, 160

occulta 158

paradoxa 161

phymatodes 152,156

pulviscula 153,160

rosella 161

rubella 153,159

rubinella 153,157

rubrococcinea 152,157

Sarraziniana 161

vinosa 152,156

Otidea 91,94

doratophora 92

leporina 42

Ovulinia 45, 64

Azaleae 65

perplexa 65

Pachydisca immutabilis 135

Pachyella atroviolacea 351

Patellaria

acericola 359

applanata 219

aureococcinea 287,288

bicolor 285

cenangiicola 307

discolor 168

ferruginea 366

Hamamelidis 363

hirneola 219

leptosperma 238

livida 350

melaleuca 202

olivacea 219 pulla nigroolivacea 219

rhabarbarina 338

Rubi 340

sanguinea 199

spermatiospora 370

riolacea 219

Patellea

cenangicola 307

sanguinea 199

Patellina Fragariae 211

Patinella

applanata 219

Brenckleana 357

hirneola 219

olivacea 219

violacea 219

Perrotia 240, 241

flammea 240, 275, 280

Pestalopezia 47, 191, 193

brunneopruinosa 192

Rhododendri 192

Pestalotia 192, 193

Callunae 193

gibbosa 192

Pezicula 295, 314, 333, 343, 349, 351, 366

acericola $334,342,343$

Alni $334,337,338$

alnicola 334,336

atroviolacea 351

aurantiaca 334,337

Brenckleana 334,341

carpinea 334,335

Corni $33+, 344$

cornicola 334,344

corylina 334,336

crataegicola $33+, 339,340$

eximia 345,346

fasciculata 335

Frangulae 312

Hamamelidis 334,348

Kalmiae 351

livida 334,350

minuta 334,348

Morthieri 334, 349

ocellata 334,345

olivascens 334,339

pallidula 351

Philadelphi 351

phyllophila 334,350 
Populi 334,346

pruinosa 334,340

Pumilionis 179

purpurascens 334,347

rhabarbarina 341,345

rhabarbarina Corni 344

Rosae 341

Rubi 334,340

spicata 334,344

spiculata 334,342

viridiatra 219,351

Peziza 182, 193, 239, 281

abdita 210

aberrans 174

Abietis 298

Abietis strobilina 99

Absinthii 226

acerina 273

acicularis 44

acuum 273

aeruginescens 98

aeruginosa 98

Agassisii 248

agrostina 259

albella 205

albida 205

albocitrina 273

albopileata 273

albotestacea 272

alboriolascens 240

alboviridis 274

albumina 145

alnea 369

alniella 148

alutipes 103

amentacea 86

amenti 85

Andromedae 304

Andropogonis 174

anomala 198

aquifoliae 216

arachnoidea 198, 289

ardennensis 340

Ariae 358

arida 268

Artemisiae 226

Arundinariae 175, 274

ascoboloidea 274

aspidicola 261

Aspidii 274 assimilis 160

astericola 208

atrata 208

atriella 211

atrocincerea 208

atrofusca 198

atroviolacea 351

atrovirens 106

Aucupariae 371

aurata 232

aurea 132

aurelia 285

aureofulva 203

balsamicola 197

benesuada 216

Betuli 335

bicolor 250

Bloxami 198

bolaris 109

borealis 249

brassicaecola 216

brevipila 274

brunnea 233

brunneola 274

Buccina 149

bulgarioides 91, 99

caesia 284

caespiticia 205

calyciformis 247, 248

calycina 243, 245, 280

calycina Abietis 283

calycina Laricis 243

calyculaeformis 274

Campanula 177, 274

candidofulva 285

cannea 274

capitata $25+$

caricina 227

cariosa 229

carneorosea 161

carneorubra 275

carpinea 334,335

Caucus 85, 86

caudata 124

caulicola 275

cedrina 103

cenangioides 264

Cephalanthi 326

Cerasi 352, 353

Cerasi Padi 360 
cerina 271

cervinula 228

chamaeleontina 275

chlora 104

chlorascens 98

chloromela 102

chrysocoma 153

chrysophthalma 282, 283

ciborioides strobilaria 99

ciliaris 255

cinerea 199, 201

cinereofusca 275

cinnamomea $3+2$

citrina 131

citrinella 161

clandestina 275

clavigera 209

Clavus 231

Clavus pallens 231

Clavus violascens 231

clypeata 351

coccinella 157

comata 275

conchella 161

concrescens 235

confluens 131

conformata 149

conorum 216

cornuta 289

coronata 111,112

corticalis 240,249

Craginiana 144

crinella 275

crispa 301

crocea 149

crocitincta 104

crossota 275

crucifera 252, 253

cruenta 158

crystallina 254

Cucurbitae 155

culcitella 195

culmicola 176

cyathoidea $1+2$

cyphelloides 284

daedalea 198

Dearnessii 118

Dehnii 208

Delitschiana 176

denigrata 224 dentata 113

denticulata 112

diaphanula 153

digitalis 276

diminuta 259

dinemasporioides 182

diplocarpa 282

discincola 199

distincta 276

doratophora 92

Duriaeana 79

carina 198

Earliana 190

earoleuca 276

echinulata 255

elatina 104

Ellisiana 190, 248

enterochroma 101

epiphylla 125

epispora 155

epixantha 276

erigeronata 200, 208

Eschscholtziae 129

eucrita 350

Eupatorii 272

eustegiaeformis 175

exidiella 216

exigua 207

extricata 276

Fairmani 201

fascicularis 301

ferruginea 149

fibriseda 158, 216, 276

fimbriifera 276

fimbriseda 276

firma 108

fiscella 183

flammea 240, 241

flavofuliginea 277

floriformis 216

Frangulae 312

Fraxini 310, 367

Friesii 147

frondicola 277

fructigena 120

fructigenum rubicola 151

fulvocana 277

fumigata 203

fumosella 126

furfuracea 300 
fusarioides 162-164

fusca 193, 194, 199

fuscescens 277

fuscidula 277

fuscobarbata 277

fuscocarpa 219

fuscosanguinea 269

gelatinosa 161

glagosa 167

glenospora 204

globularis 325

gracilipes 72

graminis 169

griseopulveracea 194

herbarum 129

heterocarpa 217

heteromera 95

heteromorpha $17+$

hyalina 252

Hydrangeae 277

hydrophila 213

hypnicola 217

hypophylla 182

hysterigena 218

ilicincola 218

illota 277

imberbis 150

incarnescens 277

incondita 84

incrustata 215

inflatula 154

inquinans 233

inspersa 277

introspecta 171

introviridis 217

irregularis 92

janthina 236

Kalmiac 278, 351

lacerata 221

Laricis 244

latebrosa 253

Lecanora 345,346

leguminum 150

Lentaginis 278

lenticularis 131

leonina 278

leucopsis 150

leucorrhodina 161

leucostigma 152, 154, 217

lilacina 232 limosclla 233

lividofusca 196

longipes 131

longipila 278

luctuosa 206

luteoalba 278

luteorubella 159

luteovirescens 131

Marchantiae 112

marginata 278

megaloma 199

melachroa 217

melaxantha 278

Meleagris 275

melileuca 202

melichroa 217

membranata 278

microspis 150

miltophthalna 217

miniopsis 291

mollisiacoides 195

multipuncta 228

mycogena 169

myricacea 278

nebulosa 111

nigra 233

nigrescens 128

nigripes 150

nigritella 229

nigrocincta 278

nigroolizacea 219

muda 257

nyssaegena 80

obscura 278

occulta 158

ocellata 345

ochracea 279

ochroleuca 108

Oenotherae 211

oleosa 164

olivacea 219

Opulifoliae 279

Osmundae 279

pallescens 133

palliderosea 279

pallidovirescens 131

papillaris 279

Pastinacae 151

patula 279

paullopuncta 217 
penicillata 279

Personii 229, 230

petiolorum 110

phlegmacea 172

Phiala 151

Philadelphi 351

phymatodes 156

Pinastri 299

pinicola 328

pinicola solitaria 328

planodisca $1+1$

plicatocrenata 372

pollinaria 255

Polygoni 206

polymorpha 233

pomicolor 104, 279

populnea 301,370

prinicola 222

prolifica $28+$

prolificans 279

protrusa 222

pruinata 199

pruinosa 300

Prunastri 360

pseudotuberosa 88

Pteridis 273

puberula 134, 279

pulveracea 268

pulverulenta 265

pulviscula 160

punctiformis 136, 279

pygmaea 257

Pyri 371

quernea 307

quisquiliarum 172

radiata 112

raphidophora 294

Rapulum 89

Ravenelii 218

regalis 158,217

relicina 279

resinaria 247

retincola 161

rhabarbarina 341

rhabdocarpa 294

rhaphidospora 291

Rhododendri 311

ribesia 317

Rosae 195

roseoalba 280 rubella 159

rubiginosa 306

rabinella 157

rufiberbis 280

rufofusca 89

rufoolivacea 296

rufula 158

rugulosa 220

Russellii 290

saccharifera 158, 217, 276

salicella 120

sanguinea 199, 217

sarcoides 236

scabrovillosa 280

scariosa 199

Schweinitziana 321

scirpina 212

sclerogena 173

sclerotionum $7+$

scrupulosa 151

Scutula 119

serotina 118

setigera 280

simillima 290

simulata 137

singularis 187

Solani 142

Solenia 260

soleniaeformis 260

solen iiformis 280

solfatera 265

solitaria 280

sphaerincola 280

sphaerophoroides 102

spiraeaecola 280

stenostoma 217

stictoidea 212

stipiticola 280

subatra 224

subcarnea 138

subgibbosa 176

sublivta 280

subiculata 194

subochracea 251

subtilissima 248, 280

succina 263

sulphurata 127

sulphurea 127, 264

sulphurea albolutea 263

sulphurea leucophaea 264 
sulphurella 252, 253, 280

tautilla 256

tela 199

tenella $1+2,21+$

Thalictri 223

theioidea $28+$

Tiliae 281

torta 106

translucida 281

tremelloidea 236

Trifoliorum 185

tuberosa 75

tuberosa strobilina 99

tumidula 151

turbinulata 263, 264

turgidella 151

uda 169

uncinata 281

Urceolus 325

Urceolus 325

Urmula 59

Urticae 142

urticina 281

urtalis 306

ustalis 306

zariecolor 263

Vectis 294

versiformis 94

versiformis livida 99

vexata 176

Viburni 306

villosa 281

vincta 194

vinosa 156

virginea 253

virginella 256

virgultorum 126

viridiatra 219, 351

viridicoma 267

viticola 321

Vitis 281

vixrisibilis 281

vulgaris 204

vulpina 281

Wauchii 285

xanthomela 97

xanthostigma 154

yogoensis 228

zanthomela 97
Pezisella 152

albella 205

albopuncta 133

aquifoliae 216

aquifoliae 216

aurantiaca 140

brassicaecola 216

californica 225

carneorosea 161

citrinella 161

citrinula 141

conchella 161

conformatum 149

crocea 149

crocitincta 104

cruenta 158

Cucurbitae 155

dakotensis 132

exidiella 216

exigua 207

Fairmani 154

floriformis 216

glagosa 167

inquilina 260

lanceolato-paraphysata 145

leguminum 150

Lythri 211

microspis 150

Oenotherae 211

ontariensis 180

Pastinacae 151

phymatodes 156

planodisca $1+1$

populina 136

puberula 134

punctformis 136

regalis 158

rubella 159

rufula 158

soleniiformis 280

Teucrii 217

tumidula 151

turgidella 151

vulgaris 204

Pesisellaster 111

radiostriatus 113

Pezoloma 111, 112

griseum 113

Phacidium

congener 189 
litigiosum 189

Medicaginis 186

Pinastri 369

Populi 345

Ranunculi 189

repandum 187

seriatum 323

Trifolii 185

Phacopsis Mülleri 168

Placangella 312

abietina $31 \mathrm{I}$

deformata 313

Morthieri 349

Prunastri 361

subnitida 358

Phaeangium 308

magn isporum 309

phaeosporum 297

punctoideum 306

Rubi 296

tetrasporum 308

Phaeobulgaria 47,233

inquinans 233

Phaeohelotium 46, 184

flavum 184, 185

Phaeopeziza

fuscocarpa 219

marchica 219

Phallus marcidus 39

Phialea 113, 114, 241

acicularum 127

affinissima 257

alniella 148

alutipes 103

amenti 85

ampla 133

anomala 131

appendiculata 119

arenicola 148

bolaris 109

carneola 149

Cassandrae 146

Caucus 86

Cecropiae 149

citrina 132

Craginiana 144

crocea 149

culmicola 176

cyathoidea 142, 149

Dearnessii 118 discreta 149

Eschscholt:iae 129

firma 108

flexipes 257

fructigena 120

fumosella 126

gemmarum 144

gracilis 119

Hedwigii 257

leucopsis 150

microspora 150

nigromaculata 123

olympiana 151

pallida 151

palliderosea 279

petiolorum 110

phaeoconia 129

rubicola $15 \mathrm{I}$

Scutula 119

Scutula Rudbeckiae 119

simulata 137

Solani $1+2$

sordida 105

sordidata 151

subcarnea 138

subgalbula $15 \mathrm{I}$

temulenta 76

tuberosa 75

Urnula 59

virgultorum 126

vitellina 119

vitellina pallidostriata 119

vulgaris 204

Phialina puberula 134

Phibalis furfuracea 300

Phillipsia 91

Phillipsiella 220

nigrella 229

purpurea 177

Phlyctidium Ranunculi 189

Phyllachora

Medicaginis 186

Trifolii 185

Physalacria inflata 13

Pirottaea 294

frondicola 277

Hydrangeae 277

yukutatiana 28I

Pithya suecica 283

Plicaria turbinata 122 
Pocillum 46, 182

hypophyllum 182

Podophacidium 46, 97

terrestre 97

xanthomelum 97

Polynema aurelium 285

Propolis ocellata 345

Pseudociboria 113, 114

umbrina 147

Pseudohelotium 113, 279

Absinthii 226

ammoides 145

canadense 265

Fa irmani 201

fibrisedum 158, 216, 276

hyalinum 252

ilicincolum 218

incrustatum 215

isabellinum 150

laricinum 139

melichroum 217

pomicolor 104

puberulum 134

punctiforme 136

sacchariferum 217, 276

strumosum 128

Teucrii 217

Pseudopeziza 47, 185

Bistortae 189

caricina 227

Cerastiorum Arenariae 189

Holwayi 185,187

Jonesii 186

Medicaginis 185,186

Meliloti 187

Populi-albae 185, 188

protrusa 222

Ranunculi 189

repanda 185,187

Ribis 185,188

singularis 185,187

Trifolii 185

Trifolii-arvensis 186

Pycnocalyx Abietis 331

Pycnopeziza 46, 106

quisquiliaris 106, 107

sympodialis 106

Pyrenopeziza 47, 162, 212, 220

Absinthii 221, 226

Artemisiae 221, 226
Artemisiae Solidaginis 227

Arundinariae 175, 274

atrata 208

californica 221, 225

caricina 221,227

Caricis 221, 228

cariosa 229

Cephalanthi 221, 225

cervinula 221,228

coloradensis 221,224

compressula 221, 225

Dearnessii 221, 227

doryphora 229

doryphora Heleocharidis 229

Ellisii 221, 224

foliicola 229

fuscorubra 226

lacerata 220, 221

leucodermis 220,223

lignicola 202

Medicaginis 186

minuta 220,223

multipunctoidea 221, 229

nigrella 229

nigritella 229

prinicola 220, 222

protrusa 220, 222

Rubi 220, 221

smilacicola 221, 227

subatra 221,224

Thalictri 221, 223

yogoensis 221,228

Rhizina nigroolivacea 219

Roesleria hypogaea 44

Rutstroemia 91, 108

amentaceae 86

americana 88

bulgarioides 99

elatina 104

firma 108

microspora 150

renispora 130

tuberosa 75

Sarcodea sarcoides 236

Sarcomyces $\mathbf{3 7 3}$

vinosa 373

Sarea brassicaecola 149

Schweinitzia 296

phaeospora 297

rufoolizacea 296 
Scleroderris 315

abieticola 332

abietina 332

acerina 359

Cephalanthi 326

fuliginosa 322

Lantanae 319

lobata 318

pallidula 351

pitya 331

ribesia 317

sequoiae 368

seriata 323

Spiraeae 320

Treleasei 330

tumoricola 318

Sclerotinia $1-5,45,49,74,89$

aestivalis 88

Amelanchieris 54

americana 50

angustior 52

bifrons 70,71

Camelliae 74, 80

Caricis-ampullacea 74,77

carunculoides 87

cinera 51

coloradensis 75,82

confundens 71

convoluta 61

Corni 58

Crataegi 55

demissa 54

Dratoni 62

Duriaeana $74,78,79$

Erythronii 72

fallax 74,81

foliicola 71

fructicola 50

fructigena 51

Fuckeliana 4

Geranii 3, 4, 59

Gladioli 5, 6, 90

gracilipes 72

gracilis 72

gregaria 56

heteroica 49

incondita 84

intermedia 75, 83

Johnsoni 55

juncigena 74,76 laxa 51

longisclerotialis 74,78

minor 74,81

narcissicola 63

nyssaegena $63,74,80$

Oxycocci 57

Padi 52

paludosa 74,77

Panicis 75, 83

perplexa 65

Polycodii 56

pseudotuberosa 87

Rhododendri 50

Ricini 62

sativa 75,84

sclerotiorum 49

Seaveri 1, 4, 53

Smilacinae 89

sulcata 79

Tiliae 2, 74, 79

temulenta 74,76

tuberosa $74,75,84$

Vaccinii 59

Taccinii-corymbosi 57

Veratri 75,82

Whetzelii 70

wisconsinensis 84

Sclerotium

bifrons 70,71

fallax 81

Gladioli 90

sulcatum 79

Scodellina 91

Scutula leucorrhodina 161

Seaverinia 45, 59

Geranii 59

Septogloeum podophyllinum 64

Septoria 210

Septotinia 45, 63

podophyllina 64

Solenia 280

anomala 198

poriaeformis 198, 199

Solenopezia 239, 281

aureococcinea 287

fimbriata 276

grisea 168

Solenia 260

Symphoricarpi 280 
trabinelloides 288

vulpina 281

Spathularia 8, 34

clavata 34

flava 34

flavida 34

flavida rugosa 34

linguatus 36

rugosa 34

velutipes 34,35

Sphacelia ambiens 79

Sphaerangium 295, 308

magnisporum 308, 309

tetrasporum 308

Tiliae 308, 309

Sphaeria 280

Aucupariae 371

cespitosa 371

conspersa 371

Cotoneastri 358

Cotoneastri Sorbi 358

dubia 353

fuliginosa 322

micula 349

padina 360

uberiformis 325

Sphaerographium

Fraxini 367

hystricinum 355, 356

hystricinum Viburni 355

niveum 349

stellatum 356

Sphaeronema $333,340,342,343$

acerinum 343, 359

brunneoviride 360

corneum 211

Coryli 336

Fraxini 367

hystricinum 355, 356

nigripes 359

pallidum 358

pruinosum 340

seriatum 323

spurium 361

stellatum 356

Sporonema pulvinatum 211

Spragueola americana 9

Stamnaria 47, 229

americana 229, 230
Equiseti 230

Thujae 229, 230

Stict is 212,315

Betuli 335

Lecanora 345

ocellata 345

Stilbum giganteum 238

Streptotinia 45, 60

Arisaemae 60

Streptothrix 60

Stromatinia 45, 89

Geranii 59

Gladioli 89, 90

laxa 51

pseudotuberosa 87

Rapulum 90

Smilacinae 89

Tapesia 47, 193, 284, 372

anomala 198

arachnoidea 198

atrof usca 198

aurata 286

balsamicola 193,197

Bloxami 198

candidofulva 285

cinerella 194, 198

coloradensis 193, 196

culcitella 193, 195

daedalea 198

derelicta 198

discincola 199

earina 193,198

fulgens 285

fusca 193, 194, 198, 199

griseopulveracea 194

lividof usca 193, 196

lividofusca fallax 197

Lonicerae 288

megaloma 199

melaleucoides Vaccinii 199

mollisioides 193, 195

prolifica 284

pruinata 199

Rhois 194

ribicola 193, 196

Rosae 193, 195

sanguinea 199

scariosa 199

secamenti 193, 197

subiculata 194 
tela 199

tenebrosa 199

tumefaciens 193, 194

zariecolor 263

vincta 194

Tapesina griseovitellina 297

Tarzetta cinerascens 111

Thelephora fimbriata 300

Thuemenidium 17

atropurpureum 18

Thyronectria py'rhochlora 366

Tremella 47, 235

agaricoides 233

sarcoides 2.36

stipitata 38

turbinata 233

vinosa 373

Triblidium see Tryblidium

Trichobelonium 46, 161, 173

albosuccineum 161, 162

hercynicum 162

leucorrhodium 161

Trichoglossum 8, 29

confusum 29, 33

Farlowi 29, 32

hirsutum 29, 30

hirsutum Wrightii 31

octopartitum 29, 32

Rehmianum 33

tetrasporum 29, 30

velutipes 29

Walteri 29, 33

Wrightii 29, 31

Trichopesiza 239, 241, 279

acerina 273

agrostina 259

albotestacea 272

alboviridis 274

Aspidii 274

brevipila 274

candida 274

capitata 254

carneorubra 275

ciliaris 255

coarctata 275

comata 275

crossota 275

distincta 276

earoleuca 276

echinulata 257
Eupatorii 272

flavofuliginea 277

fulvocana 277

inquilina 260

Kalmiae 278, 351

labrosa 278

leonia 278

lencophaea 264

marginata 278

melaxantha 278

myricacea 278

nigrocincta 278

nivea 253

obscura 278

Opulifoliae 279

Osmundae 279

penicillata 279

pollinaria 255

ponicolor 279

Pteridis 273

pulverulenta 265

punctiformis 279

relicina 279

roseoalba 280

rufiberbis 280

setigera 280

subochracea 251

sulphurea 264

Tiliae 274, 281

urticina 281

venturioides 281

viridicoma 267

Vitis 381

Trichoscypha Willkommii 244

Trichoscyphella Irillkommii 244

Trochilia

populorum 188

Trifolii 185

Tryblidiopsis Pinastri 369

Tryblidium 366

cucurbitaria 366

difforme 322

Pinastri 369

seriatum 323

Tubercularia 211

fasciculata 335

Rhois 211

Tympanis $295,306,367,368$

acerina 343,359 
alnea 368,369

Ariae 358

Aucupariae 371

bicolor 357

Cerasi 353

cespitosa 369

cinerascens 372

conspersa 368,371

conspersa alnea 369

fasciculata 368,371

Frangulae 312

Fraxini 310,367

gyrosa 372

inconstans 358

Nemopanthis 324

Oxydendri 368, 370

Padi 360

Pinastri 368,369

pithya 372

plicatocrenulata 372

populina 370

Prunastri 361

punctoidea 306

Ravenelii 310

rhabdospora 333

Ribis 317

saligna 368,372

seriata 268

spermatiospora 368,370

stictica 306

turbnata 319

Urceolus 325

viticola 321
Unguicularia 240

oregonensis 279

scrupulosa 151

Unguiculariopsis 218

ilicincola 218

Urceola

atrata 208

hyalina 252

Pteridis 273

Urceolella puberula 134

Urnula

craterium 93

terrestris 97

Velutaria 241, 295, 296

cinereofusca 275, 297

griseovitellina 297

Rhododendri 311

rufoolivacea 296

Verpatinia 45,73

calthicola 73

duchesnayensis 73

Vibrissea $8,39,179,183$

circinans 41

foliorum 40

Guernisaci 183

lutea 42

ochroleuca 43

truncorum $\mathbf{4 0}$

truncorum albipes 40

turbinata 184

Wynnea 91

Xanthoglossum 17

luteum 13

microsporum 19

Xyloma herbarum 187, 188, 208 



